Historic, Archive Document

Do not assume content reflects current scientific knowledge, policies, or practices. 

Youy

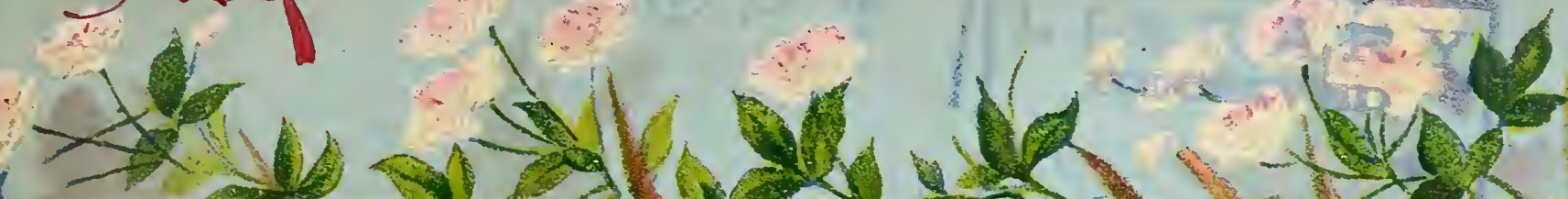

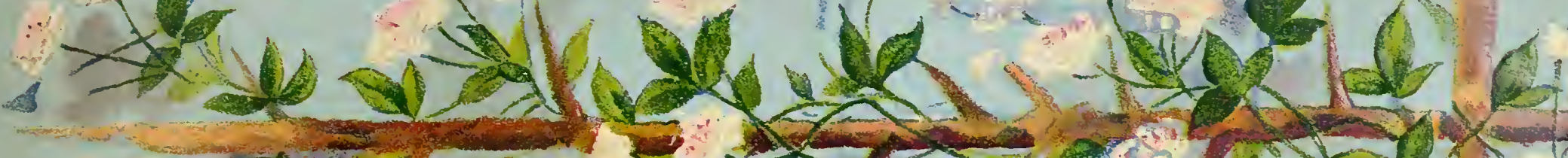
- 


\section{FLOWER SEEDS.}

Arcotis Grandis.

Aquilegia

Asters

Antirrihnum

Alyssum

Ageratum

Ampelopsis Veitchii

Balsam

Balloon Vine

Campanula

Cobæa...

Celosa

Canary Bird Flower

Christmas Pepper..

Calendula

Cyclamen

Cosmos

Chrysanthemum.

Carnation

Candytuft

Calceolaria

Canna

Cypress Vine

Cineraria

Centurea

Dianthus

Dahlia

Delphinium

Dolichos

Eschscholtzia.

Feverfew (see Matricaria)

Fuschia

Forget-Me-Not.

Geranium

Gaillardia

Gourd

Gloxinia

Globe Amaranth

Heliotrope

Hibiscus.

Hollyhock

Hyacinth Bean

Helianthus

Humulus

Lathrus Latifolius

Lemon Verbena

Latana.

Lobelia.

Larkspur

lpomea

Moonflower

Marigold

Marvel of Peru

Mignonette

Mesembryanthemum

Maurandia.

Morning Glory.

Matricaria

Mormodica

Nasturtium

Nicotiana

Phlox Drummondii

Pansy

Peas Everlasting

Petunia ..

Poppy

Pink .

Primula

Platycodium

Portulacca

Pyrethium

Ricinus

Rudbeckia

Salvia

Sweet Peas

Stocks
FLOWER SEEDS-Continued. PAGE

PAGE Scabiosa..

33 Smilax

28, 37 Sweet William

28, 38 Sensitive Plant

31, 37 Stokesia Cyanea

37 Sunflower

37 Tropæolum

37 Thumbergia

39 Tritonia.

39 Verbena

$3 y$ Violet

40
Vinca .........
Wallflowe

36 Wild Flower Garden

39 Zinnia

28 Yucca..

40
39
32

1,32

\section{VEGETABLE SEEDS.}

30, 40 Asparagus

33, 40 Asparagus Roots

39 Beans.

30, 41 Beets

39 Chicory

40 Cabbage

39 Carrot

39 Corn Salad

40, 33 Cauliflower

29, 41 Celery

30,41 Cucumber

41,33

34 Celeriac

28 Dandelion

44 Endive

41 Egg Plant

29,41

Herbs

42, 33 Kale

43 Kohl-Rabi

43 Lettuce

42 Leek

31, 43 Melon, Musk

43 Martynia

43 Melon, Water

34, 43 Mustard

43 Okra

43 Onions

46 Onion Sets

43 Peas

43 Parsnip

43 Potato

29, 43 Parsley

43 Peanuts

44 Pepper.

31, 44 Pumpkin

44 Radish

30, 44 Rhubarb

44 Rhubarb Roots.

44 Rutabaga..

44 Squash

44 Sorrel

44 Salsify

45 Spinach

44 Tobacco

47 Turnip

46, 34 Tomato

46: Mangel Wurzel.

48 Lawn Grass Seed.

47 Clover Seed

30 Cut Flower Department-

47

47 Grass Seed

46 Vegetable Plants.

48 Implements

29 Insect Destroyer

28, 48 Flower Pots

36,49

49 Scollay's Sprinklers.

48 Farm and Field Seeds

PAGE

6,25

102

12

9,25

12,26

PLANTS.

PLANTS-Continued.

PAGE

PAGE Lillies .........................80, 81, 74

Althea................................ 93

48 Amaryllis ................................. 67

48 Aster.

31 Abutilon

33 Ageratum ..........................67, 85

50 Areca

31 Achillea

31, 50 Althernanthera

50 Aspidistra.

50 Acalypha

Azalias...

50 Ampelopsis

29, 50 Asparagus

Aquilegia

Antirrihnum

Bay Trees

, 26 Box Tree

Blgnonia …................... 89, 63

5, 22 Barberies

3, 22 Boston Fern

Cinnamon Vine

8, 27 Canna

Chrysanthemums

5 Carnations..

8, 27 Caladium

7, 25 Cyclamen

8, 24 Coleus

7, 24 Christmas Pepper

Calla Lilies

Clematis

Cocos

.. 9 Calycanthus

Coreopsis

Corchorus Japonica

Clethra

Cornus

10, 21 Chionanthus

Dahlia

9 Deutzia

11, 27 Delphinium

9 Dicentra

13 Dracaena

13, 25 Echeveria

13 Fuchsias

15, 22 Ferns ...

13 Funkia

14 Ficus

14 Forsythia

15 Fernball.

14, 21 Farfugium

13, 26 Golden Feverfew

6, 26 Geraniums, 62, 63, 75, 76, 77, 85

14 Gladiolus

101 Gazania

18 Golden Day Lily..................... 91

17, 23 Gloxinia ................... 74

17 Gaillardia

17 Heliotrope

17 Honeysuckles

17 Hydrangea

18 Hibiscus.

18, 23 Hemerocallis

20 Hollyhock.

19 Hop Vines

20 Ivy

Iris

Ismene

19 Justicia

101 Jassam!ne

101 Kentia

102 Lantana

101 Latania

102 Lonicera

102 Lemon Ponderosa

20 Lemon Verbena...

$92,94,78$

78

91

91

88

85

91

79

80

79
87

87
79

87

94

80

79

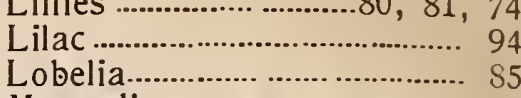

Magnolia................................... 88

Madeira Vine ............................... 85

Marguerite ............................. 81

Moonflower ............................... 80

Mesembryanthemum ............... 85

Nasturtium................. 84

Otaheite Orange........................ 81

Osage Orange........................... 95

Passion Flower........................ 81

Pansy........................................... 82

Pomegranite............................ 81

Peonies ...................................... 91

Phœnix ....................................... 86

Petunias .................................. 82

Phlox .............................................. 64

Pinks

Plumbago ................................. 81

Prunus........................................ 94

Platycodium .............................. 91

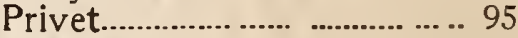

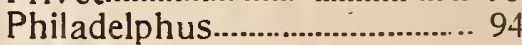

Pandanus ......................... 66, 86

Pyrus Japonica................. 94, 95 


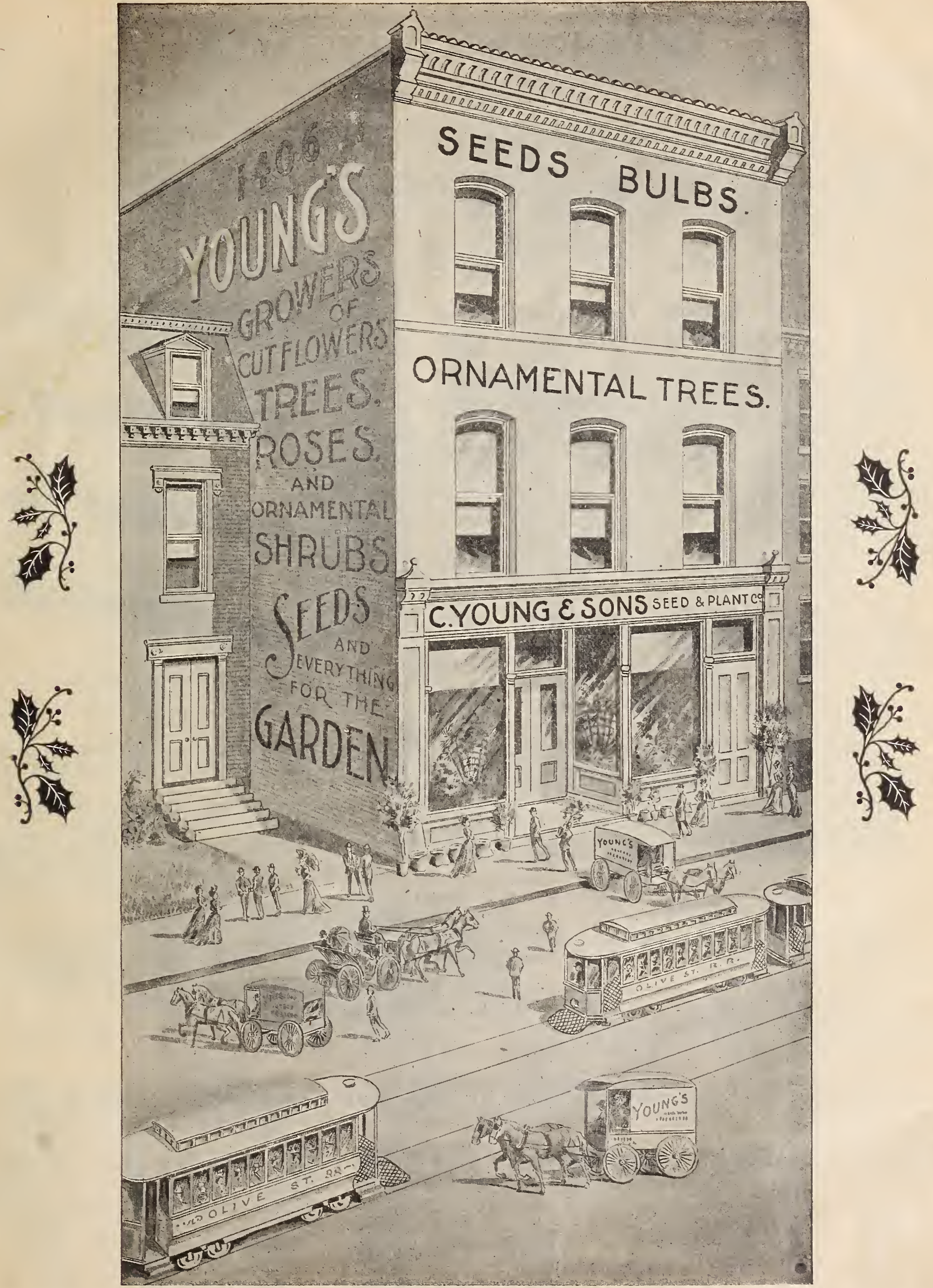

IN SUBMITTING OUR CATALOGUE for the coming season, we take much pleasure in thanking our customers for their very kind and liberal support

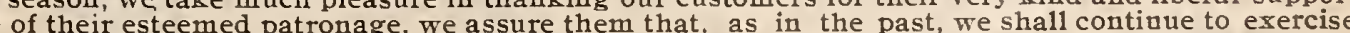
our best care in the execution of all orders which we are entrusted with. We also take this opportunity of tendering our most sincere thanks to our numerous customers who have been kind enough to recommend our firm, and we will ever strive to deserve their confidence. Soliciting the favor of your patronage, we remain,

JOHN YOU NG, President.

Willian C. YOUNG, Vice.President.

HENRY YOUNG, Secretary. 


\section{IMPORTANT ITEMS.}

7IVIE GUARANTEE every package of PLANTS, SEEDS or BULBS to reach the purchaser promptly, safely and in good condition. When we deliver them to you in good order, our responsibility ceases.

As so much depends on the care and attention given to trees, shrubs, etc., after they have been properly planted and also on the conditions of the weather throughout the following year of which we have no control, it is impossible for us to guarantee trees, shrubs, plants or roses to live or assume the risk of their growing, but after reasonable care has been bestowed on those that have been planted by us, and a loss does occur, it has always been our custom to replace them at oue-half their regular value in other stock. But we do not insure their lives.

We positively will not be responsible for the growing of newly transplanted trees, shrubs, etc., beyond the first leafing out in spring.

FREE BY MAIL-We send Plants, Bulbs and Seeds by mail except special large-sized plants, which are too large to be placed in mailing boxes.

\section{WE WOULD ADVISE ORDERING YOUR PLANTS TO BE FORWARDED BY EXPRESS}

As the Express Companies have made a special rate of 20 per cent. less than general merchandise on PLANTS, BULBS and SEEDS. When plants are ordered to be sent by express they are much larger and all the soil is left undisturbed, which makes them grow much quicker than if sent by mail with all the soil taken off the roots. We always add a few plants gratis of our own selection to help pay the charges.

SHIPPING PLANTS-All orders for plants will be held until about April 1st, when we begin shipping to the warmer states and northward as fast as the weather will permit, unless otherwise requested. If wanted for winter flowering or immediate use, state the fact and they will be shipped accordingly, though in case of severe cold storms we may hold for a few days.

QUALITY OF PLANTS-Our long experience in grow ing and mailing plants has taught us that it pays to ship strong, healthy plants, and as we guarantee their arrival in good condition, customers may rest assured they will receive the best plants to be had.

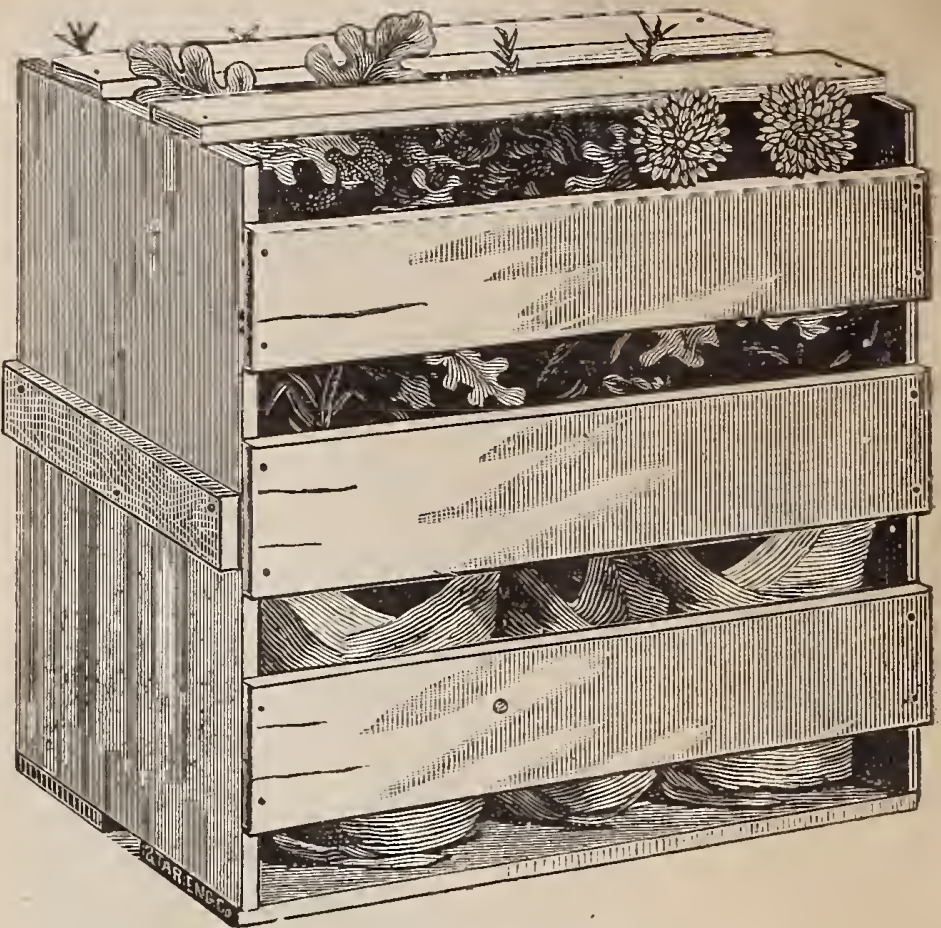

Case of Plants for Shipping by Express.

NO ORDERS FOR PLANTS by mail will be accepted for less than 50c in value without 10c for postage accompanies same.

HOW TO ORDER-Always use the order sheet and fill out the blank spaces carefully, with each article on a separate line, with the prices carried out, being careful to write your FULL NAME, POSTOFFICE, COUNTY and STATE plainly, on each letter sent us, and give street number, if any.

CHANGE OF ADDRESS-If you have changed or intend to change your address, please let us $\mathrm{know}$, and we will change it on our books so that you will receive our Seed Annual without application, at your new postoffice.

HOW TO SEND MONEY-Remit by Draft, Money Order or Registered Letter. Currency in ordinary letters is at the risk of the sender. Do not send checks or drafts on Western towns unless 15 cents is added to cover cost of collection. We decline sending goods C. O. D. unless one-half the amount accompaniesthe order to guarantee the express charges.

PLEASE SEND THE REMITTANCE WITH THE ÖRDER-We do a strictly cash business, and have no open accounts in the mail order department.

ORDERS PROMPTLY ANSWERED-All orders received by us are filled immediately on their arrival, except in the height of the busy season. They are then filled in rotation as quickly as possible, hence tlie advisability of ordering early.

OUR SELECTIONS-When purchasers prefer leaving the selections to us, they should mention in a general way what they are wanted for, and we will select the best varieties for tlieir purpose.

CUSTOMERS visiting the city and intending to purchase plants from us to take lome with them should send us their orders by mail a day or two before they intend to leave, and we will have the plants already packed ready for thems the store when they call.

SPECIAL NOTICE-While we exercise the greatest care to liave all Seeds, PIants and Bulbs pure and reliable, wedo not give any warranty, expressor implied. If the purchaser does not accept the goods on these conditions they must be reiurned at once, and the money that has been paid for same will be refunded.

PREMIUMS ON CASH ORDERS ONLY, and MUSI De Selected at the Time OPdeP Is Given: Purchasers may select the tol

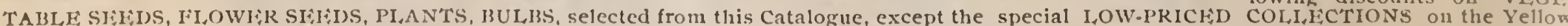

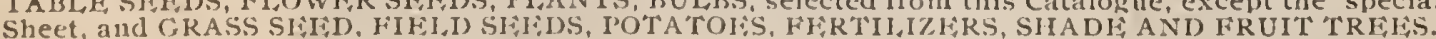

\begin{tabular}{|c|c|c|c|c|c|c|c|c|c|c|c|c|c|c|}
\hline$\$ 1.00$ & Order & select & P'rellium & to value & $10 \mathrm{c}$ & extra & On & 8.00 & Order & select & Premium & to value & $\$ 1.20$ & \\
\hline 2.00 & ، & " & . & ". & $2.5 c$ & " & On1 & 9.00 & " & " & " & " & 1.35 & \\
\hline 3.00 & “" & “. & “. & “. & $45 \mathrm{c}$ & “. & On1 & 10.00 & “" & “" & " & "“ & 1.50 & \\
\hline 4.00 & “" $\mathrm{n}$ & " & “ & “" & $60 \mathrm{c}$ & “. & $\begin{array}{l}\mathrm{O}_{11} \\
\mathrm{O}_{11}\end{array}$ & $\begin{array}{l}11.00 \\
12.00\end{array}$ & “. & $\because$ & $\because$ & $\because$ & $\begin{array}{r}1.75 \\
2.00\end{array}$ & \\
\hline 5.00 & ." & “ & “" & “. & $75 \mathrm{c}$ & '. & On & 13.00 & “. & “. & “. & ." & 2.15 & \\
\hline 6.00 & “" & “" & "“ & “" & $90 \mathrm{c}$ & “" & $\mathrm{On}_{\mathrm{n}}$ & 14.00 & " & “" & “" & ." & 2.30 & \\
\hline 7.00 & "“ & “. & " & "' & $\$ 1.05$ & “. & $\mathrm{O}_{11}$ & 15.00 & "1 & "“ & “ & " & 2.50 & \\
\hline
\end{tabular}



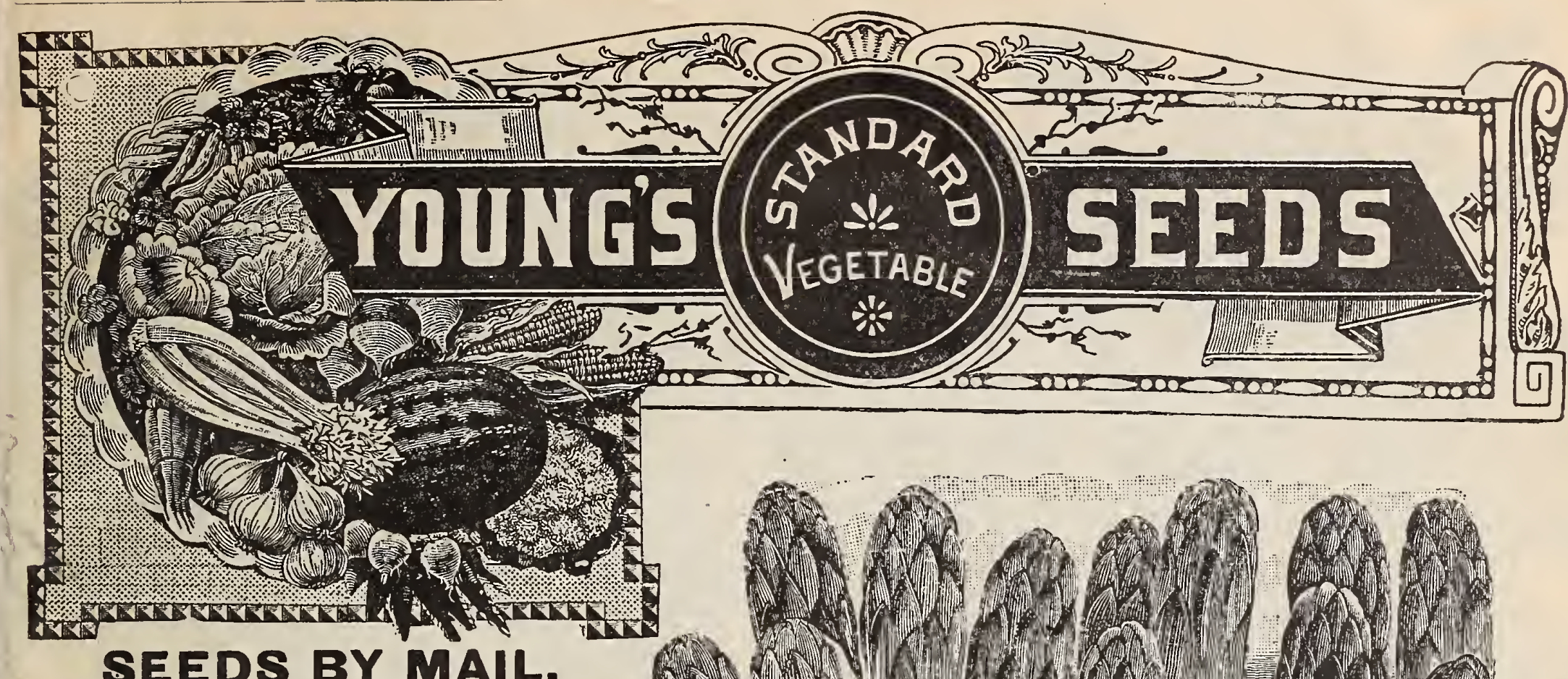

We prepay mail or express charges on all vegetable and flower seeds purchased rom this catalogue in packages, ounces, pints and quarts.

pints and quarts. may deduct 10 cents per pound on bulk seed, and 10 cents per pint and 15 cen
prices quoted.

\section{ASPARAGUS.}

Sow the seeds in drills about 1 inch deep, and the rows about 1 foot apart. Keep the soil mellow and free from weeds during the summer, and in the fall or succeding spring the plants should be set about foot apart, and the crown to permit of cutting to the center. Before winter cover the transplanted beds with about 4 inches of manure. Salt is an excellent manure for Asparagus. Sow a little on the surface in thespring and it will keep down the weeds. The young tops may be cut for the

frefy dintil the third. Perpkt.; $5 \mathrm{c}$; oz., 10c; 14 1b., 20c.; 1b. 40c

Hently $\mathrm{inch}$ in diameter. Per pltt, $5 \mathrm{c}$, variety, stalks fre$1 \mathrm{~b} .90$

VALMETTO-An improvement on Conover's, it being a lb., 80c

\section{ASPARACUS ROOTS.}

Good 2-rear-old roots of the following varieties which may be planted in spring or fall: $\quad$ Per $100 . \quad$ Per 1000

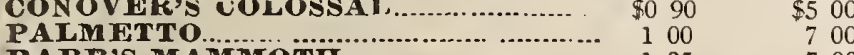
BARR'S MAMMOTH....................... 125 50 at 100 Rate, 500 at 1000 Rate.
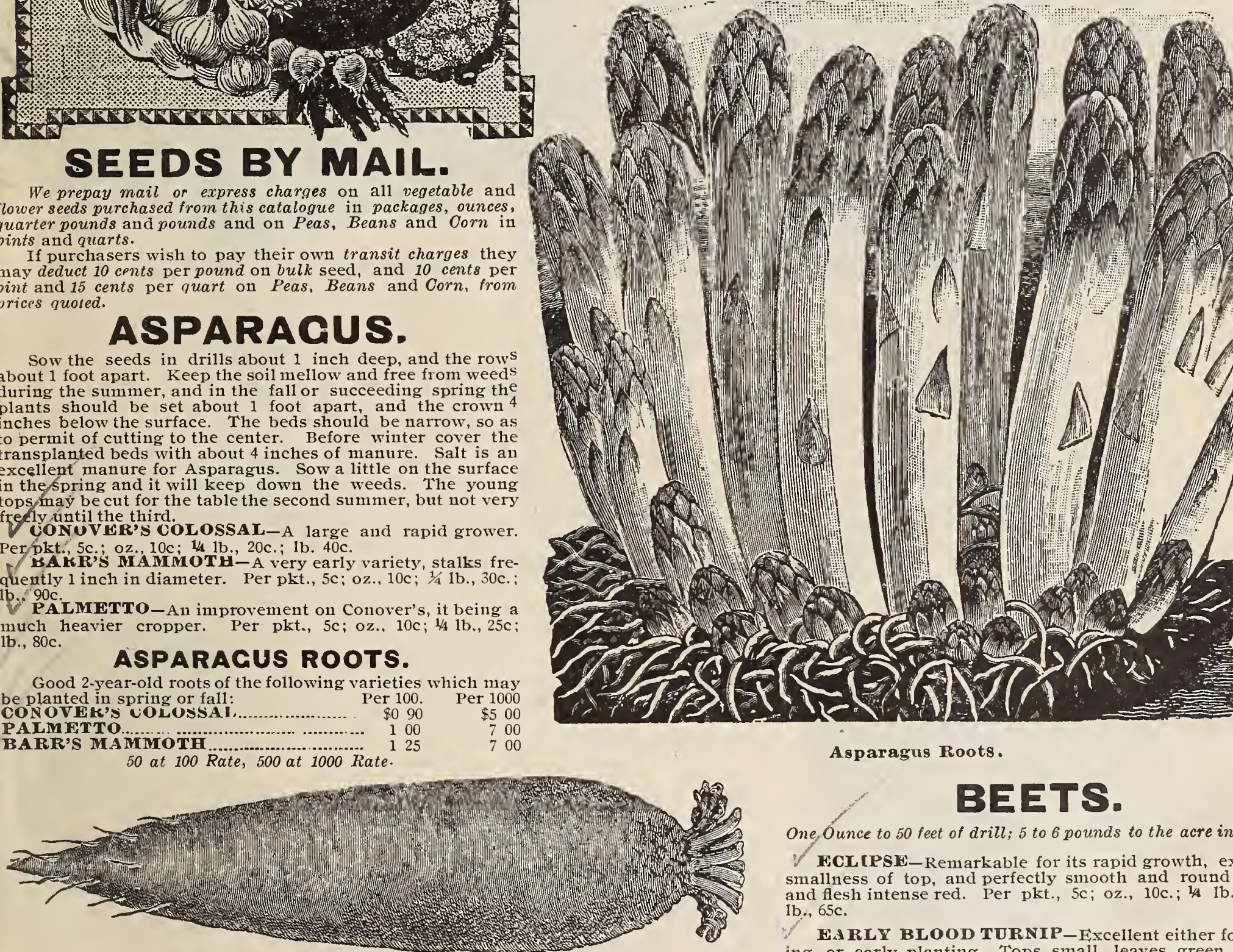

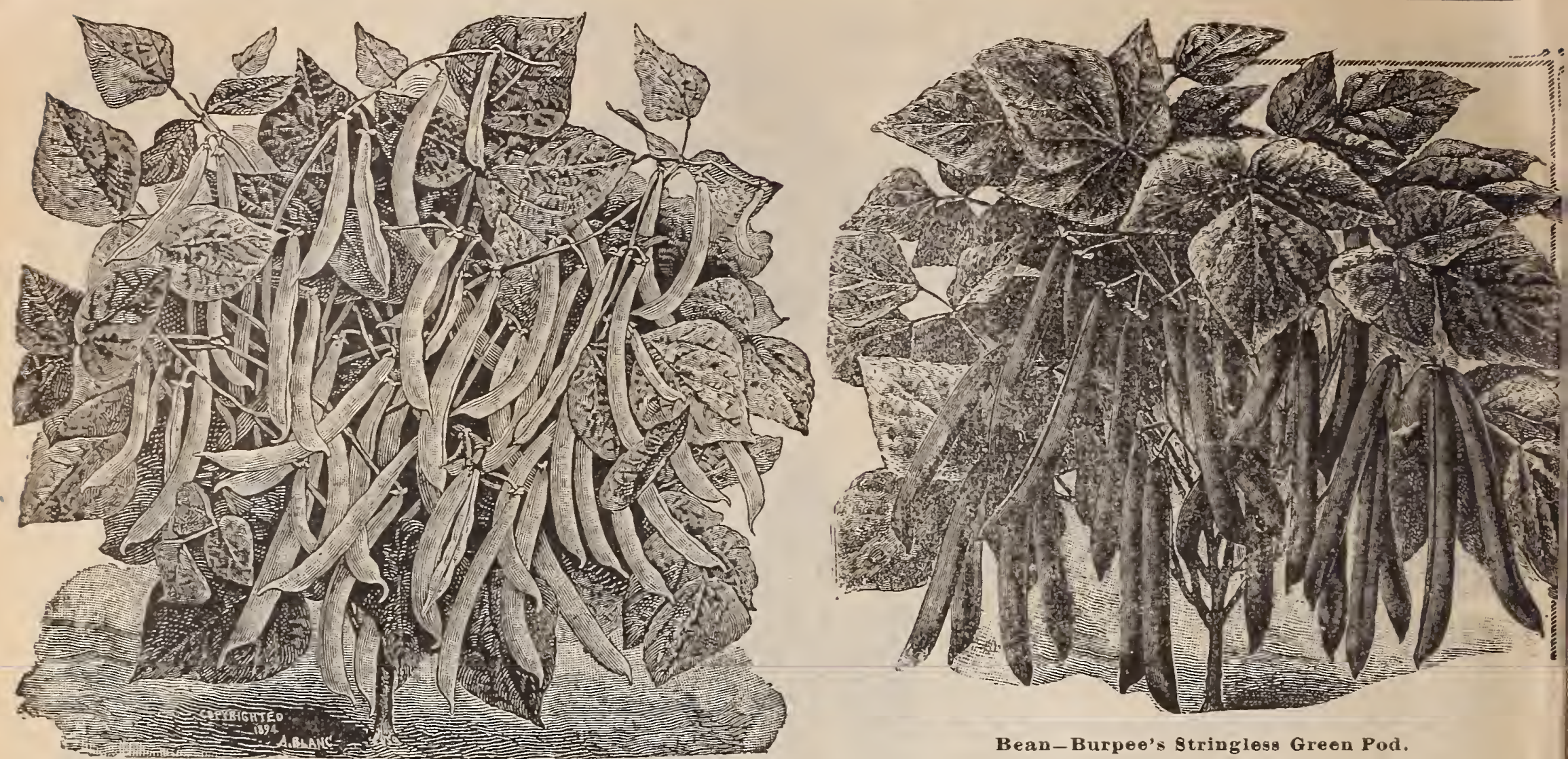

Bean-Early Red Valentine.

BEANS.

DWARF, BUSH OR SNAP.

1 quart to 100 feet of drill, 2 bnshels to an acre.)

All the varieties of Dwarf, Bnsli or Snap Beans are tender and will not bear the cold. Plant about the middle of April, if the ground is warn and the season favorable, for a snccession, and at intervals throughout the season, finishing abont the 15th of Angnst. The best mode of culture is in rows feet apart, and the beans 3 inches apart, and 2 inclies deep in the rows. Keep well hoed, and draw the earth np to their stems, but only when dry working them when wet with rain or dew will cause them to rnst and injure the crop.

\section{BURPEE'S STRINGLESS CREEN POD.}

The pods are a rich green, very round and straight, five inches long, solid, meaty and broad; they are very tender, brittle and of finest flavor, always entirely stringless even when fully matured. They are the first to prodnce pods. For either the market or home garden, no other green-podded

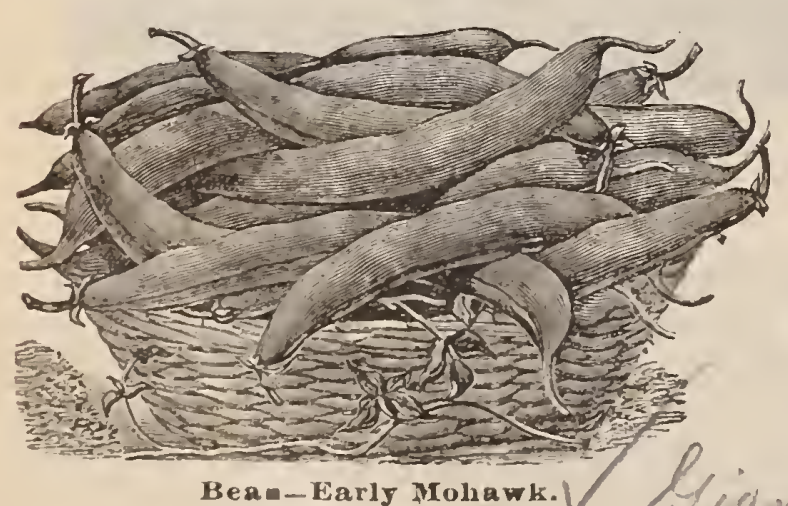

FXTRA EARLY RED VALENTINE-This is the leading variety, both for market
Kardenérs and private nse, very productive and of excellent flavor. The pods are round and tendor, and remain longer in the green state than any other variety: (See cut) FARLY MOHA WF-The hardiest of the earliest varieties; will stand more cold than
a hy other. The pods are from 5 to 6 inches\$long. A good variety for market gardeners and
pivate $y$

VARLY LONG SELLOW SJX WLF IX-It is extra early, a vigorons grower and Veps productive; very prolific; the pods are long and entirely stringless. (See cut)

GOLDEN WAX-One of the earliest rarieties. Pods long, brittle, entirely stringless, of fich golden color. As a bean for winter nse it has few eqnals.

DAVIS WHITE WAX-Immensely, productive, bearing iarge, handsome, straight pods 5 to 6 inches in length-the dry seeds being white, and of medium size. It is desirable GOLDEN-EYED WAX

GOLWN-EYED WAX-Strong, bnshy growth 15 inches in heipht: plants are heavily Bean-Early Mohawk

laden with landsome pods 5 inches in leugth and 48 -inch wide.

These prices include prepay charges on packages, pints and quarts. If purchasers pay thelr own transit charges they may deduct 10 cente per pint and 15 cents per quart from the prices quoted.

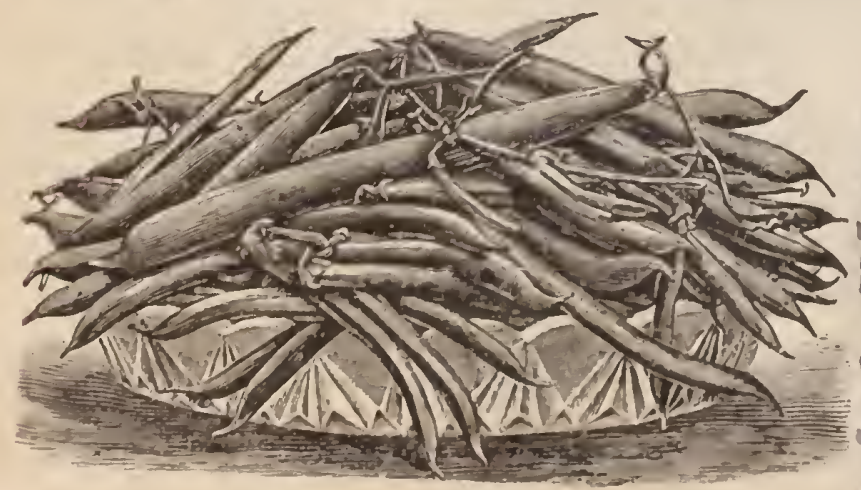

PRICL OF BUSH OR SNAP BFANS.

lHean-Long Yellow Six Weeks.
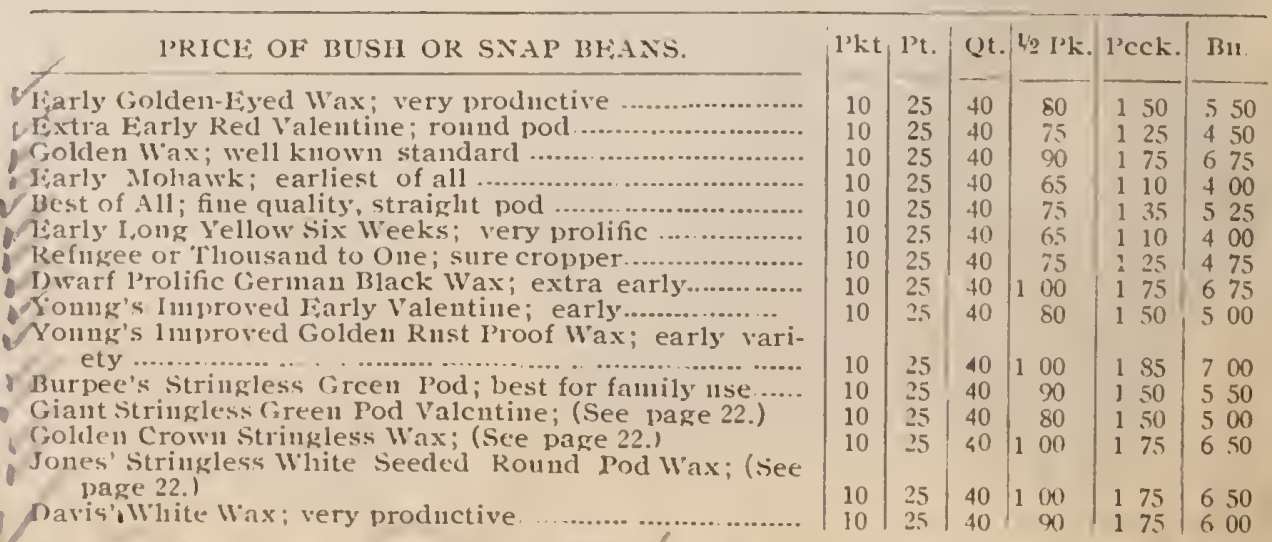


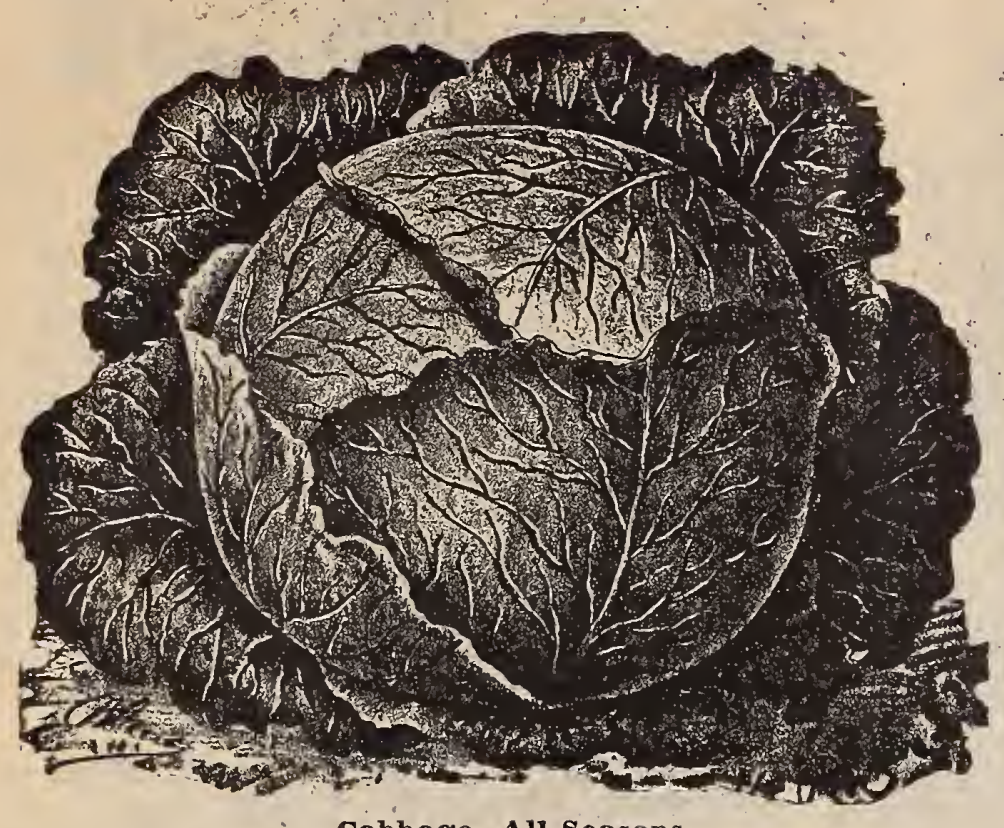

Cabbage-All Seasons.

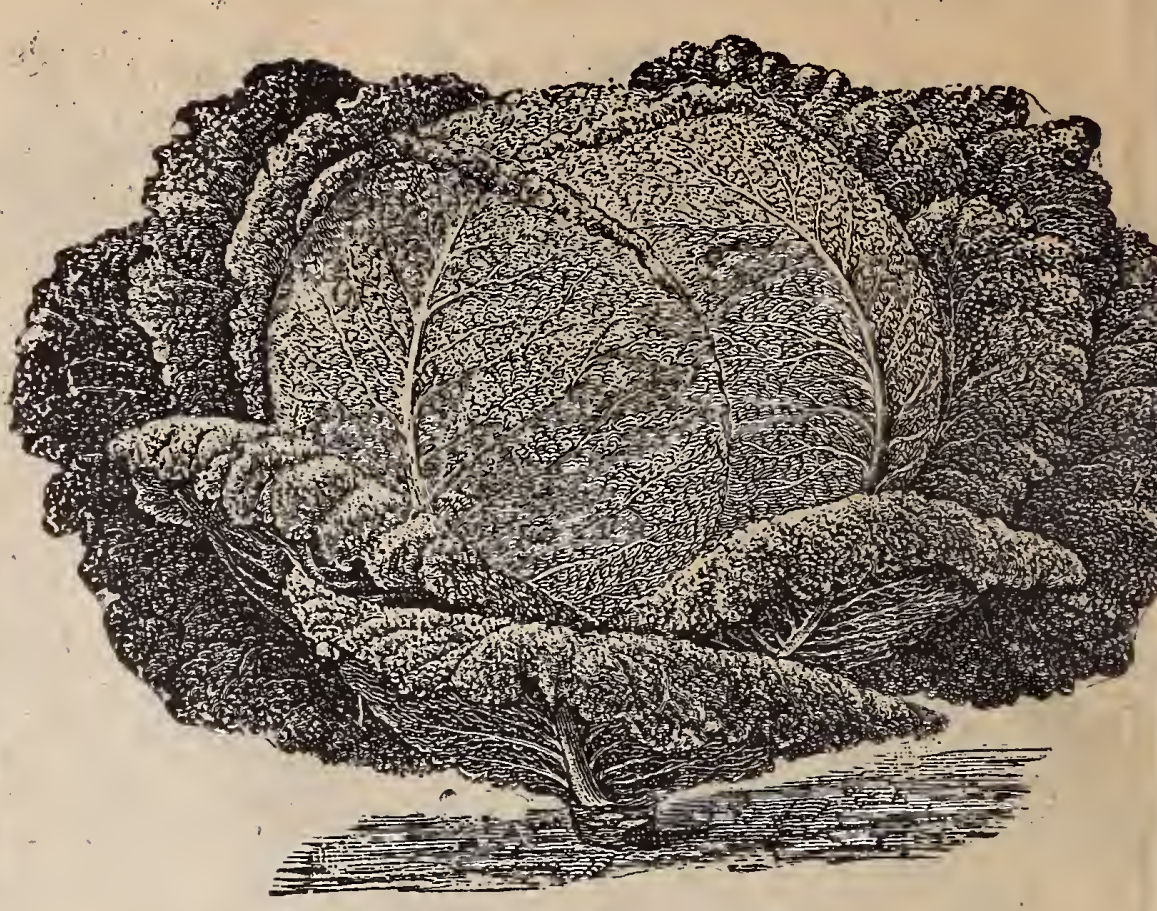

Cabbage-Mammoth Drumhead.

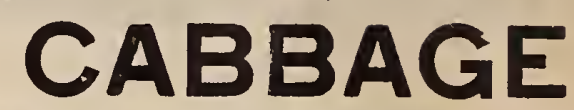

1 oz. will produce 1500 plants, $1 / 2-l b$. of seeds in beds to transplant for an acre.

In latitudes where the thermometer never indicates 20 deg. below the freezing point, the early variety of Cabbage may be sown in the open border, but in colder climates they must be sown in a hot-bed, about the middle of January or the first of February, and planted out in March or April, in a rich, deep, loaming soil, in rows 2 feet apart and 18 inches in the row. The late varieties are usually sown in the early part of May, and plants set out in July, in rows 3 feet apart and 2 feet in the rows. transplanting they must be set in other ground up to the first leaf, no matter how long the stems may be. tionably the best early Cabbage in cultivation (see cut). CHARLESTON WAKETIELDAn improvement over the old Jersey Wakefield. An improvement over the old Jersey Wakefield,
being quite as early and much larger in size of head. Early Brunswick-This is certainly one of the second earliest sorts in cultivation (see cut). second earliest sorts in cultivation (see cut),
MAMMOTH DRUMHEAD - Probably the largest variety of Cabbage in cultivation. Should be planted 4 feet apart, each way (see cut). earliest large heading Cabbage; growth compact so that it maybe set as close as the smaller Sorts. PRIUM FLAT DUTCH - (selected stock). A very popular and highly esteemed variety; in its keeping qualities unsurpassed. Both for market and family use this variety is more extensively cultivated than any other. while not as large as Jersey Wakefield, is four or five days earlier.

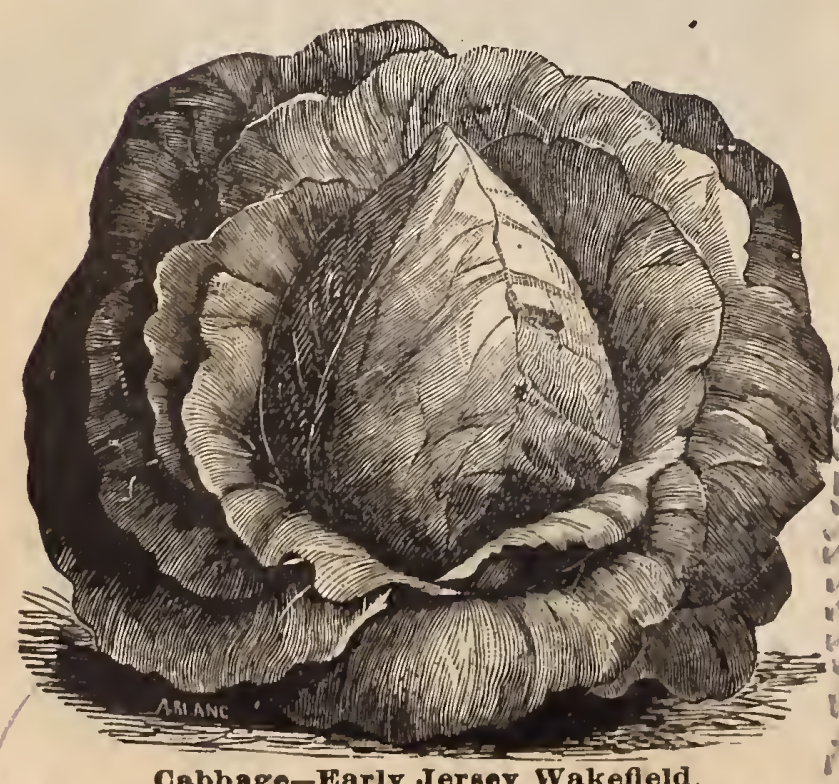

Cabbago-Early Jerney Wakefield.
These prices include Free Delivery in the U. S. If party wishes to pay their own transit charges, deduct 10 cents per pound from prices quoted. 


\section{CUCUMBERS.}

One Ounce for 50 Hills.

The plants are tender, and planting should be

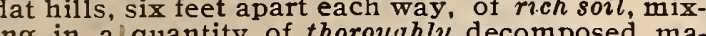
ing in a quantity of thill 15 or 20 seed mery inch along the rows, and cover one inch deep, pressing the soil firmly over them.

IMPROVED EARLY WHITE SPINEOne of the most popular varieties for both macket and table use. Vines vigorous, ruíting early aud abundantly.

NICHOLS'S MEDIUM GREEN - We consider this a most valuable variety; as a pickle sort it will be found unequale

$\checkmark$ WESTEREIELD'S CHICAGO PICKLING-This is undoubtedly the best. Cucumber for pickling. It quite young.

LIVINGSTON'S EVERGREEN -It is very hardy and probably the most prolific of all varieties: early.

WHITE WONDER--A hand some ivory white Cucumber of fine qual. ity. The fruit is about eight inches in length, very brittle, and remains solid and edible

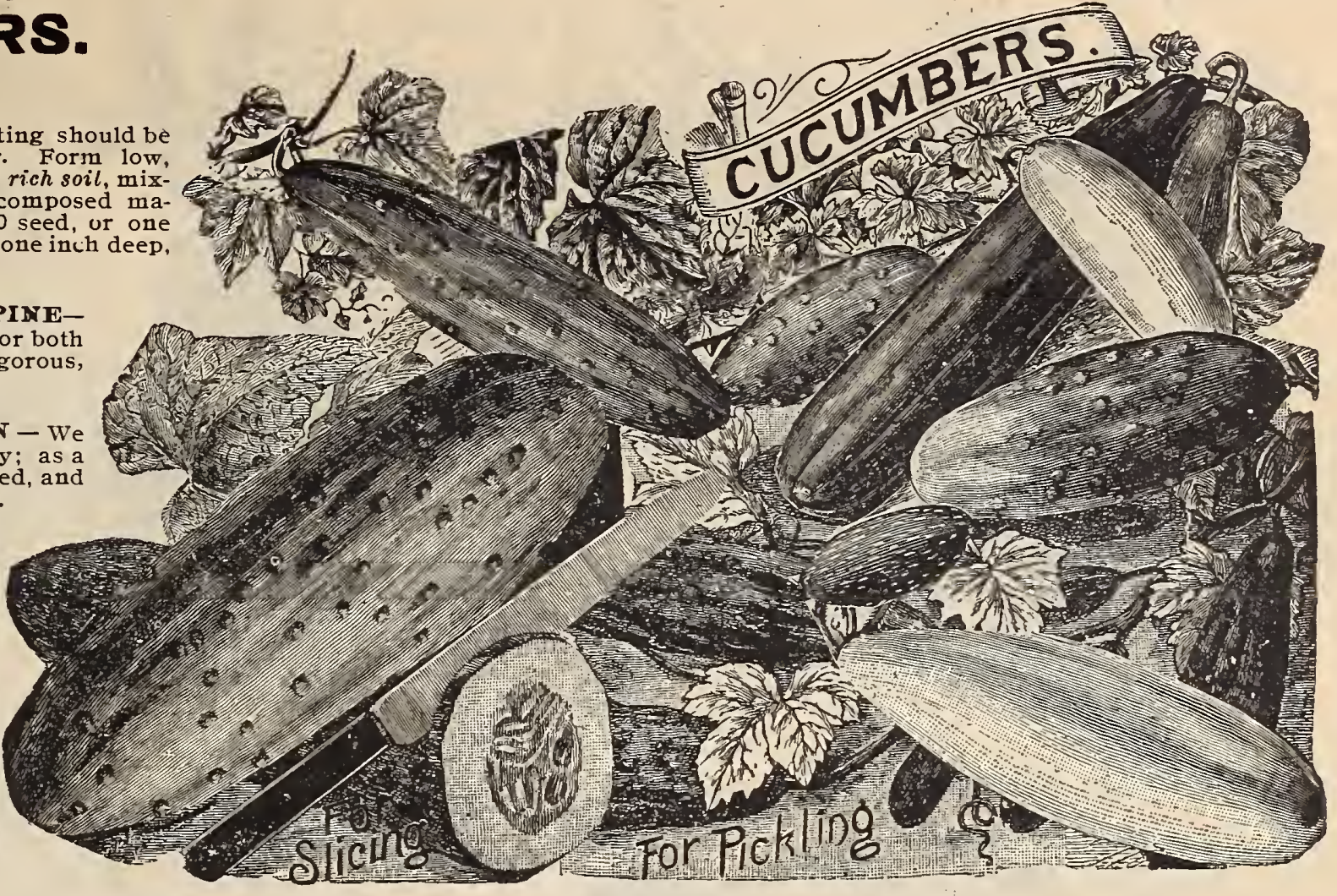

PRICES OF CUCUMBERS.

\begin{tabular}{|c|c|c|c|} 
Pkt. & Oz. & $41 \mathrm{~b}$ \\
\hline $5 \mathrm{c}$ & $20 \mathrm{c}$ & $\mathbf{5 0 c}$ \\
$5 \mathrm{c}$ & $20 \mathrm{c}$ & $50 \mathrm{c}$ \\
$5 \mathrm{c}$ & $20 \mathrm{c}$ & $50 \mathrm{c}$ \\
$5 \mathrm{c}$ & $20 \mathrm{c}$ & $50 \mathrm{c}$ \\
$5 \mathrm{c}$ & $20 \mathrm{c}$ & $50 \mathrm{c}$ \\
$5 \mathrm{c}$ & $20 \mathrm{c}$ & $50 \mathrm{c}$ \\
$5 \mathrm{c}$ & $20 \mathrm{c}$ & $50 \mathrm{c}$ \\
$5 \mathrm{c}$ & $20 \mathrm{c}$ & $50 \mathrm{c}$ \\
$5 \mathrm{c}$ & $20 \mathrm{c}$ & $50 \mathrm{c}$ \\
$5 \mathrm{c}$ & $20 \mathrm{c}$ & $50 \mathrm{c}$
\end{tabular}

CORDHOOK PIOKLING-A very prolific variety of medium size

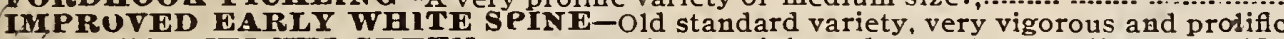

TICGOLS' M ForUM GREEN-Medium size, straight and smooth, exceedingly prolifi.

Westerfield's Chicago Pickling-Valuable for pickling fruit, medium length, color deep green.

LIVINGSTON'S EVERGREFN-Medium size, fine quality, quite large in diameter.

FARLY FRAME, OR SHORT GREEN - Fine for forcing, fruit medium

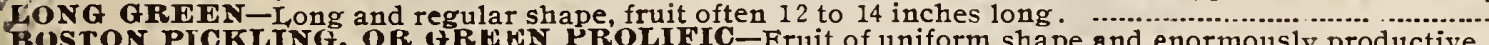

WHITE WONDER-The best white Cucumber, fruit uniform in color, size and shape.

COST IYDIA GHERKIN OK BUKR-Grown only for pickles, fruits 2 to 3 inches in

A PANESE CEIMBER-A rapid growing climber, producing an excellent quality of fruit

\section{CELERY.}

One ounce for 2,000 Plants.

Sow the seed the first of March or April. By rolling or pressing the seed frmly into the ground it has been found more satisfactory than only slightly covering it.

The seedling plants should be clipped down partially two or three times to make them short and stocky before transplanting

The ground where the Celery is to be planted should be highly fertilized and cultivated, lasd off in spaces 4 to 5 feet apart and each space being wide enough

to plant the Celery in rows 6 inches apart and from 3 to 5 rows in space.

Celery does not require to be planted in trenches as in former years. Abou continued every two weeks until entirely covered up to the leaves. This is done to bleach the stems and render them crisp.

IMPROVED DWARF GOLDEN HEART-A variety of great value. In ize it is the same as the Half Dwarf White.

GOLDEN SELE BLANCEING-This is the best celery ever raised for general purposes. Without banking up, or any covering whatever, even the outer ribs become a handsome glossy, yellowish-white color (see cut).

TWHITE PLUME-The peculiarity of this variety is the stalk portions of inner leaves and heart; they are white naturally, so that by simply tying the plants together, or bv drawing the soil against it, the work of blanching is

These prices include free delivery in the U. S. If party wishes to pay transit charges deduct $10 \mathrm{C}$ per pound from prices quoted.

\begin{tabular}{|c|c|c|c|c|}
\hline PRICES OF STANDARD CELERY. & Pkt. & $\mathrm{Oz}$ & $1 / 4 \mathrm{lb}$. & L.b. \\
\hline $\begin{array}{l}\text { PERFECTION HEARTWELL_-One of the best for } \\
\text { general cultivation, very compact and crisp.......... } \\
\text { IMPROVED DWARF GOLDWN H WART-A popu- }\end{array}$ & $5 c$ & $20 \mathrm{c}$ & $50 \mathrm{c}$ & $\$ 175$ \\
\hline GoLDEN SELF BLANCHING-The leading variety & $5 c$ & $15 c$ & $40 c$ & I 50 \\
\hline $\begin{array}{l}\text { in all markets as an early celery................... } \\
\text { WHTE PLUME-This is the earliest and most easily }\end{array}$ & $5 c$ & $30 c$ & $80 c$ & 300 \\
\hline $\begin{array}{l}\text { blanched Celery in cultivation............................. } \\
\text { GrANT WHITE }\end{array}$ & $5 c$ & $20 c$ & $60 c$ & 200 \\
\hline GIANT PAsCEL - Valuable for winter, best keeper, & $5 c$ & $15 c$ & $40 c$ & 150 \\
\hline 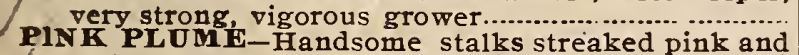 & $5 c$ & $20 c$ & $50 c$ & 175 \\
\hline OLD Wite in growth, similar to White Plumer (see pas & $10 c$ & $20 c$ & $\begin{array}{l}60 c \\
10 c\end{array}$ & 25 \\
\hline
\end{tabular}

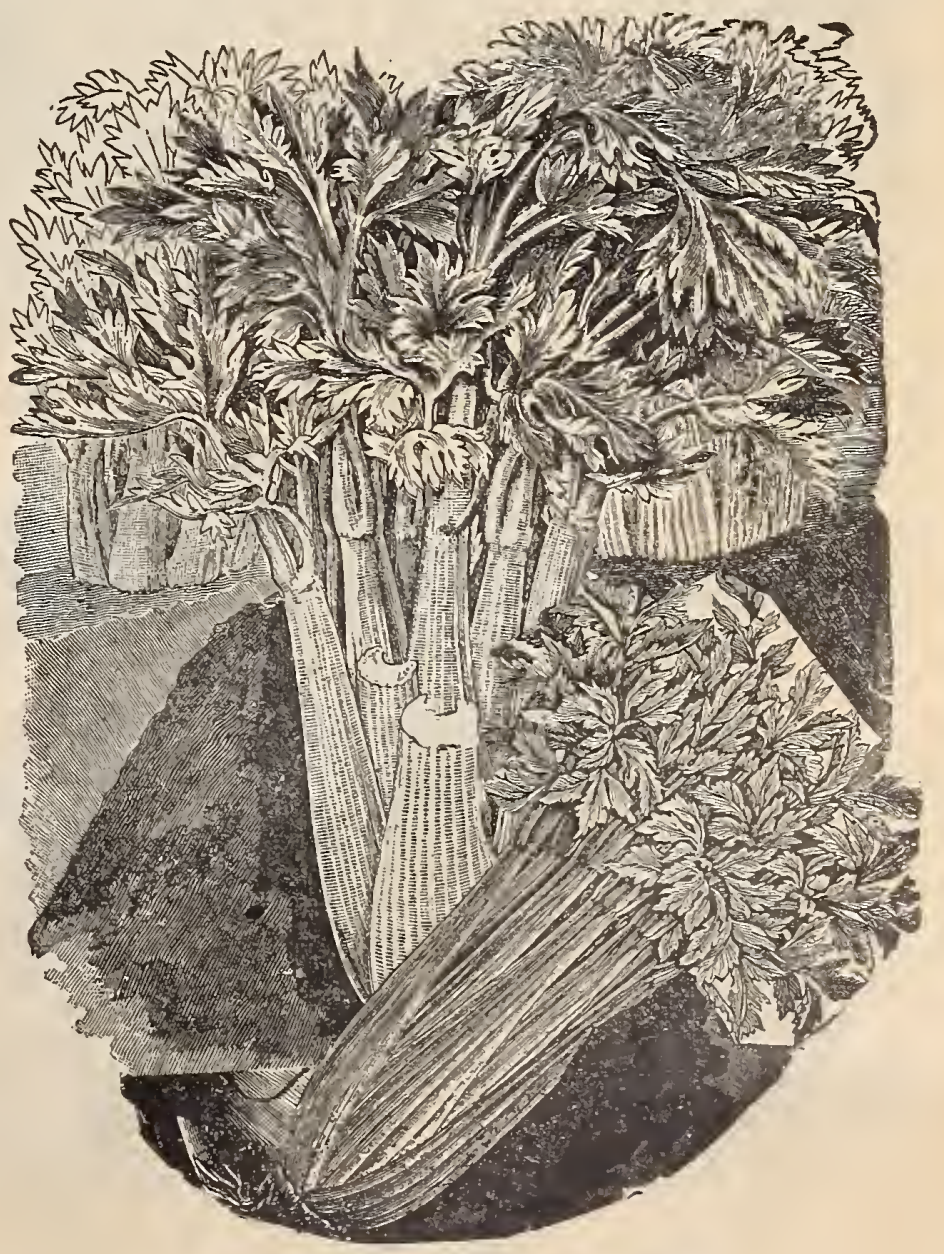

Celery Golden Self Blanching. 


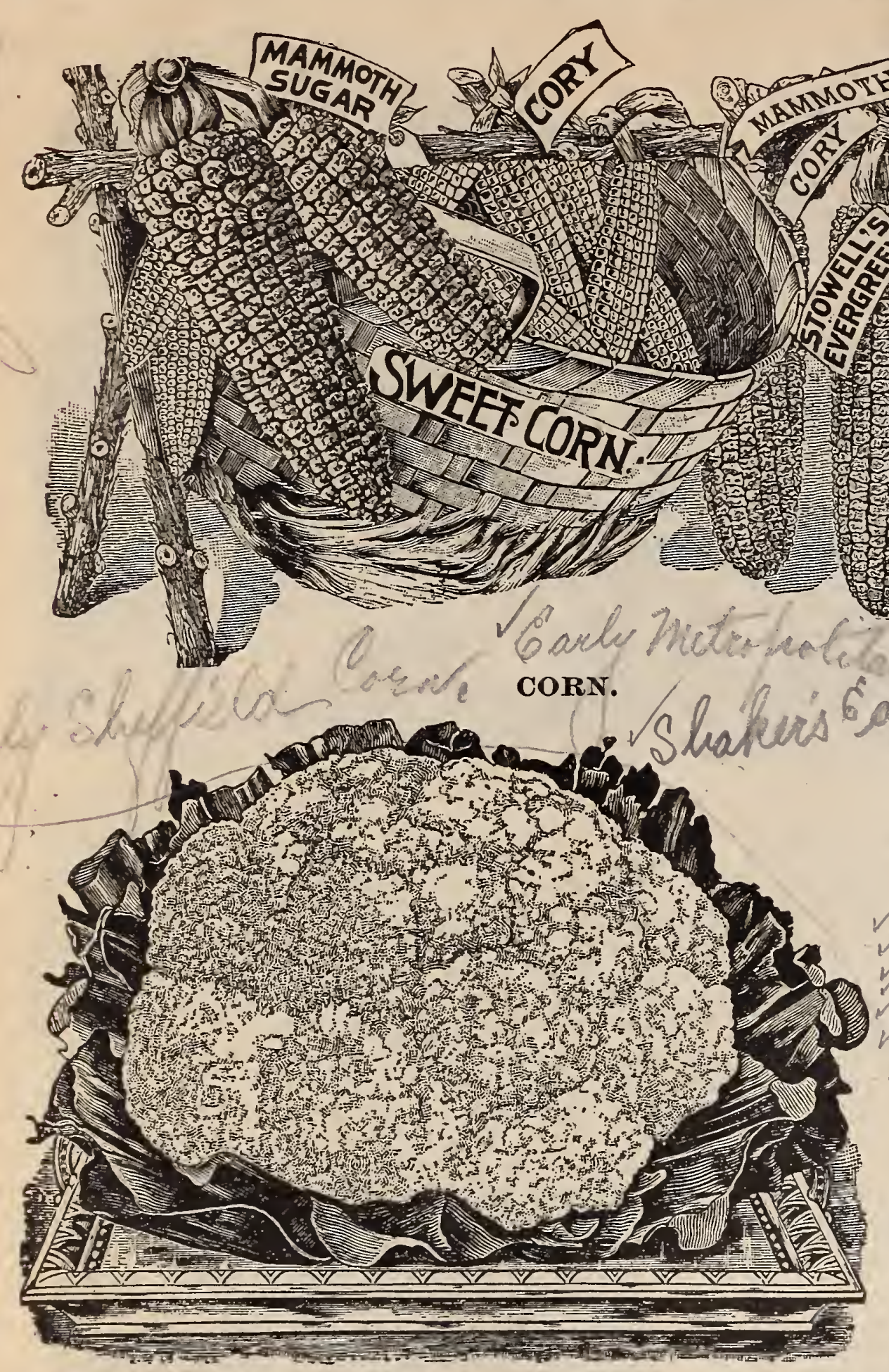

Cauliflower, Snowball

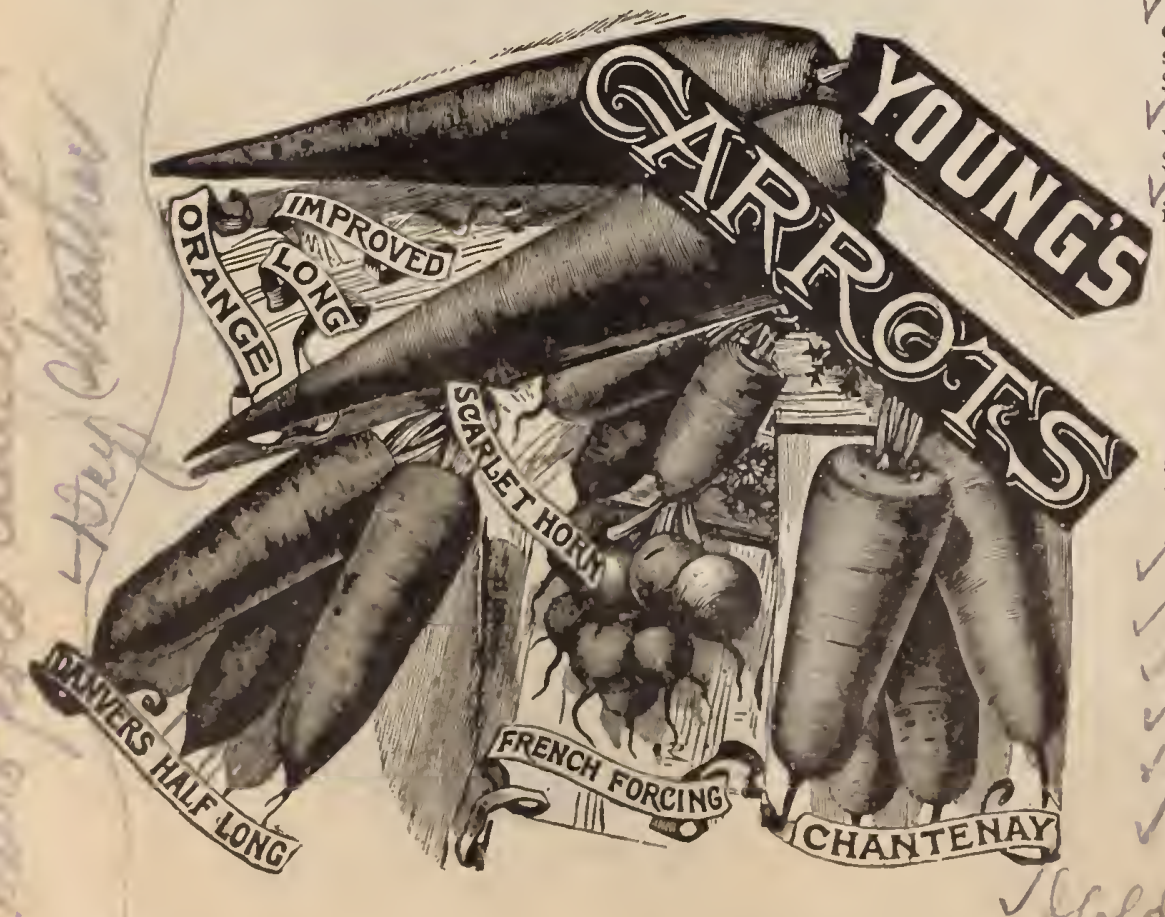

\section{CORN.}

Sweet or Sugar; quart for 200 hills, 8 to 10 quarts in hills for an acre.

All varieties of Sweet and Sugar Corn may be either sown in rows $4 / 9$ feet apart, and the seeds placed about inches apart in the rows, or planted in Thils at a distance of 3 or 4 feet each way. The taller the variety, or the richer the soil, the greater should be the distance apart. We make our first plantings in this vicinity about the frost of May, and or three weeks until the last week in July. WHITE COE-This new strain is as early as the original Cory. While the ears are of a larger size, the grains are placed more compactly. ariety of Corn retains its delicate tendern husk, which tends to keep the ears in the milk for several days longer than any other corn's EVERGREES-This is the best late Sweet Corn in every way, being large kernel, hardy and productive, sweet and tender. and remaining a long time in condition suitable for Cooking. OF ALL-This variety is ready for the table from three days to a week earlier than the Cory; of medium size, ears filled wit grains to the very tip. It may be planted quite closely on ac-

These prices include prepay charges on packages, pints and quarts. If purchasers wish to pay their own transit charges they may deduc $10 \mathrm{cts}$. per pint and $15 \mathrm{cts}$. per quart from the prices quoted.

\begin{tabular}{|c|c|c|c|c|c|c|}
\hline PRICES OF CORN. & Pkt & Pt. & Qt. & $4 / 2 \mathrm{Pk}$. & Pk. & Bu. \\
\hline & $10 \mathrm{c}$ & $20 c$ & $35 c$ & $5 c$ & & \\
\hline & $10 \mathrm{c}$ & $20 \mathrm{c}$ & $|35 c|$ & & & 20 \\
\hline , ㄱe & $\begin{array}{l}10 \mathrm{c} \\
10 \mathrm{c}\end{array}$ & $\begin{array}{l}20 \mathrm{c} \\
20 \mathrm{c}\end{array}$ & $\left|\begin{array}{|l}35 c \\
35 c\end{array}\right|$ & $\begin{array}{l}45 c \\
45 c\end{array}$ & $\begin{array}{l}75 c \\
75 c\end{array}$ & $\begin{array}{l}250 \\
250\end{array}$ \\
\hline & $10 \mathrm{c}$ & $20 \mathrm{c}$ & $35 c$ & $45 c$ & $75 c$ & 250 \\
\hline EXTRA EARLY ADAM & $10 \mathrm{c}$ & $20 \mathrm{c}$ & $35 \mathrm{c}$ & $45 c$ & $75 \mathrm{c}$ & \\
\hline
\end{tabular}

POP CORN.- WHITE PEARL-Per pkt., 10c; per CAULIFLOWER.

\section{One ounce for 1,000 plants.}

own in September or October and wintered the same as early Cabbage plants, or they may be sown in anuery or February, in a cool hot-bed. Its culture is simila for the of the Cabbage. The soil can to head they should be watered every other day, and the leaves gathered and pinned ogether over the heads to protect them from the sun and keep them white. The seed we offer is the finest procurable,

These prices include free delivery in the U. S. If party wishes to pay transit charges deduct $10 \mathrm{c}$ per pound from EARLY SNOWBALL-The earliest and best of all for forcing open ground culture. It is dwarf, with short outer leaves; always 1.00; oz. \$2.50. EXTRA EARLY DWA

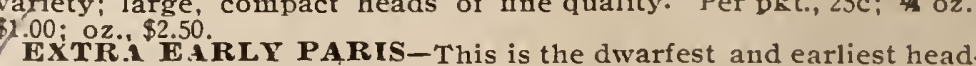
EXTR. WARLY PARIS-This is the dwarfest and earliest headC A RROT $\mathbf{S}$.

Dilled soil of a light, sandy nature, is the most suitable for Carrots a vold sewing on newly manured ground, which has a tenpart and half an inch deep. Thin out the young plants to 5 inches These prices include free delivery in the U. S. If party wishes to pay tran. it charges deduct 10c per pound from prices quoted.

\begin{tabular}{|c|c|c|c|c|}
\hline PRICES OF CARROTS. & \multicolumn{3}{|c|}{$\mathrm{Pkt} O \mathrm{Oz}$} & 1b. \\
\hline 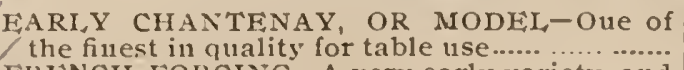 & $5 c$ & $10 \mathrm{c}$ & $30 \mathrm{c}$ & $\$ 100$ \\
\hline $\begin{array}{l}\text { FRENCH FORCING -A very early variety, and } \\
\text { one largely growu for forcing }\end{array}$ & & $10 c$ & $30 c$ & +20 \\
\hline MPROVED LONG ORANGE-The best deep & & & & \\
\hline $\begin{array}{l}\text { 1ate orange colored variety for general culture } \\
\text { EARI,Y SHORI HORN SCARLET-A very }\end{array}$ & $5 c$ & $10 \mathrm{c}$ & $30 \mathrm{c}$ & \\
\hline early standard variety & $5 c$ & $10 \mathrm{c}$ & $30 \mathrm{c}$ & 100 \\
\hline favorite variety and largely grown.................. & $5 c$ & $10 \mathrm{c}$ & $30 \mathrm{c}$ & 100 \\
\hline quality, very productive, of a ricli ora & & & $30 \mathrm{c}$ & 100 \\
\hline
\end{tabular}




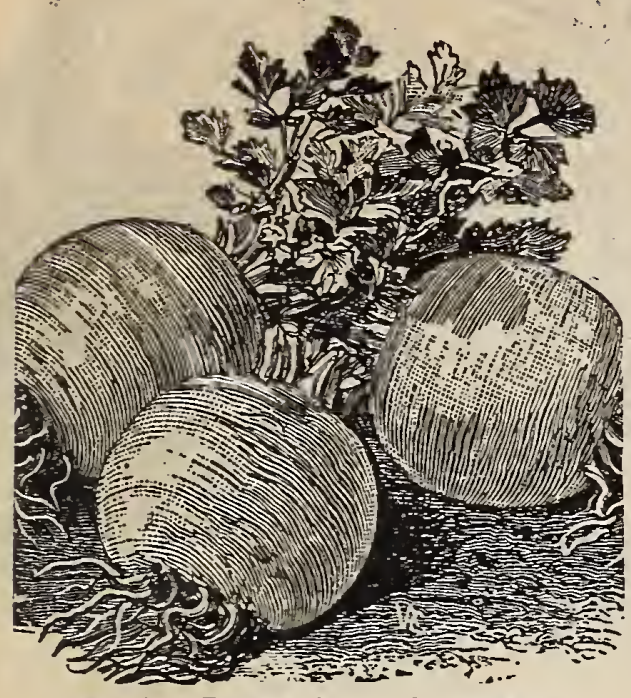

Celeriac Large Smooth Prague.

\section{ENDIVE.}

Endive is one of the best salads for fall and winter use. Sow for an early supply about the middle of April. The main sowings are made June and July, from which plantations are formed at one foot apart each way in August and September. When the plant has attained its full size, then the process of branching begins. This is affected by gathering up the leaves and tying them by their tips in a conical form.

GREEN CURLED-Leaves cut and curfled endures extreme heat; a favorite market sort. Pktét. 5c; oz., 15c; 14 1b. 40c; 1b., \$1.25.

$\sqrt{\text { WHITE CURLED-While the leaves are }}$ not so tender as the green curled, it is the most beautiful variety; the mid-rib is yellow and the leaves almost white (see cut). Per pkt., 5c; oz. $15 \mathrm{c} ; 1 / 4 \mathrm{lb}, 40 \mathrm{c} ; \mathrm{lb} . \$ 1.50$

\section{KOHL-RABI.}

This regetable is an intermediate between the Cabbage and the Turnip, and combines the flavor of both; the edible part is the turnip-shaped bulb. Sow in a light, rich soil, as early as possible, in drills 16 inches apart, and when well established thin to 6 inches apart in the row.

EARLY WHITE VIENNA-The earliest and best variety for table use; white bulb. Per pkt, 5c; 0z., 15c; 1/4 1b. 50c; 1b. \$1.75.

VEARLY PURPLE VIENNA-Differs from the above variety only in color, which is a bluish purple. Pkt., 5c; oz., 20c; 1/4 1b. 60c.; 1b. $\$ 2,00$.

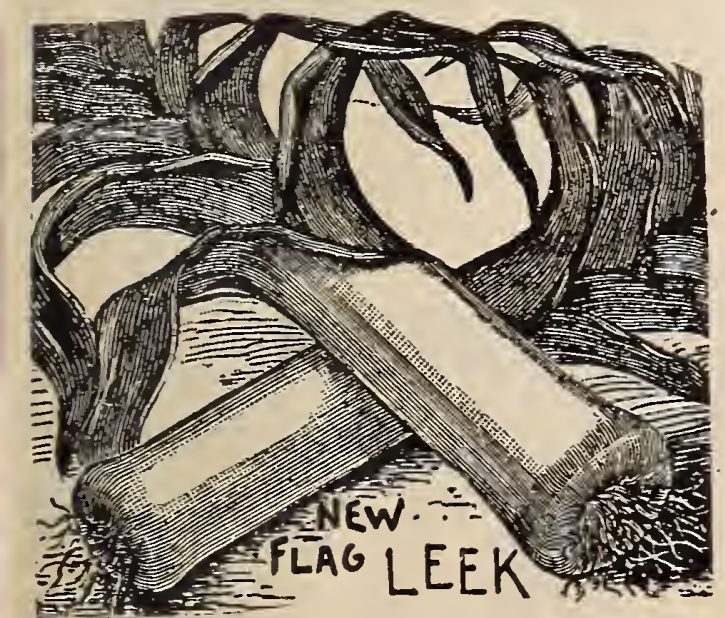

Leek.

\section{CELERIAC.}

The seed should be sown at the same time and given the same treatment as common celery. As the roots are the edible-portion of this vegetable, it is not necessary to earth it up or to handle it.

IARGE SMOOTH PRAGUE-An improved form of turnip-rooted celery producing large and smooth roots, which are almost round, with very few side roots; best variety (see cut). Per pkt., 5c; oz., 20c; 1/4 1b, 50c; ib., $\$ 1.25$.

\section{EGG PLANT.}

One Ounce frr 1,000 Plants.

The seed germinates slowly and should be started in strong heat to secure a rapid and continuous growth from the first, which is very important; when the plants are formed to rough leaves transplant to three or four inches apart, keep the bed very warm. shading from the direct rays of the sun; when the ground has become warm and all danger. not only from frost, but from cold nights, is passed, carefully transplant into very warm,
rich soil, setting the plants $2 \frac{1}{2}$ feet apart. NEW YORK IMPROVED LARGE PURPLE-This is the leading market variety evervwhere. Plant is robust, the leaves and stems being thickly set with spines, which are not found to any extent on the other varie-
ties (see cut). Per pkt., 10c; oz., 30c.; $1 / 2 \mathrm{lb}$. $85 \mathrm{c}$.

BLACK PEKIN-The fruit of this handsome variety is jet black, round in form and very variety is jet black, round in form and very
solid. It is quite early and a very superior vasolid. It is quite early and a very superior va-
riety. Per pkt., 10c; oz., 30c; $341 \mathrm{~b} ., 85 \mathrm{c}$.

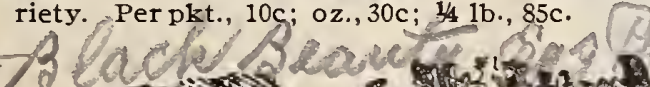

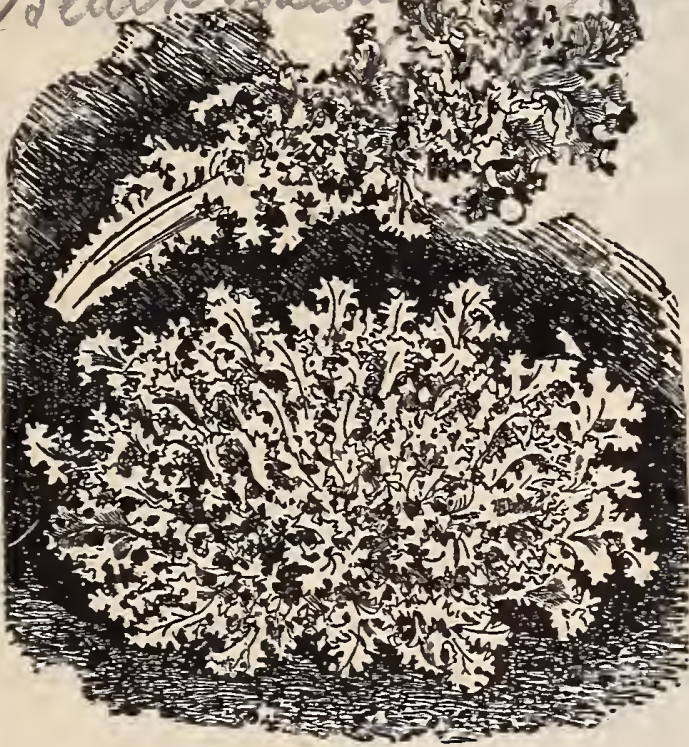

Endive, White Curled.

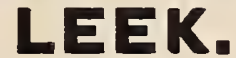

The Leek succeeds best in a light but well enriched soil. Sow as early in spring as practicable, in drilis 1 inch deep and 1 foot apart. When 6 or 8 inches high they may be transplanted in rows 10 inches apart each way as deep as possible, that the necks may be blanched.

BROAD SCOTCH or LON DOY FLAG - The favorite market variety; very large with broad leaves (see cut). Per pkt. $5 c$; oz., 15c; 1/4 1b., 35c; 1b. $\$ 1.00$

LARGE MUSSELBURGHVery large, with broad leaves. spreading like a fą; hardy and of excellent quality. Per pkt. 5c.: oz., 15c; 14 1b., 40c; 1b., \$1.25.

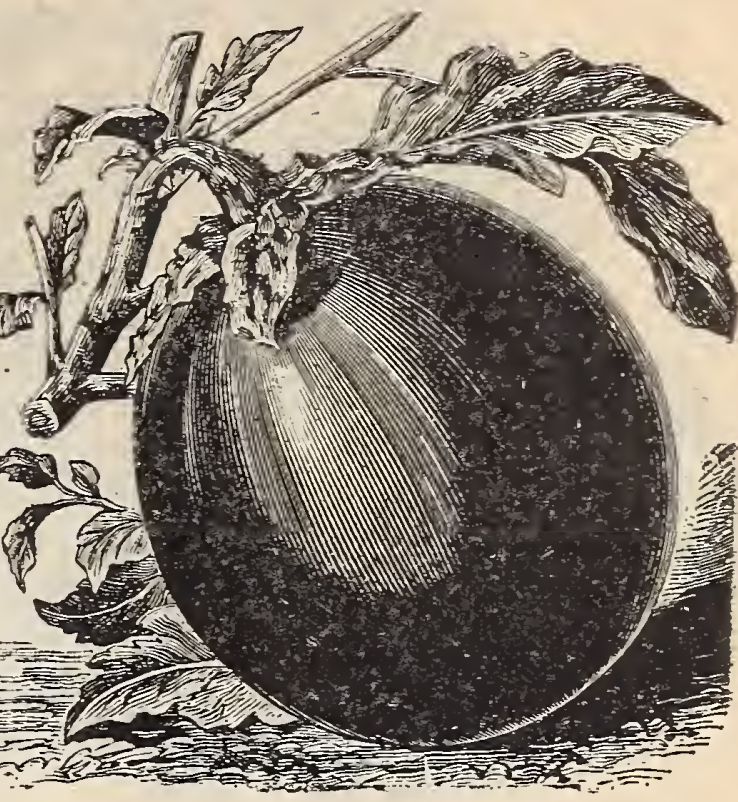

Egg Plant, Now York Improved.

\section{MUSTARD.}

1 oz. of seed will sow about 75 feet of drill.

A spring salad; can be sown as soon as the ground is free from frost. It grows rapidly, and must be cut when young. Sow in shallow drills 1. foot apart.

BROWN-Stronger and more pungent that the white. Per pkt., 5c; oz., 10c; 1/4 1b., 15c $1 \mathrm{~b}, 30 \mathrm{c}$.

WHITE-Best for salads and general use Per pkt., 5c; oz., 10c; 1/4 lb., 15c; 1b., 40c.

\section{KALE OR BOREQOLE.}

The. Kales are excellent greens for winter and spring use, and are improved by frost. Sow from May to June, covering it thin and evenly For early spring use sow in September, and pro tect over winter with a covering of straw or

DWARF CURLED GERMAN-Leaves yel lowish green, finely fringed. Sow in September for winter and early spring use:(see cut). Per pkt., 5c; oz., 15c; 1/4 1b., 25c; 1b, 65c.

CURL ED MOSBACH-The stalks attain a height of 2 feet, and will produce conținually throughout the season, the lower leaves being gathered before they become old. Per pkt., 5c oz., 15c; 14 lb., 40c; 1b., \$1.25.

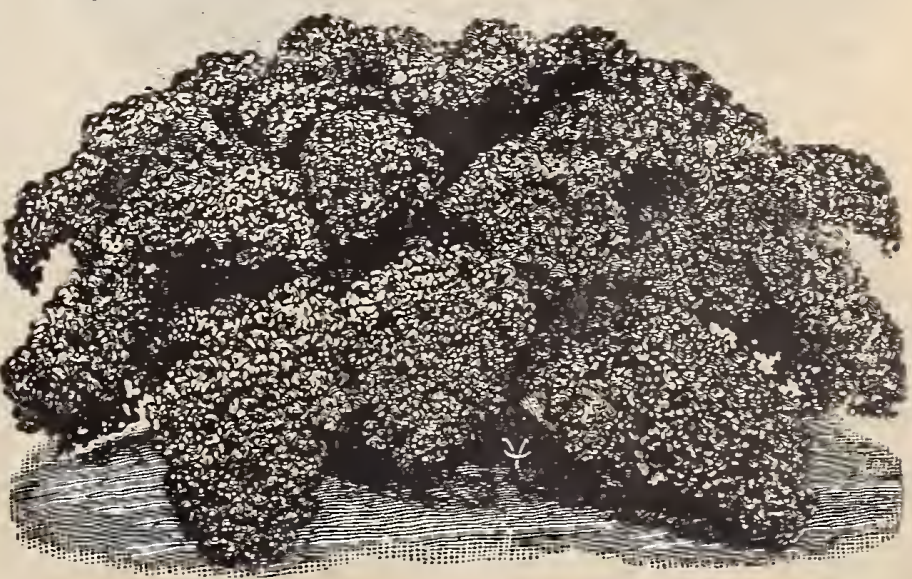

Ka]e Dwarf Carled German.

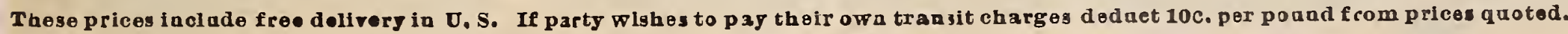



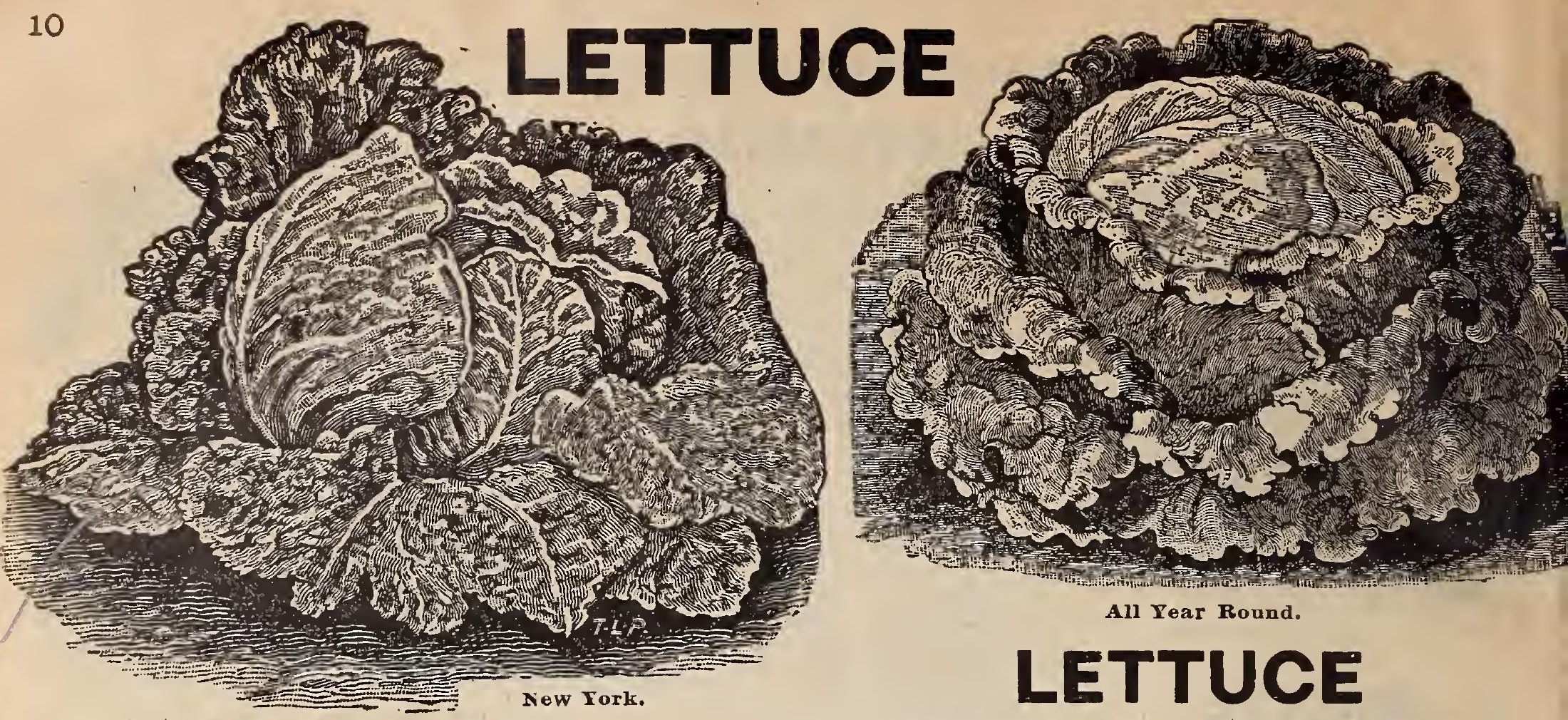

All Year Round.
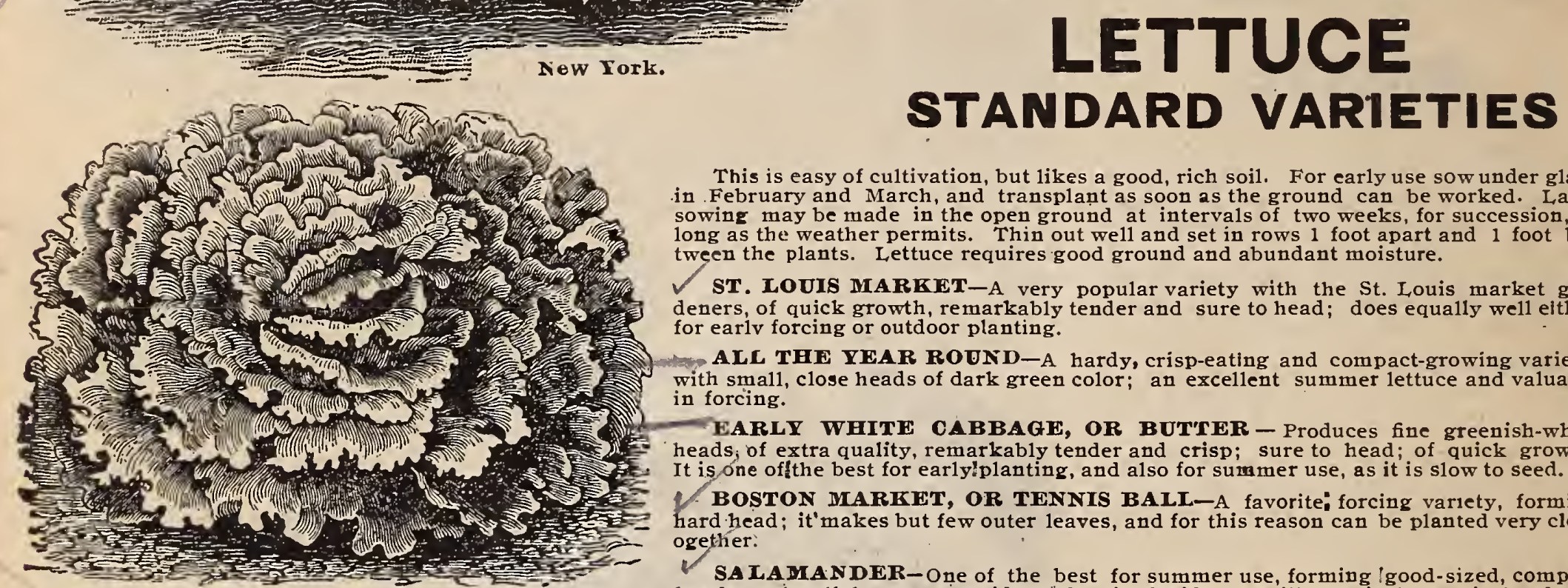

This is easy of cultivation, but likes a good, rich soil. For carly use sow under glass in . February and March, and transplant as soon as the ground can be worked. Later sowing may be made in the open ground at intervals of two weeks, for succession, as tween the plants. Lettuce requires good ground and abundant moisture.

ST. LOUIS MARKET-A very popular variety with the St. Louis market gardeners, of quick growth, remarkably tender and sure to head; does equally well either for earlv forcing or outdoor planting

ALC THE YEAR ROUND-A hardy, crisp-eating and compact-growing variety, with small, close heads of dark green color; an excellent summer lettuce and valuable heads, of extra quality, remarkably tender and crisp; sure to head; of quick growth.
It is one of the best for early!planting, and also for summer use, as it is slow to seed.

BOSTON MARKET, OR TENNIS BALL-A favorite; forcing variety, forming hard head; it makes but few outer leaves, and for this reason can be planted very close ogether:

SAIAMANDER-One of the best for summer use, forming lgood-sized, compact Balamander. heads ; color, light-green outside, and white inside. It will remain longer in head and stand a greatersamount of beat without burn!ng or running to seed than any other vari-

EARLY TERLED SIMPSON - Forms large, loose heads of thin and exceedngly tender golden-yellow, curly leaves; the best curly-leaved variety for planting outdoors. (See cut.)

NEW IORK-This variety grows to an unusual large size and solid head, with bu little tendency to run to seed. It is not a forcing variety, but is one of the best tor sum mer use. (See cut.)

These prices include free delivery in the $U$. S.

If party wishes to pay their own transit charges, deduct $10 \mathrm{cts}$. per pound from the prices quoted.

\begin{tabular}{|c|c|c|c|c|}
\hline PRICES OF LETTUCE. & Pkt. & $\mathrm{Oz}$. & $4-1 b$. & Lb. \\
\hline ick growing and hard heading variety. & & & & \\
\hline 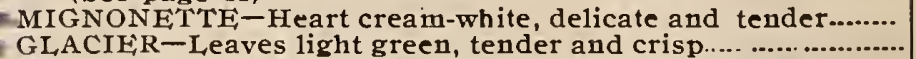 & $\begin{array}{r}5 c \\
10 c\end{array}$ & $10 \mathrm{c}$ & $\begin{array}{l}30 \mathrm{c} \\
40 \mathrm{c}\end{array}$ & $\begin{array}{rrr}1 & 00 \\
150 & 50\end{array}$ \\
\hline ONDERFUL_Very large; solid hea & $5 \mathrm{c}$ & $15 \mathrm{c}$ & $40 \mathrm{c}$ & 125 \\
\hline 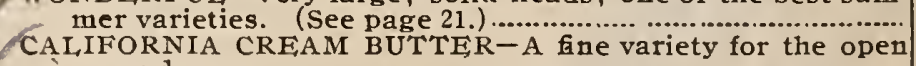 & $5 c$ & $15 \mathrm{c}$ & $40 \mathrm{c}$ & 125 \\
\hline $\begin{array}{l}\text { Ground } \\
\text { HILADELPHIA BUTTER-A hardy variety, producing solid, }\end{array}$ & $5 c$ & $15 \mathrm{c}$ & $40 \mathrm{c}$ & 12 \\
\hline $\begin{array}{l}\text { BOSTON MARKET, W. S. - Early forcing variety. } \\
\text { SALAMANDER, B. S. - Compact head, best for su } \\
\text { EARLY CURLED SIMPSON W S - Fine loose h }\end{array}$ & $\begin{array}{l}5 c \\
5 c \\
5 c \\
5 c\end{array}$ & $\begin{array}{l}10 c \\
10 c \\
10 c \\
10 c\end{array}$ & $\begin{array}{l}30 \mathrm{c} \\
30 \mathrm{c} \\
30 \mathrm{c} \\
30 \mathrm{c}\end{array}$ & $\begin{array}{lll}1 & 00 \\
1 & 00 \\
1 & 00 \\
1 & 00\end{array}$ \\
\hline $\begin{array}{l}\text { NEW YORK, W. S. - Large, solid heads; good summer sort } \\
\text { ALL, THE YEAR ROUND, OR BLACK SEEDED BUTTER, } \\
\text { W. S. (See cut.)-L, Orger heads; an excellent Summer }\end{array}$ & $\begin{array}{l}3 \mathrm{c} \\
5 \mathrm{c}\end{array}$ & $15 \mathrm{c}$ & $\begin{array}{ll}30 c \\
40 c\end{array}$ & 125 \\
\hline $\begin{array}{l}\text { EARLY CABBAGE, OR WHITE BUTTER, W. S. - Thick- } \\
\text { leaved a very hardy variety }\end{array}$ & $5 c$ & $10 \mathrm{c}$ & $30 c$ & 100 \\
\hline $\begin{array}{l}\text { GRE,FN FRINGED, OR CALIFORNIA CURLED-Ornamen- } \\
\text { ta1 in growth; desirable for garnishing }\end{array}$ & $5 c$ & $10 c$ & & \\
\hline $\begin{array}{l}\text { IMPROVED HANSON-L, Lrge heads, } \\
\text { ST. LOUIS MARKET-Solid, crisp and }\end{array}$ & $\begin{array}{l}5 c \\
5 c \\
5 c\end{array}$ & $\begin{array}{l}10 c \\
15 c \\
15 c\end{array}$ & $\begin{array}{l}30 \mathrm{c} \\
40 \mathrm{c} \\
30 \mathrm{c}\end{array}$ & $\begin{array}{lll}1 & 25 \\
1 & 00\end{array}$ \\
\hline $\begin{array}{l}\text { YLLIOW SEEDED BUTTER-Yellow heads } \\
\text { PARIS WHITE, CO.'S, OR ROMAINE-La }\end{array}$ & $5 c$ & $15 \mathrm{c}$ & $35 \mathrm{c}$ & \\
\hline $\begin{array}{l}\text { right growtlh } \\
\text { INSET, OK BLOND BEAUTY, W.S. - Large head; very }\end{array}$ & $5 c$ & $10 \mathrm{c}$ & $30 \mathrm{c}$ & \\
\hline & $5 c$ & $15 \mathrm{c}$ & $35 \mathrm{c}$ & 120 \\
\hline
\end{tabular}



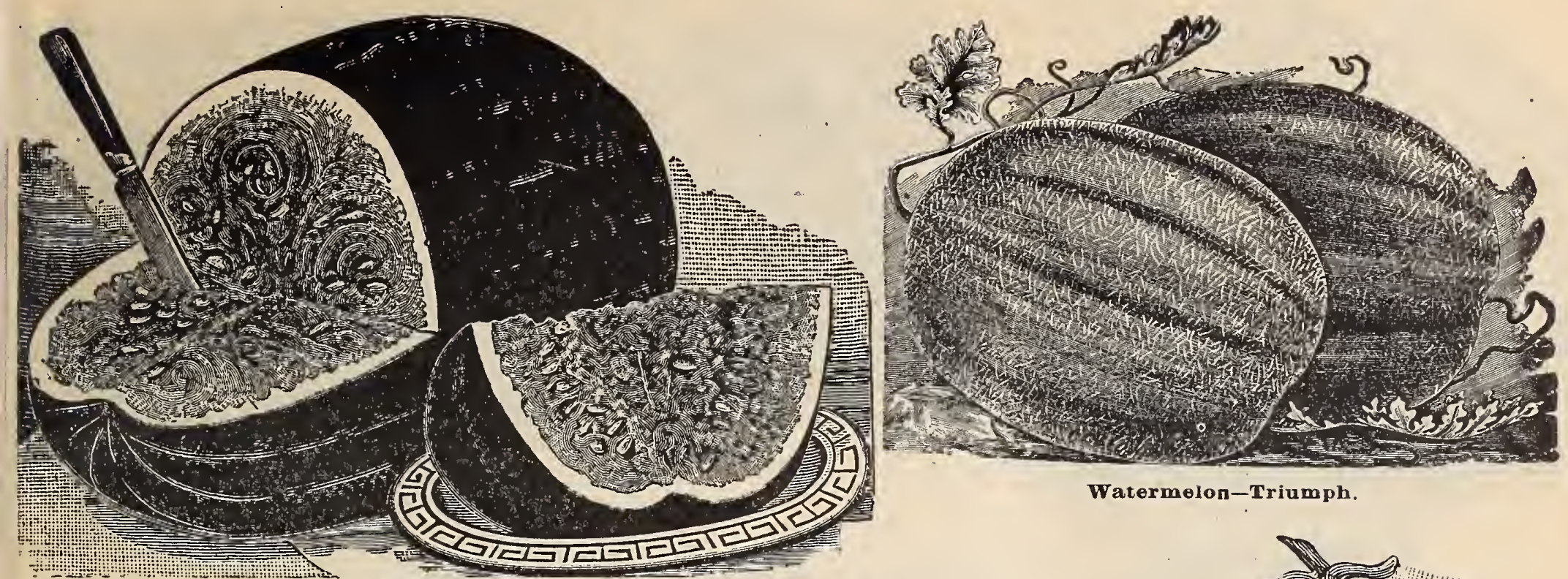

Watermelon-Triumph.

Gypsy $Q$ ueen.

\section{WATERMELON.}

COLE'S EARLY -The finest all-round Watermelon in existence. The fruits are not Iarge, seldom over 12 inches in length by 9 inches in diameter; very desirable for raising for liome use.

JUMBO JONES - In shape this melon is almost round; the skin is green with faint stripes of a lighter green f flesh bright red; excellent flavor.

$\checkmark$ HOOSIER KING-This melon grows long and of even diameter throughout the entire length. The flesh is red, very solid, sweet and lucious. (See cut)

SWHET HEART-An entirely distinct melon; good shipper, and very attractive in appearance; of a large size and shape; nearly globular in form. The flesh is a bright red, firm, solid and very tender, melting and sweet.

THE DIXIE-This watermelon possesses the rich delicious flavor of the old Mountain Swet; grows to a large size; oblong in form.

FLORIDA'S FAVORITE-This variety is one of the earliest melons in cultivation; oblong in shape; flesh, deep red.

PRICES OF WATERMEION.

BLACK DIAMOND-Large, round, skin dark green, tough; red flesh, fair quality................................................ ious flavor.

COLE'S EARLY-Extra early; thin skin; good flavor ................... JUMBO JONES-A favorite in the south; grows to a large size...... HOOSIER KING-Oblong and regular in size; very solid............ MAMMOTH IRONCLAD-Oblong; fine flavor; average 2 feet in IMPROVED LONG DIXIE-Favorite Souther $\mathrm{n}$ variety; very early

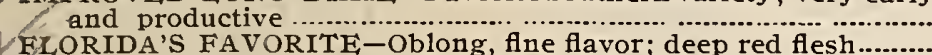
FI,ORIDA'S FAVORITE-Oblong, flne flavor; deep red flesh........
GYPSY QUEEN, OR RATTLESNAKE-Large; oblong and very CITRON COLORADO GREEN SEEDED-Best variety for preSWEET HEART-Oval form: red flesh, and very attractive in ap-

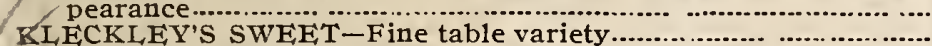
McIVER'S SUGAR-Extra sweet flavor; free from any string-

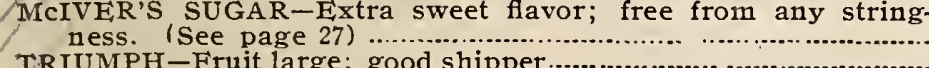
TRIUMPH-Fruit large; good shipper................
SANTIAGO-Very large; fruit of superior quality. (See page 27)

\begin{tabular}{|c|c|c|c|}
\hline Pkt. & Oz. & $1 / 41 b$ & $1 b$ \\
\hline & & & \\
$5 c$ & $10 c$ & $20 c$ & $60 c$ \\
$5 c$ & $10 c$ & $20 c$ & $60 c$ \\
$5 c$ & $10 c$ & $20 c$ & $60 c$ \\
$5 c$ & $10 c$ & $20 c$ & $60 c$ \\
$5 c$ & $10 c$ & $20 c$ & $60 c$ \\
$5 c$ & $10 c$ & $20 c$ & $60 c$ \\
$5 c$ & $10 c$ & $20 c$ & $60 c$ \\
$5 c$ & $10 c$ & $20 c$ & $60 c$ \\
$5 c$ & $10 c$ & $20 c$ & $60 c$ \\
$5 c$ & $10 c$ & $20 c$ & $60 c$ \\
$5 c$ & $10 c$ & $20 c$ & $60 c$ \\
$5 c$ & $10 c$ & $20 c$ & $6 c$ \\
$5 c$ & $10 c$ & $20 c$ & $60 c$ \\
$5 c$ & $10 c$ & $20 c$ & $60 c$ \\
$10 c$ & $20 c$ & $40 c$ & $\$ 135$
\end{tabular}

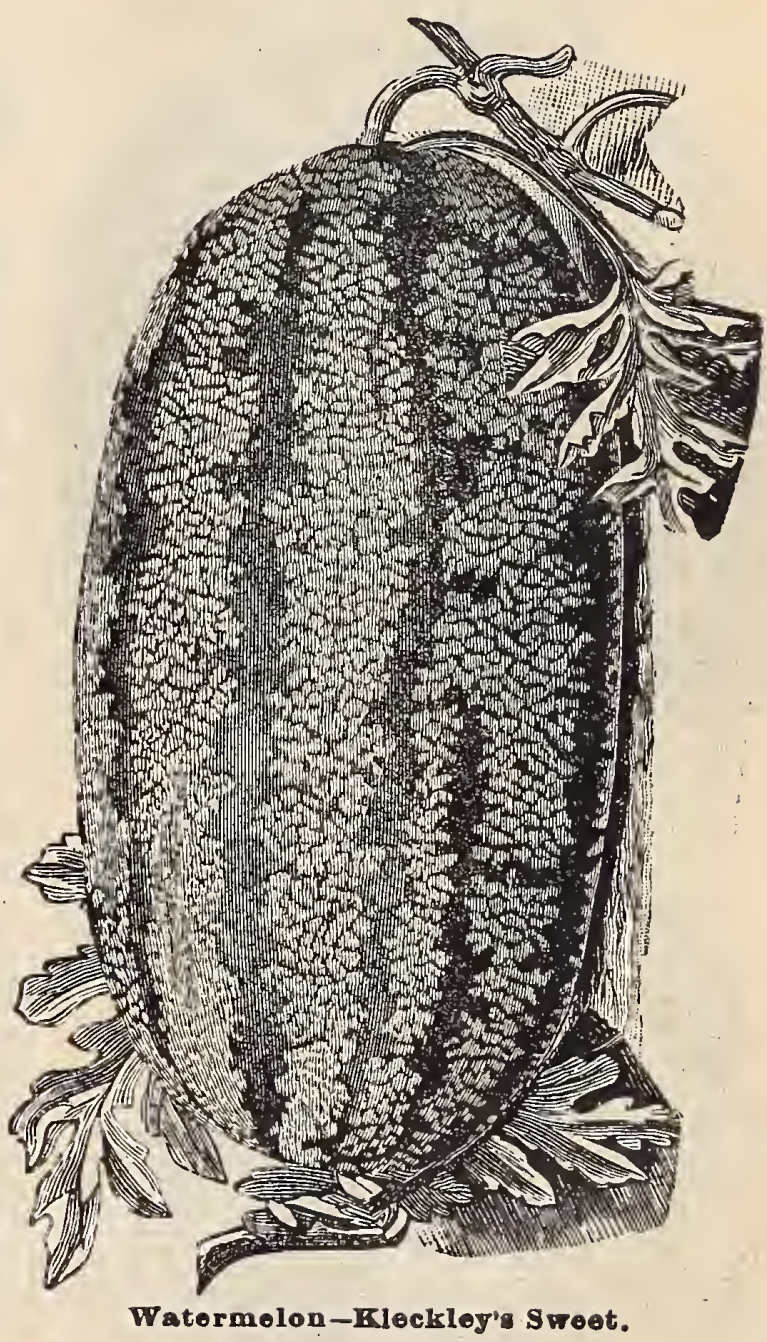

THESE PRICES INCLUDE FREE DELIVERY IN THE UNITED STATES.

IF PARTIES WISH TO PAY THEIR OWN TRANSIT CHARGES DEDUCT 10 CENTS FER POUND FROM THE PRICES QUOTED

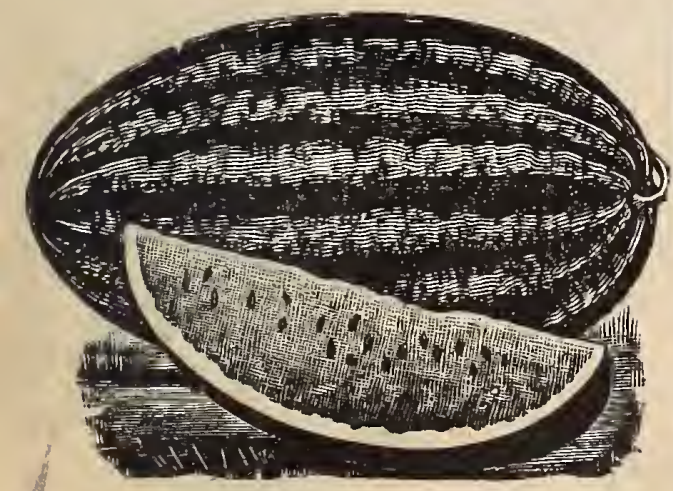

Mammoth Ironclad,

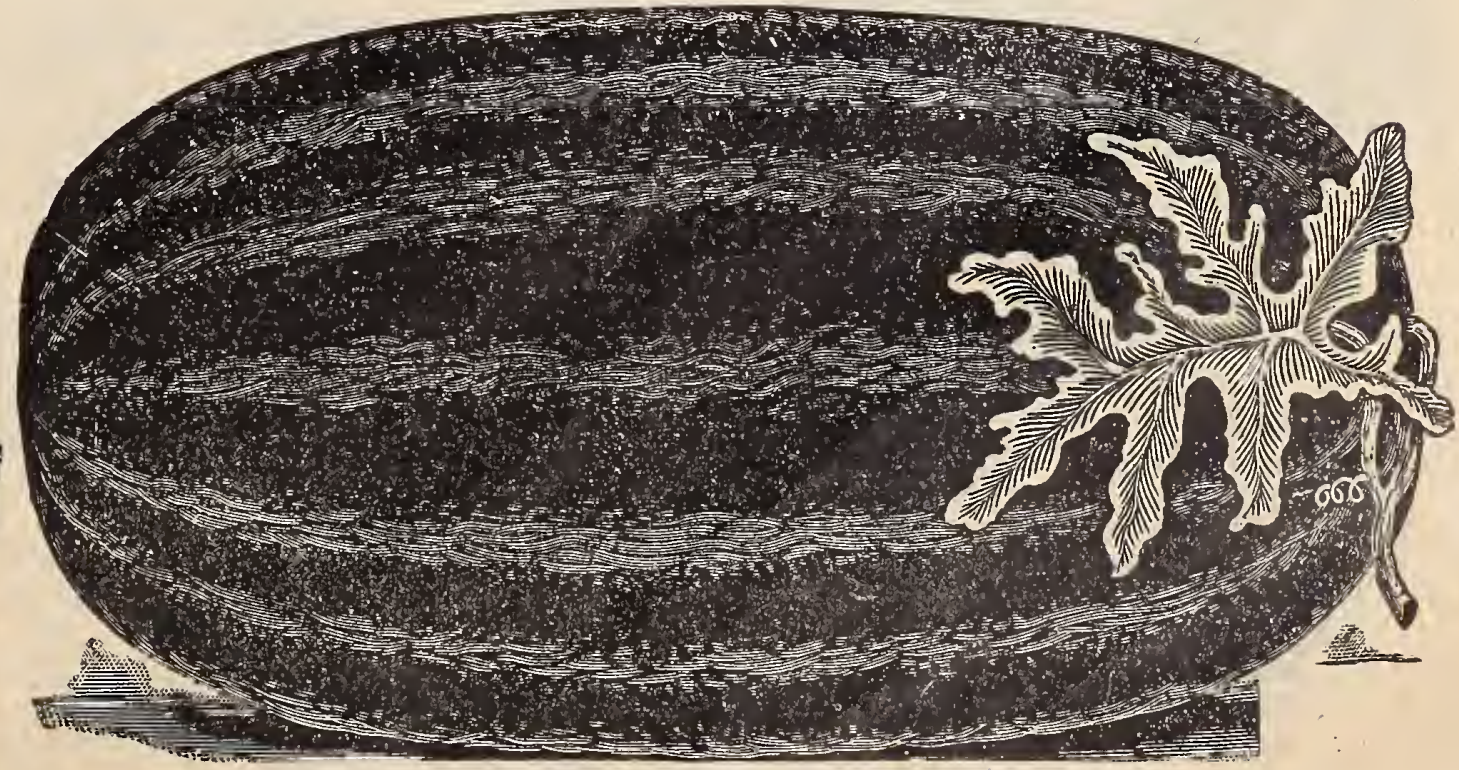

Hoosier King 


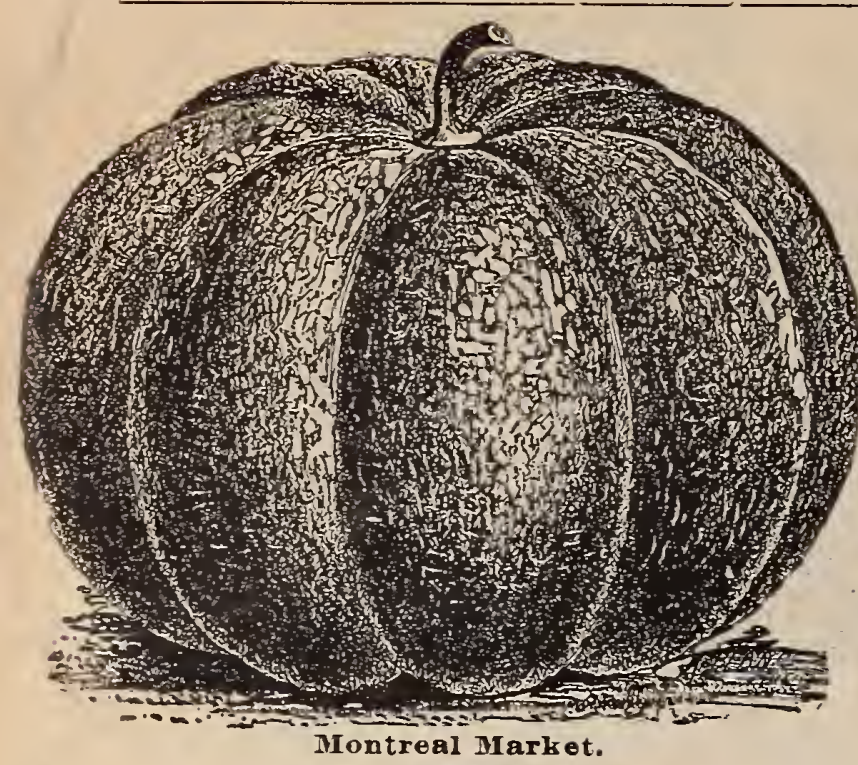

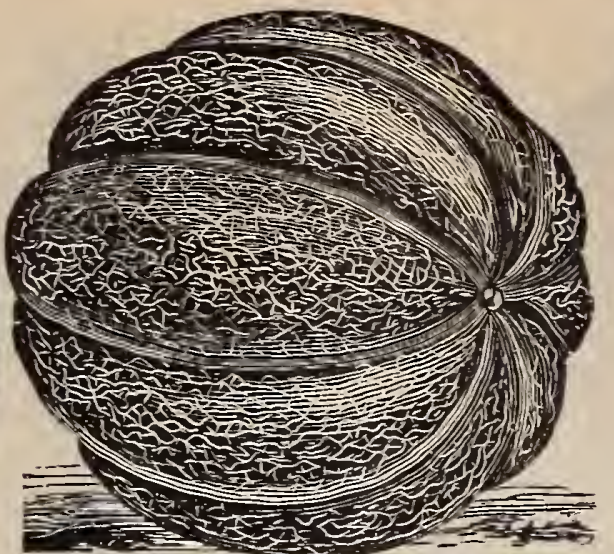

Muskmelon-Champion Market.

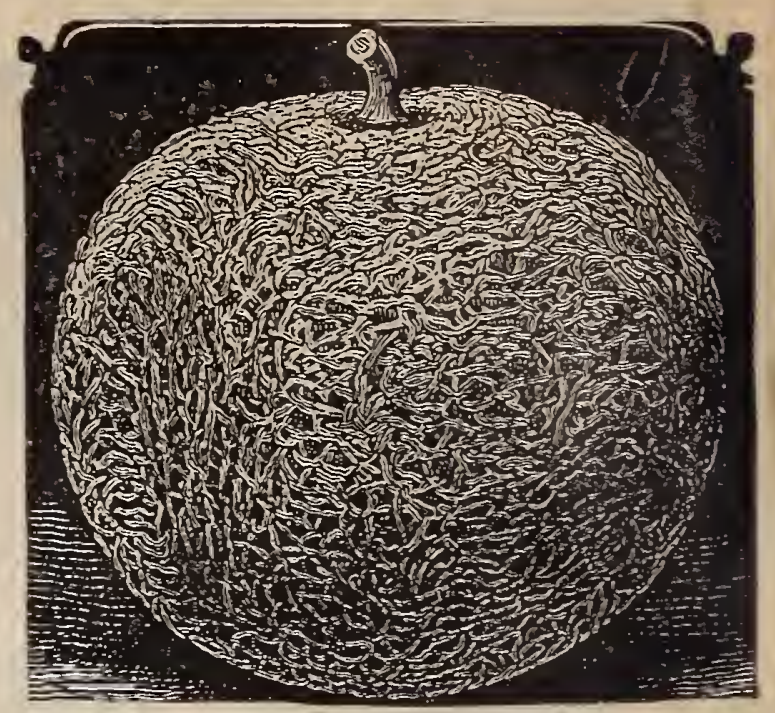

Muskmelon-Nutmeg.

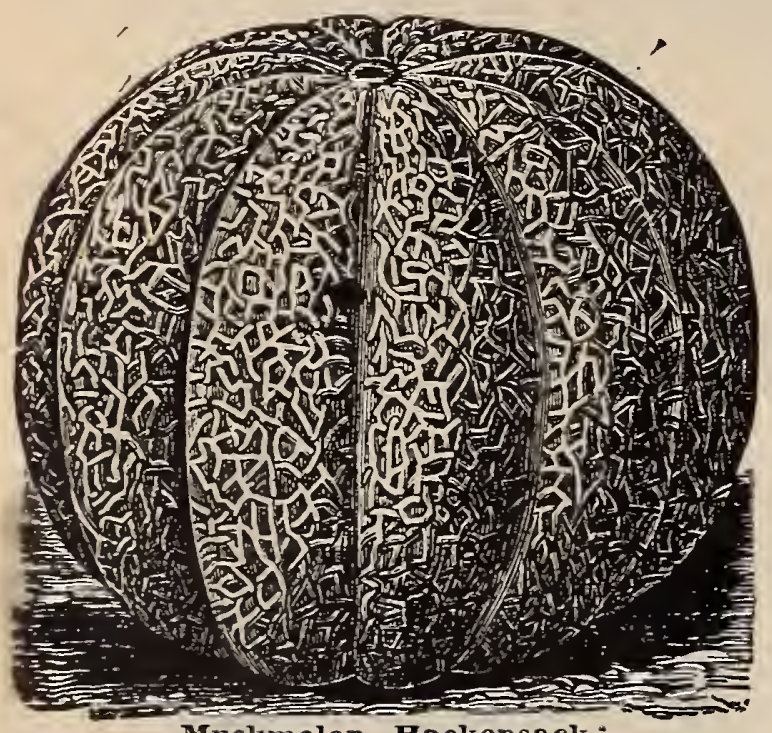

\section{MELON, MUSK OR CANTALOUPE}

One ounce for 60 hills; two to three pounds in hills to an acre.

The best soil for flue melons is a rich, warm, sandy loam. Make broad, shallow hills, 6 feet apart each way. Plant ten or flfteen seeds in each hill, after the ground has become warm. the ends of the long runners.

HACK ENSACK EXTRA EARLT-This variety is fully ten days earlier than the old Hackensack, which it resembles. It is one of the hardiest and most productive of all the varieties of Muskmelon.

JERSEY BELL_One of the earliest, best and most prolific small melons; grows very uniform in size and shape. Flesh, light green and of a very fine flavor.

MONTREAL MARKET-Fruit is nearly round, fastened at end; deep and regularly ribbed; skin, green; melting, and of a delicious flavor.

ROCKY FORD-This has become one of the most popular of small melons; the seed we offer has been grown from a carefully selected strain of netted Gem; nearly a perfect globe in shape, of a very uniform size, averaging about $1 \frac{1 / 9}{1 b s}$. each; they are thick meated, with a thin rina; skin, green; regular ribbed and heavily netted.

EMERALD GEM-This is the flnest flavor of all Muskmelons; very early ripening, and inequaled for home use or early market.

These prices include free delivery in the U.S.

If party wishes to pay their own transit charges, deduct 10 cents per pound from prices quoted.

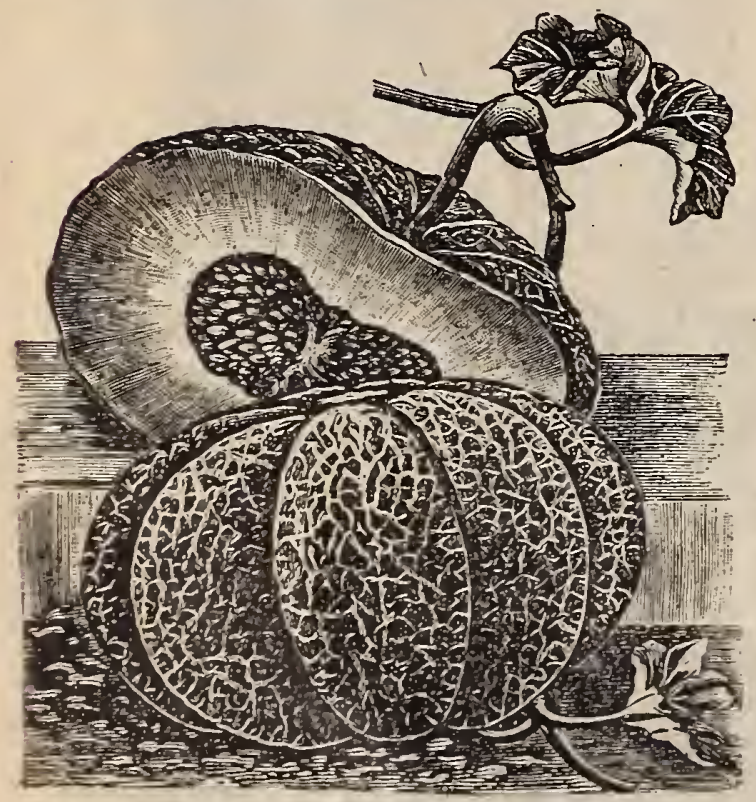

PRICES OF MUSKMIEIONS.

JENNY IIND-The best for family use (See page 26)

IONG ISLAND BEA UTY.-Fine quality, ripens very early -

CHAMPION MARKET-Splendid vari

BANOUET-Fruit small, rather late in ripening

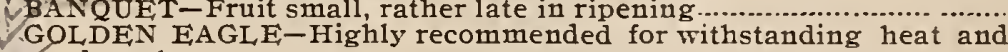

BAUL ROSE-One of the best melons for shipping (see page 26)

FMERALD GEM-Small, very productive, salmon-colored fles

EXTRA EARIY HACKENSACK-Early ripening (see cut

KOCY

JERSEY BELL-An extra early variety of good size ..................

MIILER'S CREAM OR OSAGE-Medium to large in size, oval shape

NUTMEG-An old standard variety, deep green skin (see cut)

\section{SWEET MEDICINAL HERBS}

No garden is complete without a few herbs for culinary or medicinal purposes, and care should be taken to harvest them properly. This should be done ona dry dây, just before they come into full bloom: then dried quickly and packed closely, entirely excluded from the air. Sow in the spring, in shallow drills, one foot apart, and when well up, thin out or transplant to a proper distauce apart.

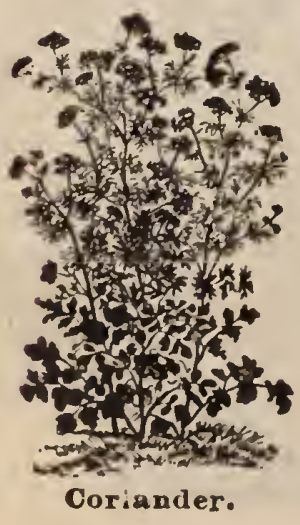

\section{PRICES OF HERBS.}

ANISE-Cultivated for garnishing and seasoning

BASII. (Sweet) - The leaves and tops are used for highly seasoned

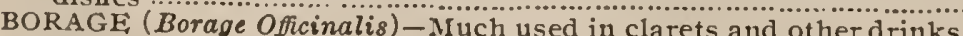
CORIANDER-Cultivated principally for its seeds, which are quite aromatic

DrLL-Leaves are used in soups and sauces, along with pickles...

FENNEL, - Leaves boiled enter into many fish sauces, and raw form a beautiful ornament

LAVENDER-A popular aromatic herb

ROSEMRAM (Sweet)-Seasoning

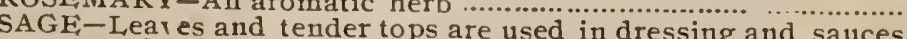

SAVORX (Summer)-For seasoning
THYME:(Broad-leaved)-For seaso

\begin{tabular}{|c|c|} 
Pkt. & Oz. \\
\hline $5 c$ & $10 c$ \\
$5 c$ & $15 c$ \\
$5 c$ & $15 c$ \\
$5 c$ & $10 c$ \\
$5 c$ & $10 c$ \\
$5 c$ & $10 c$ \\
$5 c$ & $15 c$ \\
$5 c$ & $15 c$ \\
$5 c$ & $25 c$ \\
$5 c$ & $15 c$ \\
$5 c$ & $20 c$ \\
$5 c$ & $20 c$ \\
\hline
\end{tabular}

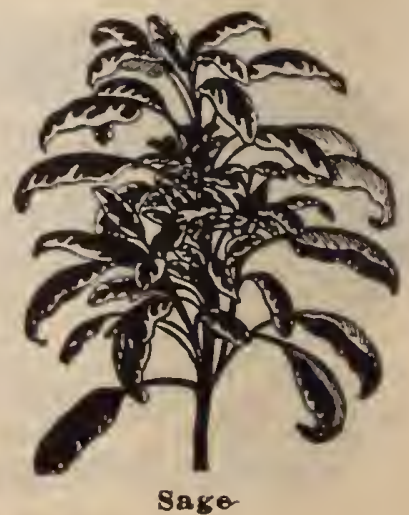



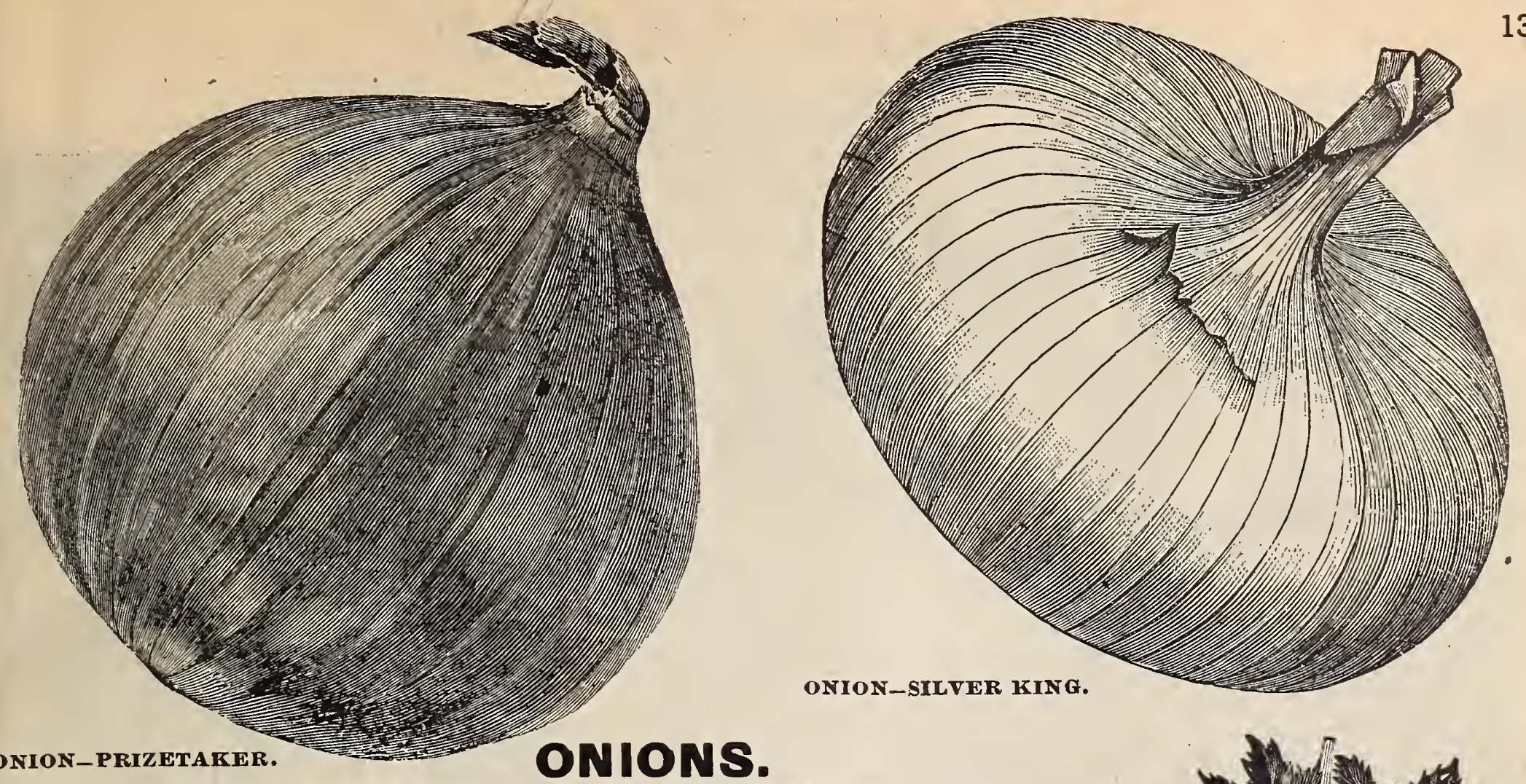

1 oz. fur 100 feet of Drill; 5 or 6 Pounds in Drill for an Acre.

The onion must have a clean and very rich soil. Use well rotted manure freely, and be sure and get th seed in as early as possible in the spring. Sow in shallow drills not less than one foot apart, and thin out whey young onions are about the size of quills. As onions grow on top of the ground, they may be allowed to pemain pretty thick.

is equally ke per, the best kind to sow for pickling.

PRIZ WTAKER-This onion grows to an immense size, measuring from 12 to 18 inches in circumfer ence, and under special cultivation they have been raised to weigh 4 to 5 pounds each. The outside skin is quite thin and of pale yellow color, while the interior is clear white. It is easily grown, medium early in maturing, and quite mild in flavor (see cut).

THESE PRICES Include freo delivery in the U.S. If party wishes to pay thelr own transit charges deduct 10c. per Ib. from prices quoted.

\begin{tabular}{|c|c|c|c|c|}
\hline PRICES OF ONIONS. & Pkt. & $\mathrm{O} z$. & 1/4 oz. & I.b. \\
\hline $\begin{array}{l}\text { WHITE PORTUGAL OR SIL VER SKIN_Best for family use, good } \\
\text { for pickling } \\
\text { RED WEATHERSIELD-Standard market, variety, productive, good }\end{array}$ & $\$ 0 \quad 05$ & $\$ 020$ & $\$ 060$ & $\$ 200$ \\
\hline 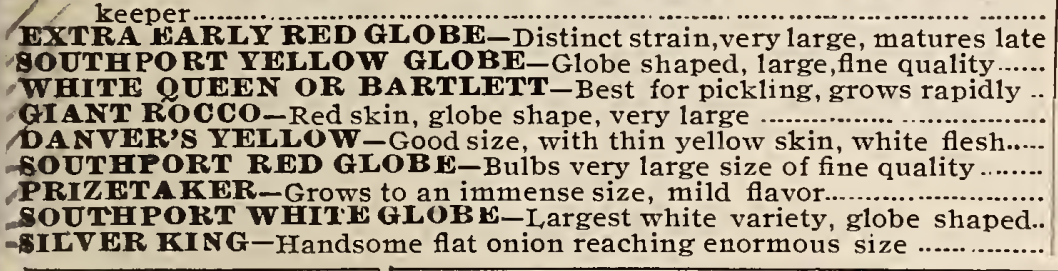 & $\begin{array}{l}05 \\
05 \\
05 \\
05 \\
05 \\
05 \\
05 \\
05 \\
05 \\
05\end{array}$ & $\begin{array}{l}10 \\
20 \\
20 \\
20 \\
20 \\
15 \\
15 \\
20 \\
20 \\
20\end{array}$ & $\begin{array}{l}35 \\
40 \\
40 \\
60 \\
40 \\
35 \\
40 \\
65 \\
60 \\
65\end{array}$ & $\begin{array}{ll}1 & 25 \\
1 & 25 \\
1 & 25 \\
2 & 00 \\
1 & 25 \\
1 & 00 \\
1 & 25 \\
2 & 00 \\
2 & 00 \\
2 & 00\end{array}$ \\
\hline
\end{tabular}

\section{ONION SETS.}

If ordered sent by express deduct 5 cents per pint and 10 cents per quart.

Onion sets should be planted early in spring in rows 12 inches apart. When raised from sets the Onions an be used in the green state in June, or they will mature in July; 1 quart to 40 feet of drill.

YELLOW ONION SETS WHITE ONION SETS

TOP SETS or BUTTONS.

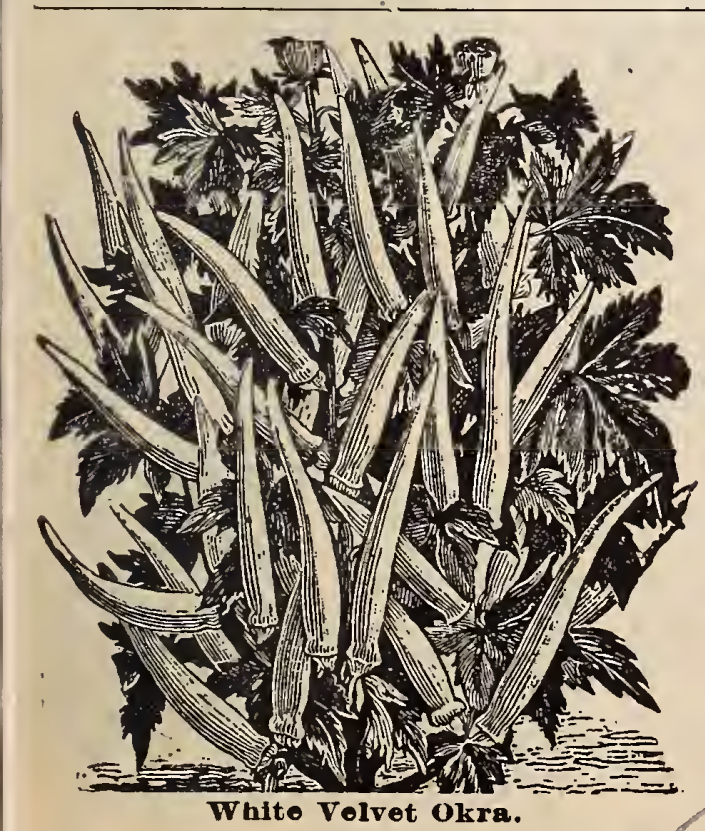

\section{OKRA OR GUMBO.}

WHITE VELVET-The pods are round and smooth and much larger, and not prickly to the touch; very productive (see cut). $1 \mathrm{~b}$ c. D'WARF GREEN PROLIFIC-Early and produc-

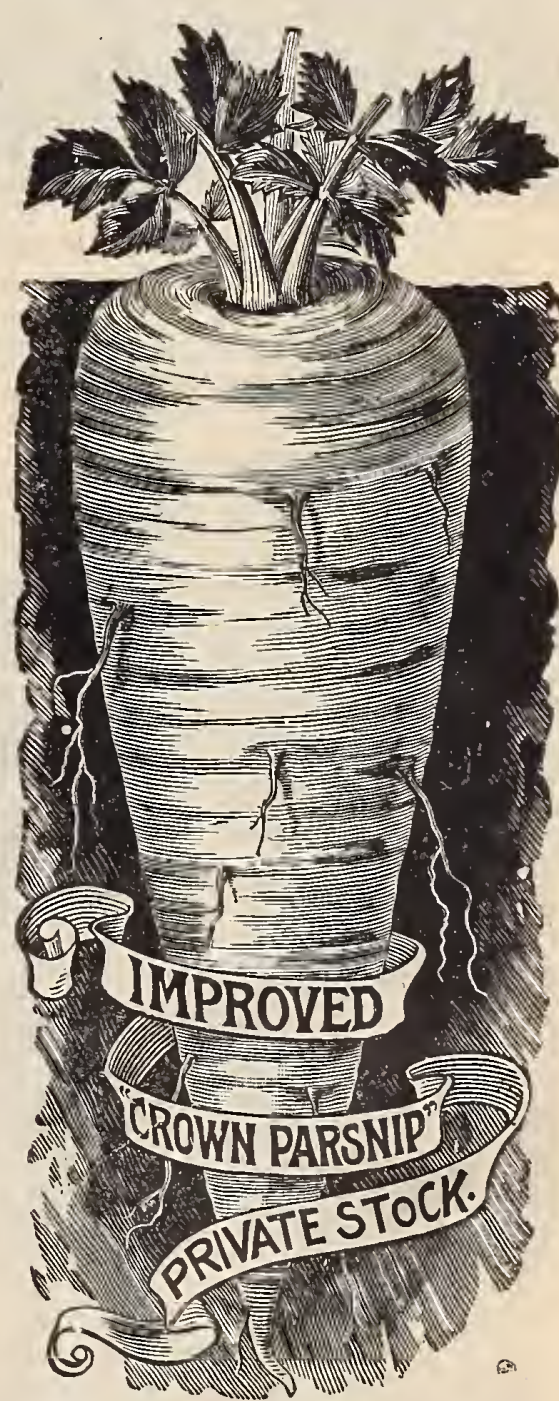

IIMPRONED LONG GREN N-Long, ribbed pods.

PARSNIP. -1 oz. for 200 feet of drill; 5 to 6 pounds in drils for an acre. Sow as early in the spring as the weather will permit in drills 15 inches apart, covering half an ingh deep. When well up, thin out to 5 or 6 inches apart in rows.

CROWN-(Abbott's Improved) Best for genéral use (see cut). Per pkt., 5c; oz., 10c: 14 ib. 20c; ib., 50c. GURNSEF-The roots do not grow so deeply as the Hollow Crown, and are larger in diameter at the shoulder, making them easier to dig. It is a very heavy cropper. Per pkt., 5c: oz., 10c; 1/4 1b. 20 c; 1 b. .50 .

\section{PUMPKIN.}

YLARGE TOURS OR MAMMOTHThis variety grows to an immense size. often weighing over 100 pounds (see cut) Per pkt., 5c; oz, 20c; $1 / 4$ 1b., 50c: 1 1b., $\$ 1.50$ vor the crookneck squash: yellow flesh, fine vor the crookneck squash: GOLDEN OBLONG-A splendid varjety for field culture; can be orown in the cornfield for winter use. Per pkt., 5c; oz., 10c: $141 \mathrm{~b} ., 25 r ; 1$ 1b., $75 c$.

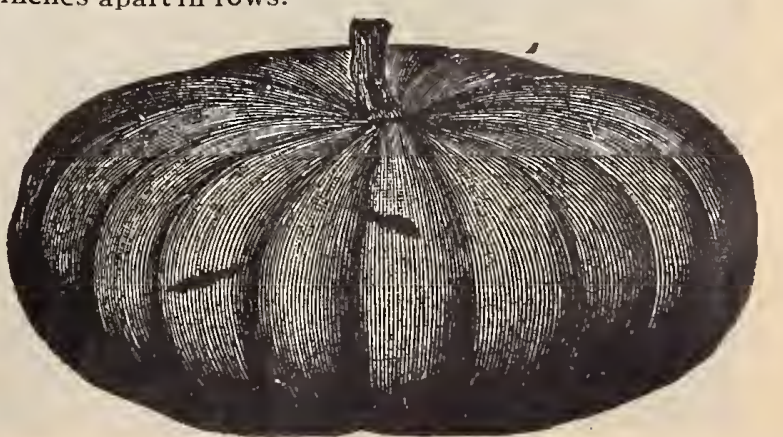

Purmpkin, Large Tours. 

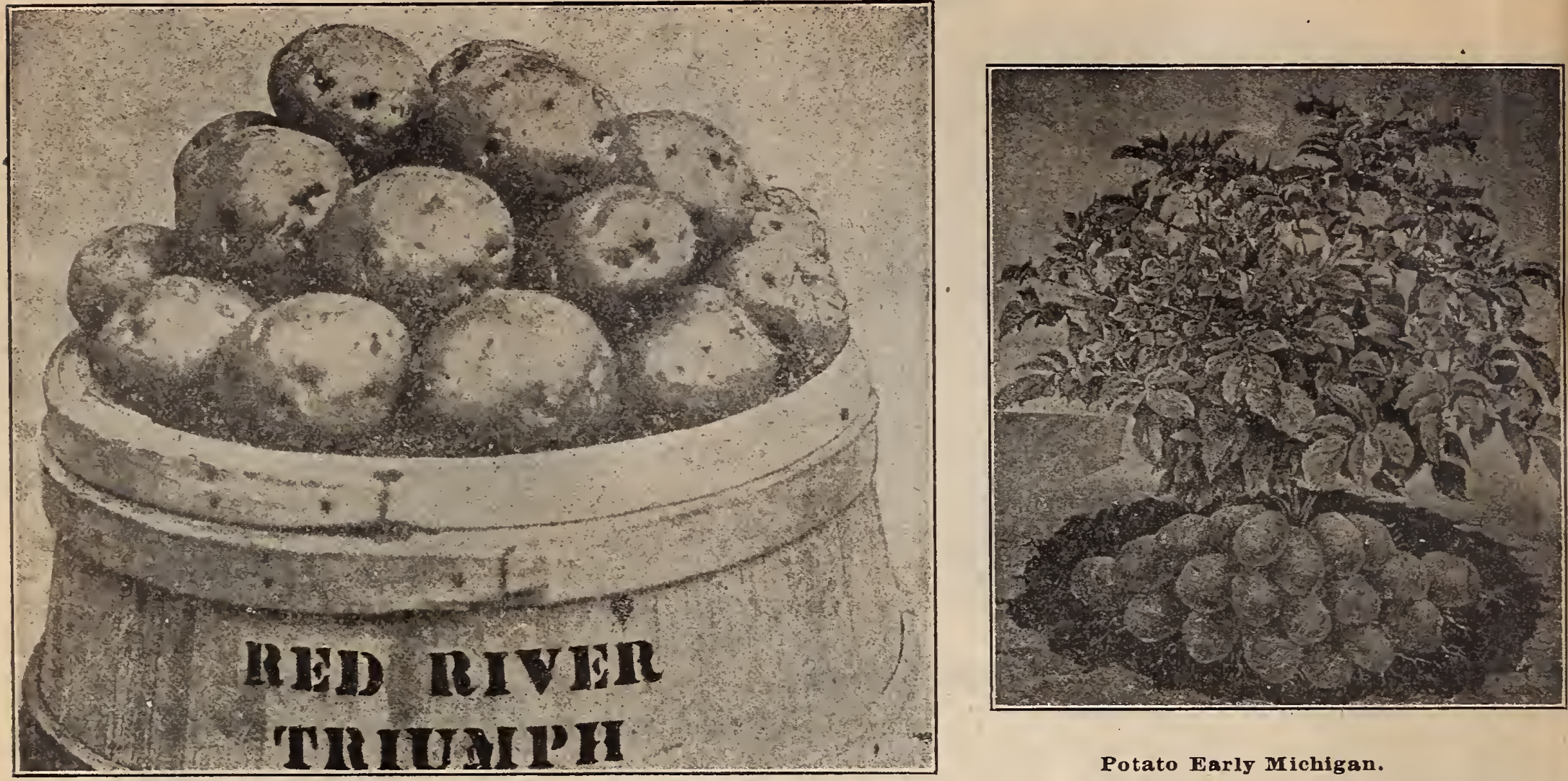

Potato Red River Triumph.

Potato Early Michigan.

\section{POTATOES.}

IN. DRILLS 3 FEET APART, 12 TO 14 BUSHELS TO THE ACRE. OUR POTATOES ARE ESPECIALLY RAISED FOR SEED PURPOSES, AND ARE NORTHERN GROWN. RED RIVER TRIUMPH-This is a very early potato. The Tubers are medium in size, of a bright red color; Popular in the south. Per Pk.

50c; Bu.. \$1.60. and appearance, being oblong and rather broad and thick, a most proliflc main crop sort: Per pt., $50 \mathrm{c}$ : bu, $\$ 1.40$.

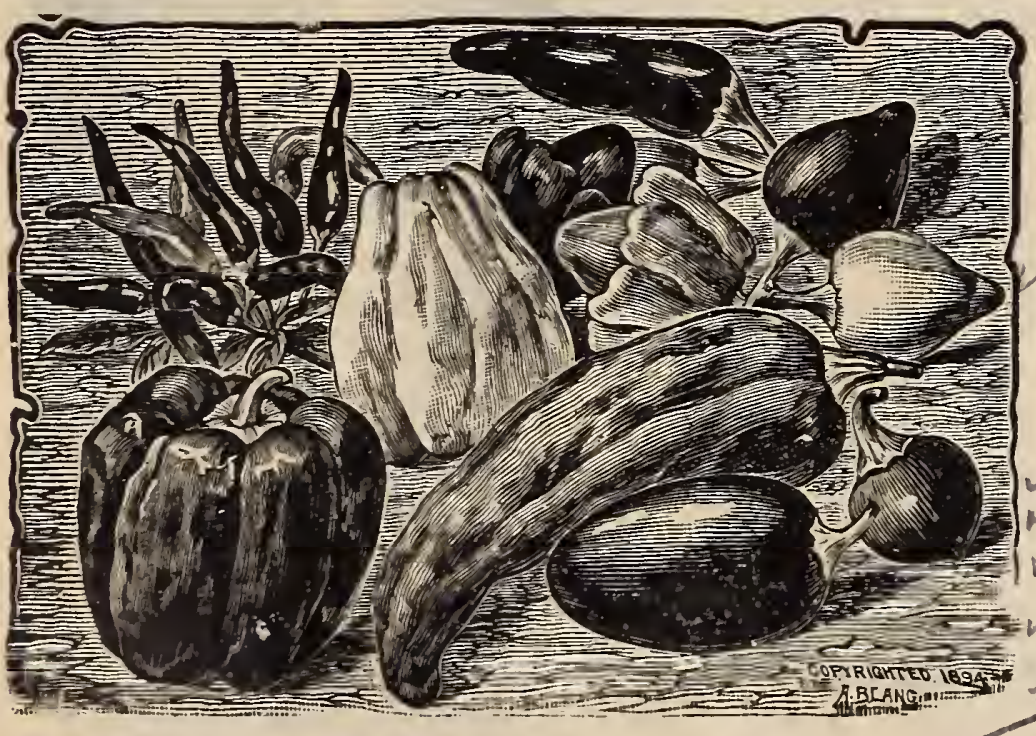

Assorted Varieties of Pepper.

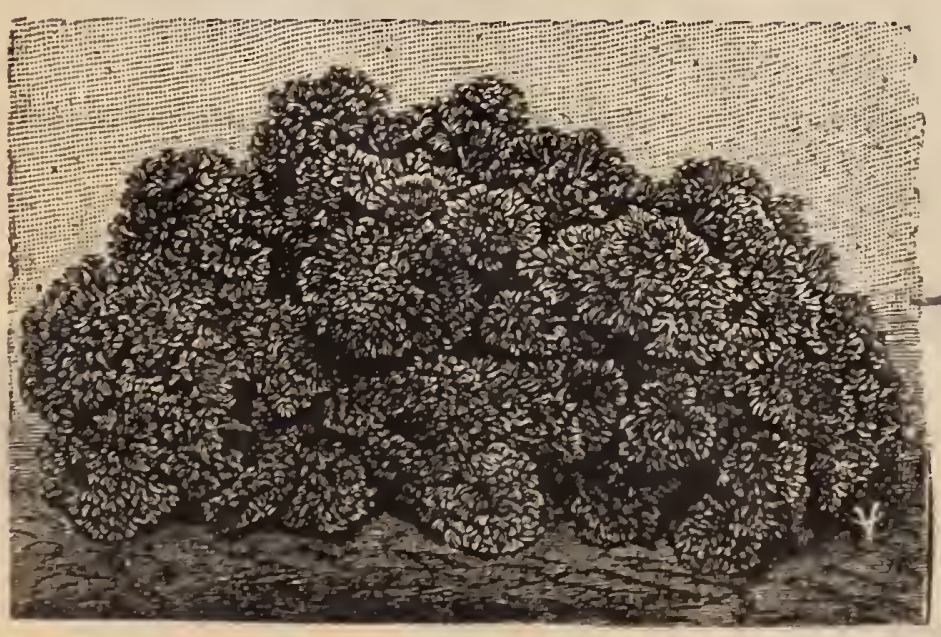

Parsiey.
PINGREE-The tubers grow in bunches very cluse together, of a good size, and of a light russet color; very few eyes, which are nearly flushed with the surface: in quality no others surpass it for a main crop.

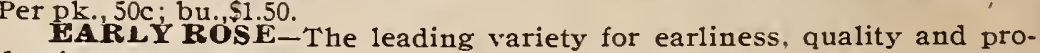
ductiveness. Per pk. 40c; bu sing voric

H R MICHIGA N-The Early Michigan is popular and deservedly so. It is fine looking, flesh and skin both pure white, well netted, of excellent quality, a strong grower. Per pk., 50c; bu., $\$ 1.50$. ith an exceedingly solid tuber, with an exceeding good table variety (see cut). Per pk., $40 \mathrm{c}$; bu., $\$ 1.40$.
RHD KIVER ARLY OHIO-Very productive, flne quality, an excellent keeper one of the best potatoes for home or market use. Per pk.,

\section{Clave \& PEPPER.}

Sow in hot-bed early in April and transplant to the open ground when the weather is favorable. They should be planted in warm mellow soil, in rows frost is past, They may also be sown in the open ground when danger of frost is past, and soil is warm and weather settled.

\begin{tabular}{|c|c|c|c|}
\hline PRICES OF PEPPER. & Pkt. & $\mathrm{Oz}$ & 44-1b. \\
\hline $\begin{array}{l}\text { RUBY KING-The fruits are bright ruby red } \ldots \ldots \ldots \ldots \ldots \\
\text { LARGE BELI, OR BULL, NOSE-Eiarly variety, rind thick }\end{array}$ & $5 c$ & $25 c$ & $75 c$ \\
\hline WEET MOUNTAIN OR MAMMOTH-Similar to Bell in & $5 c$ & $25 \mathrm{c}$ & \\
\hline 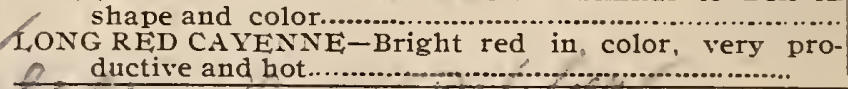 & $5 c$ & $25 c$ & \\
\hline
\end{tabular}

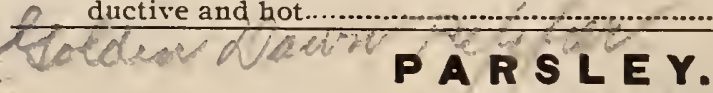

\section{$1 \mathrm{oz}$. for 150 feet of drill.}

Parsley succeeds best in a rich, mellow soil. As the seeds germinate very slowly, three or four weeks elapsing sometimes before it makes its appearance, it should be sown early in spring. Sow thickly in rows a foot a part and half an inch deep. For winter use, protect in a frame or light cellar.

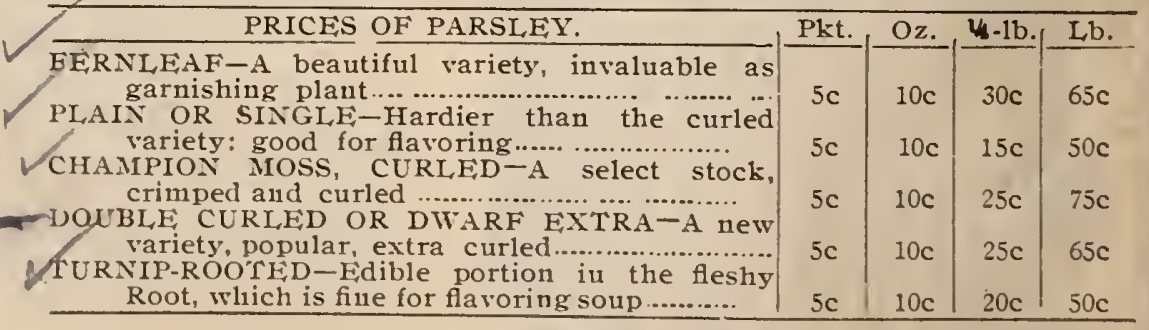

\section{R H U B A R B.}

Sow in A pril in drills 18 iuclies apart, and corer the seeds with fine soil in the plauts are strong euough, thin out to 6 soix 3 feet apart eacl way. pkt $5 \mathrm{c} ;$ oz., 15c; 1/4-1b-, 40c; 1b. 51.50 . the-1b., 50c; 1b., \$1.50. For Rhubarb Roots, soe page 100. 

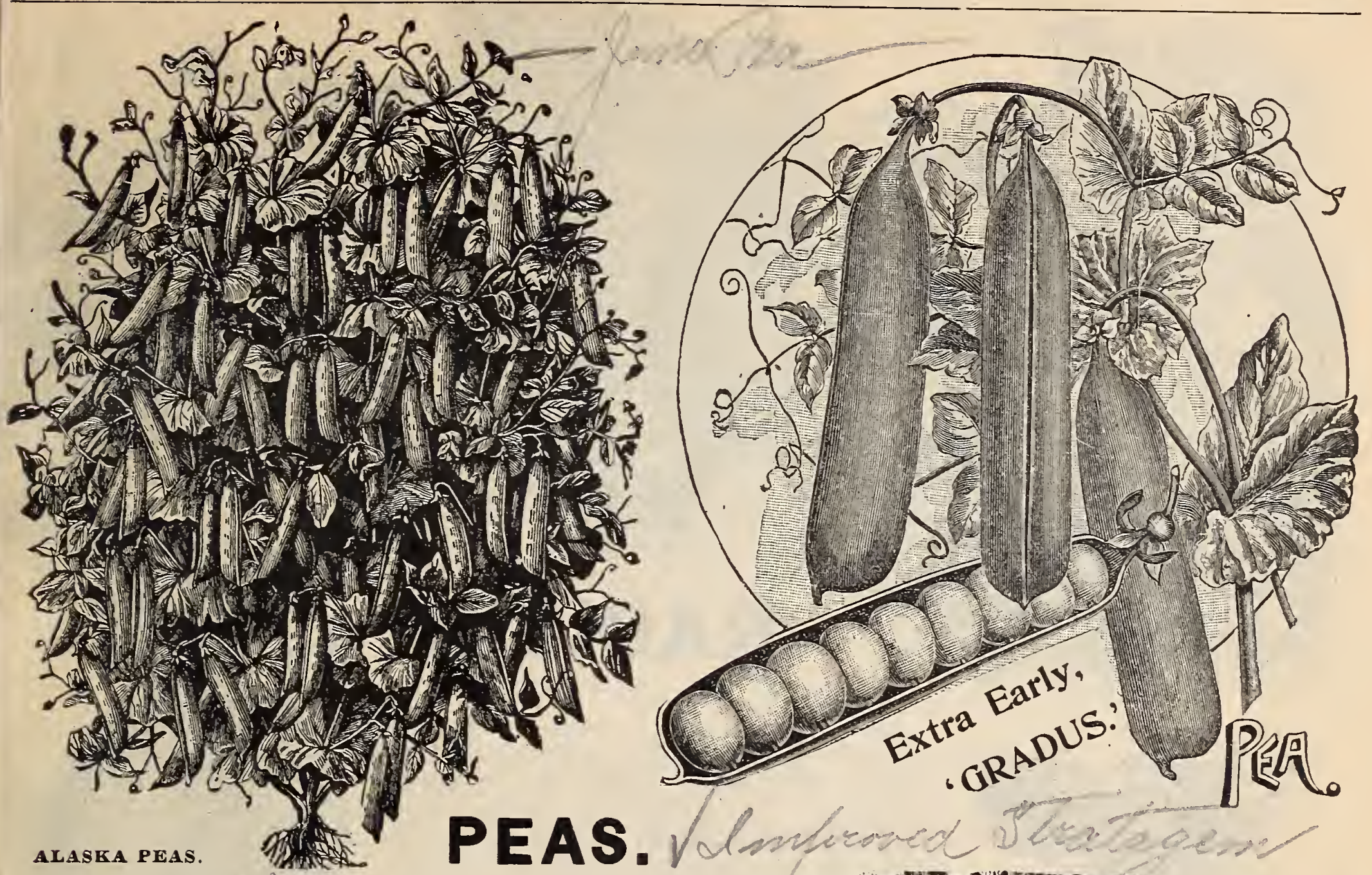

(Ons quart for 75 feet of drill; 2 to 3 bushels per acre in drills.)

Peas arrive at maturity earliest in a light, rich soil. For the early crop plant as early in the spring as the ground can be conveniently worked, and cover about 2 inches deep. The smaller varieties should be planted in rows, about 2 feet between the rows: the larger growing sorts somewhat further. Ground, to give best ing as it tends to run them more to vines than pods.

best as to earliness and u fiformity of ripening, maturing in forty days from sowing: very dwarf, growing Chly about 18 inches high. pea in cultivation; it grows about $24 / 9$ feet in height; the pods. which are a large as the Telephone, are produced

-Acknowledged to be the best of the late tall varieties. The pods are of the largest size, and of a very delicious, sweet flavor. Height. 5 feet. (See cut.)

peas, usually ready for table in 40 to 45 days from planting, only a yery few days peas, usually ready for table in 40 to 45 days from planting, only a very few days tution and wonderfully productive. This pea cannot be recommended too highly.

THESE Prices include prepay charges on packages, pints and quarts. If purchasers wish to pay their own transit charges they may deduct 10c per pint

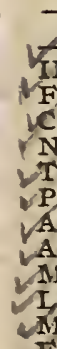

\section{PRICES OF PEAS.}$$
\text { IMPROVED STRATAGEM........ }
$$

TRST AND BES

CHAMPION OF ENGLAND......................

TELEPHONE

HITADEPHI EXTRA.......

AMERICA

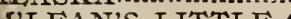

ARGE WHITE MARROWF AT

TE,

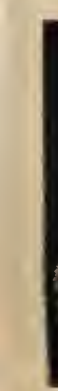

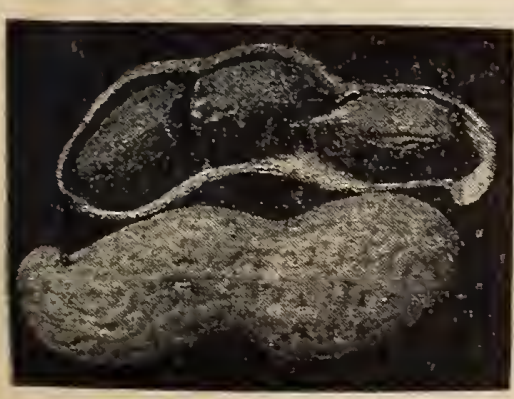

PeANuts.

\begin{tabular}{|c|c|c|c|c|c|}
\hline Pkt. & Pt. & Qt. & $1 / 2 \mathrm{Pk}$. & Pk. & Bu. \\
\hline $10 \mathrm{c}$ & $25 c$ & $45 c$ & $90 c$ & $\$ 150$ & $\$ 575$ \\
\hline $10 \mathrm{c}$ & & $45 c$ & & & \\
\hline $10 \mathrm{c}$ & $20 \mathrm{c}$ & $45 \mathrm{c}$ & $60 \mathrm{c}$ & 100 & 350 \\
\hline $10 \mathrm{c}$ & $20 c$ & $45 c$ & $90 c$ & 150 & 625 \\
\hline $10 c$ & $20 c$ & $45 c$ & $90 c$ & 150 & 500 \\
\hline $10 c$ & $20 c$ & $45 c$ & $75 c$ & $\begin{array}{ll}125 \\
7\end{array}$ & 450 \\
\hline $10 \mathrm{c}$ & $20 \mathrm{c}$ & $45 c$ & $90 \mathrm{c}$ & $\begin{array}{lll}1 & 60\end{array}$ & $\begin{array}{lll}600 \\
-0\end{array}$ \\
\hline $10 \mathrm{c}$ & $20 \mathrm{c}$ & $45 c$ & $90 \mathrm{c}$ & 150 & 550 \\
\hline $10 \mathrm{c}$ & $20 c$ & $\begin{array}{l}43 c \\
45 c\end{array}$ & $50 \mathrm{c}$ & $\begin{array}{l}140 \\
\end{array}$ & $\begin{array}{l}5 \\
3 \\
3\end{array}$ \\
\hline $10 \mathrm{c}$ & $20 \mathrm{c}$ & $45 c$ & $9 \mathrm{c}$ & & 600 \\
\hline $10 \mathrm{c}$ & $25 \mathrm{c}$ & $45 \mathrm{c}$ & 150 & 275 & 1000 \\
\hline
\end{tabular}

PEANUTS.

The Peanut thrives and produces best on a light, sandy, tolerably fertile soil. April is a suitable time for planting.

They produce from twenty-five to seventy-five bushels per acre according to the soil and culture. Per 1b. 20c.? postpaid. If ordered by express deduct 10c. pet pound.

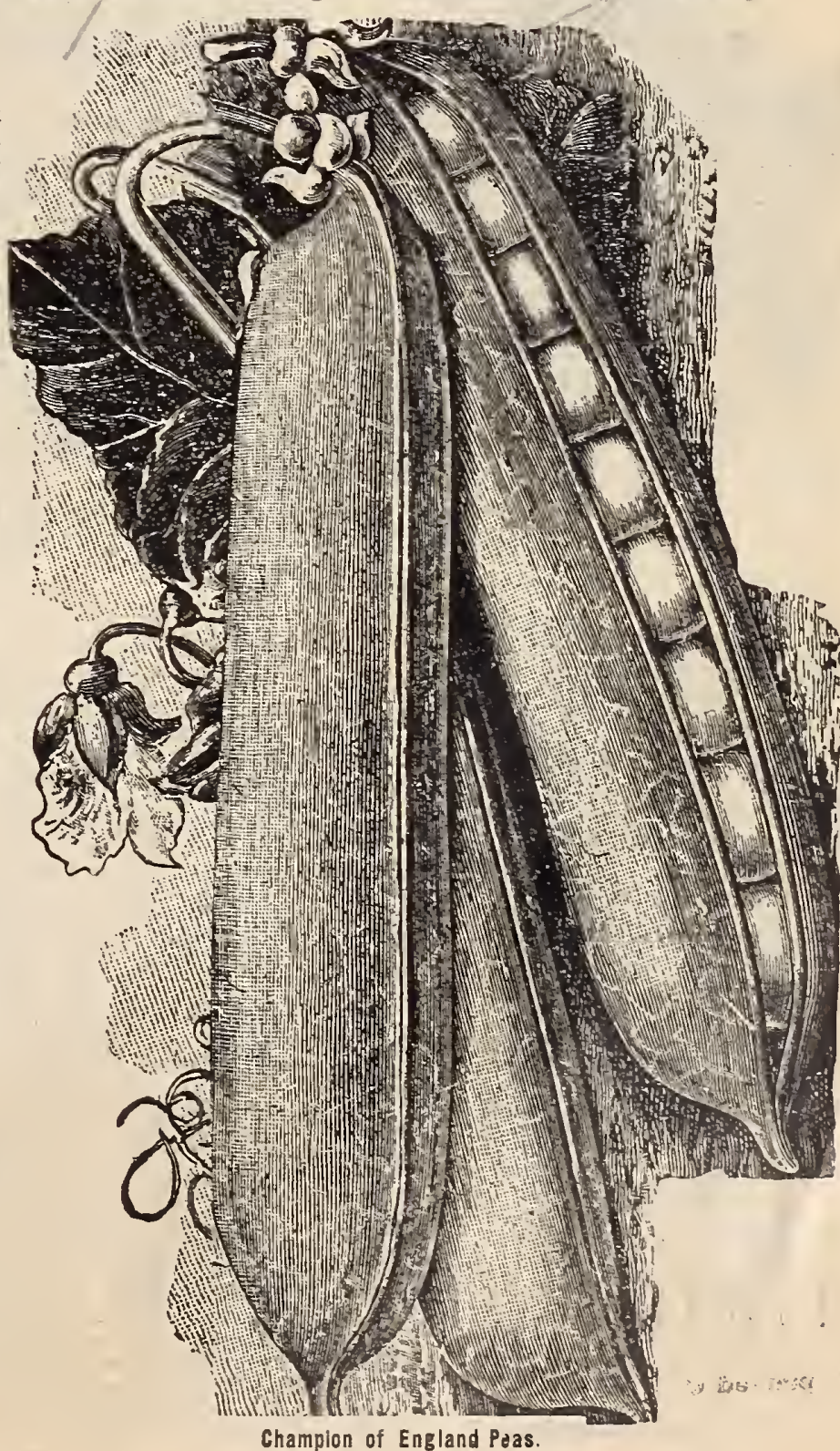



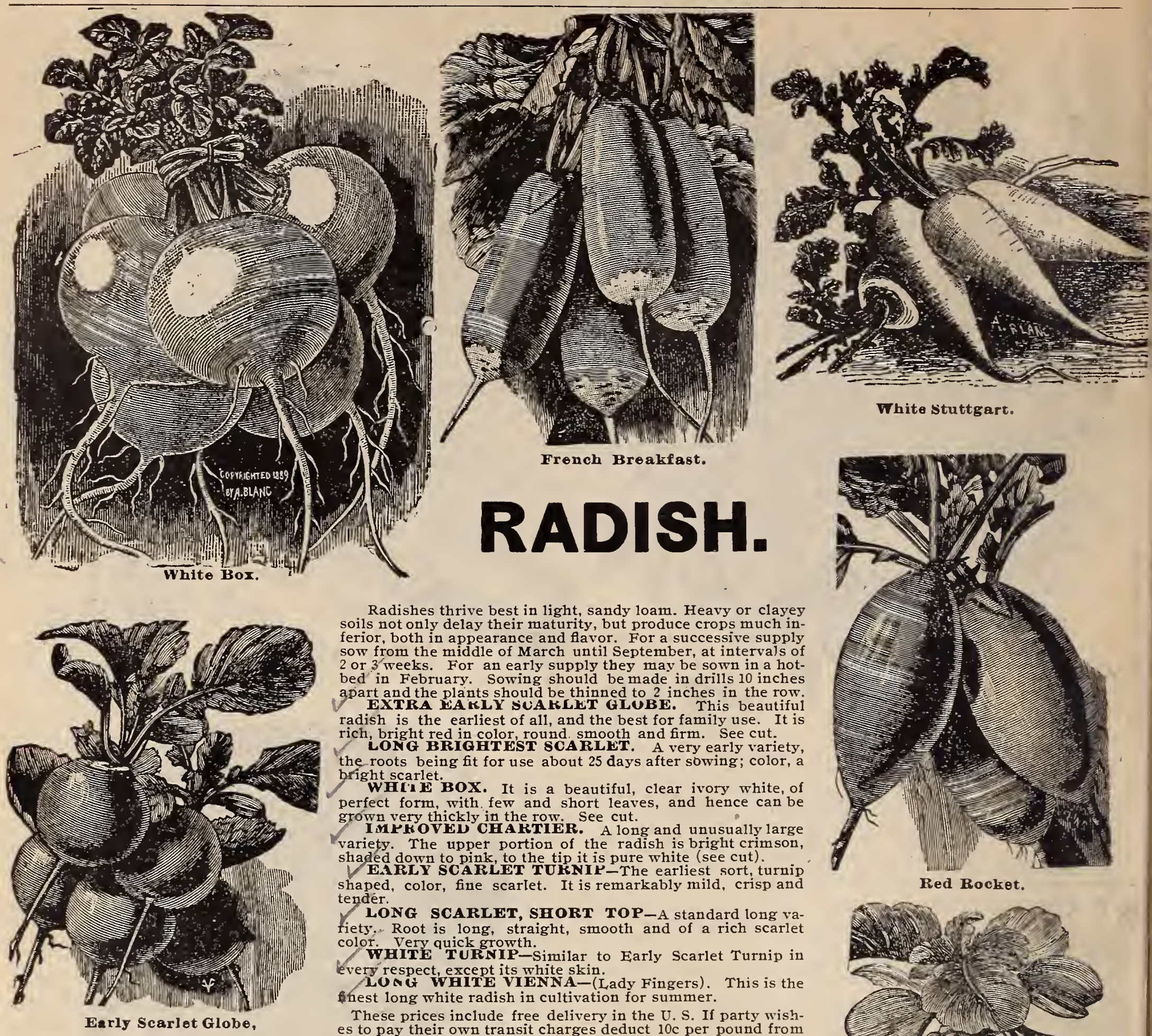

White stuttgart

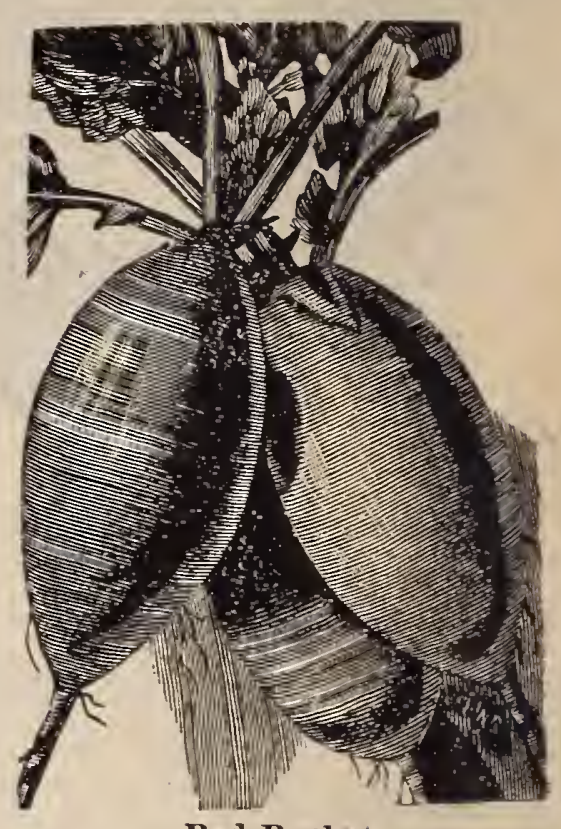

Radishes thrive best in light, sandy loam. Heavy or claye ferior both in appearance and flavor. For a successive supply sow from the middle of $M$ arch until September, at intervals of 2 or 3 weeks. For an early supply they may be sown in a hotapart and the plants should be thinned to 2 inches in the row radish is the earliest of all, and the best for family use. It is rich, bright red in color, round. smooth and firm. See cut. rich, bright red in color, round. smooth and firm. See cut. the roots being fit for use about 25 days after sowing; color, a bright scarlet. WHILE BOX. It is a beautiful, clear ivory white,
perfect form, with. few and short leaves, and hence can be grown very thickly in the row. See cut.

grown very thickly in the row. See cut. variety. The upper portion of the radish is bright crimson, shaded down to pink, to the tip it is pure white (see cut) shaped, color, fine scarlet. It is remarkably mild, crisp and tender. LONG SCARLET, SHORT TOP-A standard long va
tiety. Root is long, straight, smooth and of a rich scarlet color. Very quick growth.

every respect, except its white skin. hest long white radish in cultivation for summer.

These prices include free delivery in the U.S. If party wishes to pay their own transit charges deduct $10 \mathrm{c}$ per pound from prices quoted.

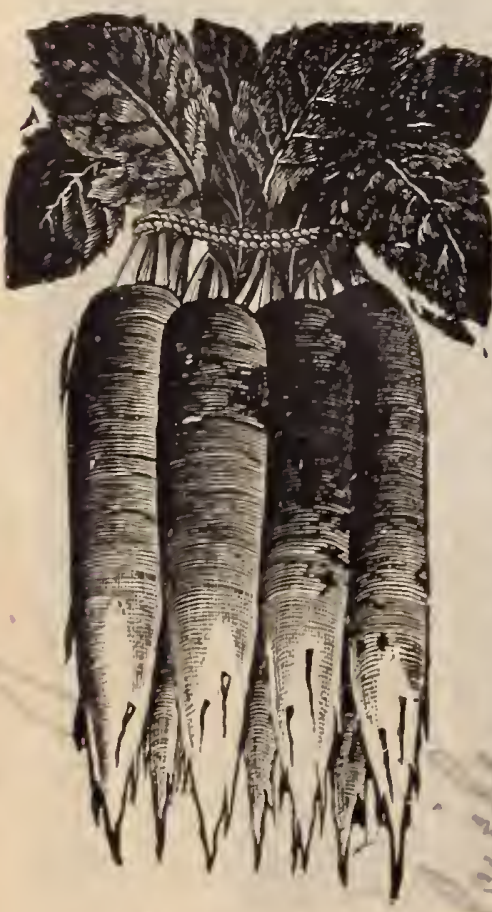

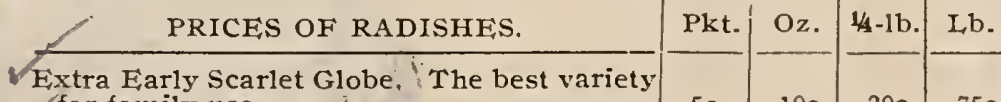

for family use White Box (see cut). Skin and flesh white. Improved

Farly Scarlet Turnip. A standard variety....
Loug Scarlet, Short Top. Earliest longirad-

ish white Vienna or Lady Finger. Fine

long white radish.

Extra Early Erfurt. Very early, quick grow-

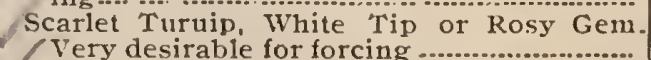
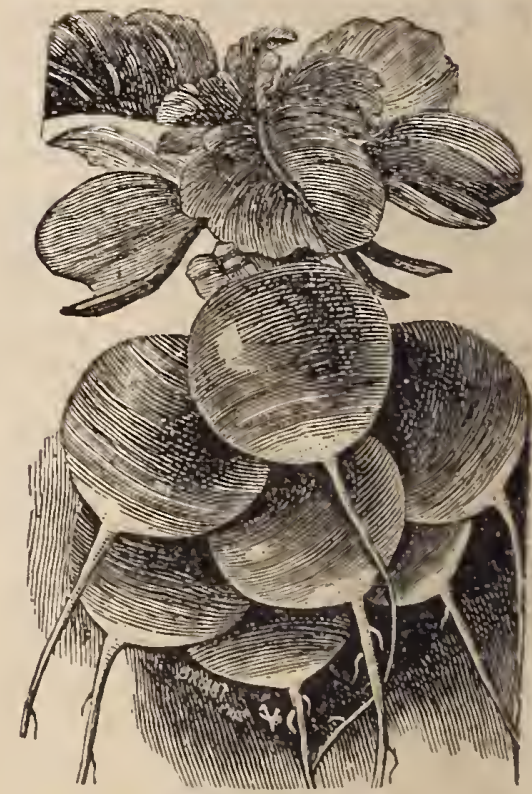

Scarlet Turnip White Tipped.

\begin{tabular}{|c|c|c|c} 
Pkt. & Oz. & 3/4-1b. & Lb. \\
\hline $5 c$ & $10 c$ & $20 c$ & $60 c$ \\
$5 c$ & $10 c$ & $20 c$ & $60 c$ \\
$5 c$ & $10 c$ & $20 c$ & $60 c$ \\
$5 c$ & $10 c$ & $20 c$ & $60 c$ \\
$5 c$ & $10 c$ & $20 c$ & $60 c$ \\
$5 c$ & $15 c$ & $25 c$ & $65 c$ \\
$5 c$ & $10 c$ & $20 c$ & $60 c$ \\
$5 c$ & $10 c$ & $25 c$ & $65 c$ \\
$5 c$ & $15 c$ & $25 c$ & $75 c$ \\
$5 c$ & $10 c$ & $20 c$ & $65 c$ \\
$10 c$ & $15 c$ & & \\
$10 c$ & $15 c$ & & \\
$10 c$ & $15 c$ & $40 c$ &
\end{tabular}

Improved Chartier.

French Breakfast (See cut). I'opular red tipped white

Round Black Spauish Winter. Black skiu, white flesh.

Gray Summer Turnip. One of the best for sumumer us

Non Plus Ultra. An extra early sort.................
NRed Rocket (see cut). Of very quick growth

$\checkmark$ Round White Summer. The best sum1ner radish ....

Triumph. A inost distinct variety (see page
White ${ }^{0}$ Rocket. An early variety, pure white.. 
O. YOUNG \& SONS CO., ST. LOUIS, MO.

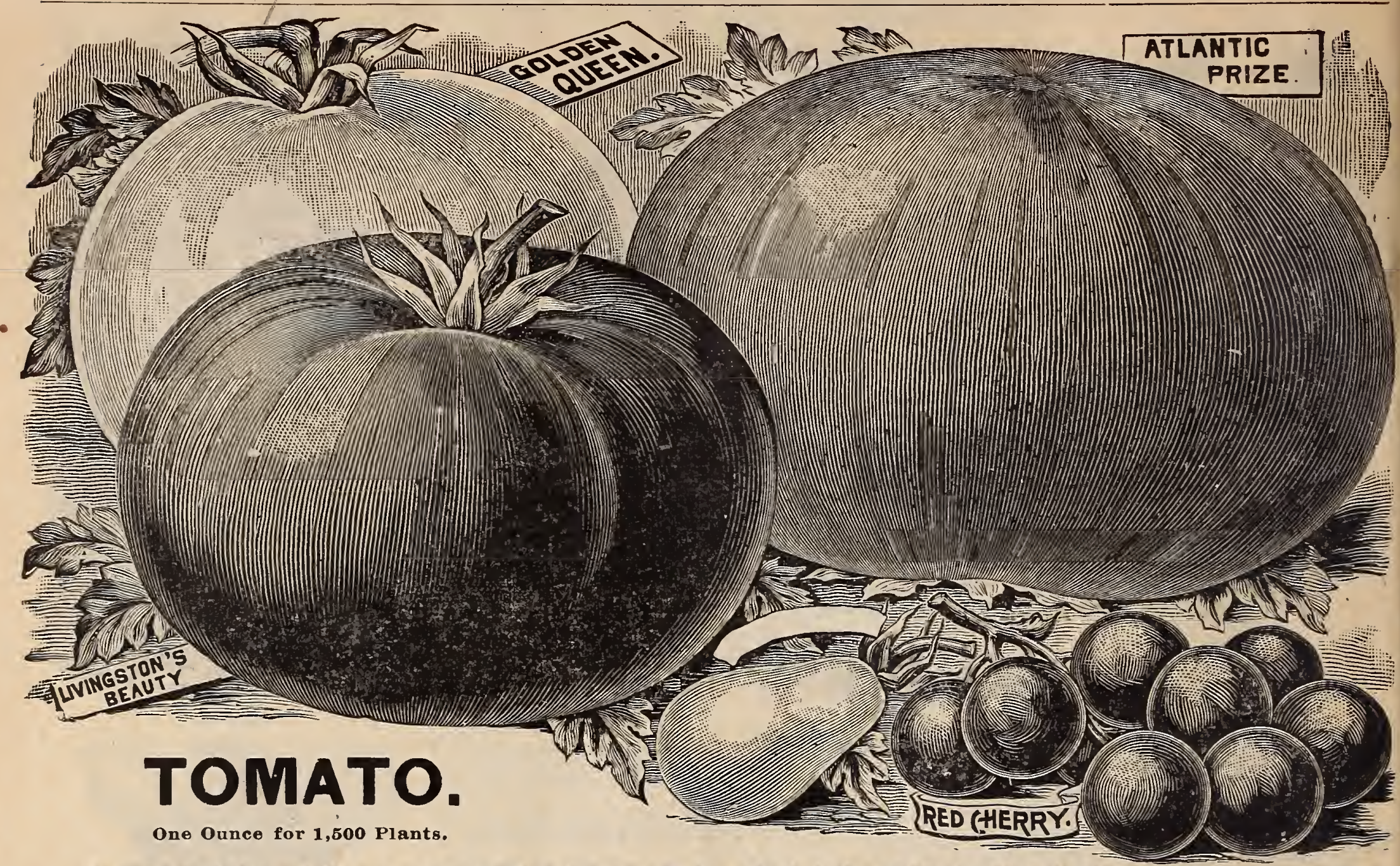

Tomatoes do the best in light, warm, not over-rich soil, sowing seed into hot-beds during March. When the plants are about two inches high, transplant in boxes three inches deep and four or 5 inches apart. Set out of doors as soon as danger from severe frost is over. The fruits will come earlier if the vines are tied to a trellis.

ATLANTIC PRIZE. This is an extra early strain, the fruit is somewhat ribbed or rough in form.. MATCHLESS. A standard main crop, very productive and handsome in appearance.

IIVINGSTON BEAUTY. Round, smooth and of a glossy, crimson color, a good mait

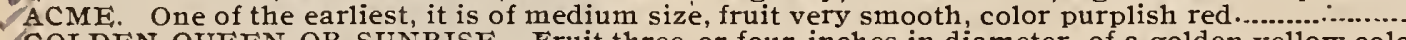

PERFECTION. Color blood-red, almost round in shape, averaging four inches in diameter

PEACH. Resembling a peach in shape, size and color, fruit averages 1/2 inches in length

RED CHERRY. Immensely productive, beginning to ripen early, the small fruits

YOW S'S

ROYAI RED A splendid main crop variety for the market or private garden

FAVORITE One of the larest Tomatoes in cultivation

HONOR BRIGHT. Very solid and will keep a long time after being picked

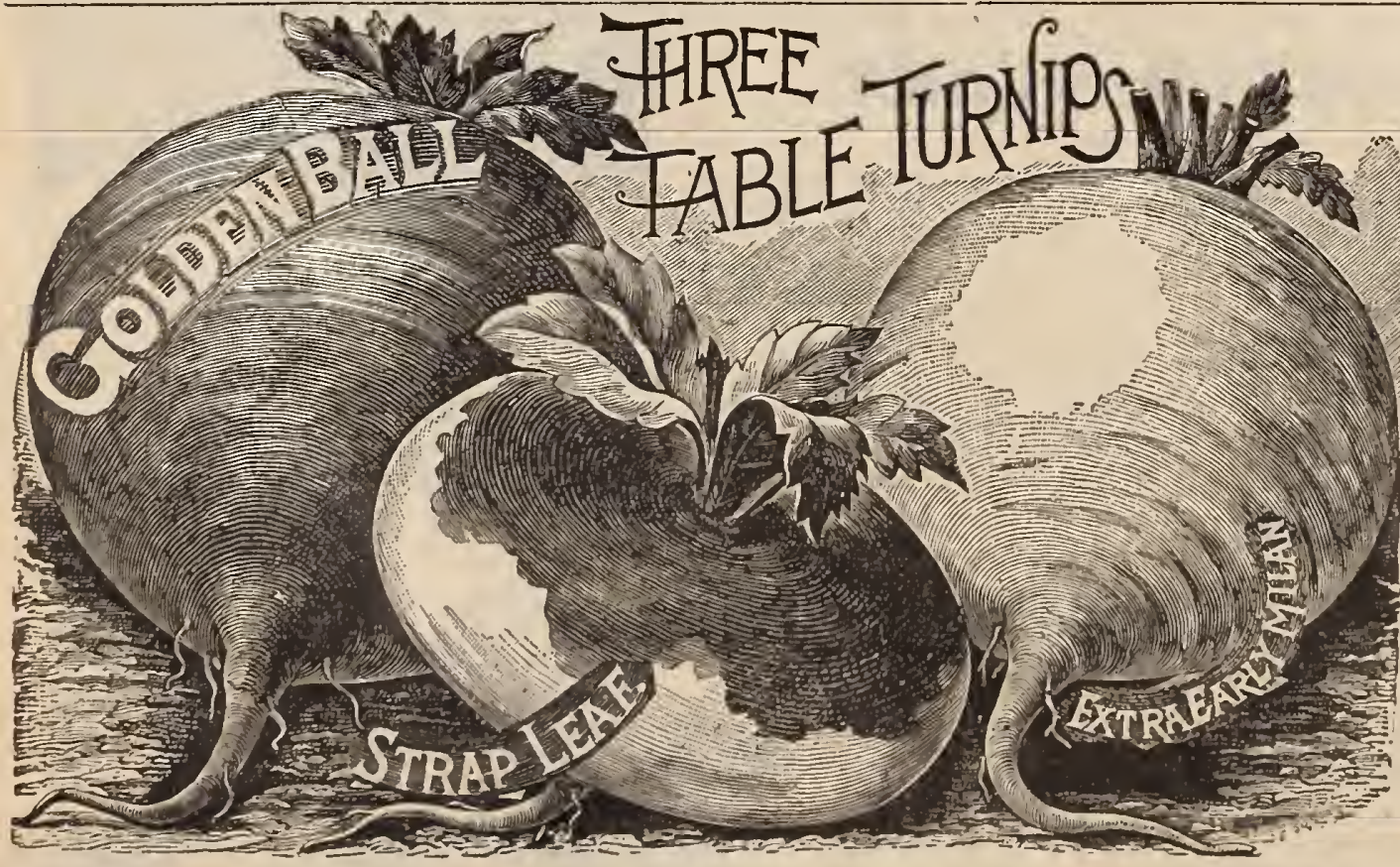

Rutabaga or Sweedes.

Cultural directions same as Turnip.

IMPROVED AMERICAN-Very hardy and productive, flesh yellow, solid and sweet; good for stock and table use. Pkt., 5c: oz., 10c: 1/4

LLNG ISLAND IMPROVED-This is undoubtedly the flnest variety of purple top Rutabagas grown; the shape is slightly oblong, with for conformity of crop is superior. Pkt., 5c:
oz., 10c; $141 \mathrm{~b} ., 15 \mathrm{c}$ : 1b., 50c.

\section{TURNIPS.}

If ordered by express deduct $10 \mathrm{c}$ per $1 \mathrm{~b}$.

One Ounce for $\mathbf{1 5 0}$ Feet of Drill. One to Two Pounds in Drills for an Acre.

Sow the seed out very early, in drills 18 inches apart and half an inch deep. When the plants are a few inches in height, thin out to six inches
apart in drills. For late crop sow in July or August, broadcast or in drills.

C EARLY REO TOP, WHITE GLOBE-A large rapid growing sort with globular shoped roots, the flesh is pure wite of PKt. Oz,

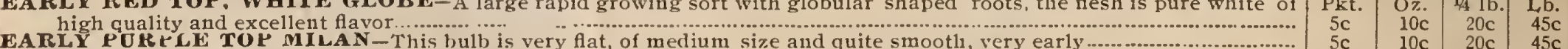
PUR P.

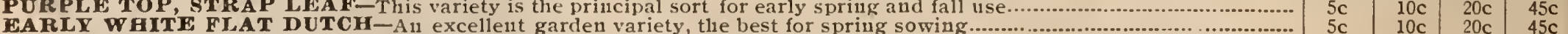
GOLDEN BALY-A rapid grower, globe shaped, briglit yellow color (see cut) ....................................................................... These prices include free delivery in the U. S, on Turnips and Tomatoes. If party wishes to pay their own transit charges deduct 10c per pound prices quoted. 


\section{YOUNG'S LAWN GRASS SEEDS.}

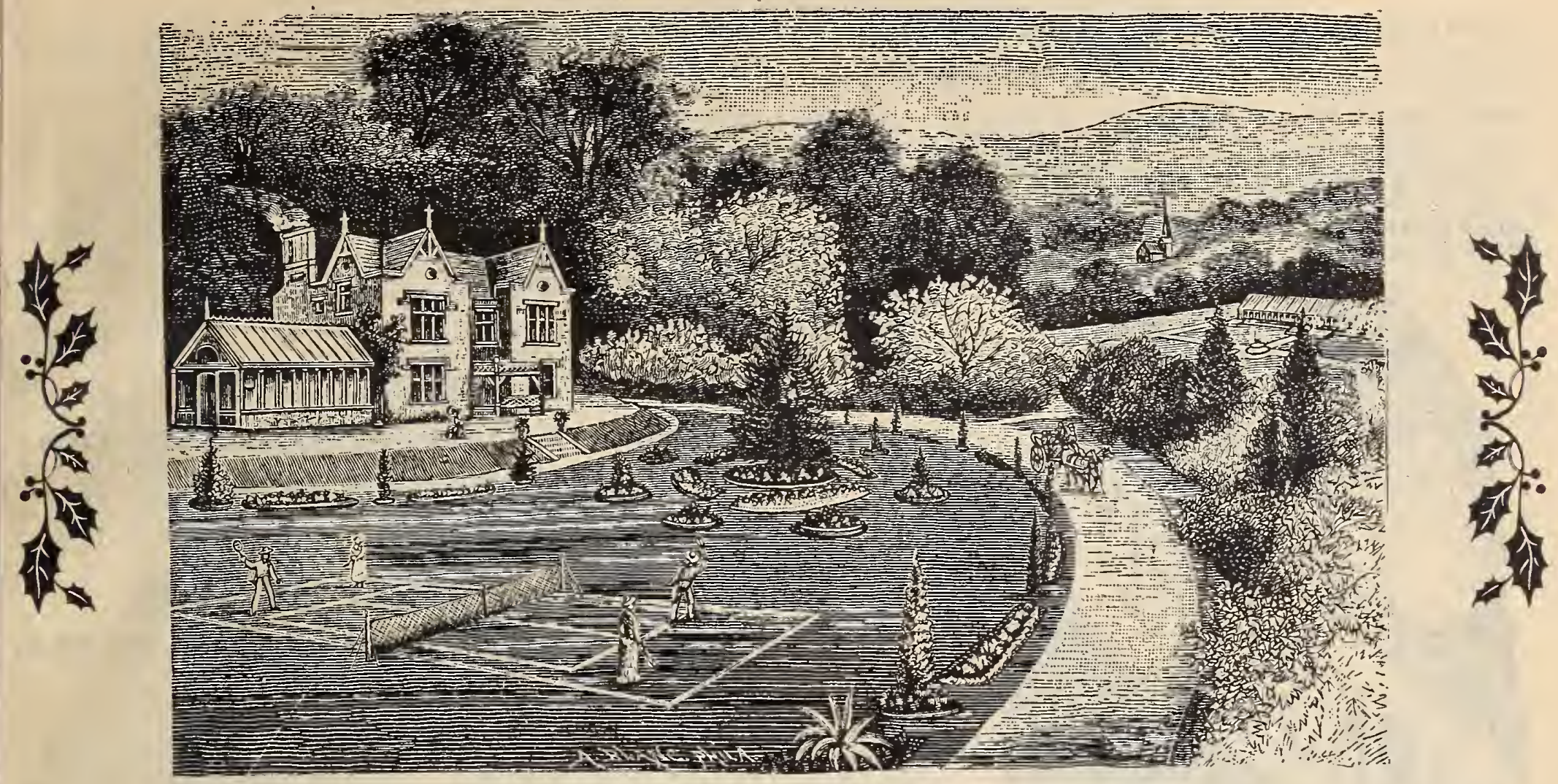

Young's Lawn Grass Seeds for Sunny Situations.

HAS NO EQUAL FOR MAKING A NEW LAWN OR RENEWING AN OLD ONE.

IN MAKING A NEW LAWN, first spade the ground well. If it is unusually poor, spread over it a layer of rich top soil to the depthilof three or four inches. As soon as the ground is thoroughly pulverized and smooth, sow our "Lawn Grass Mixture" thickly, then rake, and pat the surface smooth with the back of a spade or, if the lawn is large, use a roller. Get the seed in as early in the spring as possible. When the shoots of young grass have grown to the height of three or four inches, it should be mown with a sharp scythe; after this it should be mown every week with a lawn mower.

RENEWING OLD LAWNS. Have the lawn raked early in spring. Remove all dead grass and leaves, then sprinkle it with our Lawn Grass Seed sowing thickly the bare spots and thin spaces, so that the seed and grass will grow at the same time, forming a perfect sod. Our improved Lawn Grass Seed is the best mixture for sowing or renewing lawns. It has been carefully prepared, and thorough testing has shown it to be the best seed for sowing in this climate, producing a smooth and durable turf, that will remain green throughout the summer.

As a guide for the proper quantity to order, we may state: For making new lawns, 5 bushels per acre, or for renobating old lalons, 1 to 2 bushels per acre for a lot $15 \times 20$, or 300 square feet, I quart is required for new, or I pint for renovation.

Price per quart, 30c, by Mail. If ordered to be sent by Express or Freight, purchaser paying the charges: Quart, 25 c, peck, $\$ 1.00$; bushel of 20 lbs., $\$ 4.00$.

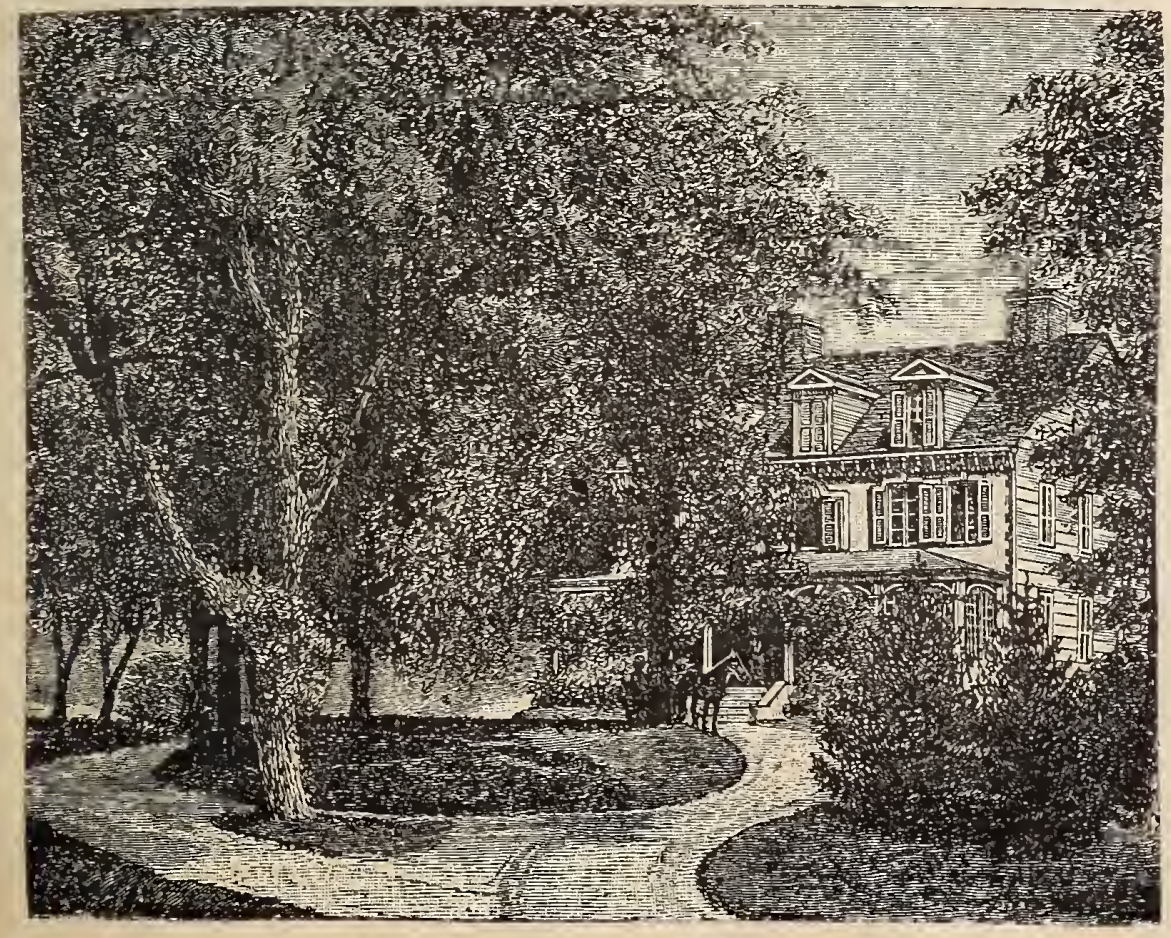

Young's Shady Nook Lawn Gưrass Seed.

\section{YOUNG'S SHADY NOOK LAWN GRASS SEED.}

There are very often some bare spots on lawns caused by the shade from trees and other objects which can not be kept green without a great deal of care. We have succeeded in making a mixture of evergreen grasses that thrive in a shady situation. With this mixture it will require no more attention to keep these shady spots green than any other part of the lawn.

Per quart, 25c; peck, $\$ 1.00$; bushel of 20 1bs., \$4.00.

\section{YOUNG'S GOLF LINK GRASS SEED.}

This is a special mixture of tough growing varieties of grasses that will withstand the extreme drought of summer

This special grass seed is highly recommended by all the clubs that have used it on their golf links.

Per quart, 25c; peck, \$1.00; bushel of 20

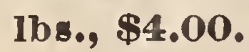




\section{GRASS AND CLOVER SEEDS.}

If Order is to be Sent by Mall, Postage Must be Added at the Rate of 8 Cents per Pound.

KENTUCKY BLUE GRASS SEED-FANCY CLEANED. 25c per b.: $75 \mathrm{c} \mathrm{pk.:} \$ 3.00$ per bu.

KENTUCKY BLUE GRASS SEED-EXTRA CLEANEU. Per b,. 20c: pk., 50c: bu., $\$ 2.00$

ORCHA RD GRASS- V valuable for either pasture or hay. Per 1b., 20c: u., $\$ 2.50$.

RED CLOVER-Per 1b., 20c: 5 lbs, 75c;"price per bu. on application. WHITE CLOVER-Valuable in mixtures both for lawns and permanent pasture. Per lb, $30 \mathrm{c}$.

MAMMOTH OR PEA VINE CLOVER-Lasts longer than most
CRIMSON CLOVER-If sown at the last of summer or early in autumn it will furnis

RED TOP GRASS SEEP-Fancy cleaned. Suitable for lawns or pasture. Per 1b., 25c; pk., 75c: bu., $\$ 2.50$

TIMOTHY, EXTRA CHOICF-Per 1b., 15c: pk., \$1.00:price per bushel on application.

HUNGARIAN GRASS-Valuable for forage or sodding. Per 1b., 10c: pk., 25c: price per bushel on application.

SWEET VERNAL GRASS-Valuable for mixing with pasture grassvarieties; grows 5 to 6 feet high. Per 1b., 30c: price per bu. on application.

s.on account of its fragrant odor. Per lb., $25 \mathrm{c}$.

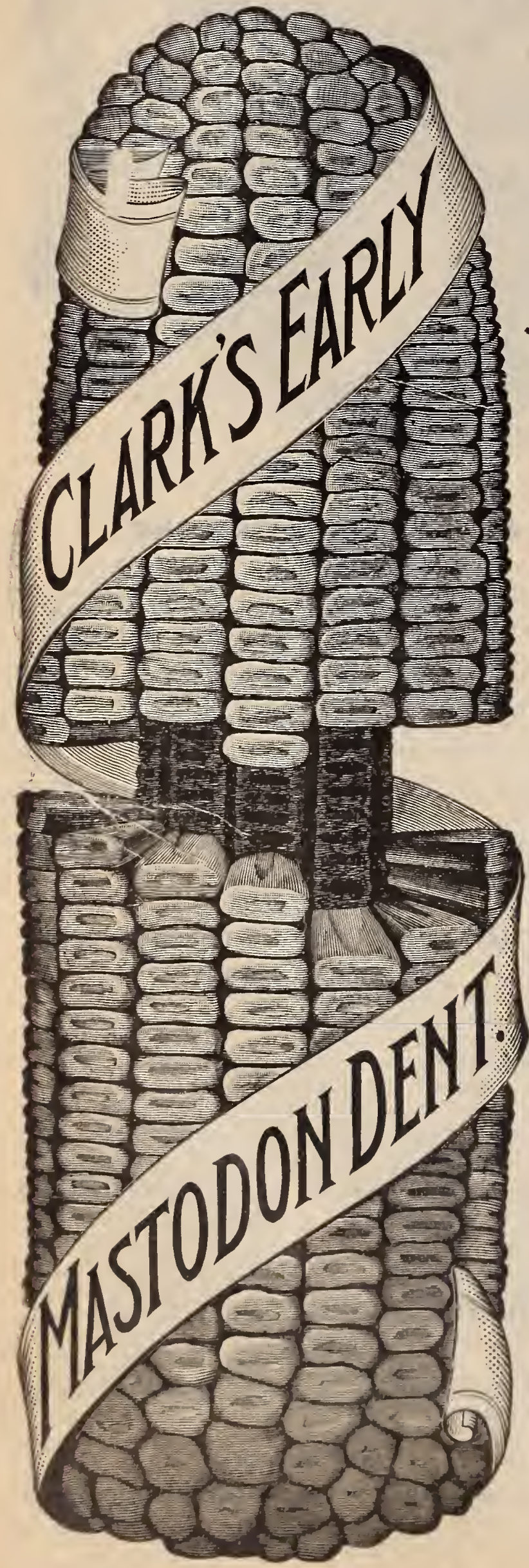

c; bu., $\$ 2.50$

ENGLISH RYE GRASS-A very valuable grass for either pastures or lawns. Per 1b., 20c; per bu., $\$ 2.50$.

BERMUDA GRASS-Suitable for the South, where the winters are not below the freez. ing point: very valuable for pastures where the summers are very hot and dry. Per $1 \mathrm{~b}, \$ 1.00$

YOUNG'S SPECIAL GRASS MIXTURE FOR PERMANENT PASTURE.

This mixture is composed of all the best standard grasses that are used for making meadows for either mowing or fastures. The average quantity sufficient to sow an acre is bushel of 18 lbs., $\$ 2.50: 3$ bushels for $\$ 7.00$. For larger quantities, write for special prices.

\section{FARM AND FIELD SEEDS.} CORN.

WHITE CAP YELLOW DENT-Thi variety is considered by all large profess ional corn growers to have more general good merit than any other corn grown. It is a very heavy yielder and a vigorous grower eren on poor land. Per pk., 40c; bu., $\$ 1.40$. CLARE'S EARLY YELLOW MASTO. DON-This is a very quick growing variety. extra large and very productive. Ears average 9 to 12 in. long, with 20 to 30 rows on the cobj/stalk bearing 3 to 5 ears, often weighing CHAMPION EARLY WHITE PEARI - This is the best of the TWhite Dent varieties. It',is pure white, a tremendous cropper, and very early, coming in from 95 to 100 days. Per pk., 40c: bu., \$1.40.

WHITE HICKORY KING-This is a pure white corn, too well-known to need any introduction. Good grower, and a larg yielder in most any situation, either
low ground. Per pk., $40 \mathrm{c}$; bu., $\$ 1.40$.

GOLDEN BEAUTY-This is a standard Yellow Dent Corn and is well named, as it is the most beautiful yellow corn grown. The long having from 15 to 20 , rows on a cob. Per \$k., 40c; bu., $\$ 1.40$.

IMPROVED LEAMING-A Yellow Dent ariety: very small cob, with a deep, long 100 bushels per acre. Per pk., 40c; bu., \$1.40. DUNGAN'S WHITE PROLIFIC-One of the largest varieties of White Corn grown: very deep grain and a small pure white cob. One of the greatest points in this corn is its
yielding capacity', it producing double the quántity of any other variety. Per pk., 40c bu.. $\$ 1.40$.

EARLY CANADA YELLOW FLINTThis Flint Coru is the hardiest aud earliest factory further Nortli than the Dent Corn.

\section{KAFFIR CORN.}

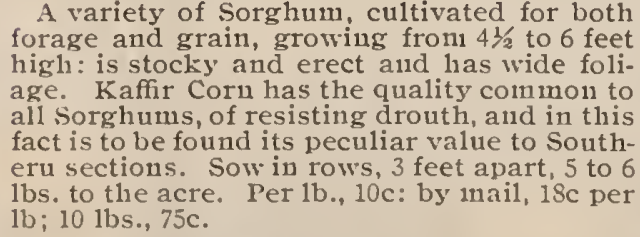

MILLET.

GERIIAN OR GOIDEN-Superior to all thers. Medimm early; 3 to 5 feet ligh. Sow
and as common Millet. Per lb., 10c; by COW OR SOUTHERN PEA. CLAY COLORED-Large seed : of a blue lay color. Per pk., 60c.

WHIP - POOR - WILL-The seeds are large, speckled brown in color. Per pk,, 60c. Prices per bushel on application.

\section{SORGHUM.}

(Cultural directions same as Corn)

EARLT AMBER CANE-An ear ly popular variety. Its distinct feature is its earliness and great yield of both sugat and 50 ; bu., $\$ 1.50$. 10c: by mail, 18c per lb.; pk.

\section{BROOM CORN.}

IMPROVED EVERGREEN-Grows about 8 to 10 feet high; stands up well, and is is long and fine. It will not get red in the feld before it is cut, but is strictly a green leld before it is cut, but is strictly a green
variety of brush. Peck, 50c; bu. (481bs.) $\$ 1.50$.

\section{BUCKWHEAT.}

SILVER HULL-This variety continues ( he flour is whiter and husks thinner. b., 10c; by mail per $1 \mathrm{~b} ., 18 \mathrm{c}$; per pk., $50 \mathrm{c}$

\section{SUNFLOWER SEED.}

(Sow 4 or 5 Lbs to the Acre)

MAMMOTH RUSSIAN - Single heads in easure 12 to 22 inches in diameter, and contain anmense quantity of seed. It is an cau be raised cheaper than corn. Per $1 \mathrm{~b}$. 10c: by mail, 18c per lb.

\section{SUGAR BEET OR MANGELS.}

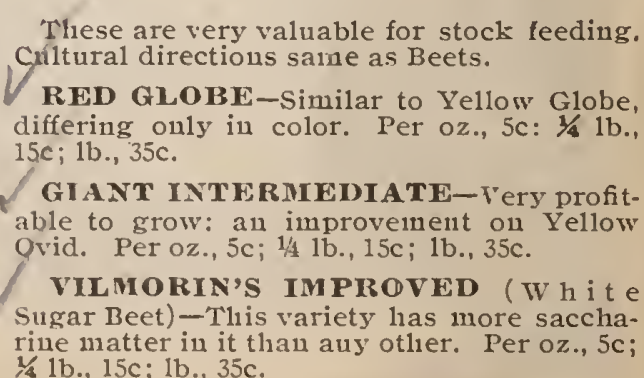




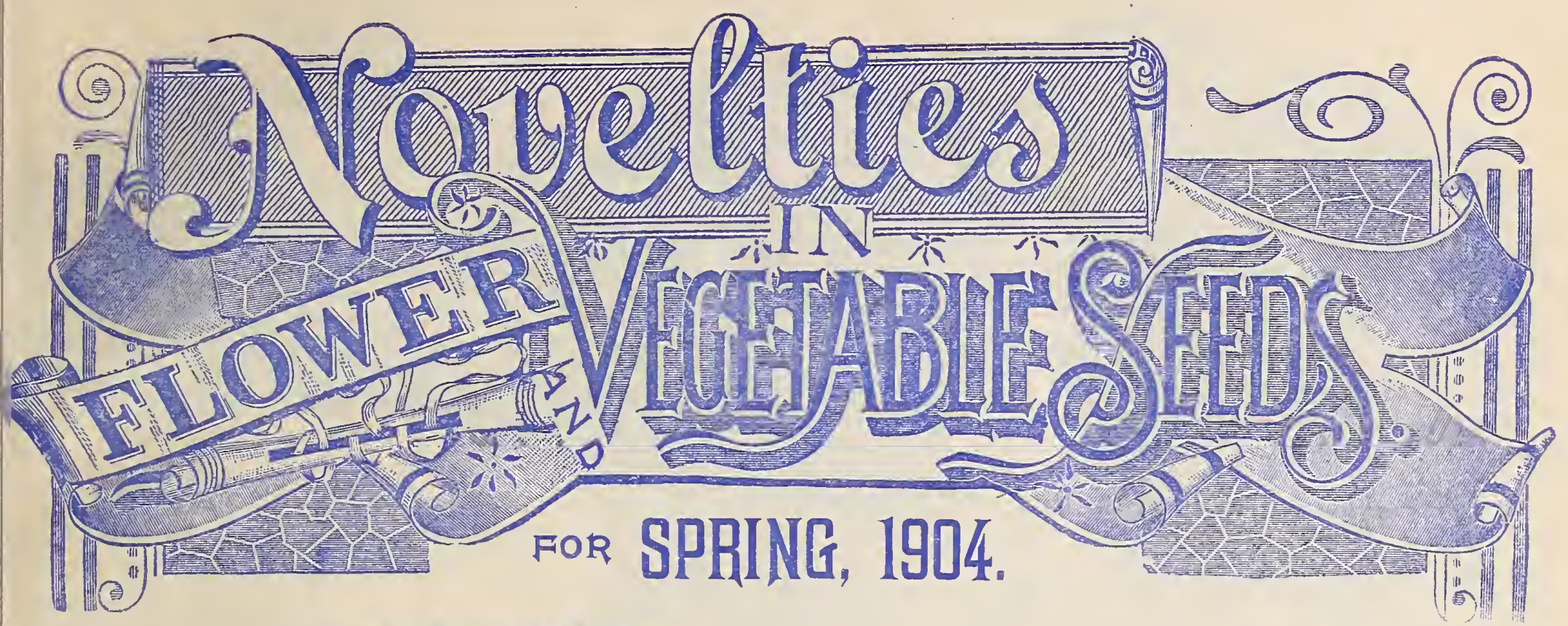

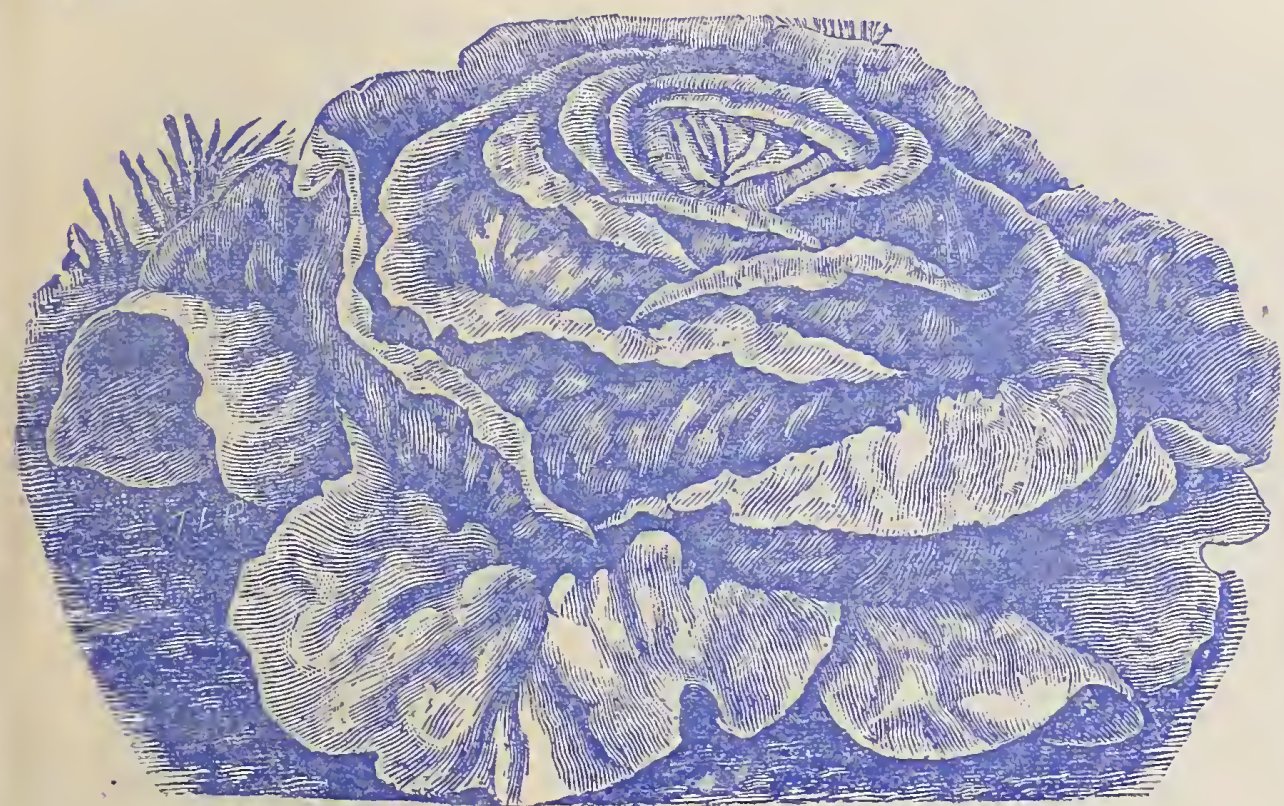

Lettuce, Big Boston.

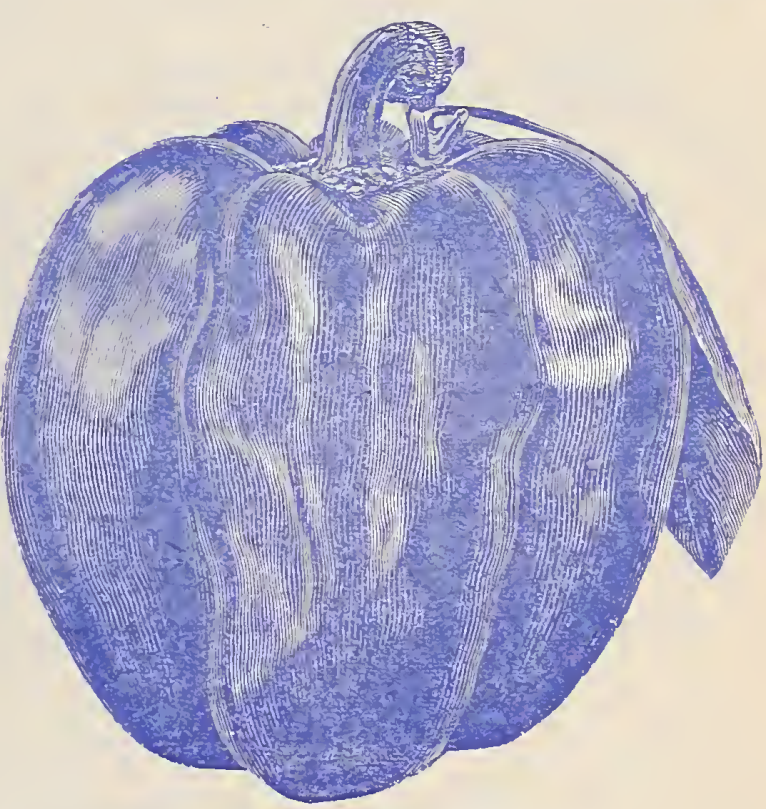

Red Pepper, Chinese Giant.

LETTUCE, BIG BOSTON.

A fue variety, similar to the Boston Market in appearance and shape. It is a nost desirable variety for general use or for market gardeners, producing large, solid heads, crisp, tender

\section{NEW LETTUCE, ICEHEAD.}

This is a grand winter lettuce and a good variety for market use being unsurpassed as to hardiness and firmness. It exceeds all others iu size, quality and taste. Color, a ligh ellowish green. It grows rapidly and thrives well in any soil (see cut). Per pkt., 10c; oz., 20c; $1 / 41 \mathrm{~b} ., 75 \mathrm{c}$

\section{LETTUCE, GIANT GLACIER.}

A magnificent lettuce. Plants, 12 in. and heads, 6 in across; leaves, light greel, with ortamental edges; inner leaves or head, white in color, and wholly tender and crisp, and free from bitter taste. One of the sorts best able to withstand drought, and to produce mild flavored heads under a hot sun. It is a fine lettuce, and we confidently recommend it for pring and midsummer use. It is almost like a savoy cabbage prove widely popular. Pkt., 10c; oz., 15c; $1 / 4$ 1b., 40c; 1 b., $\$ 1.50$.

\section{LETTUCE, WONDERFUL}

Excellent variety for supplying fine, crisp, well'blanched lettuce, during the hot summer months, withstanding both heat and drouth better than any other variety. The plants are rich, deep green, often growing more than 15 in. in diameter. The heads are solid, with the inner leaves blanched to a pure $15 \mathrm{c} ; 1 / 4 \mathrm{~b}, 40 \mathrm{c}$

RED PEPPER, CHINESE GIANT.

This is a very strong, vigorous growing variety, but of a stocky habit, seldom more than two feet in height. - It is very early in ripening and immensely productive for a large pepper. The monstrous fruits are of a thick, blocky form, and of the extremely mild, and inakes an excellent salad. "Per pkt., 10c.

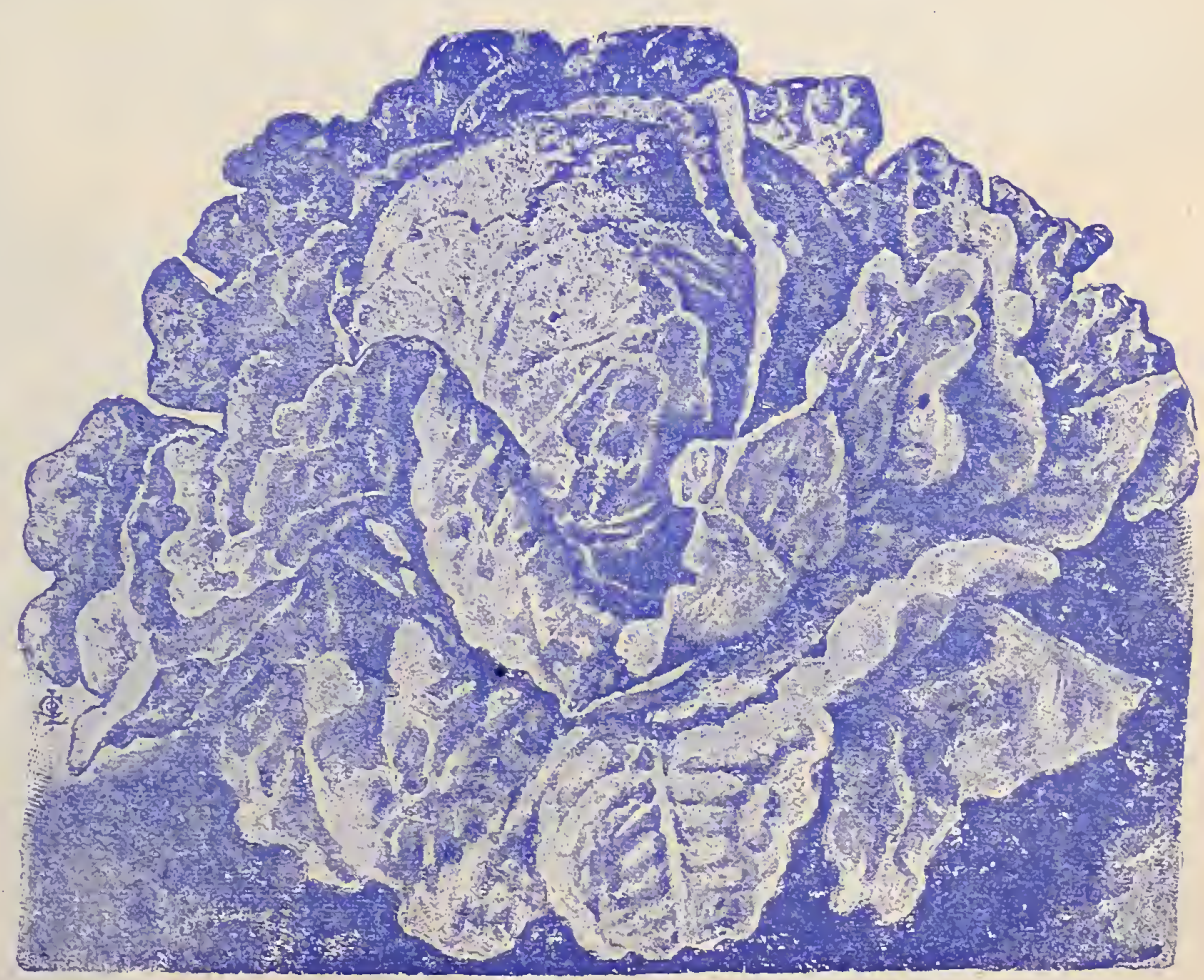

New Lettuce, Icehead. 


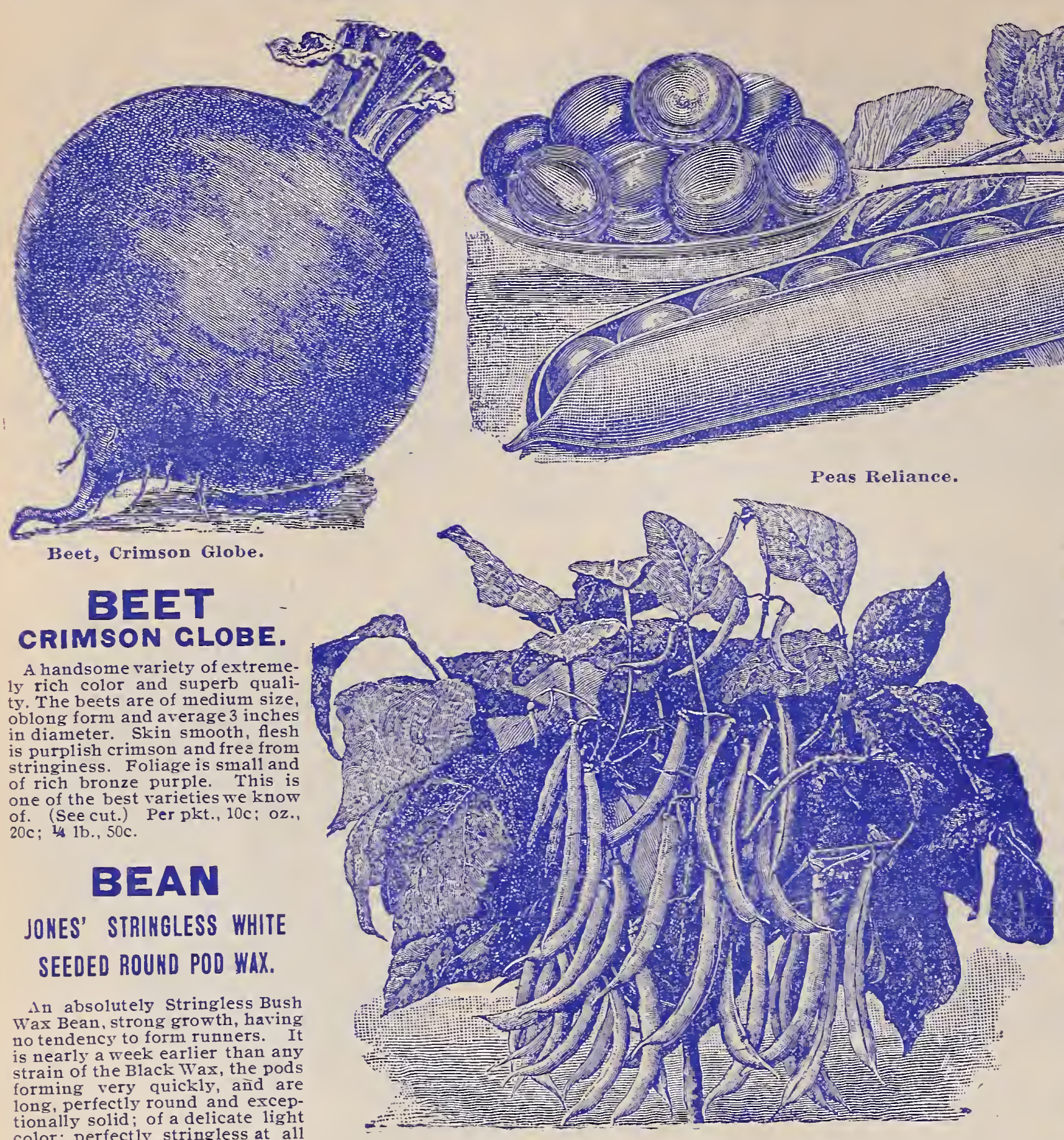

Bean, Giant Stringless Green Pod Valentine.

(1) coarseness even when past their prime, retaining its brittleness and fine table qualit
pint, $20 \mathrm{c}$; quart $40 \mathrm{c}$.

\section{BEAN \\ GIANT STRINGLESS GREEN POD VALENTINE.} valentine which it resembles. The plants are of a strong growth; very productive, pods are 5 to 6 incles rounded and green, slightly curved, very meaty, being broaless at all stages, and of a mild flavor. (See cut.) Per pkt., 10c: pint, 25c; quart, $40 \mathrm{c}$

\section{BEAN}

GOLDEN CROWN BTRINGLESS WAX.

A wew long with very round golden pods, A new long, white Seed ine a true bush in type of strong and perfectly growth, carrying its load of pods well up from the ground. It is very early, free from pod rust and blight; a pint, 20c; quart, $40 \mathrm{c}$

FOR SELFCT LIST OF VEGETABLE SEEDS SEE PAGES 3 TO 21

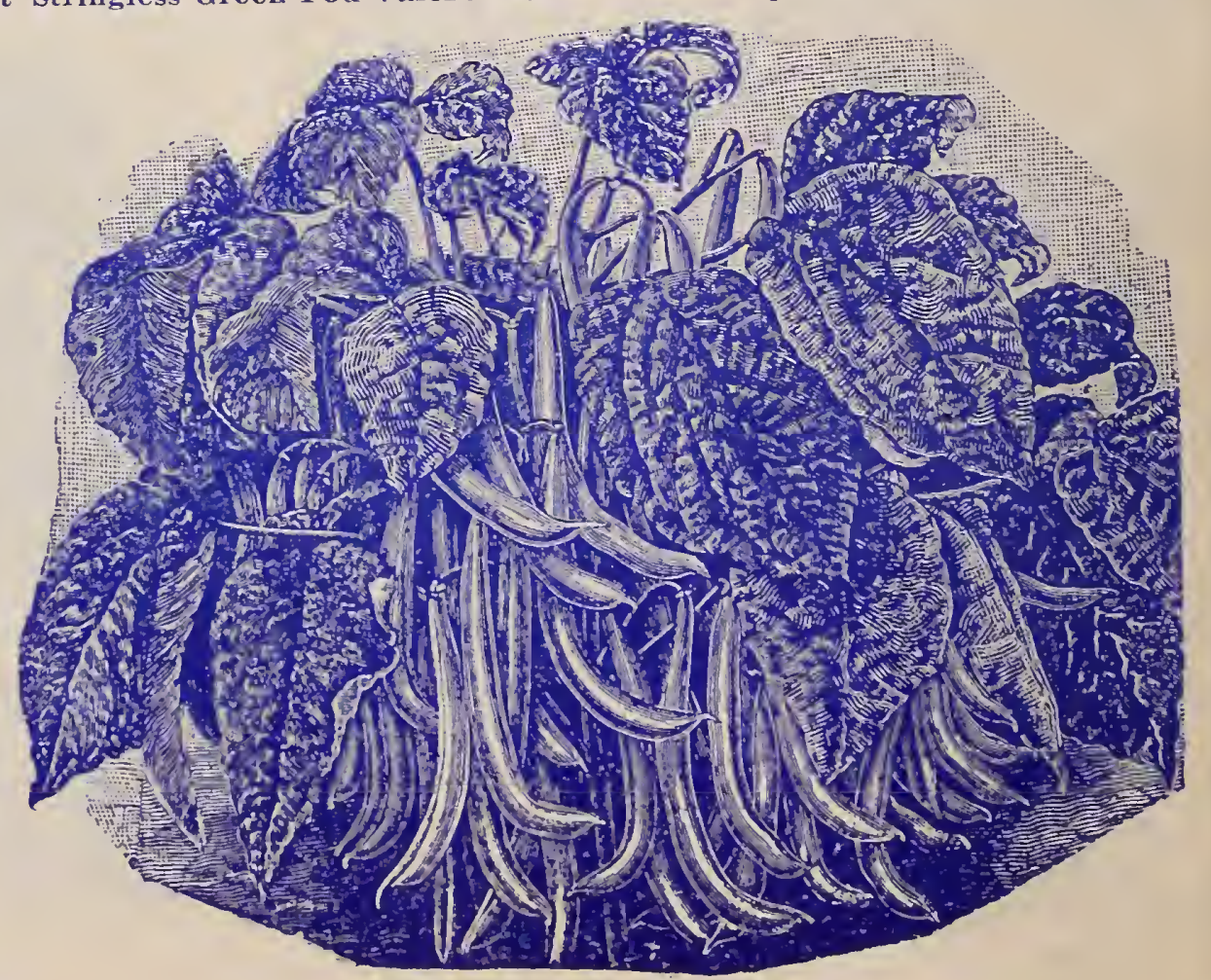

Bean, Golden Crown Stringless Wax.

\section{PEAS.}

Improved

Stratagem.

An excellent wrinkled pea, with sturdy vine, growing pods are of extra large size, often measuring five inches filled, frequently containing 10 peas to the pod. The tla-
por is first-class. Pkt., $10 \mathrm{c}$. vor is first-class.
pt., $25 \mathrm{c}$; qt., $45 \mathrm{c}$. 
TOMATO, YOUNC'S EXCELSIOR.

This variety originated with us a few years go, and up to this time we know of no other variety that can equal it in size, solidness and flavor. Under ordinary circumstances, our own grounds, last season, we had fruit that weighed nearly two pounds. The clor is bright crimson, with a slight purplish tinge. Like all large tomatoes, it is a strong, vigorous grower, and very early for its size. Enormous cropper, yielding the entire summer until killed by frost; very eldom cracks and is nearly seedless. It is the best tomato for either market or private 1se in cultivation (see cut). Per pkt, 10c: $35 \mathrm{c} ; 1 / 4 \mathrm{lb}, \$ 1.00$

\section{TOMATO, NEW STONE.}

Eery large and the best of its type in every respect. Color, a bright scarlet; smooth, and ripening evenly to the stem: a heavy cropper and good shipper. Per pkt., 5c; oz., 25c $14 \mathrm{lb}, 75 \mathrm{c}$

TOMATO,

\section{SPARK'S EARLIANA.}

This is one of the earliest bright red tomatoes. The plants are quite hardy, with slender branches and moderate growth, and are well set with fruit, which ripens very

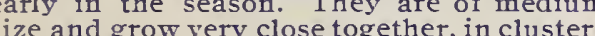
of five to seven; of deep scarlet color and are about $21_{2}$ inches in diameter, and hare very small seed cavities and a slight acid flavo (see cut). Per pkt., 10c; oz, 40c; 44 1b., 75 c.

\section{TOMATO,}

\section{ALICE ROOSEVELT.}

This favorite tomato originated in South Russia. It ranks among the earliest tomatoes in cultivation, and is of large size; smooth and globular shape; flesh is a dark scarlet color. They cont and weigh between 5 and 7 ounces; are of a superb variety (see cut). Per pkt.,

\section{SQUASH, GREGORY'S DELICIOUS.}

This is a fine variety of squash, and is best adapted to fall and winter. In appearance, it resembles the Hubbard, and has very small seed cavities; flesh, deep orange color: tender and almost of mealy dryness. No matter how it is cooked, it is simply delicious (see cut). Per pkt., 10c; oz., 15c: 4 1b., 40c.

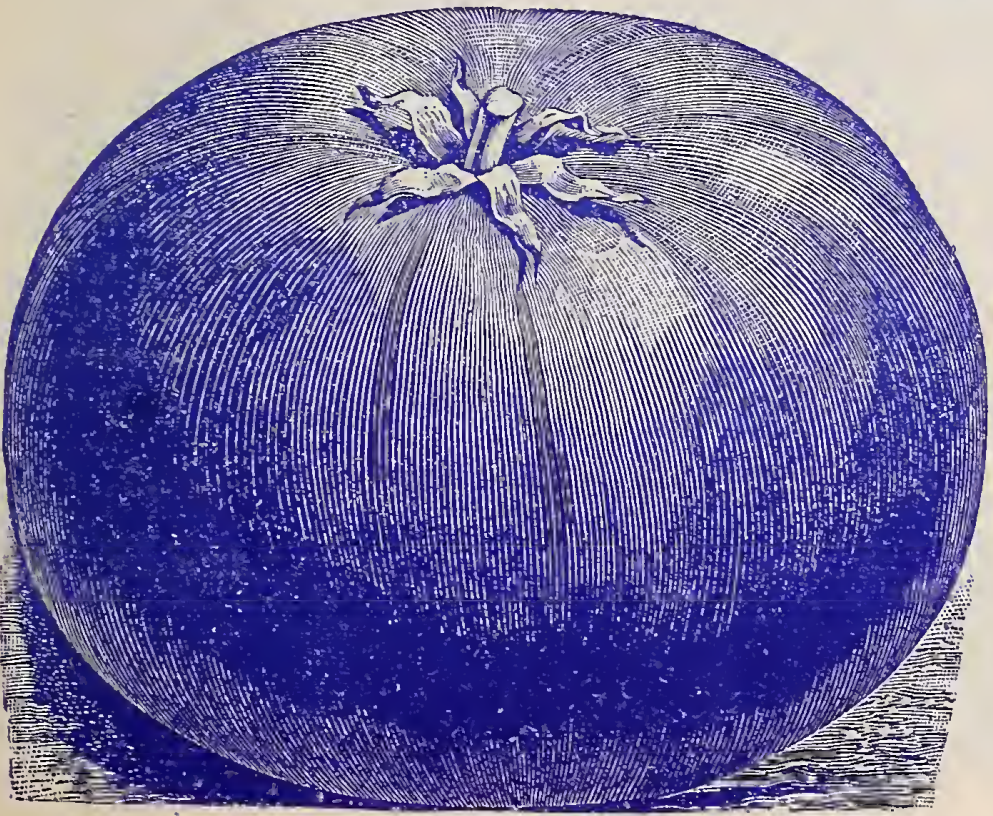

Tomato, Alice Roosevelt.

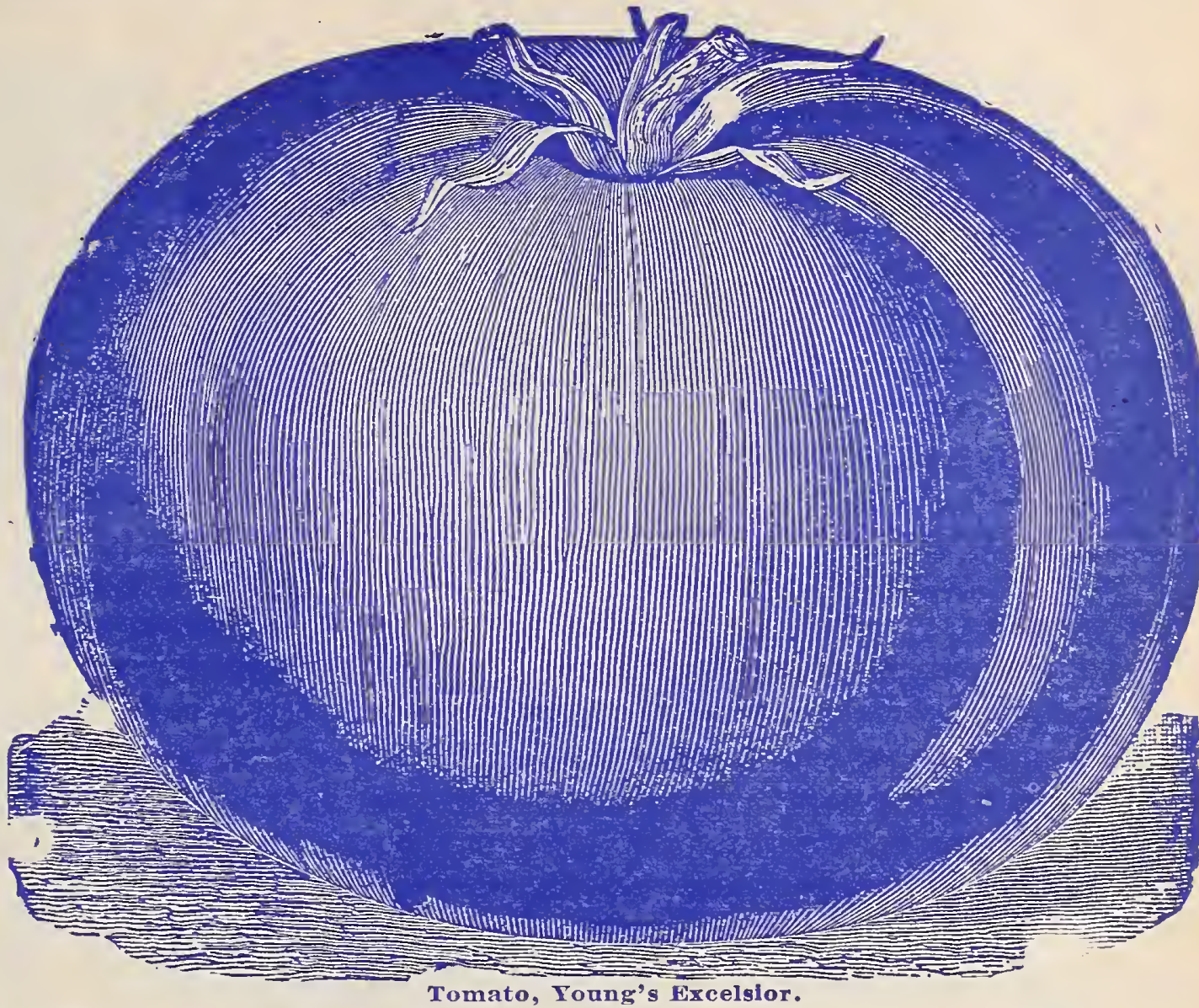

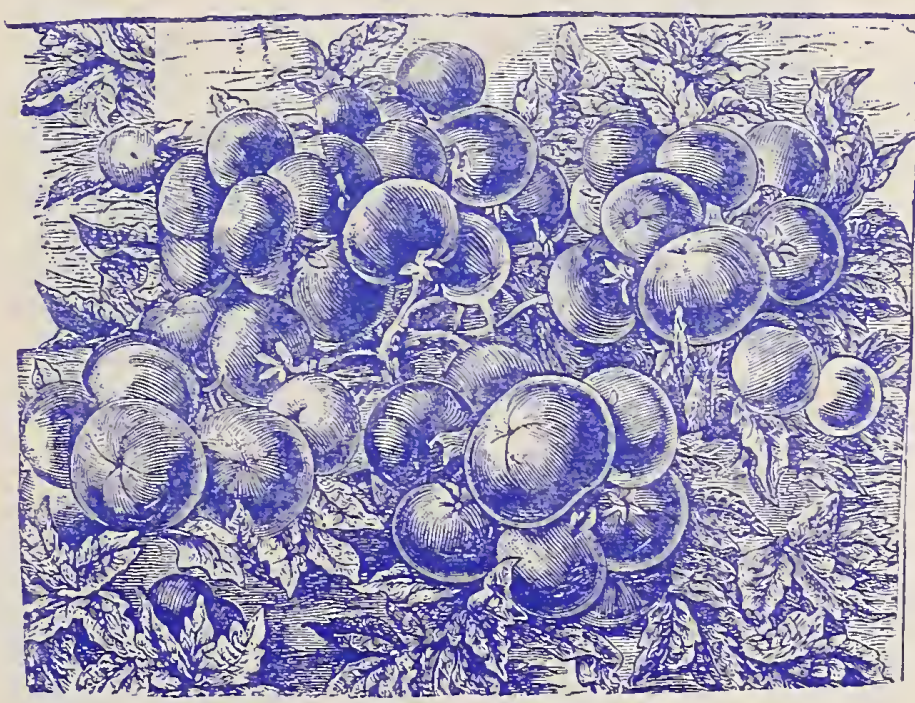

Tomato, Spark's Earliana.

\section{SQUASH, FORDHOOK.}

The flesh of this squasli is very diry and sweet. It is one of the earliest of the winter varieties, and if stored in a cool, dry place, will keep until the following June. The shape is shown in the picture. The outside color is bright yellow; inside color, straw yellow. The skin is so thin that it need not be remored for cooking. The meat is thick and the seed cavity small. The green squashes can be used at any stage of their growth. This squash is easily grown oils, and is valuable for home or for market. Immensely productive. Per pkt., 5c; oz., 15c: $1 / 41 \mathrm{~b}, 40 \mathrm{c}$

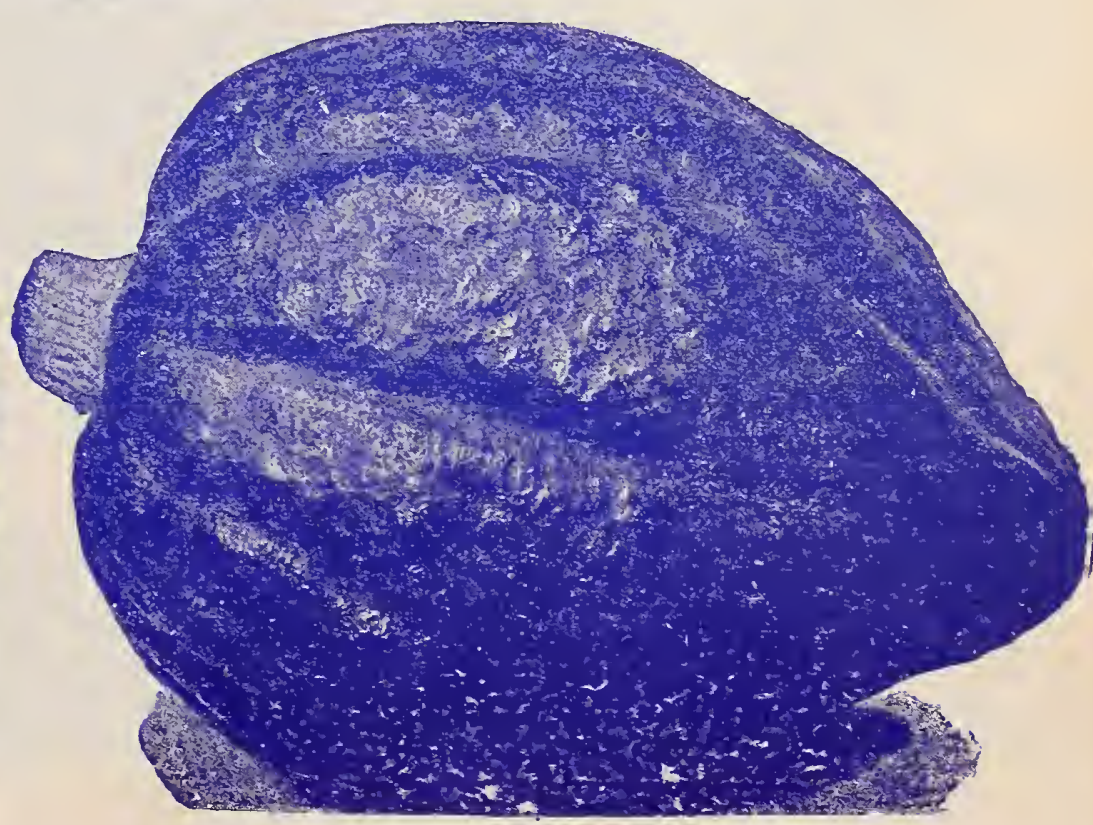

Squash, Gregory's Delicious. 


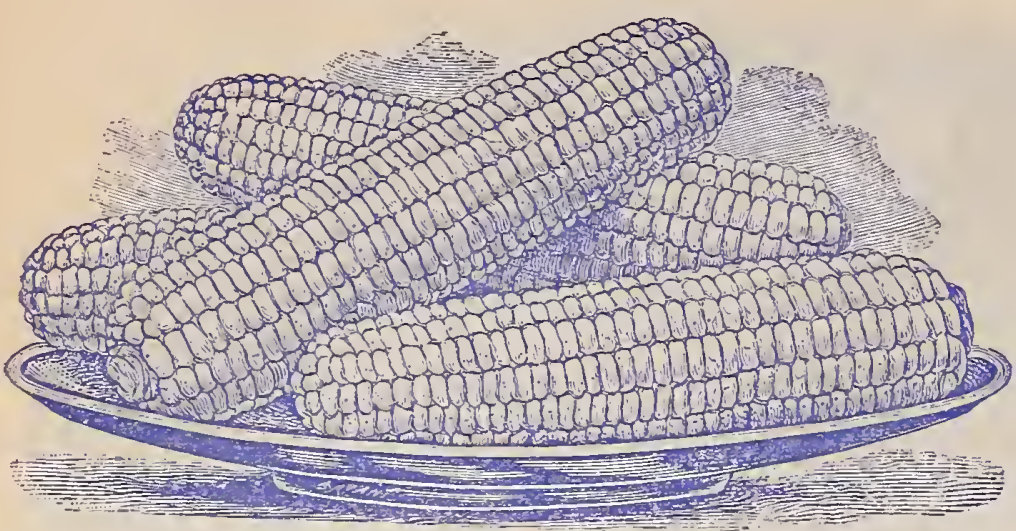

Corn, Clark's None Such.

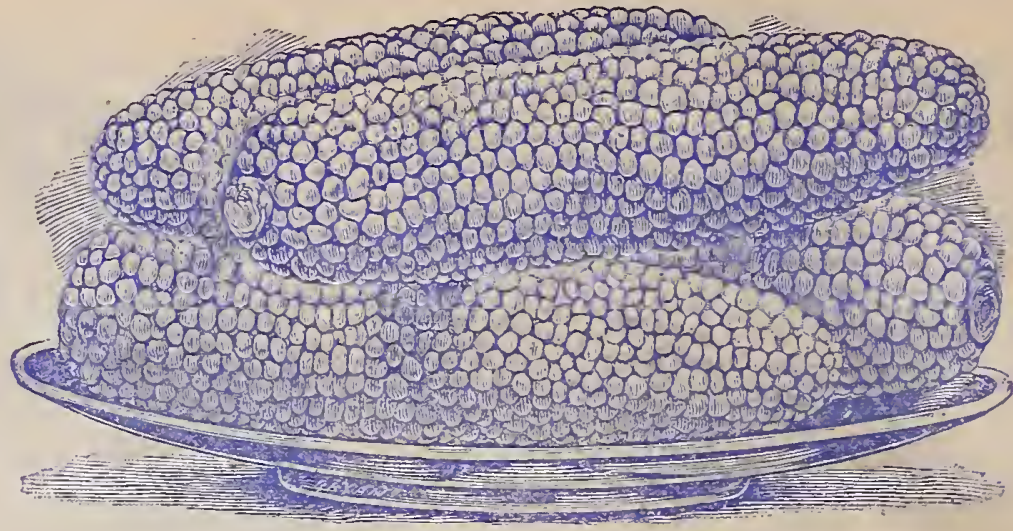

Corn, Metropolitan.

\section{SWEET CORN, CLARK'S HONE SUCH,}

This variety well deserves its name. It is one of the best second early varieties in the market. Its quality is simply delicious, and customers report that a number of the stalks contained two ears 12 inches long and were filled from end to end. It is a red cob variety and preferred by many on that account (see cut). Per pkt., 10c; pt., 20c; qt., 35c.

\section{SWEET CORN, EARLY SHEFFIELD,}

This sugar corn is a rery early, hardy variety; the stalks are strong and vigorous, growing about 5 feet high and generally bearing two large ears that are well filled to the top of the cob. The kernels are large, white and very sweet. Per pkt., 10c; pt., 20c; qt., 35c.

\section{SWEET CORN, KENDALL'S EARLY GIANT.}

The ears of this variety grow to an immense size, often measuring 10 inches and hav10 to 12 rows of corn on each cob. Kernels pure white, sweet and tender. The general report on this corn is that it is ready for use in sixty days on light soil and seventy-five days on heavy clay. Per pkt., 10c; pt., $20 \mathrm{c}$; qt., $35 \mathrm{c}$.

\section{CUCUMBER, EARLY CYCLONE,}

One of the earliest of the White Spine varieties, and a most desirable sort. It is very prolific and it fruits in bunches of three or four, which are of uniform size and shape. It is an excellent variety for slicing or pickling. Per pkt., 10c; oz., 30c; 1/4 1b., 75c.

\section{CUCUMBER, LIVINGSTON'S EMERALD.}

The fruits of this variety are very large, of rich, deep coloring and spineless skin. "The flesh is crisp and tender; perfectly round and smooth and highly recommended for table use. They diake excellent pickles (see cut). Perpkt., 10c; oz., 25c; 1/4 1b., 60c.

\section{SWEET CORN, EARLY METRO- POLITAN.}

A large eared early variety; the stalks are of a strong growth, bearing one or two large ears, set low on the stalk; the ears are about 9 inches long, and 10 to 12 rows filled with large grains of fine, sweet flavor. It is a true sweet corn and one of the best of the large eared early varieties (see cut). Per pkt. 10c: pt., 20c; qt., 35c.

\section{SWEET CORN, SHAKER'S EARLY,}

A second early variety, remarkably large for so early a ripener yields abundant crops and very desirable for the private gardener. Per pkt., 10c; pt., 20c; qt., 35c.

TURNIP, EARLY WHITE MILAN.

This is an extra early variety, well adapted for early spring and summer planting, and sown at intervals will furnish a continuous supply of the most delicious turnips. They are of medium size; very handsome; smooth and of a clear ivory white. The flesh is tender, mild and of a sweet flavor. For a white table turnip this variety is unequaled (see cut). Pkt., 10c; oz., 20c; 1/4 1b., 40c.

CUCUMBER, CUMBERLAND.

This variety is a rapid, vigorous grower; very prolific different from all other hardy sorts in being thickly set with fine spines orer the entire sur face, except the extreme stemend, and during the whole period of growth the form is exceptionally straight and symmetrical (see cut). Per pkt. $10 \mathrm{c}$; oz., 25c; $1 / 4$ 1b., 60c. 


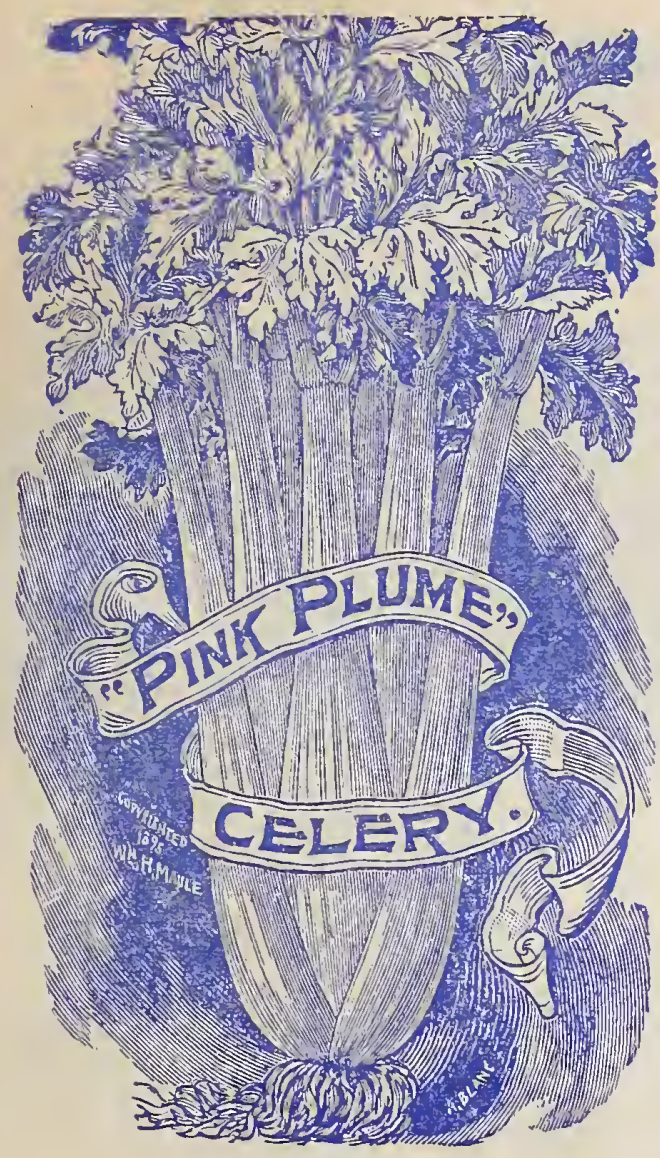

Celery, Pink PIume.

\section{CELERY, PINK PLUME.}

This is a strong, compact grower, with no tendency to rust; extra early, very solid, tender and crisp. It is a self-blanching variety, the same as White Plume or Golden Self-Blanching, requiring but a slight earthing up to blanch it. Per pkt, 10c: oz., 25c; $1 / 416 ., 60 \mathrm{c}$.

\section{NEW CELERY, WINTER QUEEN.}

This is a very valuable variety for winter and spring use, and excells all others as a late keeper. The plants are beautiful in appearance and blanch to extreme white. They grow very close together and quite compact. The ribs are perfectly solid, crisp and of a delicious flavor. It stands first as a late celery. Per pkt., 10c; oz., 25c; $1 b ., 60 \mathrm{c}$.

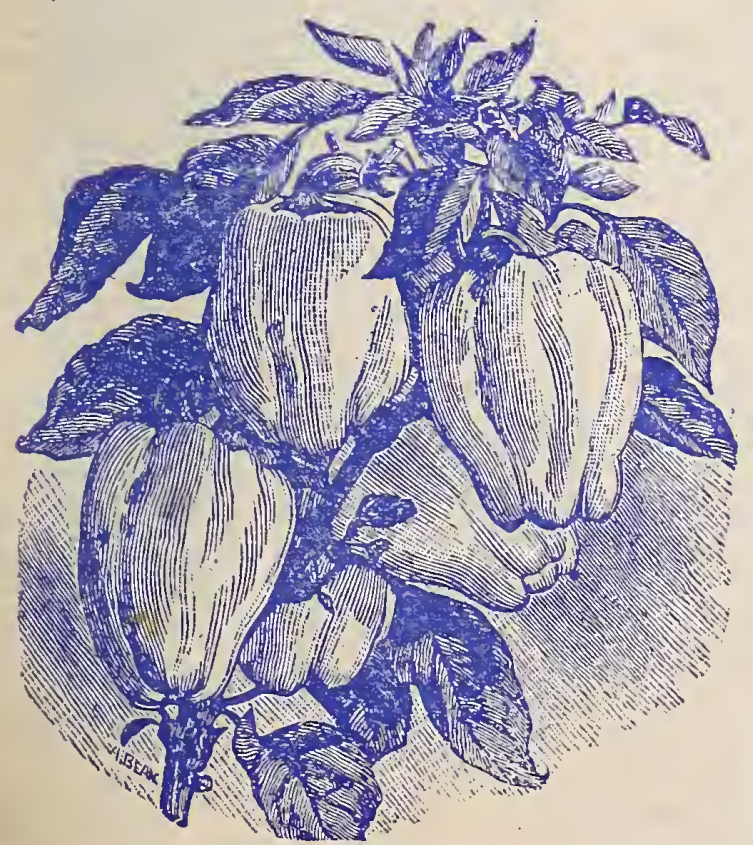

Pepper, Golden Dawn.

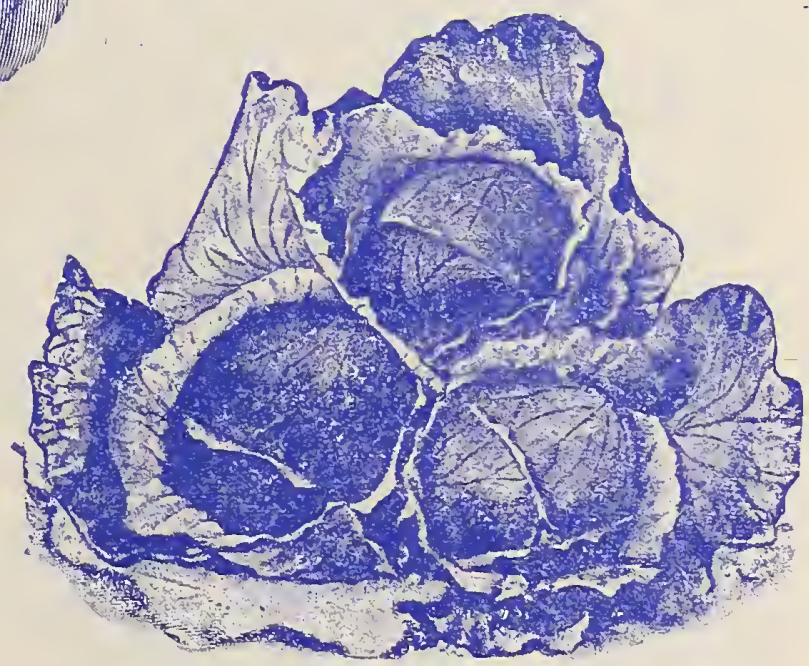

Cabbage, Dark Red Zenit.

\section{ONION, HEW YELLOW CRACKER.}

This is a comparatively new variety of oniou. It is a strong, early and quick grower and thrives well in any soil; an excellent keeper and yields abundantly. The color is a rich yellow and makes a very attractive bulb. It is medium in size and remarkably solid. Per pkt, 10c; oz., 15c; $1 / 41 \mathrm{lb}, 40 \mathrm{c}$.

\section{LEEK, BULGARIAN WINTER.}

This is one of the most desirable varieties of leek. It grows to enormous size and is extremely hardy and of an excellent flavor (see cut). Per pkt., 10c; oz., 15c; 144 1b., 40c

\section{PEPPER, GOLDEN DAWN.}

This is a fue variety of pepper. The color is a distinct yellow. which makes a handsome appearance. The flavor is mild and very sweet. An excellent variety for table use (see cut). Per pkt., 10c; oz., 25c; $1 / 4$ 1b., $75 c$.
CABBAGE, DANISH BALL HEAD.

This excellent variety originated in ${ }^{\circ} \mathrm{Den}$ mark; it is very hardy and a vigorous grower, producing large, round, solid heads with very few outside leaves, consequently, it may be planted closer together than the general varieties of cabbage. For planting late in the spring, for a fall crop or winter use, this variety has few equals as it withstands drouth and succeeds better in poor soil than most any other variety. The heads are about 8 to 10 in. in diameter It is an excellent keeper (see cut). Per pkt., 10c; oz, 25c; 14 1b., 75c

CABBAGE, DARK RED ZENIT.

This is one of the best varieties of red cabbage in cultivation. The heads are medium in size, dark red color and very finely ribbed. It is a medium early grower and an excellent keeper (see cut). Per pkt.. $10 \mathrm{c} ;$ oz., 25c; 1/4 1b, 75c.

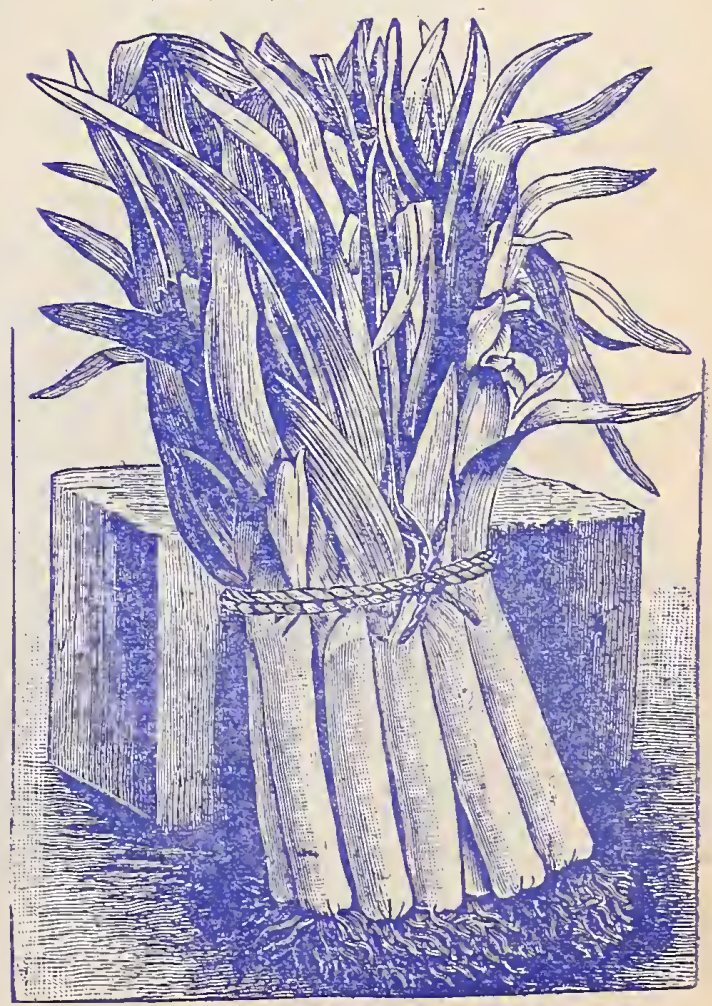

Leek, Bulgarian Winter. 


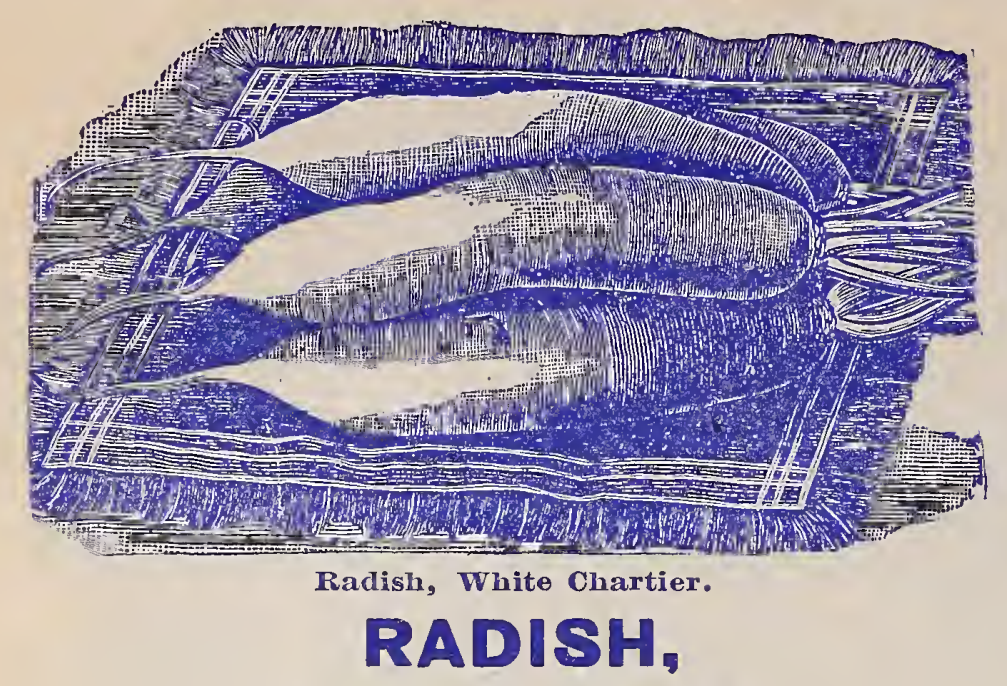

WHITE CHARTIER.

This is one of the finest white radishes we know of. It is a summer variety, succeeding best when treated as such. It matures in about 40 days from thet ime of sowing and remains fit for use about 14 days after. The flesh is pure white, crisp and tender. Mild and very valuable for slicing. A most desirable variety. (See cut.) Per pkt., 10c; 0z., 15c; 1/4 1b., 25c.

\section{PUMPKIN, NEW JAPANESE.}

The fruits.of this variety mature earlier than any other variety of pumpkin the large neck is solid, meaty. and the seeds are marked with curious indentadeep yellow, and is of an excellent quality; the skin is a deep green with darker stripes, turning to a rich golden yellow as the fruits ripen. Per pkt., $5 \mathrm{c} ; \mathrm{oz} ., 10 \mathrm{c}$; $1 / 41 \mathrm{~b} ., 35 \mathrm{c} ; 1 \mathrm{~b} ., 75 \mathrm{c}$.

\section{PUMPKIN, \\ WINTER LUXURY.}

This is a very prolific, small fruited varity of superior quality; fruits are nearly inches in diameter, flesh is a deep golden yellow, of an excellent is a deep golden yellow, of an excellent quality (see
Per pkt., 5c; oz., 10c; 14 1b.. 35c;1b., 75c.

\section{PUMPKIN,}

\section{BURPEE'S QUAKER PIE.}

This is a very prolific variety, having fruits of medium size and of the finest quality; the fruits are broad. pear-shaped to slightly oval in form; flesh very fine grained and rich in flavor, Per pkt., $5 \mathrm{c}$; oz., $10 \mathrm{c}$; $1_{4}$
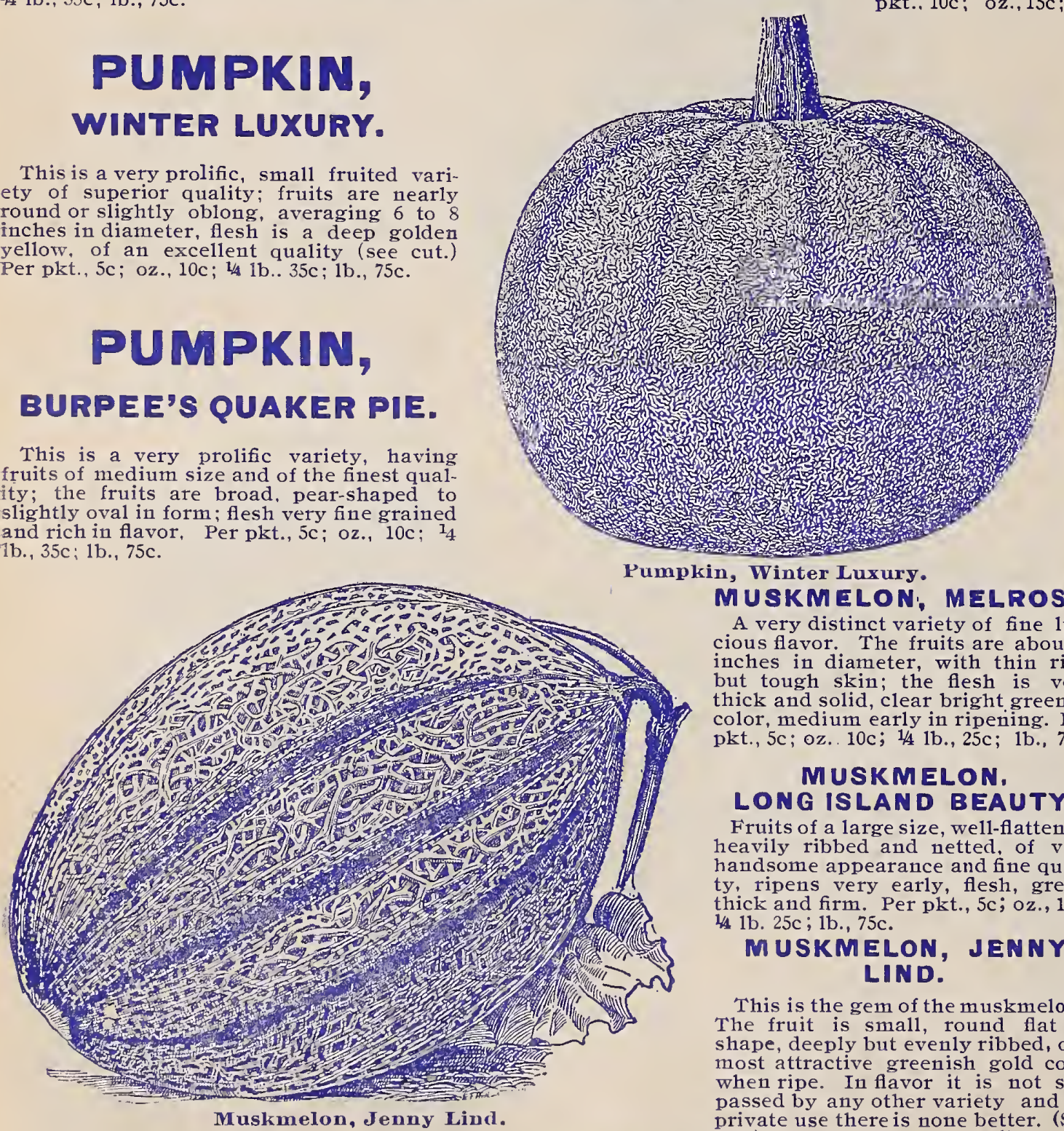

Pumpkin, Winter Luxury.

MUSKMELON, MELROSE. A very distinct variety of fine lus cious flavor. The fruits are about 6 inches in diameter, with thin rind but tough skin; the flesh is very thick and solid, clear bright green in color, medium early in ripening. Per
pkt., $5 \mathrm{c}$; 0z. 10c; $141 \mathrm{~b} .25 \mathrm{c}$; 1b., $75 \mathrm{c}$.

\section{MUSKMELON.}

LONG ISLAND BEAUTY. Fruits of a large size, well-flattened,
heavily ribbed and netted, of very handsome appearance and fine quality, ripens very early, flesh, green, tha lb. 25 ; $1 \mathrm{bm}$. Per pkt., $5 \mathrm{c}$; oz., 10c MUSKMELON, JENNY LIND.

This is the gem of the muskmelons. The fruit is small, round flat in shape, deeply but evenly ribbed, of a most attractive greenish gold color when ripe. In flavor it is not surpassed by any other variety and for private use there is none better. (See
cut.) Per pkt., 5c; oz., 10c; 14 1b., 30c.

\section{RADISH, NEW TRIUMPH.}

It is very early, being a 20-day radish, almost perfectly round with a very short top The flesh is very crisp, solid and of a mild striped horizontally with bright scarlet: striped horizontally with bright scariet; some of the roots are peppered with crimmay be grown either in the open ground or under glass. Per pkt., 10c; oz., $15 \mathrm{c}$.

\section{RADISH, WHITE ICICLE.}

This radish derives its name from the transparent whiteness of the root. When grown in the open ground it is quite early while the roots continue brittle, crisp and solid until they are fully as large as those of the Long Cardinal; it is very desirable for the home garden. Per pkt., 10c; oz., 15c.

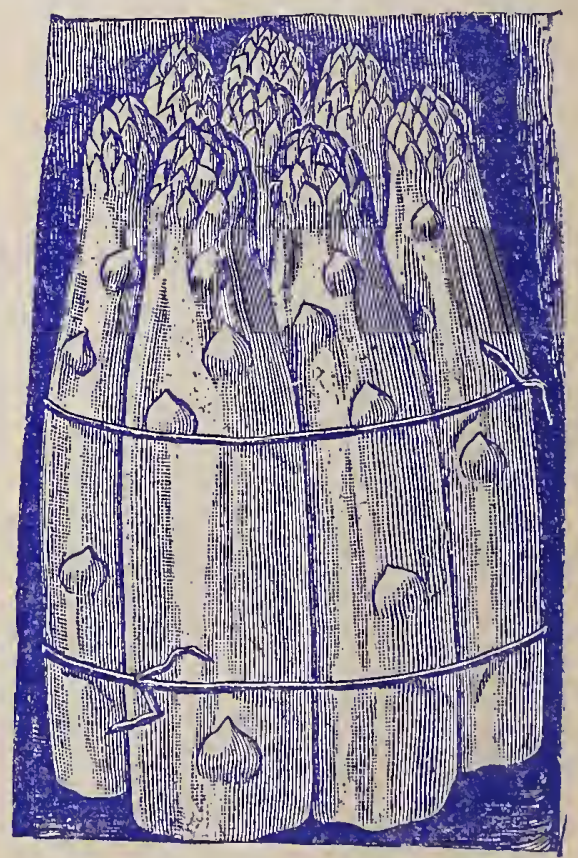

Asparagus, Columbian White.

NEW ASPARAGUS, COLUMBIAN WHITE.

An entirely new and distinct variety that produces fine white shoots, which are tender and of fine flavor. It is of very vigorous and robust
growth. This variety does not require any earthing up as in the green sorts in order to have the shoots white. (See cut.) Per pkt., 10c; oz.. 15c, 


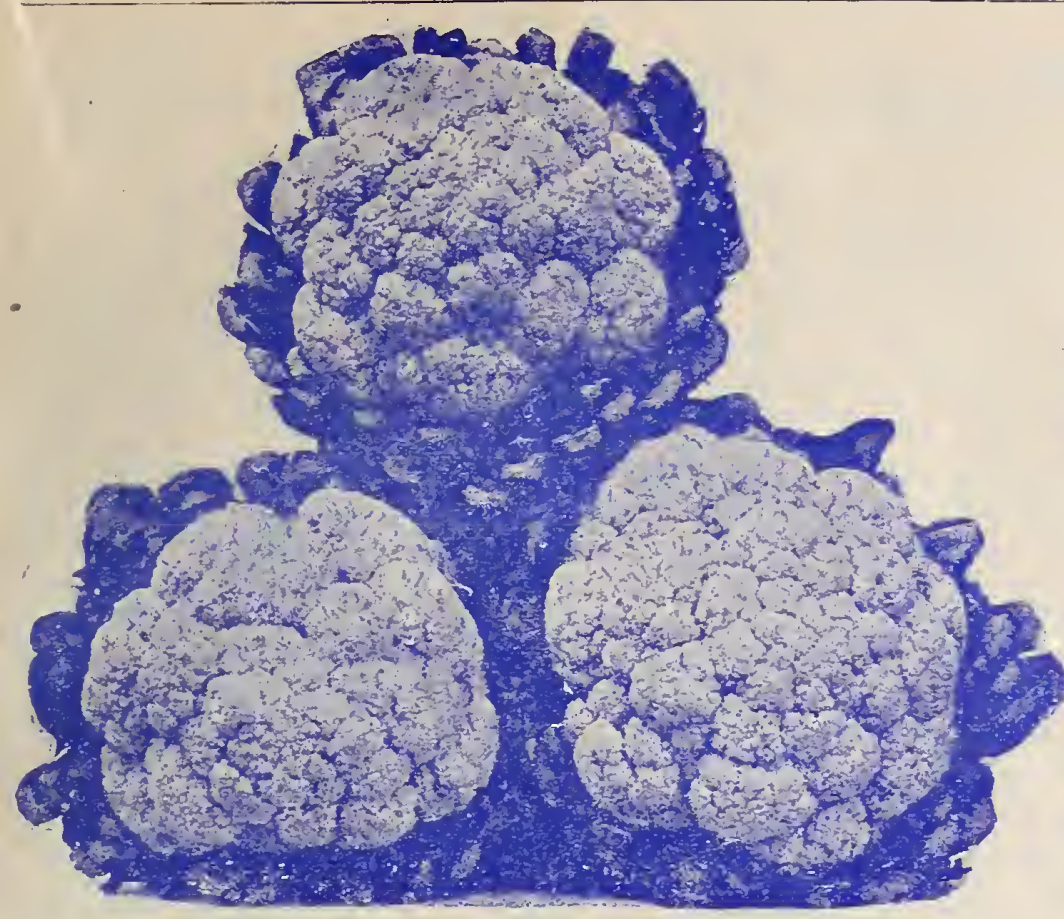

CAULIFLOWER-LATE METROPOLE.

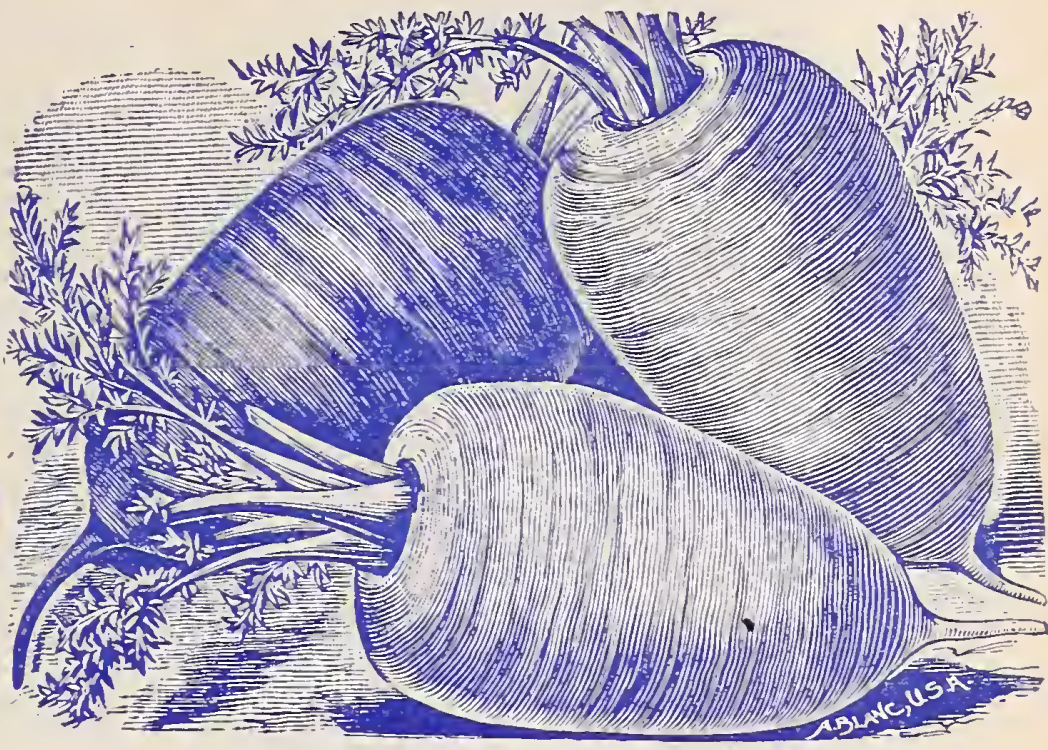

CARROT-NEW GOLDEN.ROD.

\section{Cauliflower}

Late Metropole.

This is a very fine strain of Cauliflower. Has an excellent shape and grows to an enormous size and is distinguished by its great tender ness, delicate flavor and extreme whiteness. When well cultivated 12 inches and average 12 to 15 pound each. It requires a strong soil on account of its weight.

Per pkt., 15c: 1 oz., $\$ 1.00 ;$ oz., $\$ 3.50$.

\section{Cauliflower}

\section{Dry Weather.}

This new strain originated in Den mark, but has been fully tested in America, with the most happy re sults. It produces a large, solid, pure white head. It is in all respects a first-class cauliflower, but is especi1ily and peculiarly adapt

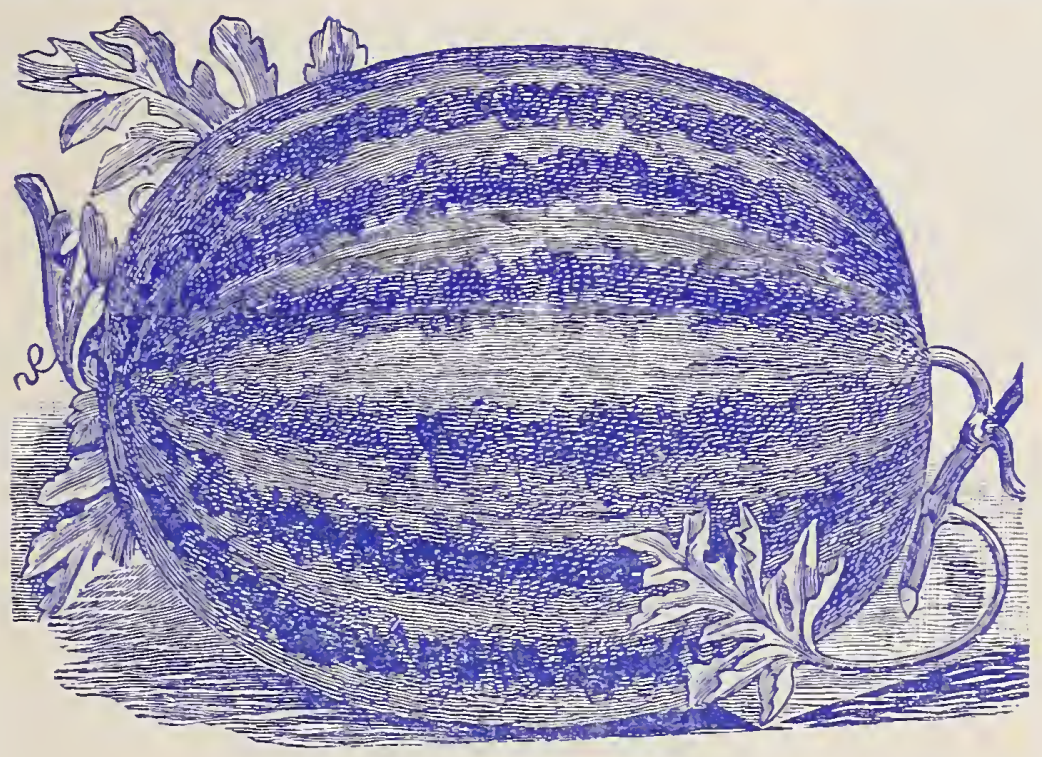

WATERMELON-MCIVER'S SUGAR.

\section{CARROT} New Colden Rod.

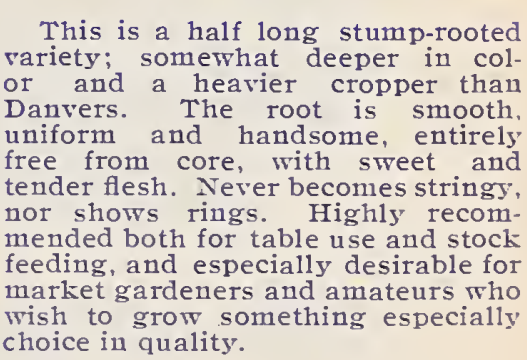
Pkt.. 10c; oz., 25c; 1/4-1b.

\section{CARROT}

\section{NEW GIANT} INTERMEDIATE. situations and to resisting the effects of droughts. It will not thrive in poor soil or under bad treatinent, as like all other cauliflowers it requires manure and culture; but it will succeed with less rainfall than any othe

Pkt., 15c; 1/4 oz.. \$1.00 ., oz $\$ 3.50$

\section{WATERMELON}

Now Mammoth santiago.

This plant grows uniformly large and long, being distinctly barre shaped, retaining the same thickness throughout the entire length with blunt rounded ends. This melon will grow in a favorable location 2 feet long by 12 to 14 inches in diameter, weighing 48 to 50 pounds. The flesh is a deep blood red color, very
acter, free from stringiness.

Per pkt., 10c; oz., 20c; $1 / 4$ 1b., 40c; 1b., $\$ 1.25$

\section{WATERMELON}

\section{Mclver's Sugar.}

This melon is oblong in shape and large in size, quite handsome in appearance and the quality is superior. The flesh is of a soft, pale pink and free from any stringiness. It is quite juicy.

Per pkt., 5c: oz., 10c; 14-1b., 20c; 1b., 75c.

\section{E G C PLANT Black Beauty.}

This variety is from 10 to 12 days earlier than New York improved. The fruits are broad, thick and almost black. The skin is rich and lustrous and the color does not fade or change any on the plant. The fruits set most freely and are ready for the market early, so that the crop can
be gathered before there is danger of frost. A fine market variety.

Per pkt., 10c; oz., 30c.
This variety is uniform in shape and where the soil is favorable it ields abundantly.

Per pkt., 10c: oz., 25c; 1/4-1b.. 75c. free from any coarse rank flavor. For table use it is unexcelled and

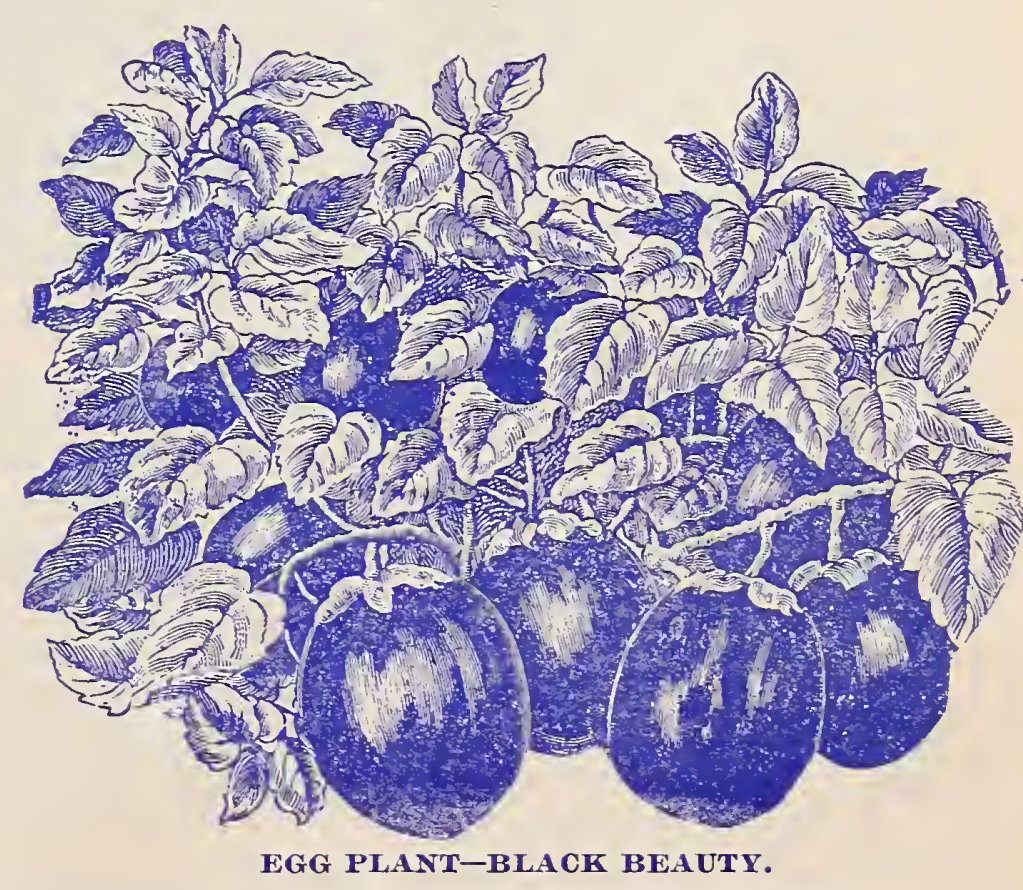




\section{Youngs Flower Seed Novelties and Specialties for 1904.}

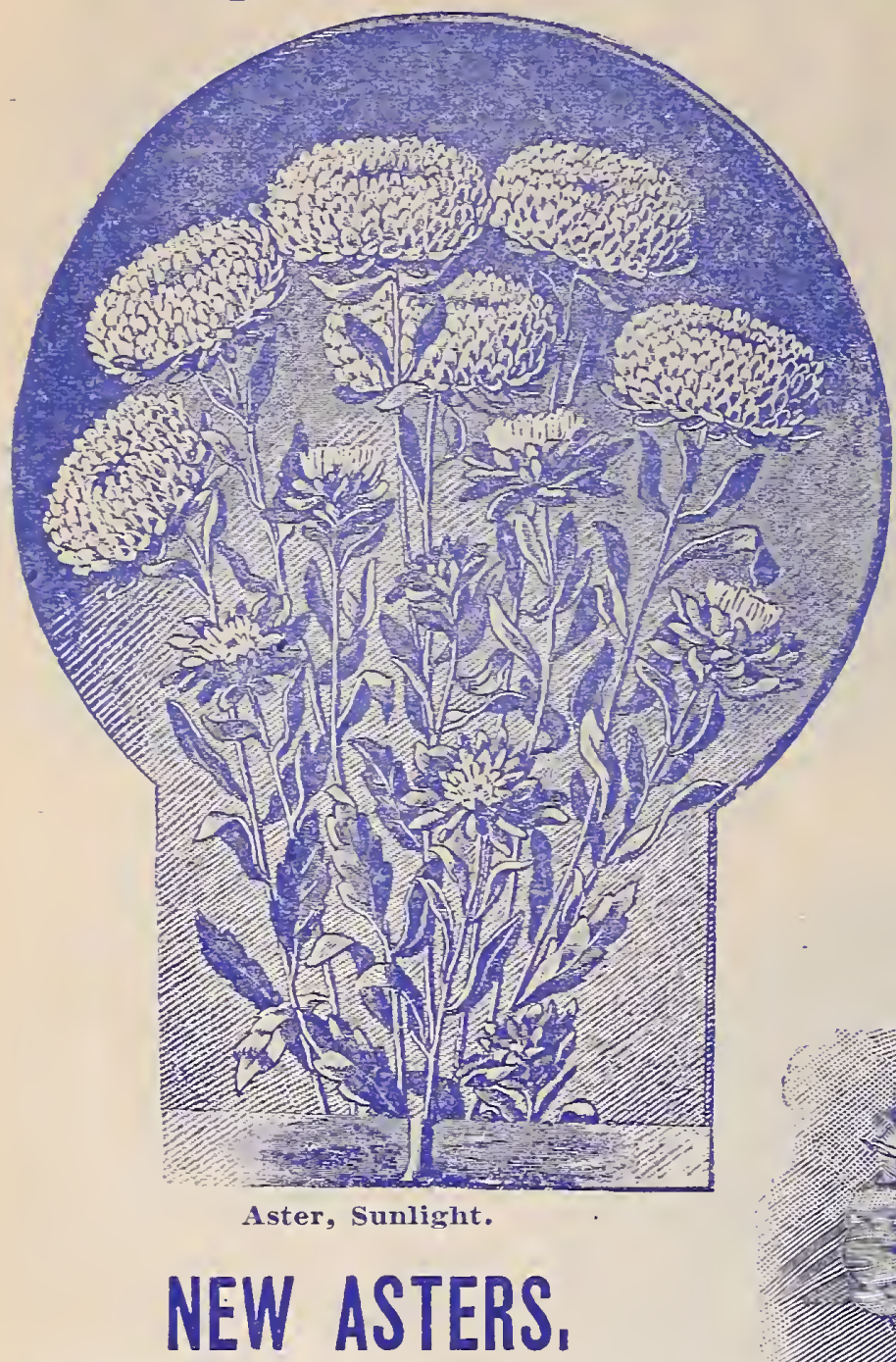

SUNLIGH'T-This is quite a novelty in asters, as it is a true sulphur yellow, a color not often met with in asters. It has long stiff stems and the flowers are 2 to 3 inches across. A good bedding variety. (See cut.) Per pkt., 10c.

JAPANESE-A beautiful type of aster, striking and distinct, and continues a long time in flower Thich is of an immense size. often mes suring 5 to 6 inches across, with long petals, cur jusly waved curled, so as to give them a stilking resemb lance to the most gorgeous Japanese Chrysanthemums. They grow 14 to 15 inches in height and are well branched. Mixed colors; per pkt., 10c

DAYBREAK-This is a magnificent variety, either for bedding out doors or for cut its perfect globe-shaped flowers are of a beautiful shell-pink color, similar.to that of the

\section{Semple's Large Flowering Branching.}

These varieties are superior to any other class of branching Aster, the flowers grow "ery large and double, often measuring four inches in diameter. They are borne on long stems, making them excellent for cuttiug. The long broad petals are frequently curled in such a manner as to give the blossoms the appearance of Chrysanthemums White - 10c Crimson ....................................

One packet of each of the five distinct colors for $45 c$, by mail postpaid.

\section{Japanese or Christmas Pepper.}

A very hadsome dwarf growing "plant which is entirely corered, in October, with a small fruit of a brilliant red color. It is of very easy culture. The seed may be sown in treated as a house plant, they are very attractive all winter. as the fruit does not drop off treated as a house plant, ther

\section{Salvia Splendens Silverspot.}

The most distinct feature of this novelty is its strikingly handsome spotted foliage. The leaves are rich, soft, dark green, with a light sulphur cream-colored spot of various

For a Select List of Flowor Seeds, see pages 37 to 50; Novelties, 28 to 36.

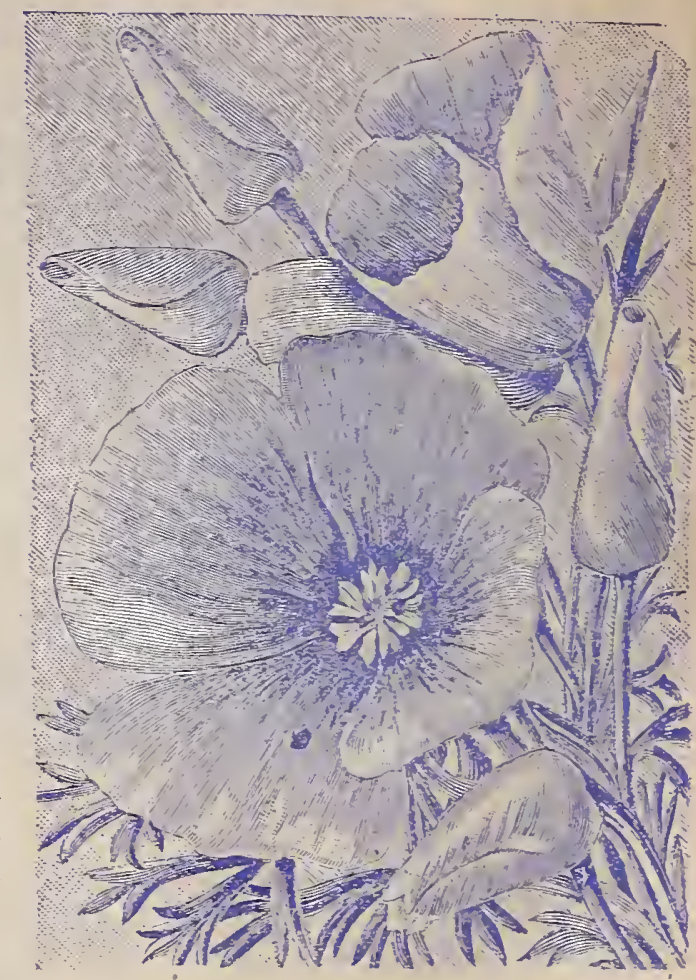

Eschscholtzia, Golden West.

\section{ESCHSCHOLTZIA.}

Golden West-The flomers of this variety are exceedingly large, often measuring 4 to 6 inches iu diameter. Color, a light canary yellow, with an orange blotch at the base of eacli petal. It is of a very easy culture, thriving well in the open ground, and flowering contiuually the entire summer, which is quite a norelty in a yellow flower (see cut). Per pkt., 5c.

BUSH-This grows into a bush, 2 feet high, with beautiful foliage; the flowers are cupshaped, borne on long stems, and a clear bright yellow color. When seed is sown early in spring they bloom in July, and continue until killed by frost. The flowers keep a long time iu water after being cut. Per pkt., 10c.

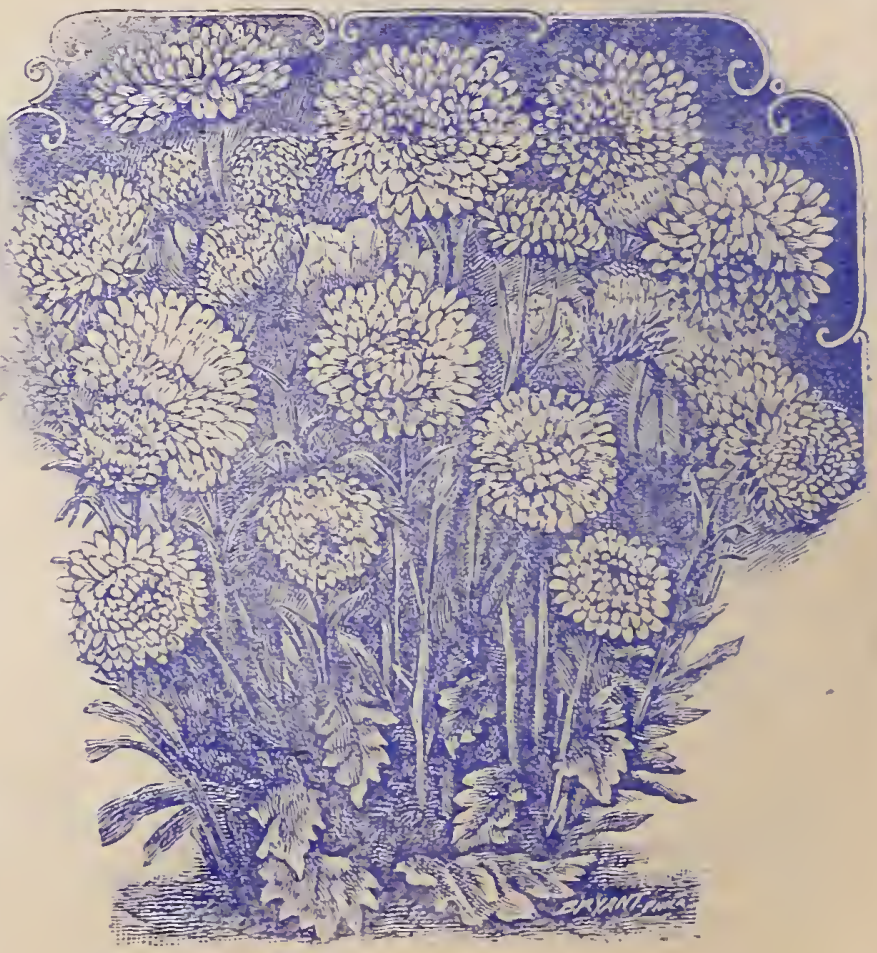

Aster-Semple's Large Flowering Brancling. 


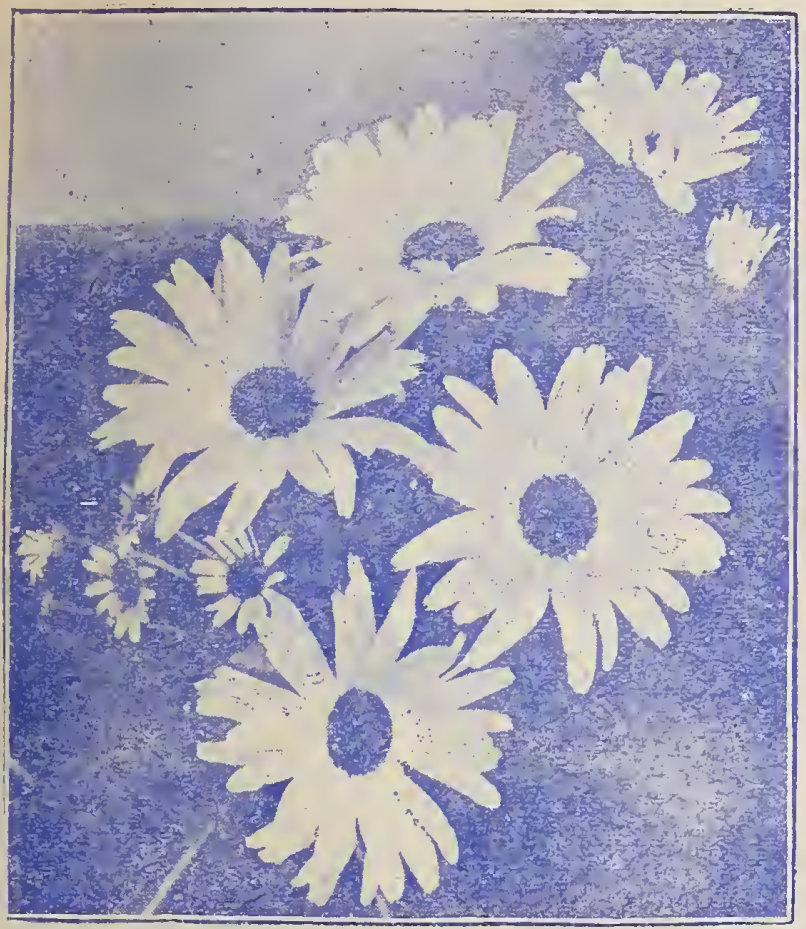

Shasta Daisy.

\section{LARKSPUR,}

\section{ELATUM HYBRIDUM NANUM.}

This variety grows from 3 to $3 \frac{1 / 2}{2}$ feet. They are of candelabra habit and produce extra large flowers in all shades of blue-from the lighest shades to the deepest indigo. A bed of this variety makes a fine show when in full flower. They bloom the first season from seed (see cut). Per pkt., 15c.

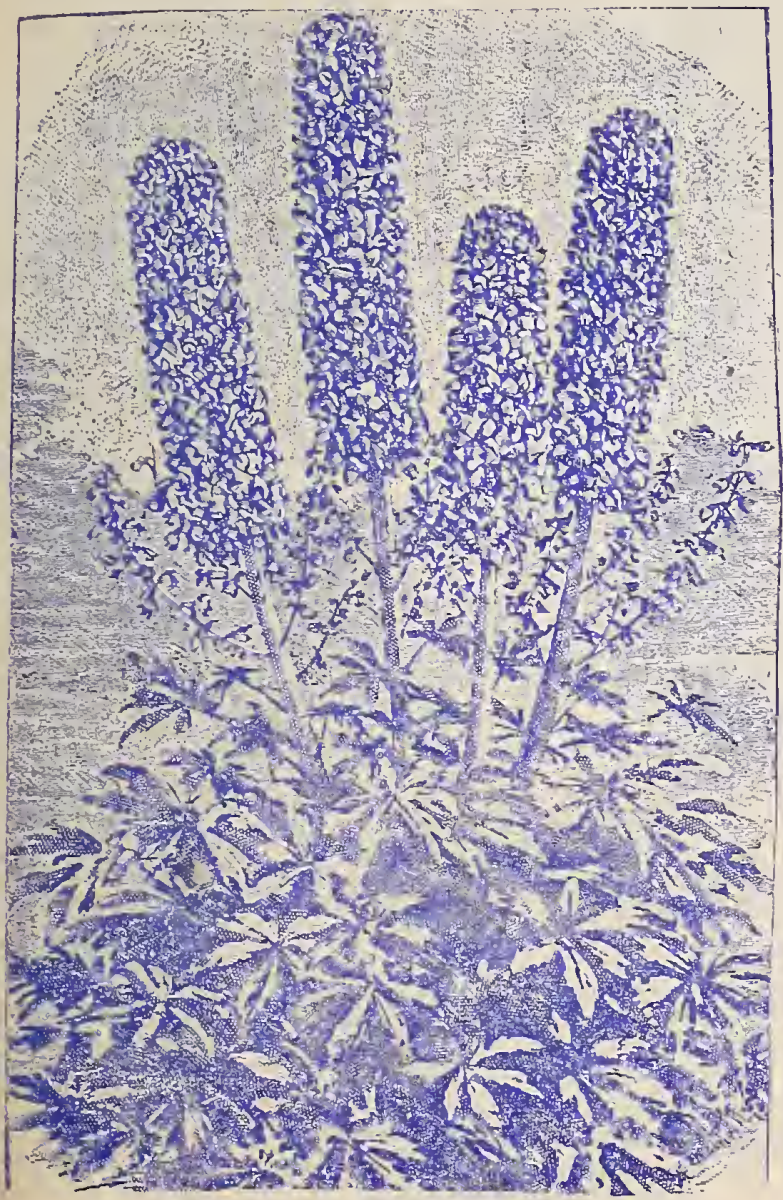

Larkspur, Elatum Hybridum Nanum.

\section{FOR-GET-ME-NOT.}

GRACILUS ALBA

(White Variety)

This is an elegant variety. The plants grow very dwarf and dense, and are entirely covered with snow white blossoms. A very profuse bloomer (see cut). Per pkt., 15c.

\section{FOR-GET-ME-NOT,} WATER FAIRY Or FAIRY EYE.

A new, ever blooming Myosotis, of a strong, vigorous growth; are of immense size; of a dark blue color, with a large, white center eye. It blooms readily from seed it is often in bloom in eight weeks from time of sowing. Per pkt., $15 \mathrm{c}$

\section{SHASTA DAISY.}

A new, hardy Marguerite from California, where it blooms contin ually all the year. It is perfectly hardy; the fowers are of the purest white. For garden decorations and cutting purposes it is of exceptional value. Per pkt., 20c.

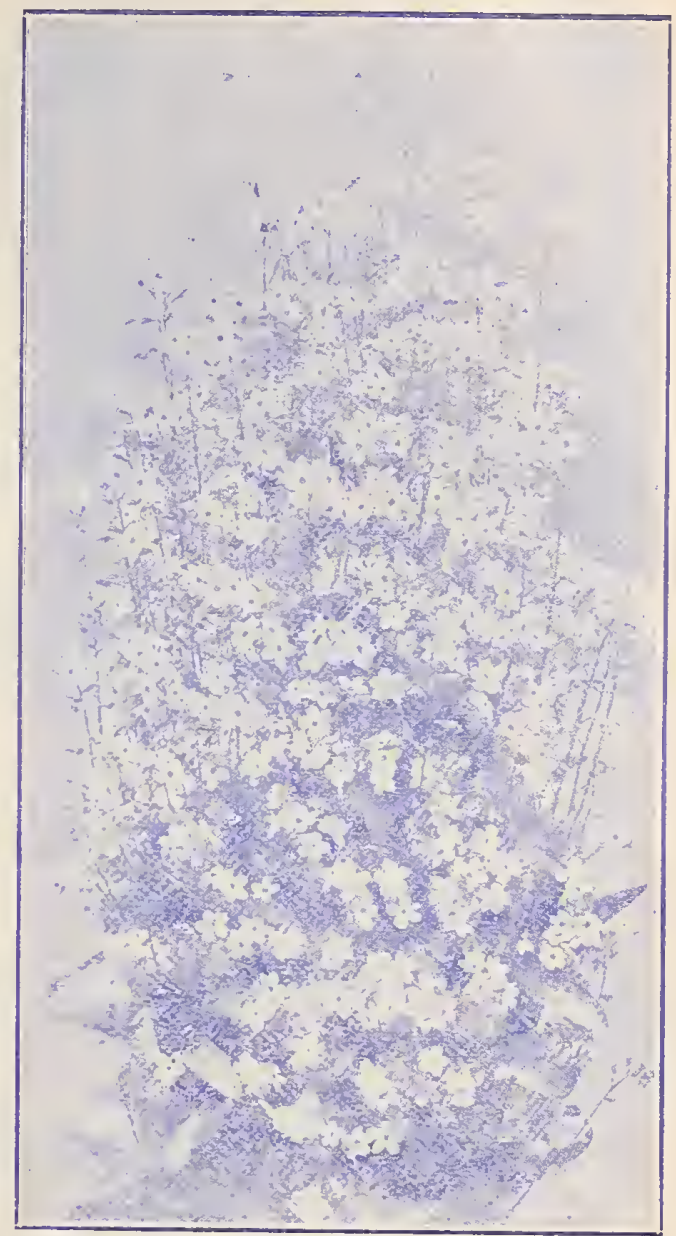

For-Get-Me-Not, Gracilus Alba.

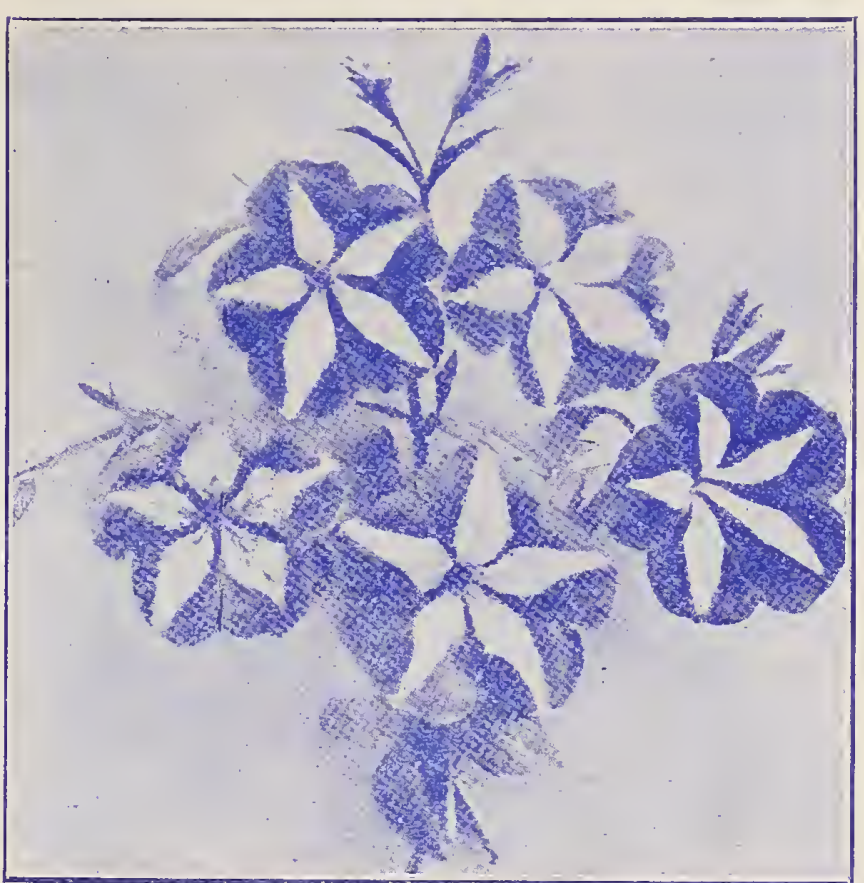

Star Petunias.

\section{STAR PETUNIAS,}

This new strain of Petunias is the result of many years of careful cultivation and is a great improvement on the other sorts. The flowers are a dark maroon and each one is distinctly marked with a five-point star which makes it quite showy. The plants branch freely and bloom most profusely. It is considered one of the best varieties of recent in troduction (see cut). Per pkt., 15c.
RUDBECKIA. BICOLOR

\section{SUPERBA.}

This variety represents semi-double or: nearly double flowering flowers, of a golden yellow to a brownish yellow color, thaving a central dark brown ring and disk. The plants grow about 2 to $2 / / 2$ feet high, and en. tirely well covered all summer until killed by frost in autumn. Per pkt., 15c.

\section{ZINNIA.} GIANT CRESTED.

The flowers of this variety are free from the stiffness of the older type; the petals being twisted, curled and crested into the most fantastic forms, which make $\mathrm{th}$ e quite distinct and at tractive. The color are of the most bril liant shades of red yellow, purple, pink and orange, which make them ver showy then planted outcoors in a border: fowering continually from June until kille by frost; mixed color 


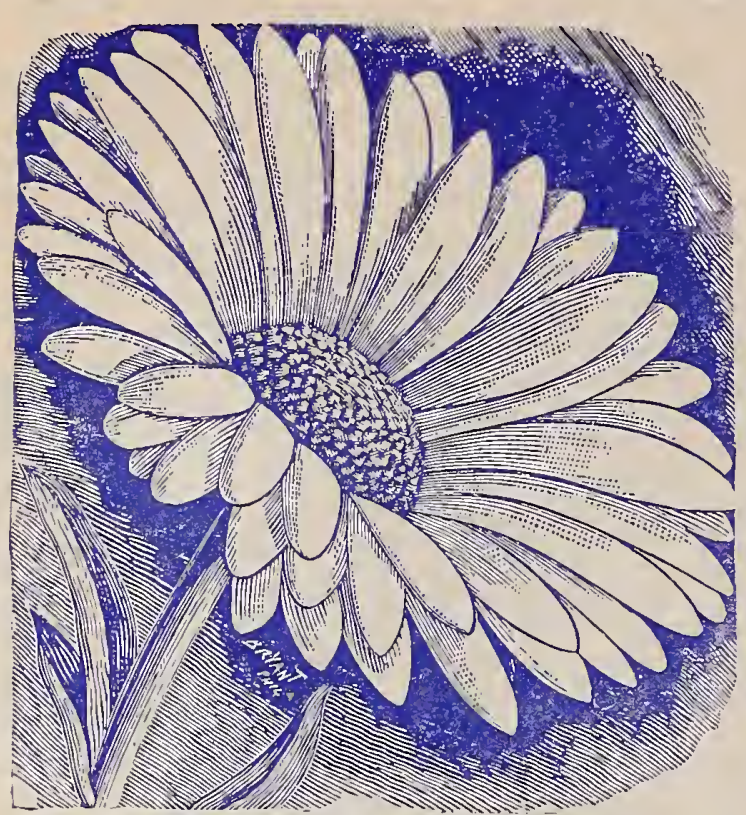

Chrysanthemum, Maxima Praecox.

\section{CHRYSANTHEMUM, MAXIMA PRAECOX.}

This variety flowers from two to three weeks earlier Than the summer flowering Chrysanthemum Marguerite and is a grand improvement. Of dwarf habit, forming compact bushes which are perfectly covered with pure white flowers. They are very lasting and a great novelty. (See cut.) Per pkt. $15 c$.

\section{COCKSCOMB}

(or Celosa.)

FLAME OF LOVE.

A splendid dwarf variety with immense ruffled combs like scarlet chenile. The depths are glowing orange scarlet. Per pkt., 10c.

\section{SPICATA.}

A beautiful garden annual in the erect pyramidal form growing to about 2,2 feet high and producing merous heads of everlasting flowers, 3 to 4 inches long. The color is light pink, changing into silver-white colors. (See cut.) Per pkt.,

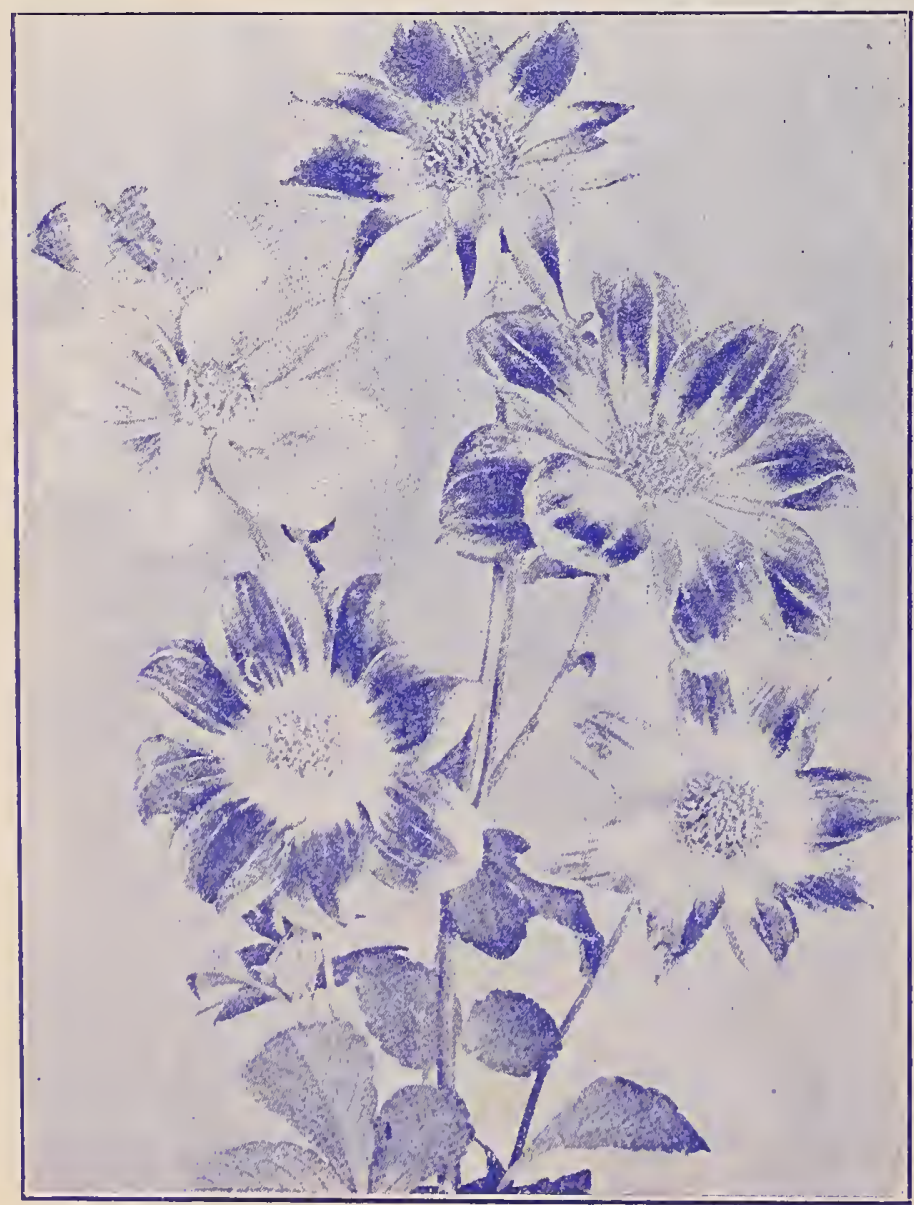

Dahlia, Twentieth Century.
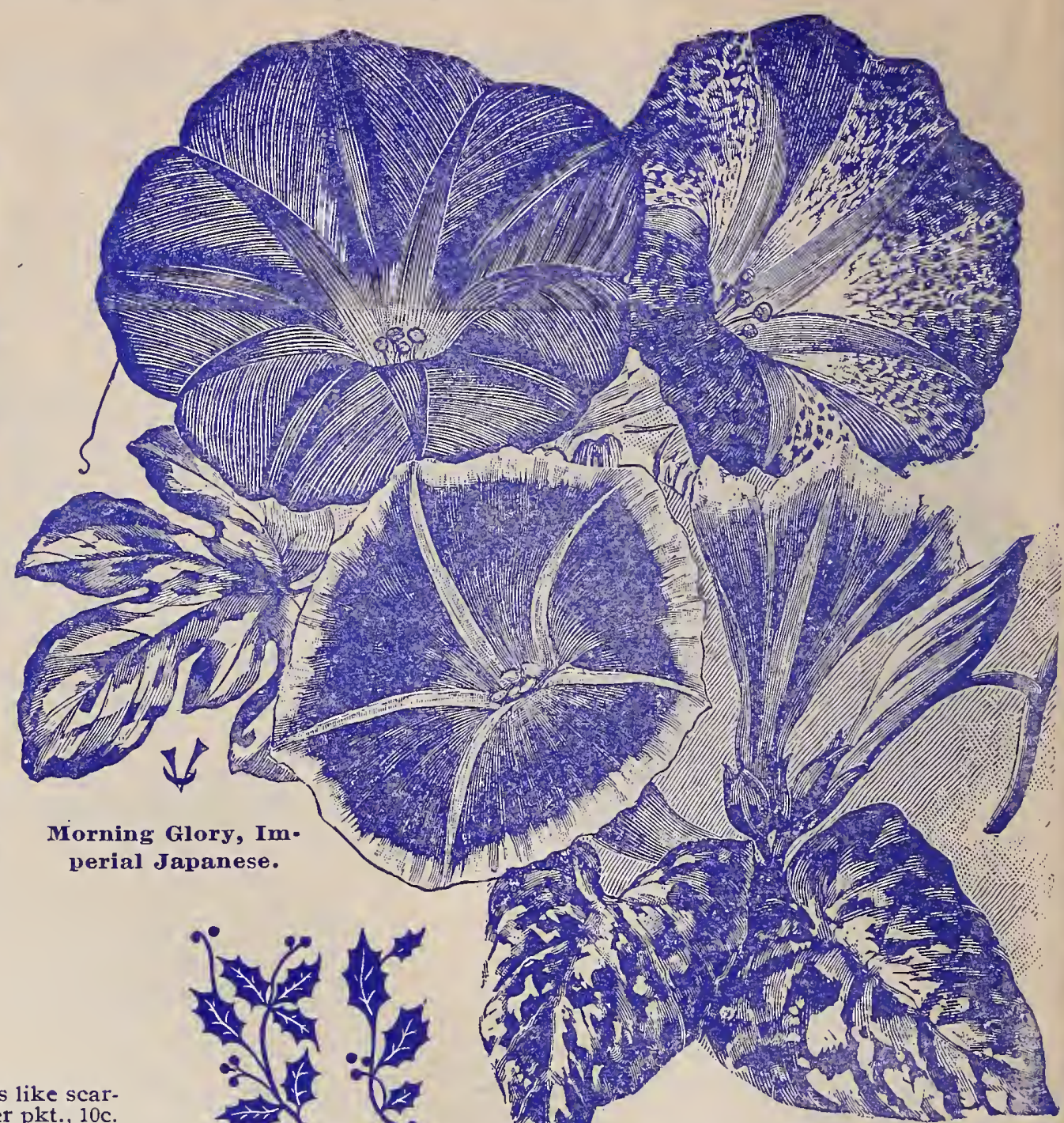

MORNING

GLORY.

Imporial Japanese, Mixed.

These are an improvement over the common varieties of Morning Glory, and whenever climbers are grown, these have a prominent place. They are of easy cul ture, and can be sown in the open ground, in a warm, sunny situation as soon as the weather is settled, and all danger of frost is past, being a very strong and rapid grower, they soon cover a large area; often attaining a height of thirt to forty feet. The varied forms of the fol iage are a decided novelty, the color and shadings of the flowers are beyond description. Our choice mixture contains nearly thirty distinct shades and colorings, ranging from deep rich purple to pure silvery white, while to many of these, the solid colors are beautifully bor dered in contrasting shades, and in others the coloring is diversified by rich tinged markings or spots of glowing colors.

Choice assortment of mixed colors. Per pkt., 10c; oz., 25c

IMPERIAL JAPANESE MIKADO -A superfine mixture of the ruffled and fringed sorts. Per pkt., $15 \mathrm{c}$; oz., $35 \mathrm{c}$.

Celosa Spicata.

\section{DAHLIA,}

TWENTIETH CENTURY.

This superb new class of Dahlias originated and developed after years of careful selecting and hybridizing. The plants are strong, vigorous growers of branching habit and grow about 4 feet high, bloom early and continue to flower intil killed by frost. The flowers are quite large, often measuring 446 to 6 inche diameter, color intense rosy crimson with white tips and a white disc around the yellow center. As the season advances the colors become lighter. A great acquisition to the Dahlia strain. (See cut.) Per pkt. 25c.

\section{MIGNONETTE.}

\section{RED GOLIATH.}

This variety is of strong growth, luxuriant foliage, spikes of flowers are immense. Per pkt., 10c.

FOR A SELECT LIST OF FLOWER SEeDS, SEe PAGES 37 TO 50; NOVELTIES, 28 TO 36. 


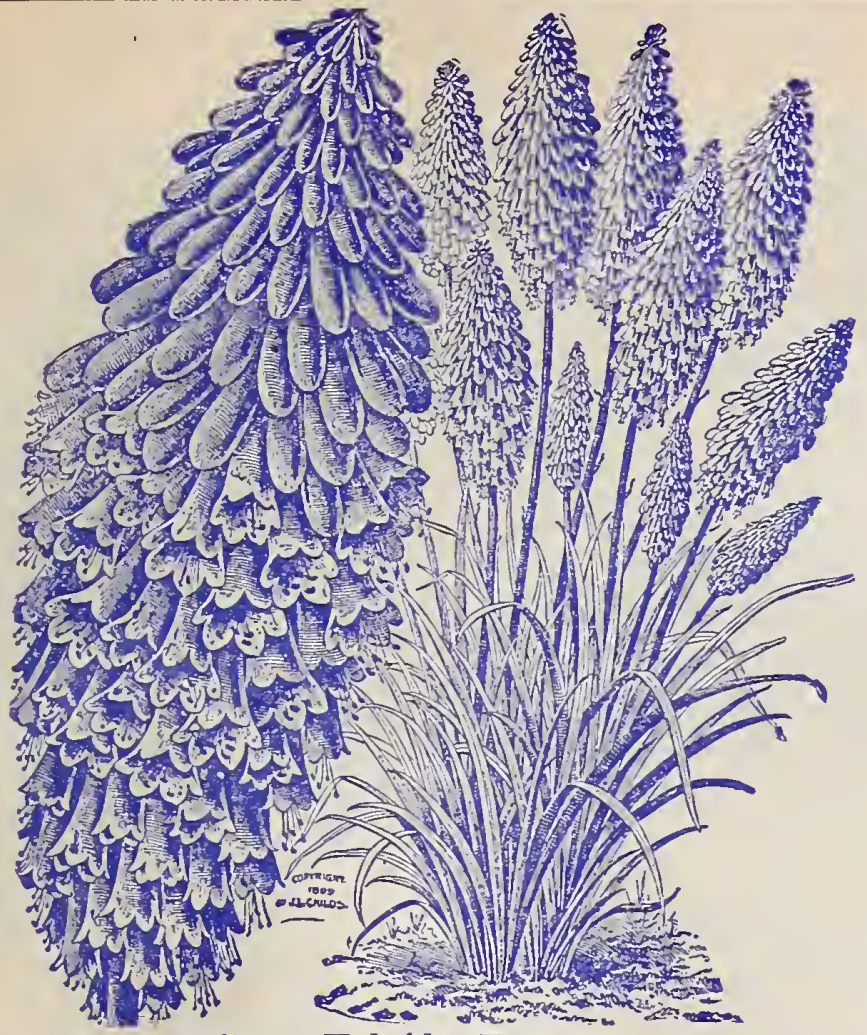

Tritoma Hybrida, Empress.

\section{NEW TRITOMAS.}

TRIUMPH-This is new variety rong grower; of branching habit at ase, throwing out two to three shoots if perfect but small heads of bloom xhich gives the plant a beautiful appearance. The color is a rich yellow which makes it quite striking. Per skt., 15c.

HYBRIDA EMPRESS - This is very attractive variety. It commences to bloom in June and coninues the greater part of the summer. The color varies from deep orange to carmine. It is easily grown from seed and blooms the first year if sown early. This variety is used a great deal for bedding and is a strong grower (see cut). Per pkt., 15c.

\section{NEW ANTIRRIHNUM}

\section{MAJUS PELORIA.}

This is a remarkably curious vaiety, which has upright tubular flowers. Color is white with garnet frill urrounding the mouth of the flowers. A very fine variety and a novelty in Snapdragon (see cut). Per pkt. 10 e.

ANTIRRIHNUM.

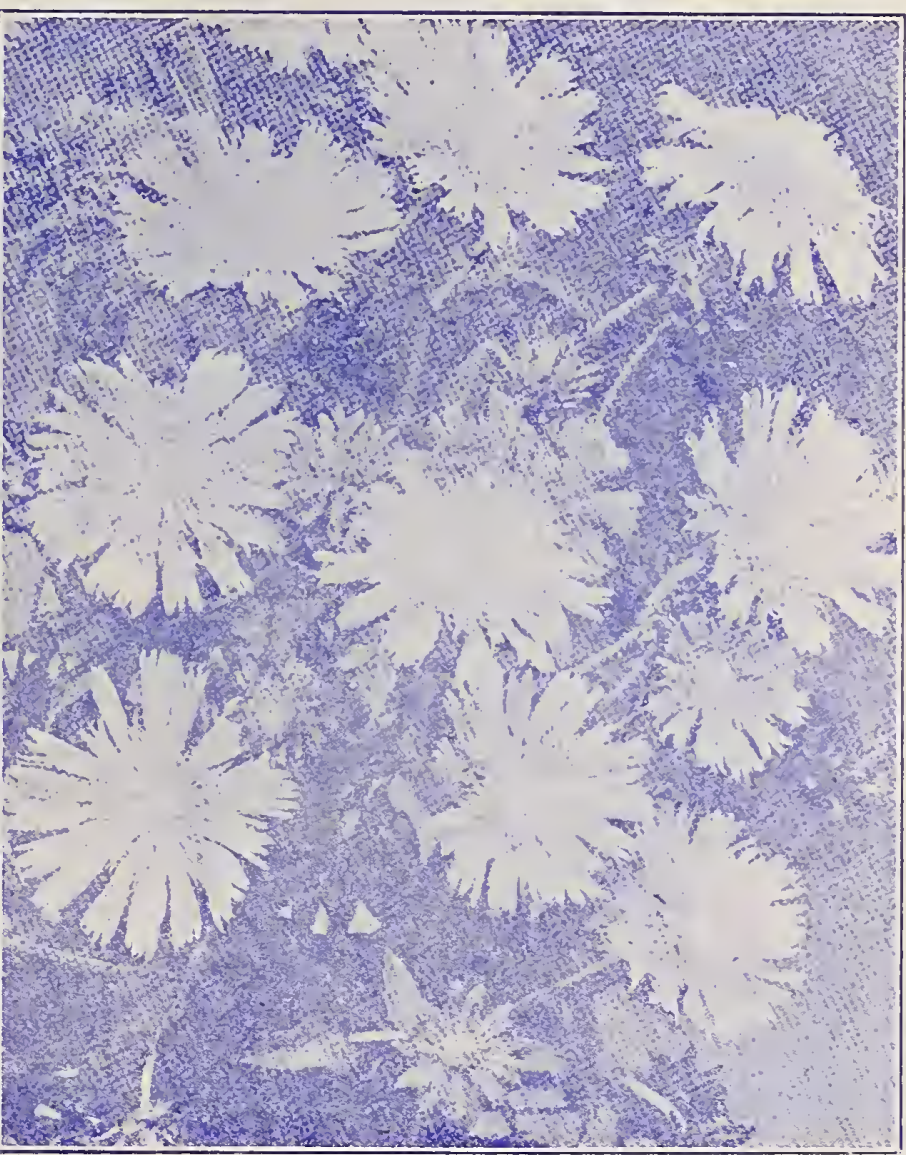

HELIOTROPE. MIDNIOHT. Dright, golden, star-like flowers distributed over the surface, The blooms are of rich golden yellow with the center of each petal marked broadly with velvety crimson-brown (see cut). Per pkt., 10c.

This variety has black stems and ery dark foliage. The flowers are a ery striking contrast in color, being variegated. light and dark purple and hite; very attractive. Per pkt., $15 \mathrm{c}$.

\section{STOKESIA CYANEA.}

This is a rare, beautiful, hardy perrenial; easily raised from seed and will flower the first year, if sown early. The plants grow about $24 \mathrm{in}$ high, each bearing 20 to 30 lavenderblue flowers It is in bloom from July until killed by frost, and is a choice variety for hardy borders and fine for cutting (see cut). See illustration on front page of cover. Per pkt., $15 \mathrm{c}$

\section{VERBENA.}

MAYFLOWER

This variety has all the character istics of the mayflower or trailing Arbutus, with the additional merit o possessing the same lorely and delicate pink and white coloring, making the flowers closely like the Arbutus. with the sam

Stokesia Cyanea.

\section{MARAGOLD.}

\section{LEGION OF HONOR.} VARIETIES.

the size of the older sorts, and the flowers more closely set on the stem. For summer flower beds they are very showy and bloum the entire summer (see cut).

THE ENTIRE COLLECTION OF ELEYEN VARIETIES, BY MAIL POST-PAID, FOR $40 \mathrm{C}$

FIREFLY-A bright scarlet, orange and white. Per pkt., 10c.

CORAL RED-Very attractive color. Per

GLDEN QUEEN-Pure golden yellow.

BLACK PRINCE-A very dark maroon, nearly black. Per pkt., 10c.

FAIRY QUEEN-A light pink, quite hand-

DELLA-A beautiful carmine, spotted yellow and white. Per pkt., 10c.

LUTEUM-A bright canary yellow. Per pkt., 10c.
BRILLIANT-Striped scarlet, golden yel low and white. Per pkt., 10c.

GHESTI A-Color, dark blood red. Per pkt., 10c.

NIOBE-A new variety of the half dwarf sort. The tips of the flowers are of a velvety crimson maroon, while the tubes are pure white: the

QUEEN OF THE NORTH-Grows about one foot high and is densely covered with large, white flowers from July unti October. Per pkt., 10c.

For a Select List of Flower Seeds See Pages 37 to 50 ; Novelties 28 to 36 .

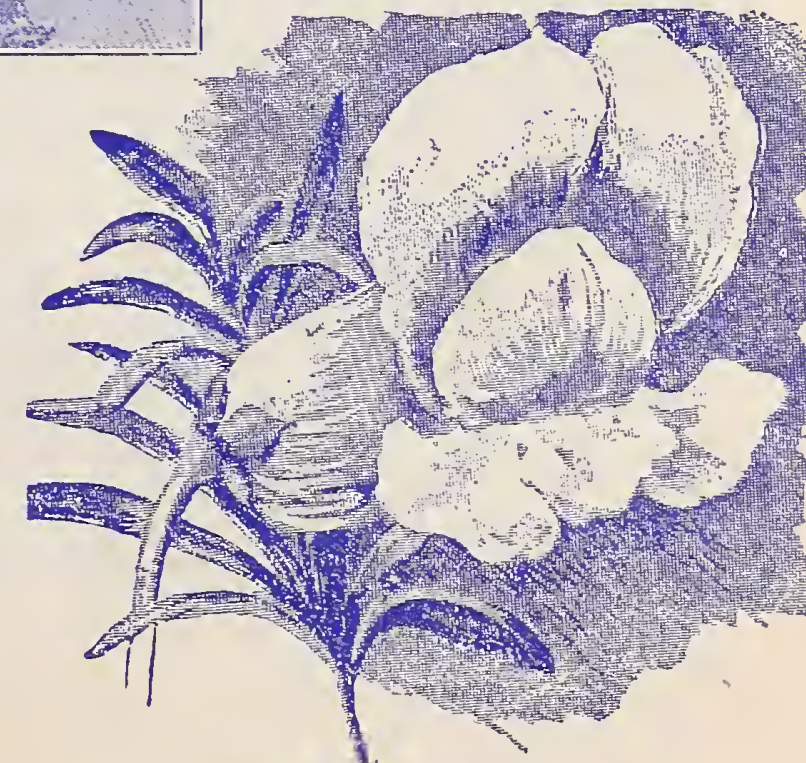

Antirrihnum, Peloria. 


\section{YOUNG'S NOVELTY GOSMOS,}

SCNFLOWER-A beautiful new variety, color golden yellow. The flowers measure 2 inches across, the plants are dwarf, growing only about two feet high and are a great improvement on the old yellow variety. Per pht., 15c

BLACK PRINCE-This is one of the showiest varieties we know of; color a dazzling red which makes the plant very attractive. Per pkt.. 15c.

TITANIA-The plants of this variety grow from three to four feet high, with fluffy flowers from 2 to 3 inches across, semi-double with irregular, lacinated petals of the purest white which are borne on slender stems in great profusion. Per pkt., 15c.

One packet of each of the three varieties, prstpaid, for $30 \mathrm{c}$

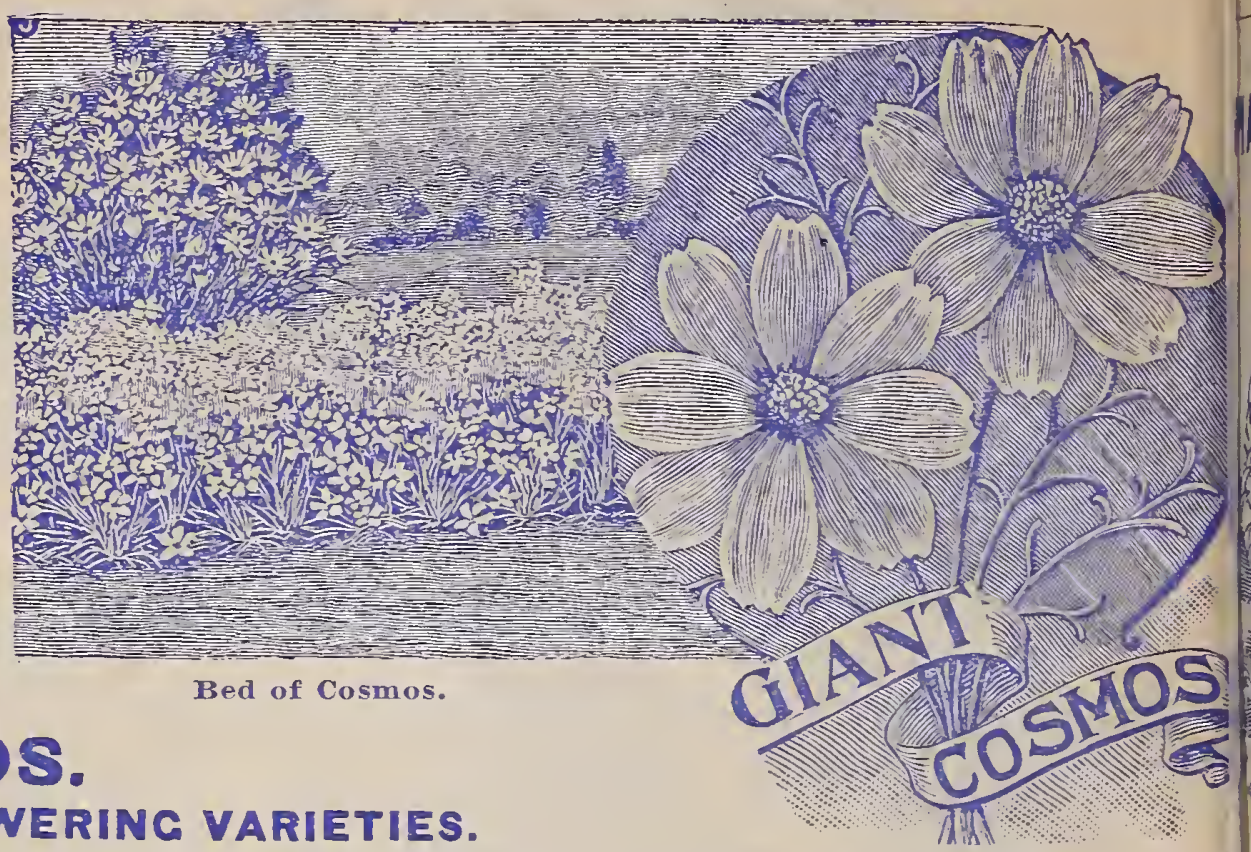

YOUNG'S MAMMOTH FLOWERING VARIETIES.

It is impossible to describe these exquisite varieties; they embrace many shades of crimson and mauve, pure white and tinted white; they a monstrous white flowers with flecked and pink edges, and pink flowers of the same type. (See cut.)

\section{PLATYCOOON JAPONICUS}

FL. PL.

(JAPANESE BELL FLOWER.)

This is a free, flowering variety with large glossy blue flowers. The inner petals alternate with the outside ones which makes the flower have the appearance of a star. It grows from 12 to 20 inches high and blooms from June until October. (See cut.) Per pkt., 10c.

\section{New California Poppy, ROSY OR'N.}

This is a fine novelty and one that deserves attention. It has rosy white petals which are delicately fluted with folds coming from the center and adorned with a light yellow. We think this will do well wherever planted. (See cut.) Per pkt., 15c.

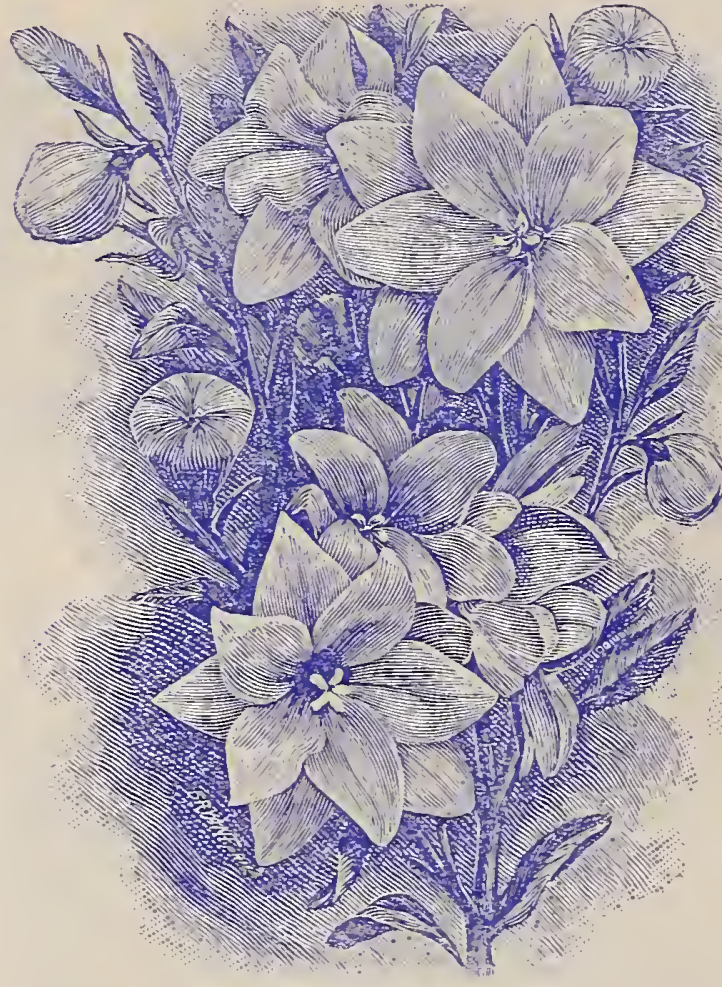

PIatycodon Japanese FI. PI.

MARGUERITE-One of the prettiest and dai tiest varieties imaginable, the flowers measure frc irregularly lacinated or fringed.

CHARMAIN - A large flower of perfect for color pure bright pink, very large, wide open flo ers, overlapping petals; the eye is encircled by rich red ring. Per pkt., 10c.

WHITE POND LILY-A lovely flower wi large, plain edged petals, so beautifully formed to remind one of a small Pond Lily. The flowe are pure white, borne on long stems; of a dwa bushy habit, growing about 4 feet high. Per pk

PINK BUTTERFLY-A magnificent variet the richest and loreliest shade of pink imaginab the flowers are very large, measuring $3 / 2$ to 4 inch across; the flowers are borne on long stems. P

DAWN-This is a very early flowering variet commencing to bloom in July and continuing isom the entire summer until killed by frost. to 5 a dwarf, compact growth, very bushy, about to 5 feet high. Flowers are of good size, the colo the petals.

The above 5 varieties of Cosmos one packet of ea by mail, postpaid, for $35 \mathrm{c}$.

COSHOS, GIANT EARLY FLOWERING.

These have been selected from all the large and best early flowering varieties; the colors are all shades of white, pink and red.

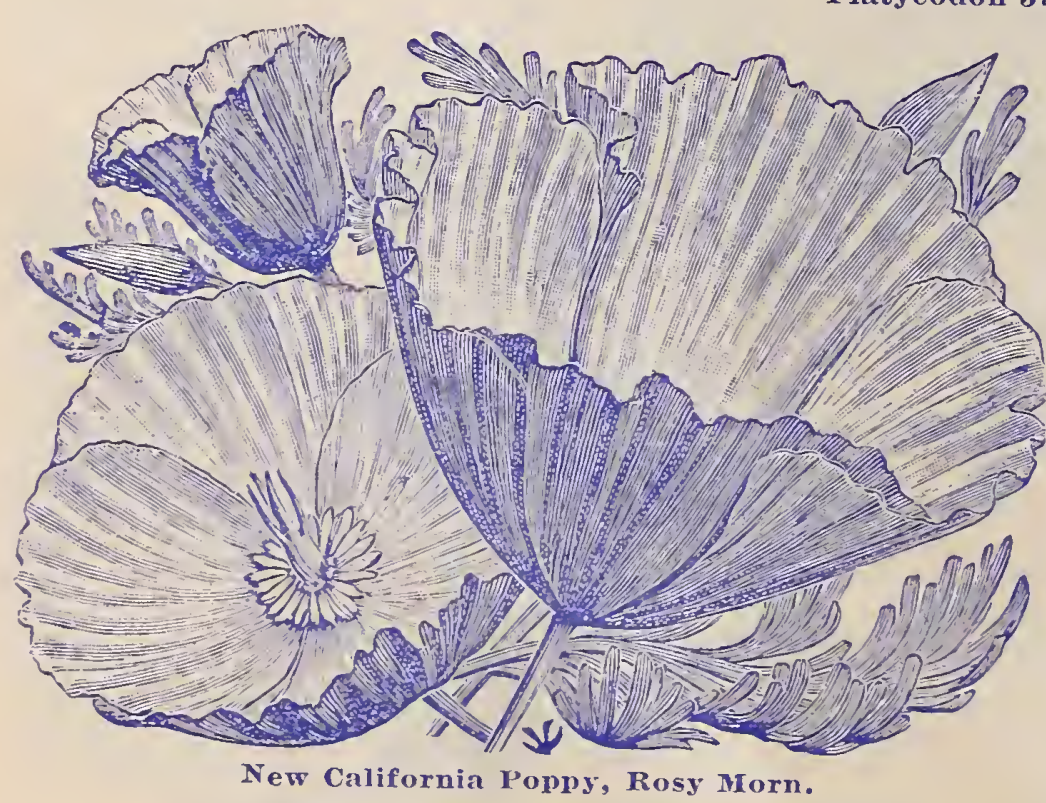

\section{POPPIES.}

YOUNG'S COLLECTION OF GIANT FLOWER ING VARIETIES.

MISS SHERWOOD-The flowers measuring from 4 to 5 inches in diar eter, and are of pure white satiny color, shading toward the margin into salmon rose. Per pkt., $15 c$.

FRINGED ACPINE-The plants form rosettes of pretty grey, gret foliage, not over 4 inches high, and throws up numerous slender flower stall beang fin stems. T

FAYAL-This is a very heatiful strain of single and double poppie and of an exceedingly strong growth. The colors of the flowers are of eres conceivable shade of red, pink, maroon, white self and variegated. Per pkt. il

STRIPED ICELAND-The flowers are striped, yellow on a bright round, which makes them very attractive. Per pkt. 10c.

MAID OF THE MIST-A magnificent single, peony-forrered whit poppy. Flowers often measuring 3 to 4 inches across, borne on long stem Per pkt., 10c.

IRRESISTIBLE-This is a very strong growing variety, often attainin height of 4 to 5 feet. The flowers are very large, color a bright pink, wit
petals fringed and tinged with white. Per pkt., 10c.

The entire collection of six varieties, one package of each variety, for 50 cents by mail, postpaid. 


\section{ARGUERITE GARNATION.}

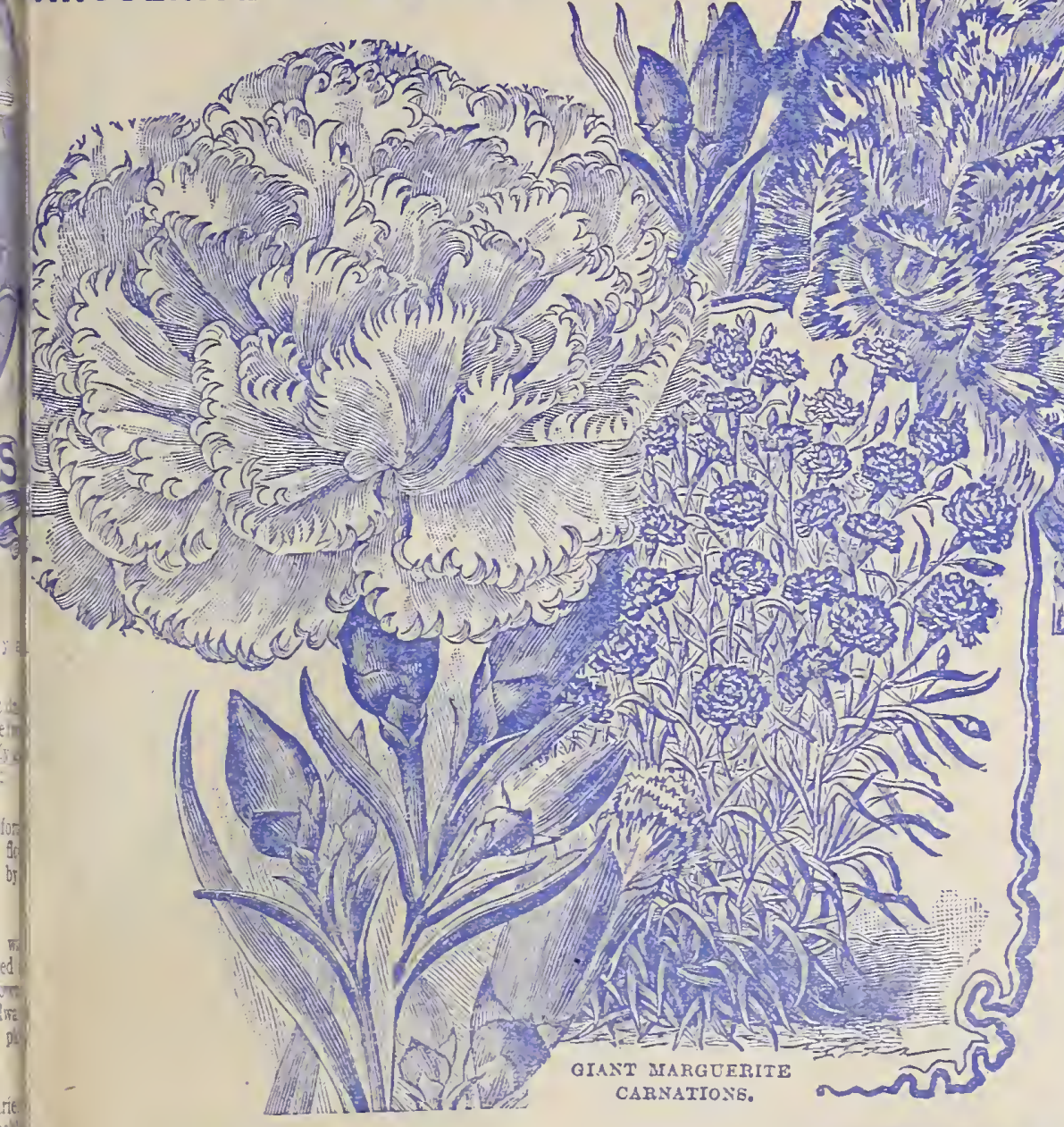

\section{DELPHINIUM.}

\section{BLUE BUTTERFLY}

his is a very attractive anmual, of a dwarf com bushy habit, rarely exceeding 1 foot in height mer dinthe foliage, and bearing during thi itramarine blue, a color that is seldom seen iltramarine blue, a color that is seldom seen in cut). Per pkt., $15 \mathrm{c}$

\section{ARCTOTIS GRANDIS. \\ (THE AFRICAN LILAC DAISY,}

remarkable handsome annual from South-west rgesca, growing luxuriantly and forming profusely ies of about 2 to $2 \frac{1}{2}$ feet in height and breadth. leaves are soft and whitish; the flower head jorne on long stems and rising well above the ss; the florets are pure white on the upper surand are embellished by a narrow, yellow zone mer until autumn. Per pkt., 20c.

\section{SUNFLOWERS.}

\section{CUT AND COME AGAIN.}

The plants of this variety form many branched pyramidal bushes 3 to 4 feet high, and - from base to summit, a continuous succession of flowers from June until killed bj Th $t$. The flowers are single, 3 to 4 inches across, on long, stiff stems and are easily grown 1 seed in a few weeks. Mixed colors. Per pkt., 10c.

Dief ORION-The petals of the flowers are curled and twisted very much like a single mese chrysanthemum. It is of very easy culture and continuous bloom, which makes ssirable to grow when flowers are wanted for bouquets. Per pkt., 10c.

DOUBLE WHITE-A very dwarf variety, seldom attaining the height of 4 feet; of hits shing habit; flowcrs very double, of a creamy white color. It is in bloom continually ems n July to November (see cut). Per pkt., 10c.

PERKIO-A new dwarf growing variety, attaining a height of about 3 feet: flowers, $2 \frac{1}{2}$ inches across, of bright yellow color, borne on very long stems; very useful for cut rers as they bloom the entire summer, thriving well in any location. Per pkt., 10c.

DIADEM-The flowers of this variety are a beautifui shade of light yellow with a :k center. They are of great value as cut flowers. Per pkt, 10c.

The Full Collection of Five Varieties post-paid for 35c, 1e base; reverse of petals pale lilac. It is o
MARGUERITE CARNATION.

GIANT FLOWERINC.

These fragrant garden Carnations flower profusely the first year from are beautifully fringed. The great after sowing tho seed in the plants may be potted in the fall. and they will bloom in the house all dow with placed in a very light win-

GIANT WHITE

GIANT RED

GIANT ROSE

GIANT MIXED COLORS

The entire collection of four distinct

MARGUERITE CARNATION. TOM THUMB. fragrant, and generally the petals merit of this Carnation is that it and potted; they will then continue to bloom in winter. Mixed

\section{CENTUREAS.}

IKING OF BLLE BOTTLES-This

SAOTEOLENS

Sing

MHRGTERITE-1

$0+$ inches in diamet

to tented

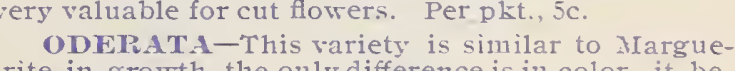

\section{GAILLARDIA GRANDIFLORA SEMI PLENA.}
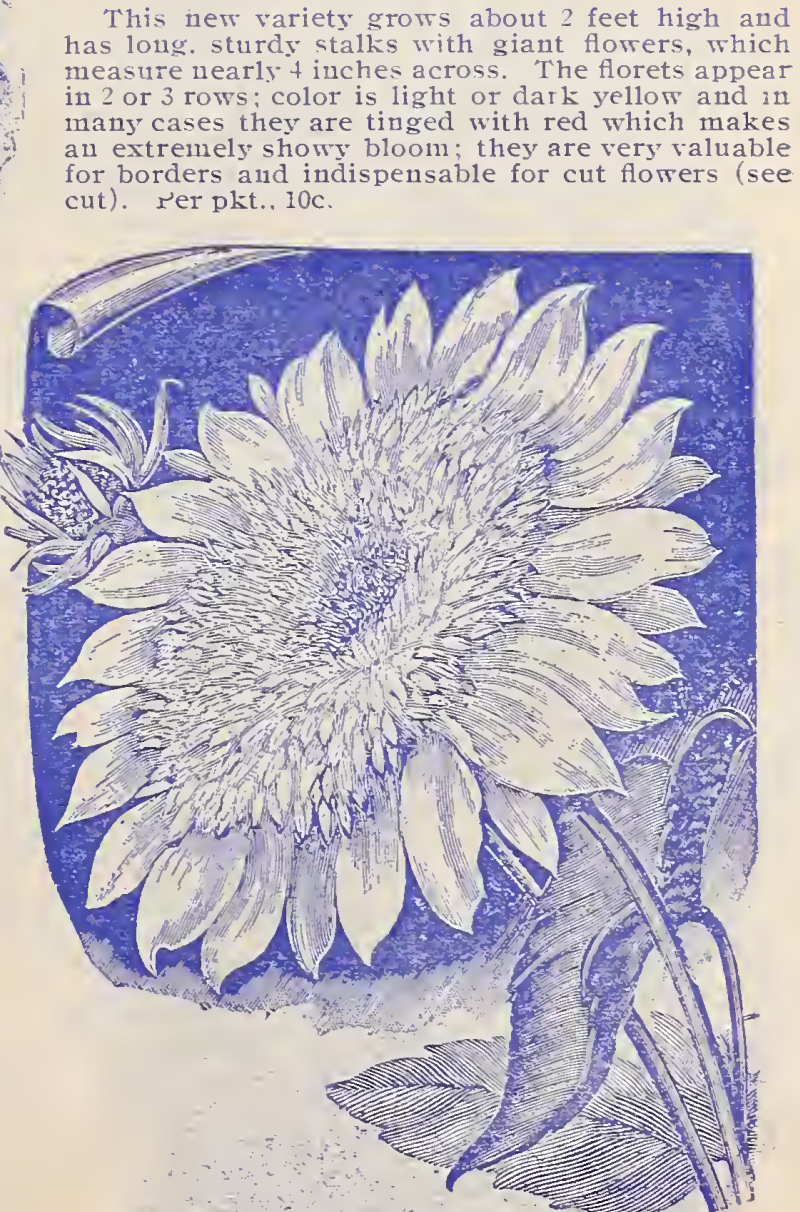

Sunflower, Cut and Come Again. 


\section{YOUNG'S NEW NOVELTY PANSIES FOR 1904.}

\section{PANSY PRINCE HENRY.}

This is a strong growing variety with flowers of ten measuring $34 / 2$ inches across. The color a blackish brown vein, blotched like the Bugnot race from PANST HERO. A fine strong growing variety both for bedding and for cut flowers. It has large and welltoward the outer petals. The plants are bushy and compact. Per pkt., 15c. PANSY PSYCHE.

The plants of this variety are perfect in habit and very floriferous. Each flower is elegantly curled and undulated, which gives it a very handsome appearance. It is a violet color, surrounded by a broad white edge. Per pkt., 15c. for 30 cents.

\section{YOUNG'S PANSIES.}

Eight distinct varieties, one package of each, for 60 cents.

$$
\text { RUBY. }
$$

Color, from scarlet, scarlet orange, wine red to rose. The flowers are exceedingly large, and BRIDESMAID.

The ground color is a delicate rosy white, rivaling in delicacy of color and beauty, the apple blossom. The center ot the flowers is regularly spotted with dark blotches to the center. Per pkt., 15c.

This variety differs from all other strains in the shape of the flowers, border of each petal being curled or waved, giving the flowers a double or globular appearance. Another feature of

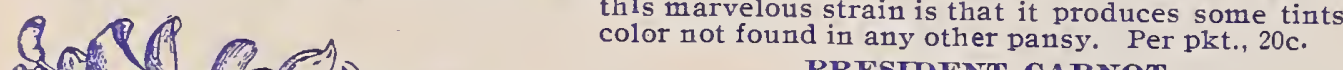
PRESIDENT CARNOT.

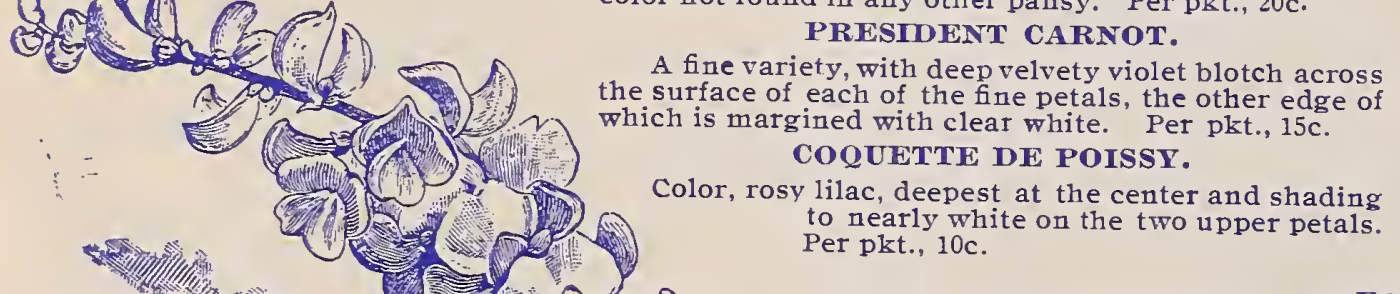

FAIRY QUEEN.

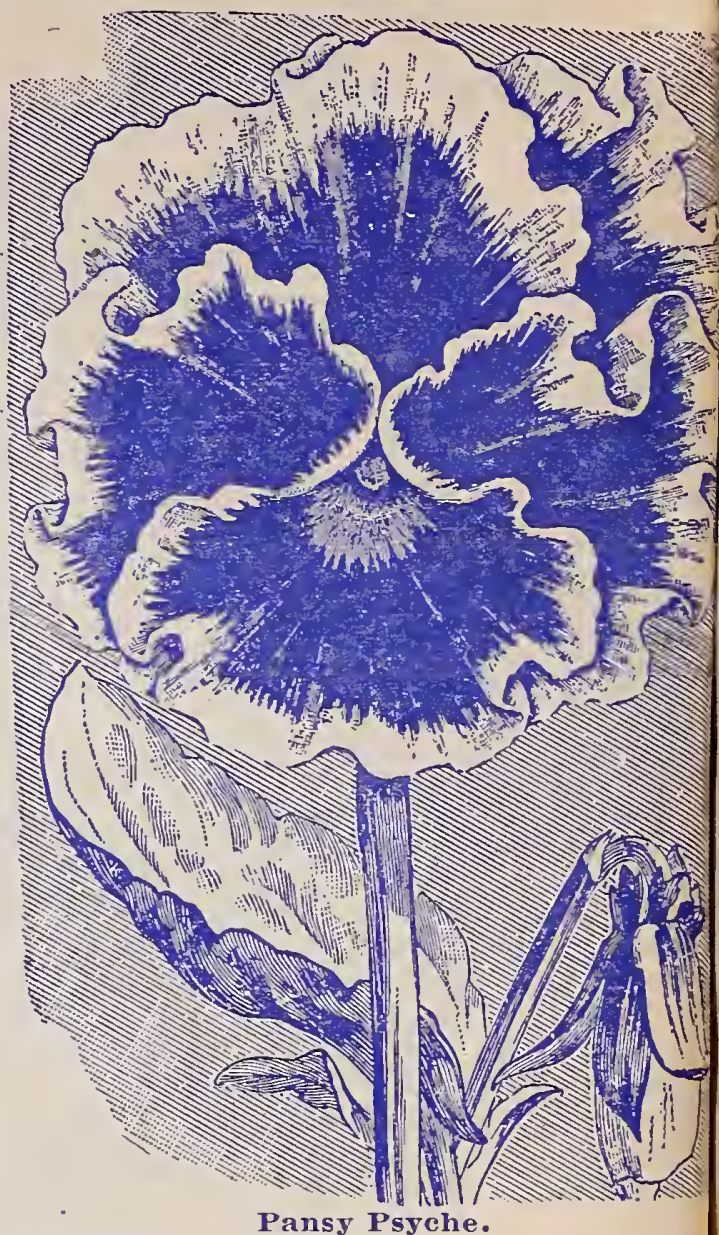

Pansy Psyche.

Color, a delicate azure blue, clearly margined with a clean-cut border of pure whit MAMMOTH BUTTERFLY

A French strain of pansies, with splashes and blotches as varied as the color of butterfly. Per pkt., 10c. EMPEROR FREDERICK.

Color, a rich deep purple with golden bronze center, with a scarlet and yellow margir very attractive. Per pkt., $15 \mathrm{c}$

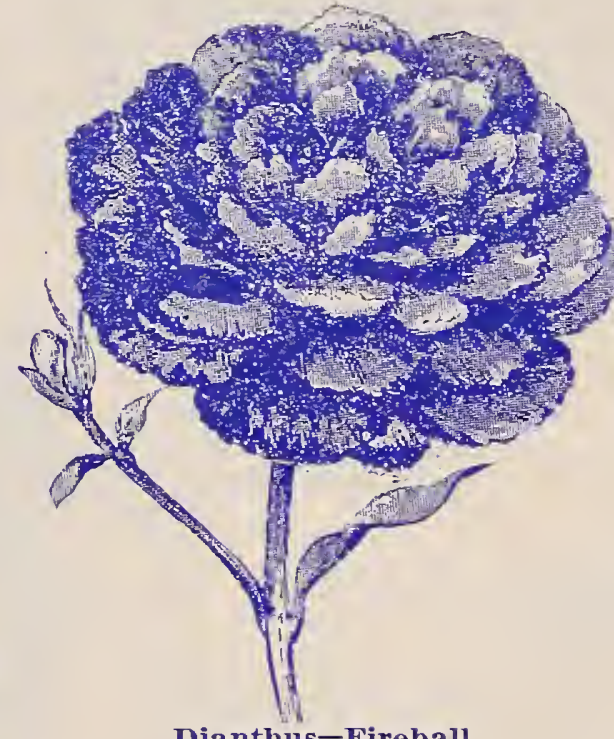

Dianthus-Fireball.

\section{DIANTHUS HEDDEWIGII DOUBLE}

FIREBALL-The flowers of this variety are bright scarlet, a color not often found in the doubl summer pinks. The bushes are about one foot hig and are thickly covered with blossoms which pr duce a dazzling effect. They are excellent for cu ting. This variety is of intrinsic merit. (See cut Per pkt., 15c.

NEW ROYAL. (Dianthus Heddewigi Nobilis). The flowers are of a beautiful shape and from 3 ? 4 inches in diameter. The petals are frilled an fringed, giving the flowers a graceful appearance Colors are a very bright blood red shade to carmin and pink and even white. Pkt., 10c.

FRINGED PINKS. (Dianthus Lacinatus Zonalis - New annual garden pinks of compact growt large single fringed flowers of bright salmon re broadly zoned around the centre with dark purpl Per pkt., 10c.

STAR PINKS. (Dianthus Heddewigi Stellaris, $p l)$.- An entirely new strain; the flowers are dou and star-shaped. All colors mixed, per pkt., 10c.

ORIENTAL PINK. (Dianthus Japanese.)-Flowers very large, many of them most quisitely fringed and crinkled. The colors range from plain white through shades of $p$ and red to the darkest velvety crimson and black. All the above colors mixed, per pkt., 10

\section{DOLICHOS.}

\section{DA YLIGHT.}

The foliage is abundant and handsome; the flowers spring out with wonderful profusion large sprays or spikes of pure white Pea-like blossoms. (See cut.) Per pkt., 10c.; oz., 25c.

\section{DARKNESS.}

The vines grow quickly, attaining the height of 6 to 8 feet when trained on poles or suitat trellises. The flower spikes are large and long, standing out well from the foliage, and thickly set with large Pea-like flowers of deep reddish violet or lavender purple. Per pkt., 1 oz., 25c.

For a Select List of Flower Seeds, see pages 37 to 50; Novelties, 28 to 36 . 


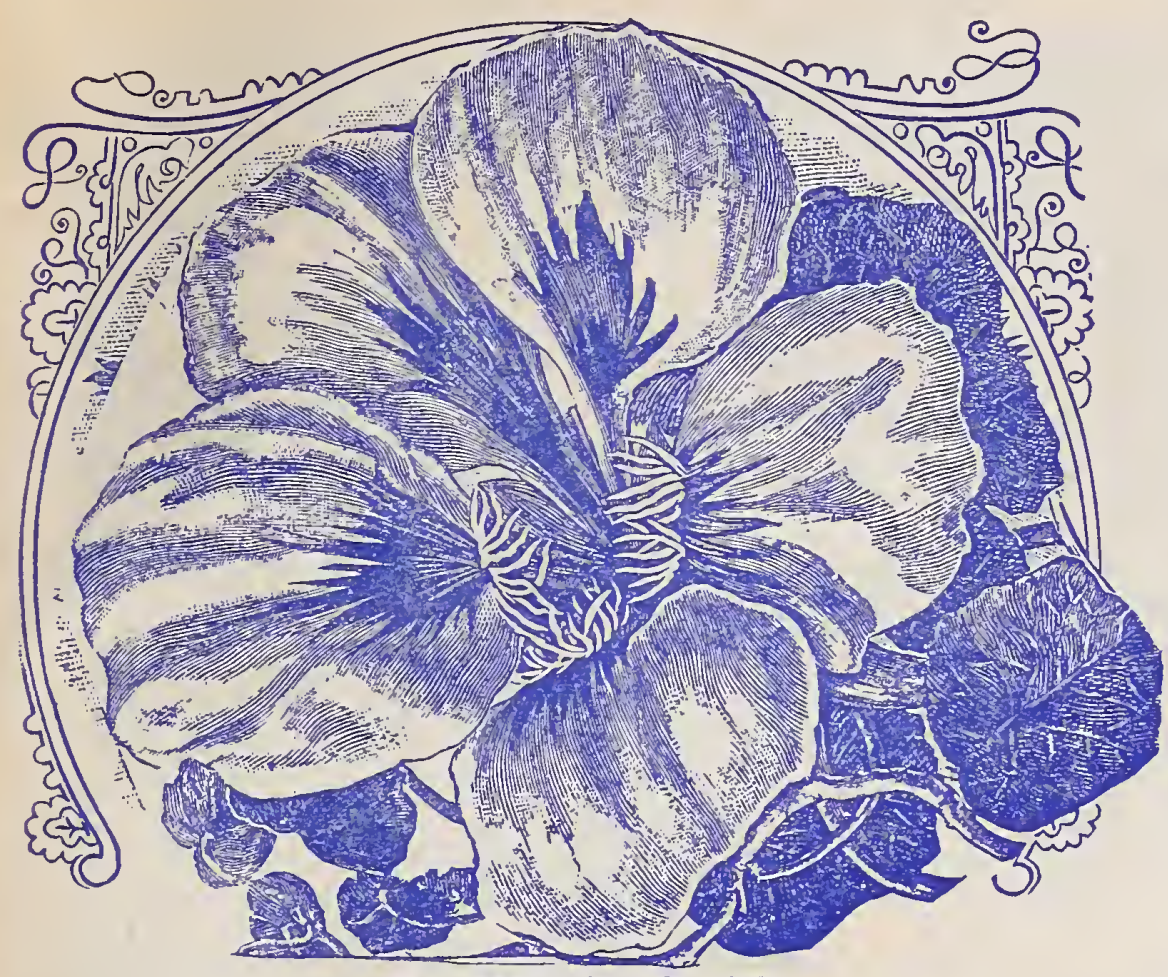

Tall Nasturtium Sunlight.

\section{NASTURTIUMS,}

Young's Novelty Collection of Dwarf and Tall Varieties.

7 Distinct Sorts. i Package of Each Variety for 30 Cents.

TALL SUNLIGHT-This beatiful Nasturtium has large foliage of a light green color, which is nearly concealed with rich golden yellow flowers that are borne very profusely the entire summer until killed by frost. The flowers are very large, often measuring 3 inches in diameter. It is a splendid climber. (See cut.) Per pkt., 10c; oz., 25c.

TALL MOONLIGHT-This variety has the same style of growth and size of flowers as Sunlight, except it is of a light straw color; it has the same crinkled effect in the petals. Per pkt., 10c; oz., 25c. TALL CHAMELEON - This new variety possesses a most unusual feature by presenting different colored flowers on the same plant. They are variously blotched, striped and bordered with these several colors, and borne in great profusion. Per pkt., 10c; oz., 25c.

HYBRIDS OF MADAM GUNTER-These Hybrid varieties are exceedingly strong-growing climbers. often attaining the height of 5 to 6 feet; they are also equally well adapted as trailing vines for vases or over the ground, being covered the entire summer with"large substantial flowers of the most brilliant shades, embracing the following colors; rose, pink, maroon, salmon, light yellow end deep orange, in self colors and in stripes and blotches

\section{NASTURTIUMS.}

Young's Collection of Giant Flowered Climbing Varieties,

8 Distinct Sorts, 1 Package of Each Va. riety for $35 \mathrm{c}$.

CLIMBING CAPRICE-Thelremark able character of this variety is in the large number of varied flowers on a single plant. The flowers are extra large, showing a combination of colors, it is. o climbing or creeping habit, with beautiful dark colored foliage. Per pkt., 10c.

CLIMBING MARGARET-Flowets very large, of light yellow color, striped and spotted, with blood red foliage and

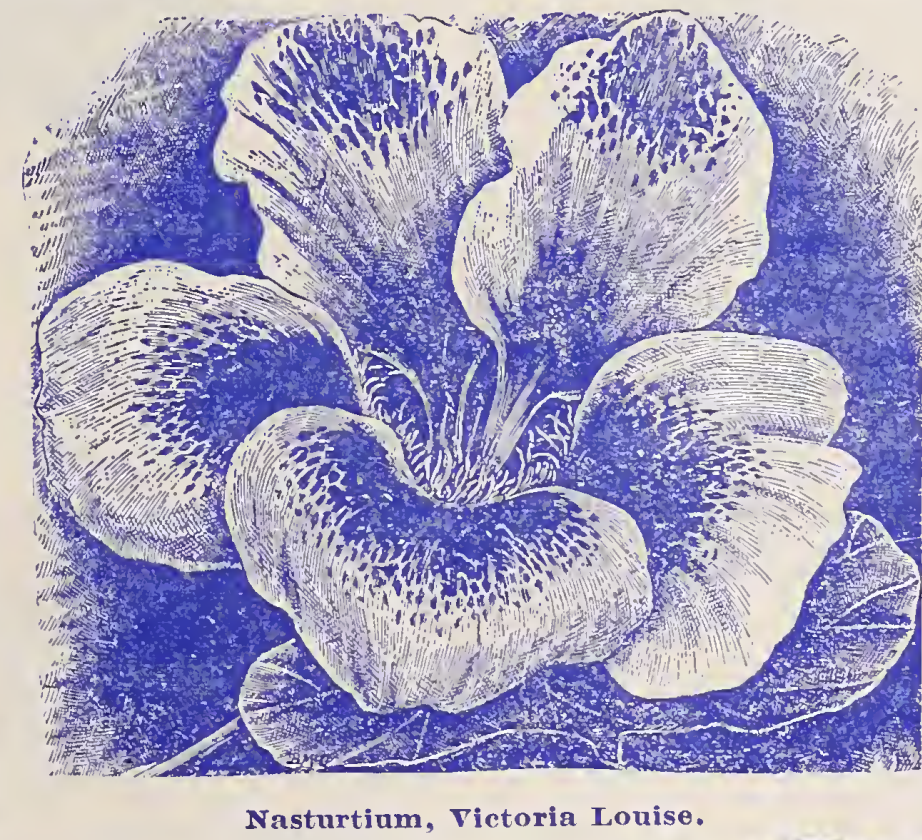

$\mathrm{n}$ the most varied manner. Per pkt. edging. Per pkt., 10c; oz., 25c. crimson. Per pkt., 5c. of colors. Per pkt., 10c. stem dark; very effective. Per pkt., 10c.

CLIMBING FIREFL $Y-A$ distinct variety of recent introduction with large flowers of a dark orange color, spotted blood red; the spur is also blood red; foliage dark green; very attractive. Per pkt.. 5c.

Climbing Primrose- Large creamy white flowèrs and brown spots foliage dark, a very vigor ous grower. (See cut.) Per pkt., 10c.

CLIMBING VICTORIA LOUISE-Flowers large, very distinct, color a creamy white with orange scarlet blotches, the calyx and the spur being a pure orange red. (See cut.) Per pkt., 10c.; oz., 25c.

CLIMBING SALMON QUEEN-A very strong growing variety, with dark green foliage. The flowers are most distinct, the colors being a soft, rich, velvety shade of salmon. Per pkt., 5c.

CLIMBING JUPITER-The flowers of this variety are exceedingly large, often measuring 3 to $34 / 4$ inches in diameter, borne on long, stiff stems, color a rich, golden yellow. Per pkt., 10c.

CLIMBING SATURN-This is the Dest dark red variety in cultivation, it is a superb flower, very large, color a deep brilliant, velvety red, whose glowing color fascinates nearly everyone.Per pkt., 10c.

SPEOIAL OFFER-These Two Collections, Postpaid, for 50 Conts.
DWARF CHAMELEON-This is dwarf form of the chameleon strain, possessing exactly the same peculiar features of producing various colored flowers on the same plant. Its dwarf habit makes it very useful for bordering or

DWARF HENISPHERE-It is of a spreading, rounded form, each plant resembling a giant round ball cut in hall and set on the flat part. The leaves are large, the color of flowers are a rich lemonyellow, with throat blotches of deep

DWARF LILIPUT-This is a very distinct variety, growing smaller in size than the Tom Thumb Nasturtium. The flowers are borne in clusters on top of each bush and of a brilliant combination

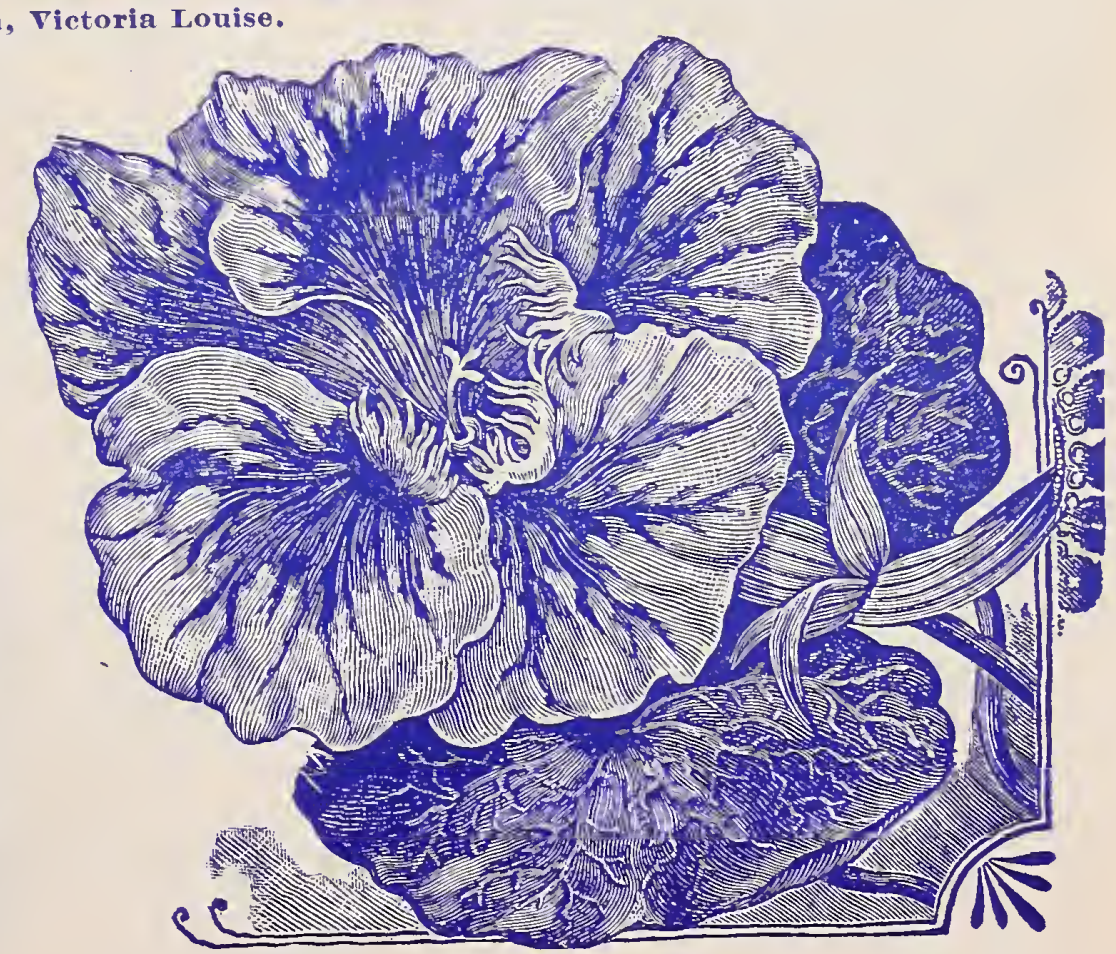

Nasturtium Primrose. 


\section{SWEET PEAS. YOUNG'S \\ NOVELTY COLLECTION.}

Six Varieties, 1 pkt. of each, 30c; postpaid.

MOUNT B A A C Flowers large and are foliage, color a clear white. AMERICAN QUEEN-The flotrers are very large, generally 3 on a long stiff stem,
color a clear salmon red. Per pkt., 10c. COUNTESS OF LATHON-The flowers are borne on long stiff stems of great substance, which gire them great lasting quali-
ties. Color delicate pink. Per pkt., 10c. LORD KENTAN-Color a fleshed crimon, deepening toward the edges, flowers LADI ORNSBY GORE-Very rigorous grower, color a primrose yellow, on stiff COCCINEA-A decided new variety, color a rich cherry red decidedly new and in-

SWEET PEAS. YOUNG'S PRIZE COLLECTION.

Contains Eight Varieties for 30c, postpaid.

SENSATION-The stems are long, flowers are generally on one stem; color a

CAPTIVATION-Magenta color rery delicately suffused with purple,
nd sometimes three flowers on a long stem. Per pkt., $5 \mathrm{c}$.

COCYTESS OF ABERDEEN-Color a very pale pink edged with

MIID OF HONOR-A fine formed flower of true hooded form; stems

PRIDE OF NIAGARA - Color carmine pink with wings almost white; usually three flowers on a stem;

MODESTY-A delicate blush self color, flowers of a large size and perfect form borne freely, 3 on long stiff m. A strong grower. Per pkt.

MrS. DTEDALE-A light carmin
LADX GRISEL HAMILTOX-Flo

\section{SWEET PEAS.} YOUNG'S SPLENDID COLLECTION.

Contains Nine Varieties, one pkt. each, for 30c, postpaid.

GORGEOUS-A vigorous grower, color orange red flowers in great profusion on long stems,

BURPEE'S EARLIEST OF ALL-This variety comes into bloom fully ten days earlier than any other variety. It grows only about two feet high; the flowers are generally borne in clusters of three on a stem; color a rich pink, with nearly pure white wings. Per pkt., 5c.

GOLDEN GLEAJI-Color a primrose yellow; very vigorous grower and profuse bloomer; individual flowers large. Per pkt., $5 c$.

SADIE BURPEE-Color a pure white. It is a strong growing, free flowering variety, individual flowers large and borne on long stem. Per

LADY NINA BALFOUR-In color it is the most delicate maure imaginable, shaded with a charming dore gray, which gives a most captivating charm to the whole flower. Per pkt., $5 \mathrm{c}$.

NAVY BLUE-Color of the flower is just what the name implies TRUE BLUE. It is a tall, strong growing variety, florrers are large, on long, stiff stem. Per pkt., 5c.

STELLA MORSE-Color creamy yellow, suffused with a light tinge of pale pink; flowers are perfect in form, large, with three flowers on long, stiff stem. Pér pkt., 5c.

SHAHZADA-Color a strong purplish maroon, without lustre, wings a velvety indigo purple, sometimes shading to lighter. Stems extra ong and usually three flowers on a stem. Per pkt., 5

COUNTESS OF POWIS-A lovely variety, the color being a glowing orange, suffused with a light purple veined in a deeper tint; wings bright clear rose. A rich, bright combination of coloring; stems strong and 11sually three flowers on a stem. PeI pkt. $5 \mathrm{c}$
It holds its color well and does not fade quickly. Per ṕkt. $5 c$

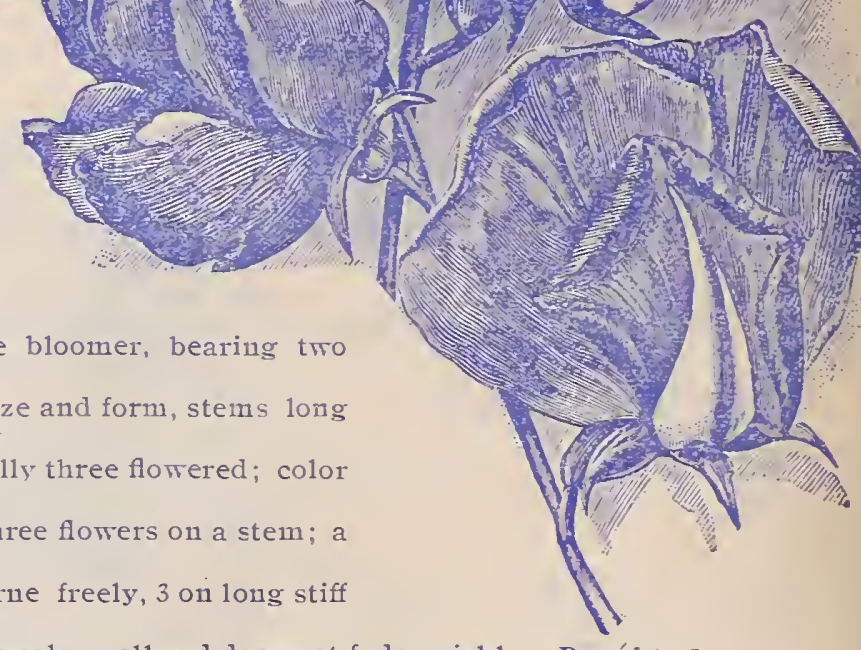

\section{SWEET PEAS. YOUNG'S CHOICE COLLECTION of Bush Varieties.}

6 Distinct Colors, 1 Pkt. of Each, for 30 , postpaid.

"'BUSH GRAY FRIAR", -Watered purple on white. 10c pkt.

“BUSH MLANCHE. BURPEE'”-Large pure white. 10c pkt.

“BUSH BLANCHE. BURPEE', - Large pure white. 10c pkt.

"BUSH SENATOR",- Striped white, maroon and purple. 10c.pkt.

"BUSH BLANCHE FERRY" -Pink and white. 10c pkt.

\section{SWEET PEAS.}

YOUNG'S COLLECTION

of Double Flowering Varieties.

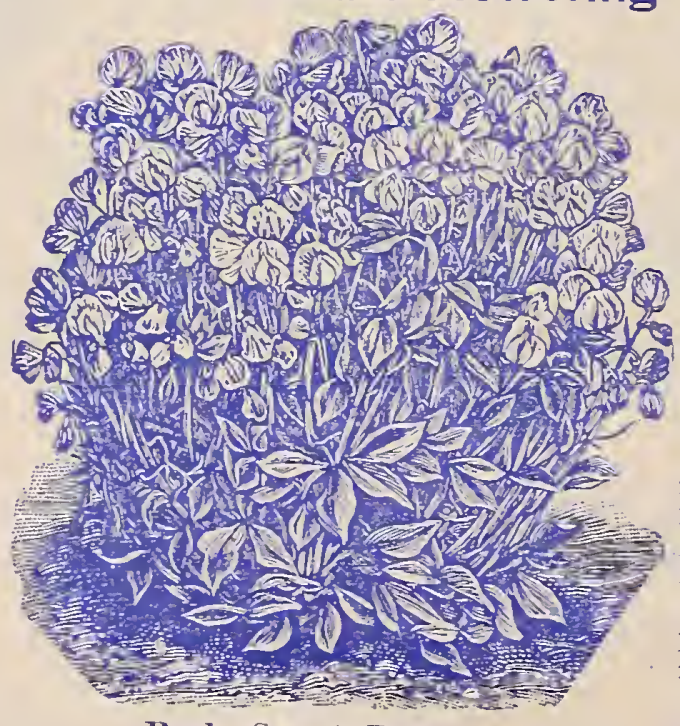

7 Distinct Colors, 1 Pkt. of Each, for $25 \mathrm{c}$.

D O U B L E APPLE BLOSSOMI-A beautiful ight pink. Per pkt., 5c. DF THE BITES-Dat blue, nearly to purple. DOUBLE Pure white; free bloomer DOUBLe. DUKE CLAREYCE-Dart OF roon; very effective. Per pkt., 5c. FLY - Light shade of lavender. Per pkt. 5c. ECKFORD-White mauve color. Per pkt., $5 \mathrm{c}$. DOUBLE SENATORStriped blue, white and
chocolate. Per pkt., $5 \mathrm{c}$. 

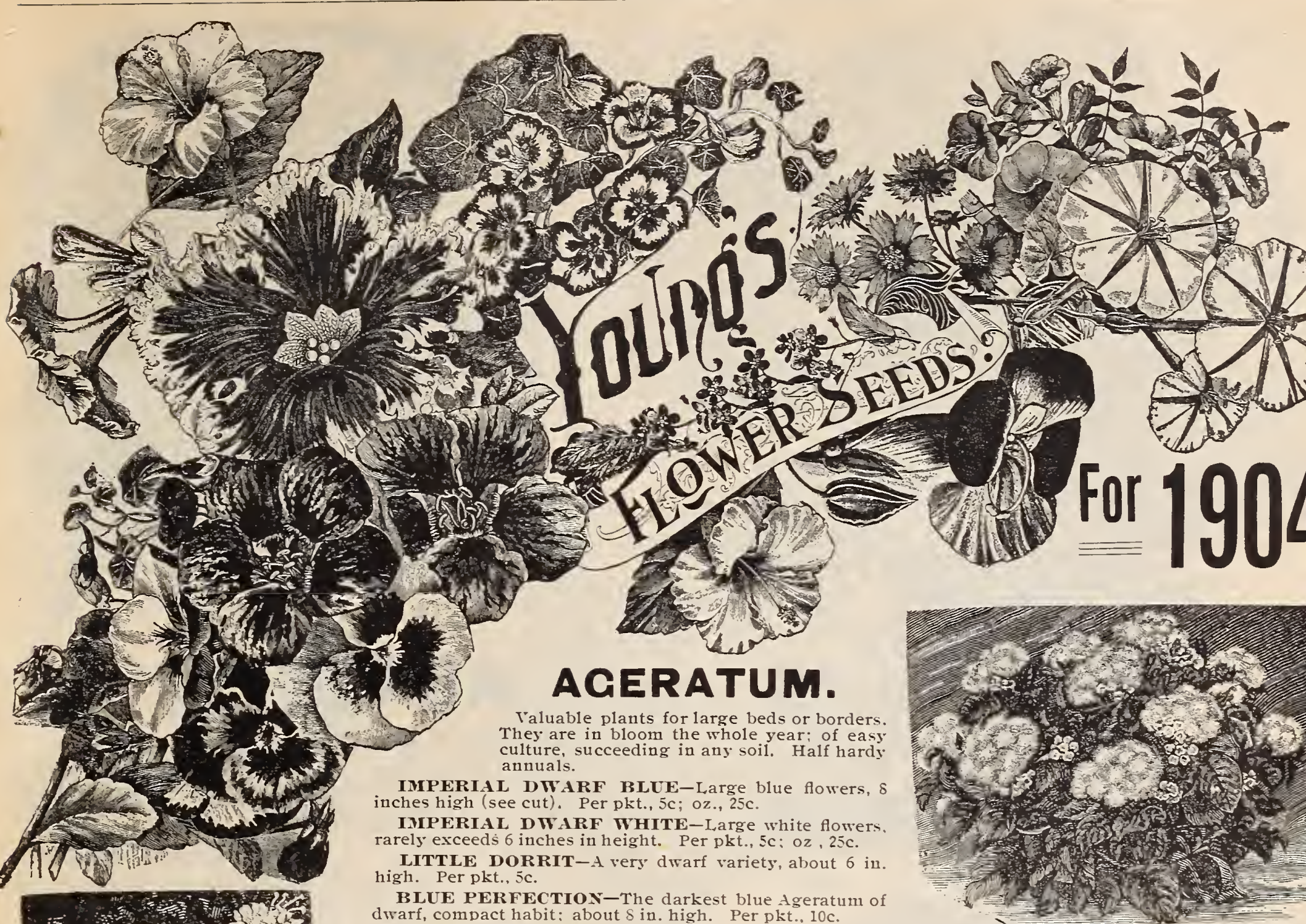

\section{AMPELOPSIS VEITCHII.}
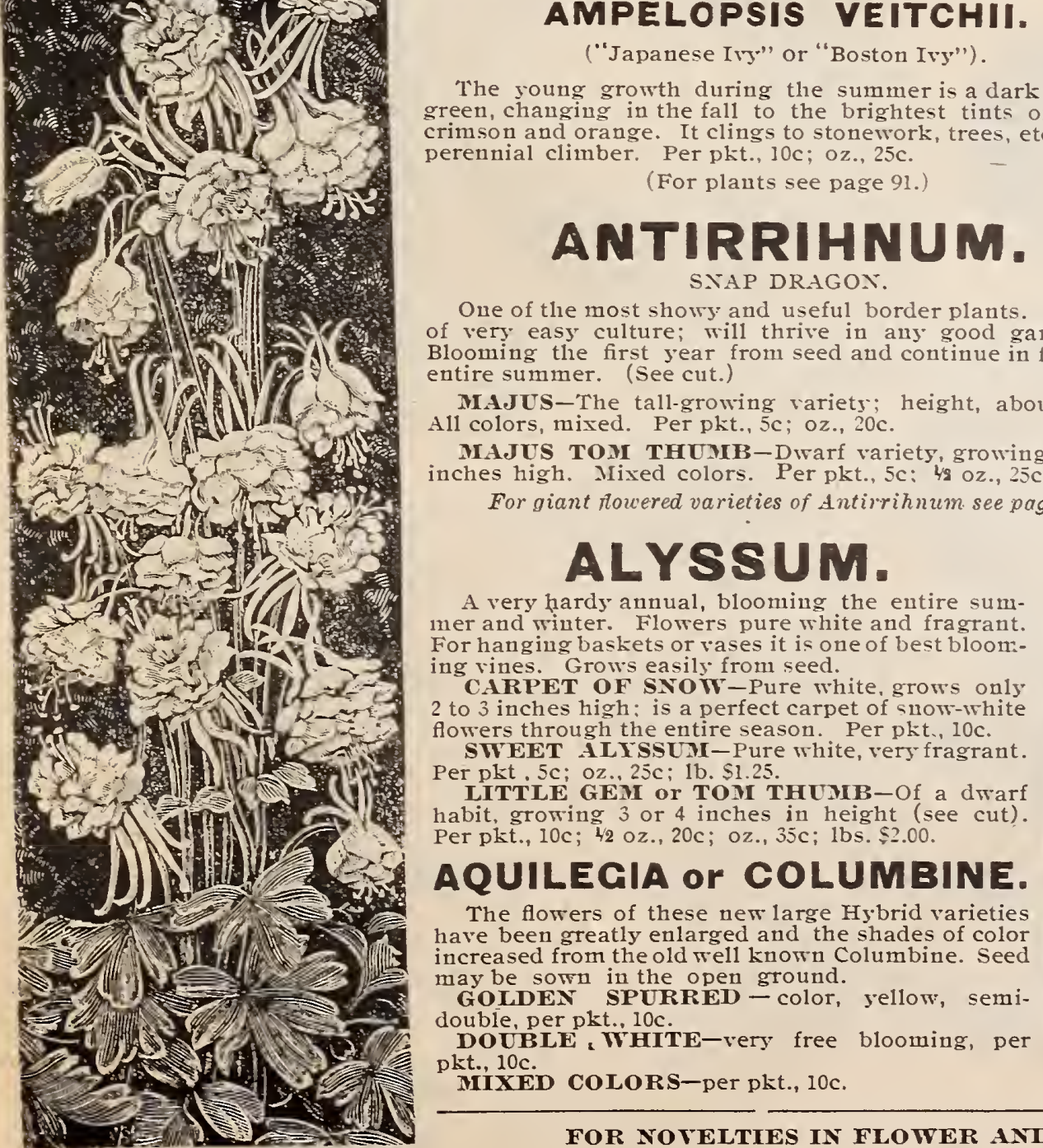

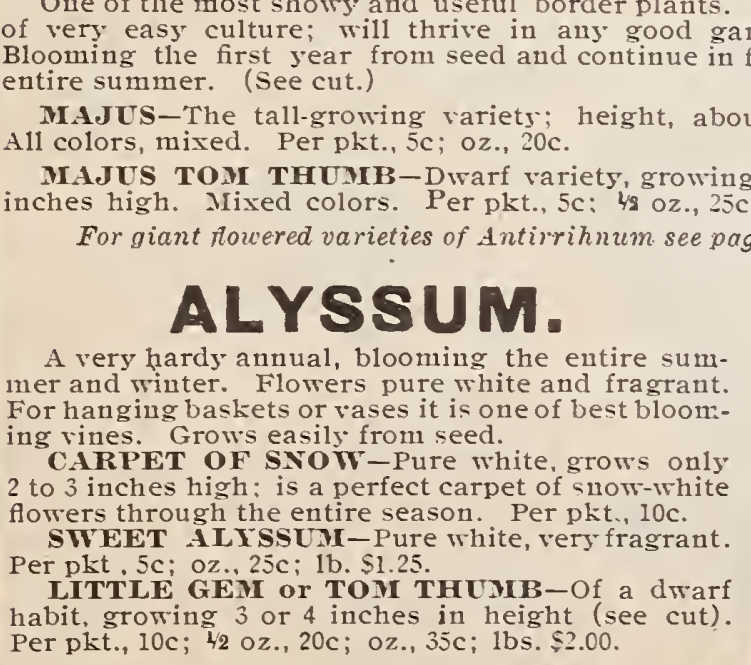

AQUILEGIA OR COLUMBINE.
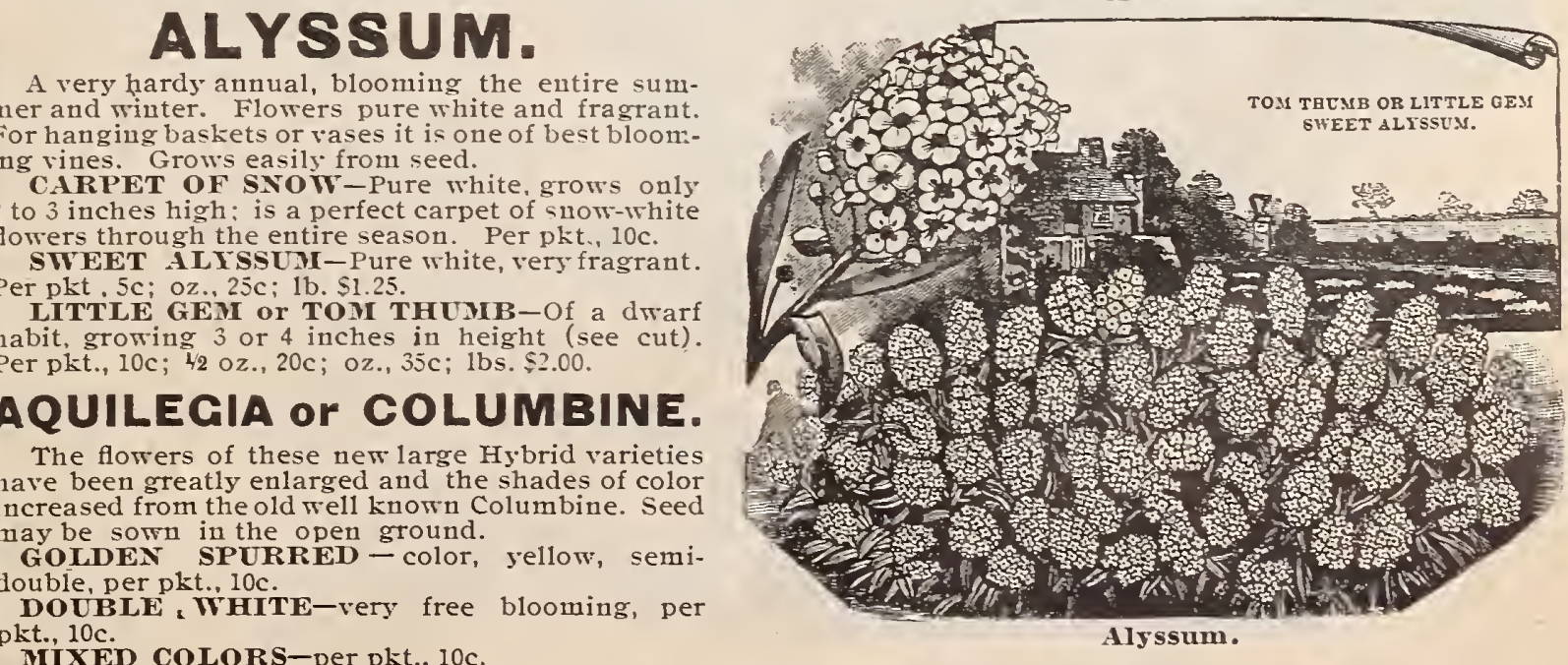

FOR NOVELTIES IN FLOWER AND VegetABLE SEEDS SEE PAGES 21 TO 36.

Aquilegia Golden Spur.
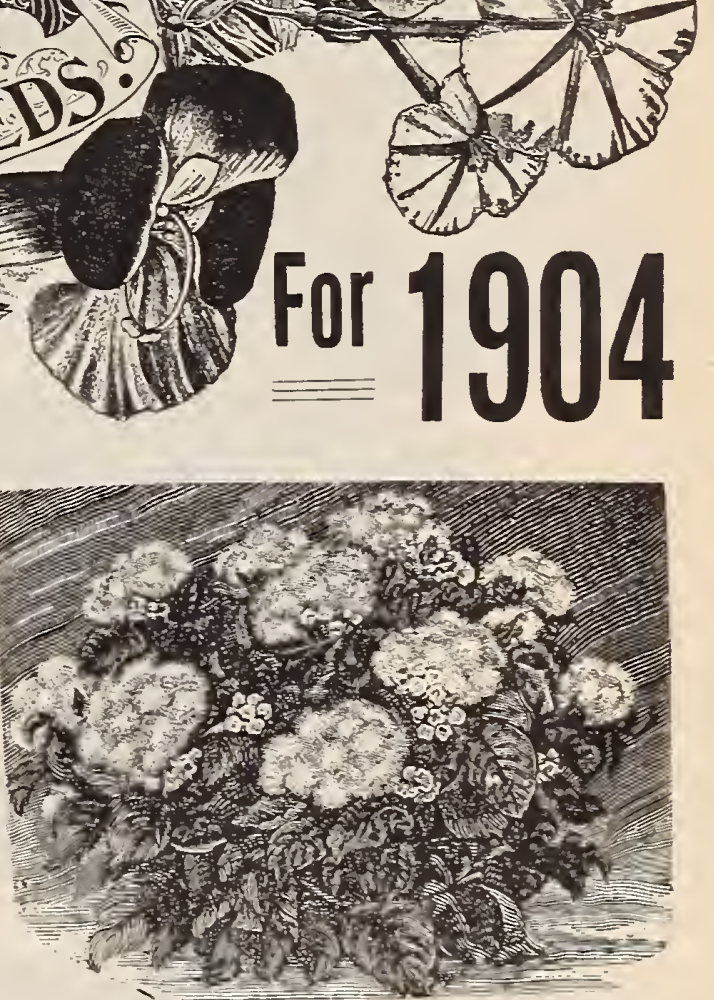

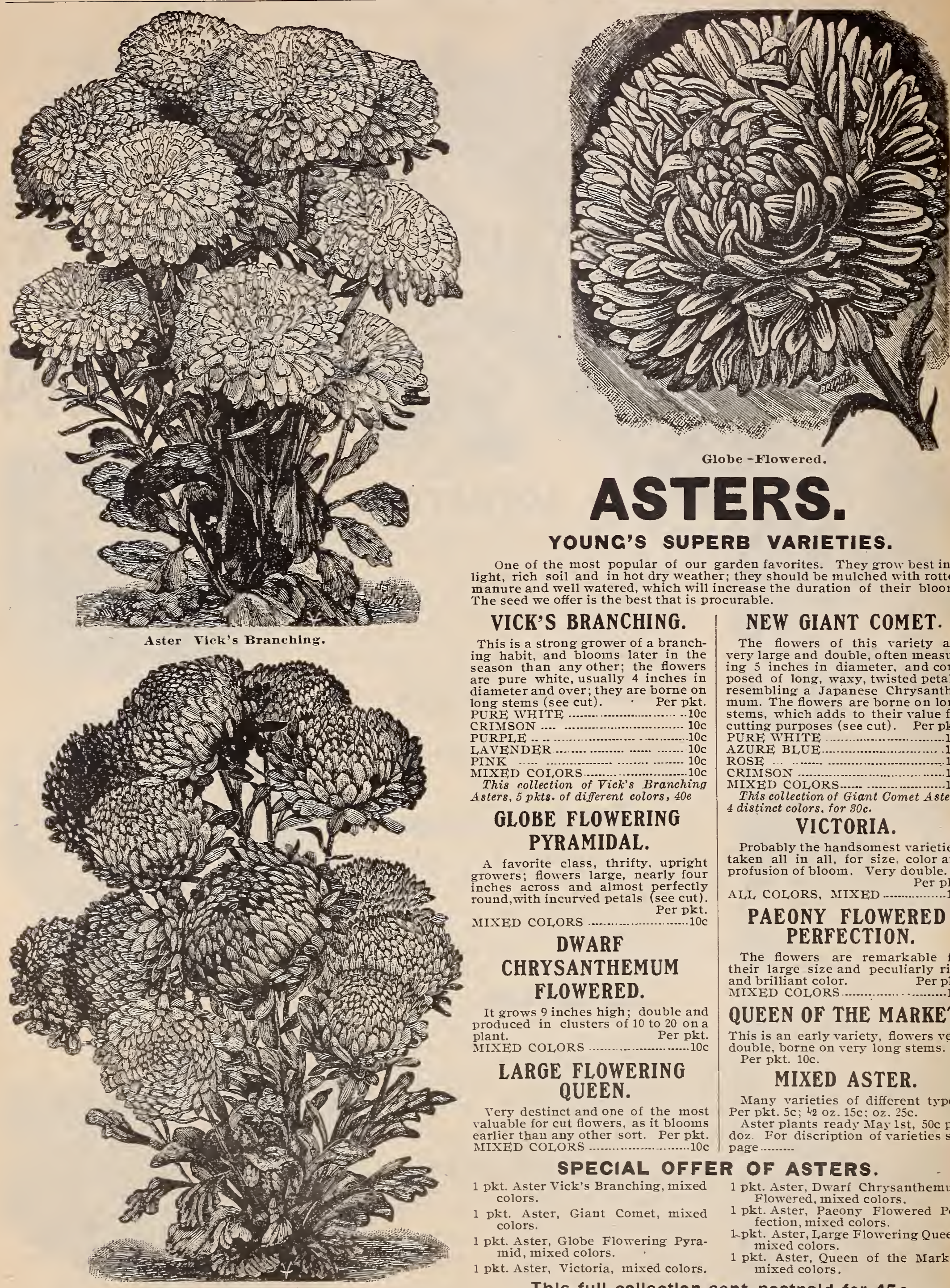

YOUNG'S SUPERB VARIETIES.

One of the most popular of our garden favorites. They grow best in a manure and well watered, which will increase the duration of their bloom. The seed we offer is the best that is procurable.

VICK'S BRANCHING.

This is a strong grower of a branching habit, and blooms later in the are pure white, usually 4 inches in diameter and over; they are borne on long stems (see cut).

CRIMSON

PURPLE $\ddot{2} \ddot{2}$

PINK

MIXED COLOR Asters, 5 pkts. of different colors, toe GLOBE FLOWERING PYRAMIDAL.

favorite class, thrifty, upright growers; flowers large, nearly four across and almost perfectly MIXED COLORS ............ Per pkt.

\section{DWARF}

CHRYSANTHEMUM FLOWERED.

It grows 9 inches high; double and

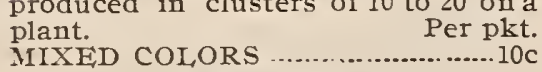

\section{LARGE FLOWERING} QUEEN.

rery destinct and one of the most aluable for cut flowers, as it blooms earlier than any other sort. Per pkt. SPECIAL OFFER OF ASTERS.

pkt. Aster Vick's Branching, mixed 1 pkt. Aster, Dwarf Chrysanthemum pkt. Aster, Giant Comet, mixed pkt. Aster, Globe Flowering Pyramixed color Thls full collectlon sent postpald for $45 \mathrm{c}$.

\section{NEW GIANT COMET.}

The flowers of this rariety are very large and double, often measurposed of long, waxy, twisted petals, resembling a Japanese Chrysanthectem. The alowers are borne on long cutting purposes (see cut). Per pkt. CRIX This collection of Giant Comet A sters. VICTORIA.

Probably the handsomest varieties taken all in all, for size, color an ALI COLORS, MIXED ….... PeI pk

PAEONY FLOWERED PERFECTION.

The flowers are remarkable for their large size and peculiarly rich $\begin{array}{ll}\text { and brilliant color. } & \text { Per pkt. } \\ \text { MIIXED COLORS .........................10 }\end{array}$ QUEEN OF THE MARKET.

This is an early variety, flowers very Pere, borne on rery long stem

\section{MIXED ASTER.} Many varieties of different types.

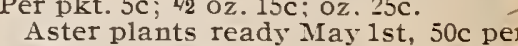
doz. For discription of varieties see Flowered, mixed colors. fection, mixed colors.

-pkt. Aster, I arge Flowering Queeu, pkt. Aster, Queen of the Market 


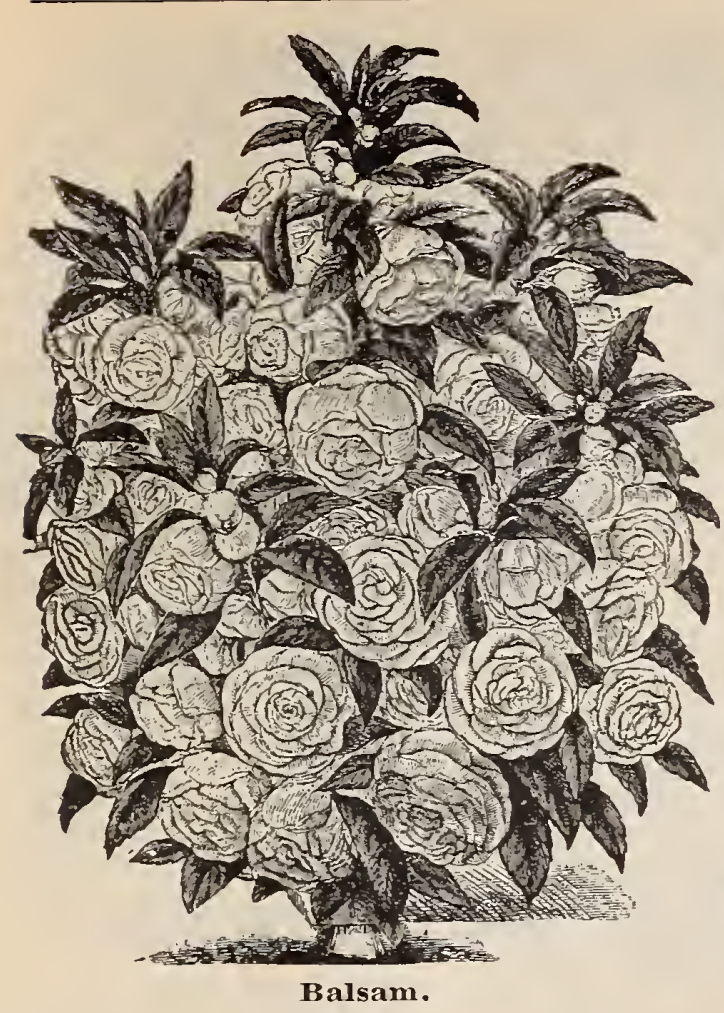

\section{BALSAM.}

(Lady Slipper, or Touch-Me-Not.)

An old favorite garden flower, thriving well in our climate, producing its gorgeous masses of beautiful, brilliant-colored double flowers throughout the entire season in great profusion of easy culture; succeeds the best in a good, rich, light soil (see cut.)

DOUBLE DWARE FLOWERING, ALI COLORS, MIXED. Per pkt., 5c: $1 / 2$ oz., $30 \mathrm{c}$ oz., 50c.

BALSAM ALBA PERFECTA-A new double white Balsam which produces extremely large flowers of the Camellia flowered type. Per pkt., 10c.

\section{YOUNG'S GIANT ROSE} FLOWERED BALSAM. Pkt. Pkt. Double, Scarlet .. 10c Double, Yellow..10c Double, Flesh ......10c Mixed Colors .....10c

\section{BALLOON VINE.}

A rapid-growing, handsome summer climber having small white flowers, which are followed by seed ressels, shaped like small balloons succeeds best in a light, rich soil and warm situation. Per pkt., 5c.

\section{CYCLAMEN.}

A free flowering bulbuous plant for house culture, producing graceful orchid-like flowers during fall, winter and spriug.

PHRSICUM SPLENDID MIXED - Per pkt., 10c

For Bulbs, see Plant Department.

\section{CINERARIA.}

Decorative plants blooming in the window or conservatory during the winter months; very showy and free-flowering; only good for a pot plant.

FINEST HYBRIDS mixed colors, per pkt., 15c
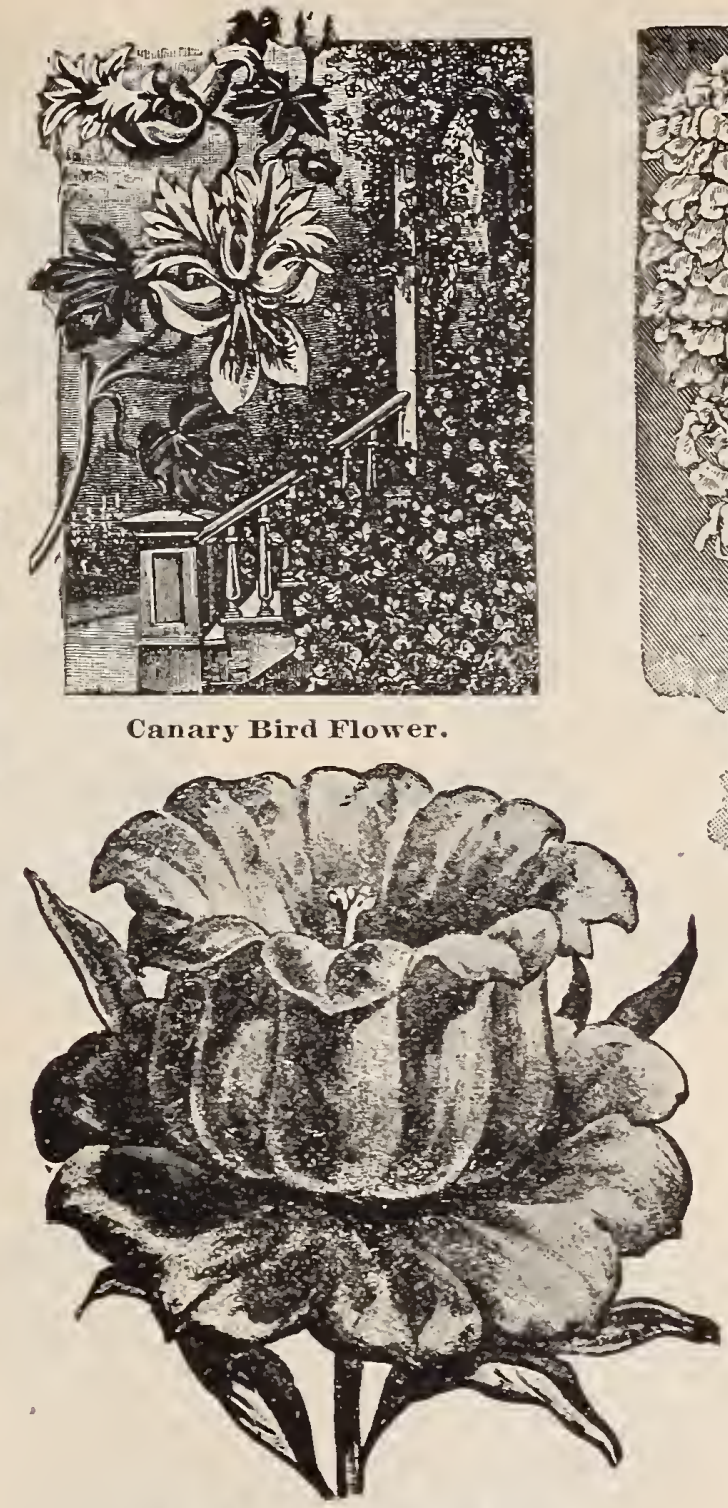

Campanula Cup and Saucer.

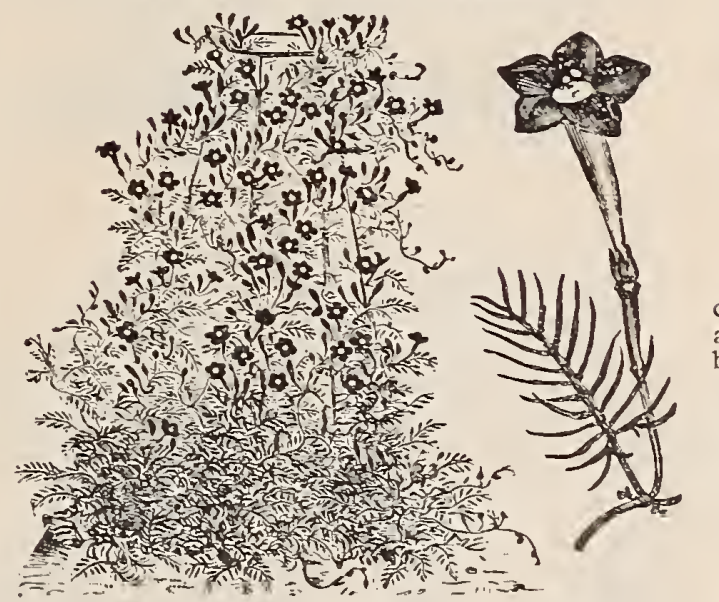

Cypress Vine.

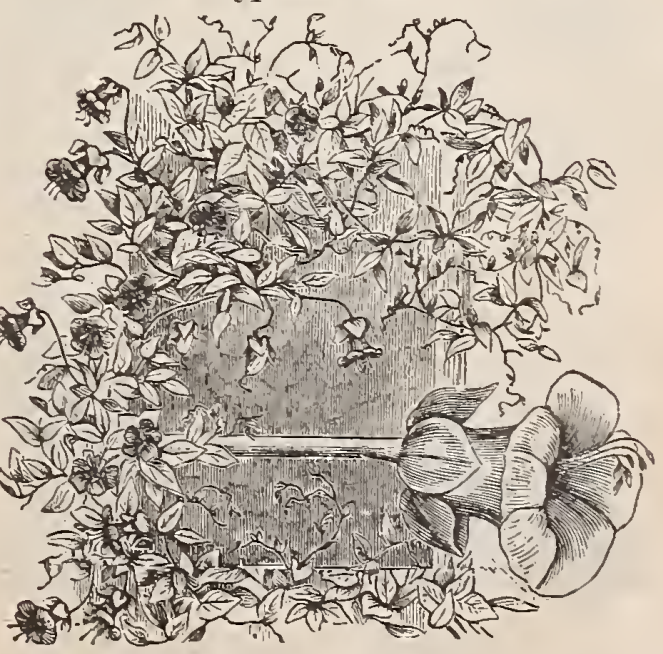

Cobaea Scandens.

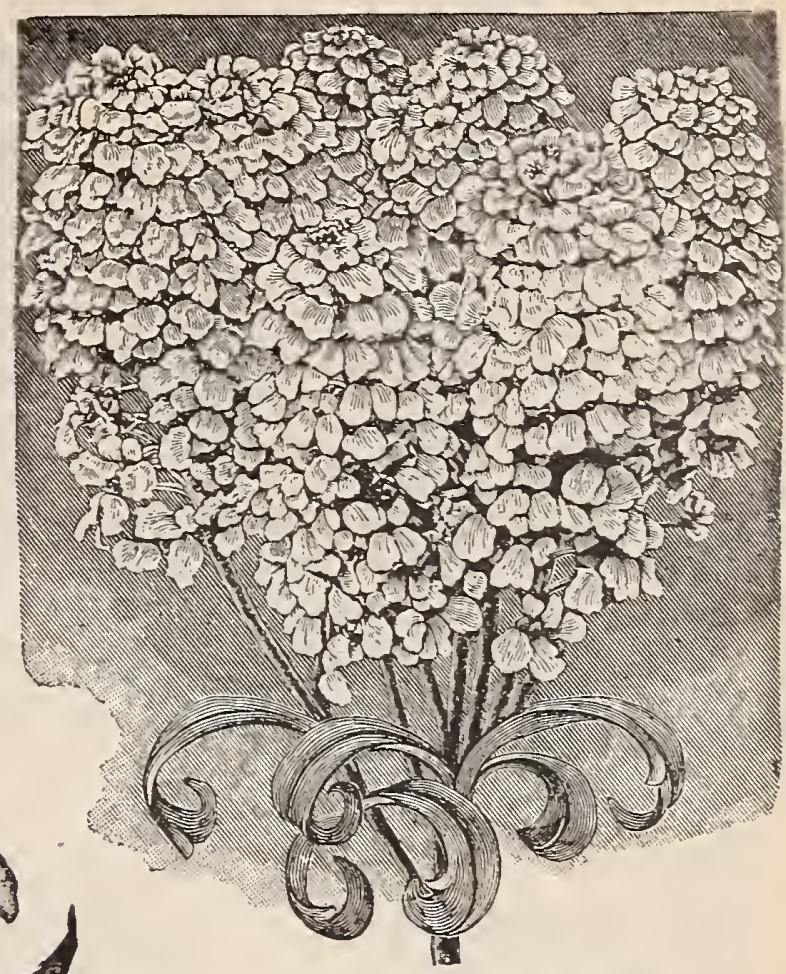

Candytuft White Rocket.

\section{CANDYTUFT.}

A beautiful and useful plant of easy culture. (

THITE ROCKET-Per pkt., 5c.; oz.. $20 c$ EMPRESS-Flowers exceedingly large and QUEEN OF ITALY-A new dwarf, erect growing variety, thickly studded with a fine Per pkt., $10 \mathrm{c}$. SNOW QUEEN-It bears but little foliage

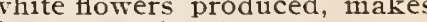

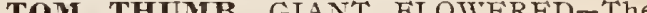
florets, as well as the heads of bloom are double florets, as well as the heads of bloom are double
the size of the old varieties. Per pkt., 5c. SEMPERVIRENS - White, a hardy, compact-growing variety, well adapted for permaGIBRALTARICA-A vigorous growing variety; colors, red, rose and white; perfectly
hardy. Per pkt., 10c.

\section{CYPRESS VINE.}

A most beautiful and attractive climber: deli-

Searlet, per pkt., $5 \mathrm{c}$; oz., $20 \mathrm{c}$.

White, per pkt., sc: oz.,

Ivy-Leafed, color scarlet, per pltt $5 c$ : $07,35 c$ Fine Mixed, per pkt., 5c; oz., 20c.

\section{CANARY BIRD VINE.}

This belongs to the Nasturtiums and is a rapid groring, delicate vine with clean, handsome blossomis (see cut.) Grows to a height of 15 to 20 feet. Prt.

\section{COBAEA SCANDENS}

A rapid growing climber with large foliage ers large, bell-shaped, of a violet blue color. In planting, place the seed edgewise (see cut.) Per

\section{CAMPANULA.}

This perennial is the mell-known, popular arge, bell-shaped flower, known everywhere as

CALYCANTHEMA ROSEA (Cup and Saucer)-Color a delicate rose pink (see cut.) Per

CALTCANTHEMA (Cup and Saucer)-All 


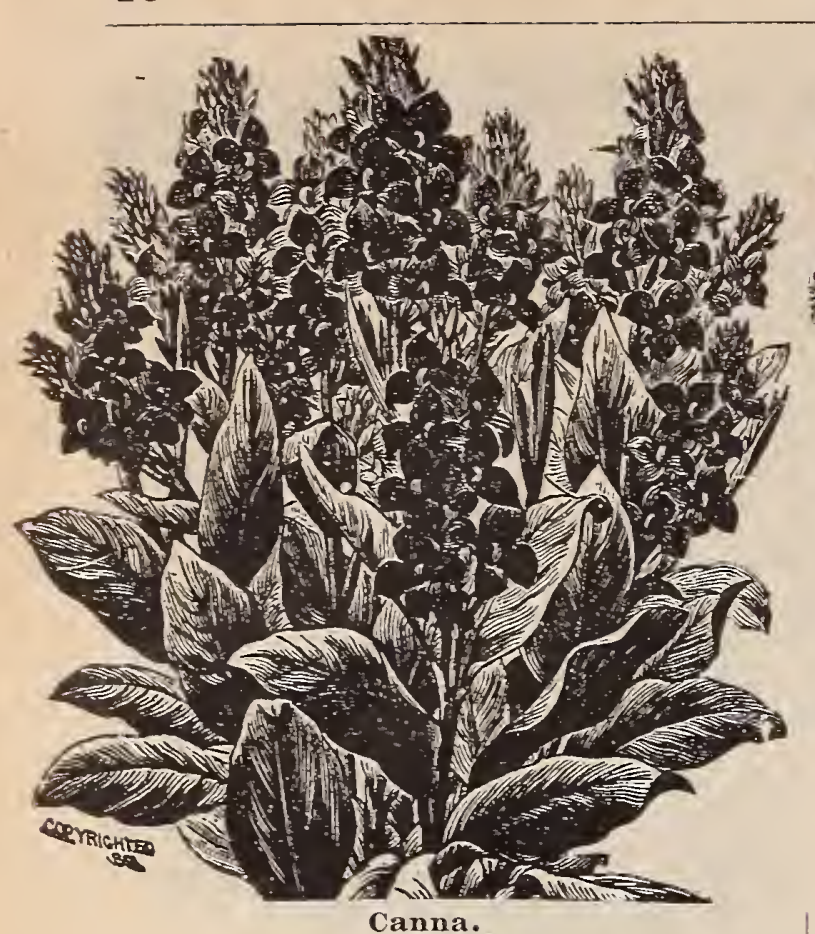

CANNA.

DWARF, LARGE FL O W ER I G , FRENCH-This is a dwarf growing variety, with luxuriant foliage and flomers as large as Gladiolas, the colors of the flomers ranging through all shades of sellom, orange and richest crimson (see cut). Per pkg. 10c; oz. 20c.

MIXED-Assorted varieties. Per pkt. 5c.

\section{cALLIOPSIS.}

These beautiful showy summer bedding annuals, with large, bright flowers, borne in great profusion all summer long, and succeeding almost everywhere.

CALIFORNIA SUNBEAM-This is an inprovement on Coreopsis Lanceolata, the flowcolor a golden yellow (see cut). Plat. 10c. DOUBLE (Tinctoria fl pl.)-The flowers are double, of rich golden yellow, with a wine ma. Per pkt. 10c.

GOLDEX WATE (Drummoudi) - Of a bushy and compact habit, and corered the entire summer with beautiful golden flowers with dark

TOM THUMB-Mixed colors, a dwarf strain; ALL COLORS, MIXED-Per Pkt. 5c, oz. 20c.

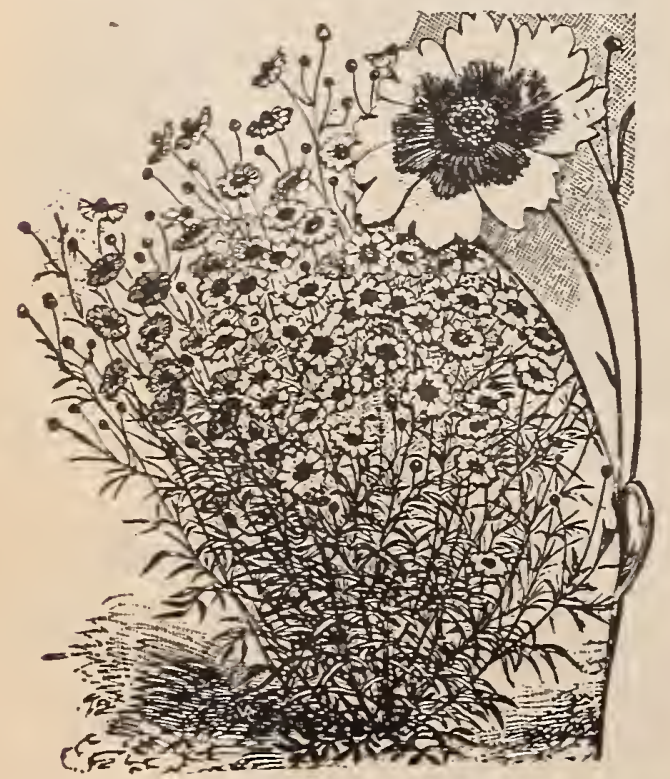

Calliopsis Sunbeam.

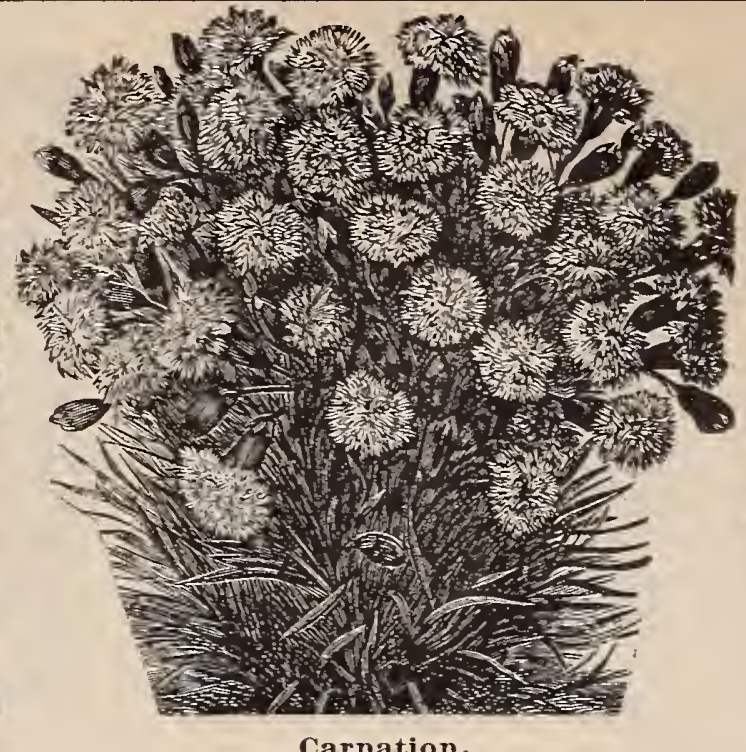

\section{CARNATIONS.}

Carnations are general favorites for their deicious fragrance and richness of colors. The seeds we offer are imported from Europe, and include novelties in double and semi-double flowers. Protect during the winter. Half hardyperennials.

PICOTEE-Choice double mixed flowers either white or yellow, bordered with purple, white or rose. Per pkt. 15c.

EXTRA CHOICE BIZARRE-Sared from an unequaled collection of named flowers. Per pkt. $15 \mathrm{c}$.

FINEST STRIPED-Flotrers are beautifully striped and variegated. Seed is saved from finest of double named flotrers. Per pkt. 5c.

PERPETUAL, OR MONTHLY-OUT OTI saving from best sorts, many of great merit. Per pkt. 15c.

\section{calendula. \\ (Or Pot Mraragold.)}

METEOR-Striped Orange on a yellow ground. Per pkt. 5 c, oz. 20c.

PRINCE OF ORANGE - Strain yellow striped around each petal with orange. Per pkt.

FATORITE - Light sulphur striped with creamy white, very double, the lightest colored variety. Per pkt. 10c.

MIXED COLORS - Per pkt. 5c, oz. 15c

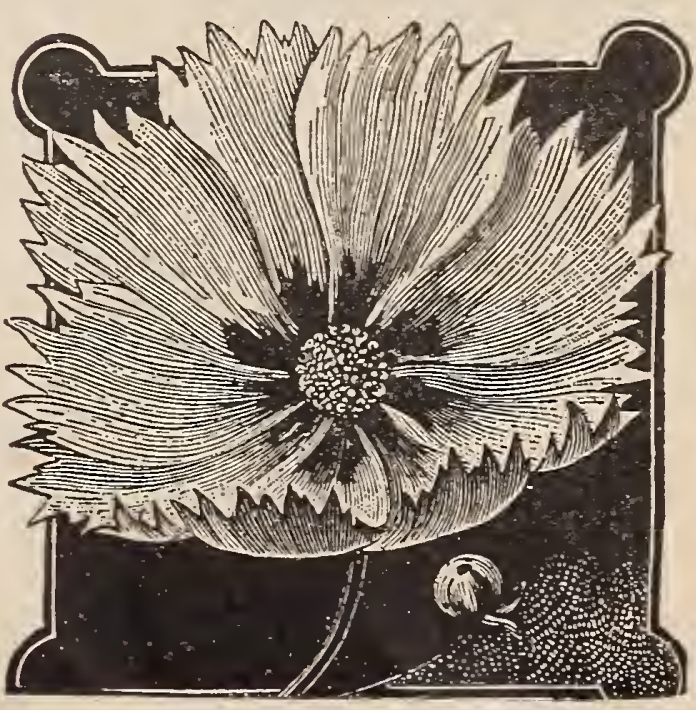

Calliopsis-Golden Ware.

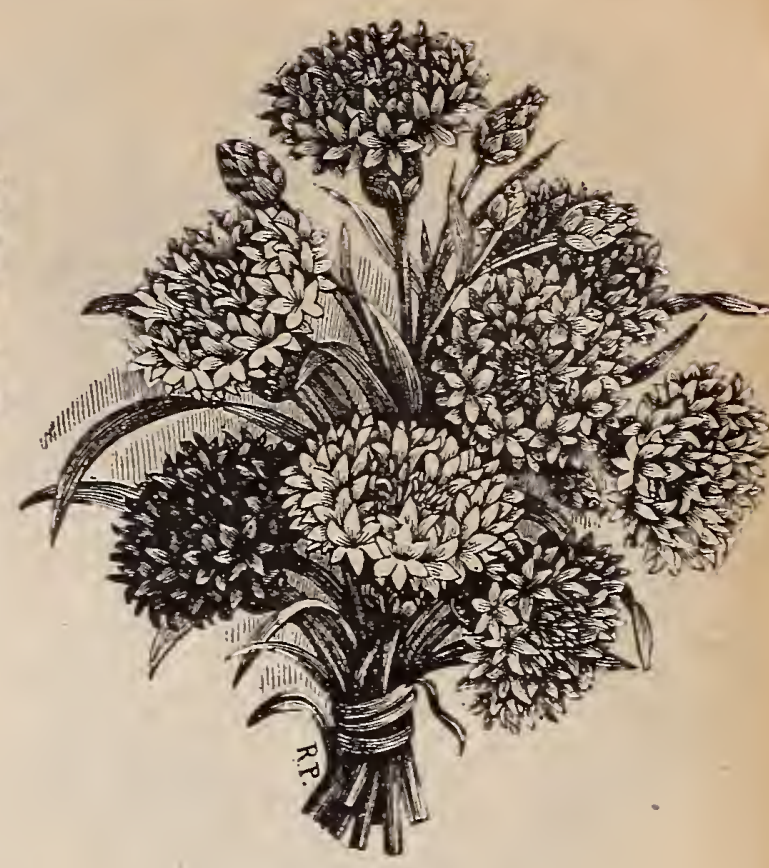

Cornflower.

\section{CENTUREA.}

(Cyannus.) "Blue Bottle," Corn Commonly known as "Blue Bottle," Corn annuads for cut flowers, blooms all summer. VICTORIA-A very dwarf variety, growing only about 8 inches high; color, bright blue, EMPEROR WILLIAM-A strong-growing ariety, producing blue flowers. Pkt. 10c.
SINGLE - All colors, mixed. Per pkt. 5c; DOUBLE-Al1 colors, mixed. Per pkt. 5c. For new varieties of Centurea, see page 33 .

\section{White-Leaved Centureas.}

CANDIDISSIMI-A round, compact plant, with silvery leaves; a valuable border plant.

GYMYOCAREA-A white leaf border plant, with flnely cut foliage, growing taller than the

\section{Chrysanthemums.}

Summer-blooming annual plants of compact growth and easy culture, producing large quantities of flowers on long stems the entire sum-

TRICOLOR CARNIATUM--Flowers, pure MAXIMUM PERFECTA-Exceedingly free flowering; rery large and well shaped; highly aluable for cutting. Single white. Per pkt. $15 \mathrm{c}$. FRUTICENS GRANDIFLORA (French border in summer and may be grown for blooming in the house in winter. Per pkt. 10c. VARIETIES-Double, from the best named

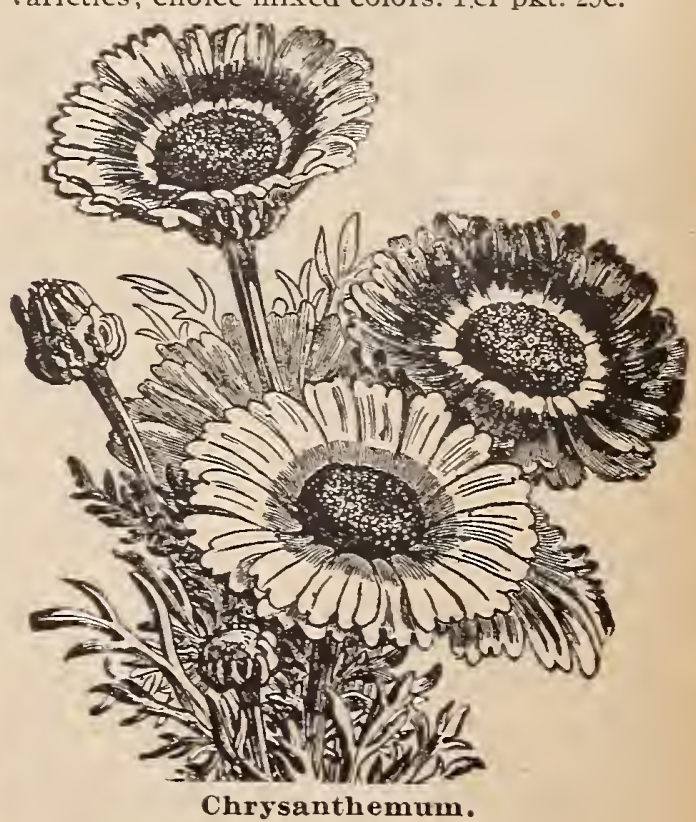




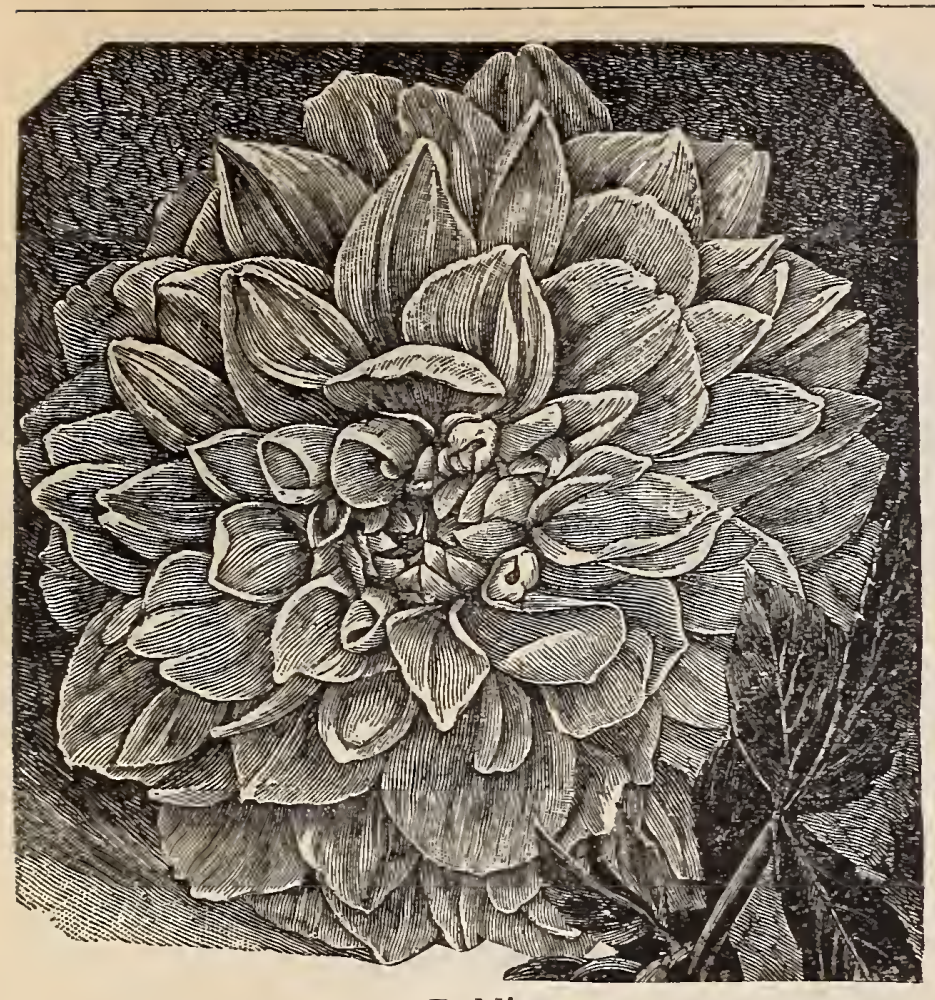

DAHLIA.

A beautiful autumn flowering plant that can be easily raised from seed as tubers. spring. (See cut.)

SI N GLE FLOWERING NIXEDLarge, showy, single flowers. Per pkt., 10c

DOUBLE LARGE FLOWERINGFinest mixed. Per pkt., 10c.
DOUBLE PONPON-Boquet or Lilliputian variety. All colors mixed. Pèr pkt., 10c.

\section{DELPHINIUMS.}

(Or 'Hardy Larkspur.)

A handsome and well-known hardy perennial, with curiously cut leaves, producing splendid spikes of flowers in great profusion bloom the first year from seed.

FORMOSUM - Hardy, blue with white center. Per pkt., 5c.

FINEST HYBRIDS-NIXED COL. ORS. Per pkt., $5 c$

\section{DOUBLE DAISY.}

A favorite plant, well adapted for edging borders and low beds. Although perennial, early. (See cut.)

GIANT SNOWBALL - Extra large, double pure white. Per pkt., 15c

LONGFELLOW- I arge, double, rosecolored flowers. Per pkt., $15 \mathrm{c}$

DOUBLE-ALL COLORS, MIXED, best German seed. Pkt., 10 .

\section{FORGET-ME-NOT.}

\section{Myosotis.}

The Forget-Me-Not is an old favorite plant bearing clusters of star-shaped delicate blue flowers with white and yellow eyes. flourishes best in a moist shady situation season. (See cut.)

ELIZA FOUROBERT-A large flowering variety with large clusters of sky-blue flowers. distinctly marked with a yellow eye. Pkt., 10c.

TICTORIA-This variety can be sown any time of the year; dwarf, bushy habit, flowers of a bright azure blue. Per pkt., 10c.

DWARF ALPESTROUS-Compact plants, flowering profusely, mixed colors. Per pkt., 10c.

PALUSTRIS-Large flowers. Pkt, $10 \mathrm{c}$
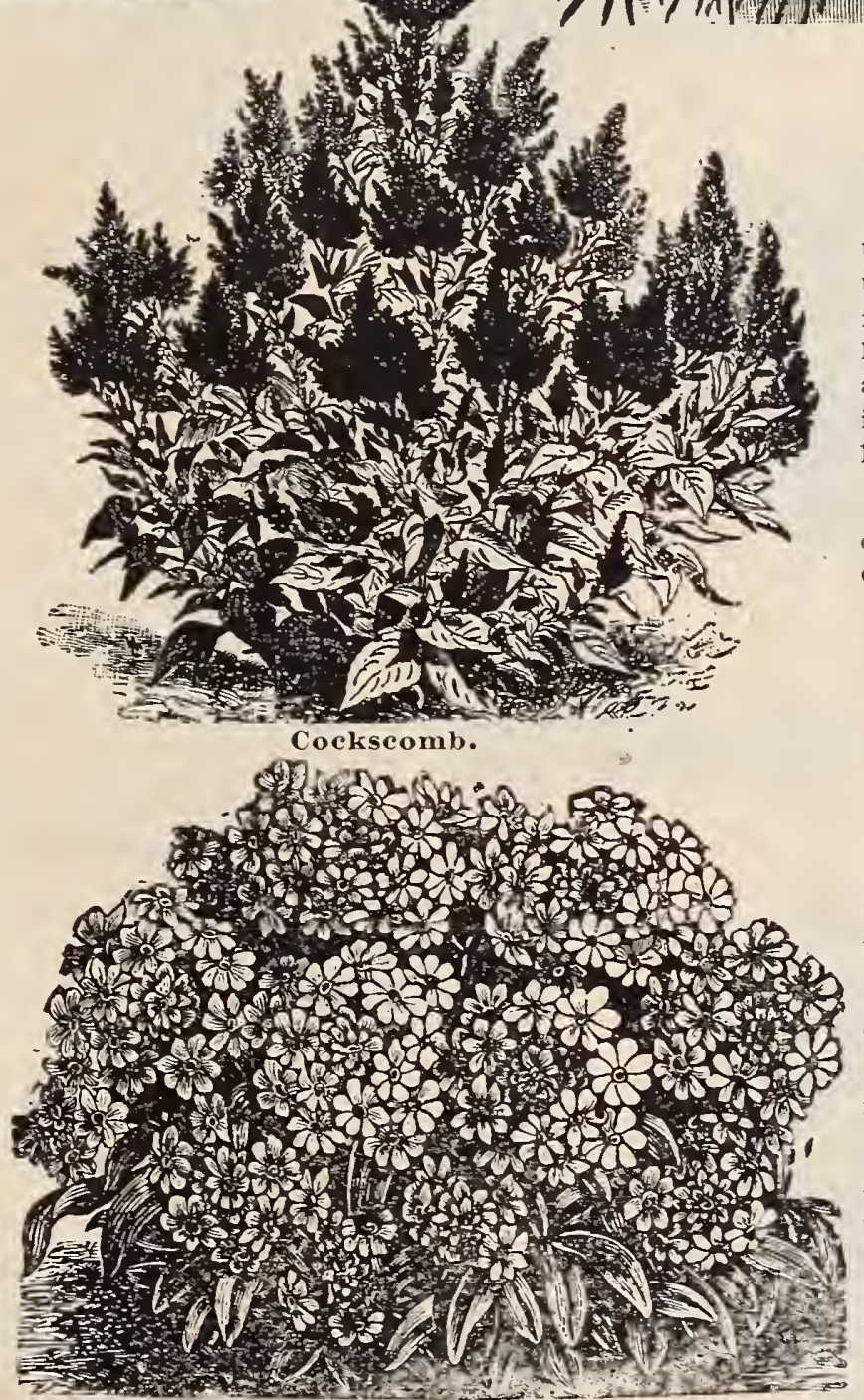

Forget-Me-Not

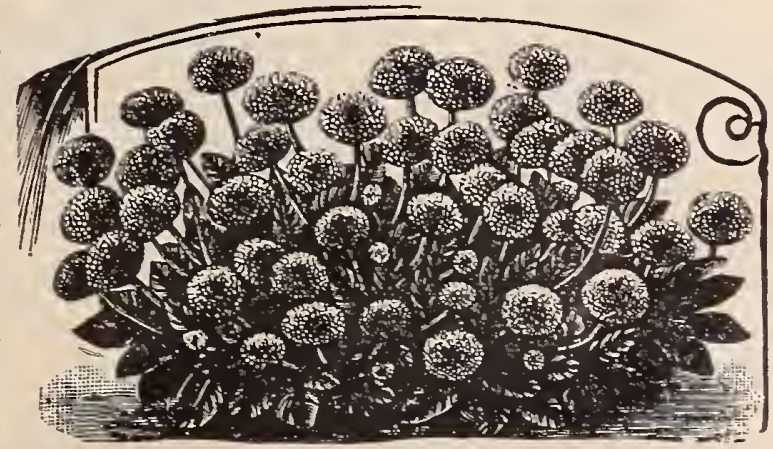

Daisies.

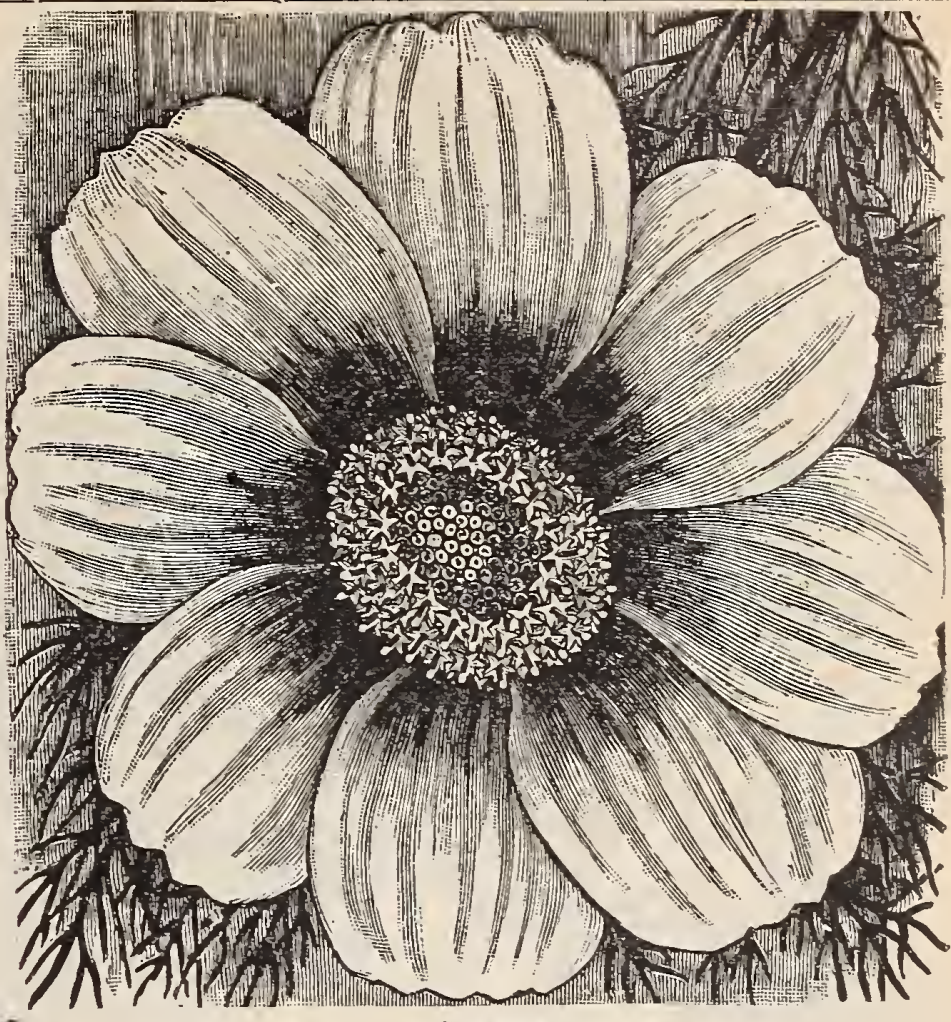

Cosmos.
A very easy-growing annual, commencing
to bloom early in the summer and continuing
unt! 1 Christmas, if protected from severe
frost. The mammoth varieties are much the
largest in size, and !f, when the plants have
attained the height of 1 foot, the center shoot
is pinched out, they will flower earlier and
keep dwarf. (See cut.)
MIXED COLORS - Per packet, 5c; 4/8
oz., 30c; 1 oz., 50c.
GIANT FLOWERED- WHITE............10c
..
..
..
.. MED...............10

COCKSCOMB.

A very free flowering plant, growing best rather light soil, producing spikes of beautiful comb-shaped flowers.

EMPRESS - Bright purple comb and dark foliage. Per pkt., 10c.

GLASGOW PRIZE-Very Dwarf; im TRIUMIPH plumed variety, grows about $2 / / 2$ feet high, of a regular branching habit. Per pkt., 10c

QUEEN OF THE DWARFS - The inches high, with pkt., 10c. MIXED-Per pk

DTARF VARIETIES-Mixed colors. Per

TALT TRIFTIES- - rixed colorn Pe

\section{FUCHSIAS.}

ly called Iadies' Ear Drops, succeed best as pot plants. If planted outdoors they

EXTRA CHOICE STRAIN OF MIXED COLORs-Per pkt., $15 \mathrm{c}$ 
C. YOUNG \& SONS CO., ST. LOUIS, MO.

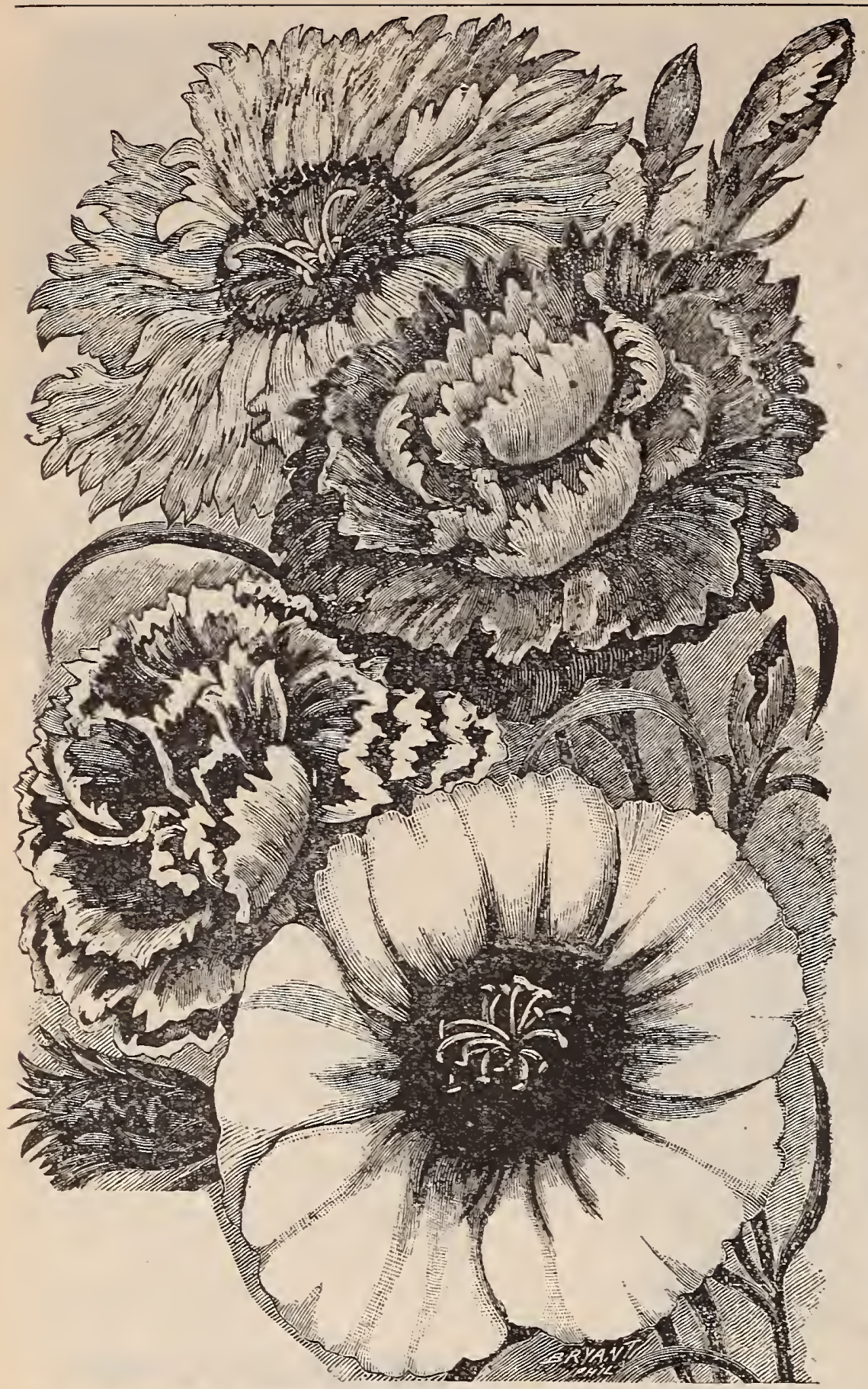

Dianthus or Japanese Pinks.

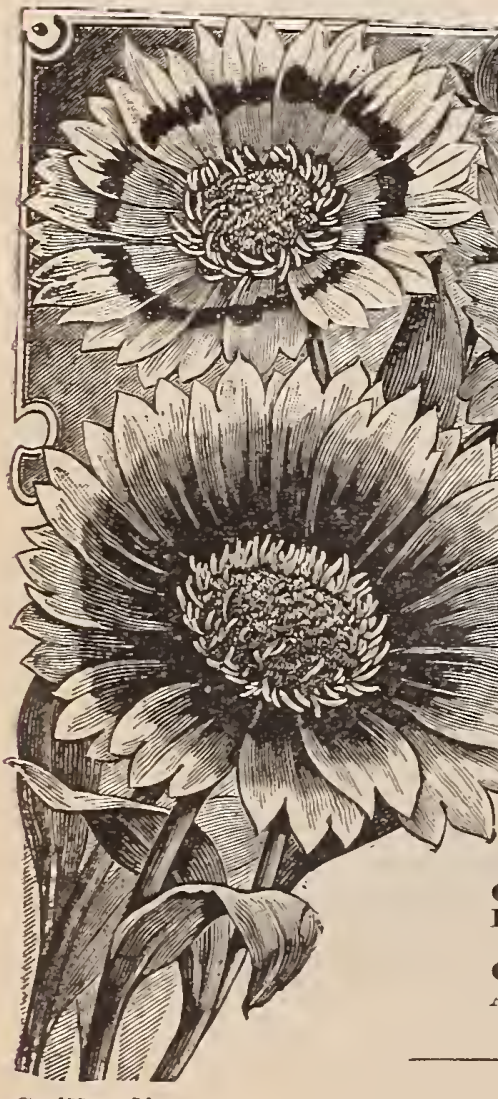

Gaillardia. Per pkt., $5 \mathrm{c}$; oz. $40 \mathrm{c}$

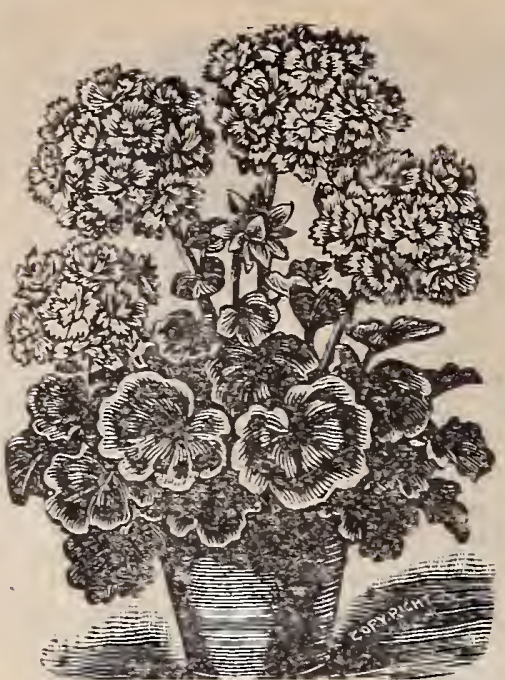

Geranium.

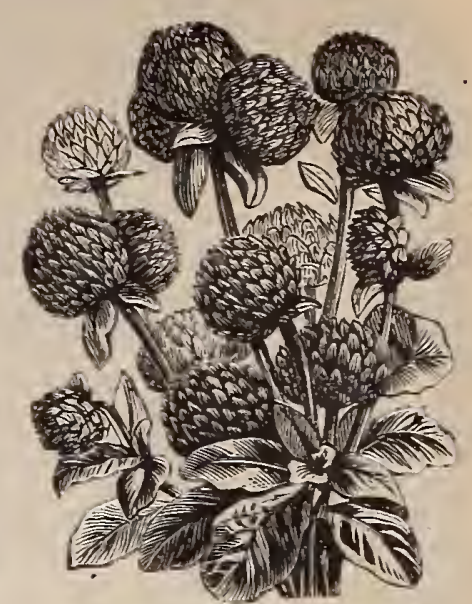

Globe Amaranthus.

\section{GLOBE AMARANTH.}

(Batchelor's Button.)

The flowers can be cut and made into ererlasting or dried bouquets. Colors, white. purple and striped. Per pkt., 5c.

\section{GERANIUMS.}

GOLDEN BRONZE-Seed is sared from choicest variegated leaf varieties. Per pkt., 20c. pkt., 25c. seed. Per pkt., 10c.

\section{DIANTHUS.}

\section{(CHINESE OR JAPANESE PINKS}

The rarieties of Dianthus known as Chinese Pinks and Japanese Pinks, are among the most brilliant of our garden flowers, and for beauty and variety cannot be surpassed. (See cut).

\section{SINCLE VARIETIES.}

EASTERN QUEEN-Beautifully marbled, large band of rich mauve upon the paler surface of the petals. Per pkt, 5 c. HEDDEWIGI (Single Japan Pink) - A rery large strain; inixed SALMON QUEEN-Flowers fringed Color, brilliant salmon.

SNOWFLAKE-White flowers of large size. exquisitely fringed LACINATUS (Mixed colors)-Finest single-fringed sorts. Per pkt., 5c. SPEOIAL OFFER: One Packet Each of the Seven Varieties for $25 \mathrm{c}$.

\section{DOUBLE VARIETIES.} DIADEMATUS (Diadem Pink)-Color, a dark crimson with very brilliant colored SNOWB WLL- Thite fringed flowers of perfect form. Per pkt., 10c

MOURNING CLOAK OR WHITE FRILL-Flowers a rich purple maroon, edged

with white. Per pkt., 10c.
MIIDNIGHT-The whole plant-stems, branches and buds are black. Per pkt., 10c. IMPERIALIS RUBRA STRIATA-Flowers rich, blood-red color, splashed and striped white. Per pkt., 10c. PLENA (China or Indian Pink)-Finest double, mixed. SPECIAL OFFER: One Packet of Each of the Six Varieties for 30c.

\section{HARDY DIANTHUS, OR PINKS.}

DOUBLE GARDEN PINK-Large fringed flowers. Per pkt., 5c.

SINGLE SCOTCH PINK-Tery fine bloomer and strong grower. Per pkt., 10c. PERPETUAL FCOWERING GARDEN PINK-Perfectly hardy; in bloom con-

\section{GAILLARDIA.}

Beautiful, hardy plant, commonly called the Blanket Flower. Exceedingly free flowering: grows almost anywhere. The colors of the flowers are golden yellow, amaranth red, claret and purple. Hardy

AMBLYODON-Clear, bright red; very handsome. - Per pkt., 5c

SUN-KISSED-Gold aud scarlet; rery large. Per pkt., $5 \mathrm{c}$.
AURORA BOREALIS-Rings of gold, crimson and white. Per pkt., $5 \mathrm{c}$.

GRANDIFLORA-Extremely large, brilliant scarlet, richly marked with golden vellow, Per plt, $5 \mathrm{c}$

LORENZIANA-Large, round heads, composed of thirty to fifty flowers. Color, orange claret and sulphur yellow

GYPSY QUEENB (Hardy)-Blooms from June till November. Color, crimson and red. Per pkt., 10c.

SPECIAL OFFER: The Entire Collection of Six Named Gaillardias, 25c. 


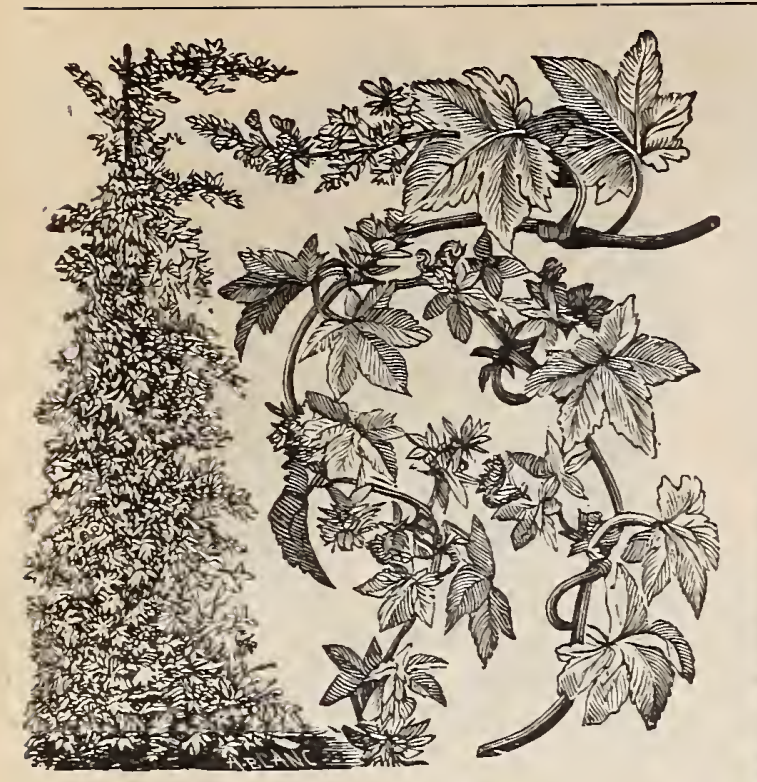

Humulus Japonicus (Japan Hop)

\section{HUMULUS.}

summer climber, often attaiuing a height of 20 to 30 feet in 3 or (See cut.) Pkt., 5c. JAPONICUS VARIEGATU II (Variegated are blotched and marked with white and gray. Per pkt., 10c.

\section{GOURDS.}

Ornamental class of rapid-growing climbers which attain a height of 20 feet in one season. CHINESE LOOFA or Dish Rag Gourd-Long, green fruit; the inside. When ripe, is a tough, Per pkt.

HERCULESE CLUB-I,arge, green fruits; 2 to

JAPANESE NEST EGG - Color, shape and POWDER HORN-Large size; shaped like a horn. Per pkt., $5 \mathrm{c}$.

pkt.. 5c. stríped fruits. Per pkt., $5 c$.
DIPPER-Very handsome variety, dipper shaped. Per pkt., 5 c.

\section{LEMON VERBENA.}

In this popular halfhardy shrub the leaves have a delicate lemon-like fragrance; flowers white. Per pkt., 10c

\section{IPOMEA.}

Tender annuals of rapid growth, with beautiful and varied colored flowers, very ornamental; use-
ful for corering arbors, trellises, old walls or ful for corering arbors, trel
stumps: also for house culture.

HEA YENLY BLUE - Flowers 4 to 5 inches across in large clusters; color light-blue. Per pkt. 10c. growing Moruing Glory, with large leaves, making a dense shade. The flow
ameter. Per pkt., 10c.

ameter. Per pkt., 10c.

bright blue; splendid. Per pkt.., 10c Pkt., 10c.

SPECIAL OFFER-One packet of the four varieties LOBELIA.

Very dwarf-growing plants. The Erinus species are the trailing varieties, most suitable for hanging baskets, rases, etc.. and the Compactas are densegrowing. use

CRYSTAL PALACE COMPACTA - DaRK blue: spleudid. Perpkt., 10c. growing. Per pkt.. 10c.

Per pkt., 10c.

\section{LATANA.}

HYBRIDA MIXED - A vigorous growing plant with a profusion of flowers all summer. Per pkt., $5 \mathrm{c}$.
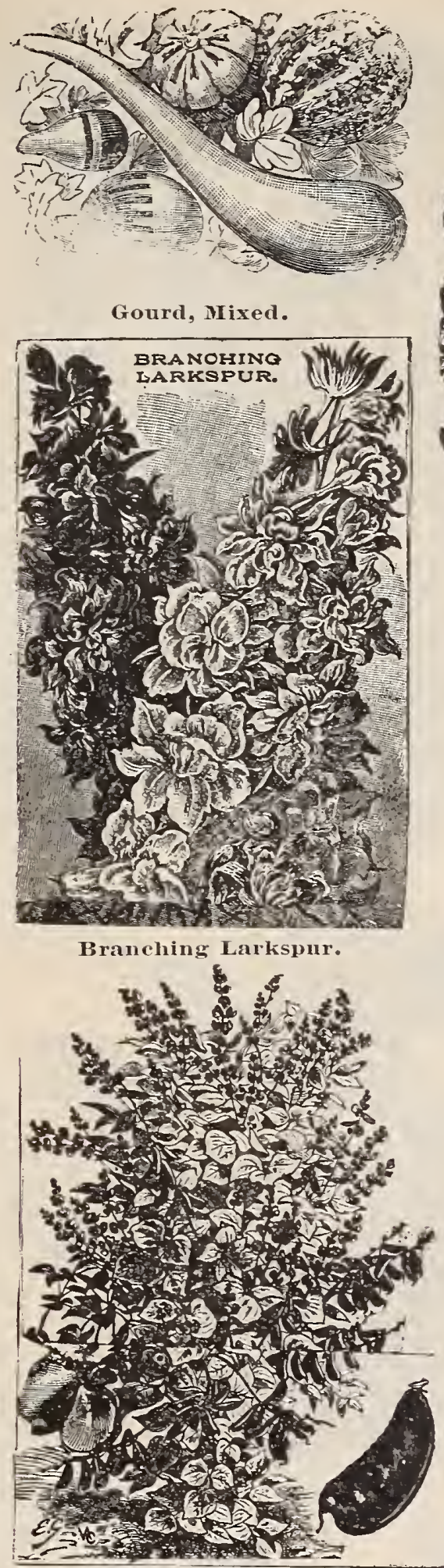

Hyaciutl Bean.

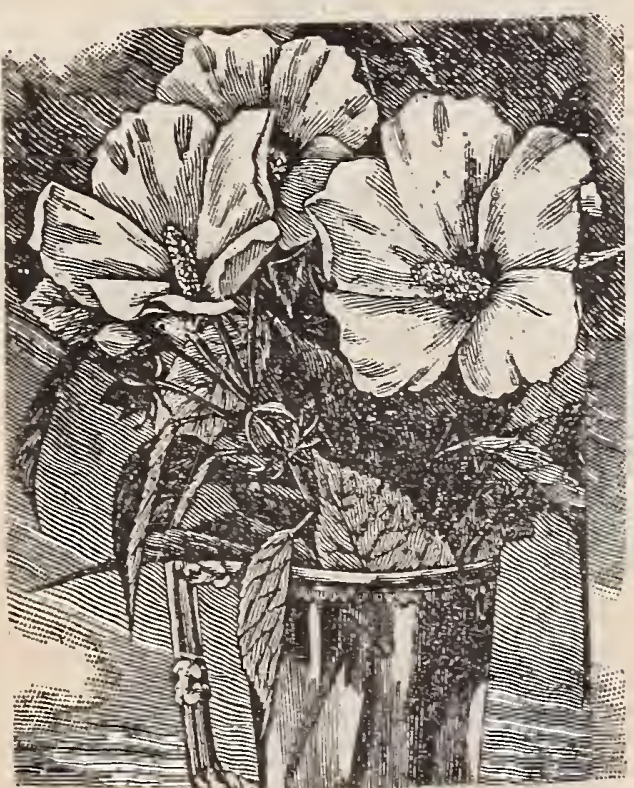

Hibiscus.

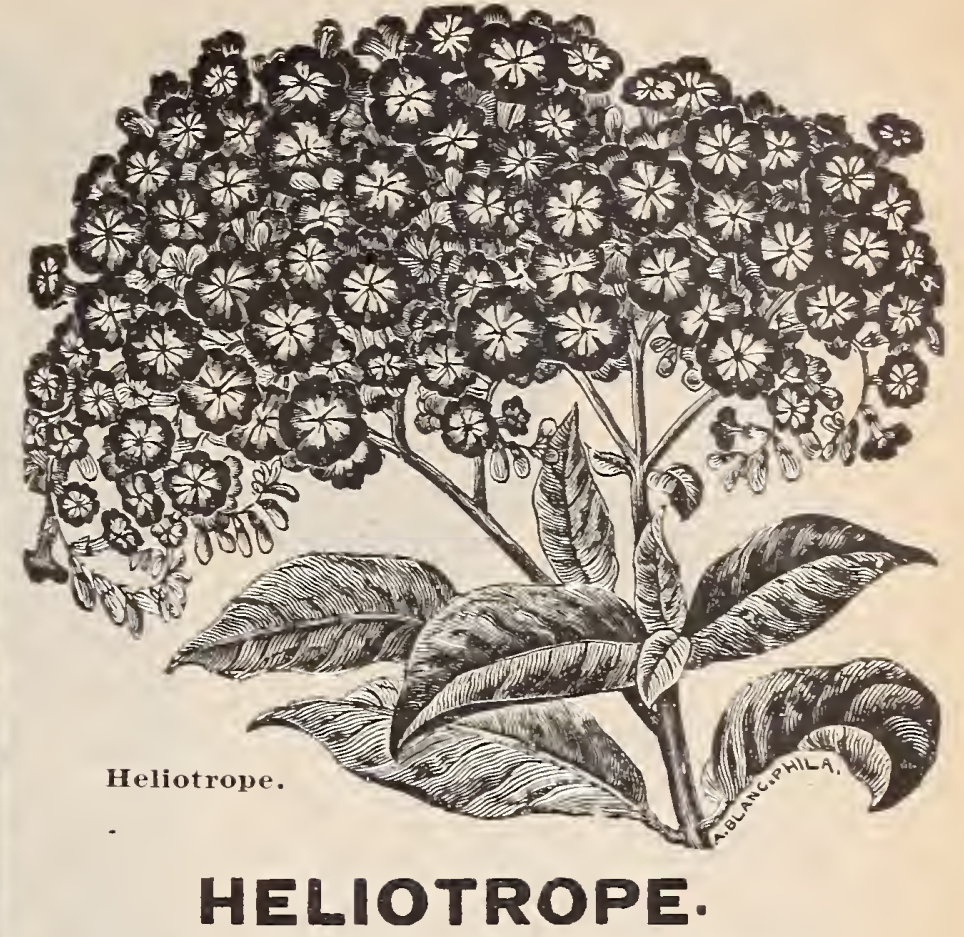

A half-hard seasou; its delightful perfume makes it a most desirafine plants for suminer mixed.

\section{HOLLYHOCKS.}

ug spikes of double and single flowers, plant, bearing SINGLE ALLEGHENY MIIXD COLORS-Fine

\section{HYACINTH BEAN.}

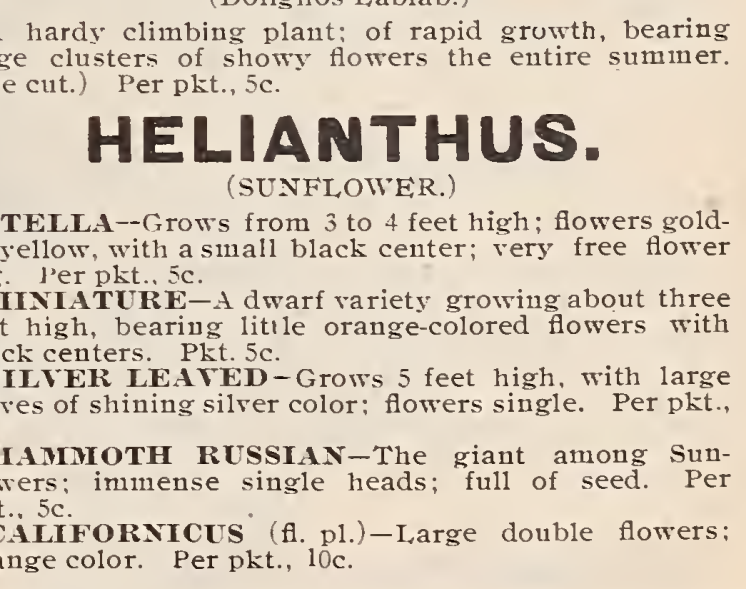

\section{HIBISCUS.}

Hardy Perennial.

(MARSHMALLOWS.)

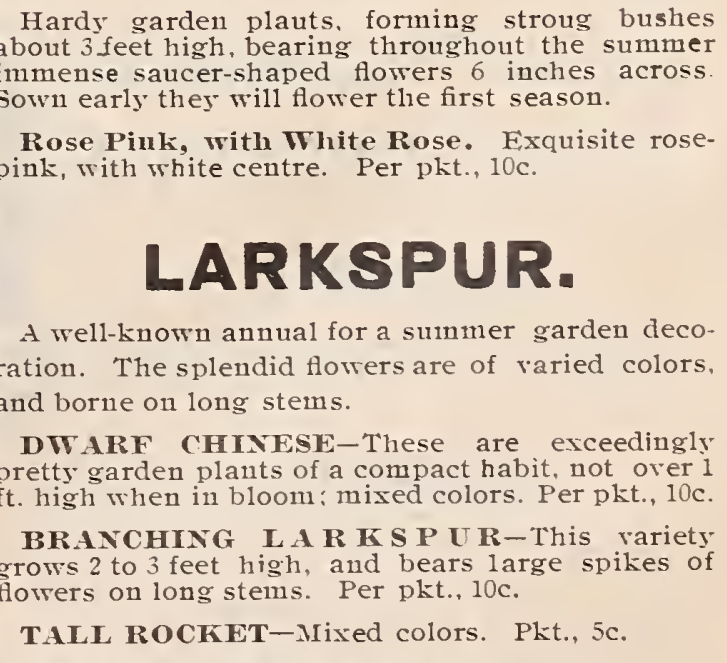
DWARF ROCKET-A dwarf variety with dou-
le flowers in various colors, Per pkt., $5 \mathrm{c}$. 


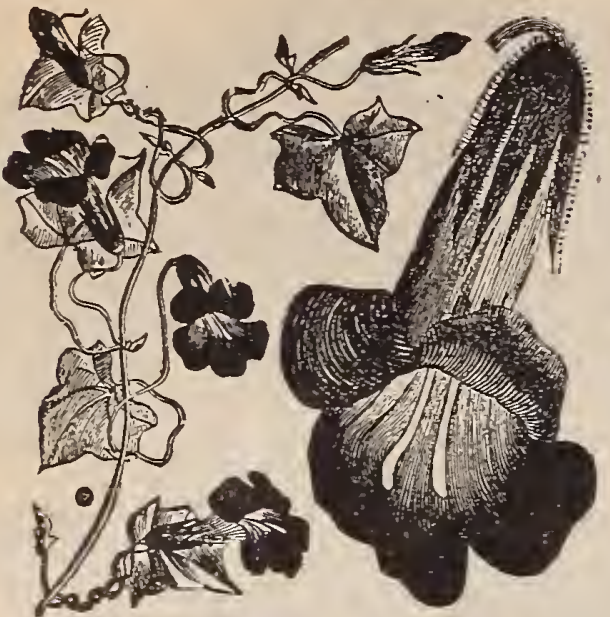

Maurandia,

\section{MAURANDIA.}

Graceful climbers for windows and conservatories, or for open ground in summer. and for covering stumps in low trellises.

BARCLA MIANA-Purple flowered. Per

GIANT FLOWERING - Mixed colors. Per pkt., 10c

\section{MORNING GLORY.}

(CONVOLIULUS MAJOR)

Handsome, showy climber of easy culture. Suitable for covering arbors, windows, trellises, stumps, etc. Will grow in almost any

SEPARATE COLORS-White, carmine rose, blue, striped and violet. Per pkt., $5 \mathrm{c}$.

I CORS ture of the above colors. Per pkt., 5c;0z., 10c.

\section{MOONFLOWER.}

(IPOMEA GRANDIFLORA)

These have become celebrated as the finest growing of all the summer climbers. They grow with marvelous rapidity, reaching a height of forty or fifty feet in a few weeks, and are covered with large, pure white, fragrant flowers in the evening and on cloudy days. For covering trellises, arbors, fences verandas and trees they are without a rival. Per pkt., 10c.

\section{MESEMBRYANTHEMUM,}

OR ICE PLANT

Dwarf-growing plants of great beauty, well suited for edging and covering rock work producing their star-like flowers in great abundance.

CRYSTALLINUM-Leaves and stems ap. pear as though covered with a coating of ice. Per pkt., 5c.

CORDIFOLIUM VARIEGATUM-The leaves are distinctly variegated with green and white. Per pkt., 15c.

\section{NICOTIANA.}

AFFNIS-A free-flowering plant that produces delightful, sweet-scented flowers th entire summer. Per pkt., $5 c$

\section{MOMORDICA.}

Very curious trailing plants, with ornamental foliage and remarkable fruit.

BASAMINA (BAISAY APPLE)-From East Indies; 10 feet. Per pkt., $5 c$

CHARANTINA (BALSAM PEAR) -10
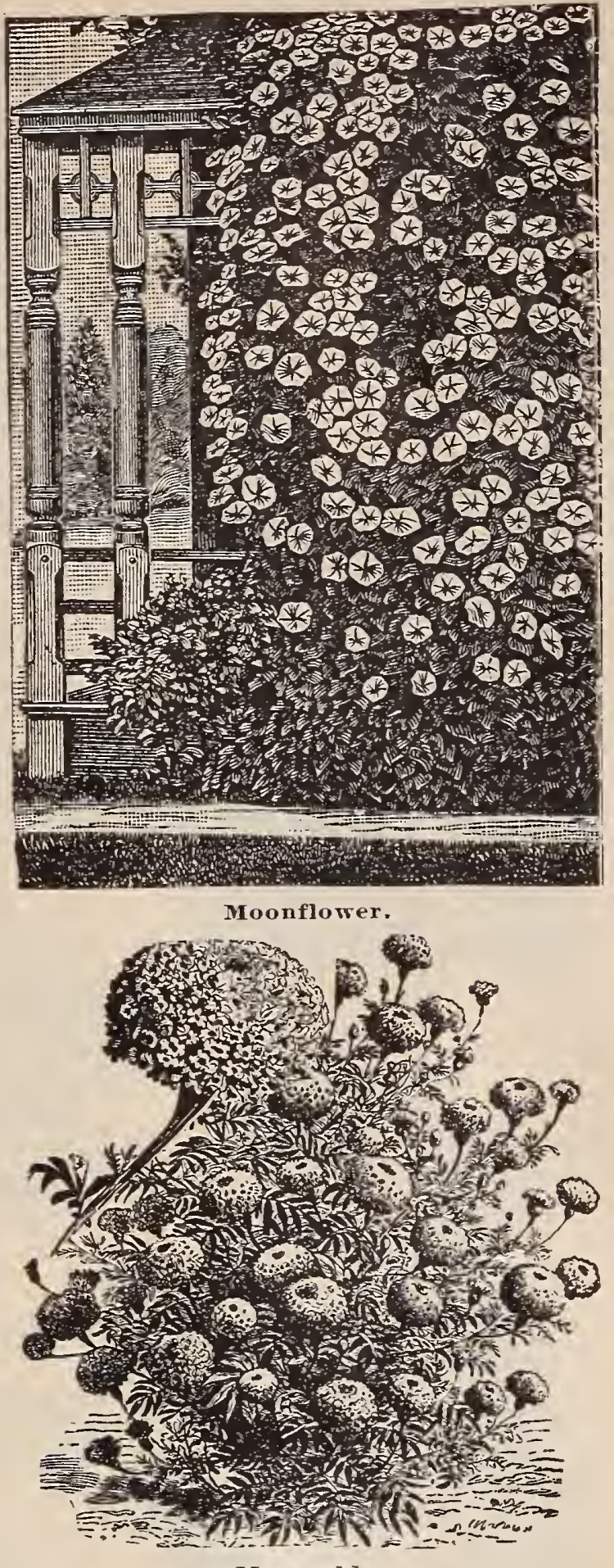

Maragold.

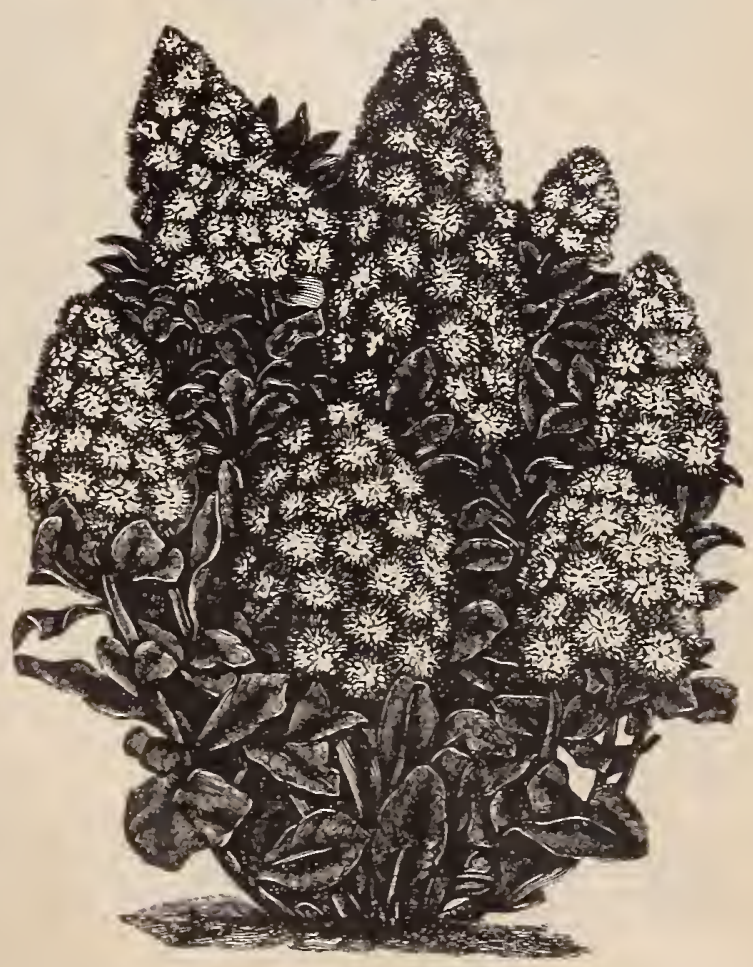

Mignonette.

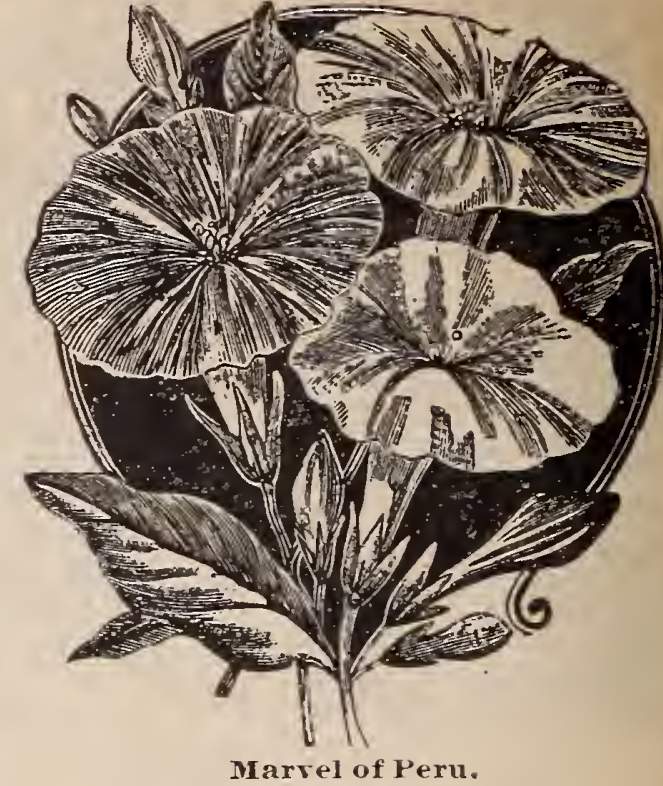

MARVEL OF PERU.

(FOLR O'CLOCKS)

The flowers, red, white, yellow aud variegated, grow in clusters on the summit of the stem. the evening.

FINEST MIXED COLORS-Per pkt., $5 c$ ? OZ., $15 c$

TARIEGATED FOI.IAGE-Mixed colors Per pkt., 5c; oz., 15c.

\section{MIGNONETTE.}

(RESEDA ODERATA)

A well known, hardy annual; in bloom the whole season, and is so fragrant that the whole atmosphere around is perfumed. No garden should be without it. (See cut).

MACHET-Dwarf and vigorous grower. Per pkt., 5c;oz., 35c.

GOLDEN QUEEN-Golden flowerș. Per PARSON'S WHITE-Pure white. Per pkt., c; oz., 20c

VICTORIA-Large flowering. Per pkt., 5c. GIANT GABRIELLE - Hardy, vigorous grower, with large spikes. Per pkt., 5c.

ALLEN'S DEFIANCE-A magnificent large flowering variety. Per pkt., $5 \mathrm{c}$.

BISMARCK-Large spike; very full rounded at the top. Per pkt., $5 \mathrm{c}$

NEW GOLDEN MACHET-Bears immense flower stalks, deliciously scented. Per pkt., $5 \mathrm{c}$.

LARGE FLOWERED, MIXED-The common sweet Mignonette. Per pkt., 5c: oz., 10c:

\section{MARAGOLD.}

A well known free flowerihg plant, of easy culture. The African is tall and strong growing and best adapted for mixed borders. The French grows dwarf and is more suitable for bedding purposes and pot culture.

DWARF FRENCH-LEMON YELLOW. Per pkt., $5 c$.

DWARF FRENCH-MIXED COLORS. Per

LARGE AFRICAN - MIXED COLORS. Per pkt., 5c.

MATRICARIA CAPENSIS ALBA.

(DOUBLE, WHITE FEVER-FEW)

A garden plant of easy culture, button shaped and very double. Per pkt., 10c. 


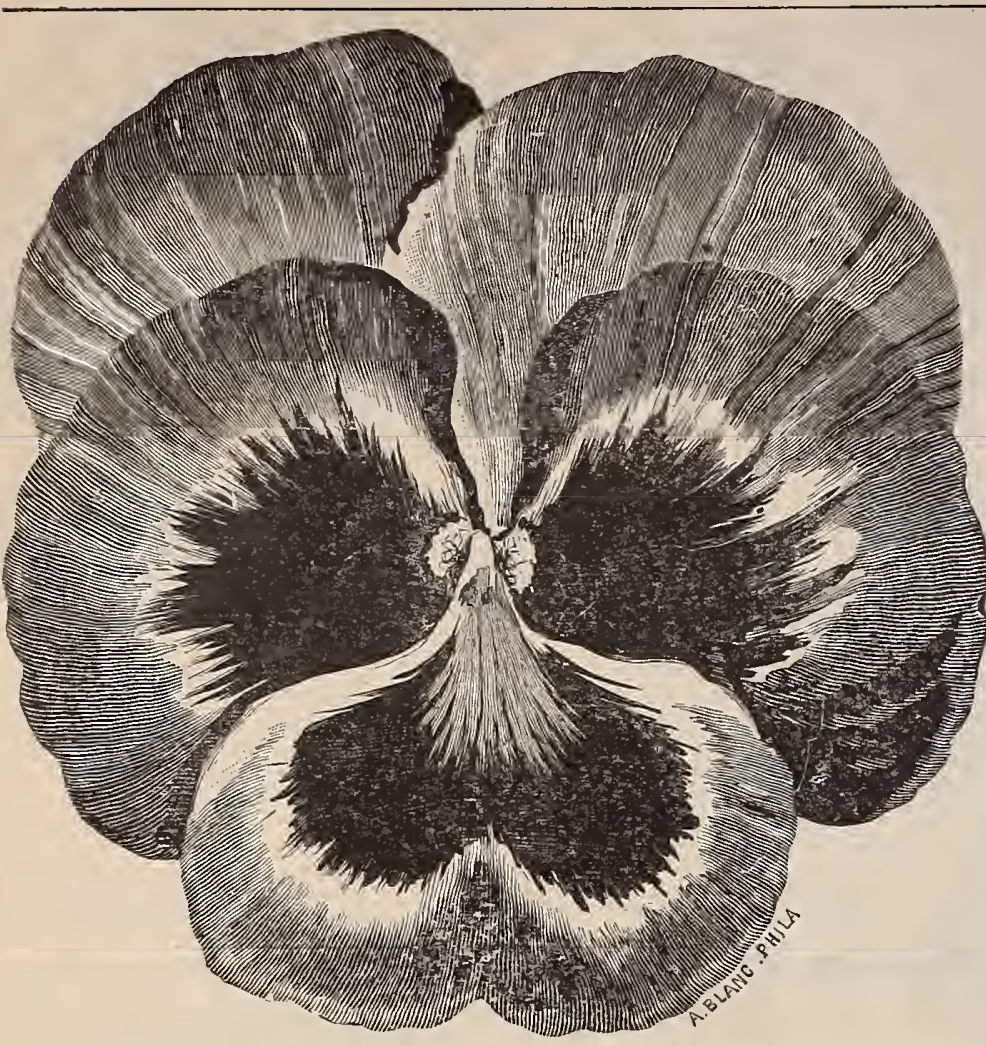

Pansies-Giant Trimardeau.

\section{PANSIES,}

\section{Qiant Trimardeau.}

A strain of Pansy which for variety, beauty, matchless forms, colors and markings have never been excelled. Flowers twice as large as ordinary Pansies.

GOLDEN QUEEN-Pure yellow spotless VIOLET BLUE-A dark marine blue, 10c. ADONIS-A very bright red, $10 \mathrm{c}$

STRIPED-Mahogany, striped with yellow. er pkt., 10c

WHITE-White blue blotches. Per pkt., 10c. LORD BEACONSFIELD-Purple, shaded white. Per pkt., 10c.

EMPEROR WILLIAM - Velvety roya purple. Per pkt., 10c.

VIOLET AND GOLD-(Atropurpurea), A triking variety. Per pkt., 10c

MARGINED--(Auriculaflora). Purple, edged MAHOGANY COLOR-Dark brown, very distinct. Per pkt,, 10c.

BLACK PRINCE-Color, pure dark velvety black. Per pkt., 10c.

YELLOW PRINCE-A pure yellow, with black center. Per pkt., 10c.

SPECIAL OFFER-One pkt. of each of the 12 distinct colors for $75 \mathrm{c}$

TRIMARDEAU - ALL COLORS MIXED Pkt., $10 \mathrm{c}$; $48 \mathrm{o} \% .65 \mathrm{c}$ : $1 / 4 \mathrm{O} \% ., \$ 1.25 ; \mathrm{Oz} ., \$ 4.50$

\section{PEAS \\ EVERLASTING.}

\section{(Lathyrus Latifolius.)}

Perennial climbers, producing beautiful, white rose and purple blossoms in graceful clusters suitable for trellises, arbors, etc.

ALRUS-Per pkt., 10c.

MIXED-All colors. Per pkt., 10c.

FOR NOVELTIES IN FLOWER ANI VEGETABLE SEEDS SEE PAGES 21 TO 36.
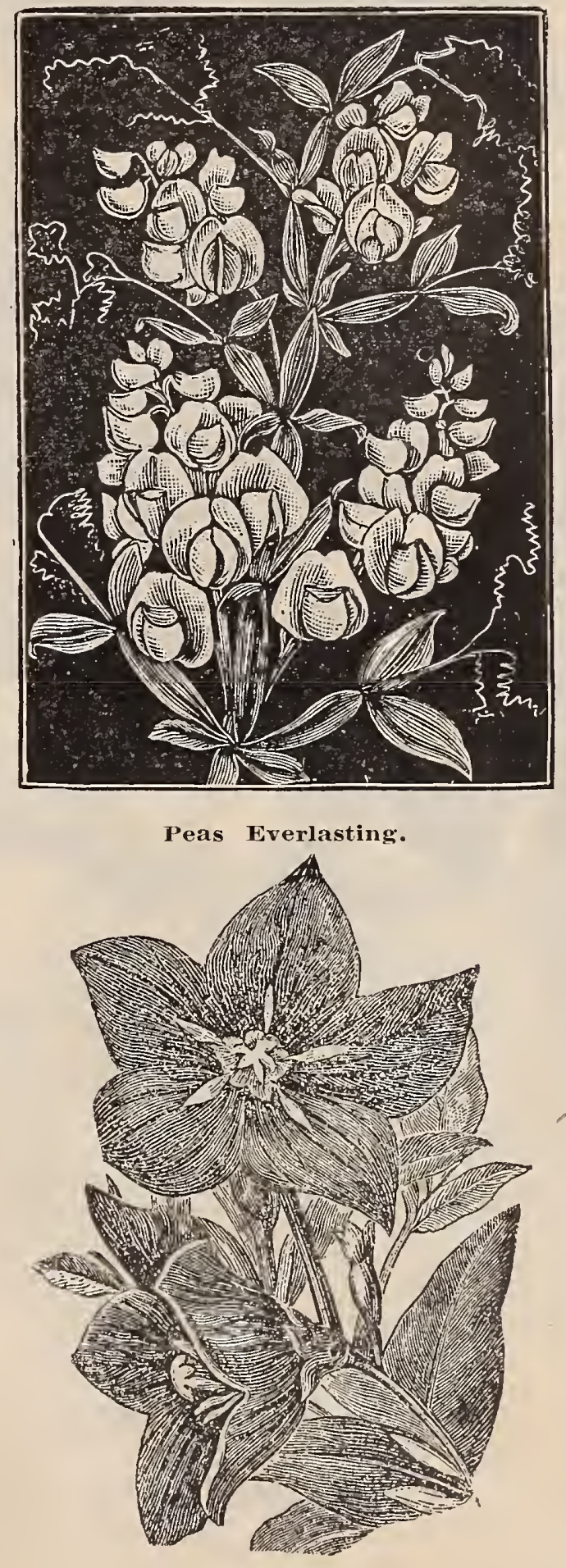

Platycodon.

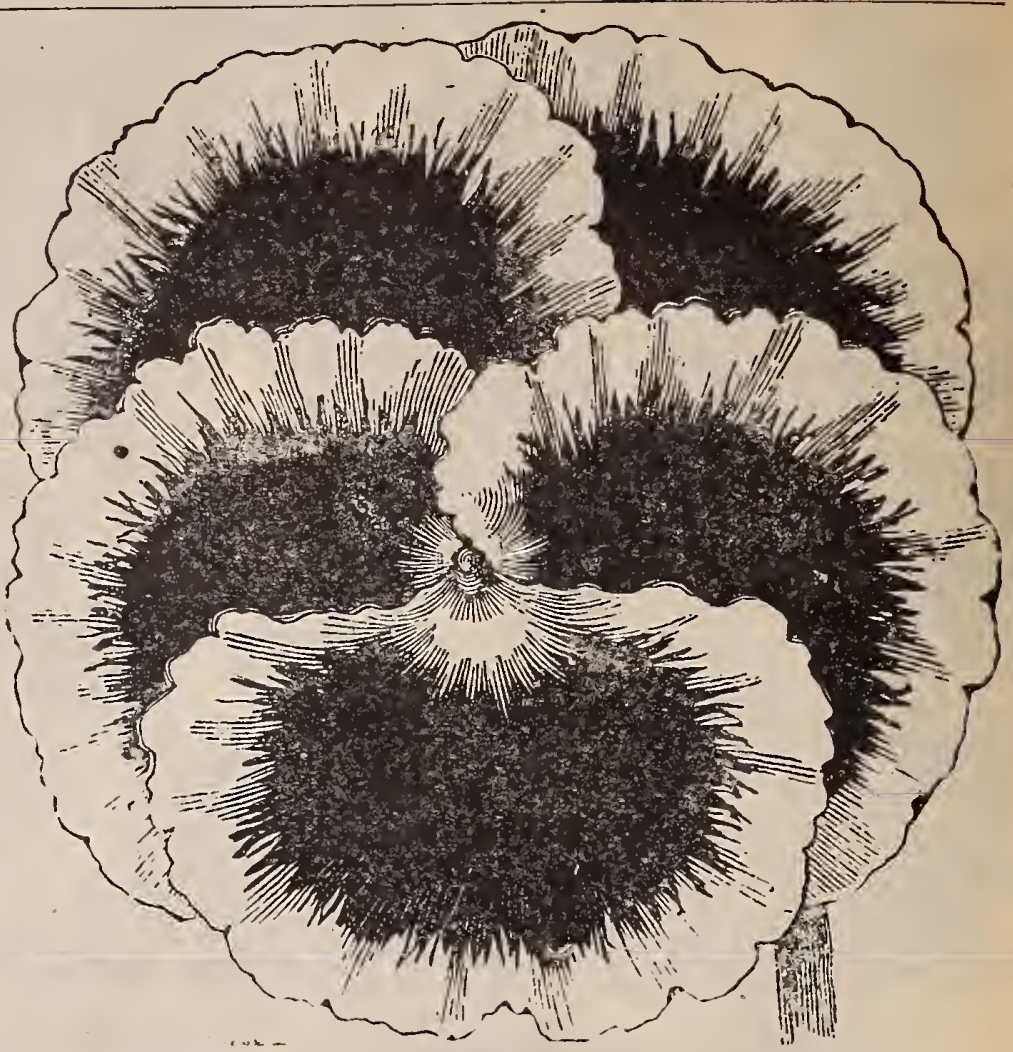

YOUNG'S IMPROVED

\section{PANSIES.}

YOUNG'S PERFECTION - Our Perfection Pansy is the cream of all fancy Pansies. Procured from all the Pansy specialists of Europe and America. Per pkt., 20c.

VICTORIA-Color, a "rich claret; large and showy. Per pkt., 10c.

GIANT ODIER-A magnificent variety, with deep rich, velvety blotches and clearly defined borders. Flowers very large. Per pkt., 20c.

IMPERIAX GERMAN-This superior strain is the result of years of careful culture and selection. Extra large: all shades of color, marbled, veined and striped, are in this variety. Per pkt., $15 \mathrm{c}$.

LARGE FLOWERING FRENCH-This new class is strong-growing and compact, producing flowers of extraordinary size. The colors are very bright, distinct and striking. Per pkt., 15c.

FANCY STRIPED LARGE FLOWERINGA flne race of striped Pansies. The blooms are exquisitely striped with soft, clear contrasting shades. Per pkt., 15c.

ENGLISH SHOW-Large, handsome flowers of regular form, very distinctly marked with bright showy colors: vigorous grower: assorted colors Per pkt., 15c

GIANT CASSIER-Mammoth flowers of richest self-color, with blotched markings. Per pkt., 20c.

BUGNOT'S SUPERB-Enormous flowers, vel rety in appearance and superbly colored. Per pkt., 20c.

SPECIAL OFFER-One packet each of the 9 distinct varieties, $75 \mathrm{c}$.

GOOD MIXED FANCY-A fair proportion of all colors. Pkt., 5c: $1 / 4 \mathrm{Oz} ., 35 \mathrm{c}$; oz., 75c;

We can supply fine young plants from the abore rariety of seeds for $75 \mathrm{c}$ per doz.: $\$ 500$ per hundred.

\section{PLATYCODON.}

Large flowering. Chinese Bell Flower. Hardy perennial; bearing large, broad, bell-shaped white or blue flowers. Per pkt, 10c.

\section{PYRETHRUM:}

PARNIFOLIUM ARUM - (Golden Feather.) Dwarf-growing, extensively used for ribbon and carpet bedding; foliage a bright yellow. Per pkt., $5 c ;$ oz., 50c. 


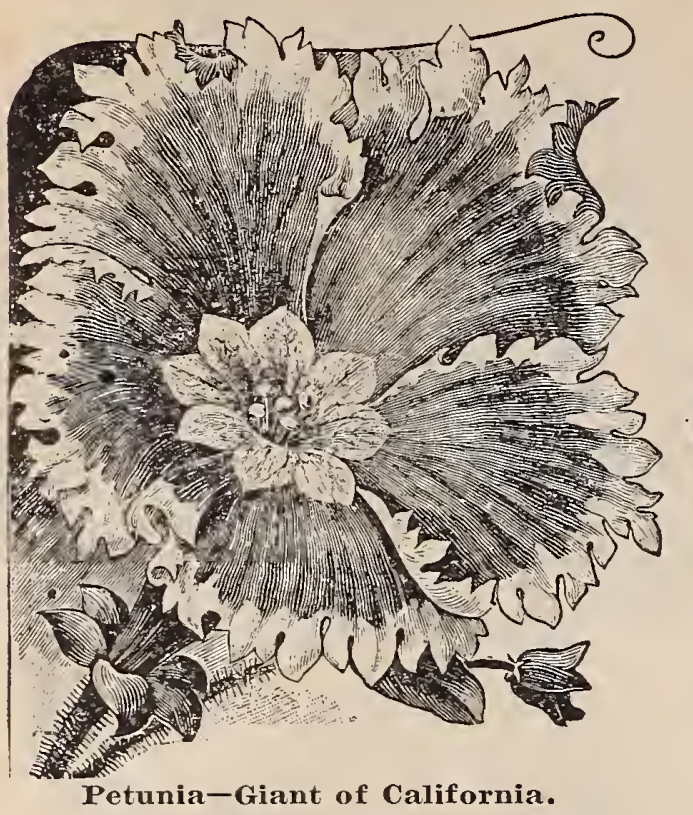

PETUN I A S.

These are the leading window and garden flowers. and few give more general satisfaction. Always full of flowers and ever an object of great beauty, commencing to bloom early and continuing a mass
of flowers throughout the season. Of easy culture. (See cut.)

\section{SINGLE GIANTS OF CALIFOR- NIA VARIETIES.}

RUFFLED GIANT-The flowers of this variety are of an extraordinary size and substance with very deep throats, and distinguished from the large

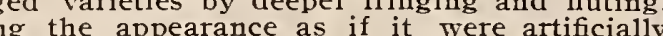
ruffled. All colors, mixed. Pkt.. 20c.

FRINGED GIANT-The flowers average 4 to 5 inches in diameter: they are of innumerable shades of color, all beautifully fringed. All colors, mixed. Per pkt., 20c.

CALIFORNIA GIANT-The flowers of this variety are of gigantic size, often measuring from
4 to 5 inches across. They are deeply mottled and 4 to 5 inches across. They are deeply mottled and pure white, crimson, lavender pink, etc. (See cut.) All colors, mixed. Per pkt., $15 \mathrm{c}$.

SPECIAL OFFER-The three distinct Giant of California varieties for $40 c$.

\section{SINGLE VARIETIES.}

HYBRIDA GRANDIFLORA-An extra large flowering variety; striped and blotched. Per

SNOWBALL-The plants are of dwarf, compact. bushy growth, completely covered with smal white flowers.

DWARF INIMITABLE-A dwarf variety. Flowers, single: color, a berry-red, with a white star-light center. Per pkt., 10c.

FINE SINGLE-All colors; very choice; mixed. Per pkt., sc: $0 z .$, , $40 \mathrm{c}$.

\section{DOUBLE VARIETIES.}

DOUBLE LARGE FLOWERING MIXEDA magnificent strain with flowers 3 to 4 inches across; very double, and all shades of color, in
crimson, white, rose and maroon blotched. Per crimson, whit.,
pkt.

\section{RICINUS.}

(Known as Castor Oil Plant and Palma Christi.)

BORBONIENSIS ARBOREUS - Very large and handsome foliage: 15 feet. Per pkt., $5 \mathrm{c}$.

GIBSONNI-One of the most ornamental and showy varieties, with dark, purple foliage. Per ZANZIBARIENSIS-A distinct variety, surpassing in size and beauty all varieties. Per pkt., 10c: MIXED VARIETIES-Per pkt., 5c; oz., 15c.
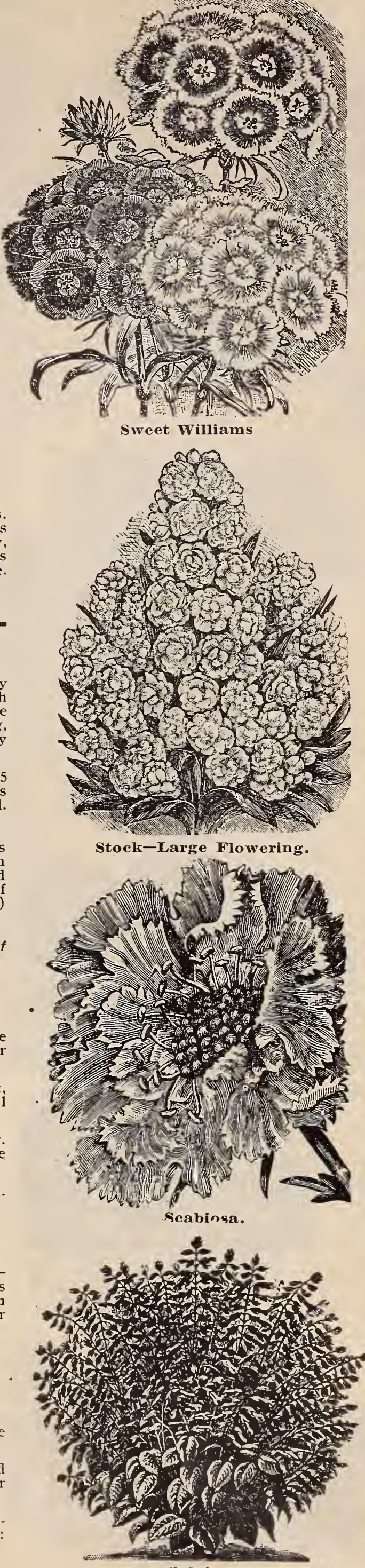

Salvia.

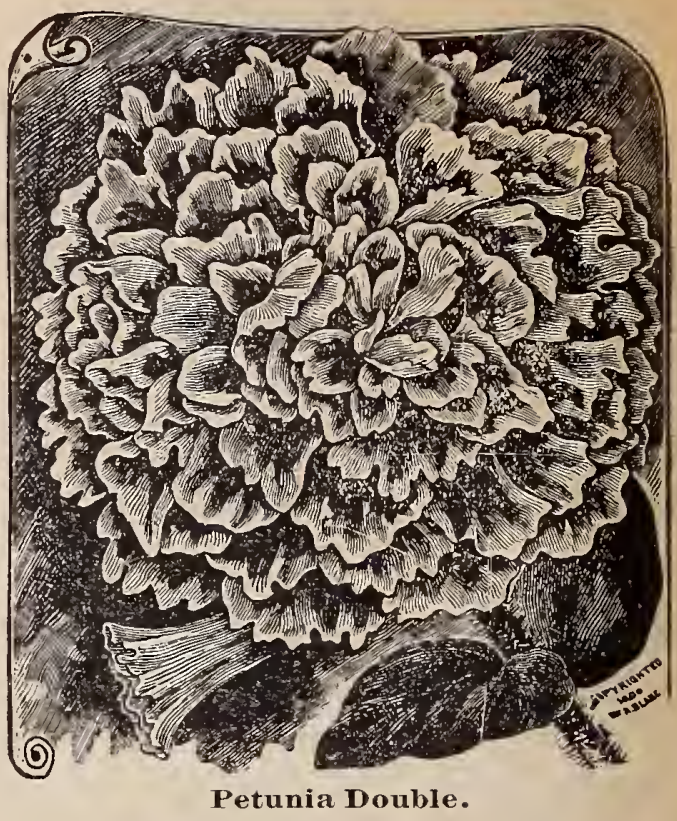

SWEET WILLIAM.

HUNT'S PERFECTION-A splendid strain flowers of many bright colors, large size and various markings, including the finest auriculaeved varieties; of all colors. Per pkt., $5 c$.

SINGLE-Mixed. Per pkt., $5 c$

DOUBLE-Mixed. Per pkt., 5c.

\section{STOCKS.}

\section{(or Gilliflowers.)}

CUT AND COME AGAIN-One of the best varieties of stocks for cut flowers; grows about 2 feet high, flowering continually from early spring until late in the fall; color pure white and very double. Per pkt., 10c.

NEW GIANT PERFECTION-A splendid variety of pyramidal growth, finest mixed. Per pkt., 10c.

DWARF GERMAN-TEN WEEK-Mixed colors. Pkt., 5c.

\section{SCABIOSA.}

NANA COMPACTA-Commonly called Morning Bride, a very free-bfooming annual. Va uable for cutting purposes. (See cut.) MIXED COLORS. Per pkt., 5c.

\section{Sensitive Plant.}

\section{Mimosa Pudica.}

A curiosity, the leaves and stems droop when touched, and fold up; a good plant for either garden or pot culture. Per pkt., $5 c$.

\section{SMILAX.}

A valuable climber, either for the house or comservatory. Per pkt., 10c; ounce, 30c.

\section{Salvia, or Flowering Sage.}

SPLENDENS-Scarlet Sage-Spikes of intensely rich scarlet flowers that continue in profusion until frost (see cut.) Per pkt, 10c.

BONFIRE-This is the finest variety of Salvia ever introduced; grows into a very compact oval bush about two feet high and producin spikes of brilliant scarlet flowers, which stand out stiff and plant to bear 200 spikes. Per pkt., 10c.

COCCINEA-Fine free-flowering. Per pkt., $5 c$ BURNING BUSH-This variety makes a compact bush about $2^{1 / 2}$ feet high and produces long drooping spikes of brilliant scarlet flowers thrown well above the foliage; a
when in full bloom. Per pkt., 10c.

For Novelties in Flower and Vegetable Seeds see pages 21 to 36 . 


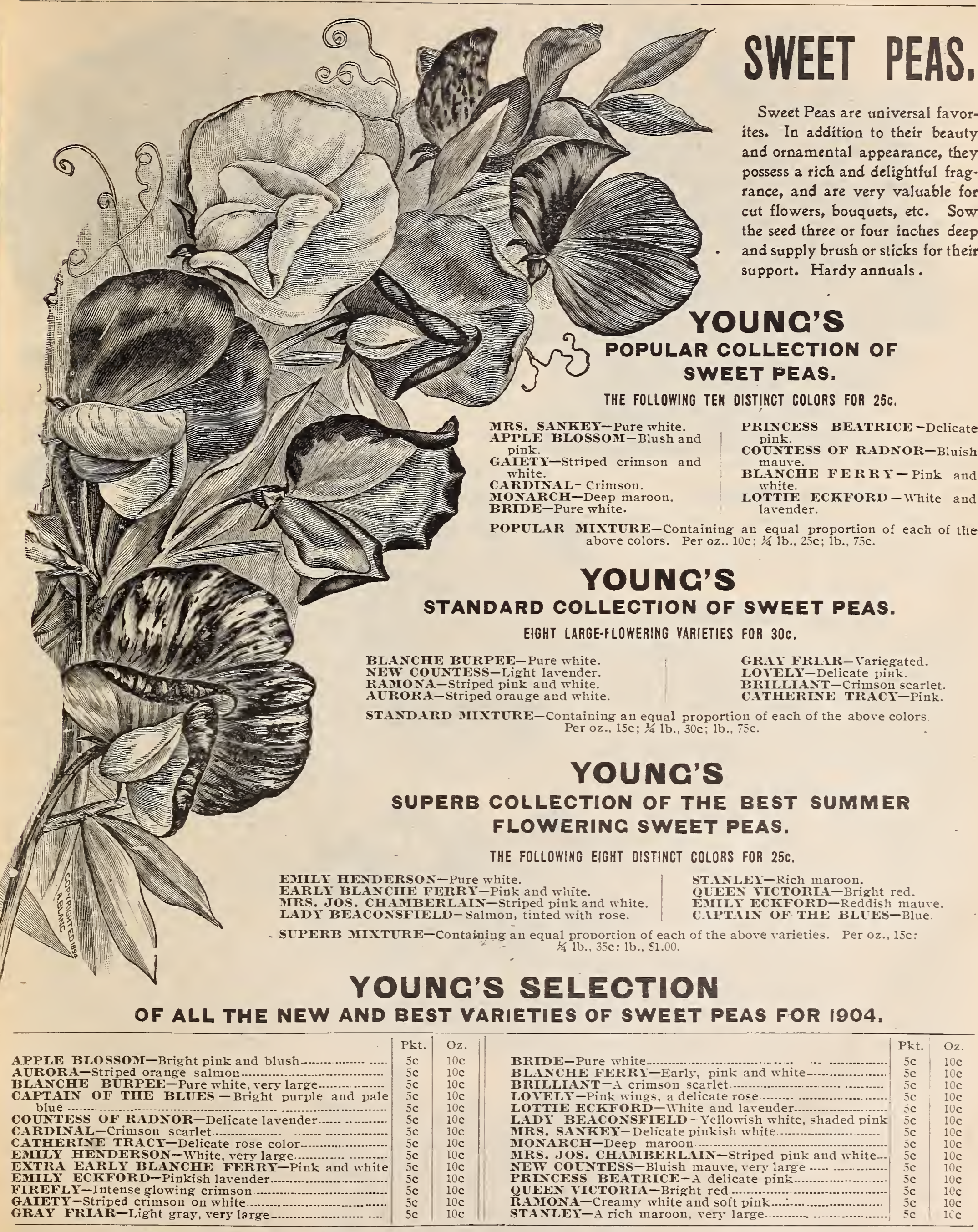

SWEET PEAS, CHOICE MUXED - A fine assortment of all choice varieties: Per oz., $5 c ; 1 / 41 b ., 15 c ; 1 b ., 40 c$

O. Young \& Sons' Co.

Dardenelle, 110

Gentlemen:-I received quite a lot of Seeds from you last Spring and they all grew rapidly; my Sweet Peas were tery fine and were admired by all who aw them. My Nasturtiums were also fine, they were the largest and finest varieties that I ever saw. Respcctfully. Jas. Galt. 


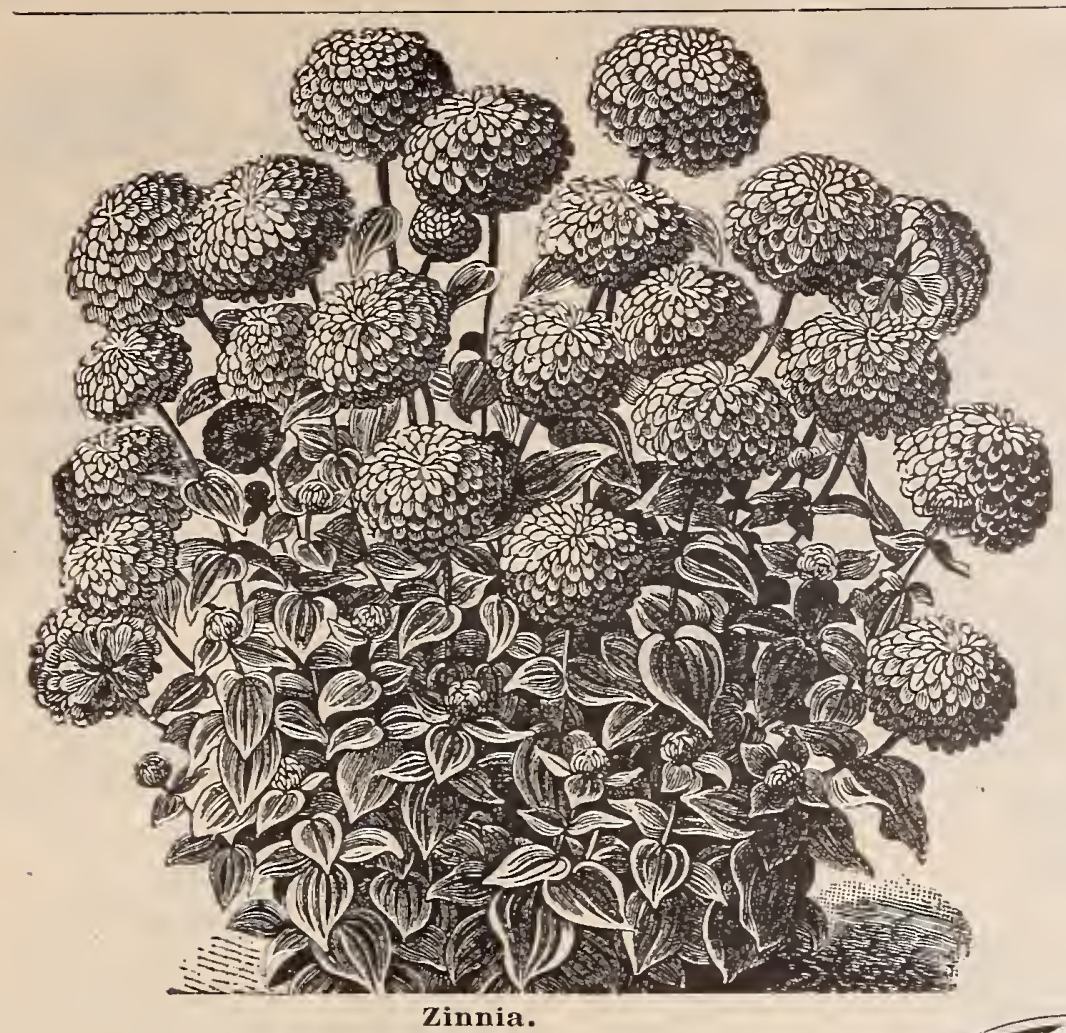

\section{THUNBERGIA.}

ALATA-Rapid-growing annual climbers 4 to 6 feet high, splendid for trailing over trel lises, fences, etc. Beautiful flowers borne in profusion; buff, white, orange, etc. Mixed colors. Per pkt., 5c.

\section{WALL FLOWER.}

Fine German mixed flowers on long spikes, deliciously fragrant; in many shades of color, chocolate and orange purple. (See cut.)

Mixed Single and Double-Per pkt. $5 c$

\section{YUCCA.}

FILAMENTOSA-An ornamental hardy plant, with large spikes of white flowers. 10c.

\section{ZINNIA.}

The plants form a handsome bush with perfectly formed double flowers, often measuring 5 to 6 inches in diameter, of easy culture and bloom continually throughout the entire summer.

ZEBRA-STRIPED-The flowers are a perfect form; distinctly striped and spotted with different shades of color. Per pkt., 10c.

ELEGANS TOM THUMB Compact bushes, not over 12 in. high by about 14 in. in diameter. Flowers are perfectly double. All colors mixed. Per pkt., 10c.

ELEGANS, All Colors MixedPer pkt., 5c.

\section{Mammoth Flowering Varieties.}

DEEP YELLOW-Per pkt., 10c.

WHITE-Per pkt., 10c.

CRIMSON-Per pkt., 10c.

GOLDEN YELLOW-Pkt., 10c

ORANGE-Per pkt., 10c.

SPECIAL OFFER-1 packet each of the different colors for $20 \mathrm{c}$.

MAMMOTH, All Colors Mixed - Per pkt., 10c.

For Novelties in Flower and Vegetable Seeds see pages 21 to 36.
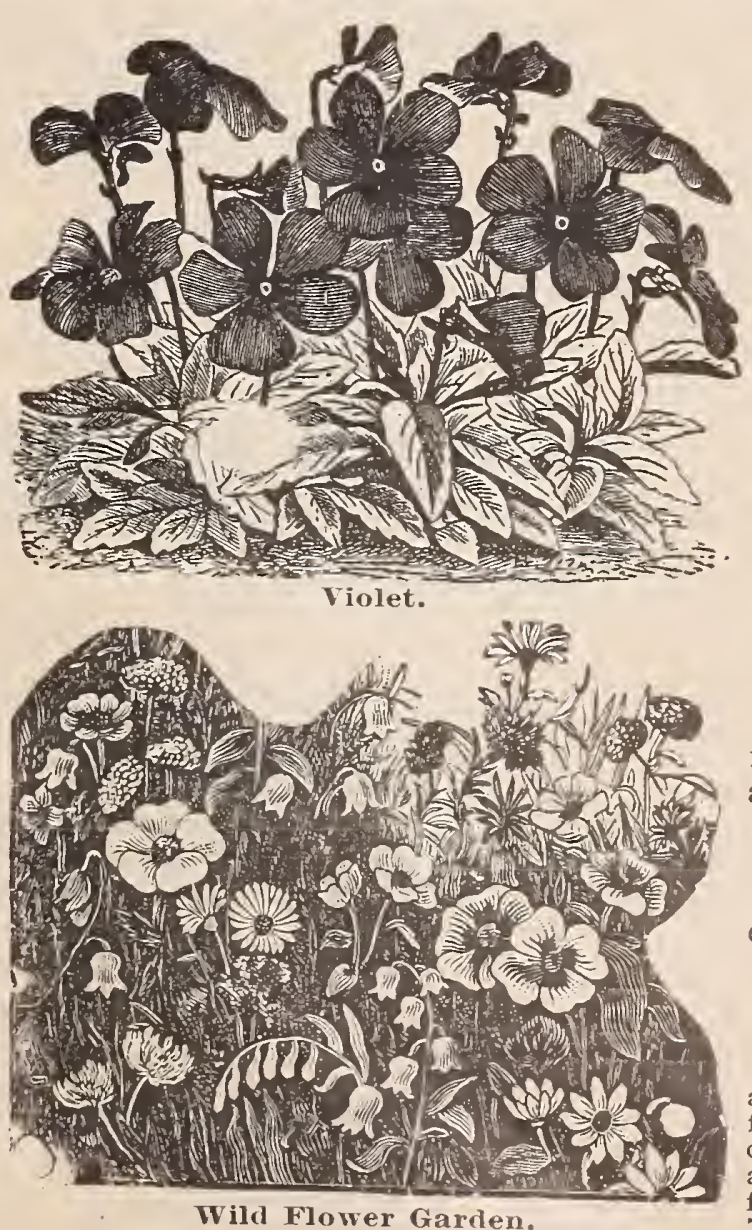

Wild Flower Garten.

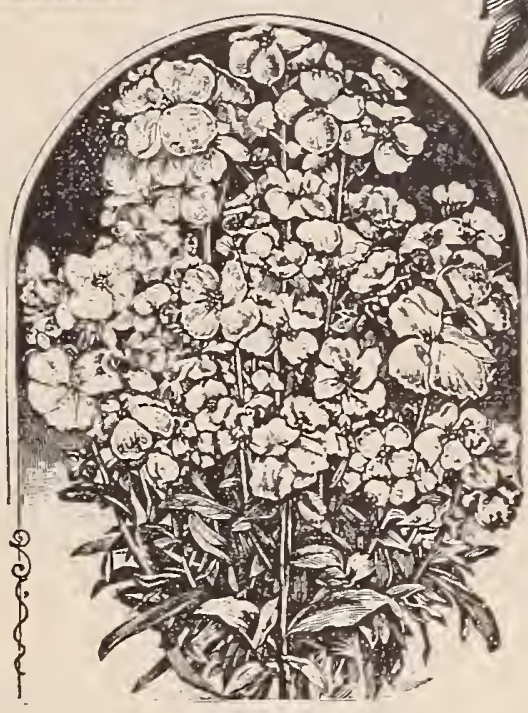

Annual Wall Flower.

YOUNG'S A URICULA-FLOWERED - A mammoth variety, having a distinct white eye or spot in centre of each petal; very striking and beautiful. Per pkt., 15c.

Choice Strains in the following Colors in separate packets. PURE WHITE .................Per pkt., 10c BRIGH'T SCARLET ….......Per pkt., 10c. BLUE ................................Per pkt., 10c. STRIPED ...........................Per pkt,, 10c SUPERB MIXTURE OF ALL COLORS

\section{VIOLET.}

Favorite hardy perennial plants, ad mired for their beauty and fragrance They flower the first year from seed (see cut)

ODERATA-Single blue. Pkt.10c CZAR - Largest flowering variety Pkt., 10c.

\section{VINCA.}

\section{OR PERIWINKLE)}

Handsome bushy plant, flowering freely during the hot summer months. nd blooms the first season from seed ALBA PURA-White. Pkt., $5 c$ ROSEA-Bright rose. Pkt., 5c. ROSEA ALBA-White with ros ALL COLORS MIXED-Pkt. 5 WILD FLOWER GARDEN. These mixed flower seeds contain more that hundred varieties of easy growing and prett den : rery 1 sable for forming a wild flower gar and on untidy bare spots of ground which ar frequently unsightly. Pkt., $10 \mathrm{c}$; oz., $25 \mathrm{c}$; $14 \mathrm{lb}$ 


\section{R O $\mathbf{A} \mathbf{A}$}

\section{Young's Roses Grow and are Sure to Bloom Everywhere. ... THEY ARE ONE OF OUR SPECIALTIES ... HINTS ABOUT ROSES.}

OUR SPECIALTY. We have for years made Roses our leading specialty. and sell aunually over half a million plants. We pay particular of established merit and new sorts, which have been thoroughly tested by us, hence we offer unequaled advantages to buyers of Roses.

OUR CLAIM. We claim that we send out larger and finer Roses than any other firm in the business. Our smallest size is larger than the finitely better. WHAT VARIETIES TO PLANT. The Ever-blooming or Monthly Roses are the only constant bloomers we have. They begin to

HARDY ROSES. This section includes the Hybrid Perpetuals and Mosses, and while they are not constant bloomers, they make a gorgeous PREPARATION OF ROSE BED. Select a sunny spot, prepare your bed by digging to a depth of eighteen inches. Any good gar season, keep the soil loose by frequent shallow stirrings, till the middle of June, when they sheen set out, which should be eary in the the bed to the depth of an inch or'so with old manure to prevent evaporation.

FERTILIZERS. Fine, well decomposed cow manure is the best for general purposes, and the results obtained from its use will be found to

WINTER PROTECTION. The Ever-blooming Roses require protection during the winter. A good way of protecting them is to bend f of boards or boughs. Any mode of protection is good that will prevent sudden freezing and thawing and does not hold moisture about the
stem, causing decay. A straw covering is apt to harbor mice. DO NOT COVER TOO SOON; wait until the plants are well matured and stem, causing decay. A straw covering is apt to harbor mice. DO NOT COVER TOO SOON; wait until the plan
severe weather is beginning; light freezing will do no harm. UNCOVER when the frost is leaving the ground.

INSECTS. The most important is the Rose-Slug, a soft slug-like animal, about a quarter of an inch long, most troublesome in June, They feed S. upon the upper surface of the leaf. REMEDY-Dust with YOUNG'S INSECT POWDER when the foliage is wet; also good to de

MILDEW. This disease is caused by sudden changes from heat to cold. REMEDY-Dust with sulphur as soon as it appears

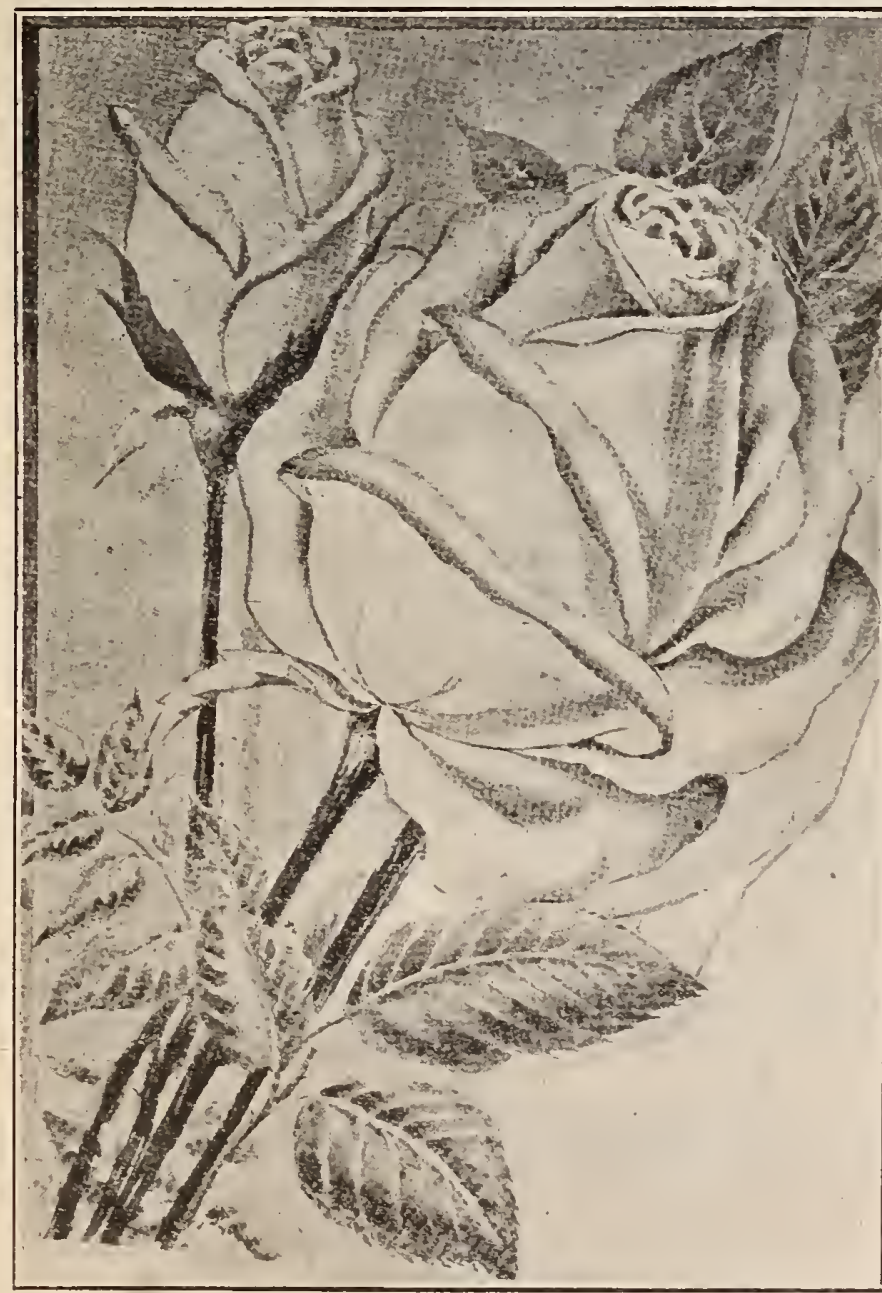

EVERBLOOMING ROSE.

\section{Pink Maman Cochet.}

This variety is well known among roses and one of the most beautiful sorts ever grown. The flowers are of enormous size, very full bright rose, and long pointed buds. It is a fine bloomer and coutinues all season. Hardy, vigorous grower and very fragrant.
tignt

Price, 1st size, 50 cents; $2 d$ size, 25 cents.

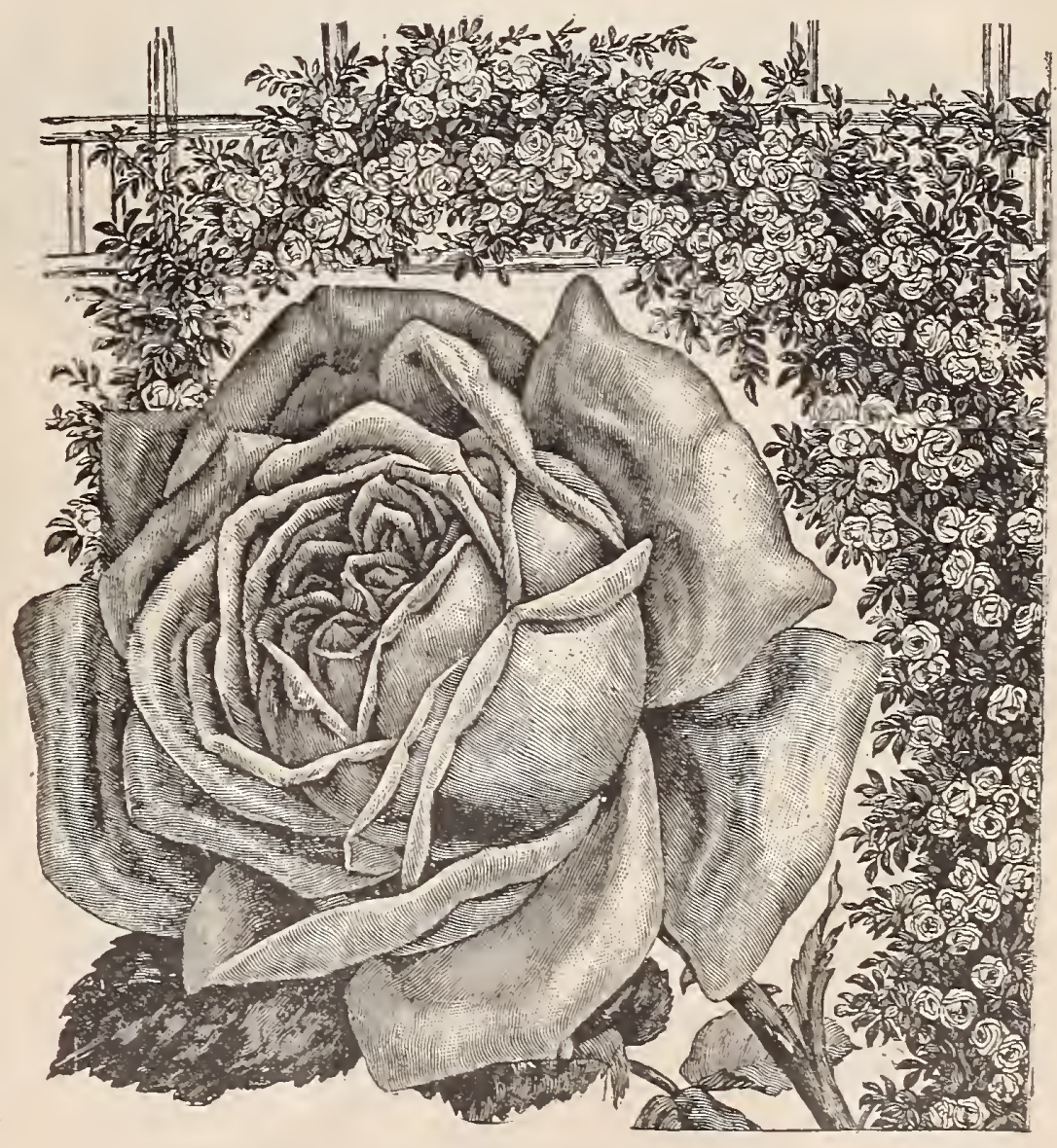

HARDY CLIMBING ROSE, Mrs. Robert Peary.

(Or, Climbing Augusta Victoria.)

A pure whice everblooming rose, probably the best of its color, of strong vigorous growth. The flowers are extra large, very deep, full and flowers and buds are beautifully formed and borne on single stems. It blooms abundantly all through the season. (See cut.) 


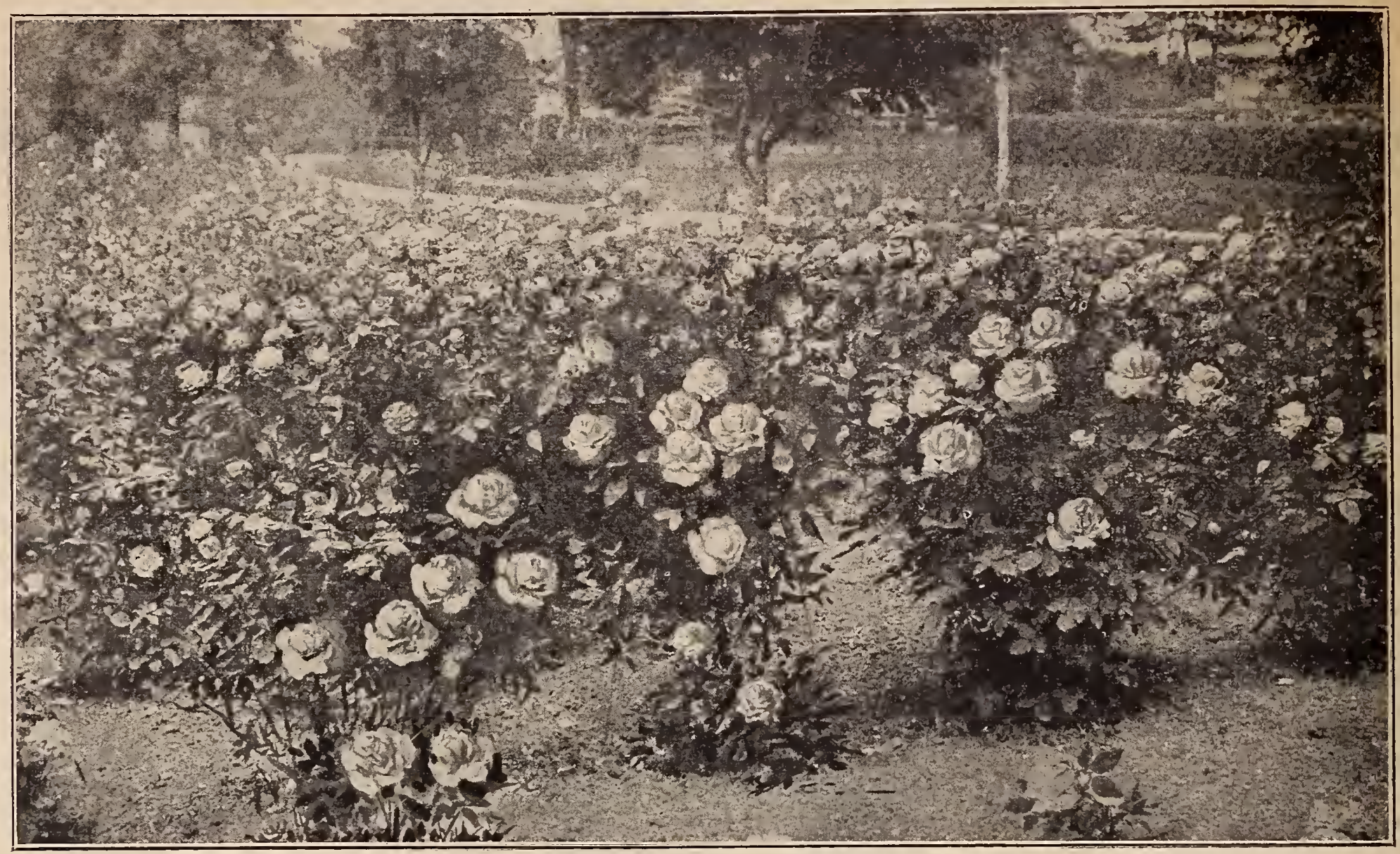

A Bed of Roses in Forest Park, St. Louis.

\section{FOREST PARK COLLECTION OF HAROY EVER BLOOMING ROSES,}

This collection contains 13 of the choicest and best varieties for out door planting. The above illustration shows their vigor, growth and free blooming qualities, which has made them so famous everywhere. By ordering the FOREST PARK COLLECTION OF ROSES you will obtain one that will give yeu entire satisfaction and a great acquisition to your garden.

No. 1. PERLE DES JARDINS - The flowers are very large and double, of perfect form. Color, a rich shade of yellow; a healthy, free grower, with beautiful foliage and unequalled in profusion of bloom. No
collection of roses is complete without Perle. Each, 1st size, 50c; $2 \mathrm{~d}$ size, $25 \mathrm{c}$; $3 \mathrm{~d}$ size, $15 \mathrm{c}$

No. z. SOUVENIR DE LA MALMAISON-When used as a bedding rose in summer has no equal, as it produces the most perfect flower in the hottest weather. Its rich, flesh-colored flowers are of immense substance to withstand our hot, dry summers. Exquisitely fragrant. Each, 1st size, 50c; 2d size, 25c; 3d size, $15 \mathrm{c}$

No. 3. MADAME SCHWALLER-This rose has the strong, firm growth of the hybrid perpetuals, the same form and finish of flowers being especially beautiful when full blown. It is very free in bloom, and has the fragrance of the old June roses. The color is a bright, rosy flesh. paler at the base of the petals, and deepening on the edges. Each, 1st

No.4. GENERAL WASHINGTON-This variety possesses all the desirable qualities of a bedding rose. The flowers are large, double an of a good form and very fragrant. Color, a deep red, shaded crimson and carmine. Each, 1st size, $50 \mathrm{c}$;

No. 5. AMERICAN BEAUTY-This new rose of American introduction belongs to the hardy hybrid perpetual class, but it blooms almost as constantly as the teas. There is no doubt that it is a good rose for out The buds are extra large, very full and double, and exceedingly sweet The color is a dark, rich crimson and most exquisitely shaded. The flowers are very lasting after cutting, keeping fresh and bright from one

No. 6. LA FRANCE-One of the most beautiful of all roses, and is unequalled by any in its delightful fragrance. The flowers are very large the season. Stands first among the roses of our climate. Each, 1st size, the season. Stands first an

No. \%. SOUVENIR DE WOOTEN-This superb rose is unquestionably one of the flnest varieties ever intraduced for summer blooming The color is a beautiful shade of carmine crimson, delicately fragrant; a constant and most prolific bloomer, every new shoot forming a flower bud. - It retains its color better than any rose of its class, and is exceedingly vigorous in growth, rendering it one of the most satisfactory roses for the
amateur to grow. Each, 1st size, 50c; $2 \mathrm{~d}$ size, 25c; 3d size, 15c.
No. 8. MADAME TESTOUT - A magnificent rose; flowers full very large, globular form; color, clear satin rose; petals bordered with tender rose; very fragrant; vigorous grower. This variety resembles La but are better formed. Each, 1st size, 50c; 2d size, 25c; 3d size, 15c.

No. 9. CHAMPION OF THE WORLD-Color, rich glossy pink, delightfully fragrant, and is such a strong, vigorous grower, that it is almost impregnable against attacks of the insects which usually destro so unequalled for the garde Every shoot is loaded with flowers. Each, 1 st size, $50 \mathrm{c} ; 2 \mathrm{~d}$ size, 25c; $3 \mathrm{~d}$

No, 10. CLOTILDE SOUPERT-One of the most prolific bloomers in the entire list. Beginning to flower when not over four inches high and continuing without intermission the entire season. The flowers ar borne in sprays, very double and handsomely formed. The outer petals are pearl white, shading to a centre of rosy pink, but varying sometimes on the same plant from pure white to deep silvery rose, a grand bedding

No. 11. DINSMORE-A true perpetual bloomer; begins to bloom almost as soon as planted, and continues all through the season. The fowers are extra large, very double and full, and quite fragrant. Color, bome fosy crimson; very showy and handsome and one of the best roses ever introduced for general planting

No.12. KAIZERINA AUGUSTA VICTORIA-An extra fine white vatiety, faintly blended with cream color; very large, full double and perfect in form. Fragrance very delightful and distinct from that of an variety. A free and vigorous grower; excellent summer bloomer. Each,

No. 13. HERMOSA-We believe the Hermosa is the best known in the entire rose family, and a universal favorite. Hardy as a lilac bush and as free-flowering as the geranium, it combines everything most desirmost in rose. The flower is cupped, finely formed and tull color, the

The third size may be forwarded by mail, but the first and second sizes are too large to be sent per mail, and must be sent per express.

SPECIAL OFFER OF FOREST PARK COLLECTION : Strong young plants, the set of 13 varieties, $\$ 1.50$, by mail or express. Large plants, the set of 13 , for $\$ 2.50$, by express only. Extra large two-year old plants, the set of 13 , for $\$ 5.00$.

When ordering, say the "Forest Park Collection", of Ever Blooming Roses.

Our Roses are All Grown on Their Own Roots. 


\section{Young's Popular collection of Hardy Monilhily Roses.}

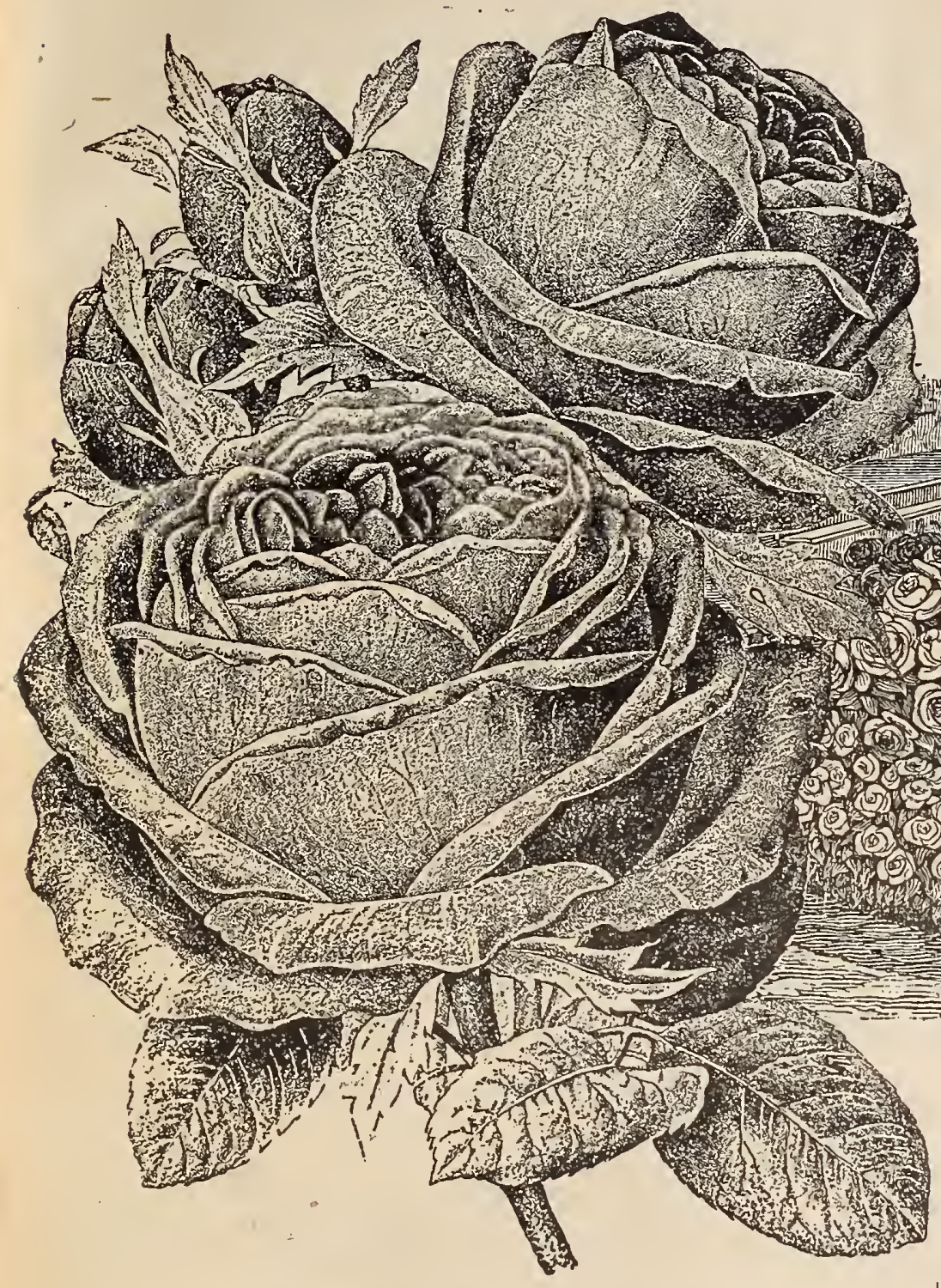

OUEEN-Is a large, free-blooming Tea Rose, the offspring of that fine old Rose, the Souv, d'un Amie; it is a continuous bloomer, producing successive crops of buds and flowers in kreat profusion; the buds are beautifuly formed, with large petals of best substance, shows the center but slightly when fully open; color pure snowy white; exquisitely Rcented; a vigorous and healthy grower; one of the best White

BRIDESM AID-A delightful new Tea Rose, a sport from the old and popular pink Tea, Catherine Mermet, but of a fine clear, dark pink, much deeper and more constant in color than Mermet; very desirable does exceedingly well in the open ground. 1 st size, $50 \mathrm{c}$; 2 nd size, $25 \mathrm{c}$ $3 \mathrm{rd}$ size, $15 \mathrm{c}$.

METEOR-One of the brightcst colored and most brilliant roses we have and is highly recommended for bedding and general planting. The color is rich velvety crimson, exceedingly bright and striking; both buds and flowers are large, elegantly formed. fully double, and borne on nice long stems. Vigorous and healthy; a constant bloomer. Ist size, 50c 2ud size, 25c; 3rd size, 15c.

SAFRANO-This is a splendid old time Rose that has not been superseded by any new comer of its class and color. It is a variety o great value, particularly for outdoor planting. It grows vigorously and has the vitality necessary to produce a continuous crop of flowers from highly for its beautiful buds and handsome flowers. The color is a bright highly for its beautiful buds and handsome flowers. The color is a brigh apricot yellow, changing to orange and fawn. sometimes
very fragrant. Ist size, $50 \mathrm{c}$; 2 nd size, $25 \mathrm{c}$; $3 \mathrm{rd}$ size, $15 \mathrm{c}$.
We have selected this collection as extra'choice varieties for planting out doors. They bloom continually the entire summer, and are perfectly hardy, requiring only a slight protection during the months of December, January and February. All the varieties are strong growers and of very easy culture.

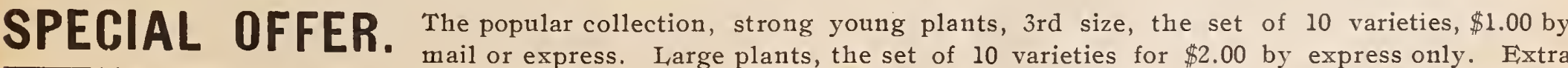
large size 2 year old plants, the set of 10 varieties for $\$ 4.00$. When ordering say the popu-

lar collection of Hardy Monthly Roses.

The third size may be forwarded per mail, but the first and second size are too large to be sent per mail and must be sent by express. 


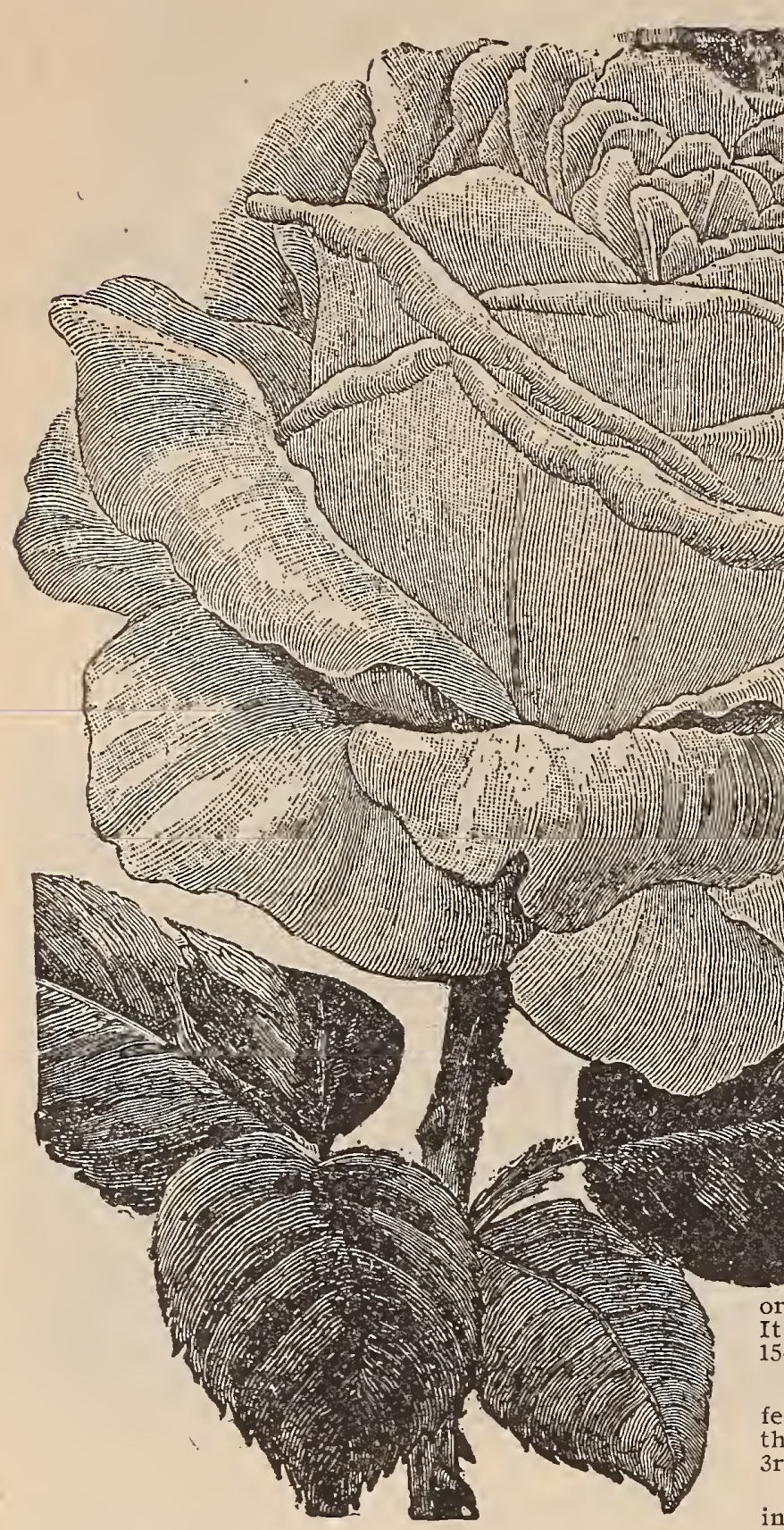

C - 


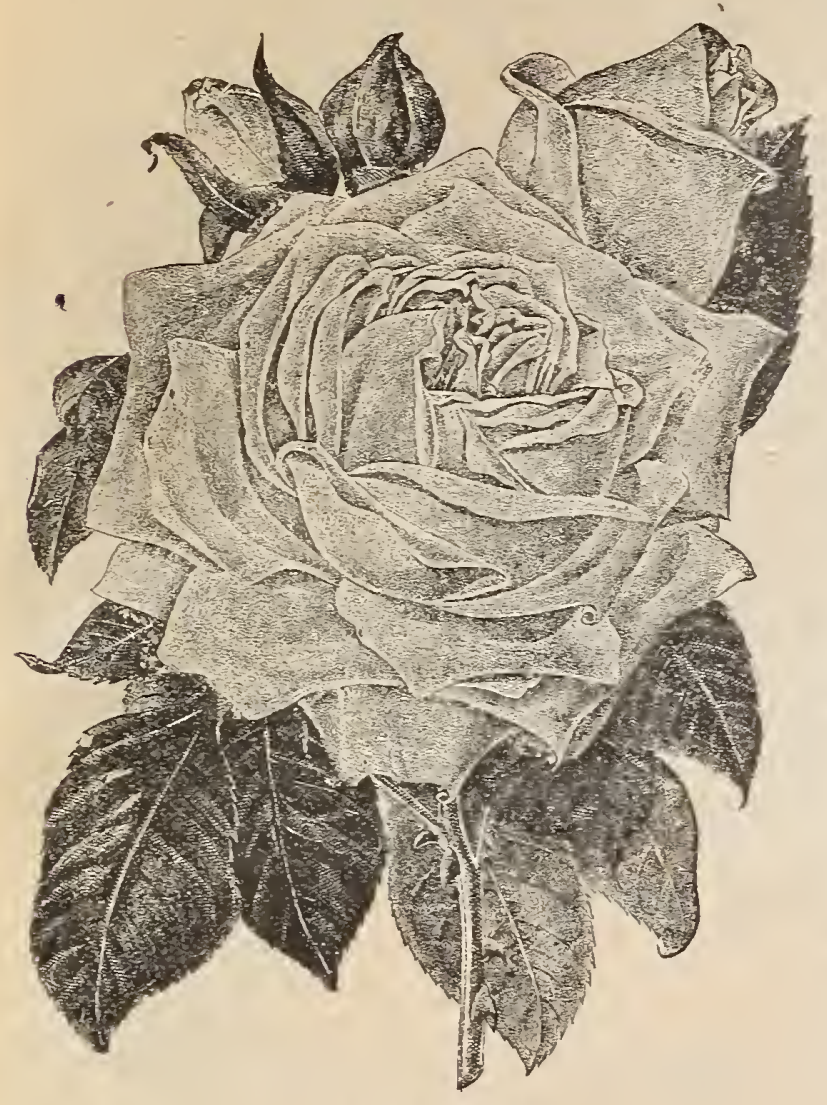

Marchal Neil Rose.

\section{Monthly Cilinbing Roses.}

That Require Protection as far North as St. Louis, Perfectly Hardy in the South.

Marchal Niel A magnific e nt a splendid variety for Southern cultivation where they attain a degree of seen in any rose; the buds and flowers are superb, extra large, liciously perfumed They are in point of beauty the first of deep golden rellow. This variety high ly esteeme , $\mathrm{r}$ genoutdoor ting, as an ommend it more highly than ever to our southern friends. and size, $50 \mathrm{c}$.

MARY WASHINGTON-The flowers are of medium size, pure white, perfectly double to the center, sweet and borne in endless numbers in clusters all summer. A vigorous and rapid grotrer. One plant of Mary Washington will produce more flowers and buds than a dozen ordinary toses. Its fragrance is size $50 \mathrm{c}$.

REINE MARIA HENRIETTE-A seedling of the Gloire-de-Dijon with bright red flowers, large, full and scented. In shape, form and size it is certainly very
distinct and beautiful. This rose succeeds well all over the South; 50c each.

\section{HARDY CLIMBING ROSES}

That will llve out of doors inpoughout the winter withoul any protection during the winter.

HELENE-A strong, rapid grower, throwing up canes 10 to 12 feet high, and making a well-formed bush in a single season. In growth and habit it is similar to Crimson Rambler, but the foliage.is better and it is almost thornless. It is larger and more double than Crimson Rambler, and borne in magnificent clusters, entirely covering the bushes from top to bottom. The color is soft violet bler. Price: 1st size $50 \mathrm{c}$, 2nd size $25 \mathrm{c}, 3 \mathrm{rd}$ size $15 \mathrm{c}$

CARMINE PILLAR-One of the real charming roses"of the year, with single flowers 12 to 15 inches in circumference: of the brightest rosy-carmine and pro. duced in great profusion. It has Saucer-shaped single Roses fully three inches in diameter, of the color that gave it its name, dot the bush must be a sight worth going miles to see. This rose is undoubtedly hardy in most sections of our country mes in all sections under protection and should be as universally grown as a Crimson Rambler. Price: Ist size 50c, 2 nd size 25c, 3 rd size $15 \mathrm{c}$.

PRAIRIE QUEEN-Clear. bright pink, sometimes with a white stripe; large compact and globular, very double and full; blooms in clusters; one of the finest. Price: 1st size. $35 \mathrm{c}$ each: $2 \mathrm{~d}$ size, $15 \mathrm{c}$ each.

BALTIMORE BELLE-Pale blush, nearly white, rery double flowers in beautiful clusters, the whole plant appearing a perfect mass of bloom. We offer this variety in two sizes. Price: 1st size, $35 \mathrm{c}$ each; $2 \mathrm{~d}$ size, $15 \mathrm{c}$ each.

RUSSELL'S COTTAGE-Dark, relvety crimson, very double and full; a profuse bloomer and strong grower; a very desirable climbing rose. Price: ist size, $35 \mathrm{c} ; 2 \mathrm{~d}$ size, $15 \mathrm{c}$ each.

CRIMSON RAMBLER-The flowers are a glowing crimson, produced in large panicles, many of which have measured as large as 9 inches long and 7 inches across, covering the plant from the ground to the top. It is a very vigorclimbing rose. Price: Extra large size, $\$ 1.00$; 1 st size, 50c; $2 \mathrm{~d}$ size, $25 \mathrm{c} ; 3 \mathrm{~d}$ size, $15 \mathrm{c}$ each.

The third size may be forwarded by mail, but the first and second size are too large too be sent per mail, and must be sent by express.

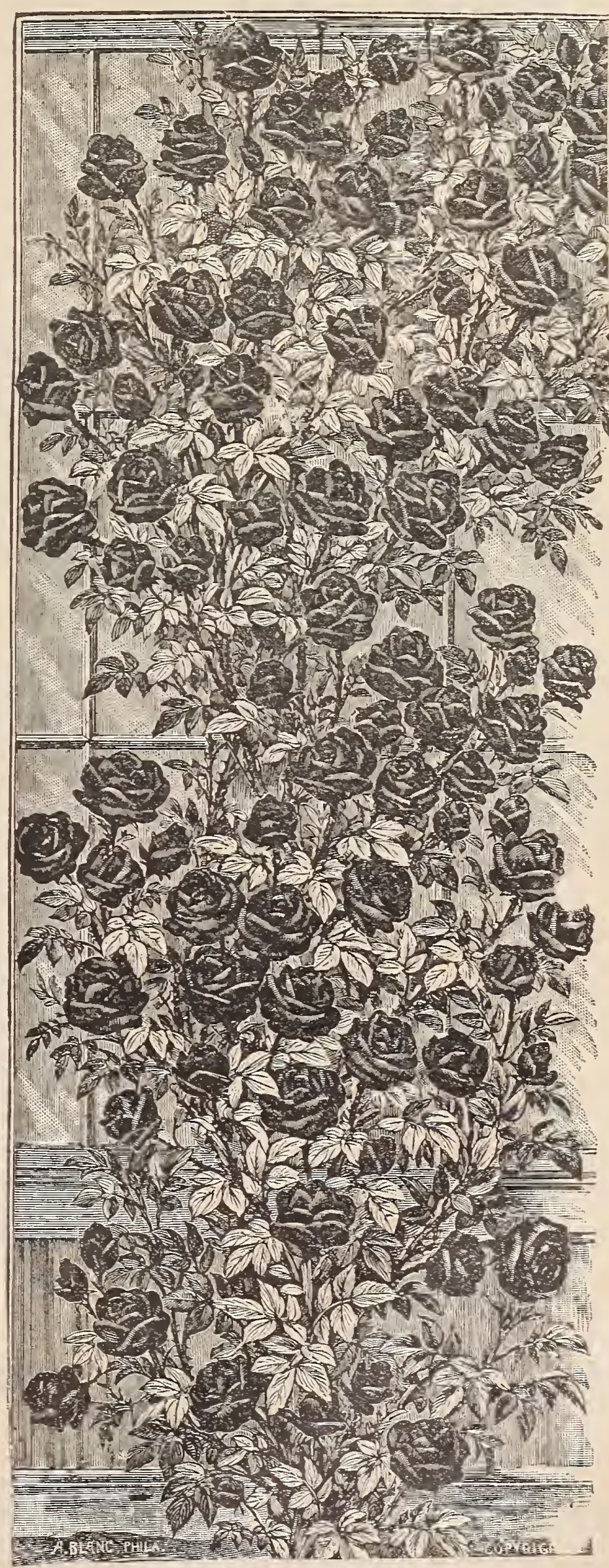

ROSE CARMINE PILLAR. 


\section{THREE HARDY EVERBLOOMING ROSES.}

\section{(PAINTED FROM NATURE.)}

No. 1, GRUSS AN TEPLITZ-Unquestionably the finest dark red, hardy, everblooming garden rose introduced to date. That it is destined to attait wide popularity is assured, for it has all the qualities desired in a garden rose. The color, when first opening, is very dark rich crimson, quickly changing to bright scarlet, shading to velvety, fiery red. One of the very brightest colored roses we know. The flowers are large, full and sweet, very showy and handsome. It blooms constantly and continues covered with flowers the.whole season. An exceedingly robust grower. First size $50 \mathrm{c}$, second size $35 \mathrm{c}$, third size $20 \mathrm{c}$.

No. 2, WHITE MAMAN COCHET-A pure white, hardy, everblooming rose that has been so long desired has been obtained in this grand variety. It has all the important qualities of a perfect garden rose, substance, size, fragrance, hardiness, vigor and profusion of bloom, rivaling the best of the monthly everblooming roses. The buds are long and pointed; an ideal shape for a rose, a nd keeping a long time when cut. Whenerer fine roses are grown or a hardy white everblooming rose is wanted, the White Maman Cochet should be planted. .First size $50 \mathrm{c}$ each, second size $35 \mathrm{c}$ each. third size $20 \mathrm{c}$ each.

No. 3, FRANZ DEEGEN-A new rose. Seedling from Kaiserin. This beautiful yellow Hybrid Tea is a fine grower, having dark leathery foliage and the good habit of throwing up numerous heary canes, each one being crowned by a glorious flower of large size. Composed of large petals, the outer petals are of about the color of Perle Des Jardins, a rich shade of yellow: theinger petals a good orange shade, rery deep an It is a constant bloomer, opening its buds freely. A strong. healthy grower,
during 1902 . First size $50 \mathrm{c}$ each, second size $35 \mathrm{c}$ each, third size $20 \mathrm{c}$ each.

SPECIAL OFFER-Tbese 3 varieties, first size, \$1.25.

ON THE FRONT OF COVER WE ILLUSTRATE

\section{TWO BEAUTIFUL FLOWERS. (PAINTED FROM NATURE.)}

CLIMBING ROSE CLOTHILDE SOUPERT (New Hardy Rose)-Among bedding roses Clothilde Soupert has long held the premier position, and in this new variety we have a counterpart of this popular rose, but of a strong, vigorous climbing habit. In color it is identical to the parentFrench-white with rosy centre-but somewhat larger in size. Its strong constitution, vigorous, healthy growth and free-blooming qualities should make this one of the most popular hardy climbers. Extra strong plants $75 \mathrm{c}$ each; 1 st size $50 \mathrm{c}, 2 \mathrm{~d}$ size $35 \mathrm{c}, 3 \mathrm{~d}$ size $20 \mathrm{c}$.

STOKESIA CYANEA (Cornflower Aster)-A very useful, hardy perennial, grows readily in any location and flowers continually from midsummer until late in the autumn. The flowers resemble the Aster in shape and are produced in clusters. Color a deep blue. Very valuable for planting in hardy herbaceous borders. Price $25 \mathrm{c}$ each.

SPECLAL OFEER-One extra strong size plant of Climbing Rose Clothilde Soupert and one Stokesia plant for 80c.

\section{ON THE BACK OF COVER WE ILLUSTRATE}

\section{THREE BEAUTIFUL HARDY CLIMBERS.}

(PAINTED FROM NATURE.)

No.1-W. C. EGAN-This new rambler is a very strongland robust rower. often attaining the height of 10 to 15 feet in one season. Perfectly hardy and requires no protection in the winter when planted outdoors. The for Extra strong plants, $75 \mathrm{c}$ each; first size $50 \mathrm{c}$, second size $25 \mathrm{c}$ each, third Extra strong

No. 2-PHILADELPHIA-It blooms in grand clusters. Flowérs 2 to $24 / 2$ inches across, perfectly double to the center; excellent substance and very durable. Color pure deep rich crimson, far brighter and more intense than any other rose of its class. Does not fade or wash out, but holds its bright dazzling color to the last. Has handsome foliage, does not nildew, and is an early and abundant bloomer. Undoubtedly the brightest and best of all Hardy, Crimson climbing Roses to date. Unequaled for covering porch trellises, screens, fences, etc. Perfectly hardy, needs size $25 \mathrm{c}$ each, third size $15 \mathrm{c}$ each.

No. 3-THE BEAUTIFUL FRAGRANT WHITE VINE CLEMATIS PANICULATA-It is as hardy as a hop vine, and a clean, thrifty, robust PANing vine of graceful habit, with attractive glossy foliage and corered in the most delicious fragrance. No other vine so completely covers itself with flowers. An arbor or portico over which this clematis is trained is a wall of white for the time being, and what makes it the more striking is that nearly all the other rines have ceased blooming that time. The panicles of bloom are very pretty for cutting. The star-like florets with panicles of bloom are very pretty for cutting. The star-like forets with each.

SPECIAL OFFER-The two Roses and one Clematis, first size only, $\$ 1.25$.

\section{NEW HARDY YELLOW ROSE SOLEIL D'OR.}

A perfectly hardy yellow rose, robust and very vigorous, the buds are conical in shape and of a lovely- yellow color. The flowers when expanded being large, very full and rounded, centre petals merely incurved of a superb color, averaging from gold and orange to a reddish gold and haded with Nasturtium red; the open flowers often measure $3 \frac{3}{4}$ inches across. Our stock of this variety is only: First size, 2 -year-old, $75 \mathrm{c}$.

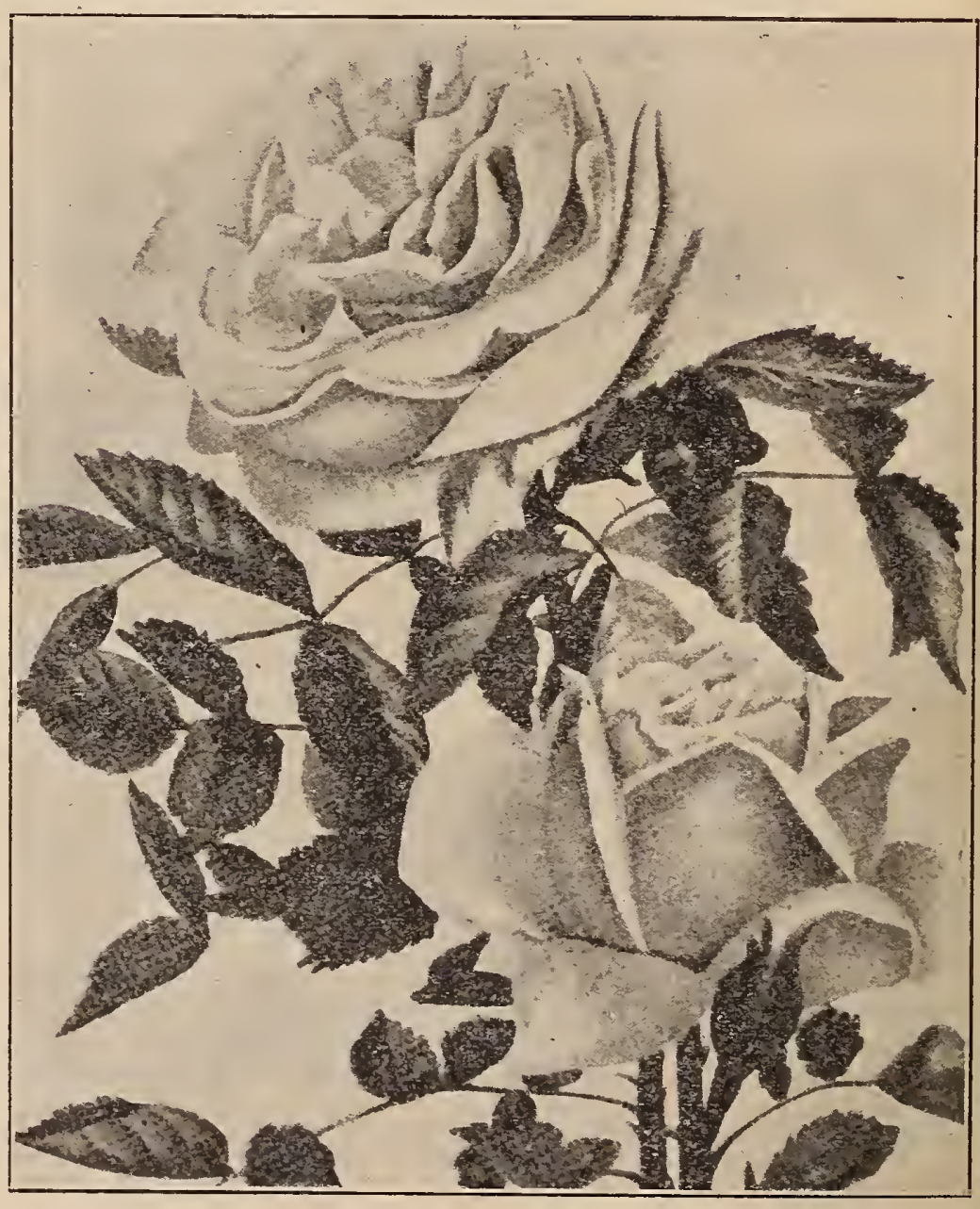

ROSE SOLEIL D'OR.

Our Roses are all Grown on their own Roots. 


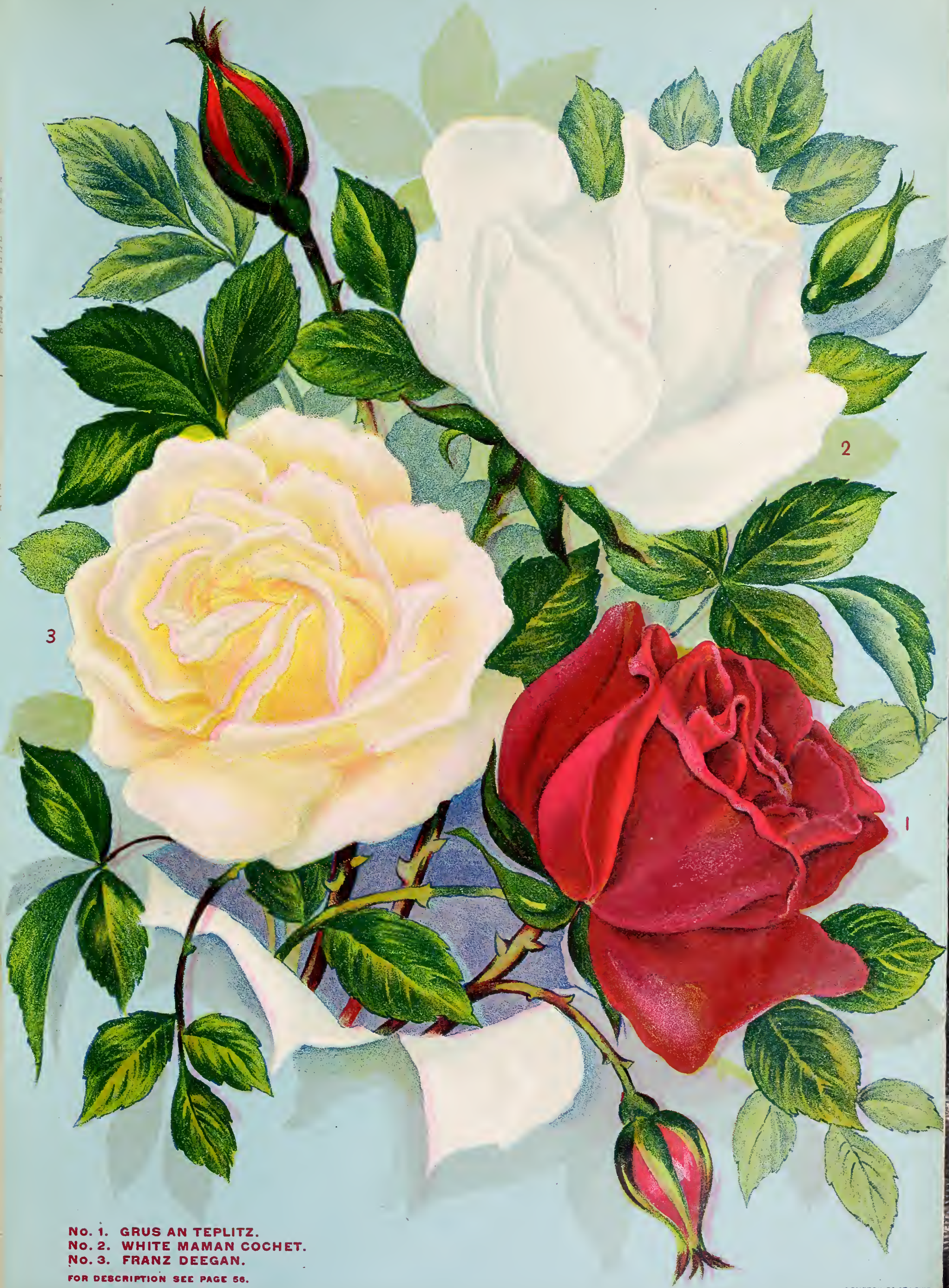

FOR DEECRIPTION SEE PAGE $5 O$. 


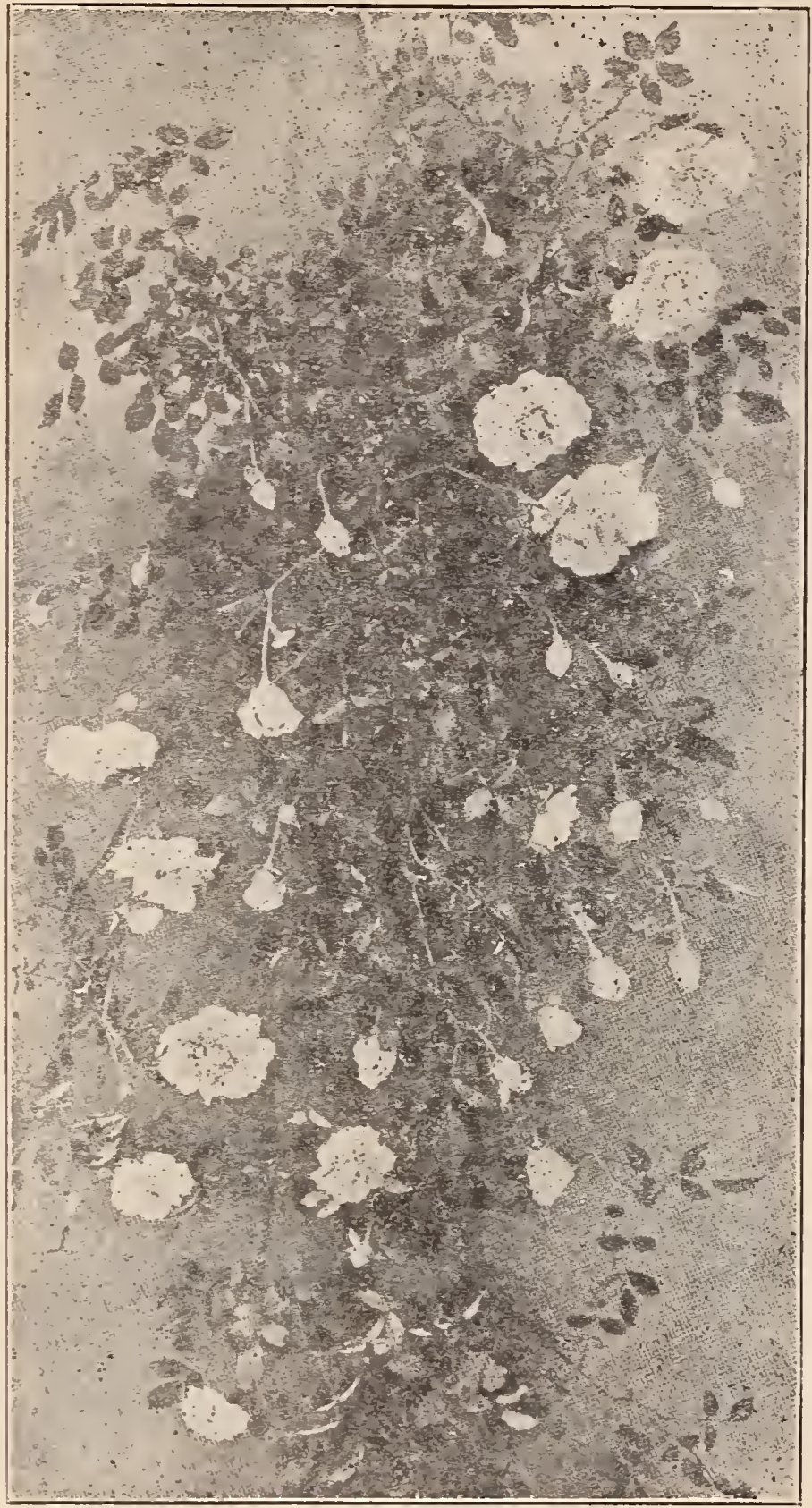

Wichuraiana or Hardy Memorial Rose.

\section{The Hardy Memorial Rose.}

FOR USE IY CEMETERIES. It is difficult to conceive anything e appropriate, beautiful and enduring for covering graves and plot in cemeteries than the Hardy Memorial Rose. It creeps along the ground as closely as an ivy, growing ten

produced in great profusion, in clusters on the ends de branches, after the June Roses are past, from the firstwee The flowers are single, pure white, witli a golden-yellow disc, 5 to 6 (n) Banksin Roses. Price 1 st size plants from 5 inch pots, $50 \mathrm{c}$ each. $2 \mathrm{~d}$ size, $25 \mathrm{c}$ each. d size, $15 \mathrm{c}$ each: $\$ 1.50$ per dozen.

\section{THE SET OF FOUR LA FRANCE ROSES.}

PINK LA FRANCE-One of the most beautiful of all roses and i unequaled by any in its delightful fragrance. The flowers are very large,

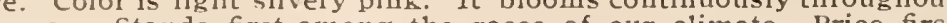
WHITE LA FRA NCE-A seedling from "La France." retaining the perance and blooming qualities of the parent varietse. Price, 1 st size, 2 years old, $40 \mathrm{c}$; 2d size, 25c; 3d size, $15 \mathrm{c}$. the fourkes. characteristics of the type, with the blooms three to four shafusion upon long stems, very large and double. The growth is rigoro: s, with beautiful light green foliage. Price, 1st size, two years old, $40 c$, 15 size, 15 .
size,

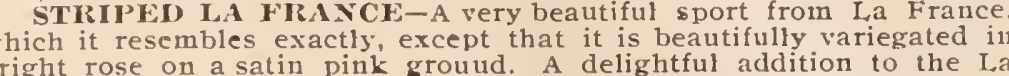
bright rose on a satin pink grouud. A delightful addition to the La SPECIAL OFEER-The full set of four La France Roses, $1 \mathrm{st}$
size, \$1.50; 2d size, 75c; 3d size, 50\%. Our Rosen are All Grown on Thoir Own Roots.

\section{New Pedigree Evergreen Roses.}

The most remarkable achievement and improvement of a new and distinct type of Hardy Roses that has been made for a generation. The growth is rearkable for its freedom; a single plant, four years old, covering a space of 240 quare feet, with long shoots, twelve to twenty-five feet in length, completely viering the ground with its bright glossy foliage and showy fragrant flowers the foliage of all is leathery in texture, shiny, and not only proof against inects, but Evergreen, that is, keeping the foliage all winter; a characteristic in

EDWIN LONSDALE-A strong, healthy grower, with dark glossy-green A very profuse bloomer. Flowers, 2 to 3 inches in diameter; quite nd size, 25c; 3d size, 15c.

WM. K. HARRIS-A rose with the same peculiar and charming fragrance Bon Silene. It is a vigorous grower with bright green shining foliage. (1st size, 50c; $2 \mathrm{~d}$ size, 25c; $3 \mathrm{~d}$ size, $15 \mathrm{c}$.

WM. F. DREER-This very distinct and beautiful rose is of strong growth, rith rather sinall foliage. It blooms freely in clusters. Bud similar to Mrme. in Lambert, creamy ngly fragrant. 1st size, 50c; $2 \mathrm{~d}$ size, 25c; $3 \mathrm{~d}$ size. $15 \mathrm{c}$.

PROF. C. S. SARGENT-In this new seedling we claim to have secured perfectly hardy climbing yellow rose. It is a very strong grower with deeptheen shining foliage. Very rich deep golden yellow in bud; open flowers of fine rm, very double, 2 ine party opened flower is quit these old popular varieties. 1st size, 50c; $2 \mathrm{~d}$ size, 25c; 3d size, 15c.

ROBERT CRAIG-This is one of the most beautiful and desirable roses in entire collection. An extra strong grower, with rich, glossy, dark-green liage. It forms an extremely pretty bud, in form and character similar to a Tea Rose, yellowish or light apricot in tint. The open flower is perfect in every ith apricot, deepening to the center, and very rich in tint. 1 st size, $50 \mathrm{c} ; 2 \mathrm{~d}$ size,

JOHN BURTON-A conspicuous and distinct variety, very strong in growth ith rather small, healthy foliage. The flowers are medium in size, very double, and of a delicate pink or peach color, similar to La France. This exceeding ly 作

SPECIAL OFFER-The full set of six varieties: 1 st size, $\$ 2.50 ; 2 d$ $\$ 1.00 ; 3 d$ size, $60 c$.

The third size may be forwarded per mail, but the first and second sizes are Torge to be sent per mail and must be sent by express.

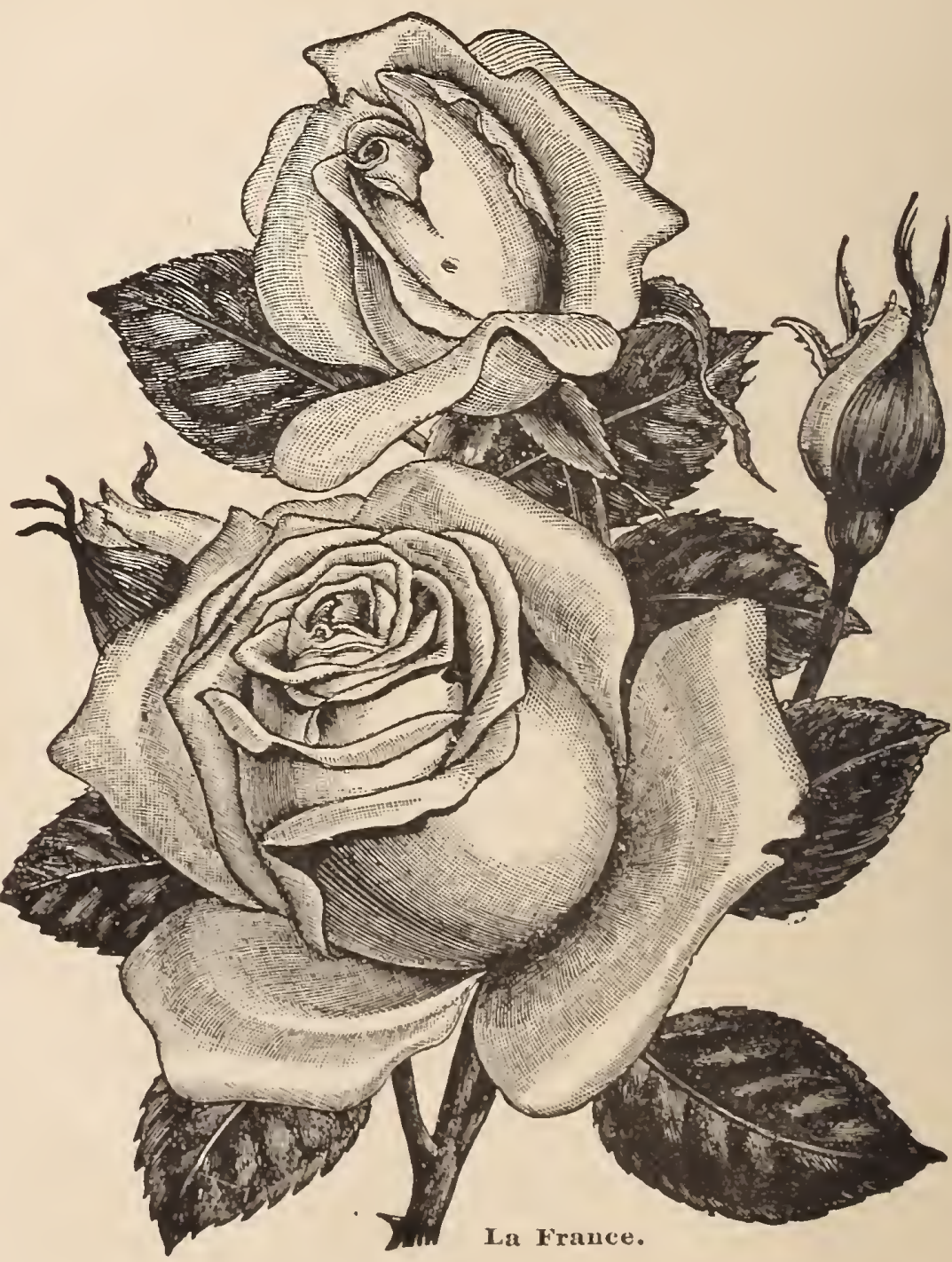




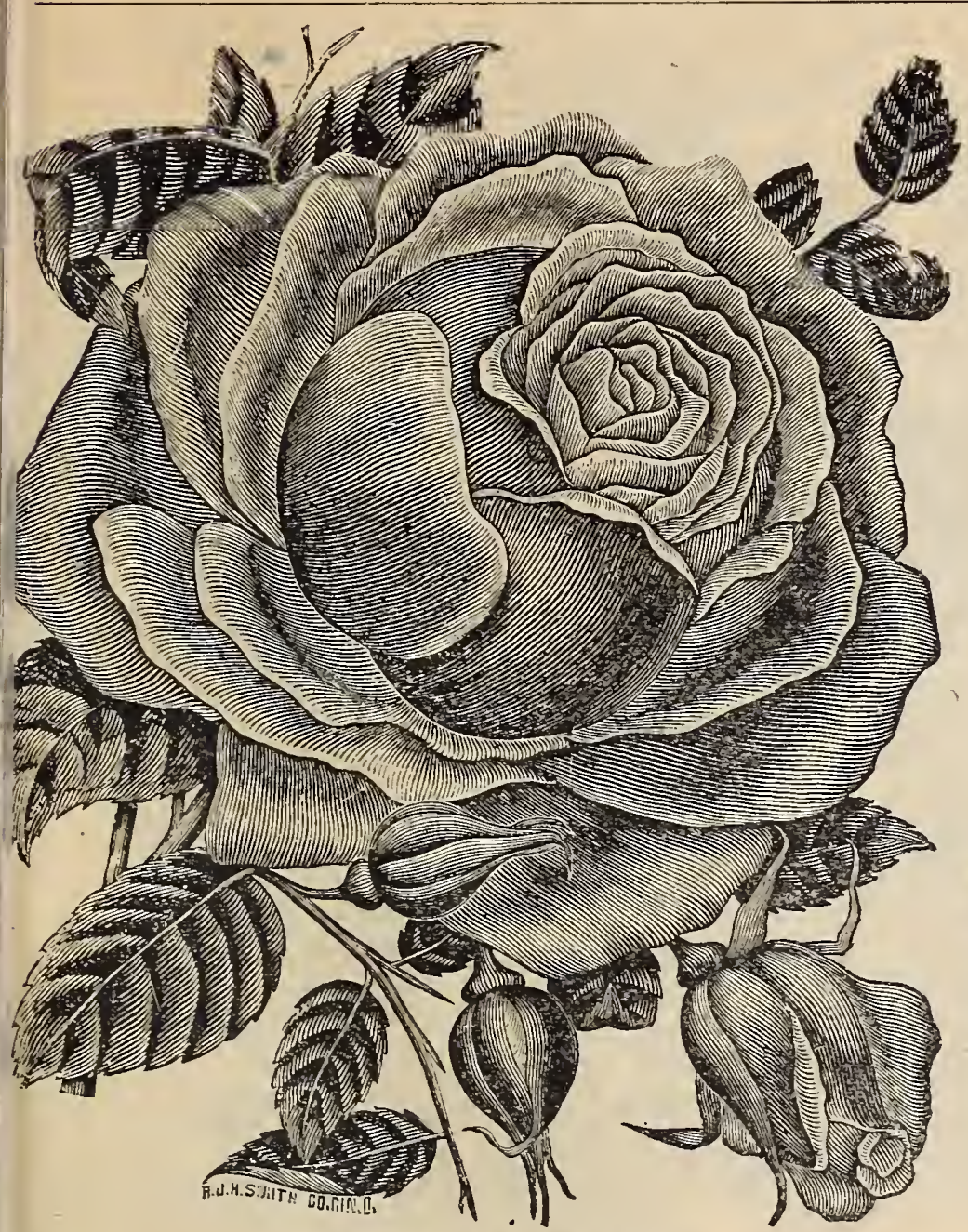

Rose, Francis E. Willard.

\section{THE SIX BEST VARIETIES OF NEW ROSES FOR THIS YEAR,}

We offer these only in two sizes. 1 year old stock, about 12 to 14 inches high, $2 \mathrm{~d}$ size and $3 \mathrm{~d}$ size about 5 to 6 inches high. Either of the sizes will flower this summer if planted out doors.

FRANCIS E. WILLARD-A strong, vigorous grower and a true ever-blooming variety. The flowers are of a large size and perfect in form. Color pure white. Delightfully fragrant. $2 \mathrm{~d}$ size $1 \mathrm{yr}$. old, 30c each (see cut), 3d size, 20c each.

COUNTESS DUSY-An everblooming white rose which we believe has no superior in size and freedom in flowering. The color is a pure satiny white and deliciously scented. $2 \mathrm{~d}$ size, 1 year old $30 \mathrm{c}$ each; $3 \mathrm{~d}$ size, $20 \mathrm{c}$.

ALLIANCE FRANCO RUSSIA-A very large double well shaped rose of rounded form. Color a soft glowing orange and copper, flushed and shaded with bright crimson. Exquisitely fragrant. 2d size, 1 year old $30 \mathrm{c}$ each; $3 \mathrm{~d}$ size, 20c each.

GAINESBOROUGH-This is a hardy everblooming cose and we doubt if there is any other variety that is equal to this in freedom of growth and profusion of flower. A good strong grower with beautiful foliage. Color a delicate tint of pinkish white. Flowers and buds very large and fragrant. 2d size, 1 year old, $30 \mathrm{c}$ each: $3 \mathrm{~d}$ size $20 \mathrm{c}$ each.

AMELTA SAZAIME MORIN-One of the best hardy monthly roses for outdoor planting. It is a dwarf, compact grower, flowering continually the entire summer. Color white shaded with blush. Delicately fragrant. 2d size, 1 year old, $30 \mathrm{c}$; $3 \mathrm{~d}$ size, $20 \mathrm{c}$ each.

ENGLAND'S GLORY-A very beautiful rose of recent introduction. The color is an exquisite shade of deep shell pink; petals of a n enormous size. An exceedingly strong grower, throwing up heavy shoots which are crowned with long heavy buds and when fully matured make a flower equally as large as an American Beauty. 2d size, 1 year old, 30c each; $3 \mathrm{~d}$ size $20 \mathrm{c}$. each.

SPECIAL OFFER-The full set of six varieties $2 d$ size, 1 year old, $\$ 1.75$; $3 d$ size $\$ 1.00$.

The third size may be forwarded per mail, but the first and second sizes are ton large to be sent per mail and must be sent by express,

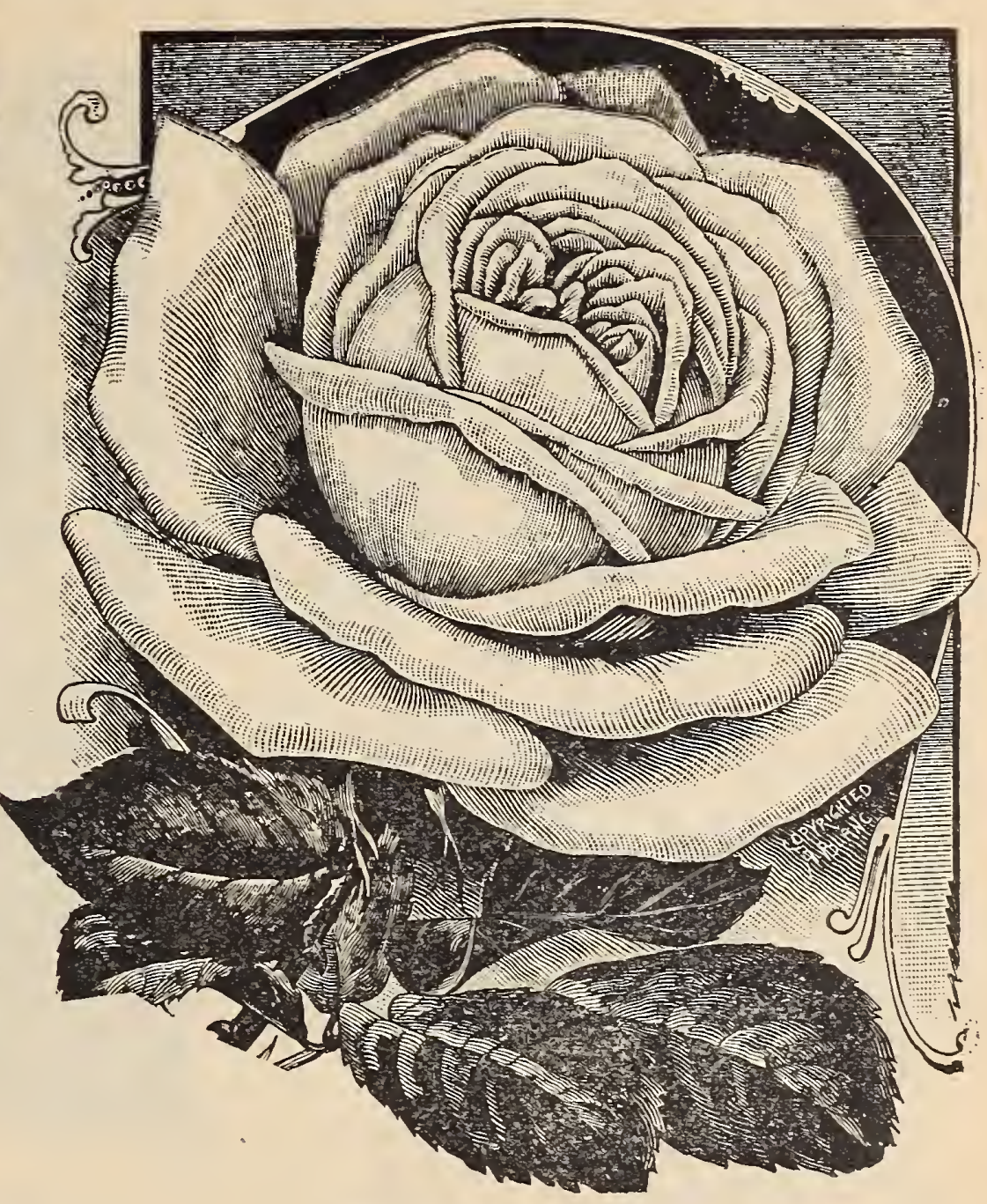

Rose, Angusta Halem.

SEVEN HARDY MONTHLY ROSES OF RECENT INTRODUCTION Which We Have Selected As THE BEST FOR OUTSIDE PLANTING.

CHRISTINE DE NOUE-This beatiful hardy monthly tea rose should be in everybody's collection. The color is exceptionally fine, a very deep red. A robust grower making a large bush in a short time. Blooms constantly the entire summer. 1st size $35 \mathrm{c} ; 2 \mathrm{~d}$ size $25 \mathrm{c}$; $3 \mathrm{~d}$ size $15 \mathrm{c}$. BURBANK-A hardy, everblooming rose, which with a slight protection in winter has proven itself to be hardy in any location. The color of fowers is a rich shell pink deepening to carmine crimson. It is a very compact grower, blooming when only a small size and continuiug until the severe cold weather sets in. 1st size $35 \mathrm{c}, 2 \mathrm{~d}$ size $25 \mathrm{c}, 3 \mathrm{~d}$ size $15 \mathrm{c}$ each.

MR. ROBERT GARRETT-A hardy everblooming rose. The flowers are almost entirely double and extra large. Buds long and beautifully shaped The color is a soft, rich pink. A remarkably strong grower. producing flowers abundantly. Very fragrant. 1st size $35 \mathrm{c}, 2 \mathrm{~d}$ size $25 \mathrm{c}$ $3 \mathrm{~d}$ size $15 \mathrm{c}$.

AUGUSTINE HALEM - A hardy evertlooming rose that flowers as freely as a Tea rose. Color a beautiful dark crimson, very fragrant. (See cut.) 1st size $35 \mathrm{c}, 2 \mathrm{~d}$ size $25 \mathrm{c}, 3 \mathrm{~d}$ size $15 \mathrm{c}$

MRS. OLIVER AMES-A hardy everblooning rose that for vigorous. healthy growth and continuous bloom cannot be excelled. The color is soft pink changing to a brighter shade when
fragrant. 1st size 35 c, 2 d size 25 c, 3 d size $15 c$.

SOUVENIR DE PIERRE NOTTING-I

with stout stems and thick, glossy green
large and handsome, somewhat cup shaped.

shading darker to the center and very

throughout the entire season until
1st size $35 \mathrm{c}$, 2d size $25 \mathrm{c}$, 3d size $15 \mathrm{c}$.

MOSELLA-A strong growing

from most all insects that infest rose.

ter, shading to white at the outer edge of the petal

bloomer, seldom being without blossoms the entire

$2 \mathrm{~d}$ size $25 \mathrm{c}$, $3 \mathrm{~d}$ size $15 \mathrm{c}$

SPECIAL OFFER-The full set of seven varieties, all first size for $\$ 2.00$ Second size, \$1.50. Third size, 75c.

The third size may be forwarded per mail, but the first and secouc sizes are too large to be sent per mail and must be sent by express. 


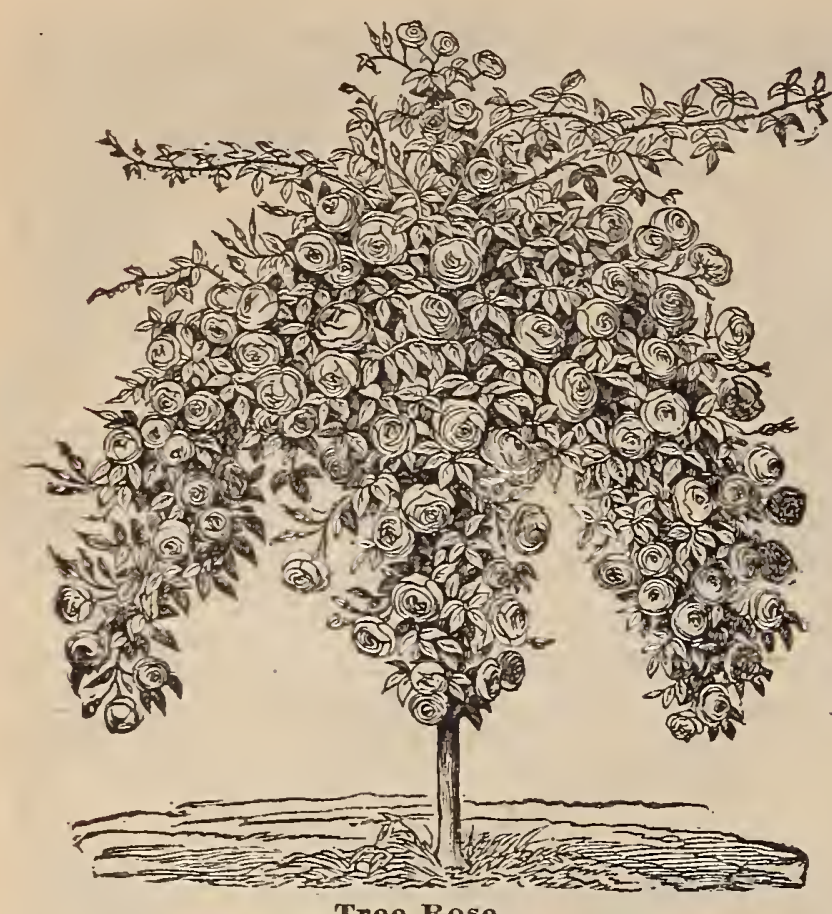

\section{TREE ROSES.}

The Tree Roses are grafted on hardy rose stalks 4 to 5 feet high, are tree-shaped and when in full bloom are objects of beauty, making handsome plants for the lawn or We have the following named varities. They have been

PRINCE CAMMILLE DE ROHAN-Deep Crimson.

PAUL NEXROY-A bright pink; large.

MARGARET DICKSON-A clear ro

MAGYA CHARTA-Clear rose red.

GLOIRE DE MARGOTTIN-A dazzling red.

GEN. JACOUEMINOT-A bright crimson.

GARIA BAUMANY- Crimson Termillion.

MRS. JOH LAING-A clear shining pink.

ULRICH BRUNNER - Color a glowing crimson.

Strong plants, well branched, of any of the above varieties,

\&1.00 each: $\$ 9,00$ per dozed.

\section{ROSES.}

LOW BUDDED DORMANT ŚTOCK.

This stock is without leaves as shown in the illustration. $25 \mathrm{c}$ each.

\$2.50 per dozen. Dormant roses cannot be supplied after A pril 15th.

MARGARET DICKSON-White.

GEN. JACQUEMINOT-Brilliaut crimson.

MAGNA CHARTA-Dark pink.

MRS. JOHN LAING-Bright pink.

PAUL NEYRON-A bright shining pink.

MADAME CHAS. WOON-Rosy crimson.

BARONESS ROTHSCHILD-Bright rosy pint.

COQUETTE DES BLANCHE-Pure

ALFRED COLCOMB-A bright pink.
GLORIE LYONAISE-Color salmon yellow

After April 15th we can furnish extra selected plants from same tock already started to grow in pots at 50c each. $\$ 5.00$ per dozen.

ROSA RUGOSA.

or JAPAN ROSES.

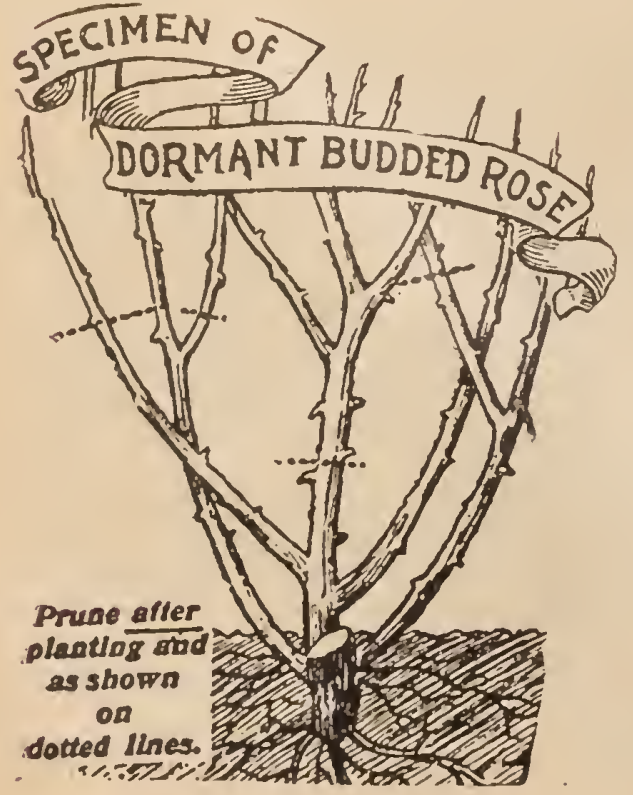

The flowers of this variety are 3 inches across and are produced in clusters, bloom all season, succeeded by large orange scarlet fruit. See cut. IROSA RUGOGA ALBA ROSA RUGOSA RUIBRA-Red. MME. GEOIRES BRUANT-White. Price, dormant plants
(up to April 15) 25c eacli;

This class of Roses when once planted into the ground live from year to year without any care or protection in winter. They flower profusely in June with an occasional flower in the summer and fall months.

MARGARET DICKSON-Beyond question the finest white Hybrid Perpetual Rose yet introduced. The flowers are large in size; color is a pure waxy white, petals very large; a free bloomer. 1st size, $50 \mathrm{c} ; 2 \mathrm{~d}$ ize, 25c; 3d size, 15c.

GLOIRE DE MARGOTTIN-The flowers are very large and deliciously scented. The color is a clear dazzling red. One of the most brilliant roses ever seen. 1st size, 50c; $2 \mathrm{~d}$ size, 25c; 3d size, $15 \mathrm{c}$.

ULIICH BRUNNER-Cherry red; a grand rose, very free blooming ist size, $50 \mathrm{c}$; $2 \mathrm{~d}$ size, $25 \mathrm{c}$; $3 \mathrm{~d}$ size, $15 \mathrm{c}$

MAGNA CHARTA-Dark pink; one of the easiest roses to grow. 1st size, 50c; $2 \mathrm{~d}$ size, $25 \mathrm{c}$; $3 \mathrm{~d}$ size, $15 \mathrm{c}$

MRS. JOHN LAING-Rich, satiny pink, delicious fragrance: blooms constantly. Ist size, 50c; 2d size, 25c; 3d size, $15 \mathrm{c}$

GEN. JACQUEMINOT-Brilliant crimson, the most widely popular Ist size, $50 \mathrm{c}$; $2 \mathrm{~d}$ size, $25 \mathrm{c}$; $3 \mathrm{~d}$ size, $15 \mathrm{c}$.

MADAME PANTIEl - It is the best of the white Hybrid Perpetual roses. Grows in any location. Well adapted for cemetery planting. 1st a 50c; $2 d$ size, $25 \mathrm{c}$; $3 \mathrm{~d}$ size, $15 \mathrm{c}$

PAUL NEYRON-The flowers are large. Color a bright, slining, clear pink." Very double. 1st size, $50 \mathrm{c}$; $2 \mathrm{~d}$ size, $25 \mathrm{c}$; $3 \mathrm{~d}$ size, $15 \mathrm{c}$.

BALL OF SNOW-White, occasionally showing light pink; flowers of good size. 1st size, $50 \mathrm{c}$; $2 \mathrm{~d}$ size, $25 \mathrm{c}$; $3 \mathrm{~d}$ size, $15 \mathrm{c}$.

PRINCE CAMILLE DE ROHAN-Color a deep, rich, velvety crimson. 1st size, 50c; $2 \mathrm{~d}$ size, $25 \mathrm{c}$; $3 \mathrm{~d}$ size, $15 \mathrm{c}$.

SPECIAL OFFER. 1st size, strong 2-year-old plants, the full set of 10 varieties for $\$ 4.00$. 2d size, $\$ 2.00 ; 3 \mathrm{~d}$ size, $\$ 1.00$.

The third size may be forwarded per mail, but the first and second sizes are too large to be sent per inail and must be sent by express.

\section{ENGLISH SWEET BRIER ROSE.}

Valuable for the refreshing fragrance of its leaves, No garden slould be without a plant of it. It serfectly liardy, and once it is planted, little, if any, care is necessary. Price $35 \mathrm{c}$ each; doz. $\$ 3.50$.

HARRISON'S YELLOW ROSE.

The old fashioned Harrison's Vellow Rose is one of the finest, pure,deep yellow hardy roses ever grown. Large size plants $35 \mathrm{c}$ each. 


\section{Young's Novelties and Specialties in Rare Plants for 1904.}

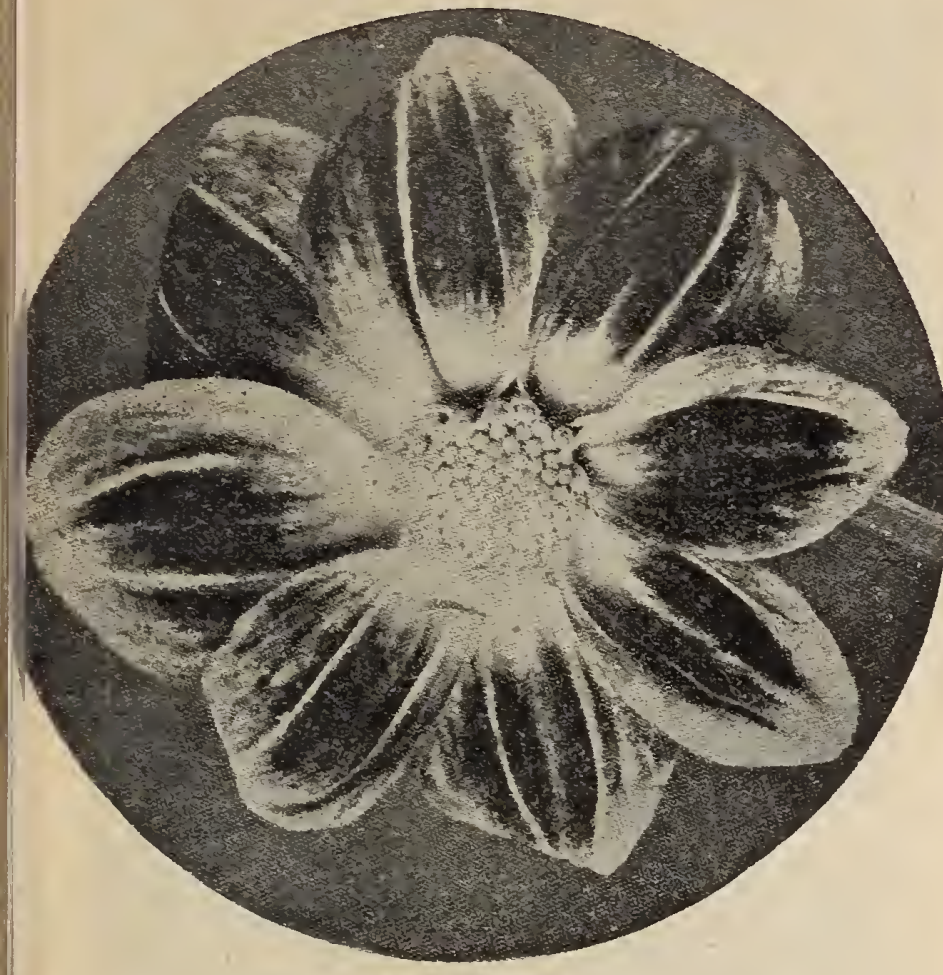

Dahlia, 20th Century.

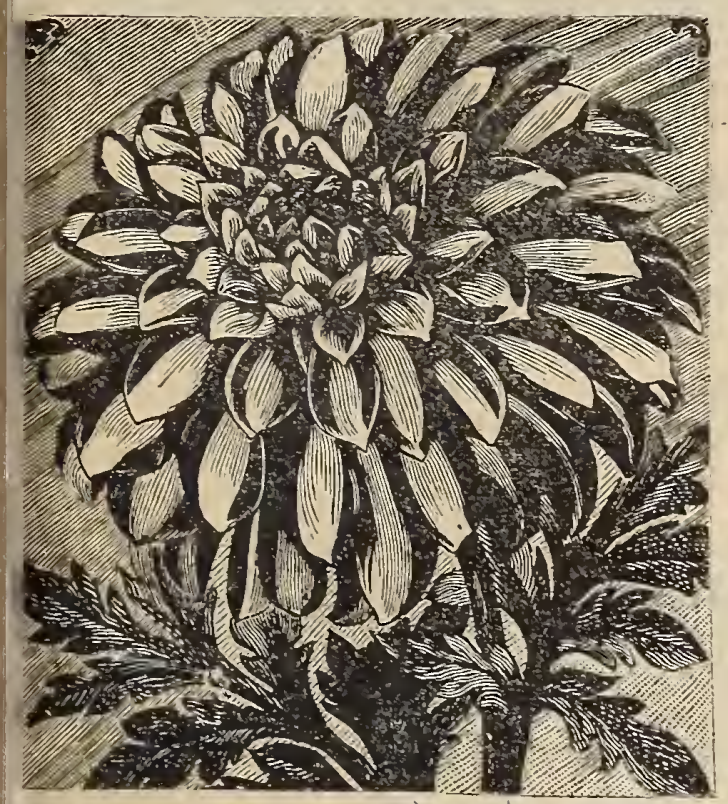

Cactus Dahlia.

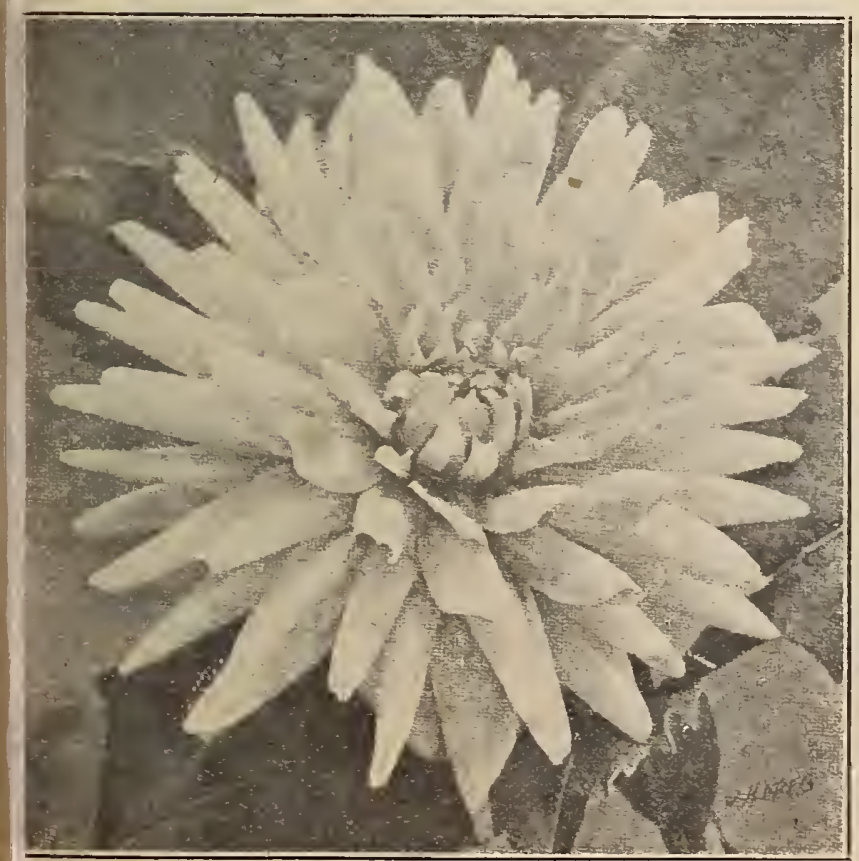

Dahlia, Fern Leaf Beauty, ach.

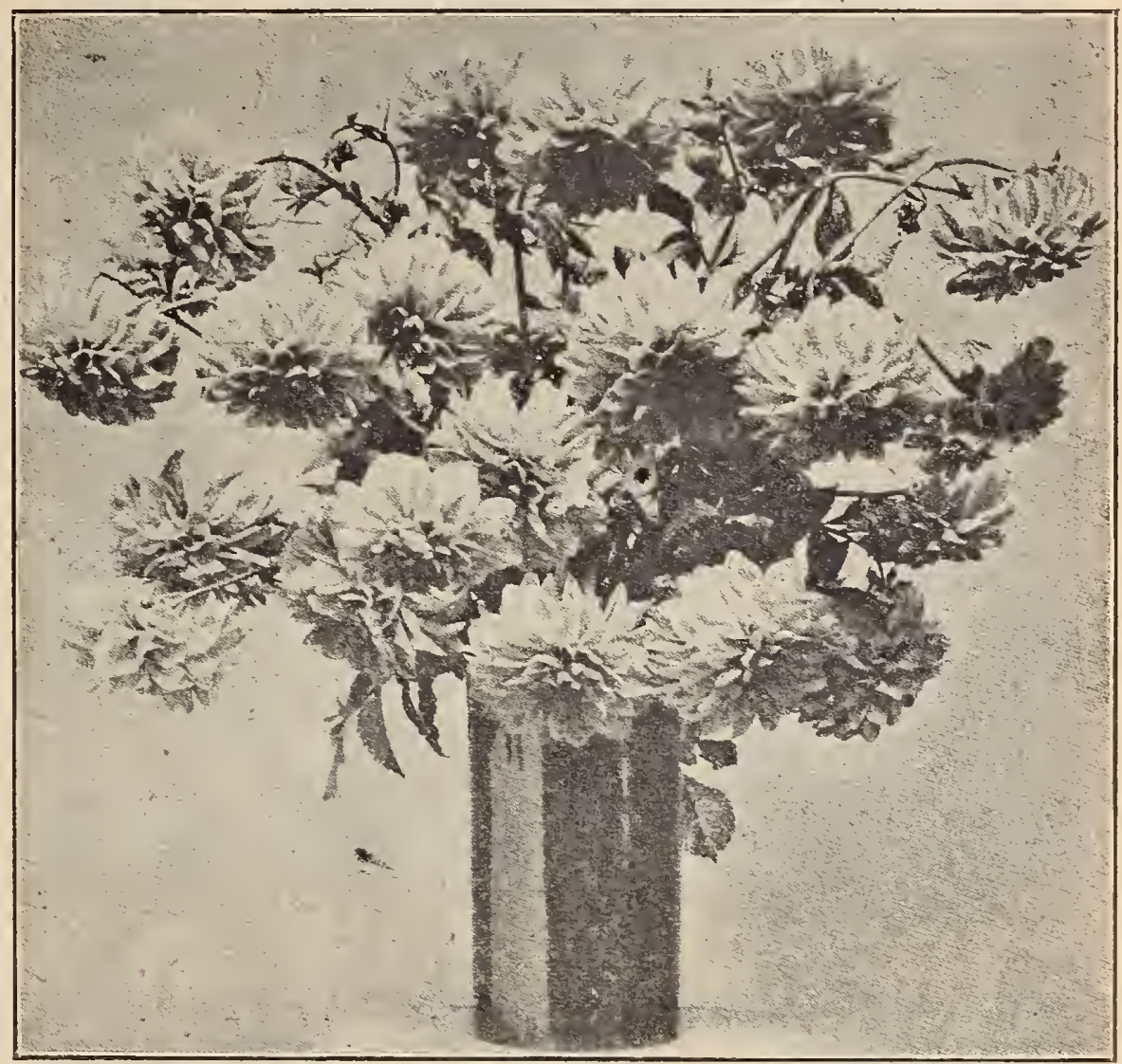

Dahlia Clifford W. Bruton.

FIVE BEST VARIETIES OF DOUBLE DAHLIALS.

\section{Selected out of the Norelties of Last Seasou.}

CLIFFORD W. BRUTON. - The best yellow; of immense size, perfect form, and of the finest nary yellow. A tall. vigorous grower, and extremely free bloomer, 25c each.

HENRY PATRICK. - A superb pure white variey, of large size, 25c.

LYNDHURST. - One of the best bright scarlets, and invaluable for cutting; $25 \mathrm{c}$ ea $\mathrm{h}$.

WILLIAM AGNEW.-Of intense glistening scarlet-crimson, and always a mass of color. $25 \mathrm{c}$

ZULU.-Rightlv named "The Black Dahlia." Jet black, changing to black maroon; 25c each.

Special offer. The full set of five for $\$ 1.00$.

D A H I A S.

A collection of Six Single Dahlias, selected as the best of the novelties of last seasou. DAHLIA, 20th CENTURY. - It is impossible to describe this exquisite variety. The flowers are very large, $4 \frac{1}{2}$ to 9 inches in diameter. The color is extreme rosy crimson with white tips and ALBA SUPERBA.--The grandest pure white single Dahlia ever produced. The flowers are of fine form and produced freely on long stems, $25 \mathrm{c}$ each.

BLACK BIRD.-Black, changing to rich, velvety maroon, with a bright red spot at the base of ach petal. Distinct and valuable. $25 \mathrm{c}$ each

GOLD STANDARD.-Pure deep yellow, a strong, vigorous branching grower and continuous bloomer. 25c each.

LAWRENCE KRAMER.-The color is a deep, bright, rosy pink of the richest, brightest shade, without tint or blemish. $25 \mathrm{c}$ each.

MARS. - White and violet, bordered and shaded dark rich crimson, tipped white; an early and profuse bloomer. $25 \mathrm{c}$ each.

Special Offer. The full set of 6 choice varieties for $\$ 1.25$.

\section{DECORATIVE DAHLIAS.}

RFD HUSSAR, - The color is purest cardinal red without trace of purple or crimson, ery strong, vigorous grower, of branching habit. $25 \mathrm{c}$ each.

BLACK PRINCE.-The best of its type; color intense velvety maroon, almost black. $25 \mathrm{c}$ each.

FERN-LEAVED BEAUTY.-Beautiful fern leaved sort; white, striped deep crimson. $25 \mathrm{c}$ each.

EUREKA - The flowe rs are large, of deep rose color and fine regular form; an early and profuse bloomer on long stems. $25 \mathrm{c}$ each.

Special Offer. The full set of 4 varieties for 80 c.

FOUR NEW AND RARE CACTUS DAHLIAS.

ADMIRAL SCHLEY - The color and marking is a bright crimson with a broad white stripe through the center of each petal; profuse bloomer. $25 \mathrm{c}$ each.

BRIDESMAID. - Pale primrose, shading to delicate rose toward the outer petals: beautiful form and free. $25 \mathrm{c}$ each.

EARL OF PEMBROKE.-Color a bright plum, deeper and inore velvety toward the center; petals long, pointed and regularly arranged. $25 \mathrm{c}$ each.

KONIGEN WILAELMINA.-Deep crimson, richly shaded; a free and continuous bloomer. 25c each.

Special Offer. The set of 4 varieties for $80 \mathrm{c}$ 


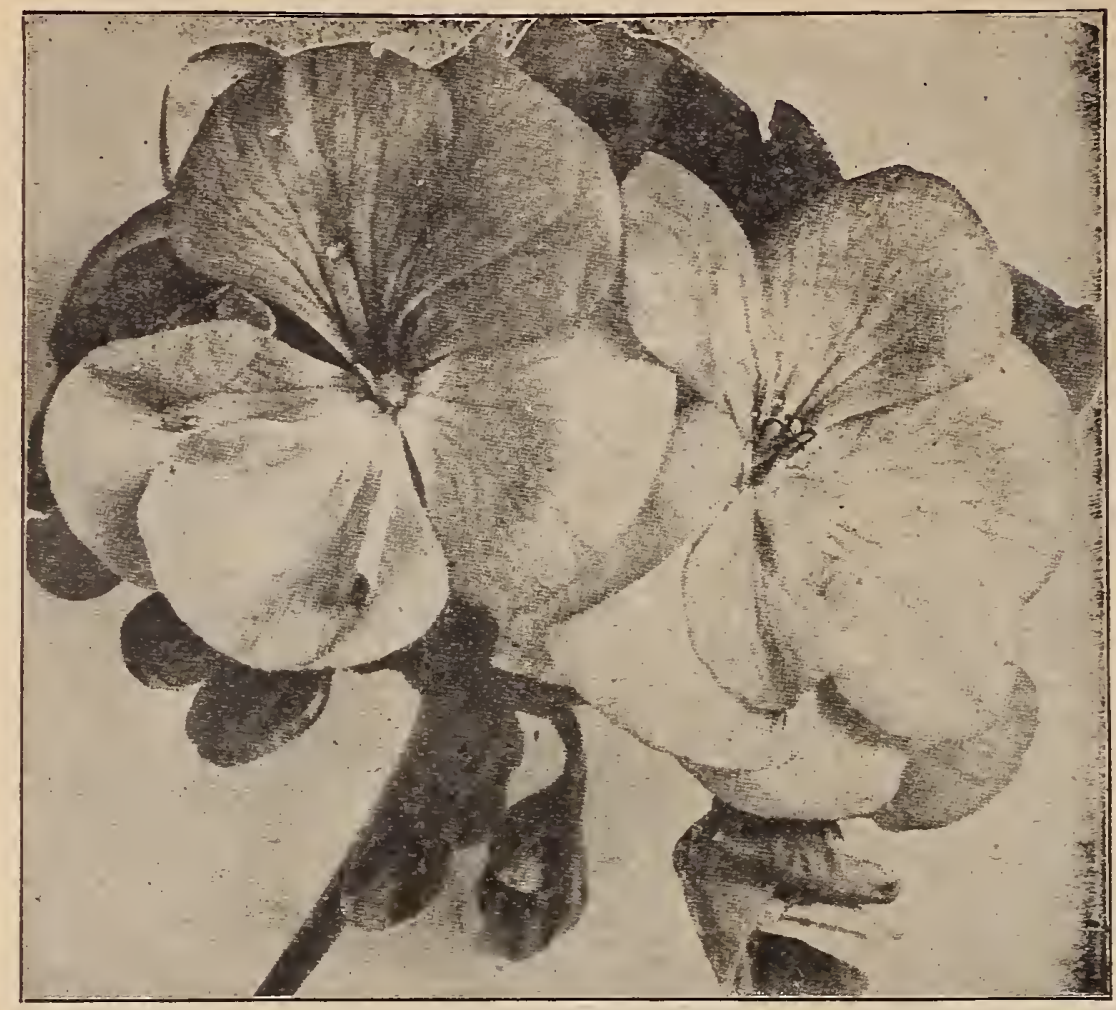

Geranium-Louis Fages.

\section{THIS LIST CONTAINS THE CREAM OF ALL THE}

\section{NOVELTY G ERAN IUMS} CATALOGUED FOR THE PAST TWO SEASONS. GERANIUMS-SINGLE VARIETIES.

CLIDE. - We have found this variety to be a grand flotrering Geranium of the Bruant ty pe, and consider it the best bedding Geranium of all varieties. Color
of the flower is a bright rermillion red. The flowers are absolutely perfect of the flower is a bright rermillion red. The flowers are absolutely perfect
in shape color and make-up: trusses exceptionally large and borne in immense in shape color and make-up: trusses exceptionally large and borne in immense
spherical balls, often measuring twelve inches in diameter. It makes a compact, dense growth, and has all the qualities that go to make the perfect bedder JEAs yoch

(lis variety has enormous trusses, florets semidrible, LE BARDE. - A robust grower, Florets large. semi-double, of good, regular form: color deep China pink. The upper petals have a mark lilac-Thite, a fine new variety: $20 c$ each.
PRECLRSEUR. - This is a strong grower and a very free bloomer, has fine trusses of single white flowers of a very-large size and spreading form. Thi promises to lead all other whites in the whole bedLOUIS FAGES. - The florets are quite round very large and full, combiued in good trusses color a very rich, pure pink white eye with ca mine markings; extra. (See cut.) $20 \mathrm{c}$ each.
ROBERT CHARLIE. - Flowers seni-double throwing six or eight large petals: color a ross mauve marked white on the upper petals, au en der. $20 \mathrm{c}$ each.
Special Offer. The full set of 6 varieties for $\$ 150$.

Geraniums-Double Varieties. E. H. TREGO.-We have tested this variety for the past year and can truly say it is the largest flower and brightest scarlet geranium we have y'e purposes. The florets are regular in for n, more than semi-double, and about two and a lalf inches in meter. Trusses, enormously large. 20c each. double with two white blotclies: a stocky grower. wlth large trusses, perfect florets, and a continuous bloomer. The finest double pink variety that we have seen, $20 \mathrm{c}$ each (5) compact grower: flowe r rery large, of an mususually good form; color, a MARQUIS CASTELLANE. - A dwarf grower ith immense flowers about two and a lialf juche in diameter. Color, two beantiful shades of red, very distinct This magnificent pred variety ranked as fine as Viand in the open ground, which is the lighest Le we can give it as a leerder. $20 \mathrm{c}$ each.

LE COLOSSE.-Monstrous size trusses of wary petaled flowers: semi-rlonille; or. orange scarlet of a yellowish shade-produciug very latge trusces in orea $20 c^{\prime}$ each.

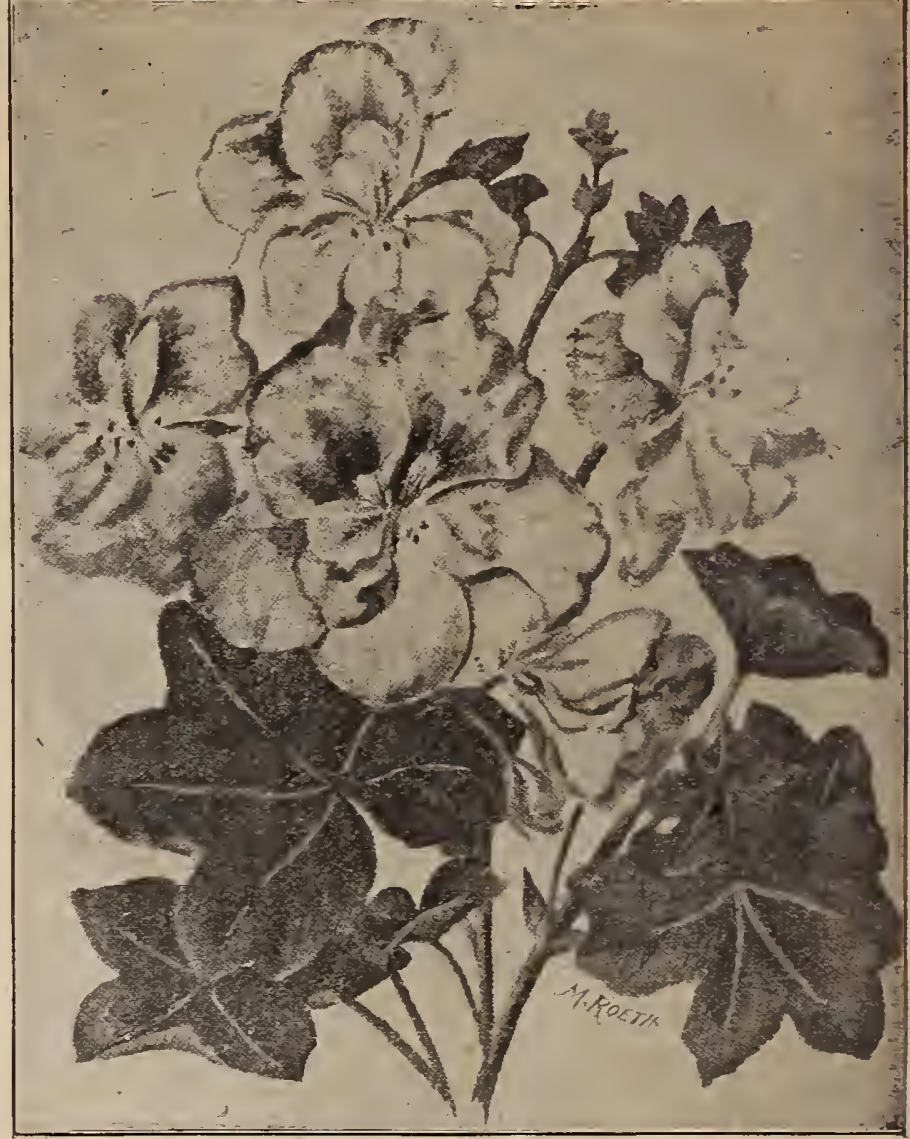

Geranium-Achievenent.

\section{GERANIUMS-IVY LEAF.}

ACHYEVEMENT. - Habit is sturdy, like the Zonale, while foliage is a combination of Zouale aud Iry. Florvers, large, with nice col a cut.) $20 \mathrm{c}$.

ETINCELANT. - An excellent scarlet variety: strong grower free bloomer: color, scarlet; best of its variety. $20 \mathrm{c}$.

MRS. HAIVLEY - A rery deep pink color, flowers, laree in fine large trusses, on long stems, a beautiful new color. $20 \mathrm{c}$ each. Special Offer. The set of 3 varieties for $50 \mathrm{c}$.

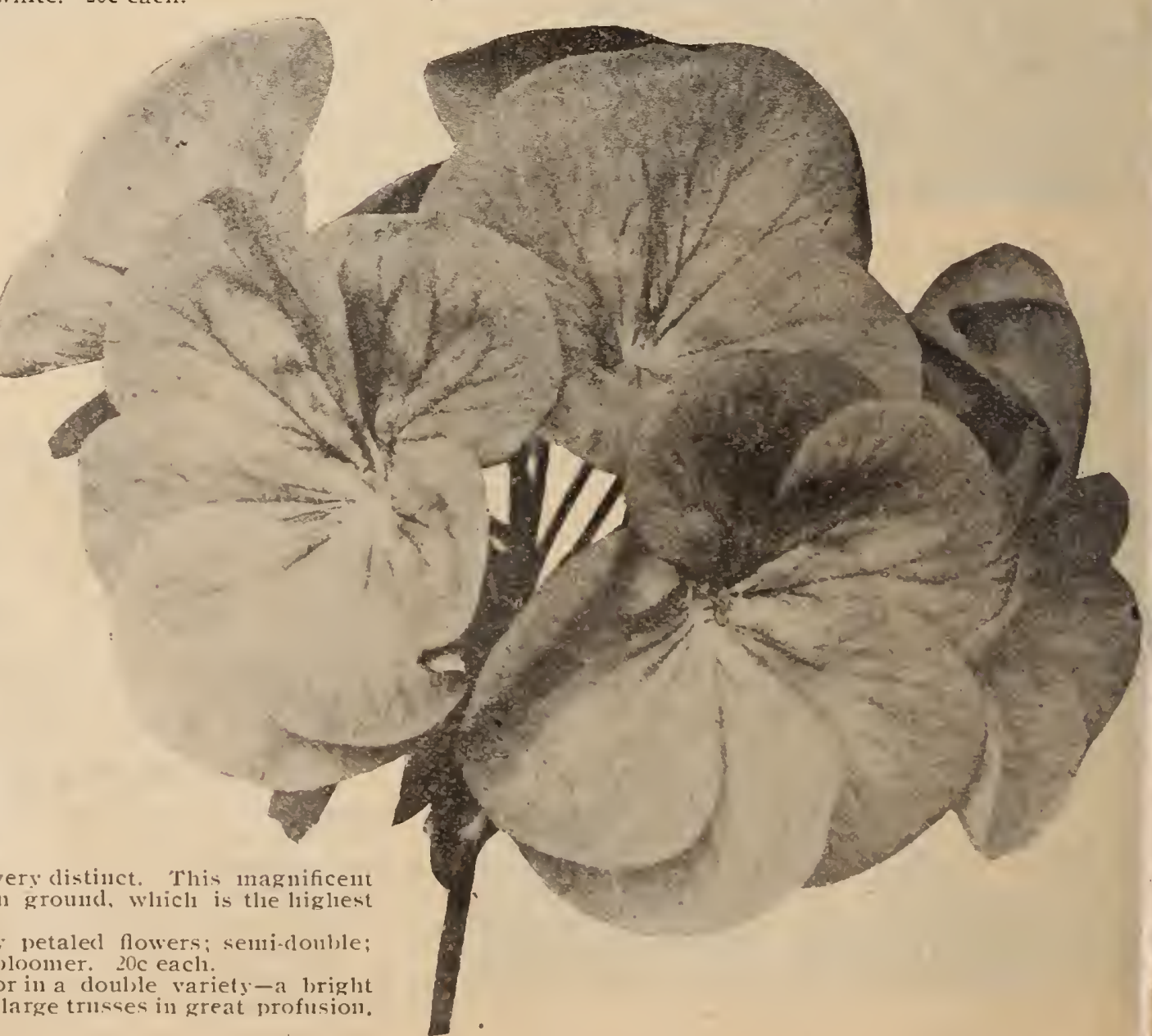

qeraninu-Clyde. 


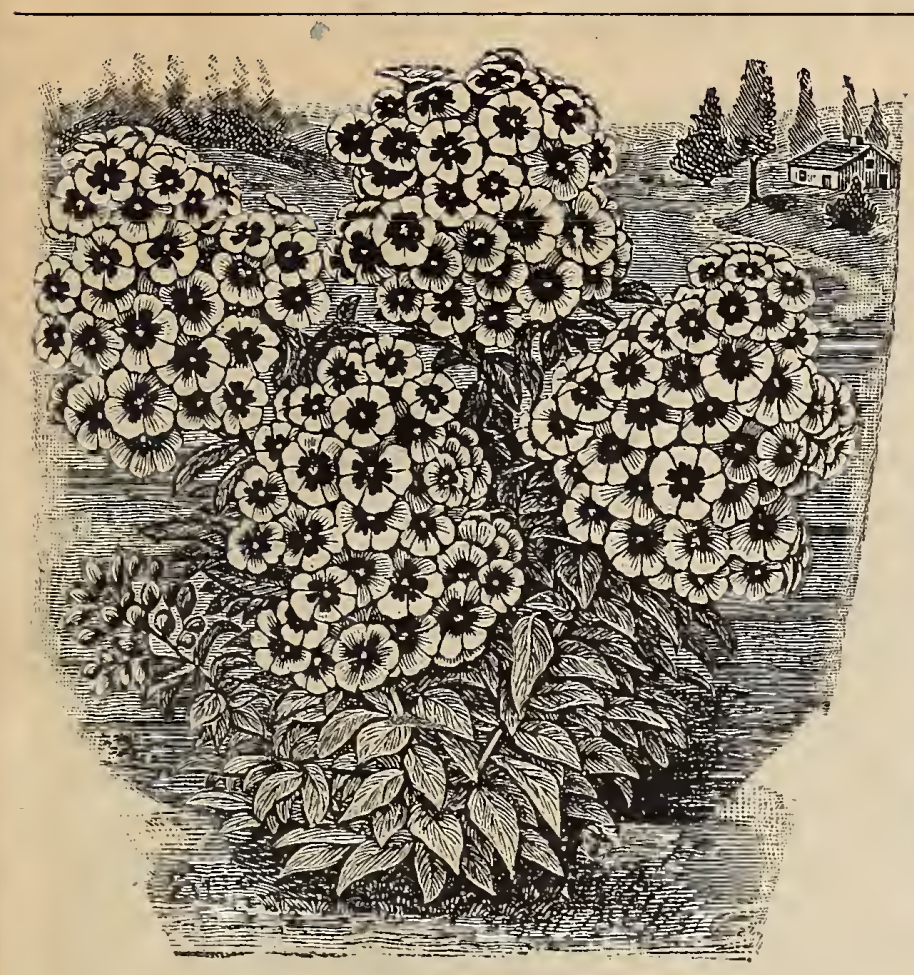

Hardy Phlox.

\section{Young's Hardy Phlox.}

These Phloxes are perfectly hardy and live out in the open oround all winter without any protection. Few plants give better satisfaction, as they continually from June until september and the individual florets are twice the size of the old tine phlos. and the shades of colors the brightest, richest and clearest.

ANDREAS HOFEER-Pure white, early fiowering, $15 \mathrm{c}$ each.

AQDILON-Carmine rose, shaded salmon, $15 \mathrm{c}$ each.

BRIDESMAID-White with crimson center, $15 \mathrm{c}$ each.

JULES FINGER-White with red eye, 15c each.

PANTHEON-Salmon rose, very fine, $15 \mathrm{c}$ each.

LILIPUT-Bright magenta, with crimson eye, $15 \mathrm{c}$ each.

SUNSHINE-Salmon pink, with rose eye, $15 \mathrm{c}$ each.

LA FONDRE-Purplish crimson, with carmine center, $15 \mathrm{c}$ each.

CROSS OF HONOR-Rose striped white center, $15 \mathrm{c}$ each.

THEBAIOE-Salmon red with crimson eye, $15 \mathrm{c}$ each.

The full set of 10 varieties for $\$ 1.25$.

\section{Hardy Scotch Pinks.}

Valuable dwarf hardy garden plants that will grow anywhere and increase in beauty every year; they have a delightful clover-like fragrance that adds to
their value for cut flowers. When fully developed the plants are a perfect mass of bloom for a long time.

JULETTE-White, with maroon bands, fragrant. $25 \mathrm{c}$ each.

EARL OF CARLYLE-White, beautifully marked with maroon. each.

ALBA (Fimbriata)-Pure white, deeply fringed. 25c each.

HER MAJESTY-Pure white, very large. $25 \mathrm{c}$ each.

LAURA WILMER-Color white, with deep maroon bands in center

Blooms the entire summer. 25c each.

SPECIAL OFFER-The full collection of 5 distinct varieties of flowering clumps for $\$ 1.00 ;$ in small size plants, from $2^{1} 2$ incl pots, 10e each: $\$ 1.00$ per dozen.

\section{GERANIUMS.}

Lady Washington or Pelagoniums.

.

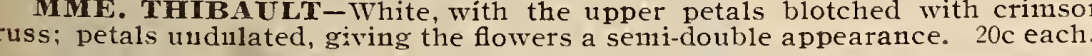

DOROTHY - Rosy salmon, with dark inaroon blotches on upper petals, richly shaded plum color und the throat; petals prettily fringed, Price, $20 \mathrm{c}$ each.

MRS. ROBERT SANDFORD-A great double white variety, one of the finest; the flowers are

large, beautifully ruffled along the edges of the petals. Price, $20 \mathrm{c}$ each.

SANDFORD'S SURPRISE-A bright red with dark blotches on upper petals, surrollnded with

broad white bands with bright red spots in center of each. Price, $20 \mathrm{c}$ each.

SANDFORD'S WONDER-A splendid semi-double white flower with some blooms showing a all maroon spot on upper petals, which are heavily fringed. $20 \mathrm{c} \mathrm{each}$

SPECIAL OFFER-The set of 5 varieties, $75 \mathrm{c}$.

\section{BIGNONIA GRANDIFLORA. (Trumpet Creeper.)}

A Hardy Rapid Growing Vine.

This is a grand improvement over the old variety. The flowers afe much larger and produced more profusely. Color, orange and yellow, trumpet-shaped and blooming in clusters. Very useful for covering old stumps and unsightly places. Strong 3 year old stock. 50c each.
Hardy Scotelı Pinks. Laura Wilmer,

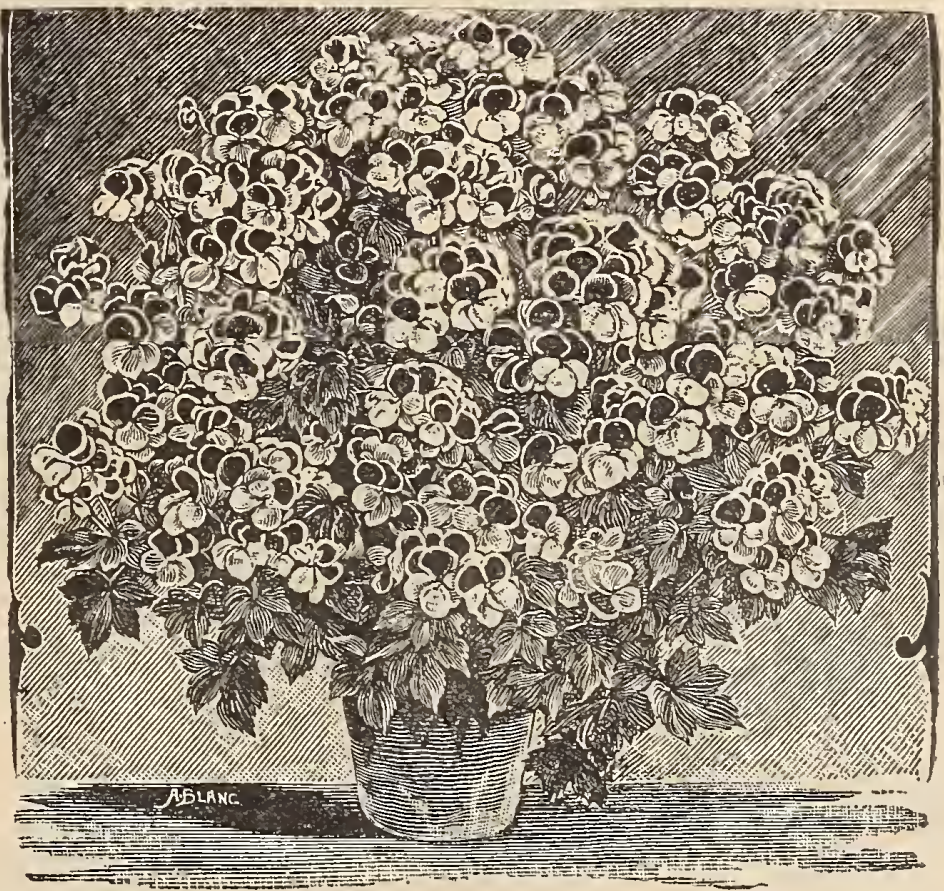

Pelagonium, or Lady Washington Geranium,

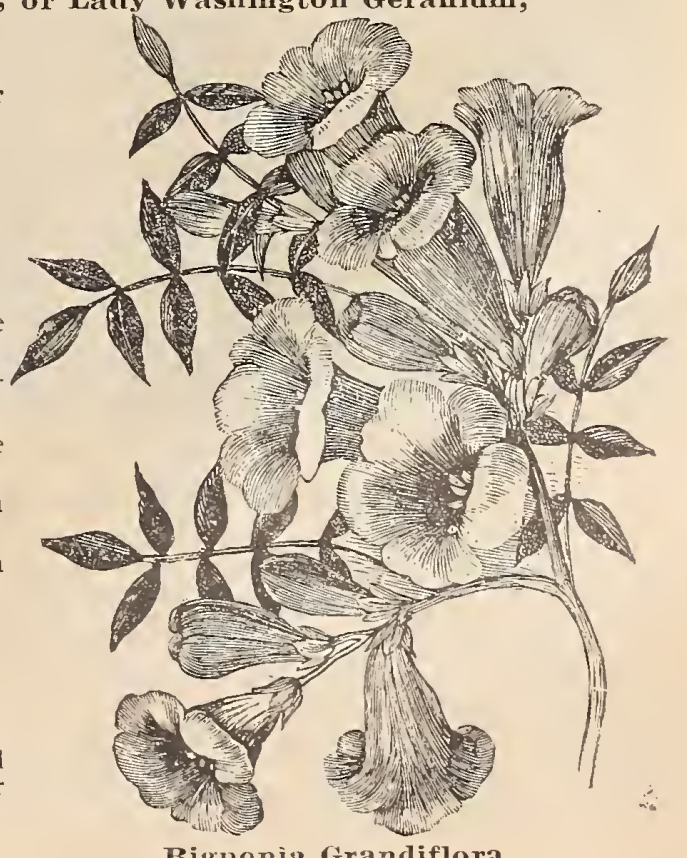




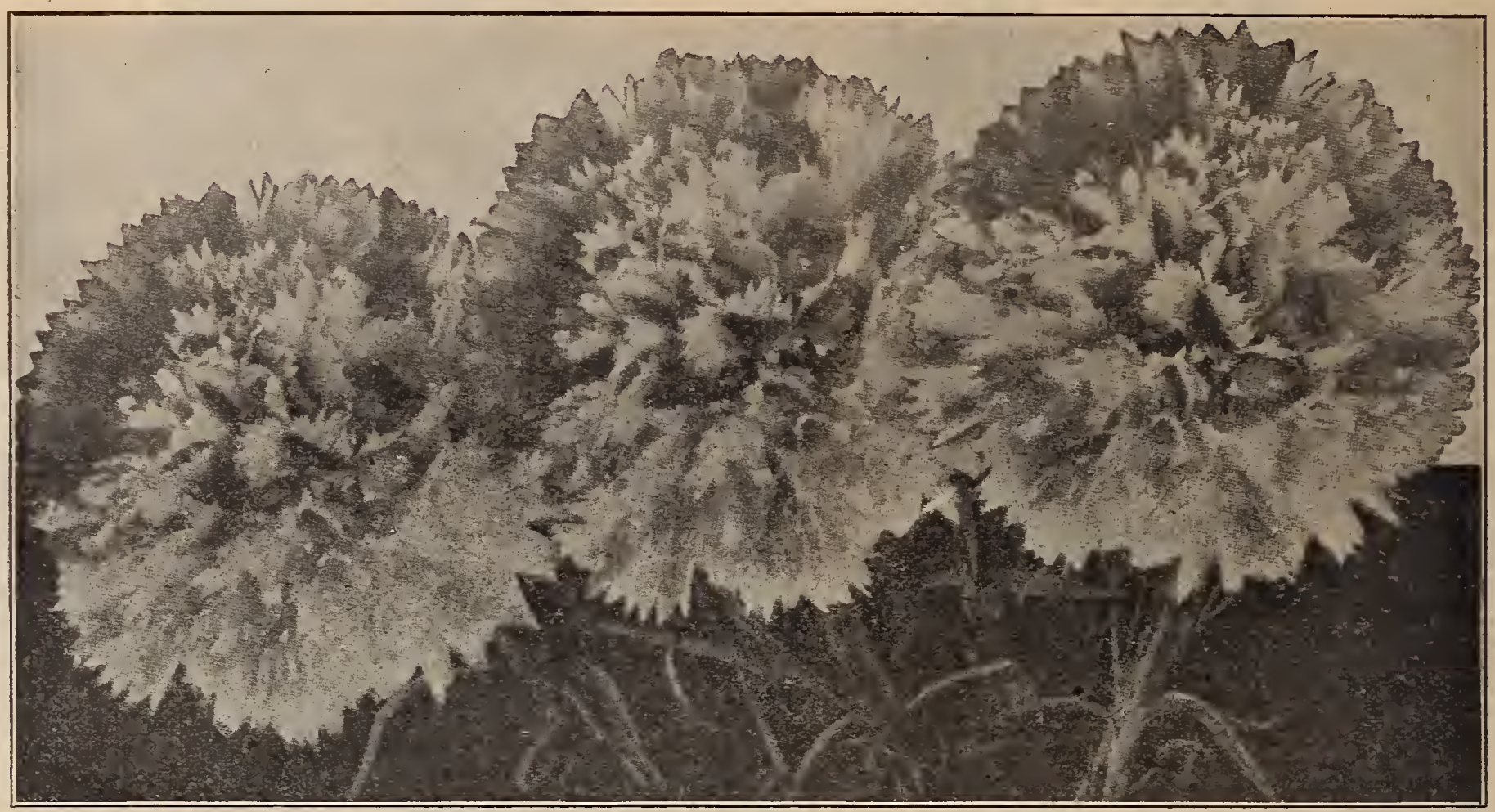

Novelty Carnations for 1904.

\section{Young's Carnations Selected from the Best Novelties of 1903.}

ADONIS-This variety is the largest size Red Carnation yet introduced. It is nearly three inches in diameter. The color is a beautiful carmine red, a very vigorous, easy, quick growing variety, propucing long, perfectly straight stems throughout the entire season. One of the Choicest Carnations in existence. Price, 20 cents each.
IRS. A. L. NELSON-This is described as being one of the most profuse blooming pink Carnations in existence. Color is a pure glistening pink. The growth is stroug, clean and vigorous, stems 2 to 24, feet, very strong and erect. The calyx is perfect and flowers do not burst. It is an early, profuse, and continuous bloomer. Price, 20 cents earh. Price, 20 cents each we know of: very fragrant. The flowers are borne no long, stiff, wiry stems. This variety is free from all kinds of disease.

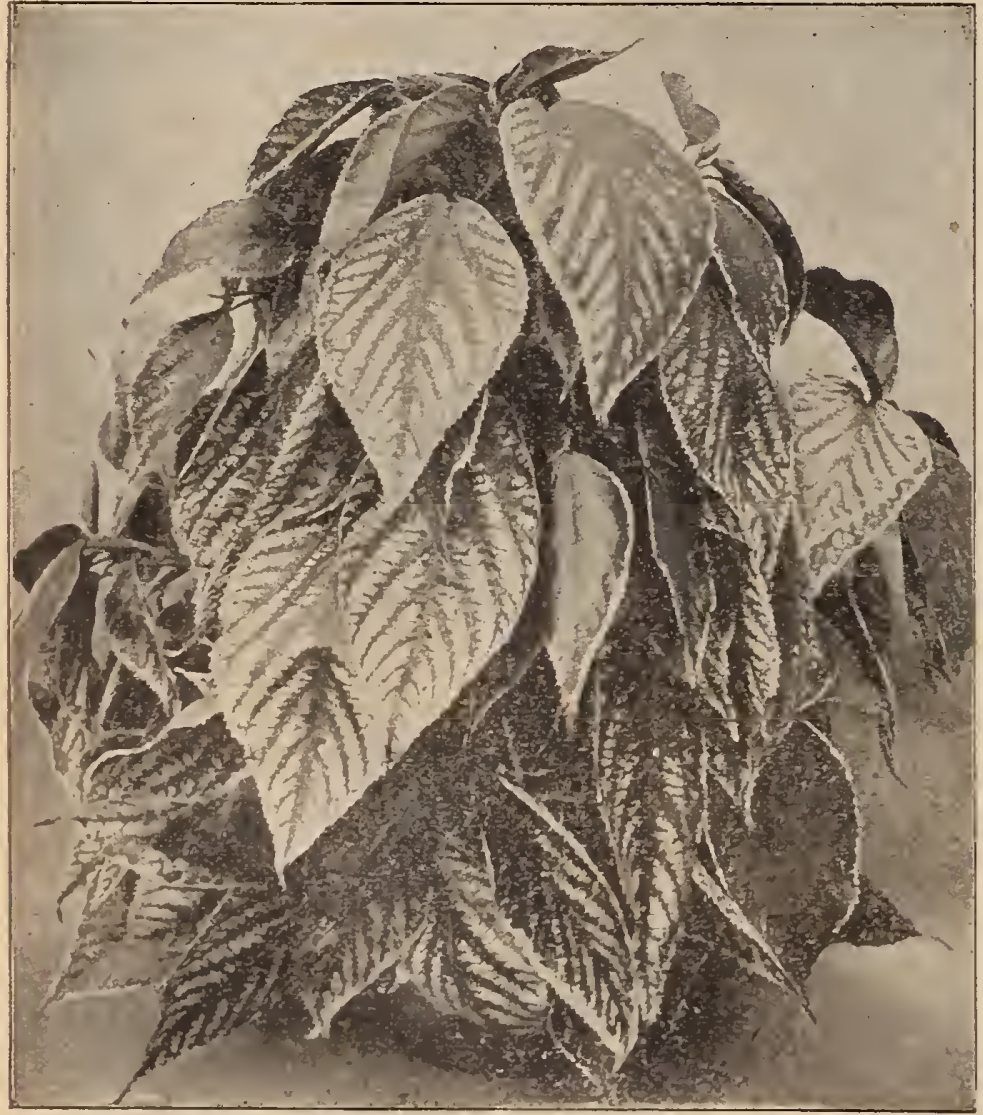

Acalypha Bicolor Compacta

THE NEW BIC FOUR COLEUS.

(1) Coleus the best novelties that we liave sentout for years. They are a new cleparture from the Coleus of the ordinary type, their foliage being very large, mon CLEVELAND-A very claruning combination of dark crimson, deep maroon and clear CHICAGO-A grand variety of the golden type. Foliage pure bright golden, bordered with green, changing to a pure golden variety in the liot CINCINATI-Bright pink shaded with maroon and bordered with green. Fine large foliage; excellent bedder. Price, $35 \mathrm{c}$ eacli.

ST. LOUIS-The finest variety of the collection, foliage very large, color a brilliant red. Tlie same variety, last season, planted in a solid bed looked as brilliant as a bed of red Geraniums, from a distauce. Price, 35c eaclı.

FULL SET OF FOUR, \$1.00. 


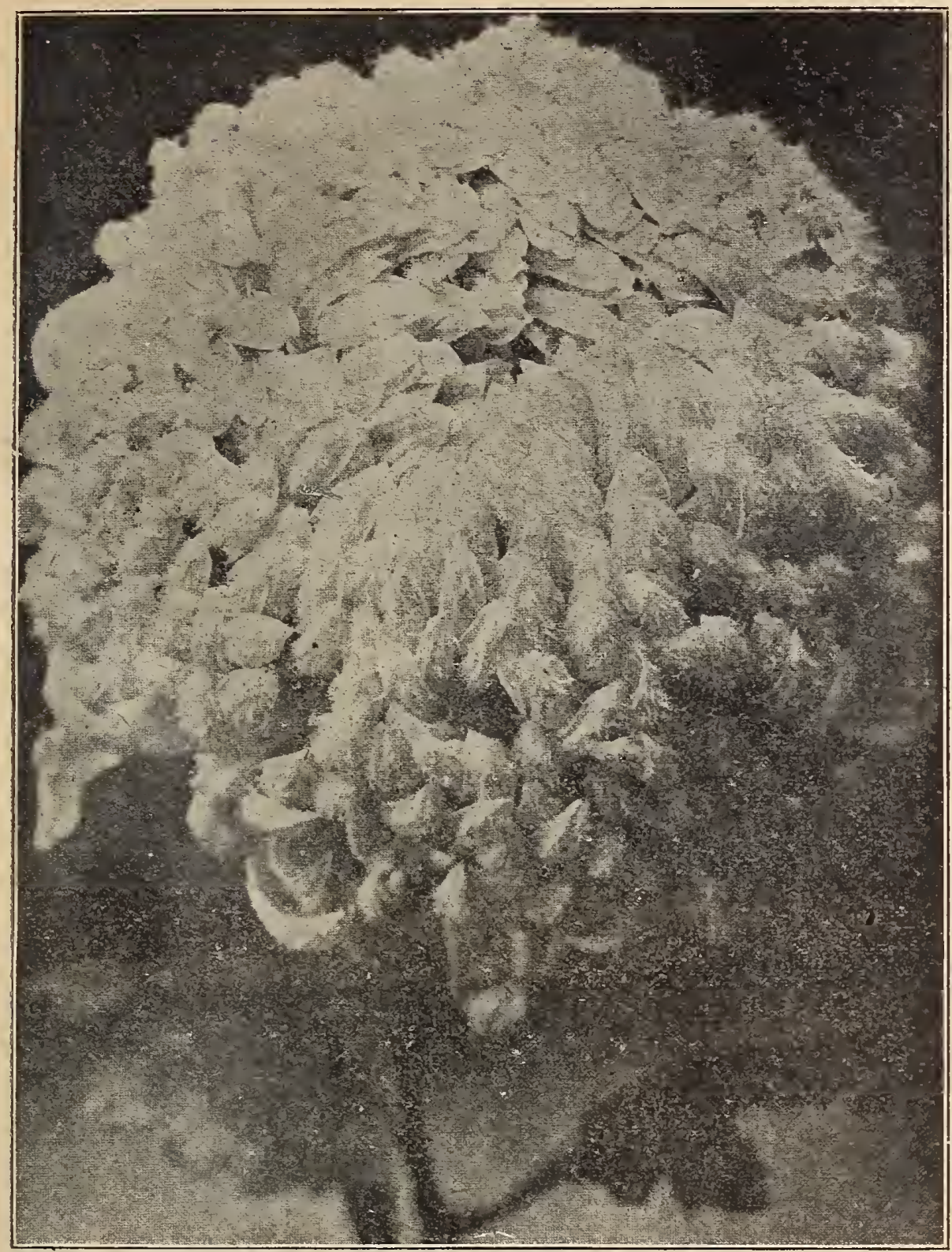

\section{CHRYSANTHEMUMS,}

The Seven Best Varieties Selected From
all the Prize Winners of 1903 . F

ESTELLE-Color pure white, very early flowering, good!grower and dwarf habit. Highly recommended as the best of all the early varieties. Price $20 \mathrm{c}$ each.

MDLLE. MARIE LAGER-Closely incurving blooms of large size. The color is pearl pink, deepening to a very bright shade at the base of petals. In habit it is dwarf June planting only reaching three feet in height. Stems are stiff and fully covered with handsome foliage. It is perfectly uniform, perfecting every flower. Date of bloom ing is Oct. 20th. Price 20c each.

CONVENTION HALL-Closely resembles the Queen in stem, foliage and form. Color, white, of an exceedingly pure tone. Very broad center petals, incurving closely tubular ray florets. It is unquestionably the finest white that has been produced for many years, no white excepted. Price $20 \mathrm{c}$ each.

MISS MINNIE BAILEY-A seedling from Mrs. Per rin, possessing good stem and foliage, but surpassing thavariety in fullness being fully double under all conditions Color bright pink, similar to that of Mrs. Perrin, although a trifle lighter. Height $3 \frac{1}{2}$ feet. Price $20 \mathrm{c}$ each.

W. H. BUCKBEE-The color is yellow and in habit very dwarf, with petals loosely arranged. Good keeper. Best bud about Sept. 15th. Height $3^{1 / 2}$ feet. Price 20c. each.

ETHELYN-A Japanese incurred. Petals, light rose pink at the base shading lighter at the tips. A very handsome formed flower which is sure to become popular when well known. Price 20c each.

F. J.TAGGART-The inost striking novelty of recent years. The best of all the hairy or plumed section. A great advantage over all yellows in this class, being perfectly double and the hair-like filaments more pronounced. Color a light yellow. Flowers 8 inches in dianneter. Price 20c each.

SPECIAL OFFER-Tle set of : varieties for $\$ 100$.

Chrysanthemum, White Bonafon.

\section{CANNAS.}

\section{The Best Seven Varieties of Cannas Se- lected from the Novelties of 1903.}

AUGUSTA-(Cuba). Flowers 5 inches across, intense scarlet, widely bordered with clear golden yellow. Fntirely distinct. Three feet high. Price 25c

BRANDYWINE-The beautiful bronze-leaved Canna. A healthy vigorous grower of 4 to 5 leet. Color is intense vinous red dappled with deep crimson two or three petals are sometimes narrowly edged with bright gold. Price 25 c.

DUIKE OF YORK-I, argest and most magniflcent of tle variegated Cannas. Color a beautiful, rich, deep crimson, with a throat of curiously mottled creamy white, and each petal exquisitely edged with an irregular border of fine gold. Light green foliage, very tough: a strong grower

KING HUMBERT-The flowers are as large as the largest of the Orchid flowering cannas. The flower is a bright orange scarlet streaked with crimson. The foliage is bronze with brownish green stripes, large, thick and leathery, in fact the finest foliage of all Cannas, combining the beautiful flower stalks with the grand foliage make an ideal Canna. Extra strong robust grower, height 4 feet. Free flowering. Strong growing plants, 50c, each.

SHENANDOAH-A splendid red or bronze-leaved variety and the most unique novelty to date. The foliage is rich ruby red, exquisitely veined and tinted like some rare hot-house plant. It bears fine large trusses of beautifully waxy, rose-pink f wers, and unlike other red-leaved sorts, is a most early and abundant bloomer, highly ornamental. Price 25c.

VICTORY-Height 5 to 6 feet. Extra strong. robust grower, throwing up immense flower stalks, each stalk having from 7 to 9 flower spikes.

ith an irregularband of yellow. We know of no Canna equal to it. Price $50 \mathrm{c}$ each. MRS. C. E. WARD-Height 3 feet. Green foliage. Color a brilliant crimson scarlet. The flowers are very lare
and borne in large spikes. The habit is dwarf and compact, and the spikes stand well above the foliage. Price $25 \mathrm{c}$.

SPECIAL.OFFER-The full set of 7 varieties for 1.75 .

NEW DWARF CANNAS.

A remarkable new dwarf variety of Cannas, which make a compact little clump of handsome green leares surmounted with a fine display of brilliant colored flowers. They rarely exceed 2 feet in height.

FAIRY QUEEN-Color orange scarlet, bordered with yellow. $25 \mathrm{c}$ each MOTTLED OUEEN-Color orange yellow spotted red. $25 \mathrm{c}$ each. 


\section{New Golden Pandanus.}

\section{(Pandanus Sanderi)}

This sterling novelty was first sent out last fall, and it is without a doubt the most important addition in many years to the comparatively sinall ist of really first.class decorative plants, and one that a plant for the conservative the int in position wher a decoratives, pife and In subject. In gent its leaves are longer and rore recurve exces the the gives the plant a leave gracefol rich rich golden-yellow, while the heart of the plant presents a bronzy-orange coloring.
high in 6 inch pots, $\$ 3.00$.

\section{New Boston Sword Fern, Or Ostrich Plume Fern.}

(Nephrolepis Piersoni]

This new fern was introduced last spring as the inost important addition to this line of plants in many years. The plant possesses the same vigorous growth that is characteristic of the Boston Fern, with long graceful fronds, but with each Pinnae or leaf$1 \in t$ subdivided so as to form a perfect minature frond.

This is well shown in our illustration, though it convers but slight idea of their grace and plume like beauty. The fronds grow broad and heary, and measure, when fully developed, least 6 iuches across, increasing in beauty as they develop. large stock enables us to offer this new plant at greatly reduced prices. Strong plants in 4 inch pots, 50c each. Strong plants in 6 inch pots. $\$ 1.00$ each.

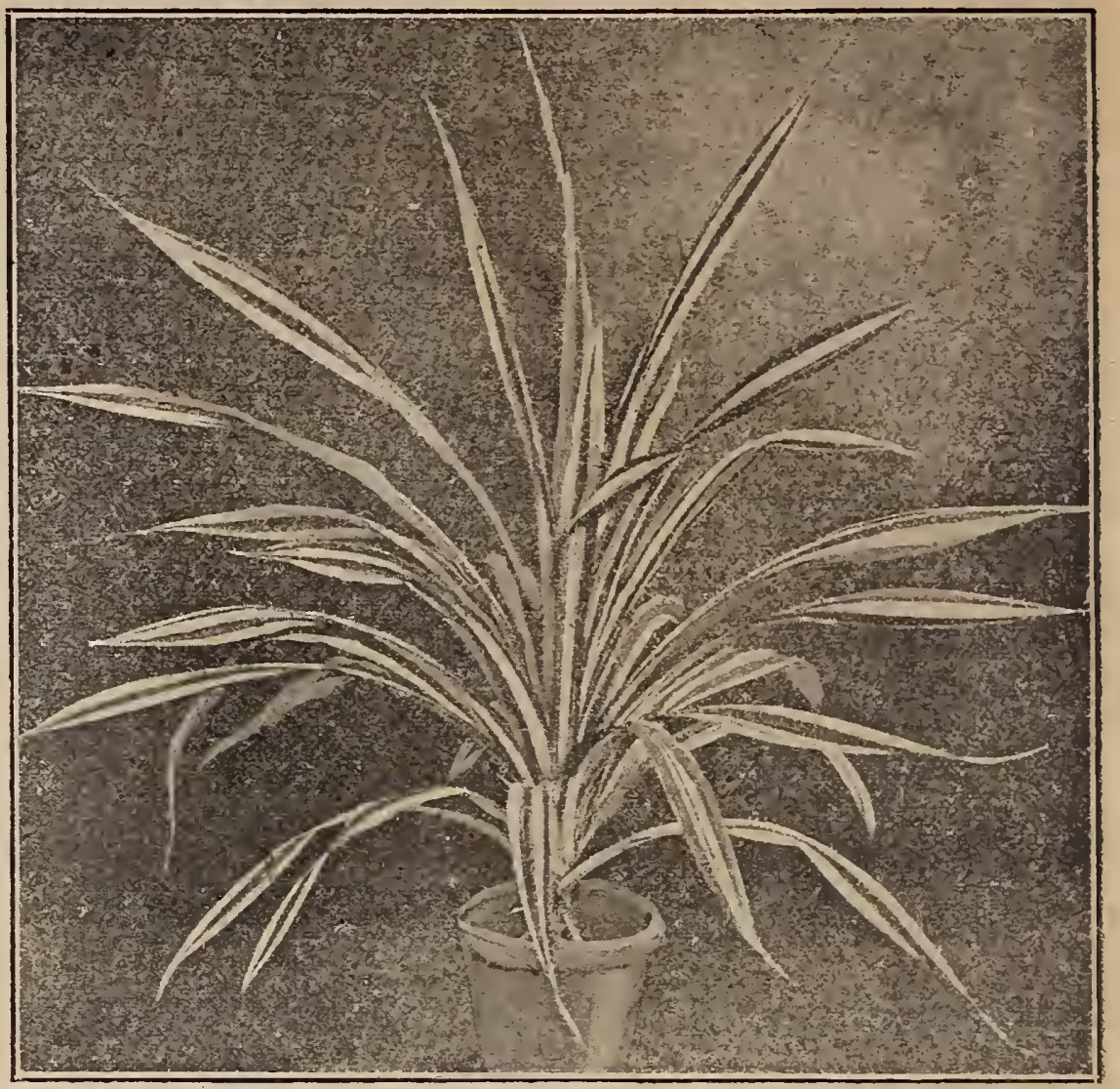

The Golden Pandanus. (Pandanus Sanderi)

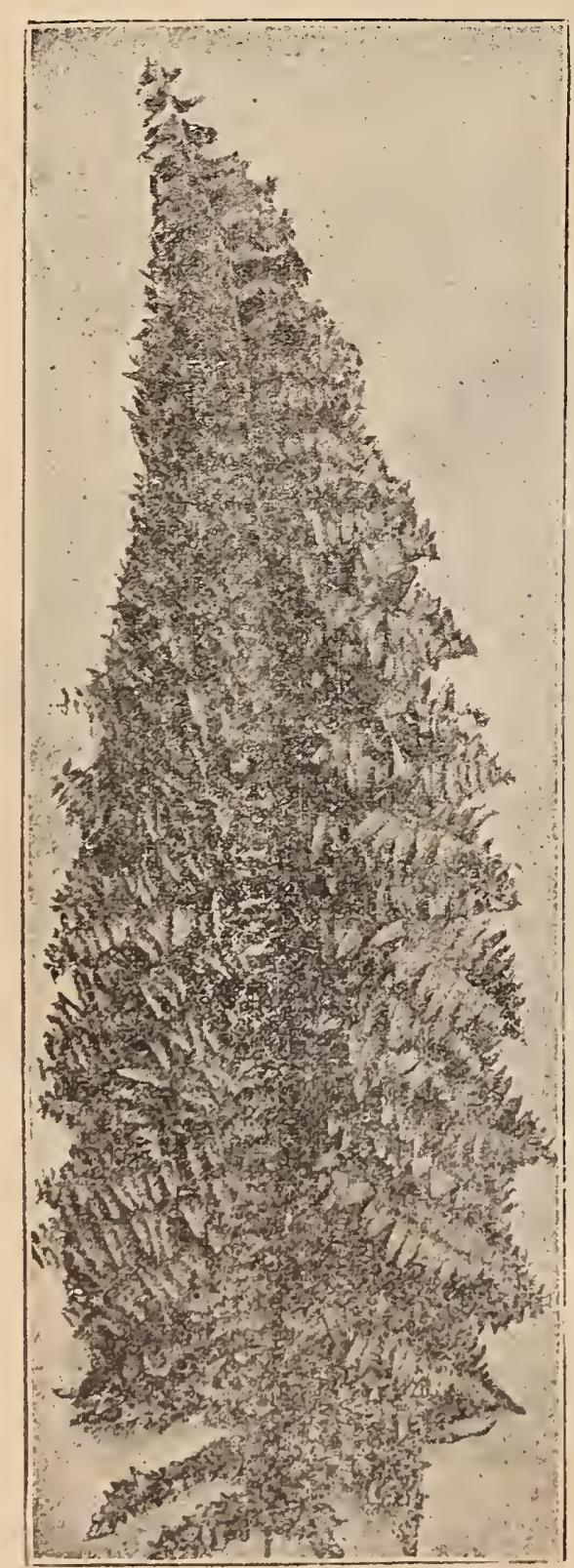

New Boston Sword Fern,

or Ostrich Plume Fern.

\section{BEGONIAS.}

\section{DOUBLE FLOWERING.}

BOULE DE NEIGE-A very strong grower, bearing large double pure white flowers, occasionaly lightly tinged with pink, in great "profusion the entire summer. $25 \mathrm{c}$ each,

TRIUMPH DE LORRAINE-A very profuse bloomer, quite double with nice imbricated petals; color of buds and flowers when opening a bright scarlet changing to a cherry carmine when fully open; stamens bright yellow contrasting nicely with the colors of the flowers. $25 \mathrm{ceach}$.

NANCY-Leaves of the most beautiful form, of a glossy green color; flowers extra large and very double; color a soft pink. $25 \mathrm{c}$ each.

SPECIAI OFFER-The full set of 3 varie. ties for 60c.

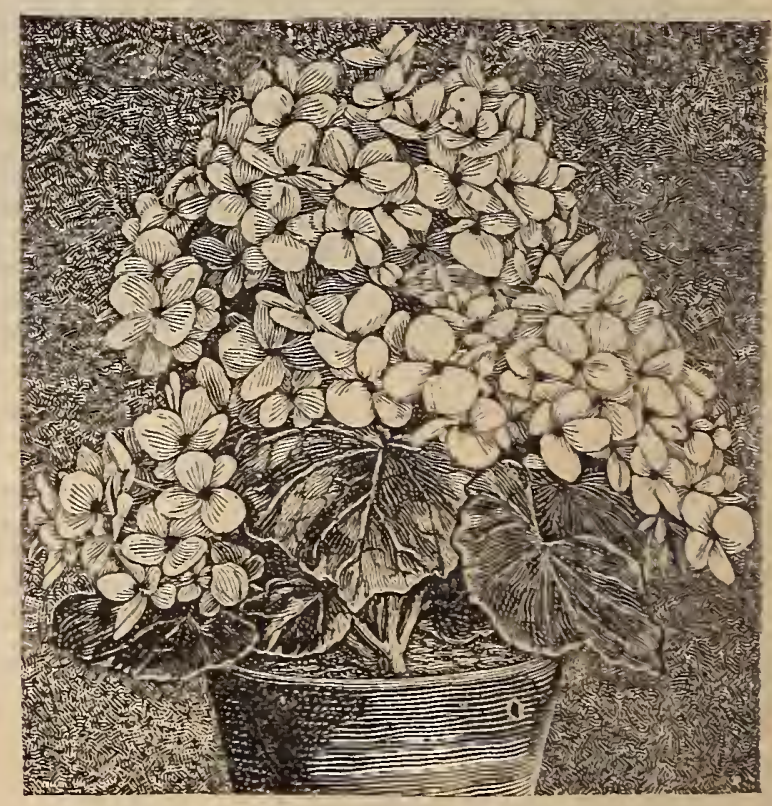

Single Flowering Begonia.

\section{BEGONIAS.}

\section{NEW SINGLE FLOWERING VARIETIES.}

PROFUSION-Flowers 'bright pink, produced ereuly all over the plant; one of the best for house or summe $t$ beddiug. $20 \mathrm{c}$ each.

FOURNAISE - Flowers produced in large drooping panicles of a bright red color; resembling those of the old begonia Fuchoides, but twice as large. 20c each.

VESUVE-One of the most free floweriug varieties grown; very effective when grown up into large plauts: flowers bright coral red, borne iu large clusters. $20 \mathrm{c}$ each.

SI'ECAL OFFER-The full set of 3 varieties for 500

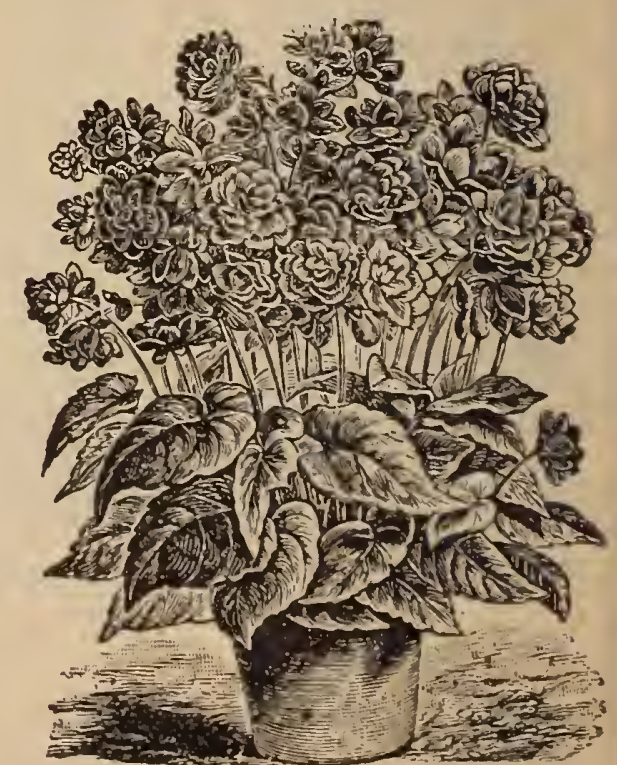

Donble Flowering Begronia. 


\section{YOUNG'S SUMMER FLOWERING PLANTS, GRAPE VINES, SMALL FRUITS, TREES, SHRUBS, ETC.}

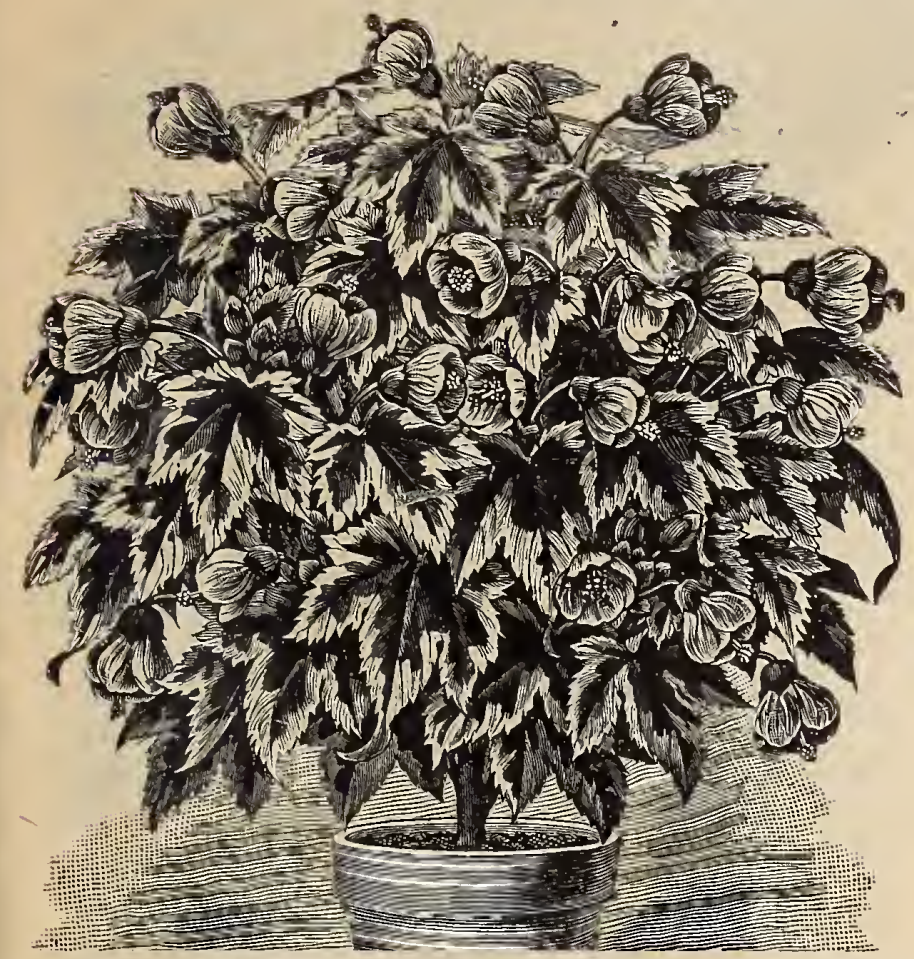

Abutilon, Souvenir de Bonn.
ABUTILON

(or Flowering Maple.)

McKINLEY-Plants dwarf and
hort jointed producing exquisite large cupped blossoms by the score all sum

ellow. Each, 20c. ing decorative foliage, being equally as valuable as Palms, Crotons or Dra-

splendidly. Each, 15c.

ECLIPSE-This is really one, of the best of all pot plants. It is always in 15c each. blotched creain and yellow, bright, purplish red flowers, uster. Each, 15c. the largest size; round and open; rich, sort. Each, 15c. er of delicate pink color. $15 \mathrm{c}$ each. Special Offer the full set of six $A b-$ ACALYPHA

SANDERIANA-It is of strong, free growth, with large dark gree leaves, from each axle of which, one to
two feet long and nearly one thich, rope-like spikes of velvety crimson flowers are gracefully suspended, as shown in our illus-
tration. The plant is in flower the year around, and is as easily grown as a coleus, simply requiring tration. The plant is in flower the year around, and is as easily grown as a ce
a.warm temperature to develop its full beauty (see"cut) Price, 25c each.

\section{AZALEAS.}

Ouriazaleas are an especially fine lot in all sizes, in, shades of pink, crimson, rose-color, white, pink and white variegated. There is nothing equalling Azaleas for flowering in the house, (Must be sent by express.

Fxtra large size, 26 inches diameter, in budlor bloom First Size, 18 inches diameter, in bud or bloom

\section{AGERATUM.}

PRINCESS PAULINE-A most distinct variety of dwarf, compact habit, rarely exceeding five inches in height, its peculiarity being that both

STELLA GURNEY-A short, compact grower and extremely free blooming, and color is intense blue. 1t can be used as a border arouud geraniums. Each 10c; $\$ 100$ per dozen.

MEXICANUM VARIEGATUM-This variety has beatiful variegated foliage, green with a narrow edge of white. 10c each; $\$ 100$ per dozen.

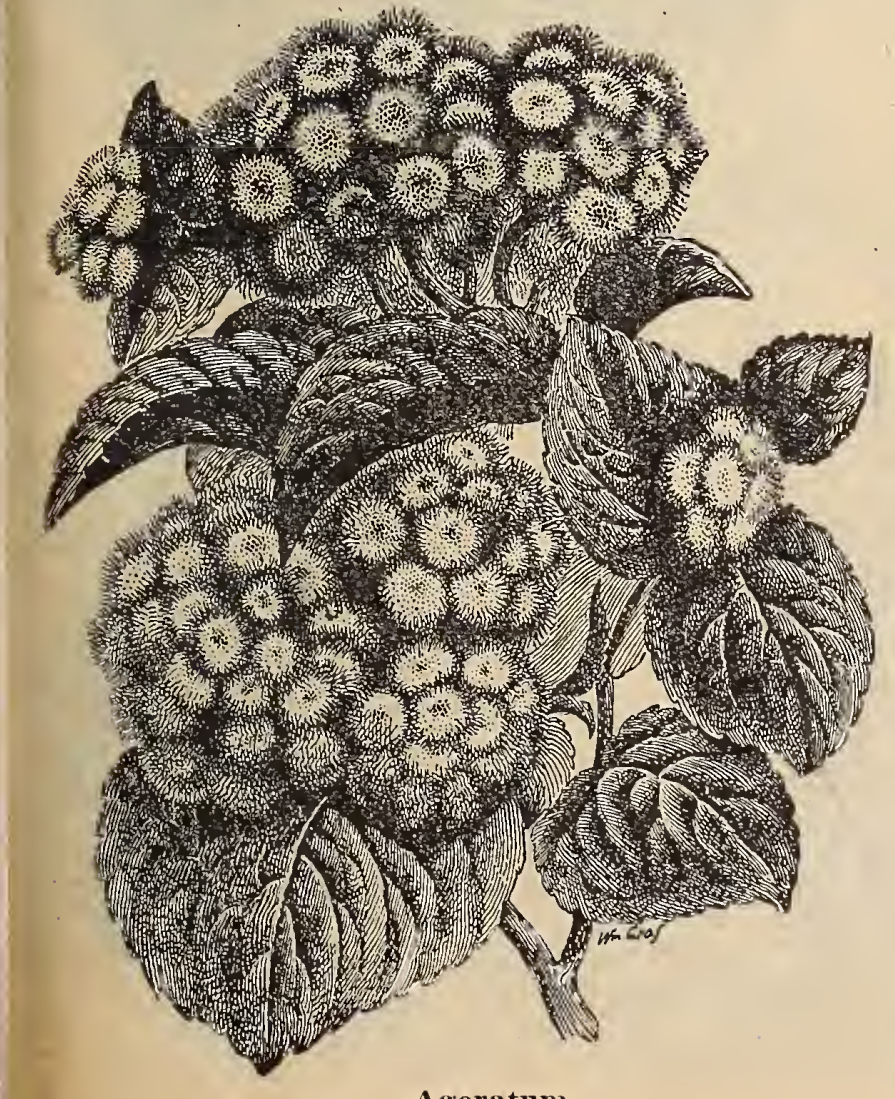

\section{AMARYLLIS.}

\section{$\rightarrow \rightarrow 0<\ll$}

These are the showiest and most gorgeous of all the bulbous plants grown. They are best adapted as pot plants for window or conservatory lower can approach their beauty. To grow Amaryllis successfully grow A rest

VITTATA HYBRIDA-T h e $y$ are very attractive, and only suitable for pot culture. Fine, large flower-
ing bulbs that will flower during the winter or spring. $75 \mathrm{c}$ each.

BELLA D O N NA MAJOR. (Belladonna Lily) - A variety of spikes often a utow youn two to three feet high growers pure white. $25 \mathrm{c}$ each.

JOHNSONII : The Barbadoes Spice Lily)-A very strong growing ariety, producing spikes of flowers inches high, bearing trum pet shaped fowers of a rich, glowing scarlet.

FORMOSISSIMA (Jacobian Lily) - Offered by some as the scarbeautiful house plant, beariug dark scarlet flowers in great profusion.

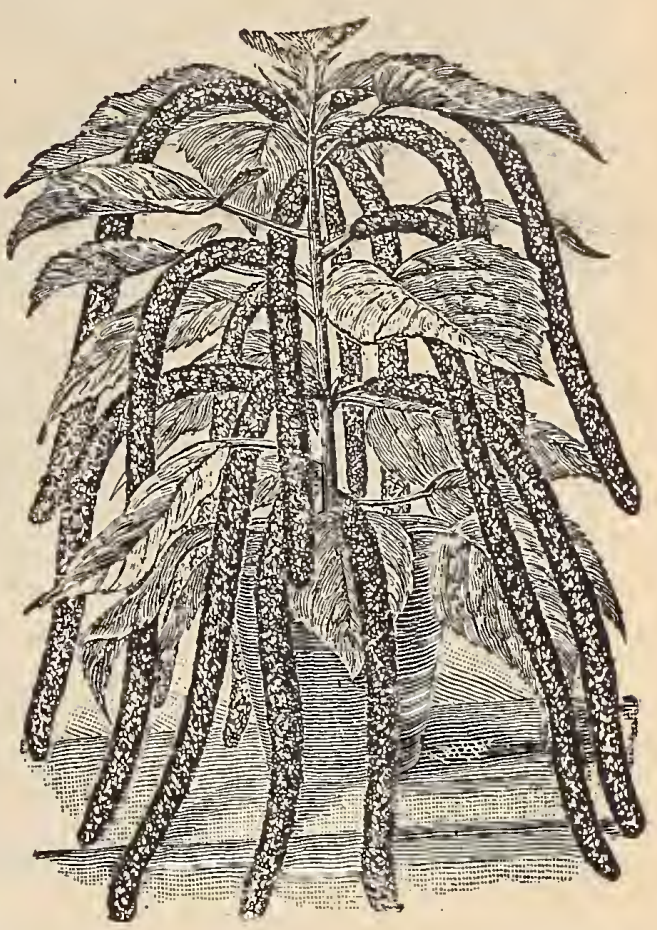

Acalypha Sanderiana.
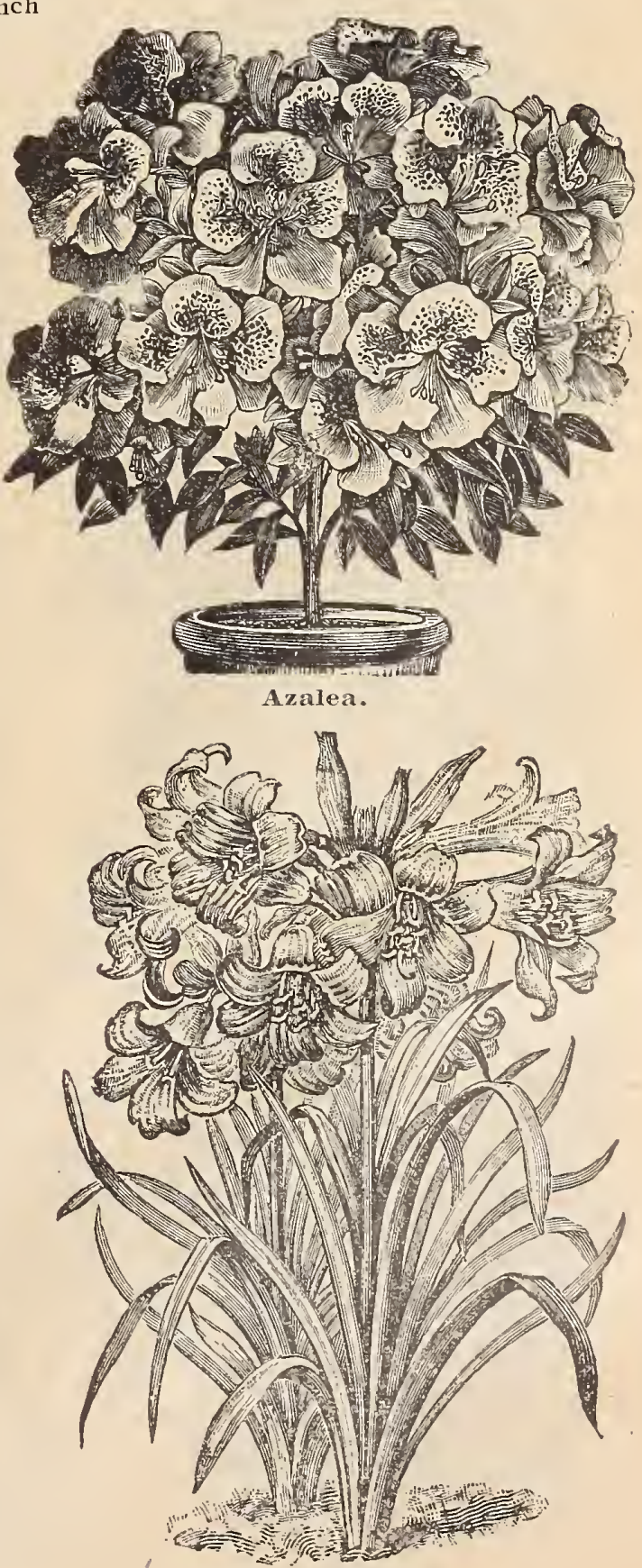

Amaryllis Jolnsonii. 


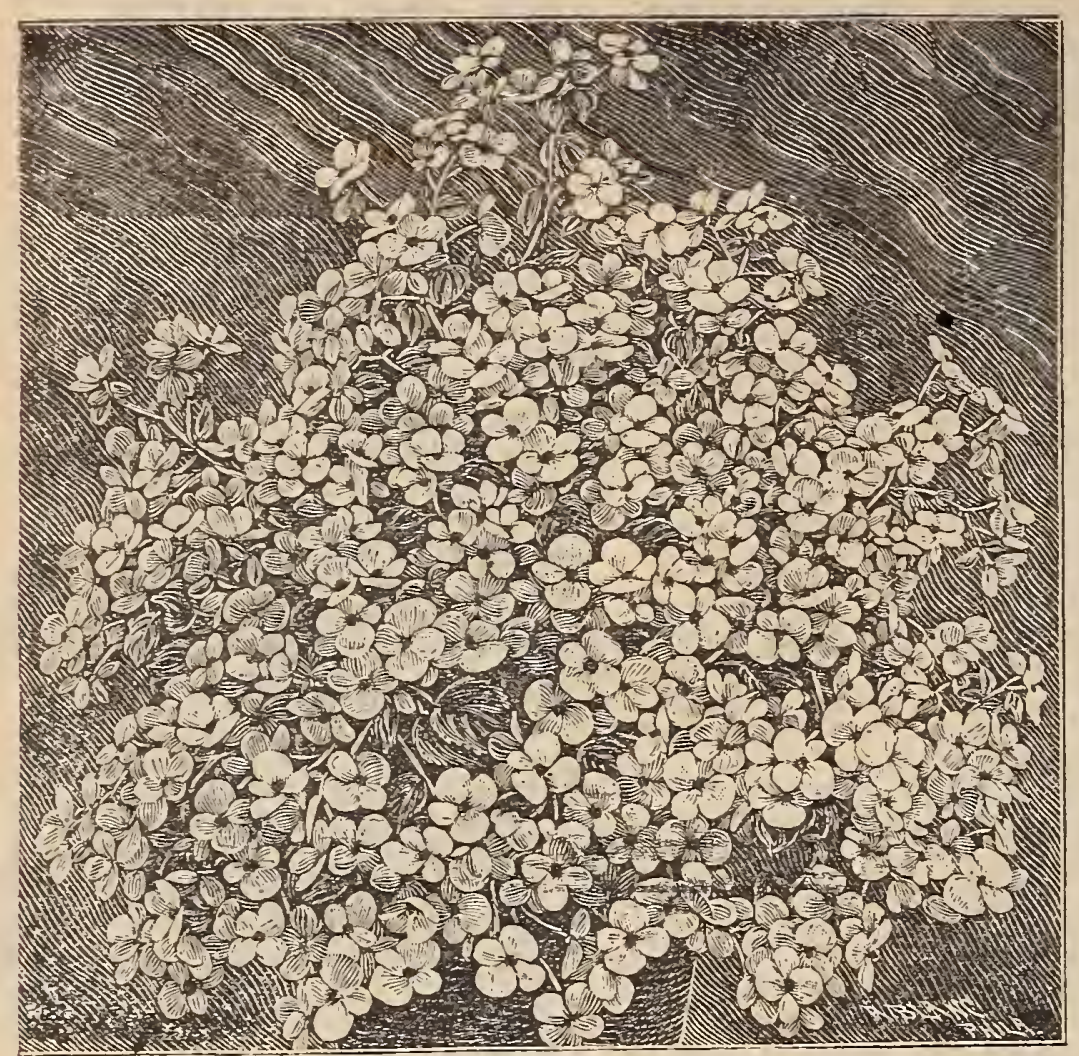

Begonia, Gloire de Lorraine.

ox 0 . गे 101000 og. 1 . N1 o. 2 .

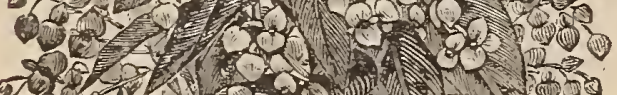

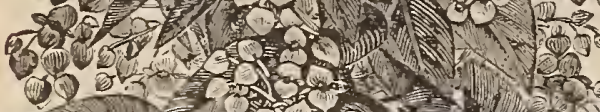

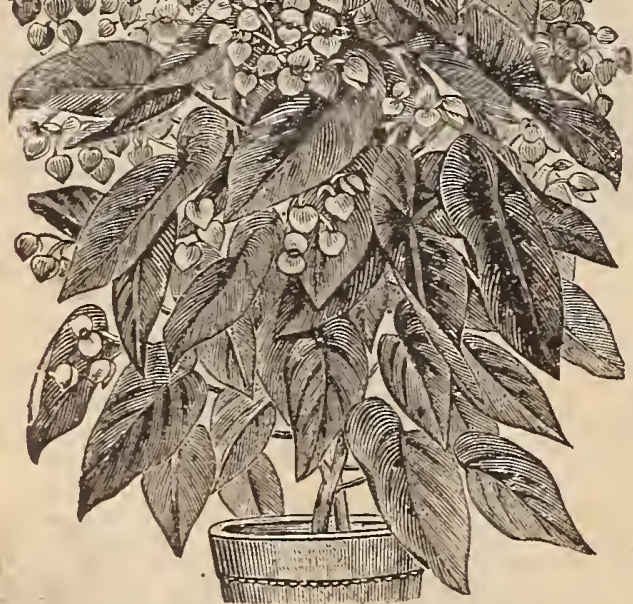

Begonia, Rubra

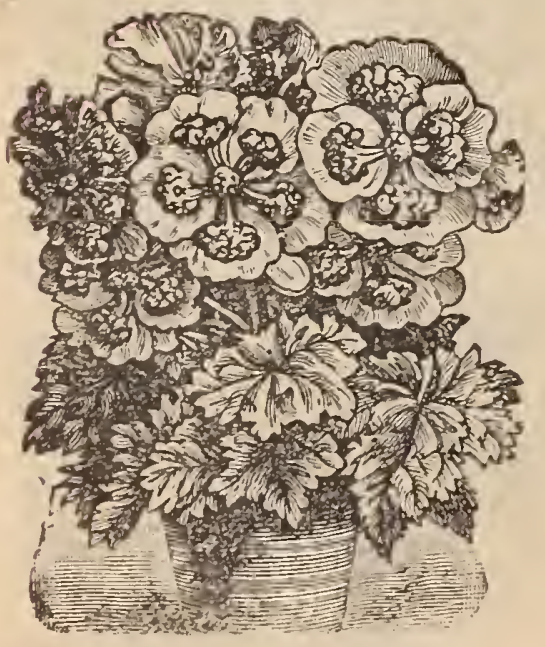

Begonia, Double Tuberose Rooted.

\section{BEGONIAS.}

\section{Flowering Varieties.}

GLOIRE DE LORRAINE-This is the grandest winter-flowering Begonia yet has no equal as a blooming plant, i being completely covered with pink high. (See cut.) Price 35c each.

ALBA PICTA-A distinct variety leaves glossy green, thickly spotted with
silvery white: ARGENTEA GUTTATA-The leaves are oblong in shape, of a purplish bronze color, with silvery markings; the fowers
are white. $20 \mathrm{c} \mathrm{each}$.

METALICA - A fine erect growing Begonia. with dark, rough leaves; a free M. De LESSEPS--A charming variet on order of Argenta Guttata; the leaves are a bronze green beautifully spotted. A very strong growing variety that wili PURITY-The finest pure white $\mathrm{Be}$ gonia grown. Its marvelous freedom of bloom and close. compact growth combine to make it
plants. $20 \mathrm{c}$ each.

PICTAVIENSIS - Leaves large and beautiful: spotted flowers, a delicat pink. 20c"each.

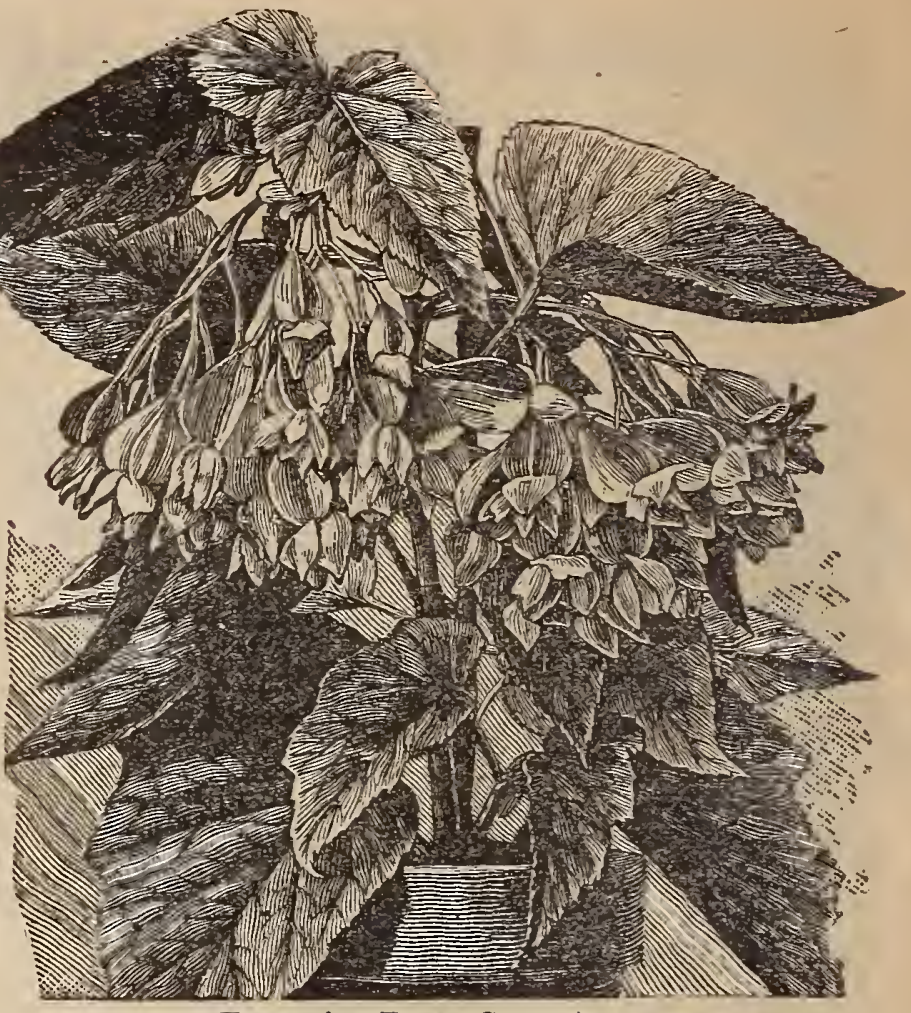

Begonia, Pres. Carnot.

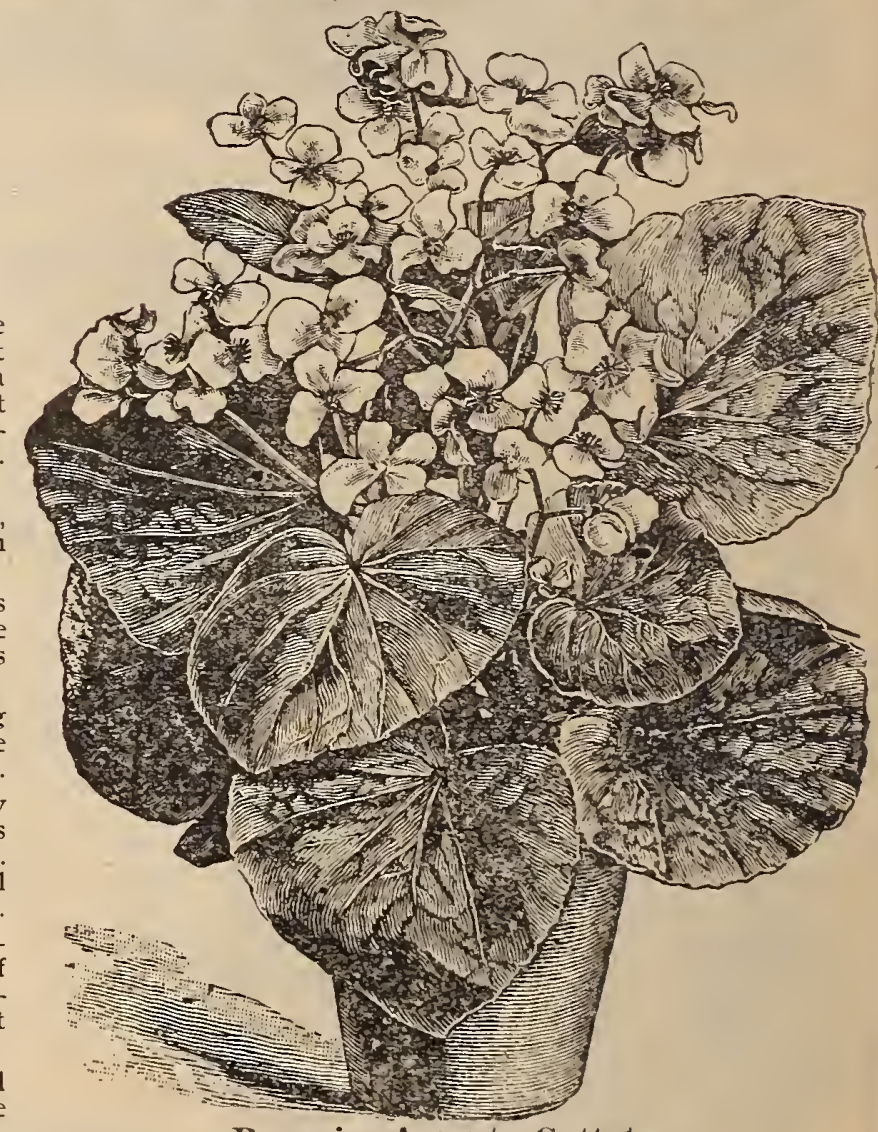

Begonia, Argenta Guttata.

PRESIDENT CARNOT - Strong-growing variety of stiff, upright habit, foliage deep green, underside purplish red; flowers beautifu

RUBRA-A dark, glossy green leaves and scarlet flowers borne in

THURST or upper side, is a brony green, shaded with crimson and olive. Flowers rosy' white, in large clusters, well above the foliage. (See cut.) 20 SOUV. De PRES. GAULIN-A beautiful variety. The bloom is a most rosy vermillio

VERNON BIJOU-Color intense brilliant scarlet, a grand plant for summer bloouling, making one of the fluest bedding plants. 20c SPEOIAL OFFER-The full set of 12 Begonias for \$2.00.

BEGONIA, TUBEROSE ROOTED.

A class of Begonias that is very popular for bedding and pot cult Aring is bright and flowers bright and lasting. They SINGLE FLOWERING VARIETIES-The following colors: white, pink,scarlet,crimson and yellow started plants, $25 \mathrm{c}$ each in pots. DOUBLE FLOWERING VARIETIES--In the same colors as the single varieties; already grown in pots. (see cut.) $40 \mathrm{c}$ each.

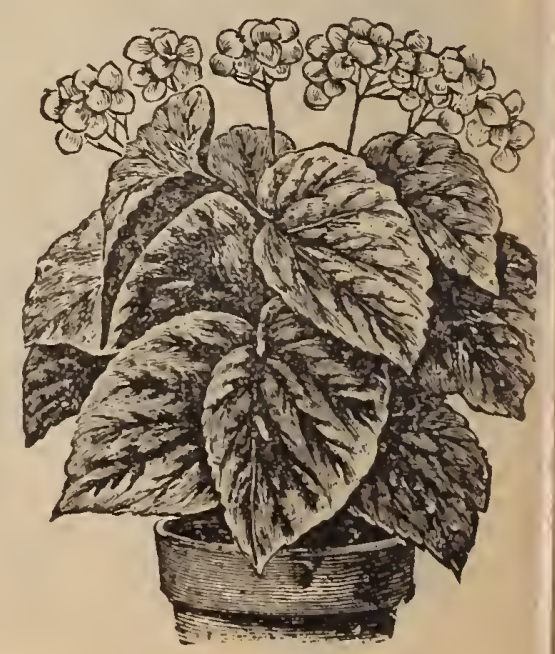

Begonia, Thurstoni. 


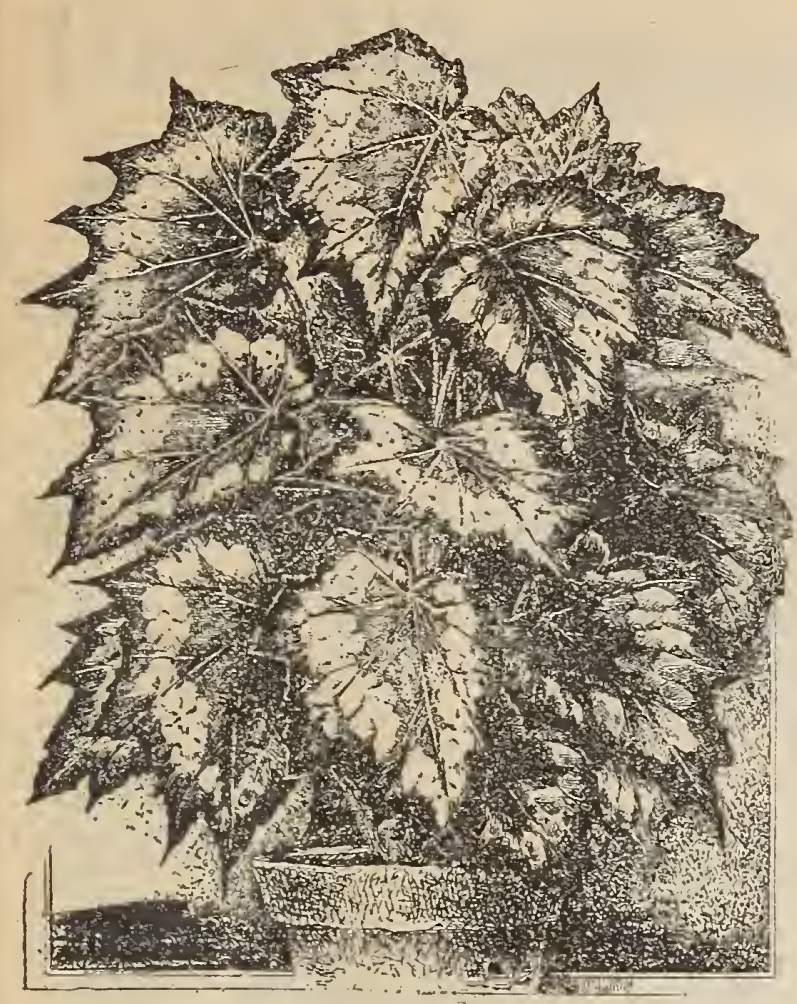

Begonia-Ed. Kennedy.

\section{BEGONIA REX.}

\section{(or Ornamental I,eaf.)}

BERTHA MCGREGOR-The center of leaf is datk, the body of leaf bein. COUNTESS LOUISE ERDODY-

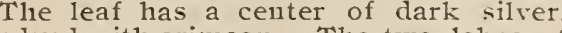
edged with crimson. The two lobes at until in a full-grown leaf; there are four of these curves lying on top of leaf.

EDWARD KENNEDY-The The leaf is very much serrated mith points, a light band and dark cente LOUISE CLOSSON-One of the richfamily. Center of leaf deep bronze with broad band of silvery rose edged bronze. LESONDSII-The markings are well margined with white on a greenish brown. QUEEN VICTORIA-Bright, s i 1 ye reen, of crepe-like texture, with reddish IANICATA AUREA-Laro leaves beautifully blotched with creamy

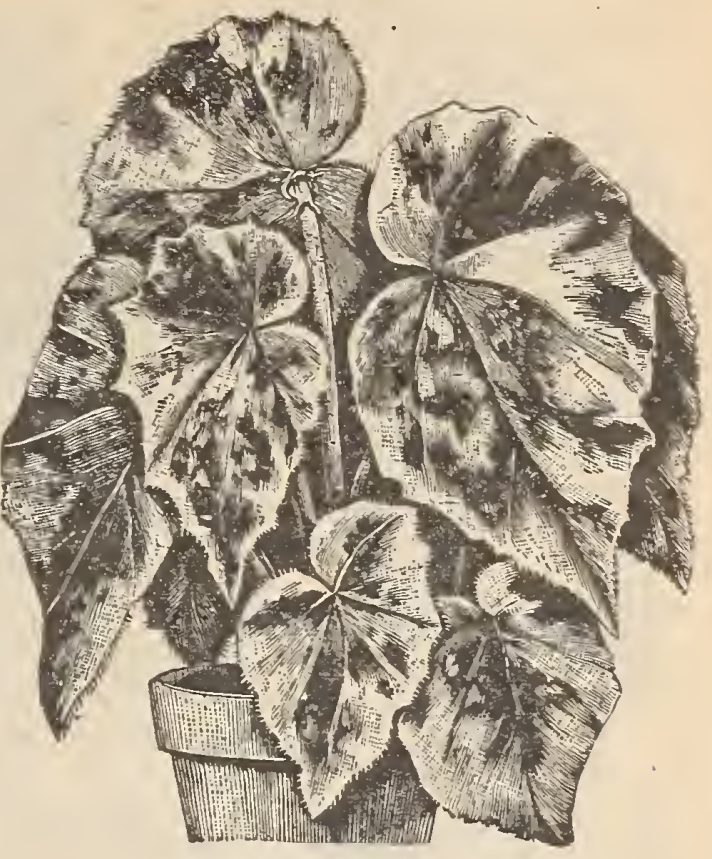

Begonia-Manicata Aurea.

SIIVER FLEECE- Color of leaf, a dark silvery gray, bordered with edge of darker SPECULAT - Leaves are in the form of a grape leaf chocolate: veins of a light pea green; the whole leaf spotted with silver: in bloom it is magnificent. $25 \mathrm{c}$ each.
PERLE HUMPHRE - Color of leaf bronze green, covered with biotches and splashes of silvery white:

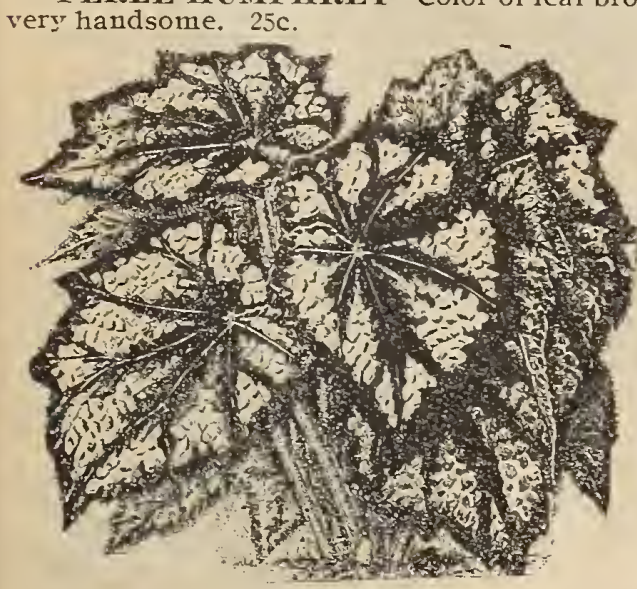

SPECIAL OFFER-The full set of 12 Rex Begonias for $\$ 2.00$.

\section{CALADIUM.}

GIANT-FLOWERED CALADIUM,

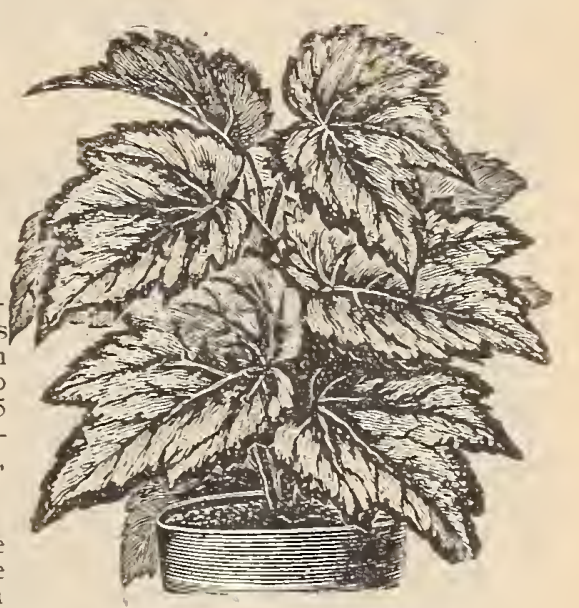
plant on the lawn. The leaves often attain the length of three feet by twenty inches wide, and have a rich. tropical effect. When extra large leaves are ranted, give a liberal supply of water and

Begonia-Iesondsii.

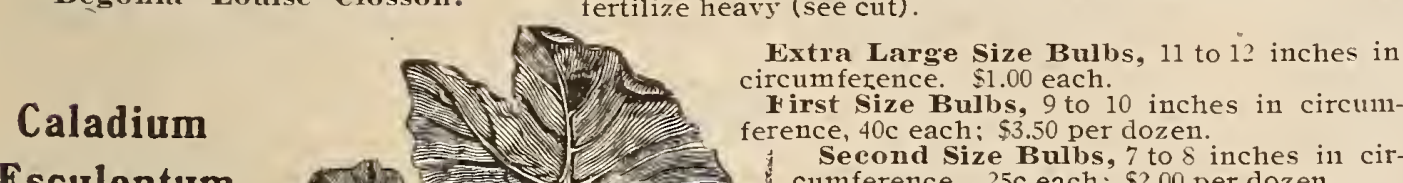

Esculentum.
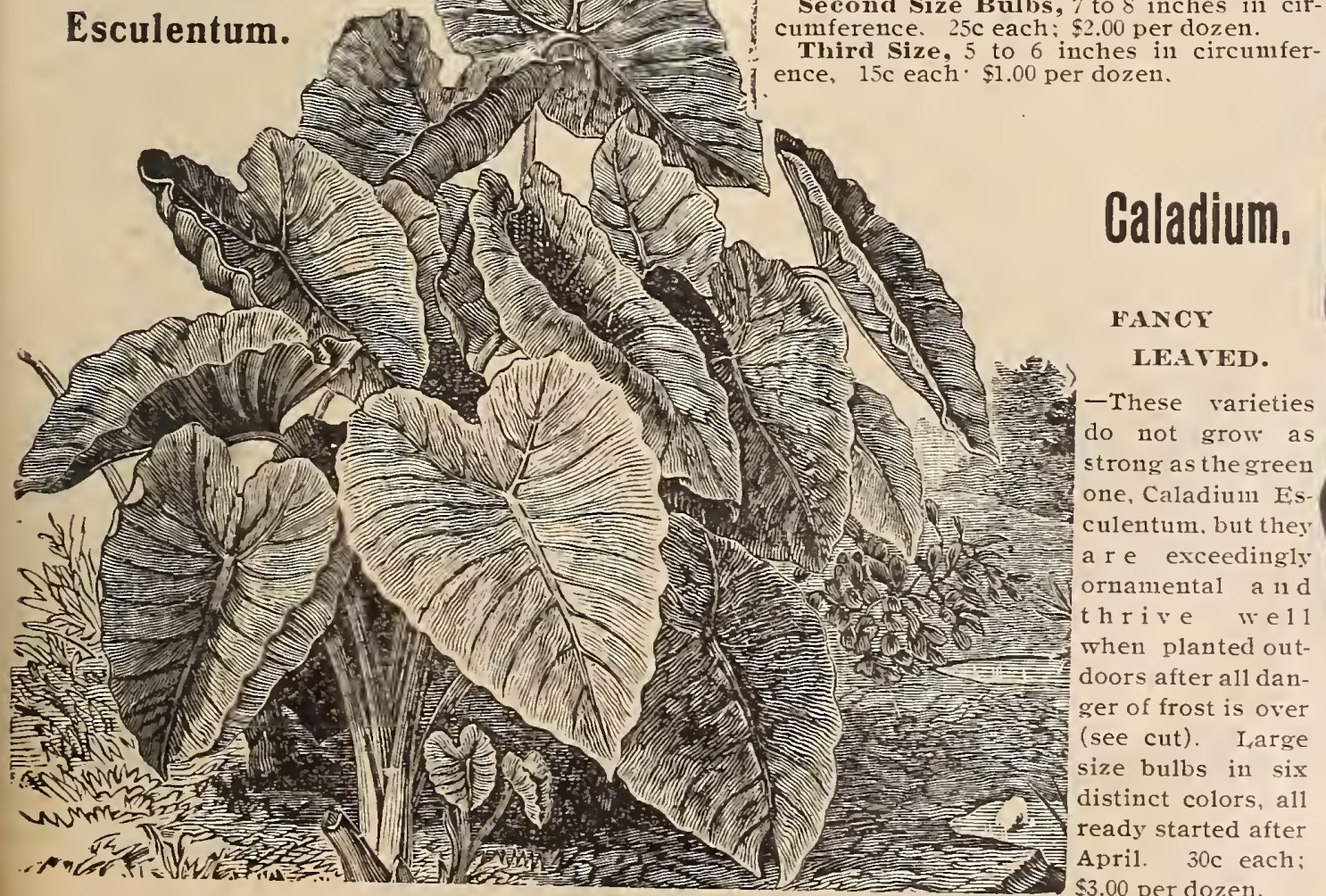

LEATED.

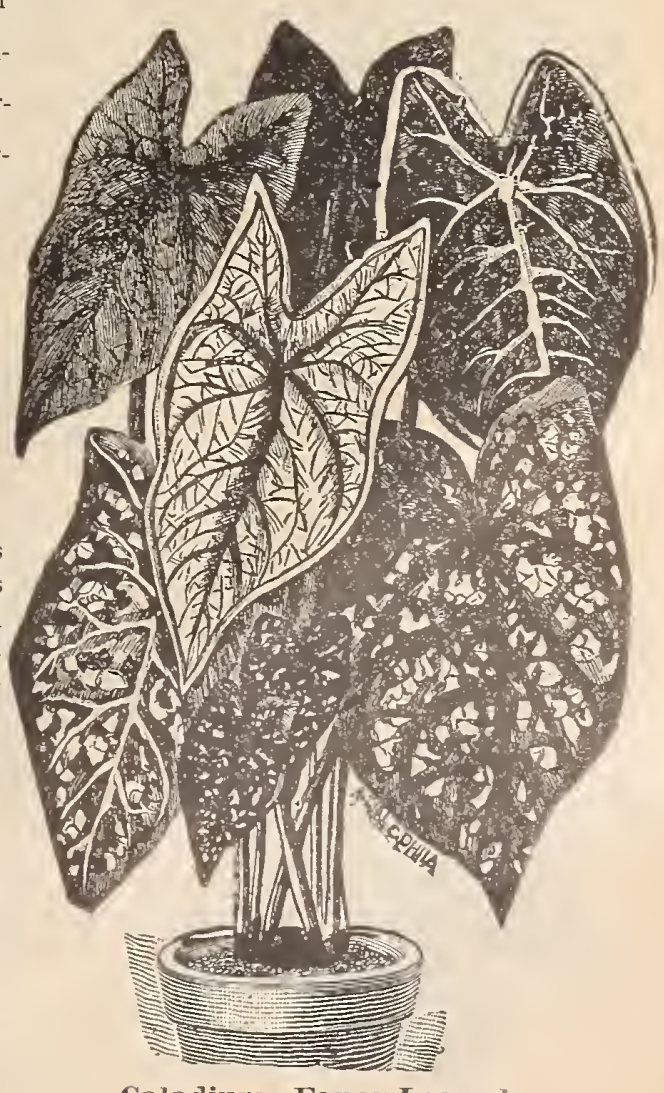

Apris.

Caladium-Fancy Leared. 


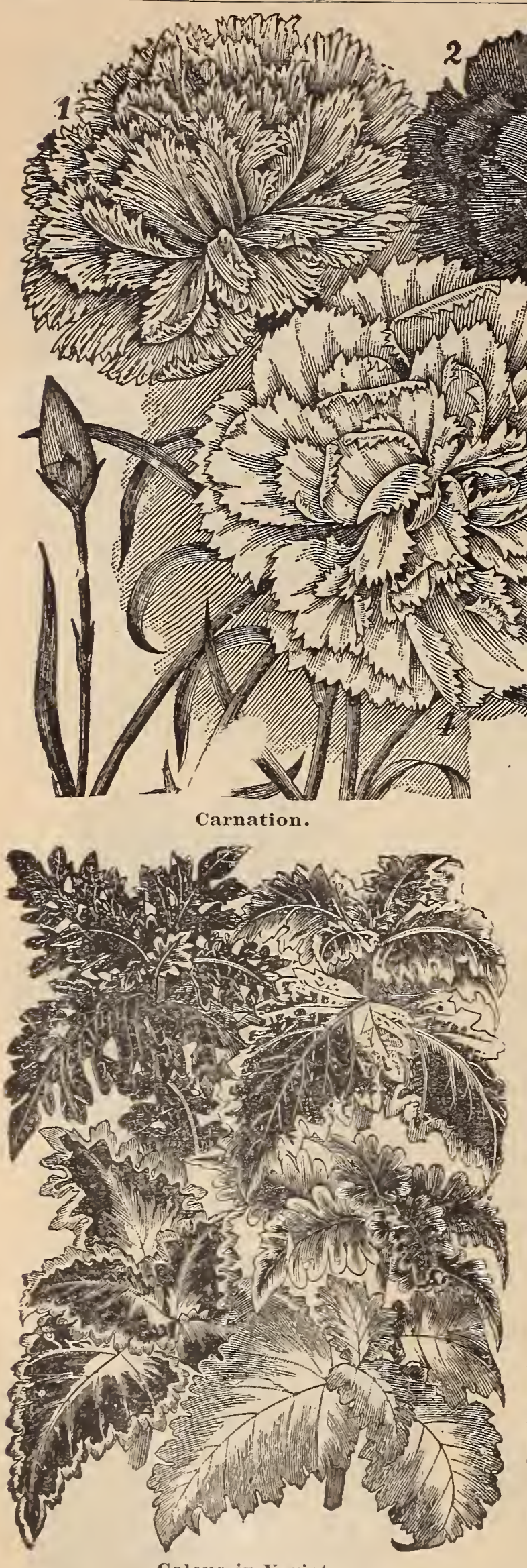

CARNATIONS. YOUNG'S Superb Collection

\section{-OF- PERPETUAL} Flowering Varieties

APOLLO - Color a bright, vivid crimson, large flowers long stiff stem, good grower G. H. CRANE - A large flowering scarlet variety. It comes into flower early and continues throughout the season, producing an average of 3-inch flowers on long stiff

DAIBREAK-Flowers large very full; color, a delicate, pure, bright flesh, with no salmon shadings; a free biooming va-
riety. 10c each. -

FLORA HILL-Color, a pearly white, size $2 \frac{1 / 2}{2}$ to $3 \frac{1}{2}$ inches in diameter. Delightfully grant, flowers borne on good stiff stems $2 / 2$ to $34 / 2$ feet long. 10c each. - Color, a briti:

FRANCIS JOOST-Color a cerise pink, a shade deeper than $\mathrm{Wm}$. Scott, of which it someMELBA-A delicate shade of light pink, very lovely and pleasing to the eve, fiowers aver$2 l_{2}$ to 3 inches in diameter. $10 \mathrm{c}$ each.

WM. SCOTT-Bright pink, size of flowers medium to large on long stiff stems, a very free TRIUMPH-Color, a light pink, flowers shading lighter to the center. Flowers heavily ged, full and well filled in the center, size 3 inches across. 10c each. The color is a deep ce. pink approaching a brilliant carmine, it does not fade early after being cut. $10 \mathrm{c}$ each. PROSPERITY-This is unquestionably the largest carnation of any color ever before ofered, the flowers measuring 4 inches in diameter. The flowers are full and double and have a delightul clove fragrance. The color is a pure white ground. overlaid with shadings of soft ink, reminding one of the beautiful tints seen in Azaleas snd Rhododendrons. $10 \mathrm{c}$ each.

GOVERYOR ROOSEVELT-A brilliant scarlet, heavily shaded with maroon; flowers 3 oldiug the flowers

QUEEN LOUISE-Color a pure white; flowers very large and of a good substance; stems ESTELLA-The ideal Scarlet Carnation, for it blooms freely, producing an abundance of bright scarlet flowers. Very strong clove fragrance; form excellent: stem strong and stiff:
fowers 3 to $3 y_{9}$ inches in diameter. Price, 10c each.

\section{SPECLAL OFFER-The full set of 14 varieties for $\$ 1.00$.}

\section{COLEUS.}

A very useful foliage plant, growing vigorously out of doors the entire summer. No other foliage plant can for a moment bear comparison with them, so vivid are the colors. The 作

FOREST PARK BEAUTY-The leaves are much larger and broader than the old varieties and more compact. Color is a bright pink shaded with deep maroon with golden yellow the of the leaf, with a green border on the edge; stands the dry weather when planted out ors in a border, also handsome wheu grown in separate specimens. 15c each; $\$ 1.50$ per doz. FLAMBO-Dazzling carmine rimmed with velvety maroon. $10 \mathrm{c}$ each. ILLUMIN ATION-Narrow lacerated leaves, yellow bordered with greeu. 10c eacli. MISS RETTA KIRKPATRICK-Large white, center shaded with yellow, 10c each.
MANOLE HAZARD-Brilliaut red. The richest and brightest colored variety yet in.

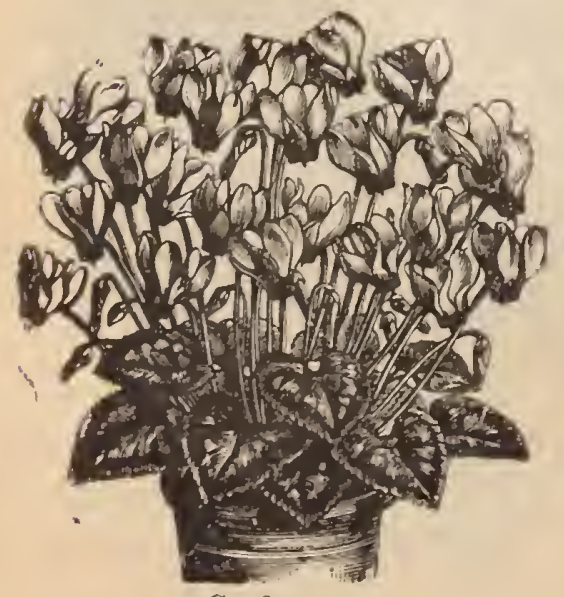

1IRS

1I. Iris-Curiously blotched a nd spotted with maroou, red, yellow and green, $10 \mathrm{c}$ each.

YEGRANS-Beautiful velvety maroon. 10c eacli.

MRS. F. SANDERS-A distinct variety. Crea ay white ceuter, eveuly bordered, greeu blotclied, crin1SHTTING SIN=Rich brouze-crimson, bright goldell edge. $10 \mathrm{c} \mathrm{each}$

SOTV. GURNSEY - A very charming combiuation of bright crimsol, deep maroon and clear yellow. 10c SOUTH PARK BEAUTY-Bright golden yellow, excellent bedder. 10c each.

SENIRISE-Golden yellow and maroon, $10 \mathrm{c}$ each.
VERSCHAF FELTI-Rich velvety criuson, the best of all for bedding. 10c eacli.

SI'ECIAL OFFER-The full set of 15 varieties for 900 . Any of the above varieties, except For. est Park Beauty and Souv. Gurnsey, per 100, $\$ 5.00$.

\section{CYCLAMEN, PERSICUM GIGANTEUM.}

These are very strong plants and arein bloom from January until May, making a very handsome plant for vindow decoration or conservatory. They require a liberal supply of water wheu iu bloom. In three disPlants from 4 iucli pots, $50 \mathrm{c}$ eacli; 5 inch pots, $75 \mathrm{c}$ each; 61 ucli pots, $\$ 1.00$ each. 


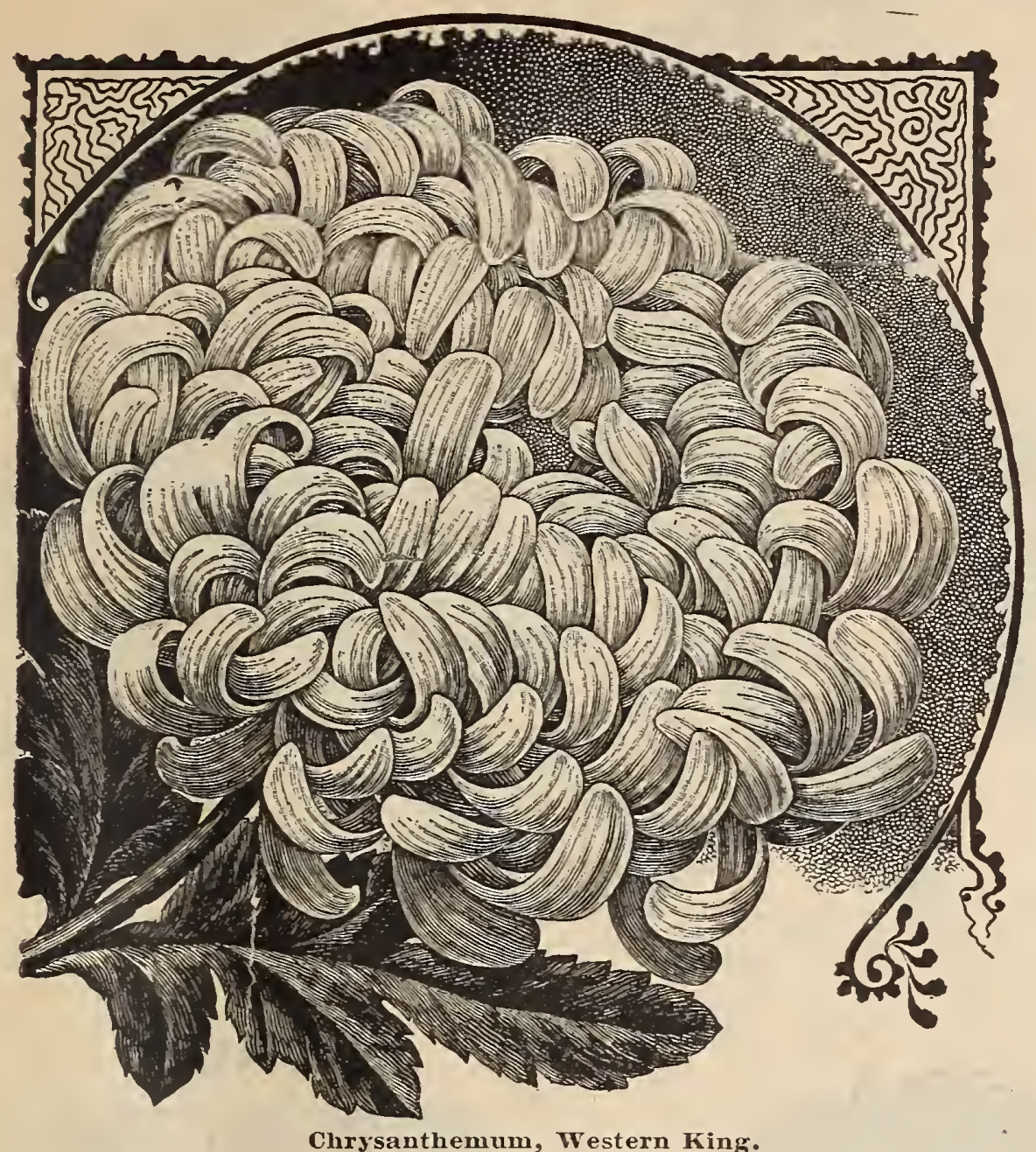

\section{CHRYSANTHEMUMS.}

ST. LOUIS PRIZE SET.

\section{All Large Flowering Varieties and} Prize Winners

TIMOTH EATON-This is the largest globular Japanese incurved Chrysanthemum raised up to the present time fowers are round and perfect in shape, stems very stiff with often measure 9 inches across. $15 \mathrm{c}$ each.

COL. D. APPLETON-A magnificent yellow variety of immense size, the flowers are of the large globular Japanese incurved variety, color a clear bright yellow of great depth and solid, not showng any center; specimen fowers often measre 8 inches across. $15 \mathrm{c}$ each.

VIVIAN MOREL-An exceedingly large variety of the Japanese type, color a deep pink with lighter shades in the

THE QUEEN-The largest white chrrsanthemum, a vigorous grower and has such strength of stem that it carries its (lowers erect. $15 \mathrm{c}$ each.

H. L. SUNDERBRUCH-One of the very finest exhibition yellows; size enormous but not at all coarse, fine habit and free grower. 150 ent

IANARIVA-Reflex form, color a delicate blush with a lighter shade in center, making a very striking and artistic flower, grand variety for exhibition; specimen flowers measure inches across. $15 \mathrm{c}$ each.

GOLD MINE-A magnificent sort bearing all large perfect flowers, color a clear golden yellow, stems stiff, one of the

INTENSITY - A large reflexed flower, color a bright crimson. Strong, upright growth. It has no equal as a exhibition

WESTERN KING-It is a flrst rate white, notable for its superb form and substance. It is extra large and the petals which are somewhat pointed, incliue to incurve. The growth is of moderate height. (See cut.). 15c each.

TIOLESCENT-An exceedingly enormous large flower with stems strong and stiff, color center petals white, outside petals tinged with violet. A deep well formed flower. $15 \mathrm{c}$ each

SPECIAL OFFER-The full set of 10 varieties for $\$ 1.25$.

\section{CHRYSANTHEMUMS.}

\section{General Collection of the Best Standard Sorts.}

CYRUS H. MC CORMICK-Vigorous grower, bearing massive flowers. Color deep yellow shaded with bronze red. $10 \mathrm{c}$ each.

GEORGE W. CHILDS-The best deep self-colored crimson variety, of immense size without a shade of brown. 10c. each.

GOLDEN HAIR-Fine deep rounded flower of amber yellow, broad, incurving petais. $10 \mathrm{c}$ each.

HELEY BLOOD GOOD-Clear pink, flowers often measuring 7 inches in diameter. $10 \mathrm{c}$ each.

J. SHRIMPTON-Bright crimson, of largest size and perfect form. 10c each.

GLORY OF THE PACIFIC-A magnificent pink: one of the earliest, ready to cut Oct. Sth. Dwarf habit, trong stiff stem and excellent foliage. 10c each.

GOLDEN WEDDING-Flowers of very large size, on stiff, erect stems, petals hoth long and broad, color deep, bright gold, of shining texture. A perfect Japanese of most beautiful form. Each 10c.

MRS. J. PEABODY-Very large pure white: from 8 to 9 inches through and 6 to 7 inches deep, extra fine build and finish. $10 \mathrm{c}$ each.

MERULA-A dwarf Japanese Incurred of a beautiful shade of light pink. Good single stem variety. $10 \mathrm{c}$ each. PRES. WM. R. SMITH-Color a beautiful clear flesh pink, very heavy in substance, on stiff stems; the form of the flower is very beautiful in all its stages. 10c each.

MAUD DEAN-Splendid shade of pink, almost rose. Distinct and valuable variety. $10 \mathrm{c}$ each.

MODESTO-This is of the finest yellow. It is intense in color, unsurpassed in size. 10c each.

MRS. PERRIN-The flower is of incurving form, full and with finish as fine as satin. Color rose pink, $10 \mathrm{c}$ each.

MRS. HENRY ROBINSON-A perfect form of exceptional merit, large and well-finished. An early, white, blooming with us Oct. 5th, fine substance and rery lasting. 10c each.

PINK IVORT-It is identical with Irory in every respect except color, which is a beautiful shell pink. 10c each.

PITCHER \& MANDA-The outer petals are pure white, center is a bright deep yellow, the two colors being

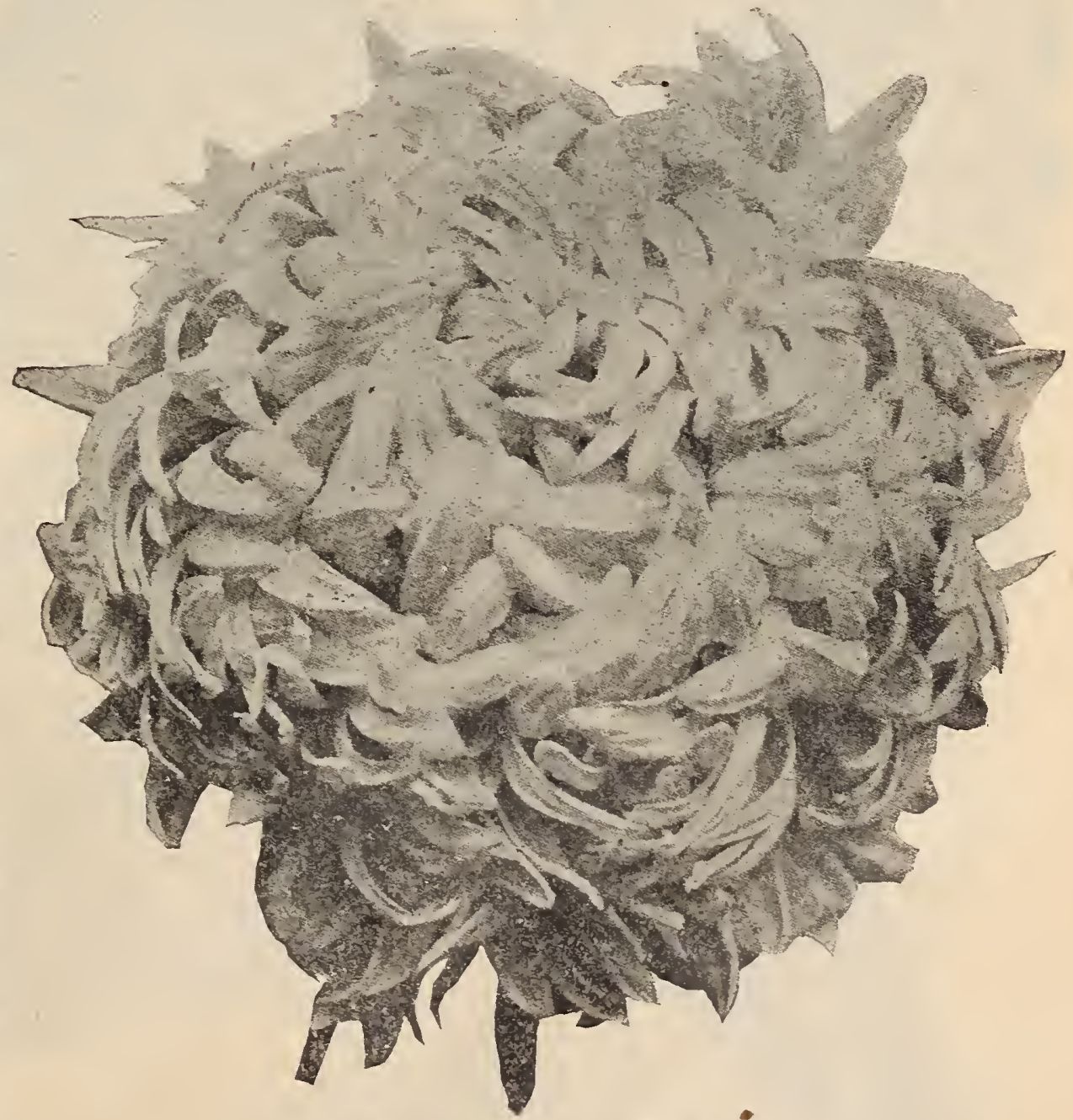

Chrysanthemum, Jerome Jones.

W. H. RIEMAN-Color a rich golden yellow, flowers very large, 10 to 12 inches in diameter. $10 \mathrm{ceach}$.

ROBERT M. GRA - A terra cotta color, petals covered with a very dense hairy growth. 10c each.

SUPERBA-Japanese incurved, color bright pink, a tine variety. 10c each.

WM. H. LINCOLN-Grand flowers, immense size, very double and full, beautiful incurved form; color clear chrome yellow, reverse of petals fine cauary. Each. $10 \mathrm{c}$. 


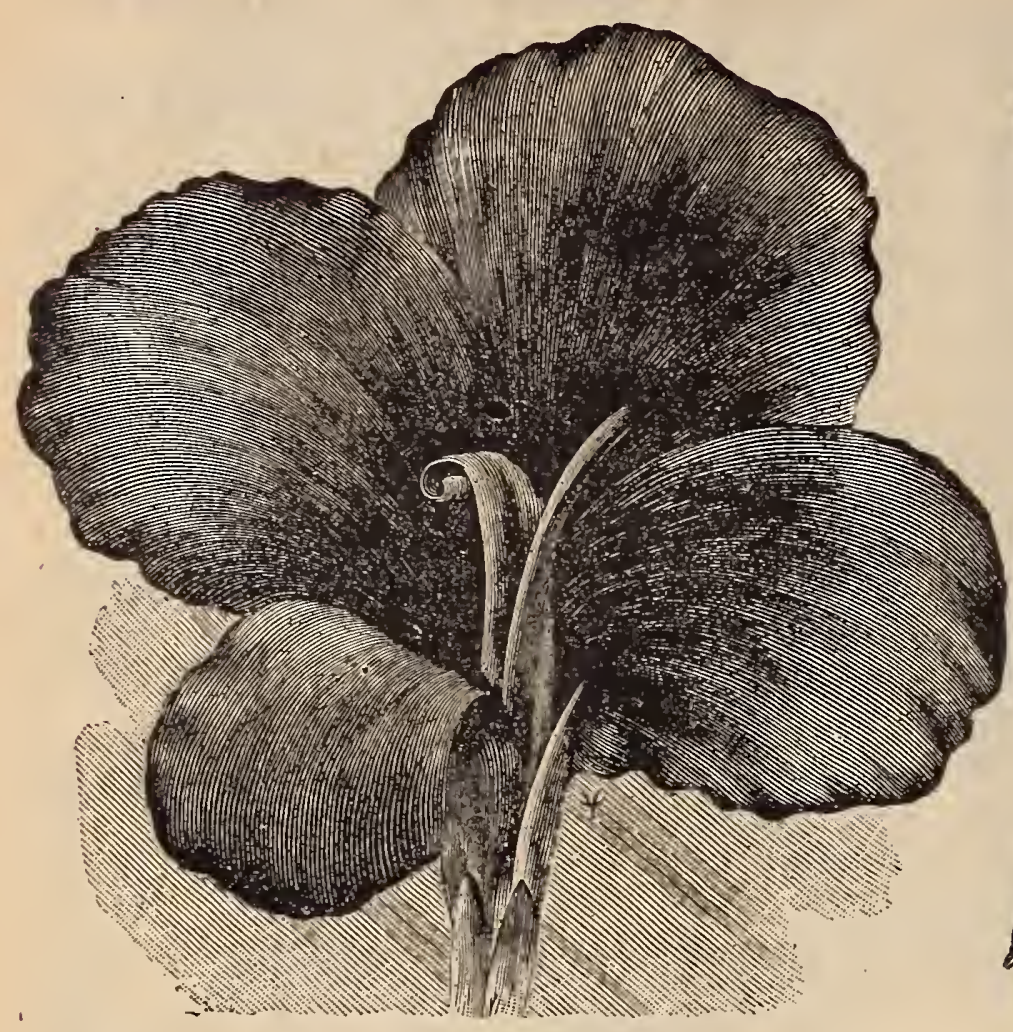

Canna Black Prince.

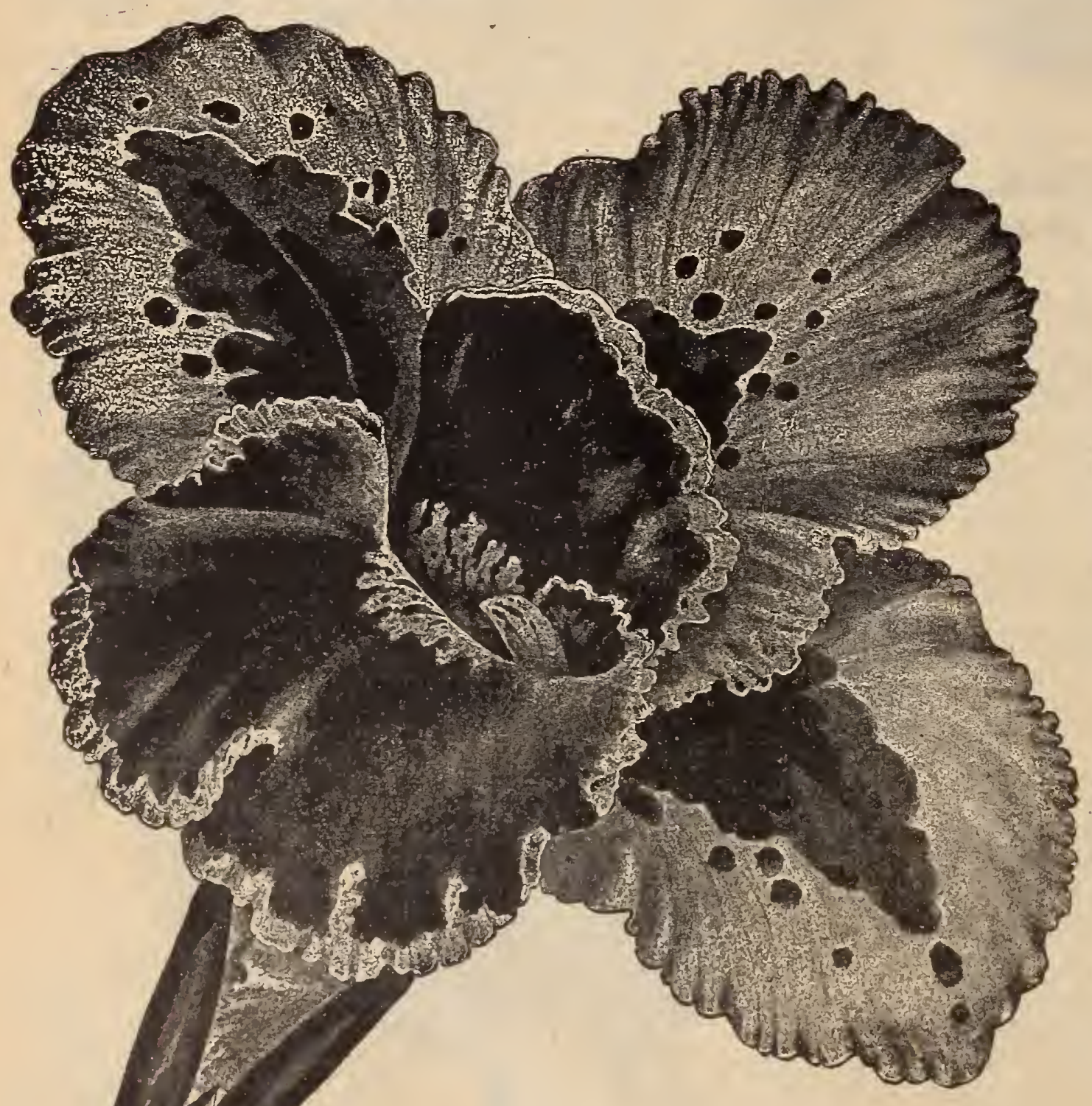

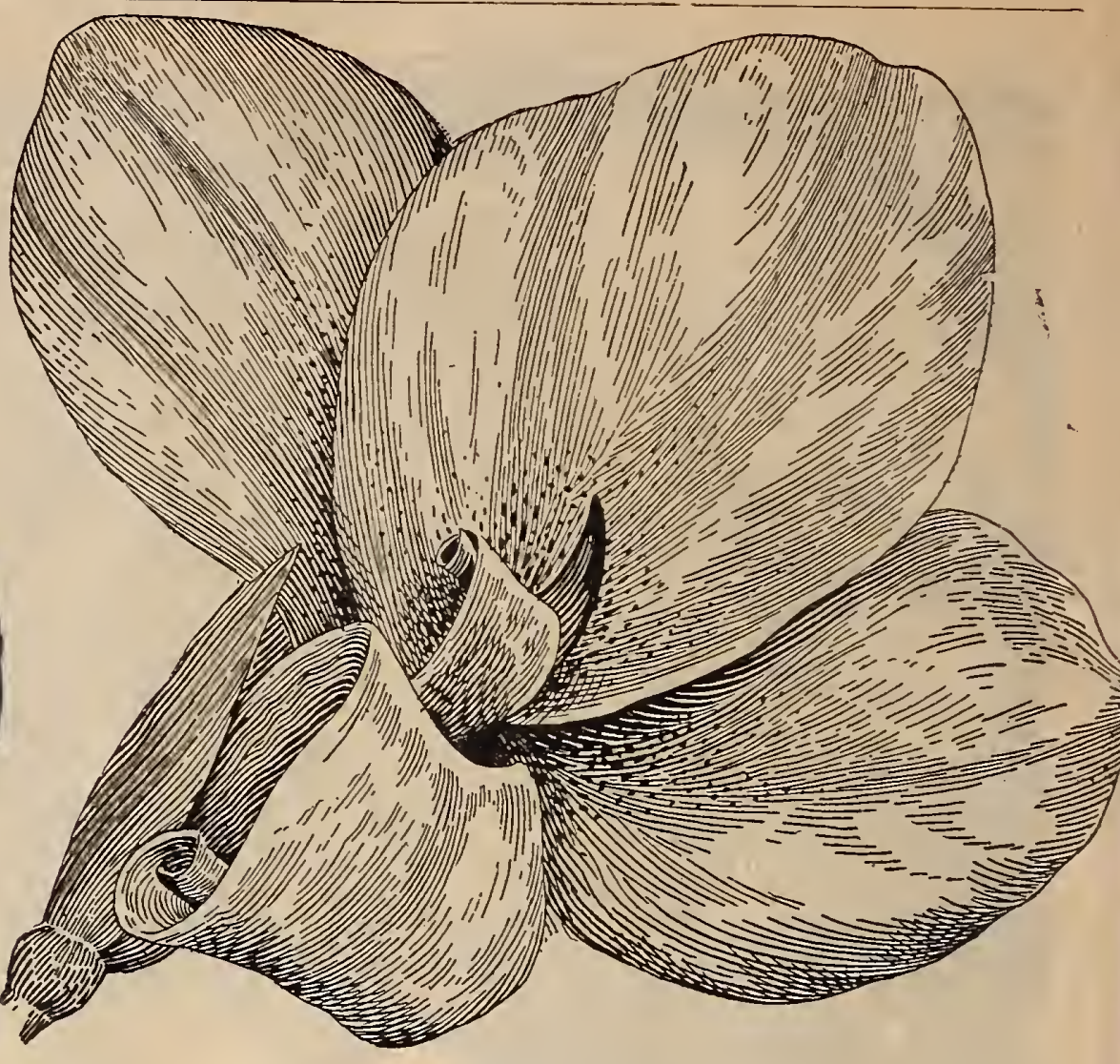

Canna Burbank.

\section{SUPERB COLLECTION}

-OF-

\section{ORCHID FLOWERING CAAHAS}

Selected as the very best varieties that are grown. They are all vigorous growers, and height 414 feet.

BURBANK-Orchid flowered. The flowers are truly gigantic in size, the upper petals spreading fully seven inches, and the form is really semi-double. Toward the inner part the petals show fine crimson spots; all the rest of the flower is a most beautiful rich canary yellow. Very strong grower, witli leaves having a texture like rubber. (See cut). $20 \mathrm{c}$ each.

BLACK PRINCE-This is the largest dark red Canua in cultiration; color, iutense dark velvety crimson, almost black. Flowers frequently six inches across, bolc erect growth three to four fee fade or burn under the hottest sun. (See cut).

CONQUERER-This is best of the orchid fowering varieties. The color is a rich orange carlet spotted bright maroon, and beantifuly dged golden. The petals are three inclies long ind two inches broad, very thick and durable; he fowers do not burn or fade easily in the hot sun. 20c eacli.

MRS. KATF GRAY - A large o r c h i d Flowered Canna. The indwidual flowers are round and full, of a clear wine color beautifully suffused with gold, stand the hot simmmer without burning; a very free bloomer, very showy and attractive; it is a stron

PWVNSYIV A I A very large deep scarPeNNSYL rinislet forrered Camina, seven to eight inclies broad borne on splendid branching spikes: color , borne on splendid branching spikes $25 \mathrm{c}$ each.

Canna, Sam Trelease Improved.

SAM TRELEASE MMPROVED-The flower opens out flat; with its very broad petals, which are of good substance, makes a nearly perfect circular flower; the color is rich glowing crimson; the edges and the center are marked ient height to show them to the best advantage. (See cut). $25 \mathrm{c}$ eacll. 


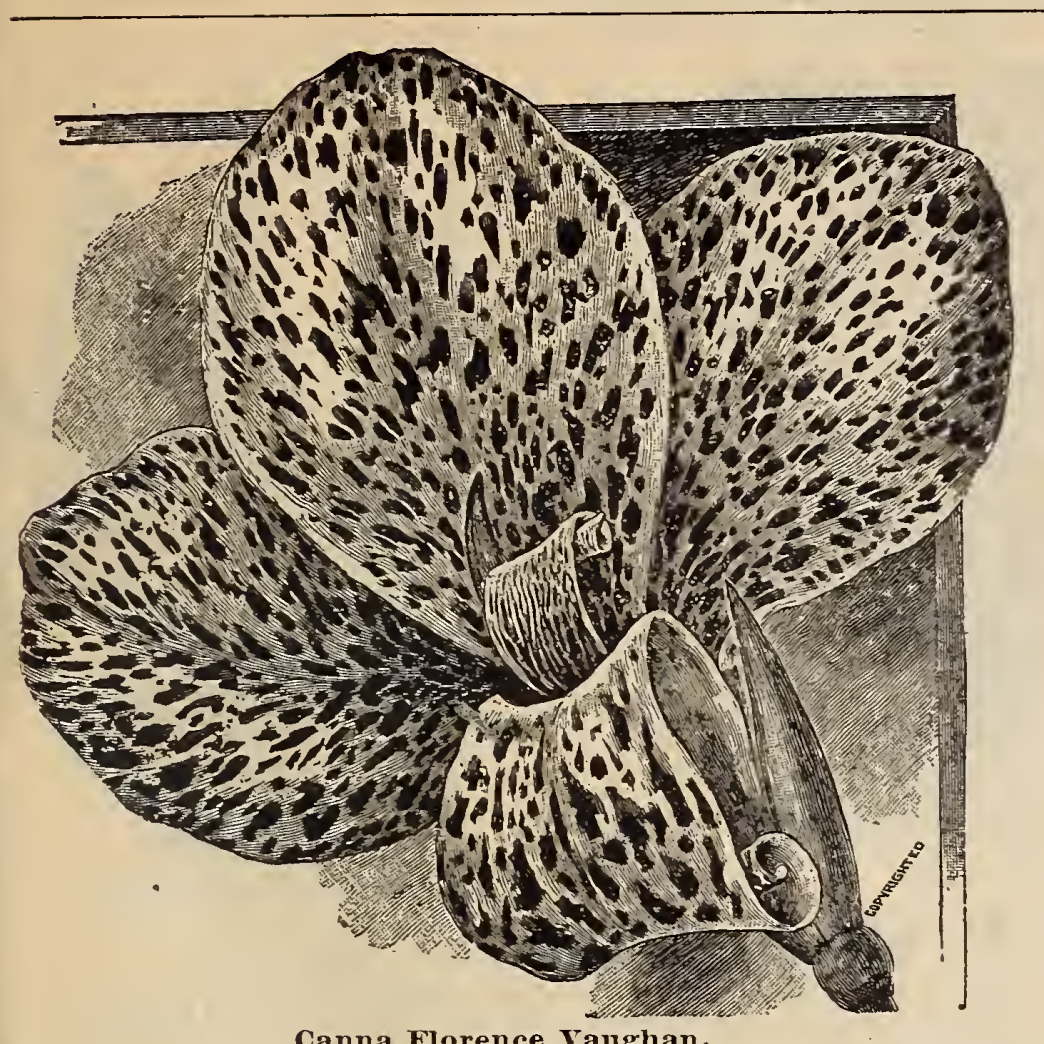

Canna Florence Vaughan.

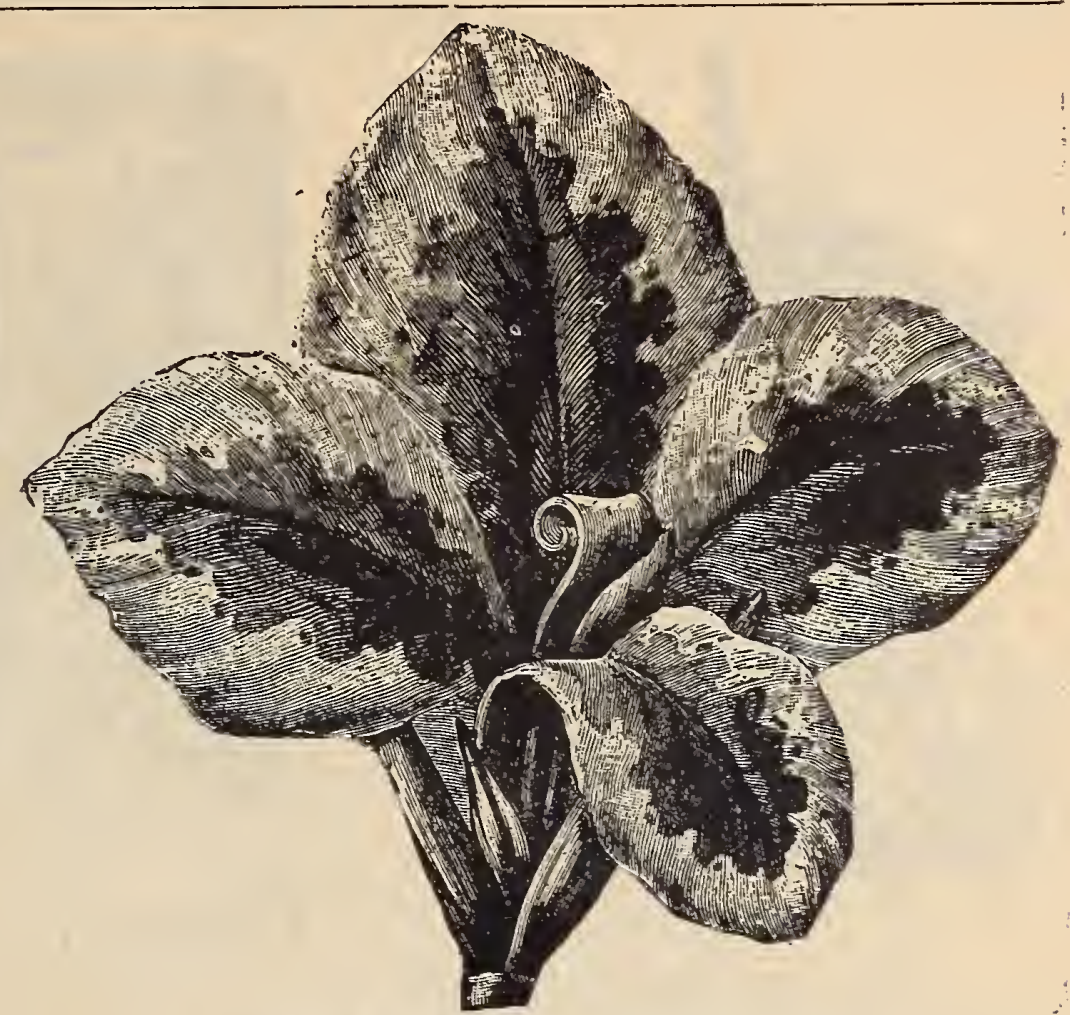

Madame Souvenir D'Antoine Crozy.

\section{YOUNG'S}

\section{GENERAL COLLECTION OF EVERBLOOMINC CANNAS.}

PAUL MARQUANT-The individual flowers are large and are a peculiar shade of salmon, overlaid slightly with a soft rosy carmine, $15 \mathrm{c}$ each. SOUVENIR DU PRESIDENT CARNOT-Vermillion scarlet, bronze foliage: very large flower. $15 \mathrm{c}$ each.

FLORENCE VAUGHAN-One of the finest yellow spotted varieties. In color it is a bright rich golden yellow, spotted with bright red; the flowers are of the largest size. See cut. $15 \mathrm{c}$ each.

LURAY-A handsome and pleasing deep rosy pink, and no doubt one of the best of its class:

MADAM CROZY-Flowets of dazzling crimson scarlet, bordered with golden yellow; a rich combination of colors, very dwarf in habit, rarely exceeding 4 feet in height. $15 c$ each.

MADAM SOUVENIR D'ANTOINE CROZY-The flowers are large with well rounded petals which are of intense scarlet crimson, rich and dazzling, and are bordered with a broad rich golden yellow border, $15 \mathrm{c}$ each PHILADELPHIA-Both the trusses of bloom and the individual color is the clearest shade of glowing crimson scarlet. $15 \mathrm{c}$ each.

\section{CANNAS}

\section{WITH DARK RED FOLIAGE.}

BRONZE SEEDLING-A beatiful foliage variety, color a clear shining bronze, flowers medium size, of a bright crimson color; robust grower, standing the heat of summer well. 20c each : $\$ 1.50$ per dozetr.

BLACK BEAUTY-This is the handsomest foliage Canna ever introduced. The leaves are of the richest bronze purple color, shaded with black, the edges of the leares bearing a peculiar wavy margin; where foliage effect is desired, nothing richer or more handsome can be found, 20c each; $\$ I .50$ per dozen.

\section{THE QUANTITY OF CANNAS USUALLY REQUIRED TO PLANT A BED.}

Many of our customers write us in regard to the number of Cannas that it requires to fill a bed of certain dimensions. In answer to this question we offer the following suggestions:

Plant Cannas about 18 inches apart each way; the tall varieties for the center of bed, and the dwarf growers for the border.

For a round bed $\boldsymbol{\gamma}$ feet in diametcr it will take 19 plants, 10 feet 37 plants, 13 feet 61 plants.
ASIA-The flowers are of large size, open out well and are produced rery freely. The ground color is a rich, bright yellow, with stripes an dashes of bright

CHARLES HENDERSON-A grand variety of a fine crimson color Its habit of growth is very compact. rarely exceeding $34_{2}$ feet in height which makes it desirable for bedding. Price, $15 \mathrm{c}$

CHICAGO-Brilliant orange scarlet, an exceedingly free bloomer and a strong grower. $15 \mathrm{c}$ each.

DUKE OF MARLBOROUGH-The flosers are a deep, rich crimson maroon, with velvety appearance and good substance, the almost black uds and rery close head giving it a still darker look. $15 \mathrm{c}$ each.

DAVID HARUM-Dark bronze foliage, strong grower and one of the freest blooming Canna. Flowers are of large size, color a bright vermilion spotted. $15 \mathrm{c} \mathrm{each}$

SPECIAL OFFER-The full collection of 12 varieties for $\$ 1.50$. DRY ROOTS-In a dormant state until May 1st; only in colors red, yellow, pink and spotted yellow. 10e each, \$1.00 per dozen.

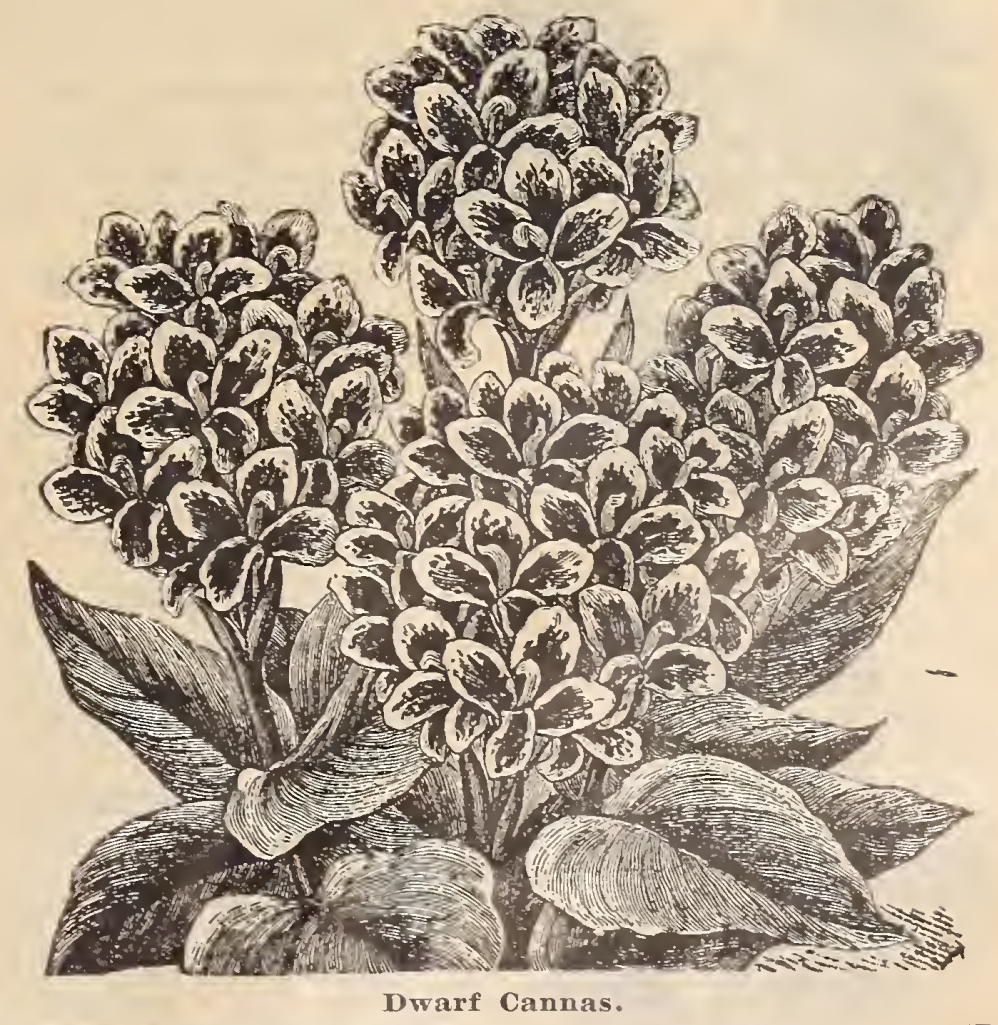




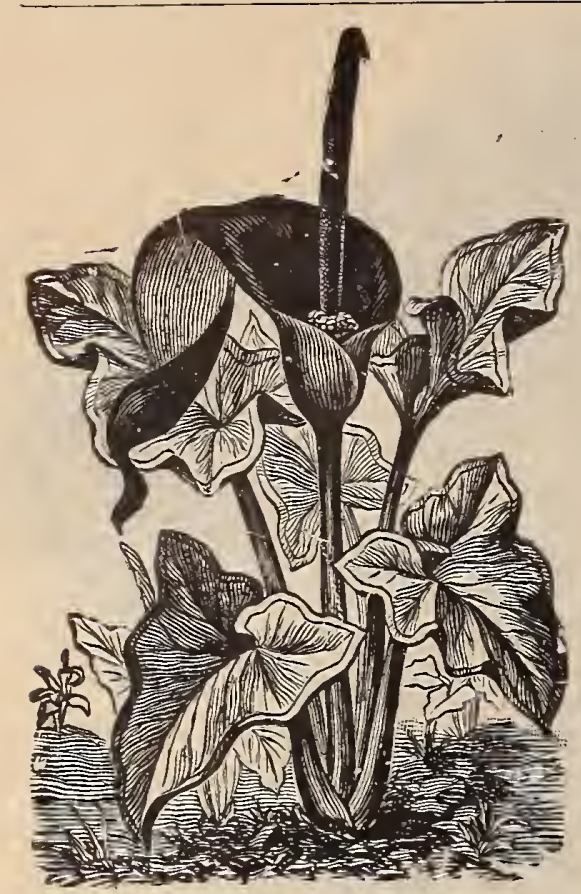

Black Calla Lily.

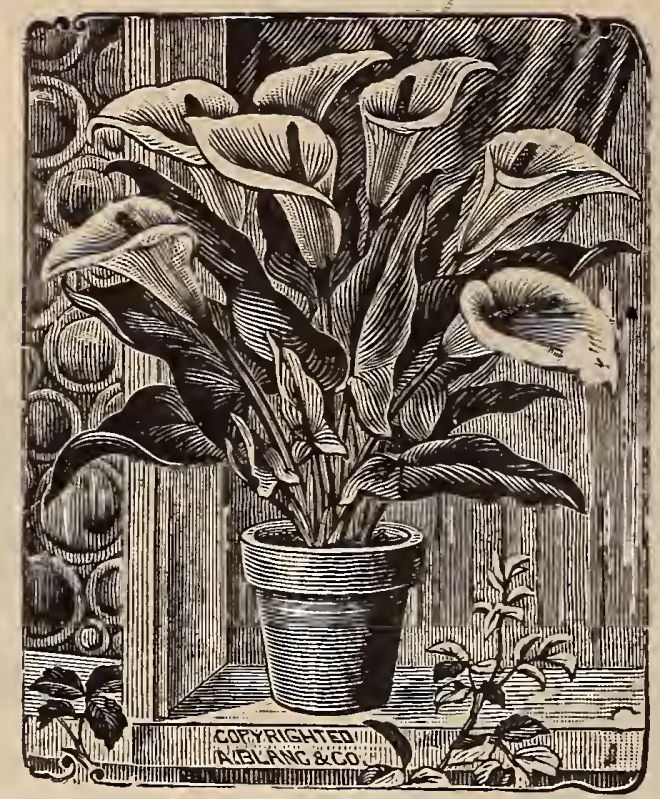

White Calla Lily.

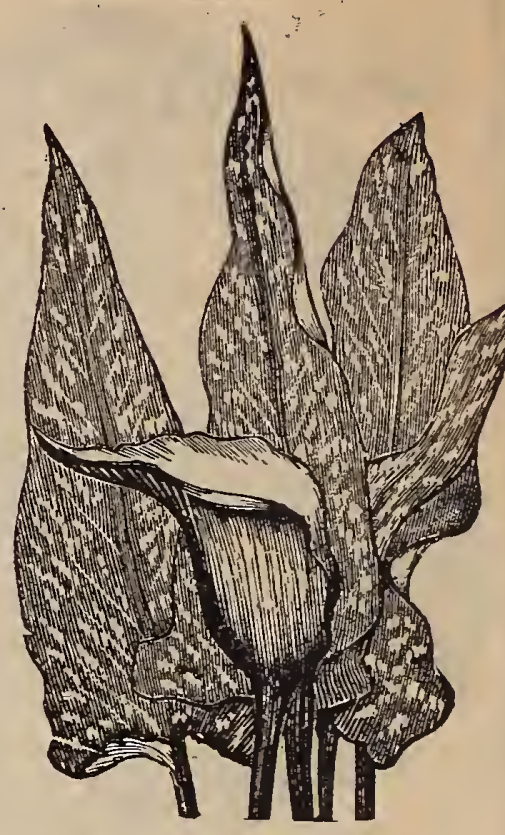

Spotted Calla Lidy.

WHITE CALLA, OR LILY OF THE NILE-An old favorite plant, which should be found in every collection. It grows freely and produces large, pure white blossoms during the winter and spring. (See cut). They require a very rich soil and should always be watered when they

SPO The dark green leaves being beautifully spotted with white; in other respects the plant is the same as the old favorite white Calla, except being of smaller habit. It flowers abund-

antly in the garden during the summer months. (See cut). Started piants, 25e each. culture. (See cut). Started plants, 25c each. SPECIAL OFFER-The full set of Three Callas for 60c.

\section{DAHLIAS.}

MPROVED DOUBLE FLOWERING VARIETIES-These are the most beautiful and attractive of all the summer and autumn flowers. Field grown roots in the following colors separate-Bright Red, Pure White, Pure Yellow, Striped, Violet, Purple- $\$ 2.00$ per dozen. Dry Roots, $20 \mathrm{c}$ each; started plants after May 1, 10c each, \$1.00 Per dozen.

\section{FUCHSIA.}

TRILOBA-This is the best of all the double white varieties. It blooms continually all through the summer. Of a very dwarf and compact habit. Price 20c each. bronze color, veined red with a slight tinge of yellow. The flowers are bright purple, with bright red sepal, an attractive variety in foliage and flowers. It is a very free bloomer and strong grower. 20c each.

BLACK PRINCE - Single; large corolla, well expanded; of a reddish rose, tube and sepals waxy carmine. A very distinct variety.

$$
\text { 20c each. }
$$

CHARMING - Entirely distinct from any other variety. The flowers are of an intense, rich carmine (see cut). Price 20c each.

MRS. MARSHALL-White tube and sepais; bright, rosy scarlet corolla; flowers large and bold; free bloomer and grower; single. Price, 20c each.

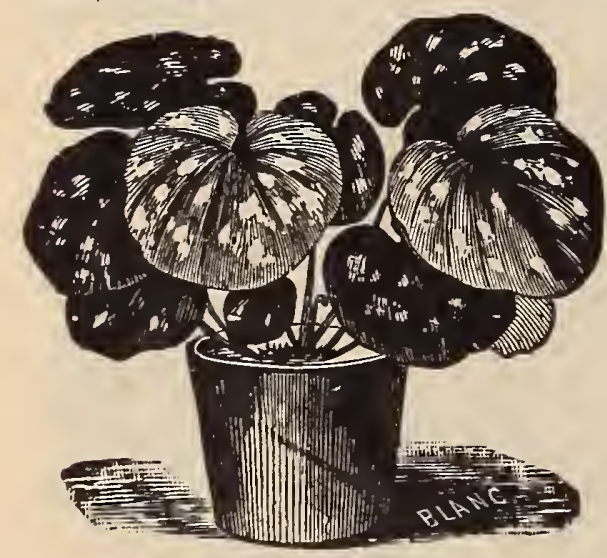

Farfugium Grande.

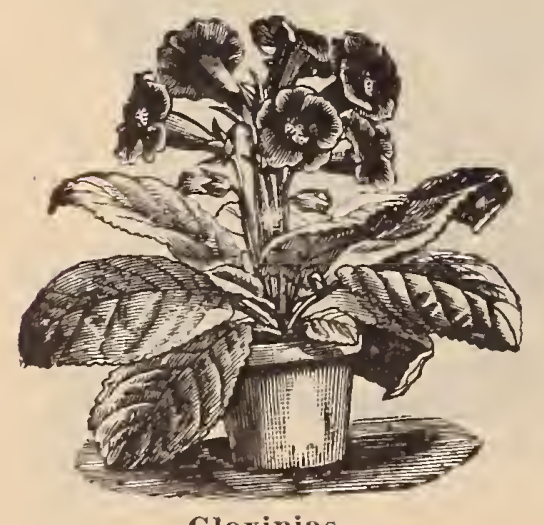

Gloxinias.
ROSAIN'S PATRIE-Fine double, white, tube and sepals rosy carmine,

PHENOMENAL-E $\times \mathrm{tr}$ large, double purple corolla. large, double purple corolla. SPECIAL OFFER - The full set of 7 varieties for $\$ 1.00$.

\section{FARF UGIUM GRANDE.}

A first-class ornamental plant for pots, well adapted for house culture. The leaves are thick and leathery, dark green with yellow spots, an excellent plant for center of hanging basket. Price, 25c

\section{GAZANIA.}

SPLENDENS-A most useful plant for vases, of useful plant yellow flowers ioc each, $\$ 1.00$ per dozen.

\section{GLOXINIAS.}

Charming plants of dwarf habit producing large and splendid blooms in the greatest abundance under the commonest culture. Is pure white with throats of blue, scarlet, rose or crimson, or the tubes are of bright color bulbs. Each 25c; doz. $\$ 2.50$.

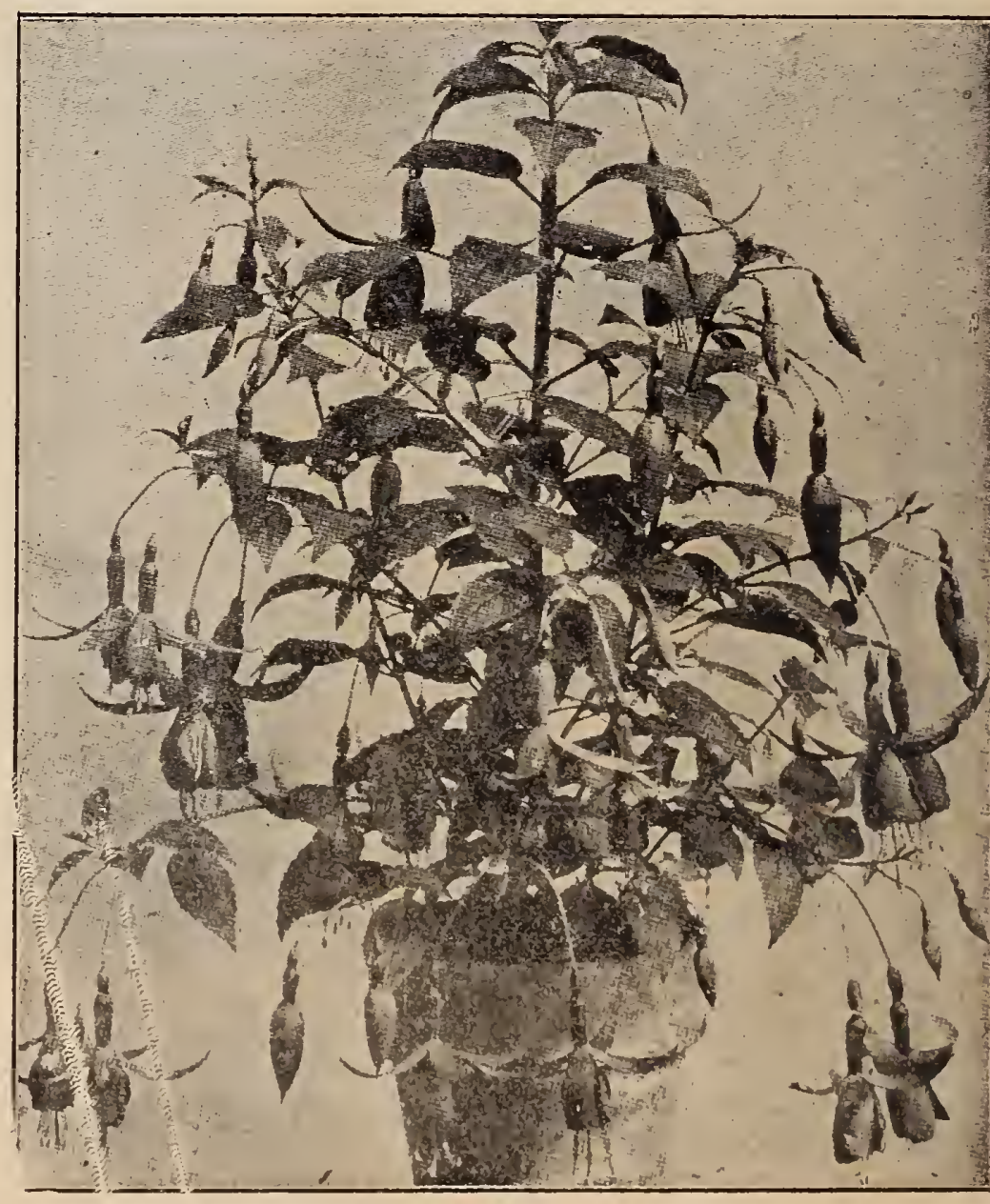

Fuchsia-Charming. 


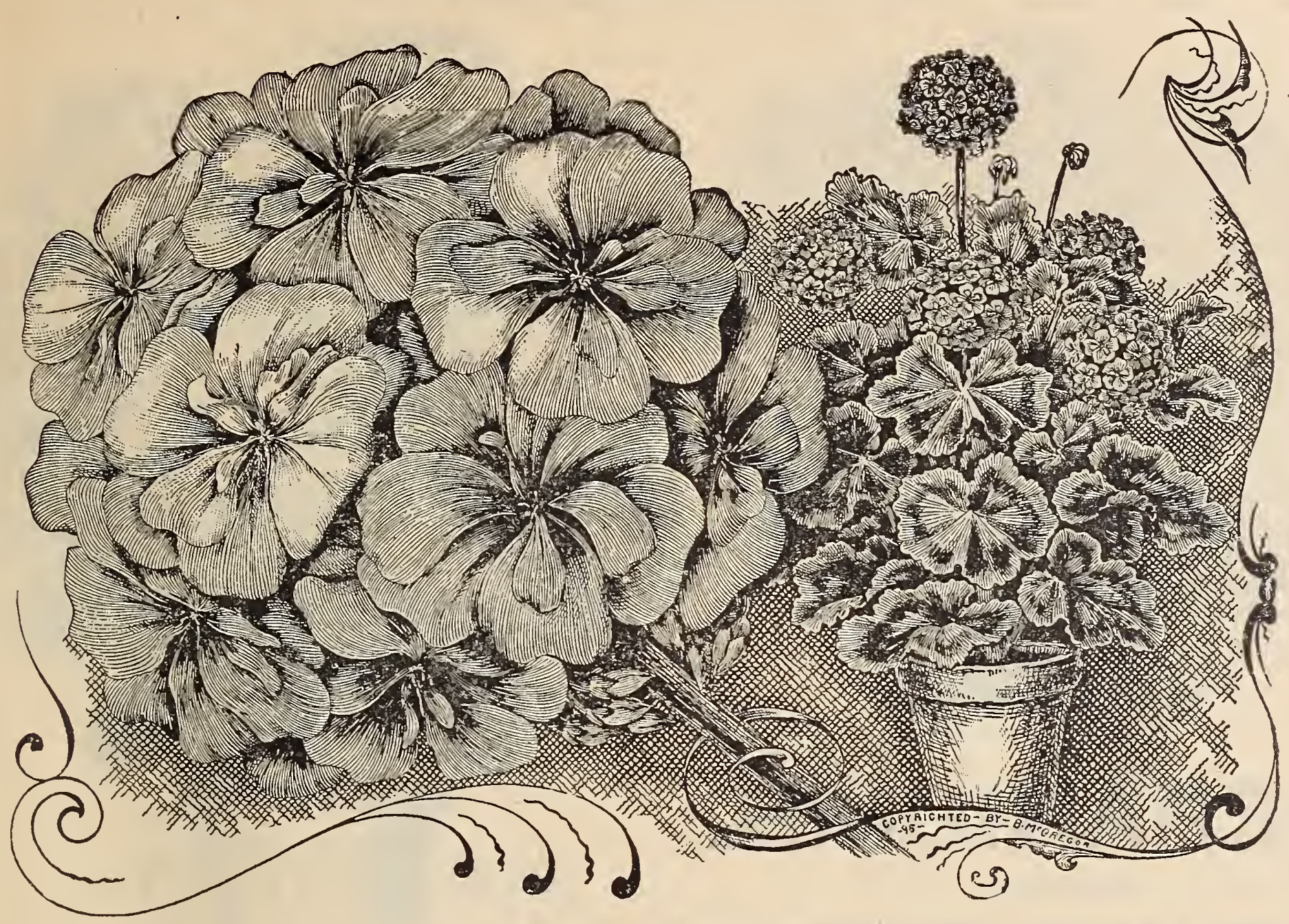

Geraniums-Bruant Type.

\section{Geraniums Sunproof.}

\section{THE TEN BEST VARIETIES}

That were selected from our trial grounds. Last summer we had thousands of stock Geraniums planted in our grounds, and during July and August they were a blaze of glowing scarlet, pink, white, and all the different shades. The universal comment of visitors was: "There is not an inferior sort in the field."

COLUMBIA-A inagnificent new Geranium of an entirely new shade Florets large and round, a beautiful cardinal with a white eye. $15 \mathrm{c}$ each. CAPT. DREYFUS-Color, a bright cherry red; trusses large and thrown high above the foliage by the long strong foot stalks. An exceedingly useful sort for bedding. $15 \mathrm{c}$ each.

MRS. GORDON LINZEE-The floret is of enormous size, perfectly round, the color pure rosy salmon, pink at the center and around the margin. $15 \mathrm{c}$ each.

MRS. CHAS. MOLIN-One of the best single salmon Geraniums for bedding purposes. Color, a clear peachy salmon; florets and truss large. It is literally a mass of bloom throughout the summer season. $15 \mathrm{c}$ each.

MME. LANDRY - Free and constant in bloom throughout the season. The trusses and forets are large; color clear apricot-salmon shading to copper with a white eye. $15 \mathrm{c}$ each.

MIME. J. CIBIEL-Immense round, perfect flower, in enormous trusses; center a bright aurora salnon, with white eye and bordered with broad flesh-white border. A grand distinct and beautiful variety. $15 \mathrm{c}$ each.

ROSA BONHEUR-Flowers on long, rigid stems, forming fine trusses of bright rose color; one of the largest of this type; very effective when planted out doors:

THOS. MEEHAN-Very large trusses; florets semi-double; color, a beautiful brilliant majenta rose. A new color in the type. 15c each.

TEMPEST-A single variety, dazzling orange with yellow shadings. very near approach to the long talked of yellow Geranium. $15 \mathrm{c}$ each.

VILLE DE POITIER-Semi-double Bruant; color, bright vermillion scarlet; large trusses; forets large, sometimes exceeding two inches in

SPECIAL OFFER-The full collection of 10 varieties for $\$ 1.00$.

\section{GERANIUMS.}

\section{TEN GRAND BEDDING VARIETIES.}

ACTEON-A Bruant type raised by Gerbeaux. Color, the most brilliant scarlet; upper petals tinted rosy lilac; semi-double; very fine. $15 \mathrm{c}$ each.

ALICE OF VINCENNES-The ground color is rosy pink, heavily veined and bordered with intense scarlet, center white; a very brilliant combination of colors. Price, $15 \mathrm{c}$ each.

FLEUR DE ROSE-This is a great improvement on Jean Viand, it is deeper in color. The form of flowers is more perfect, and it is of even better habit and makes fine specimens for pots. 15c each.

MRS. E. G. HILL-Single; florets $2 \frac{1}{4} \times 2$ inches. The center of each petal is a soft, light salmon, bordered with rosy salmon and veined deep rose. $15 \mathrm{c}$ each.

M. LOUIS FAGES-A beautiful compact grower; flowers of the largest size; trusses fine; semi-double; clear, bright orange scarlet. Extra fine. $15 \mathrm{c}$ each.

GEN. FITZHUGH LEE-Very large florets of the showiest arrangement of white and crimson; a fine grower, standing the sun well. 15c each

S. A. NUTT-Rich, dark crimson; the flowers are of perfect shape and large size; the trusses massive and produced in great number; close compact habit. $15 \mathrm{c}$ each

PETER BURNET-One of the prettiest varieties on our place. The French pronounce a ravishing color; pure yellowish pink salmon, rery high and clear; the flowers are double and of a beautiful form; a very good grower. Price $15 \mathrm{c}$ each.

TRIUMPHANT-Flowers very large and double; color a bright capicine red; one of the very best of the orange scarlet class, and excellent variety for out-door planting. Price, $15 \mathrm{c}$ each.

VAN DAEL-Bruant type. Center bright, silvery rose, bordered white; single; large trusses, $15 \mathrm{c}$ each.

SPECIAL OFEER-The full set of ten varieties for $\$ 1.00$.

\section{Or the both sets of 20 varieties for $\$ 1.80$.}




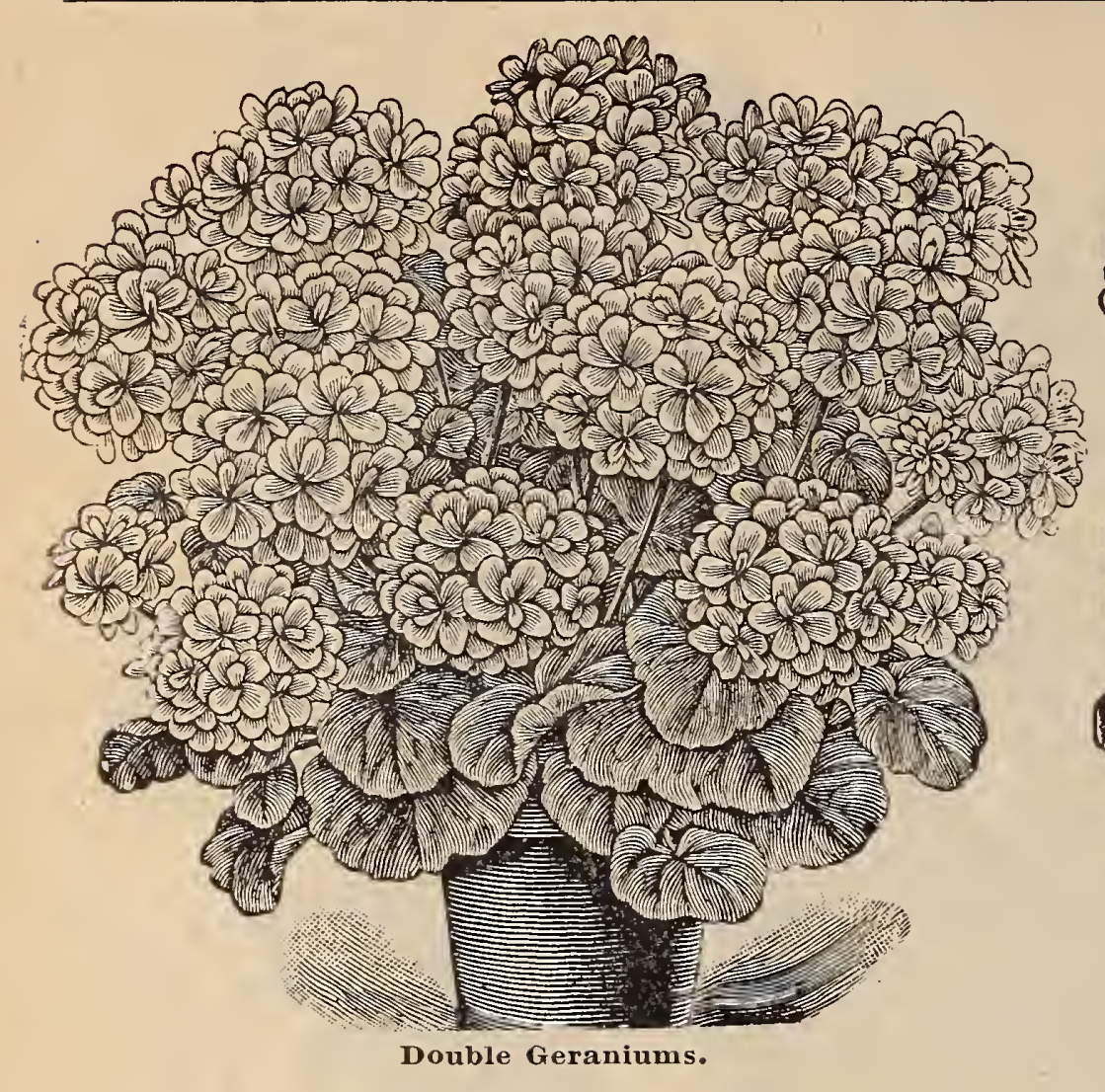

\section{GERANIUMS.}

9 Best Double Flowering
Varieties.

ATTRACTION-Pale blush, shaded with delicate lavender, flowers large, trusses immense. $10 \mathrm{c}$ each.

BISHOP WOOD-A grand variety of the most perfect habit, with numerous trusses of very large carmine-shaded crimson flowers. 10c each.

BERTHA DE PRESILLY-A very robust branching variety, covering the plant continually with bloom. The flowers are large, semidouble, of a bright silvery rose color. Very effective. $10 \mathrm{c}$ each.

JEAN DE LA BRETE-Large camelia-shaped florets, color a rosy carmine shading to scarlet and vermilion, marbled in white at the centre. Very showy variety. 10c each.

LA PILOTE-Among double Geraniums there is nothing finer. The color is a deep scarlet of exquisite shade. The floret is very regular in form more than semi-double and about $2 \frac{1 / 2}{2}$ inches in diameter. 10c. each.

M. REMY MARTIN-Color bright rose with large spherical trusses. $10 \mathrm{c}$ each.

RICHELRU-Fine large trusses of fiery scarlet flowers with shadings of crimson and maroon; dwarf; foliage clean, stands the sun well; distinctly zoned. $10 \mathrm{c}$ each.

SWANLEY DOUBLE WHITE - without seeing it, one would scarcely believe the dwarf growth and free-flowering of this wonderful variety. Dense green leaves throwing up numerous trusses of the purest white at every joint, and continue to do so through the year. $10 \mathrm{c}$ each.

UNCLE JOSH-A magnificent bedding variety; color distinct light solferino, with violet flushings and light red markings on all the petals. 10c each.

SPECIAL OFFER - The full set of 9 Varieties for ' $75 \mathrm{c}$.
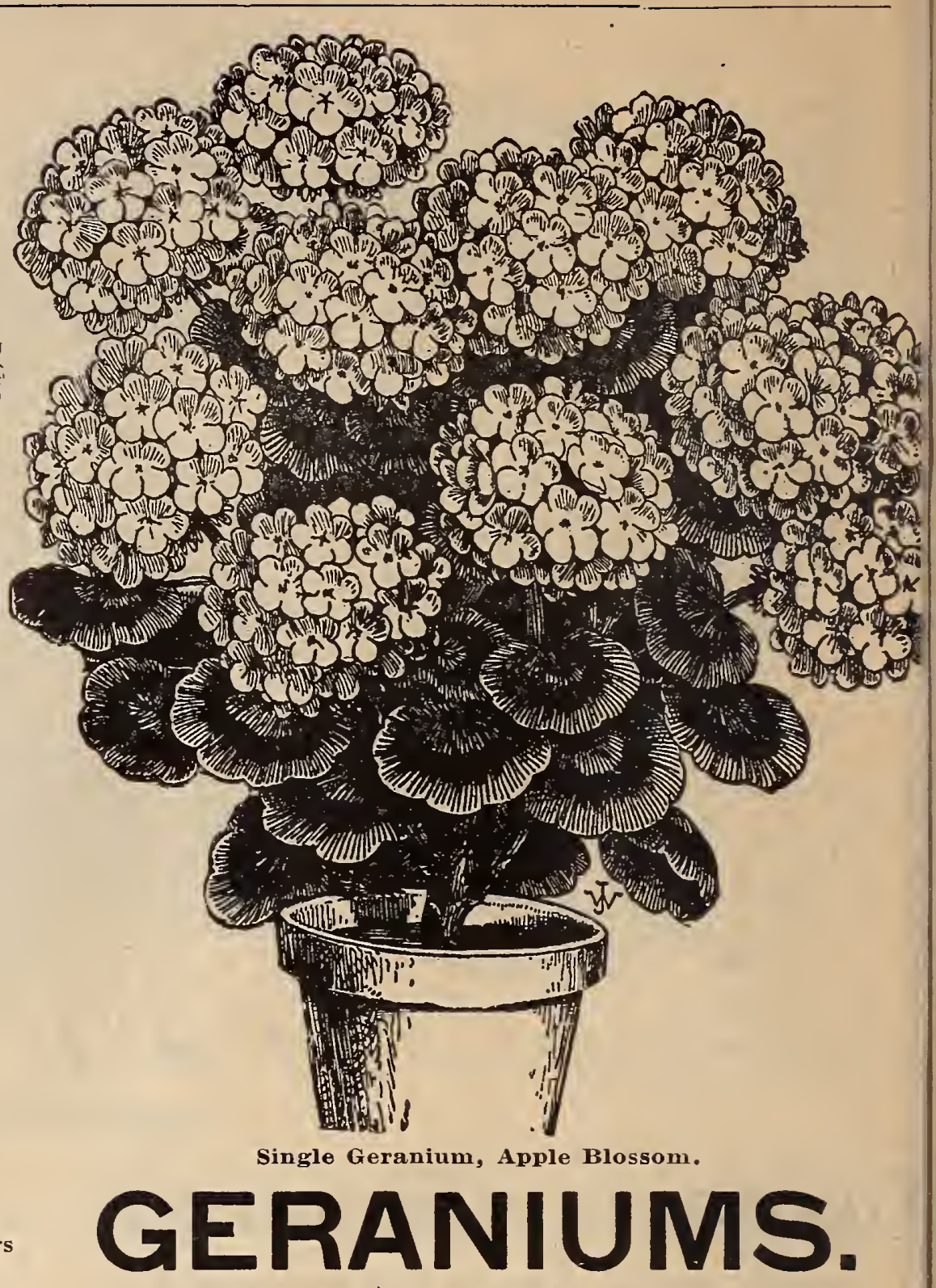

\section{Best Single Flowering Varieties.}

APPLE BLOSSOMS-Trusses of pearly white, shaded with rose pink, resembling a mass of apple blossoms. 10c each.

GLARE OF THE GARDEN-The flowers are borne in enormous trusses, often measuring five to seven inch
most brilliant shade of scarlet. $10 \mathrm{c}$ each.

LILY-White, very slightly tinted with pink; the largest flower of its color in cultivation. 10c each.

LADY BROOKE - Petals lapping and of great substance, quite round. Color, white, with delicate pink mark in the center, very striking trusses of fine form and immense size. $10 \mathrm{c}$ each.

M. A. BLANC-A most distinct and pleasing shade of salmon, with a light shading in the center; trusses are very large and composed of an immense number of florets. A single variety; the finest salmon flowered Geranium to date. $10 \mathrm{c}$ each.

MASSAGE D. LEMOINE-Gigantic flowering variety, which sells as fast as can be grown. Its flower pips are nearly three inches across. Color, light salmon, shaded with crean; a real gem. 10c each.

QUEEN OF THE WEST-The best bedding Geranium in cultiva tion; grows freely and blooms in the greatest profusion. light glowing scarlet: in flne trusses. We can furnish these by the dozen or hundred. 10c each.

TOUR EIFFEL-Semi-double. This variety is large and perfect in form, a dwarf, healthy and strong grower, and a grand bedding sort. Color of flower, bright orange scarlet; trusses of immense size. 10c each.

SPECIAL OFFER-The full set of 8 Varieties for $75 \mathrm{c}$. 


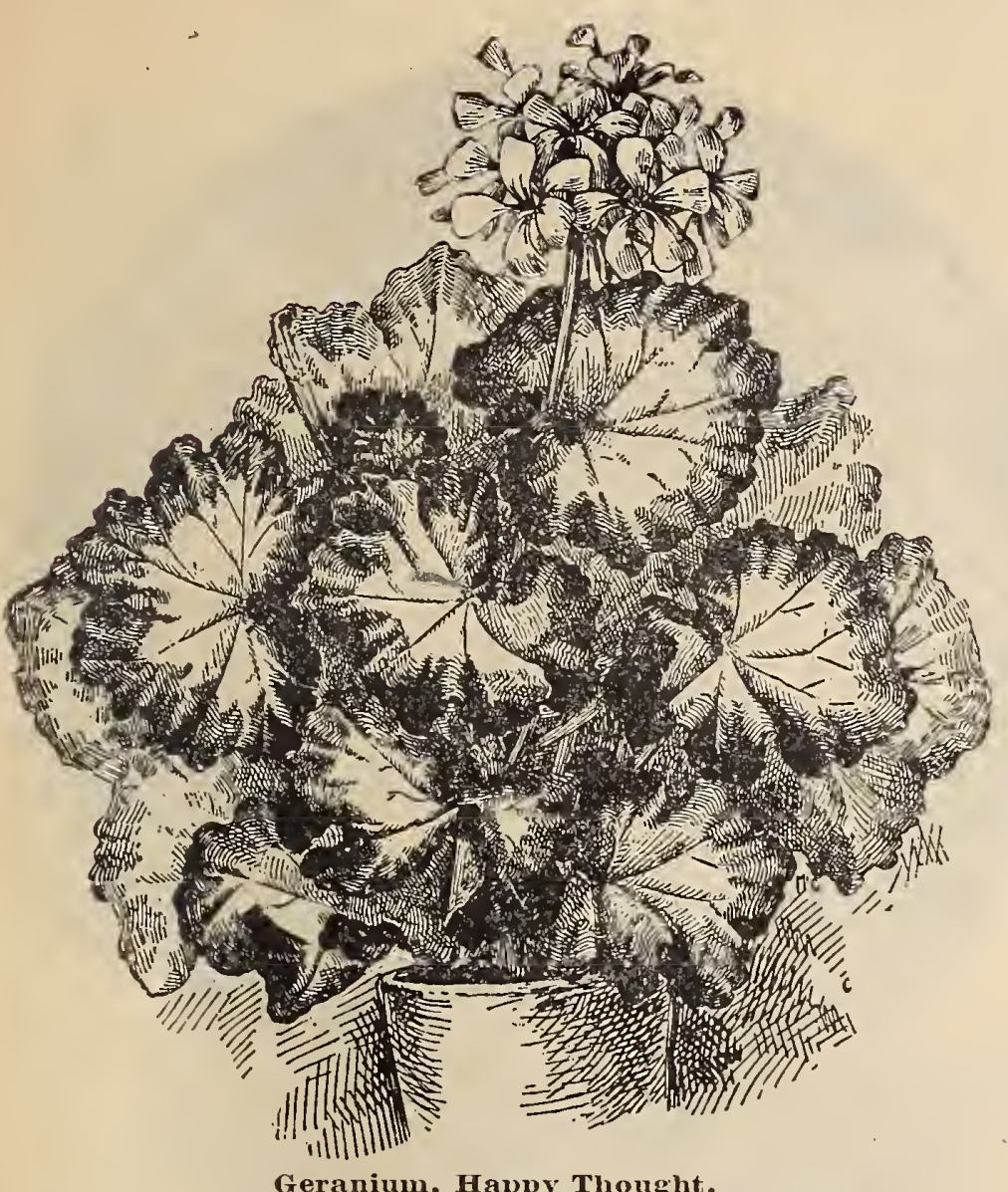

Geranium, Happy Thought.

\section{GERANIUMS.} SILVER-LEAVED.

WILLIAM LANGGUTH-New Silver-leaved Geranium. The most free flowering of its class. Flowers double, bright red; large extra blooms rising from the white colored foliage quite magnificently. Price, $20 \mathrm{c}$.

HAPPY THOUGHT-Light cream, almost white center, with a dark gieen band about the light zone; edge of leaf, a bright green. (See cut.) Price, 20c each.

MOUNTAIN OF SNOW-A fine, strong grower; center of leaf, bright green, with a broad, silver white margin; flowers scarlet, well above foliage; good for bedding. Price, 10c each.

SILVER FLEECE-Dark green foliage, distinctly margined with white; a robust grower. Price, $10 \mathrm{c}$ each.

MAD. SALLEROI-A very compact variety of Silver Geranium; very fine for massing or bordering; a thrifty, healthy grower, rarely reaching a height of more than 6 inches; leaves very small. of a peculiar clear green, edged with pure white

MRS. PARKER - A double flowered, silver leaved. Foliage deep green, broadly margined creamy white; flowers perfectly double; color, clear bright pink. Price, 10c each

SPECIAL OFFER-The full set of 6 varieties for $70 \mathrm{c}$.

\section{BRONZE-LEAVED.}

CORINNE-Clear, golden-yellow foliage; flowers double, trusses good size color, fiery orange. Price, $20 \mathrm{c}$ each.

GOLDEN HARRY HIEOVER-Golden bronze foliage; small leaf with dark chocolate zone on bright yellow. Price, 20c each.

MRS. POLLOCK (Golden Tricolor)-This is the best golden-leaved variety he leaves are a clear yellow, margined with scarlet and green; flowers, brigh scarlet. Price, 20c each.

MARSHALL MeMAHON-Excellent bronze foliage; holds its color well in sun and storm. Clear scarlet flowers. Price, $20 \mathrm{c}$ each.

SPECIAL OFFER-The full set of 4 varieties for $60 \mathrm{c}$.

\section{IVY-LEAVED.}

JEINNE D'ARC-Flowers very large, of the purest white; fine habit; free Howering; distinct and fine. 15c each.

MRS. JOHN G. DAY - The flowers are very large. Color, a very intense shade of crimson rose, brilliant and glowing; extremely free growing. 15c each.

MRS. MAYS - Its flower pips are nearly three inches across. Color, light salmon, shaded with cream; a real gem. 15c each.

SOUV. CHAS. TURNER-One of the handsomest Ivy Geraniums. Florets $2^{1 / 2}$ inches, in trusses 6 inches across. The color is a deep, bright pink, approaching scarlet; the upper petals feathered maroon. $15 \mathrm{c}$ each.

MICHAEL-Flowers double and of enormous size, equally as large and double as the finest Zonale; color, deep scarlet, with carmine shadings. $15 \mathrm{c} \mathrm{each}$

SPECIAL OFFER - The full set of 5 varieties for 60c. Large size plants, in bud or bloom, 25c each: the set of 5 for $\$ 1.00$.

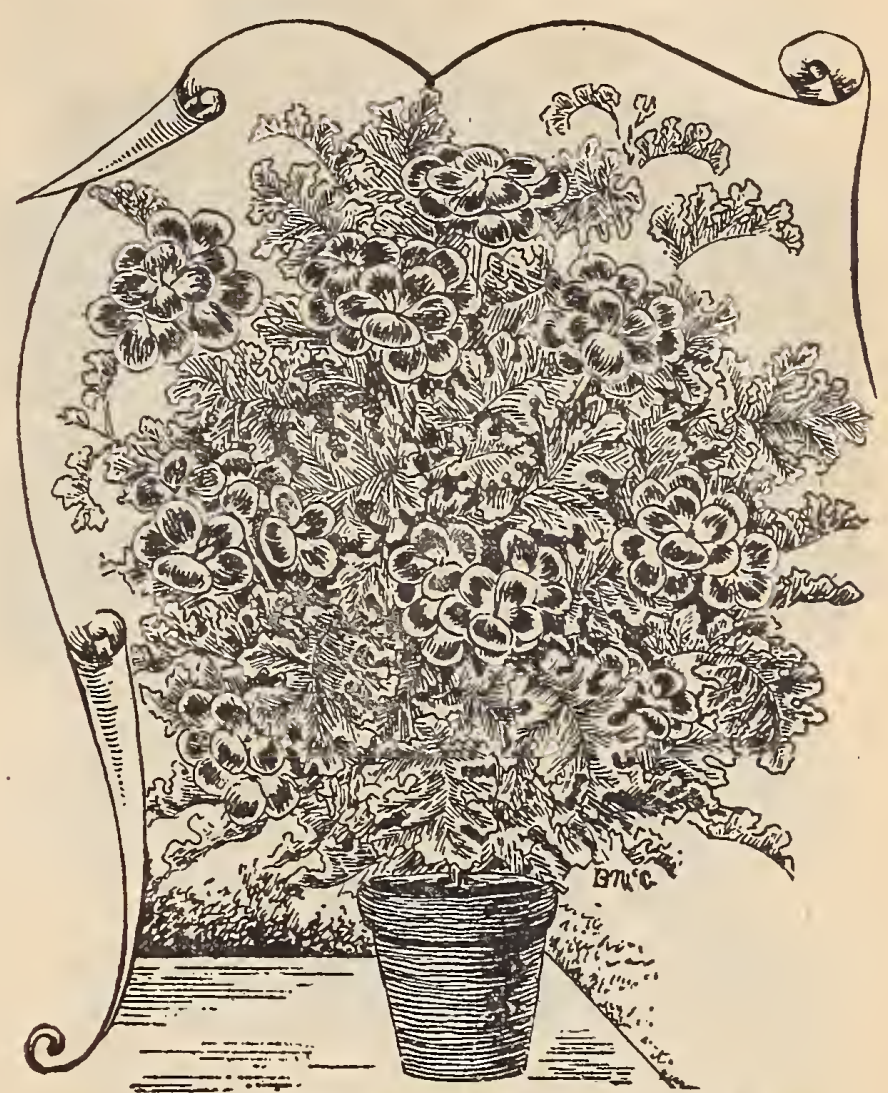

Rose Geranium, Scarlet Flowering, Mrs. Taylor.

\section{SWEET-SCENTED VARIETIES.}

APPLE-SCENTED - Has a fragrance of pineapples; well known favorite. Price, $25 \mathrm{c}$ each.

LEMON-Small leaves, growing erect; of a delicious lemon fragrance. Price, 10c each.

MRS. TAYLOR-A distinct variety of the scented geranium, with a strong rose fragrance; a large deep, scarlet flower (see cut). Price, $15 \mathrm{c}$ each.

NUTMEG-One of the most fragrant; somewhat resembles the Apple Geranium in growth and fragrance. Price, 10c each. ROSE-Too well known to need description. They are indispensable in the formation of bouquets. Price, 10c each.

SHRUBLAND PET-A bushy grower; leaves curled at the edge. With distinct fragrance. Flowers rose-colored, 10c each.

FERN - LEAVED OR SKELETON LEAF - Very handsome, deliciously scented. 10c each.

SPECIAL OFFER-The full set of 7 for $60 \mathrm{c}$.

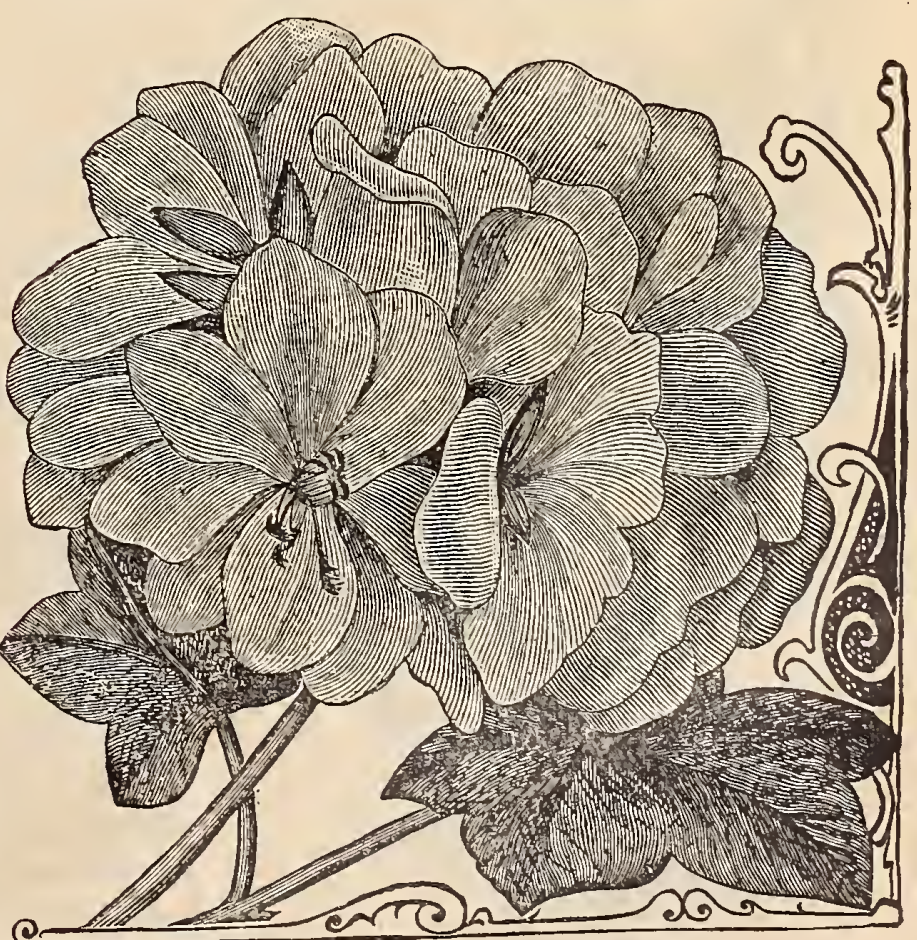

Geranium, Ivy Leaf. Souv. Chas. Turner. 


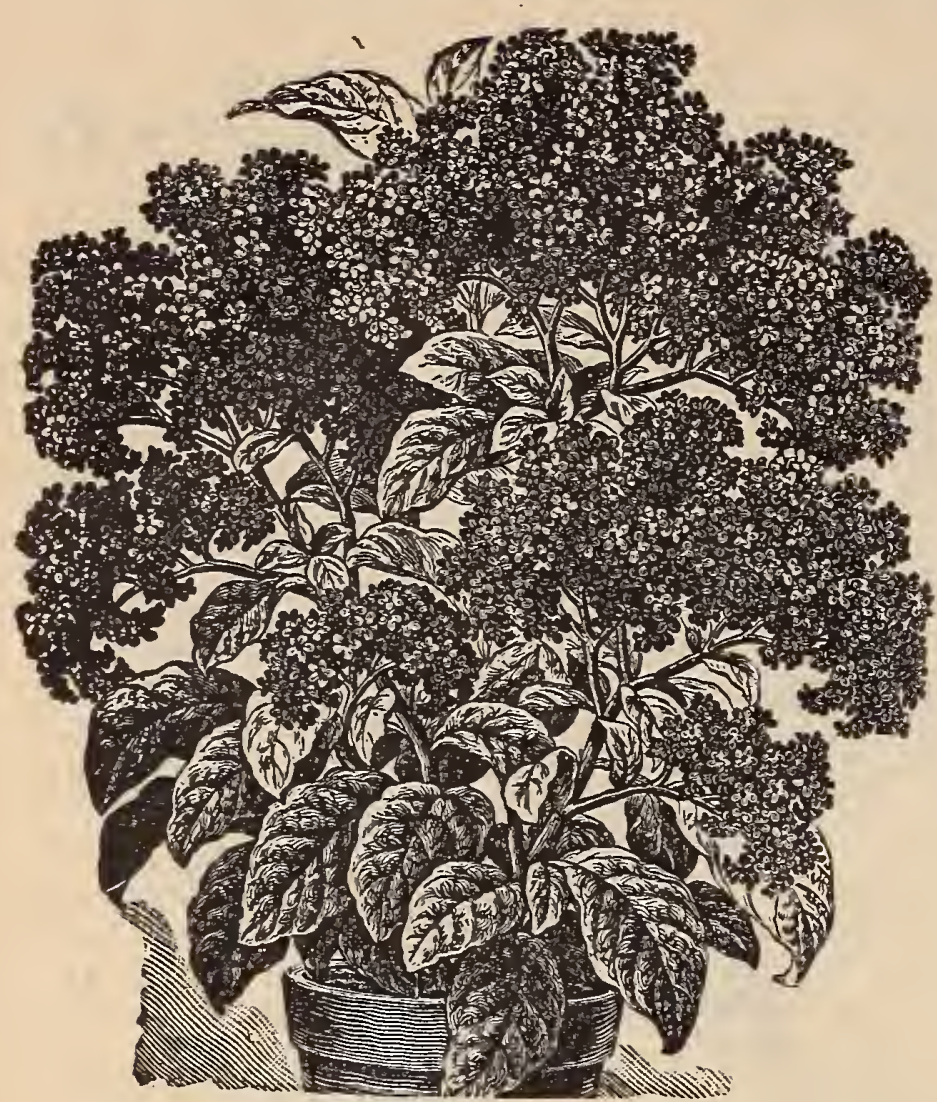

Heliotrope.

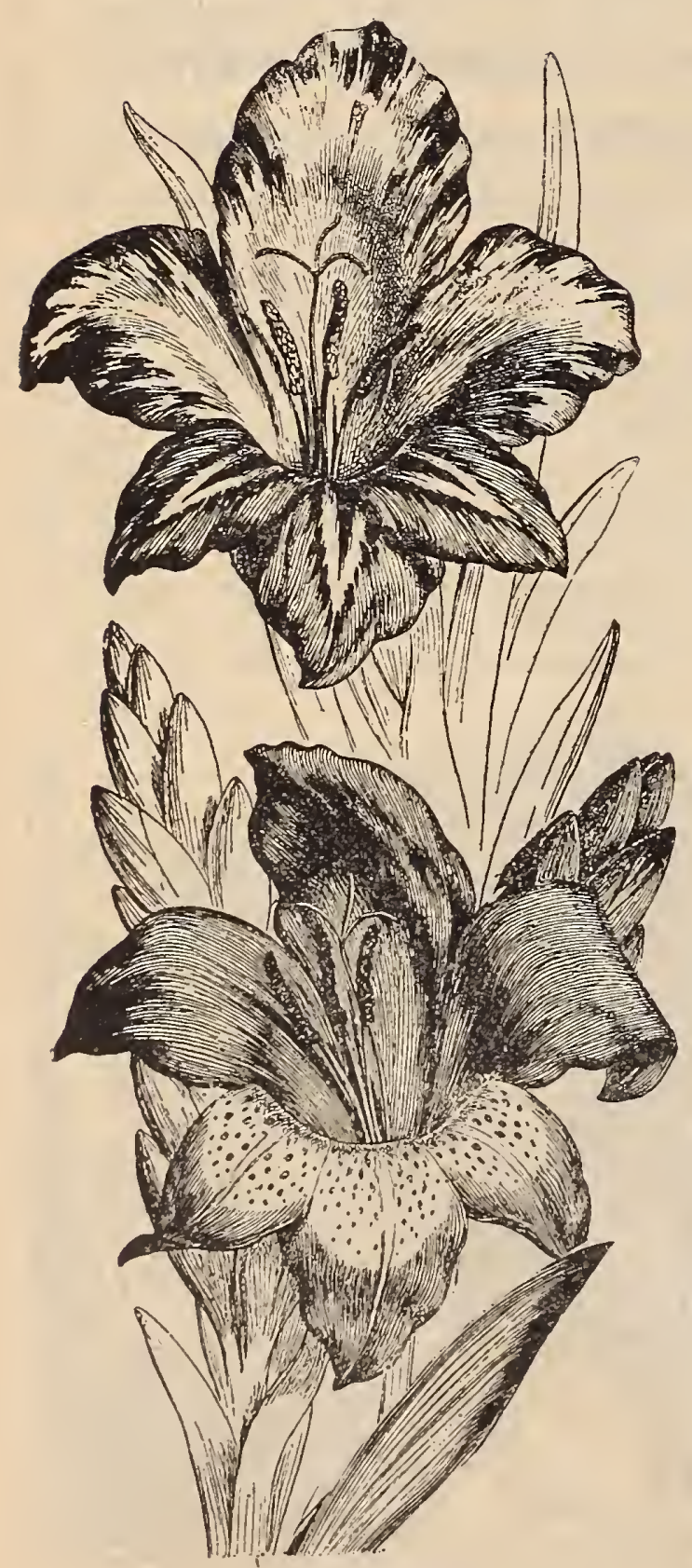

Gladiolus. 7.00 per 100 .

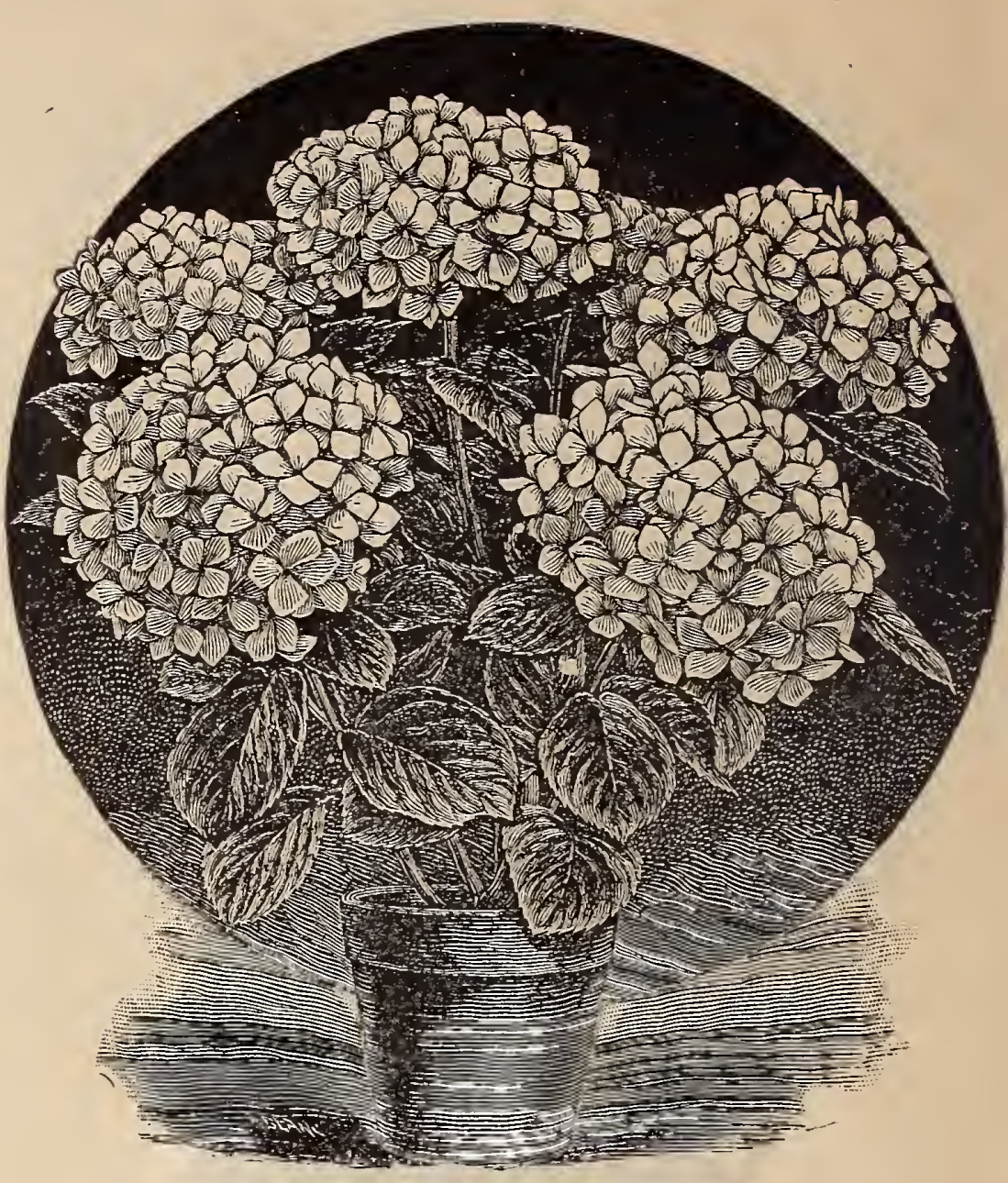

Hydrangea. Otaska Specimen Plant.

The Gladiolus are one of the fnest features of the flower garden during the summer and autumn months. Plant (after danger for freezing.is past) in ordinary soil, 3 inches deep and 6 or 8 nches apart. Each bulb produces from one to three spikes. By planting Gladiolus at intervals of a couple of weeks from early in April until July, flowers can be had constantly from June until They should be taken up in the fall and kept in a dry cellar until spring.

GROH contains the best varieties of all the new and large flowering hybrid sorts of Europe and America.
In our judgment this is the finest strain of Gladiolus grown. Price, $10 \mathrm{c}$ each; $\$ 1.00$ per dozen;

LEMOINE' S BUTTERFLY HYBRIDS, MIXED-The remarkable richness of the colorings of this class rival the finest orchids. 30c per dozen; $\$ 2.00$ per 100 . AMERICAN HYBRIDS-This is our leading general mixture and is composed of fine sorts
in all colors in first size bulbs only.

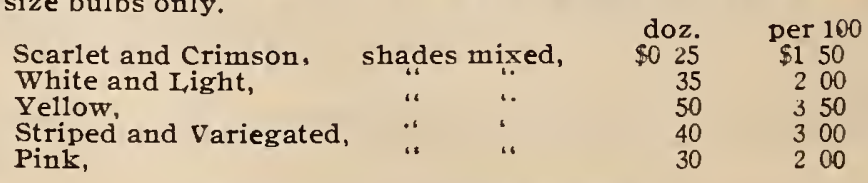

\section{HELIOTROPE.}

\section{CIANT FLOWERING VARIETIES.}

PURPLE AND GOLD-Foliage is bright, golden yellow and marked slightly with a delicate green, the deep lavender color of the flower contrasting admirably with the varying foliage. Price,
PRINCE CHARMANT-A dwarf-growing variety with handsome foliage. The trusses of flowers are exceedingly large and of a lovely tint of bluish mauve color. Price, $15 \mathrm{c}$ each

"CZARINA-A robust grower. Color, deep indigo blue with white eye; enormous trusses of the "Giant"type. Price, 15 ceach.

D-Semi-dwarf and very robust; panicles very large, and the florets of the very largest size yet obtained. Mauve, passing to lilac and tender rose, with clear white eye. A remarkably fine novelty. Price, $15 \mathrm{c}$ each.

and large and of great substance, and an FLEUR D'ETE-This is Each, $15 c$ aimprovement on the old, light-colored varieties. Fach $15 \mathrm{c}$

in SAPHIRE-A beautiful variety of the richest blue violet-purple color, with large and distinct WPECIAL OFFER-The Foll Set of Eight Varieties for $\$ \mathbf{1 . 0 0}$.

\section{HYDRANGEA.}

HORTENSIA-A splendid variety that will always be a favorite; its growth is strong and upright, forming excellent plants for pot culture; flowers extensively for Faster. Color, pink

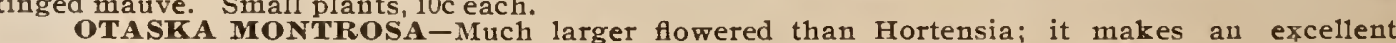
specimen plant for the porch or lawn; flowers are produced in enormous trusses of intense pint owers. Blooms the entire season. Small plants, $10 \mathrm{c}$ each.

Large Specimen Plants of Both of these Varieties in Bud or Bloom, \$1.50, \$2.00 and $\$ 2.50$ each. 

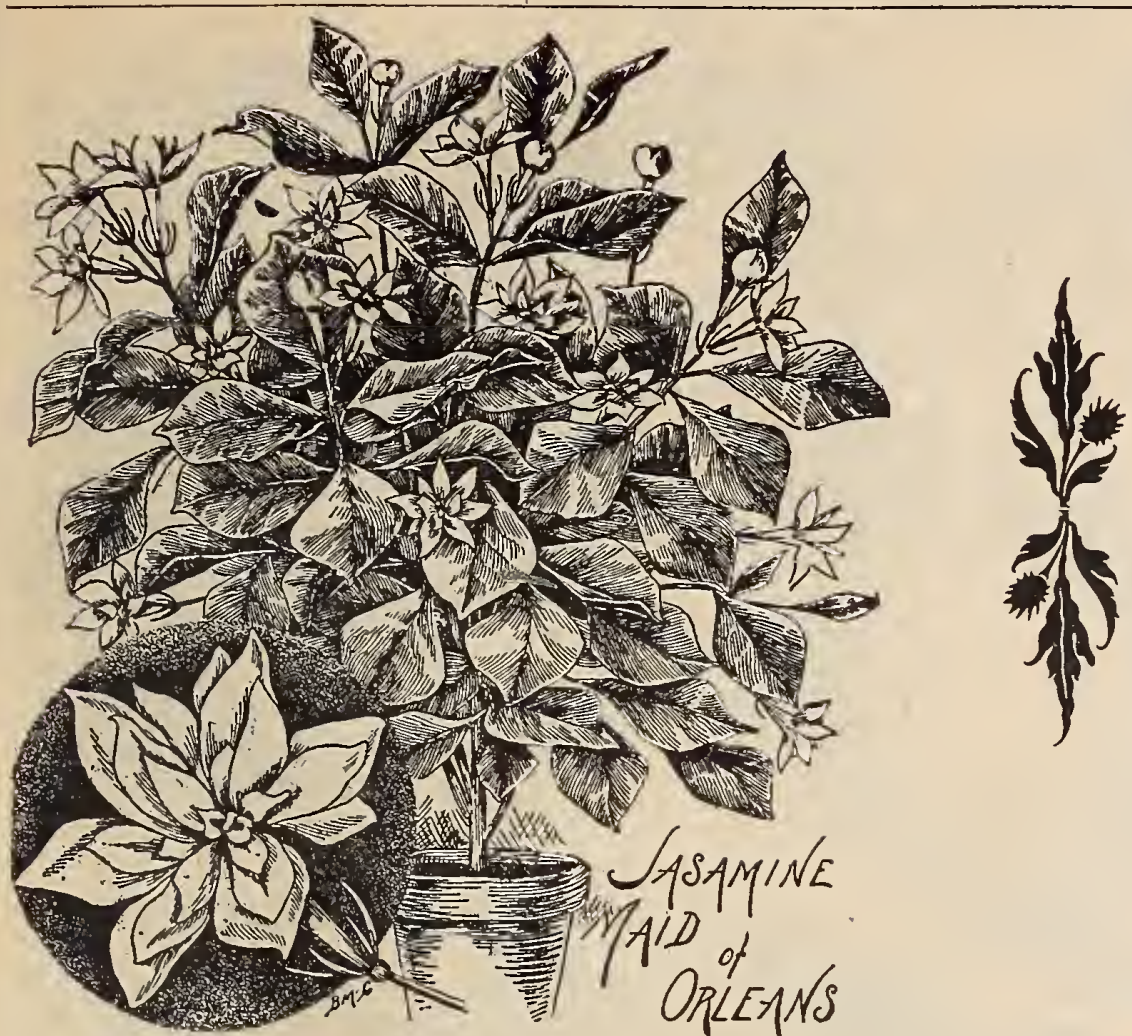

\section{HIBISCUS SINIENSIS.}

\section{CHINESE HIBISCUS)}

Well-known evergreen tender planted out during the summer. They flower freely during the entire summer, and even in the winter, if kept in a light, sunny situation.

PEACHBLOW-The flowers are double and single on the same plant, and from 4 to 5 inches in diameter; of a charming rich clear pink color, with a small deep crimson center; an entirely new and most beautiful shade. It blooms abundantly and continuously even on small plants during the entire summer and fall months. Price, $15 \mathrm{c}$ each.

A URANTIACUS-Fine double pure salmon. 15c each.

MINIATUS SEMI-PLENUS-The finest and most brilliant semi-double vermillion scarlet, with flowers 4 inches in diameter. $15 \mathrm{c}$ each.

SPECIAL OFFER-The full set of 5 varieties for $50 c$.

Limited quantitv of large size plants in bud or bloom, 18 to 24 inches

high, well branched in any of the above varieties, $75 \mathrm{c}$ to $\$ 1.50$ each.

\section{JASAMINES.}

MAID OF ORLEANS - A very attractive sort, with good size double flowers, bloomrofusely all summer. Small plants, $15 \mathrm{c}$ each

GRAND DUKE-This Jasamine is very easily grown: even small plants bear a profusion of very double cream white flowers, having a delicious perfume. Small plants, $15 \mathrm{c}$ ea. GRANDIFLORA (Catalonian Jasamine)-Flowers pure white, star-shaped, of exquisite fragrance. Small plants, $15 \mathrm{c}$ each.

CAPE 'Gardenia Florida)-This variety

REVOLETUM-Flowers bright yellow, very fragrant, bloom from May to October.

SPECIAL OFFER-The full set of 5 varieties for $75 \mathrm{c}$.

A limited quantity of large size flowering plants of any of the above varieties, 50c each.

\section{LANTANA. \\ (Or SHRU BBY VERBENAS)}

The brilliant color, robust growth and profuse blooming habits of the Lantana, render it one of the finest bedding plants that grow.

ALBA PERFECTA-Pure white, very fine. Price, $10 \mathrm{c}$ each.

CALIFORNIA-Color, pure yellow; very dwarf and bushy; abundant bloomer. Price, $10 \mathrm{c}$ each. MICHAEL SCHMIDT-The flowers fresh and sparkling; of a brilliant yellow, passing into purple HARKETT'S PERFECTA-A new variety, orange and crimson flowers and golden variegated ge. Price, $10 \mathrm{c}$ each

\section{LANTANA---WEEPING VARIETY.}

A plant of rapid growth and graceful drooping habit. Has come into high favor as a basket or vase plant. The flowers are delicate rosy lilac, borne rreely all over the plant at the base of every leaf stalk. or vases, where its bright colored bloom forms a perfect mound of flowers. 10c each.

\section{ISMENE CALATHINA.}

A grand summer flowering bulb, producing throughout the season large Amaryllis-like, pure white, fragrant blossoms. Keep the bulbs in a dry, warm place, and plant out in June. Bulbs can be taken out in October, and, after a few weeks' rest. potted and flowered in the house in winter, or kept over for planting out another season. (See cut.) $25 \mathrm{c}$ each

\section{LEMON VERBENA.}

A universa favorite and invaluable for its fragrant leaves. Very useful for bouquets. Price, $15 \mathrm{c} \mathrm{each.}$

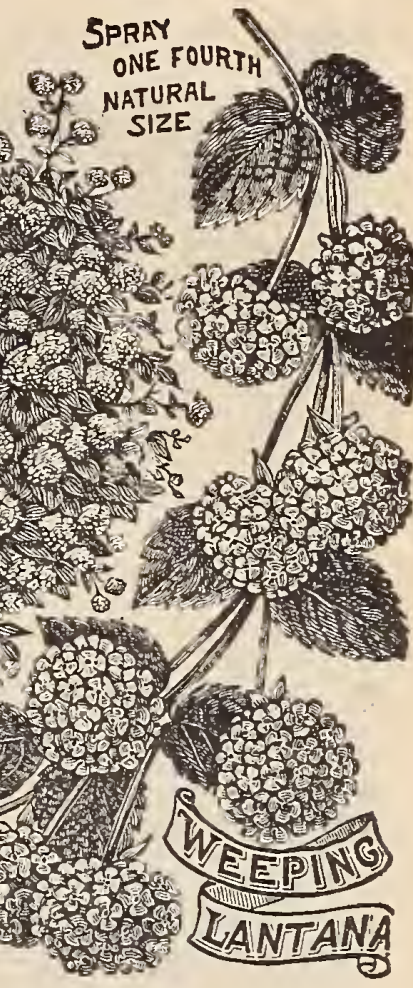

ONE FOURTH

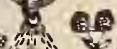
,
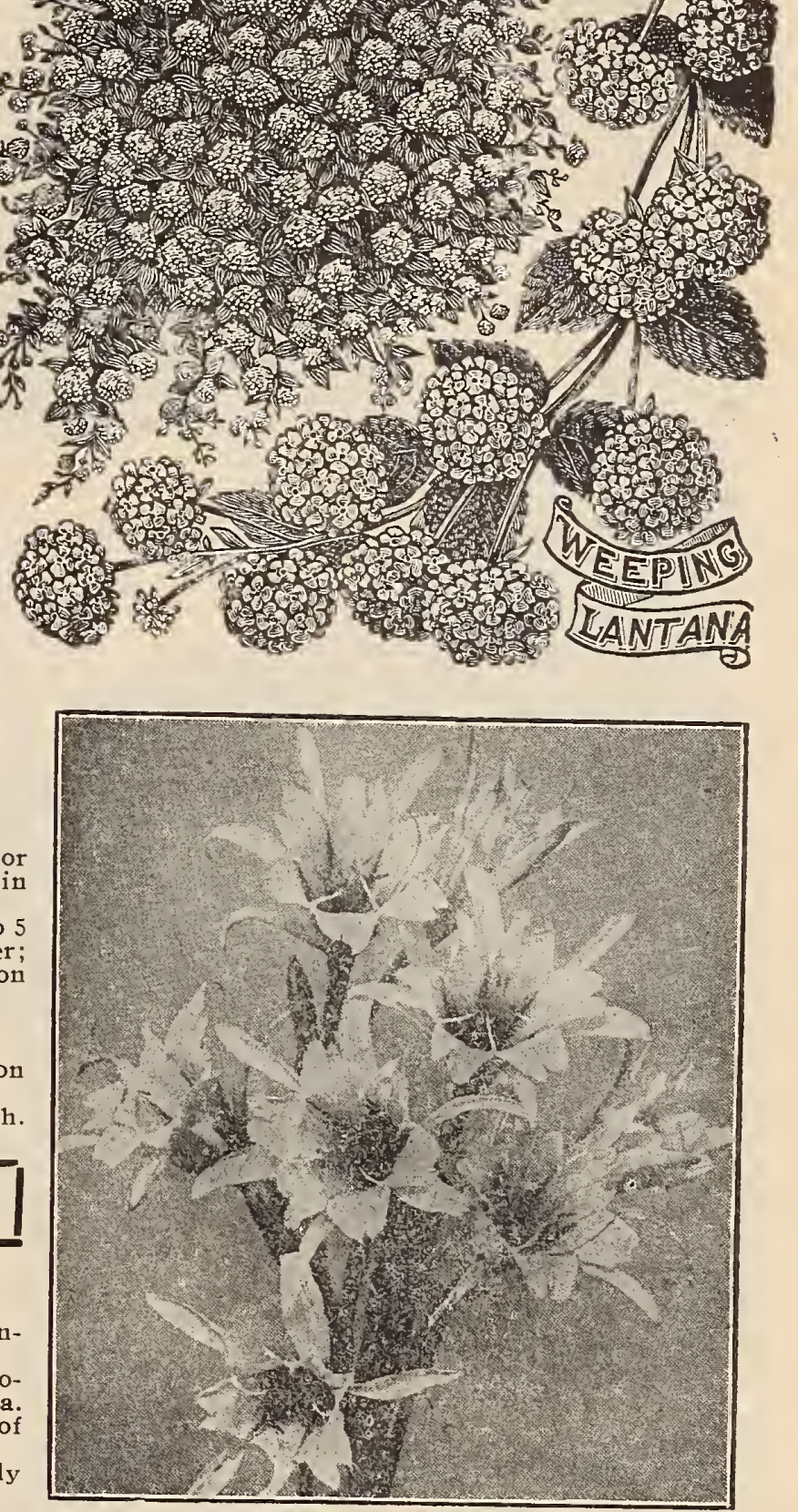

Ismene Calathina.

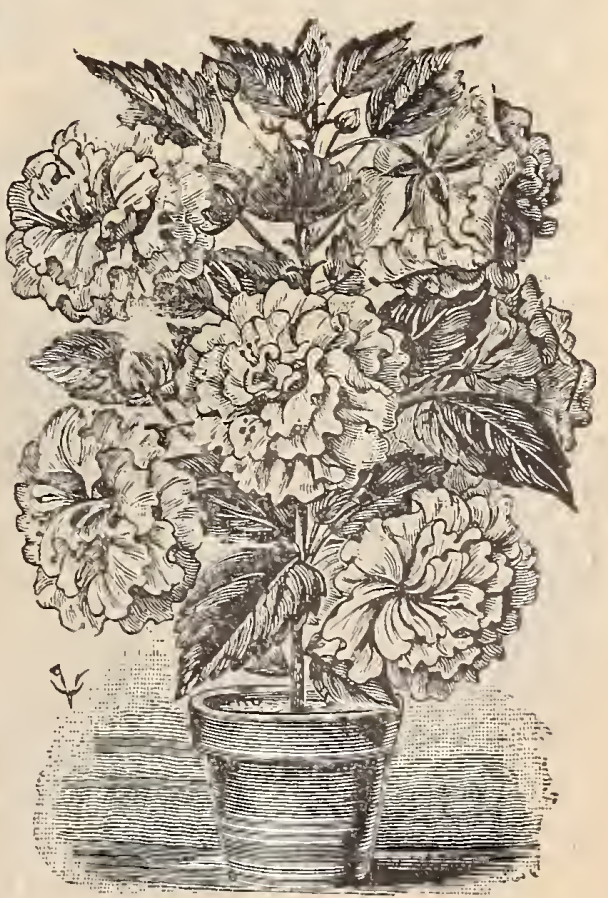

Hibiscus Peachblow. 


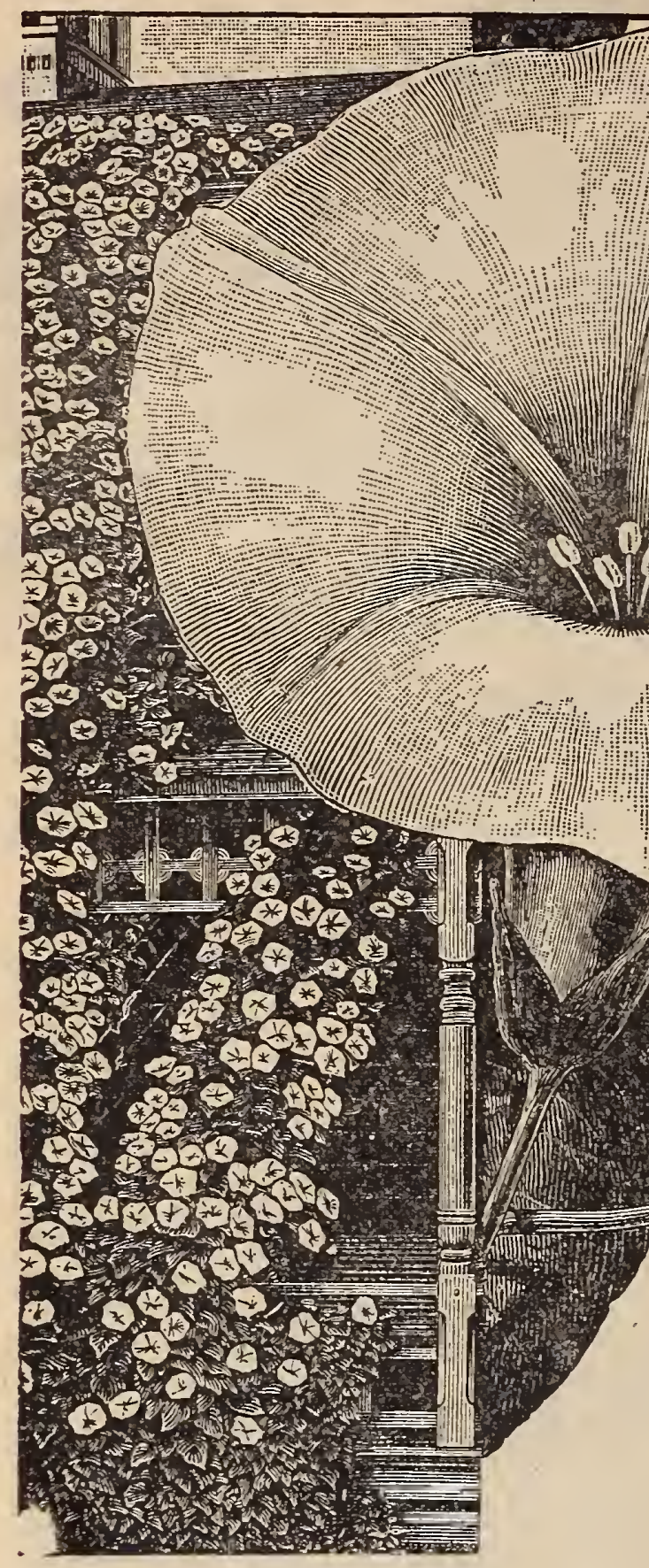

Magnolia Scented Moonflower.

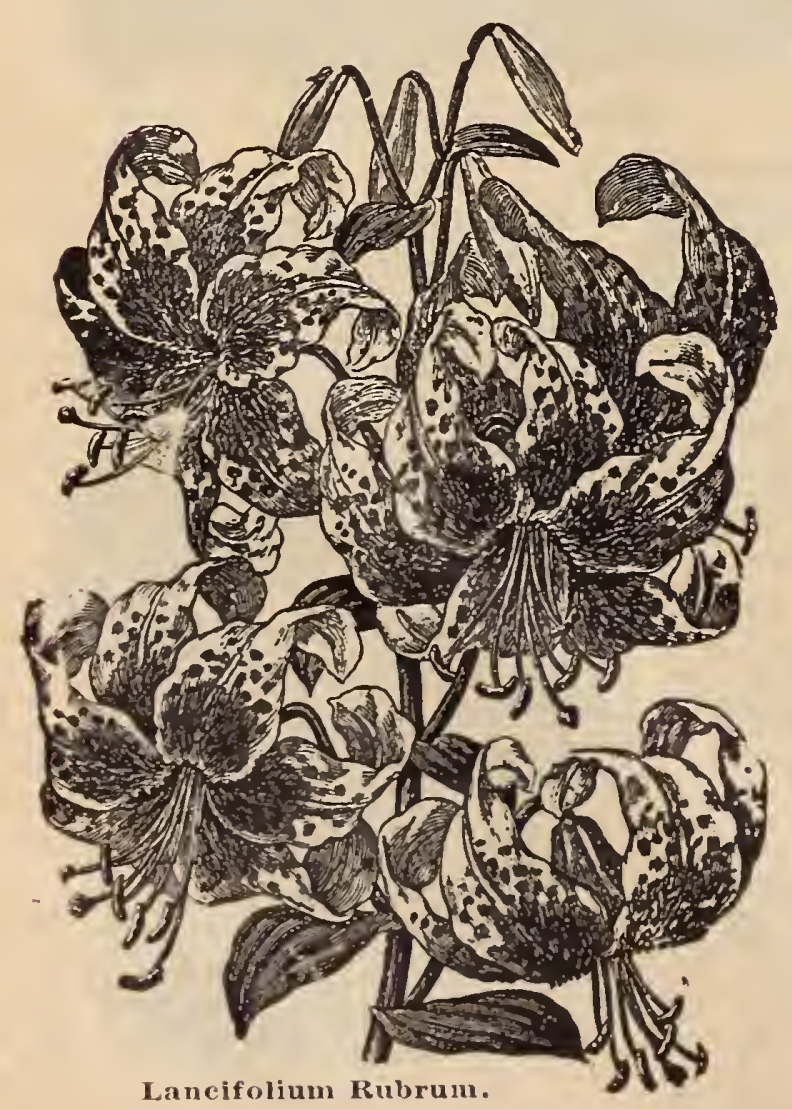

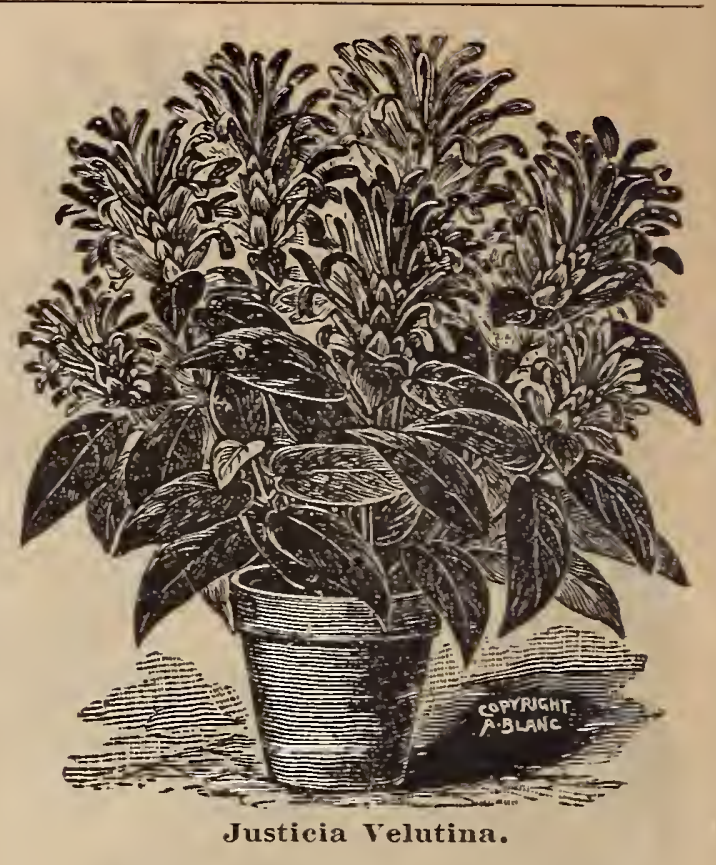

JUSTICIA VELUTINA.

A free flowering dwarf variety of the old form farorite Justicia Rosea. Flowers bright pink, produced in large feathery heads the whole sea son. I5c each.

\section{LILY BULBS.}

LILIUM CANDIDUM (or St. Joseph Lily)This is the favorite White Garden Lily. It grows three to four feet high, and flowers in the open ground about the first of $\lrcorner$ une. Flowering size bulbs, 20c each.

LILIUM AURATUM-Decidedly the most beautiful of all Lilies. Large, white petals; spotted with chocolate crimson, and have a bright golden band through the center of each. Flowering size bulbs; $25 \mathrm{c}$ each.

DOUBLE TIGER LILY-Bright orange red flowers, spotted with black. Flowering size bulbs, 20c each.

SINGLE TIGER LILY-Orange Salmon, spottedblack. Flowering size bulbs, 20c each. LANCIFOLIUM ALBUM-Pure white, Flowering size bulbs, 25c each.

LANCIFOLIUM ROBROM-White, shaded with rose and spotted with red (see cut) Flowering size bulbs, 25c each.

SPECIAL OFFER-The full set of six varieties for 90c.

\section{LEMON PONDEROSA, Or WONDERFUL LEMON.}

It is a true everbearing variety. The tree has fruit in all stages of derelopment. some enormously large. INo budding or grafting is necessary. The plant is of easy culture. flowering and fruiting in any good ordinary soil. Price, 50c each.

\section{MOONFLOWER.}

\section{TRUE MAGNOLIA SCENTED.}

One of the most rapid climbing vines in existence.

RED (Ipomæa Mexicana Palmata)-From Buenos Ayres. A red morning glory with large tuberous roots, bearing rich, violet crimsonflowers; a beauty, should be treated like dahlia. Price, extra large plants, 35c; 2d size, 20c.

WHITE (Ipomæa Grandiflora)-There are few plants that are as satisfactory as this. One lady says that it was trained on strings to a balcony 25 feet high and 40 feet wide, and from August to November it was covered nightly with its white. moon-like flowers, from 5 to 6 inches in diameter. It has also a rich jessamine-like odor at night. It is called the Moonflower because of its rare peculiarity of bloomng best at night, although it also expands it flowers in dull days. It grows everywhere, where there, are old trees, walls or strings to cling to (see cut). Price. extra large plants, 35c; $2 d$ size, 20c.

BLUE (Ipomæa Leari)-This makes a splendid companion to.plant with the White Moonflower. It is equally rapid in growth and free flowering, blooming in the moruing or on dull days. The flowers are the most intense violet blue, with reddish purple rays, and are six inches across. Extra large plants, 35c; 2 d size. 20c.

SPLCIAL OFFER-When three of the large size are ordered, we will send them for \$1.00; second size, 3 for 50c. 


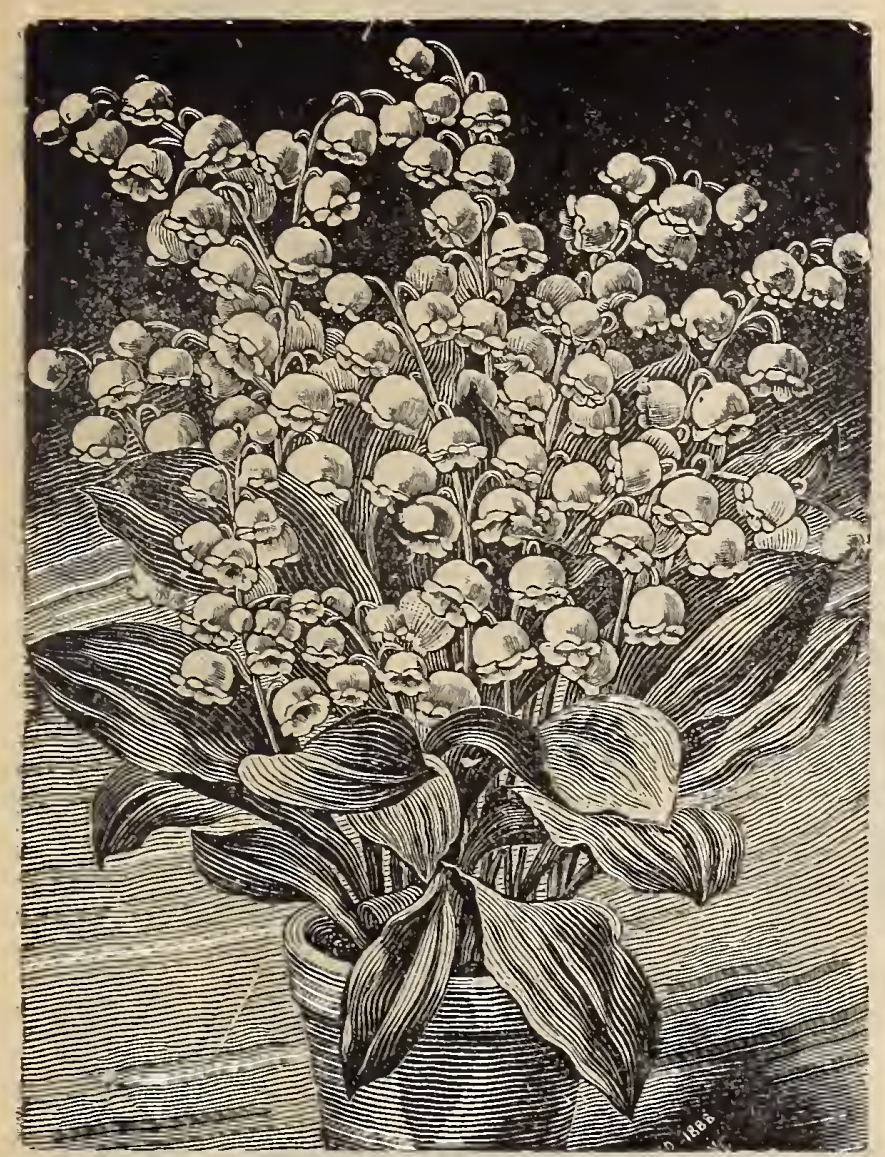

Lily of the Valley.

\section{LILY OF VALLEY.}

This beautiful little flower is quite hardy. Choose a partially shaded place in the garden and plant the roots about six inches apart and two inches deep. It is especially adapted for planting in cemeteries, as it requires no care after being
once planted. Price, per dozen roots, 30c; per 100,\$1.75.

\section{OTAHEITE ORANGE.}

The best orange for pot culture. Plants dwarf and symetrical in form. Flowers freely with a delightful orange fragrance. Fruits edible; only half the size display of blossoms or fruit. 15c each. Large specimen plants by express, 50c.

\section{MARGUERITE OR PARIS DAISY.}

WHITE-A ray of white petals around a yellow disc, blooms winter and summer; fine for bedding or pot culture; flowers like the field daisy in size and appearance; a good winter bloomer (see cut). Price, large plants in bloom, 25c; small size, 10 cents.

SOLEIL DOR-Rather dwarf plant; bright golden yellow flowers, disc and center being the same shade. These two varieties make a beautiful contrast. Prices, large plants in bloom, 25c; small size, 10c.

\section{PASSION FLOWER.}

(Passiflora.)

Everyone is familiar with the beauty and graceful climbing habit of Passifloras. They are valuable for window culture and can be planted in the open ground during the sumer.

CONSTANCE ELLIOT-A valuable novelty with large, handsome and very fragrant flowers of pure ivory white, with raised center. Price, $20 \mathrm{c}$ each.

PFORDTI-A beautiful blue flower, shaded with rose. It blooms freely when only a foot high, and is the best sort for window culture. Price, $20 \mathrm{c}$ each.

\section{PLUMBAGO.}

\section{(Lead-Wort.)}

CAPENSES-Of dwarf, spreading habit, growing 4 to 6 inches high; useful as an edging plant or for the rockery; covered with beautiful deep blue flowers during the summer and fall months. $15 \mathrm{c}$ each; $\$ 1.50$ per dozen.

\section{POMEGRANITE.}

JAMES VICK-IMPPROVED. This is a decided improvement on our old sort, James Vick. sent out by us some eleven years ago. Its habit is dwarfer and more com-
pact and blooms earlier and is constantly blooming. Bright, single scarlet. One year old, $75 \mathrm{c}$ each; smaller size, $25 \mathrm{c}$

\section{CHRISTMAS PEPPER, OR JAPANESE PEPPER.}

A very valuable and quick growing red berried plant which is very attractive from October until March; it requires to be treated as house plants in
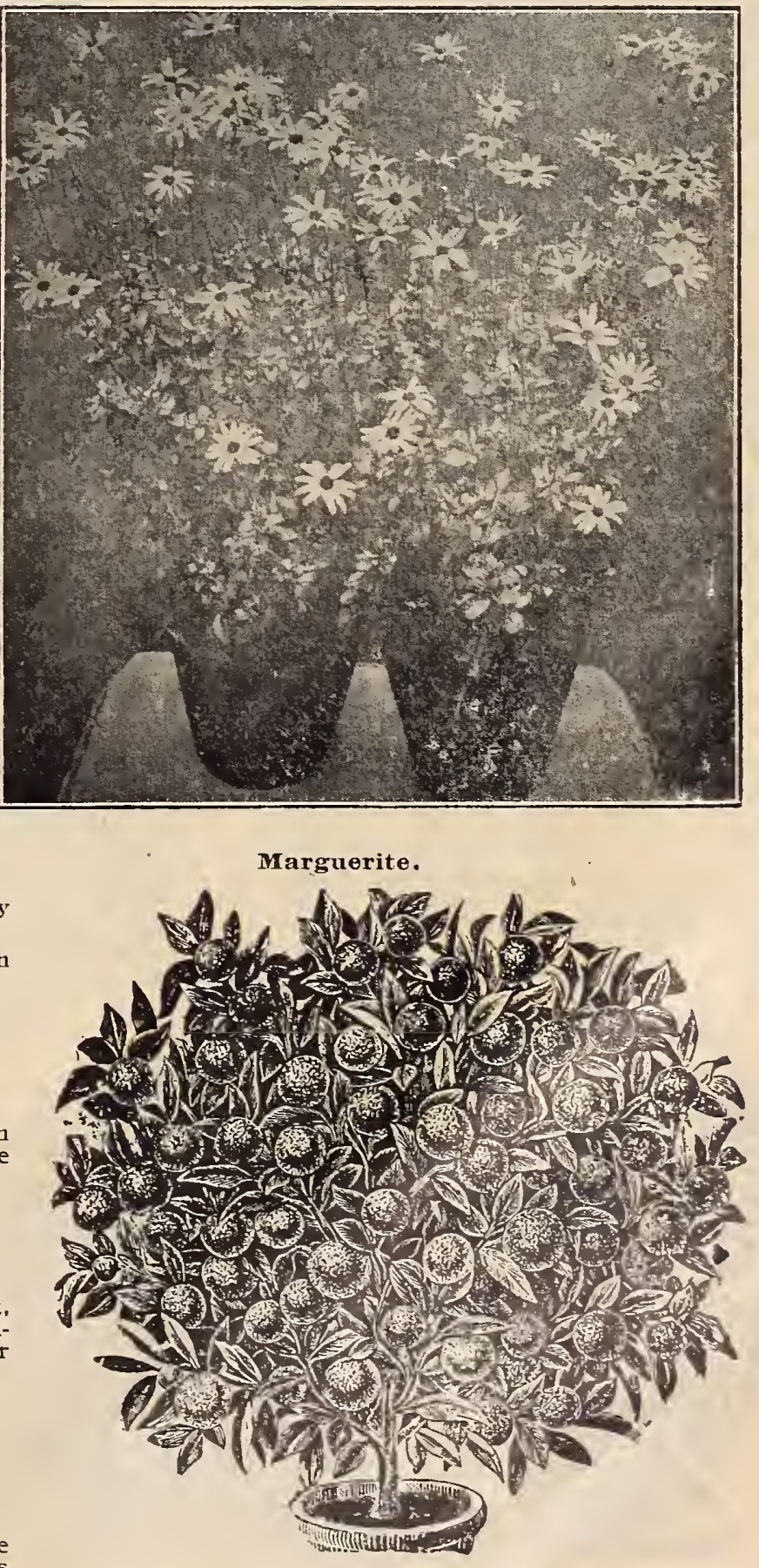

Otaheite Orange. 


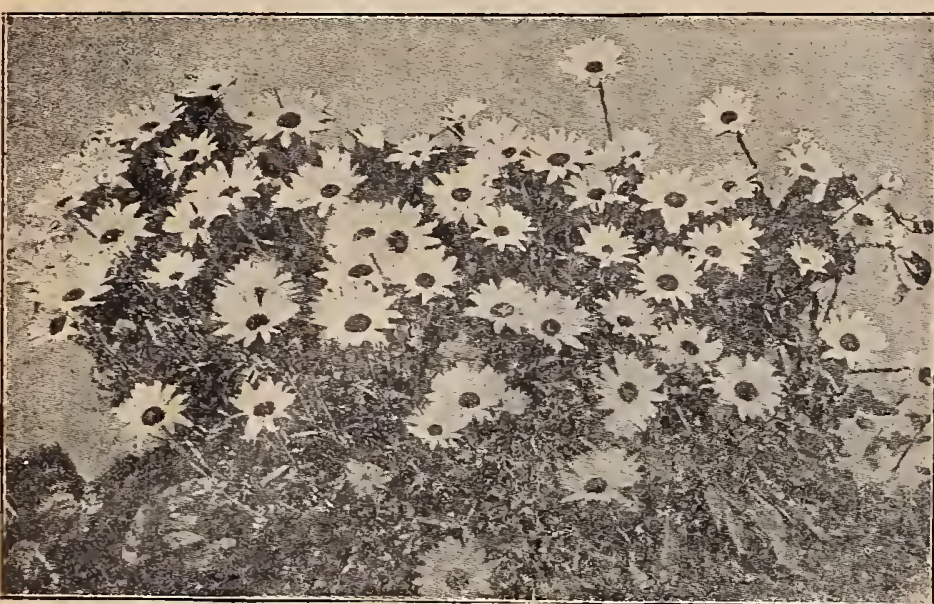

\section{SHASTA DAISY.}

This is a new daisy plant that was recently introduced from California. It is claimed to be a very hardy plant, flowering very reely in the Autumn, about the same time as chrysanthemum and continuing the entire winter. The fowers are very large, often measuring 12 inches in circumference and remains a long size flowering plants, $50 \mathrm{c}$ each.

\section{PETUNIAS.}

DOUBLE-This Petunia is one of the finest bedding plants. The brilliancy and variety of its colors, combined with the duration of its blooming period, render it invaluable for garden decoration. Our collection is unsurpassed for brilliancy of color and size of blooms. They include all the brightest shades of pink, purple, rose, white, etc. Price, $20 \mathrm{c}$ each; $\$ 1.50$ per doz.

SI NGLE GIANTS OF CALIFORNIA-These are an exceedingly large variety in all shades of color, from pure white to the deepest purple; some are blotched and striped in every conceivable way, while others are exquisitely fringed. They are very showy and attractive when planted outdoors. Price $15 \mathrm{c}$ each, $\$ 1.50$ per doz,

\section{SALVIA.}

SACVIA-A. RAGNEA U-Early flowering, does not grow over 15 to 18 inches tall and blooms as soon as it becomes well rooted and continues until frost. This is entirely different from what we bave heretofore offered as dwarf early flowering Salvia. Flowers brightest scarlet, produced in grand spikes. $15 \mathrm{c}$ each; $\$ 1.50$ per dozen.

FIRE BALL-The dwarfest and most compact of the Scarlet Salvias, with dark foliage completely covered with erect spikes of dazzling scarlet. It is early in bloom and continues in clean bright condition throughout the season. $15 \mathrm{c}$ each; $\$ 1.50$ per dozen.

SPLENDENS (Scarlet Sage)-Most gorgeous plants with spikes of intense vivid scarlet flowers. The flower spikes measure 10 to 12 inches in length and there are as many as 200 spikes on a well-growu plant. They continue to flower most profusely all summer and until killed by the late frosts. $10 \mathrm{c}$ each ; $\$ 1.00$ per dozen. SPECIAL OFFER-The full set of:3 varieties for $30 \mathrm{c}$.

\section{YOUNG'S PANSIES.}

Who does not like a pansy? No one. It comes so quickly after the dull dreary winter, and its color and markings are so beautiful that everyone exclaims. "I like a heartsease." As to their culture, give them a good, rich soi and they will grow and thrive anywhere and beyond replanting, will bloom eigh months without attention. Yo wrow could be seen they would be planted in every garden

YOUNG'S GIANT TRIMARDEAU-Fine young plants from this superb, arge-flowering strain. Each, 10c; per dozen, 75c. aised from raised from seeds obtained from
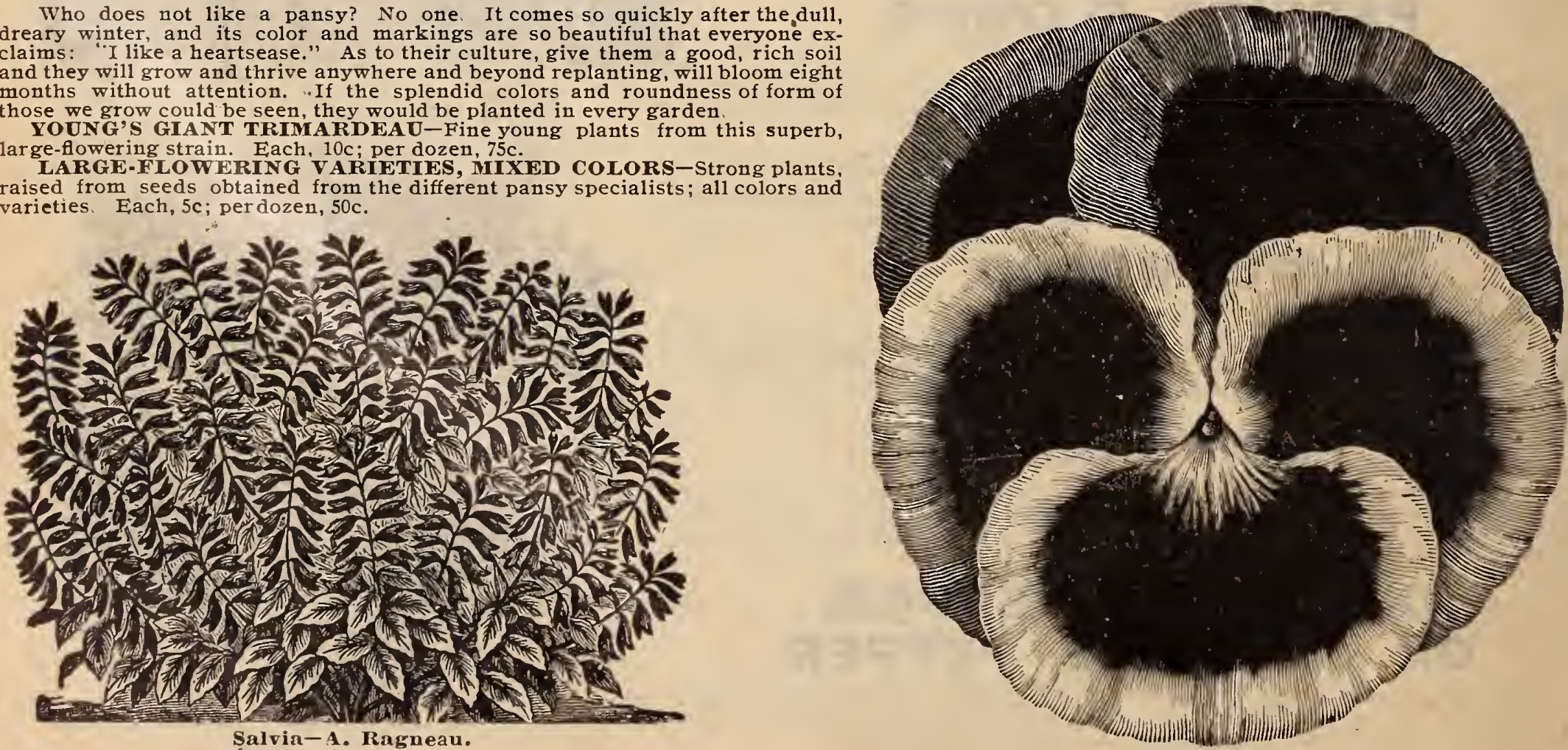


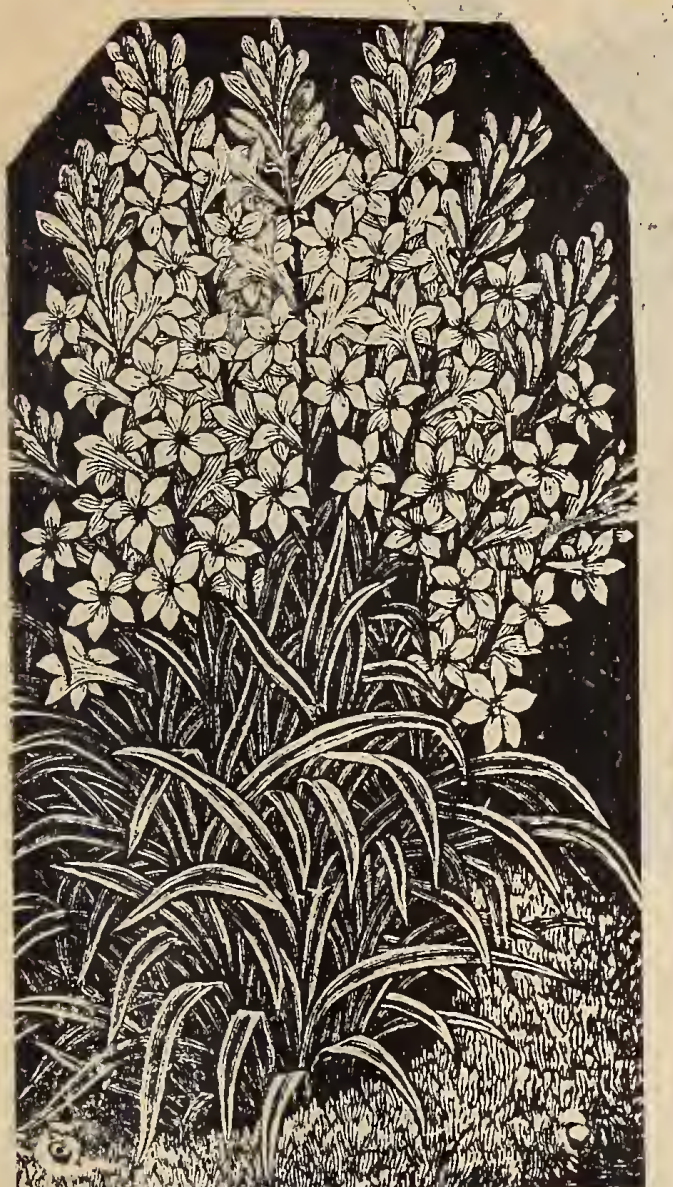

\section{Young's Everblooming Tuberose Bullbs.}

A wonderful new single tuberose that blooms continuously from early in July until it is stopped by frost. Unlike any other tuberose it flowers the year after from the same

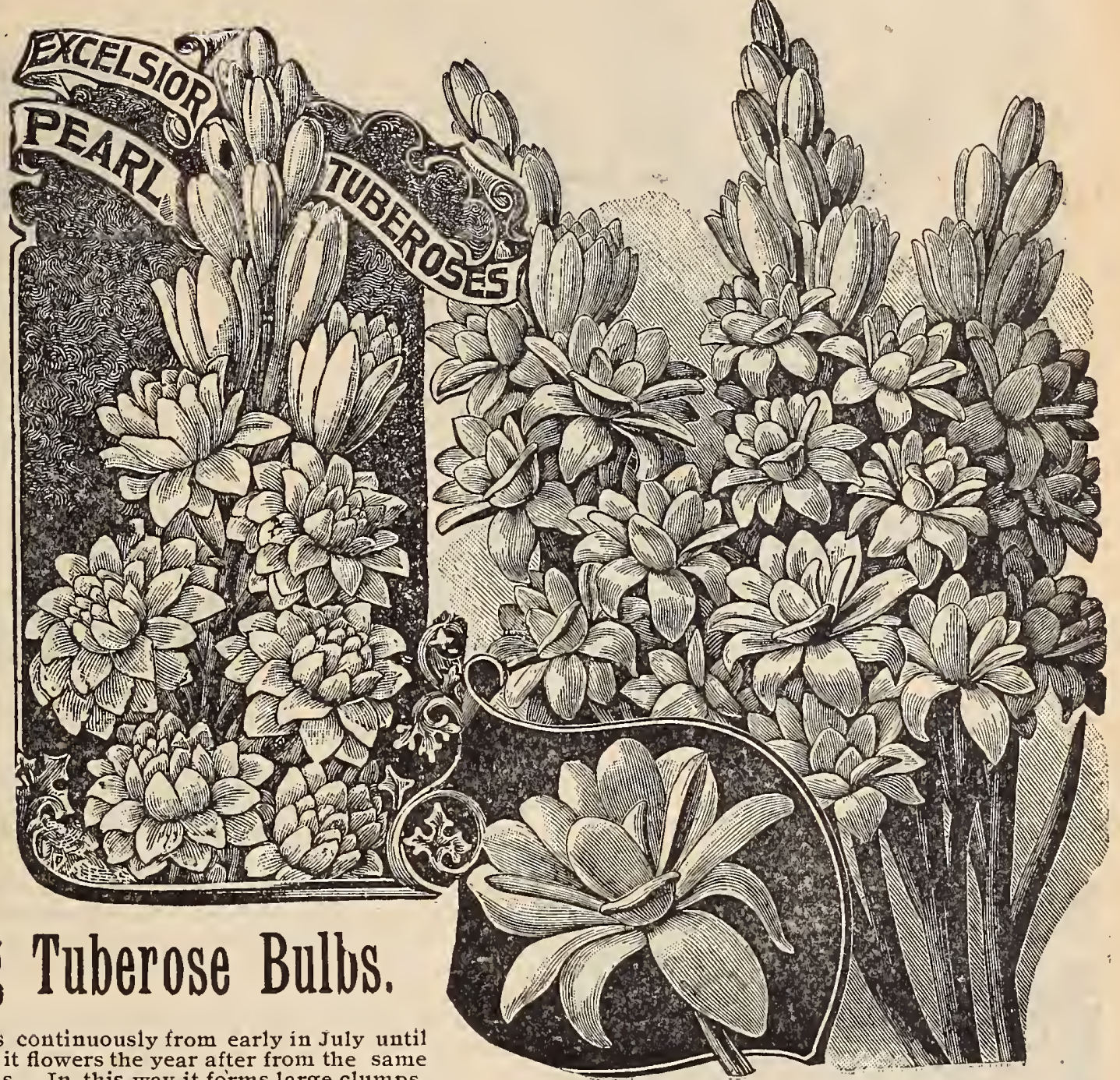
frequently having fifteen to twenty large spikes in full bloom at one time. The im-

fregre two years old, extra large sized and will be sure to bloom in great profusion this season. Fach, $6 \mathrm{c}$; per dozen $50 \mathrm{c}$; per 160 . $\$ 2.50$.

\section{YOUNG'S DOUBLE EXCELSIOR PEARLTUBEROSE BULBS}

\section{Are noted for their fine quality, extra large size and sure blooming qualities. Average size of bulbs 4 to 6 inches in diameter.} EXCELSIOR PEARL-Grows about 18 inches high; blooms very earl
each; per dozen, 75c. Price by express, 7c each; per dozen, 50c; per 100. $\$ 3.00$. each; per dozen, 30c; per 100,\$2.00. STARTED IN POTS, ready April 15, which insures them flowering early in the season. $15 \mathrm{c}$ each; $\$ 1.50$ per dozen.

\section{VERBENAS.}

From an extra choice
$5 c$ each; 50c per dozen.

\section{VIOLET8.}

IMPERIA L-This is the freest double-fiowering violet that we know of. It is entirely free from disease of any kind. Color a deep violet purple; deiciously fragrant; howers are or ants, 20 . ta very long stems. Young plants, price $15 \mathrm{c}$ each.

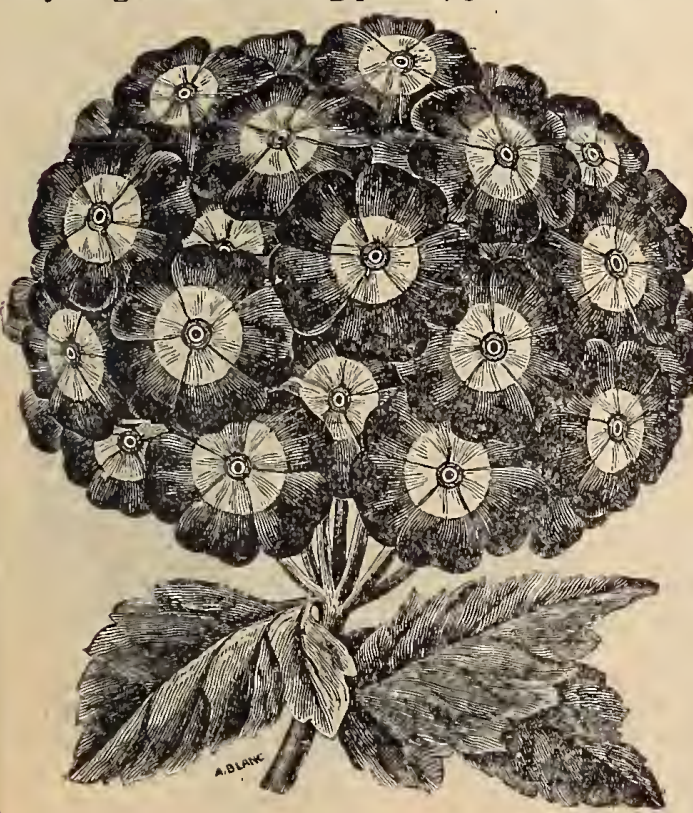

G A I LL A S - Anther large flowering lighter in color than a France, but equally as fragrant. Young the full set of three VINCA, Or Perrywinkle.

This is a most attractive plant, bloomng the entire summer eason, forming a feet in height and diameter.

C O I, O R - Rose, White, a n d White New Giant Verbena.

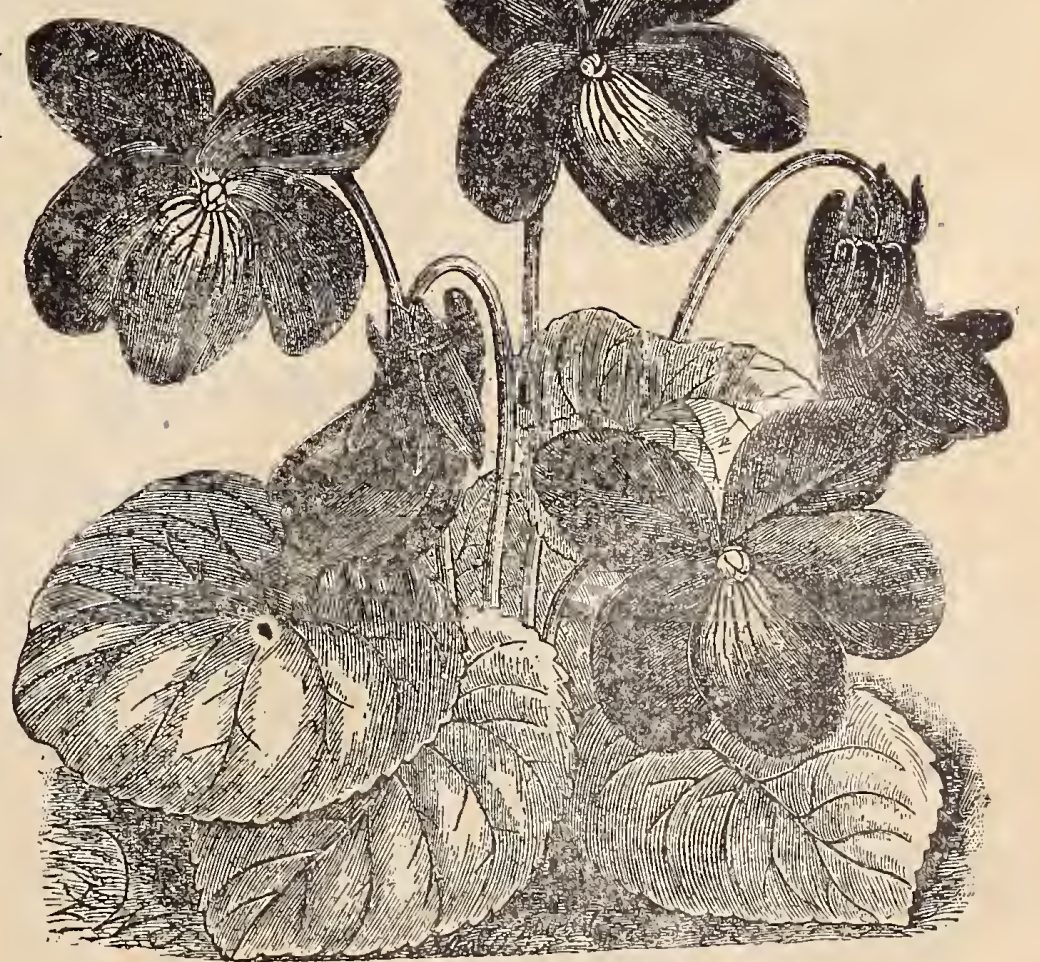




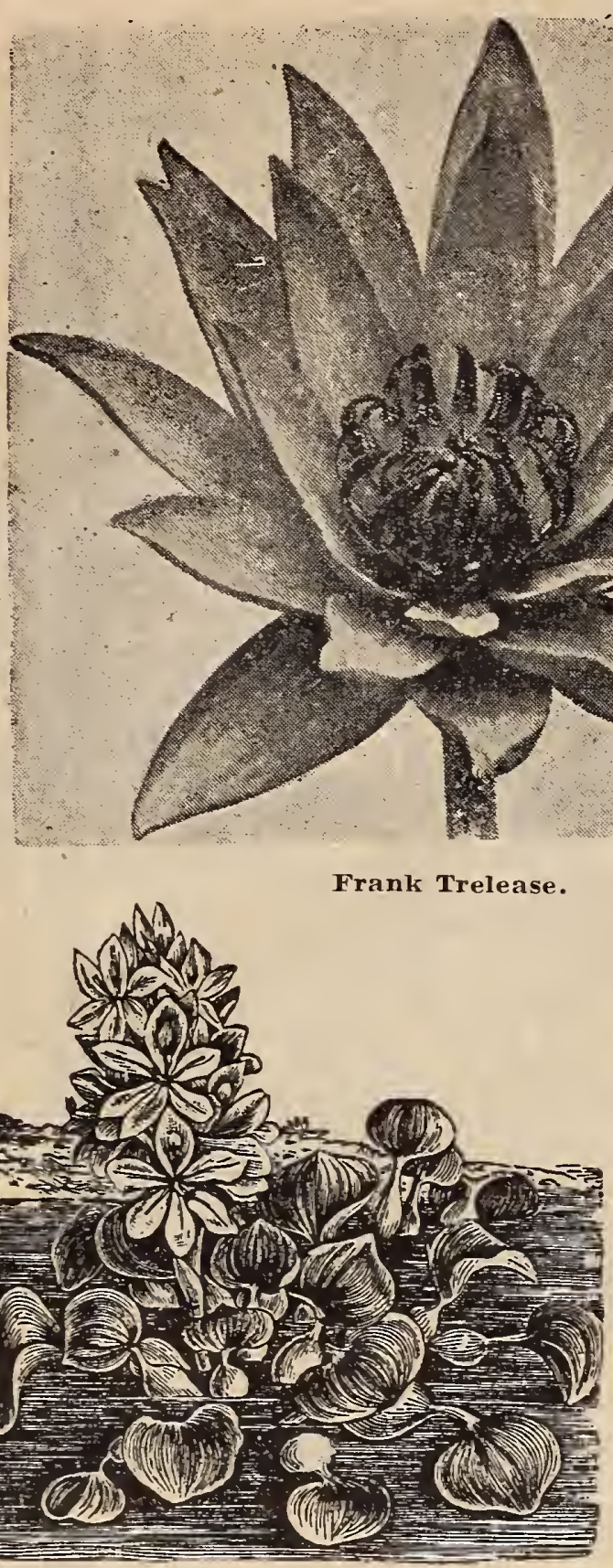

Water Hyacinth.

WATER HYACINTH - One of the most remarkable, curious and beautiful plants we have ever grown. Instead of growing in soil, it floats in the water. Each fluwer is larger than a silver dollar; color, a soft lilac rose, sparkling as if covered with diamond dust. Will grow in the open air in summer and in the window in winter, in anything whlch will hold water. (See cut.) Price, 25c each; $\$ 2.00$ per dozen.

WATER POPPY - Small oval leaves and showy flowers of bright lemon color, standing a few inches out of the water and producing freely all summer. Fasily grown in a shallow tub or pan. Price, $20 \mathrm{c}$ each
The cultivation of Aquatics is of the simplest. Their requirements are sunshine, water and plenty of rich soil. They are divided into two classes, hardy and tender. The former may be planted in ponds or sluggish streams, from early in the spring until August, and, under the same conditions as our native Water Lily, will grow luxuriously and flower profusely the entire season. Provide the same conditions in artificial ponds or tanks, and the results will be equally satisfactory. Plant the tender varieties at the approach of warm weather and when the water is warm. The plants can be grown in pots, where protection can be afforded them until safe to transfer to summer quarters. The after-treatment is the same as for the hardy varieties. When grown in tubs only the moderate growers should be selected. In storing in tubs through the winter they should be kept where it is not warm enough to excite growth or so cold as to freeze.

FRANK TRELEASE-This superb tender night-blooming water lily surpasses all other red varieties by the brilliancy and depth of the rich glowing dark crimson of its flowers. 9 to 10 inches in diameter: glossy, dark, bronzy red, resembling in color the foliage of the Black Beauty Canna.

MARLIACEA CHROMATELLA-A very free and vigorous grower; flowers 4 to 6 inches across. bright yellow color; leaves deep green, beautifully blotched with brown. A free and contiuuous bloomer. 50c each.

PARROT'S FEATHER-An aquatic hangiug plant. Planted in water-tight hanging basket. so water can be kept standing on the surface of the soil. it will trail down over the sides in a most charming manner. In a tank or lake it prefers shallow water. Price, $15 \mathrm{c}$ each; $\$ 1.50$ per dozen. NYMPHAEA FLAVA-This is a true waterlily, with yellow flowers and a delicate perfume. Its leaves are beantifully variegated with brown. It is a very desirable variety either for pond, tub or aquarium. Price, $30 \mathrm{c}$ each.

NMMPHAEA ODORATA-Our native water lily: flowers pure white and veryfragrant; when grown in rich mud it will produce flowers 6 inches and leaves 18 inches across. Price, $25 \mathrm{c}$ each.

NYMPHAEA ODORATA SULPHUREA-A handsome yellow-flowered form of our native ariety. Price, $\$ 1.00$ each.

NYMPHAEA ODORATA ROSEA (Oape C(d Water Lily)-This is the famous pink water lily of Cape Cod. It possesses all the desirable qualities of the white-flowertd species, hardiness, freedom of bloom and delicious fragrance. Price, 50c each.

NYMPHAEA ZANZIBARENSIS AZUREA-Blue Zanzibar lily; flowers 4 to 6 iuches across. $50 \mathrm{c}$ each.

NYMPHAEA ZANZIBARIENSIS ROSEA-Pink Zanzibar lily; similar to the blue, except iu color. Price, 50c each.

\section{Hardy Flowering Plants For Out-Door Planting.}

ASTERS Strong plants, grow in 3-inch pots, well established, from Vick's large branching and choice Victoria strain; in four distinct colors-white, lavender, red, pink, etc. 50c per dozen; $\$ 3.50$ per 100.

NASTURTIUM - I) warf or tall-growing; strong, well-grown plants, from 3-inch pots, in the leading colors. $60 \mathrm{c}$ per dozen; $\$ 4.00$ per 100 .

PHLOX DRUMMONDI-Flowers the entire summer; very attractive and showy, in six distinct colors. $10 \mathrm{c}$ each: $60 \mathrm{c}$ per dozen; $\$ 4.00$ per 100 .

SWEET PEAS-We grow 3 to 5 peas in a $2 / 2$ inch pot. They can be planted out in the garden after it is too late to sow the seed, and are all of the best varieties and a choice assortment of colors. 35 c per dozen: $\$ 2.50$ per 100 .

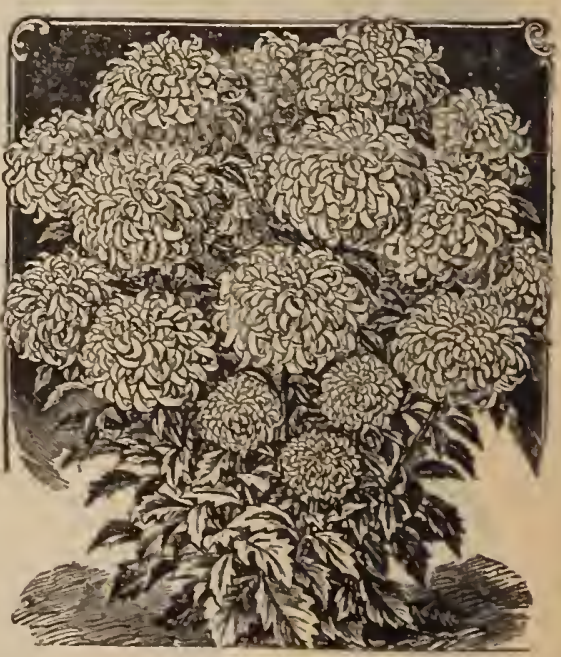

Aster. 


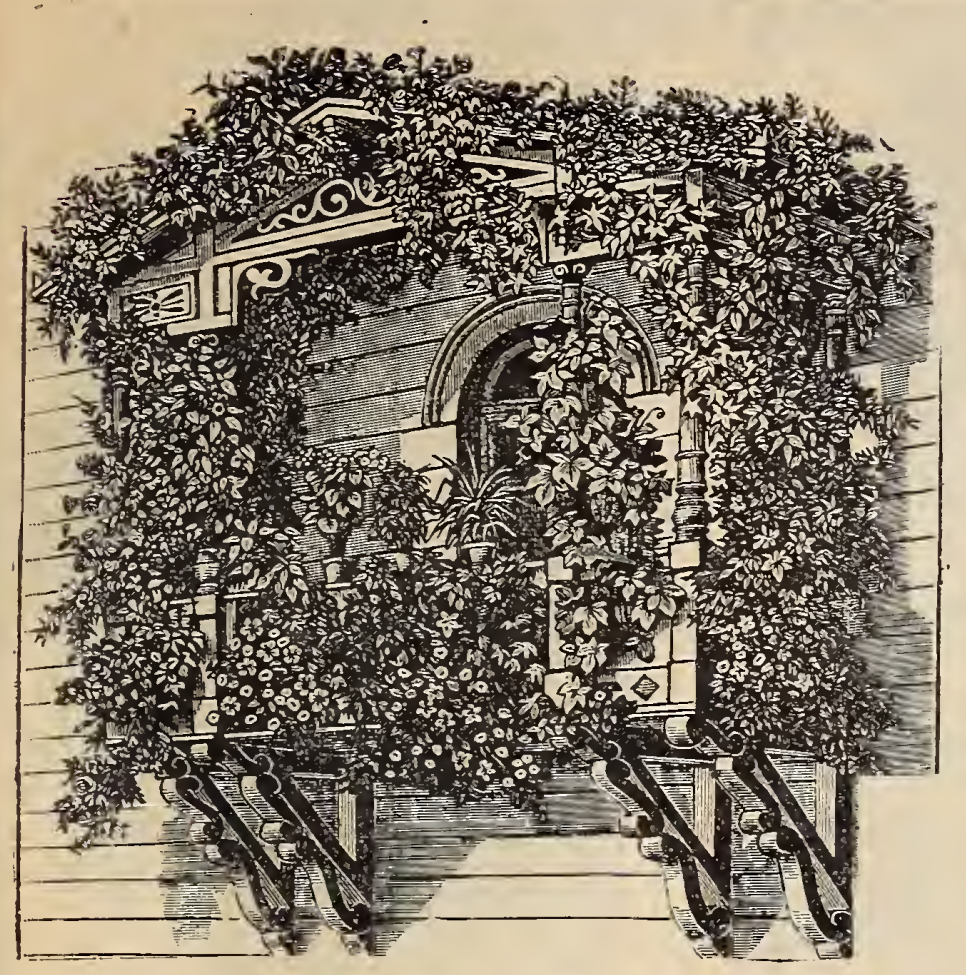

Assorted Vines.

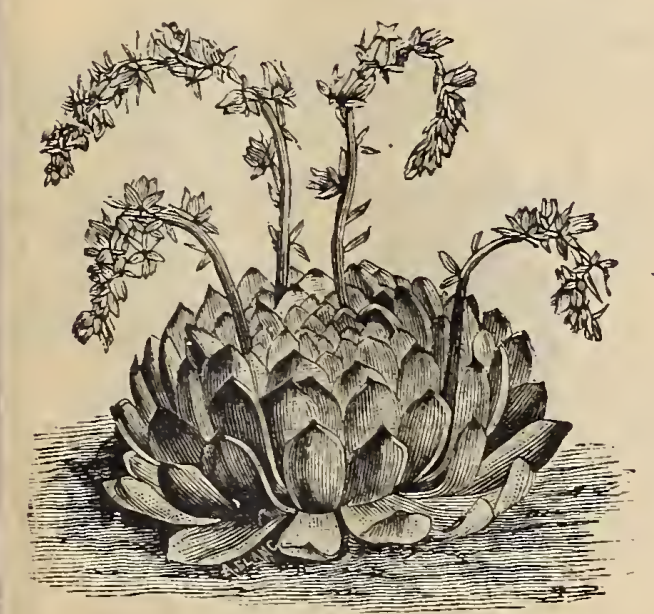

Eeheverias.

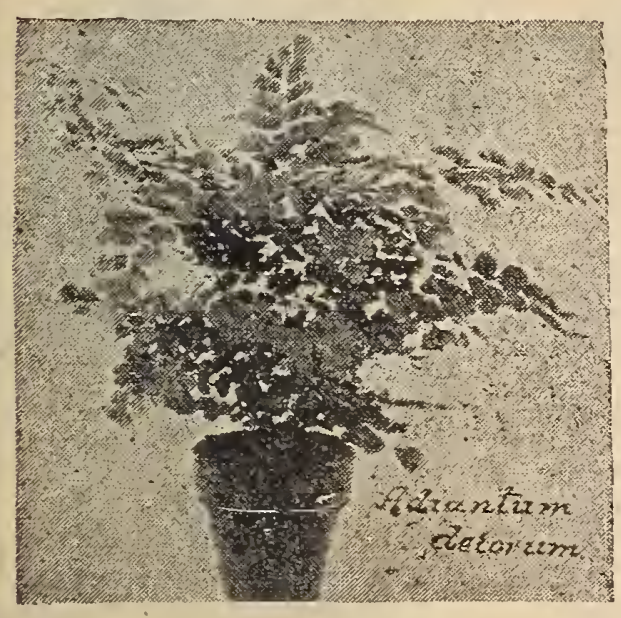

Adiantum.

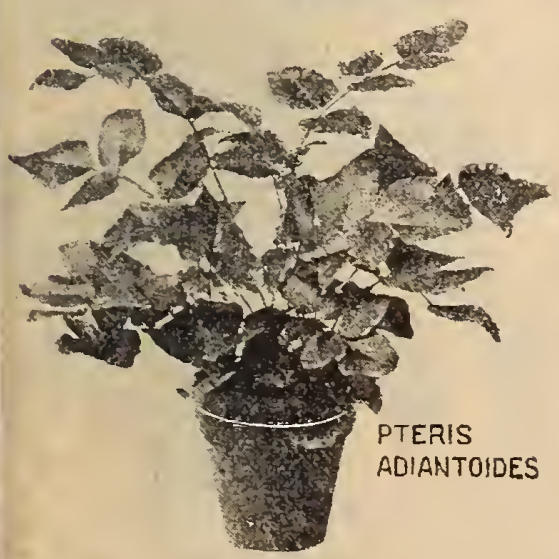
bouquets. $15 \mathrm{c}$ each size. 25c each. quickly. 15c each. 25 c each. 20c each.

\section{VINES AND TRAILING PLANTS.}

Sultable for Plantlag in Hanging Baskets, Vases, Rockeries, Trolllses and Porches.

MESEMRRYANTHEMUM CORDIFOLIUM VARIEGATUM - A beautiful variegated leaved variety of the ordinary Ice Plant, with star-like GROUND IVY, VARIEGATED-It has light green leaves bordered with pure white. Hardy; excellent for cemetery. Each, 10c; $50 \mathrm{c}$ per doz. $\$ 4.00$ per 100 .

LOBELIA-A very pretty running vine with delicate foliage florers a bright lilac, blooms freely. Price $10 \mathrm{c}$ each; 75c per doz.; $\$ 4.00$ per 100 .

VINCAS or PERRYWINKLE. Major Variegata-Variegated foliage, white and green.' $15 \mathrm{c}$ each.

Minor-(Creeping Myrtle). Generally used for planting in cemeteries. 15c each; $\$ 1.50$ per doz: $\$ \$ .00$ per 100 .

Elegans-Leaves dark green with lighter shade of green in center $15 \mathrm{c}$ each.

SMILAX-No climbing plant in cultivation equals this in graceful beauty of foliage (see cut.) Each, 15c; $\$ 1.00$ per dozen.

IVY, German or Parlor-(Railroad Ivy.) Rapid growing vine, leaves light green. $10 \mathrm{c}$ each; $50 \mathrm{c}$ per dozen.

ing in ing in cemeteries and elegant vines for trailing over windows and flower stand $\$ 1.00$ each:

MADEIRA VINE Or IIGNONET TE VINE-The Madeira Vine is a beautiful climber, with thick, glossy, light green leaves and long trusses of mignonette colored flowers: very fragrant. The tuber roots are planted as soon as the danger of frost is over. 5c each: $40 \mathrm{c}$ dozen.

\section{BORDER PLANTS.}

For Edging Flower Beds and Making Special Designs In Flowers on Lawns, Etc.

ALTHERNANTHERAS-Very dwarf grower in three colors : green, striped yellow, browu, striped pink and green striped red. 10c each; $50 \mathrm{c}$ per doz; $\$ 4.00$ per 100

GOLDEN FEVERFEW-A dwarf porder plant, with golden yellow foliage; keeps in good condition all summer. 10c each; 50c per dozen; $\$ 4.00$ per 100 .

CENTUREA GYMNOCARPA, (Dusty Miller)-A white-leaf border plant, growing 6 to $S$ inches high. $10 \mathrm{c}$ each; $50 \mathrm{c}$ per dozen; $\$ 4.00$ per 100

ALYSSSUM, Double-A white-flowering border plant, growing about 4 inches high and flowering the entire summer. 10c each; 50c per dozen: $\$ 4.00$ per 100.

AGERATUM, TOM THUMB-Dwarf, growing in two different colors, light and dark blue. 10c

each; $50 \mathrm{c}$ per dozen; $\$ 4.00$ per 100 .
Variegated-Foliage light, lavender flowers. $10 \mathrm{c}$ each; $50 \mathrm{c}$ per dozen; $\$ 4.00$ per 100

SANTOLINE-A very dwarf-growing plant with variegated foliage. $10 \mathrm{ceach} ; 50 \mathrm{c}$ per doz.; $\$ 4$ per 100.

ECHEVERIA - Hen and Chickens). This variety grows very compact like small balls; color a light green: thrives well in a hot, dry situation, and cannot be surpassed for ma king monogram letters ard on lawns. $10 \mathrm{c}$ each; $75 \mathrm{c}$ per dozen: $\$ 5.50$ per 100 .

GERANIUM, MAD. SALLEROI - A silver-leaf geranium which grows very dwarf and makes an attractive border. $10 \mathrm{c}$ each; $75 \mathrm{c}$ per dozen.

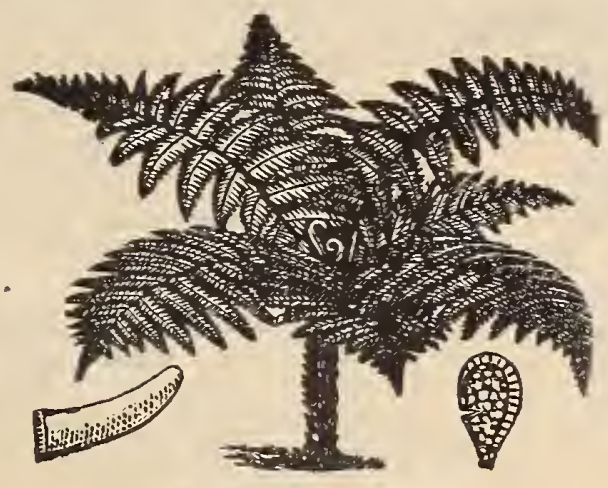

Blechnum Brazilense.

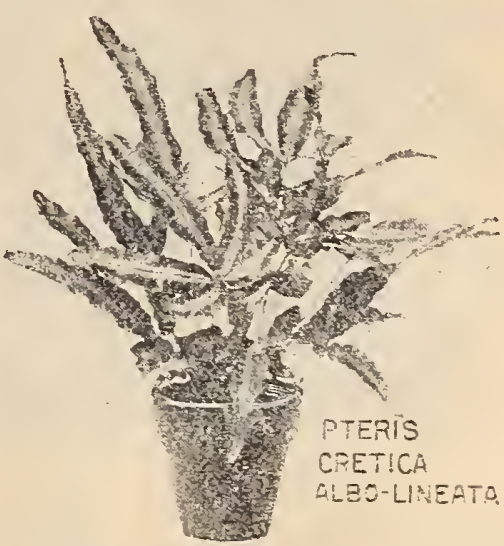

HARDY GROWING FERNS.

ADIANTUM DECORUM-The finest of all the maiden hair. 15c each.

ADIANTUM CUNEATUM-The popular maiden hair fern, the most graceful and useful for

ALSOPFYLLA AUSTRALIS-The Australian tree fern is very robust, and grows to a gigantic

BLENCHNUM BRAZILIENSE-The Brazilian tree fern, 25c each.

CIBOTIUM SCHIEDEI-One of the best tree ferns in"cultivation. Grows to a large size and is as hardy as a palm. Specimen plan $\$ \$ 1.00$ and $\$ 2.00$ each.

ONEPHRODIUM UNDULATEM-(Sword Fern.) lA very graceful fern, growing very easily and

NEPHROLEPSIS DAVALIODES, FURCANS-A highly ornamental production from Jara, with long, deep crested fronds of a glossy green color. 15c each.

PTERIS SERRULATA, CRISTATA NANA COMPACTA-A new and beautiful fern of the Pteris variety, of spreading habit. $25 \mathrm{c}$ each.

PTERIS ARGYREA-A strong-growing fern with large, broad fronds, variegated green and white.

PTERIS ADIANTOLDS-A very hardy fern, dwarf growing, 20c each.

PTERIS CRETICA ALBA LINEATA-Easily grown, variegated white and green. $20 \mathrm{c} \mathrm{each.}$

PTERIS LEPLOPHYLLA-A very handsome dwarf growing variety with silver and green foliage

LARGE SPECIMEN PLANTS of any of the above varieties except Cibotium schiedei for 50 cents each. 


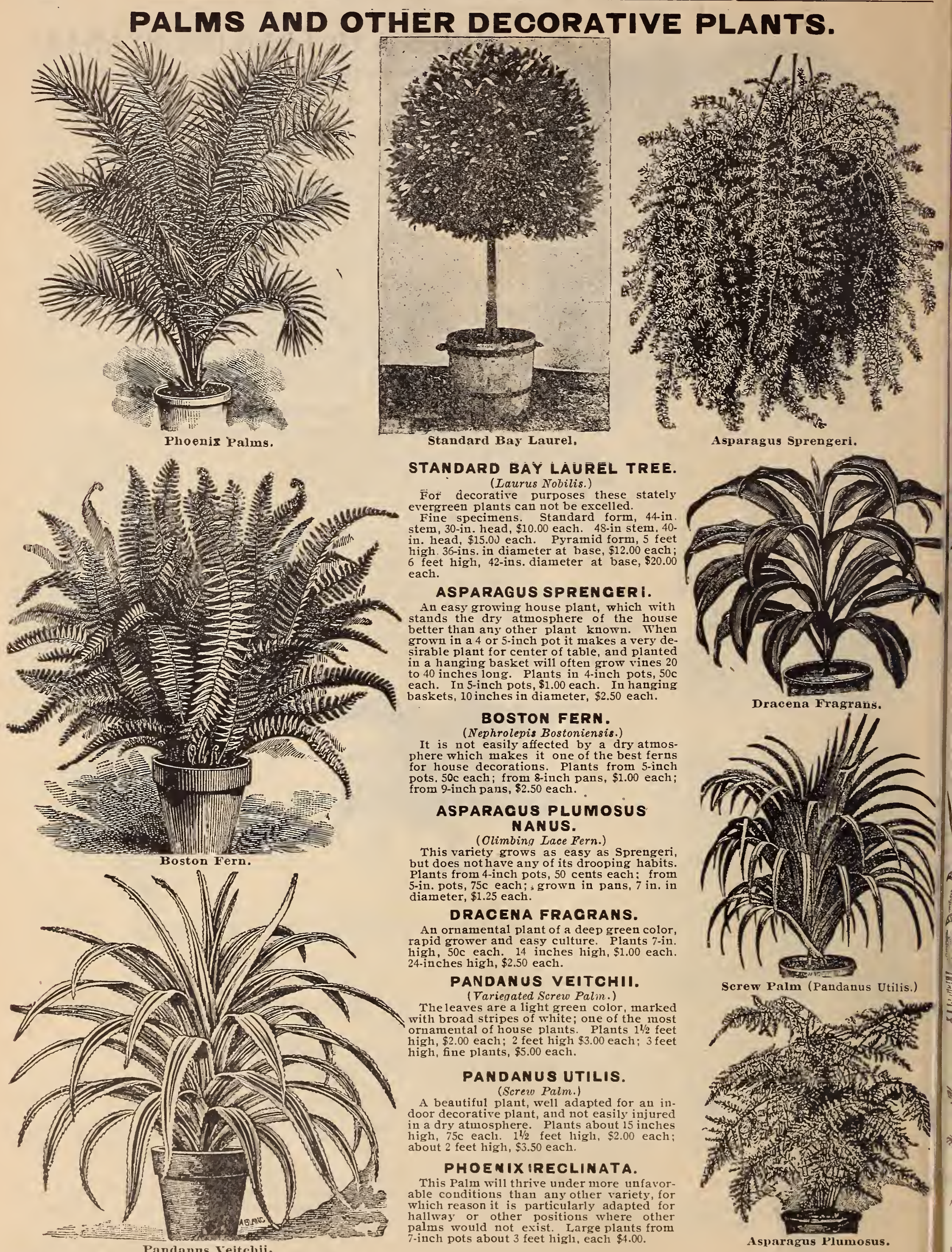

Suitable for house culture, which are grown in choice specimens, that can only be shipped by express. 
PALMS AND OTHER DECORATIVE PLANTS.

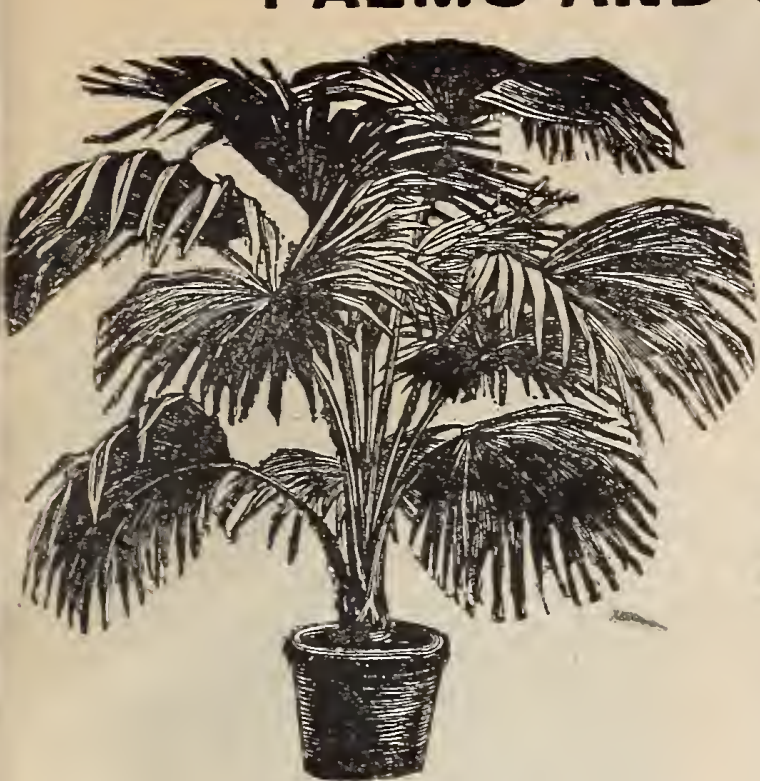

Fau Leaf Palm, (Latania Borbonica.)

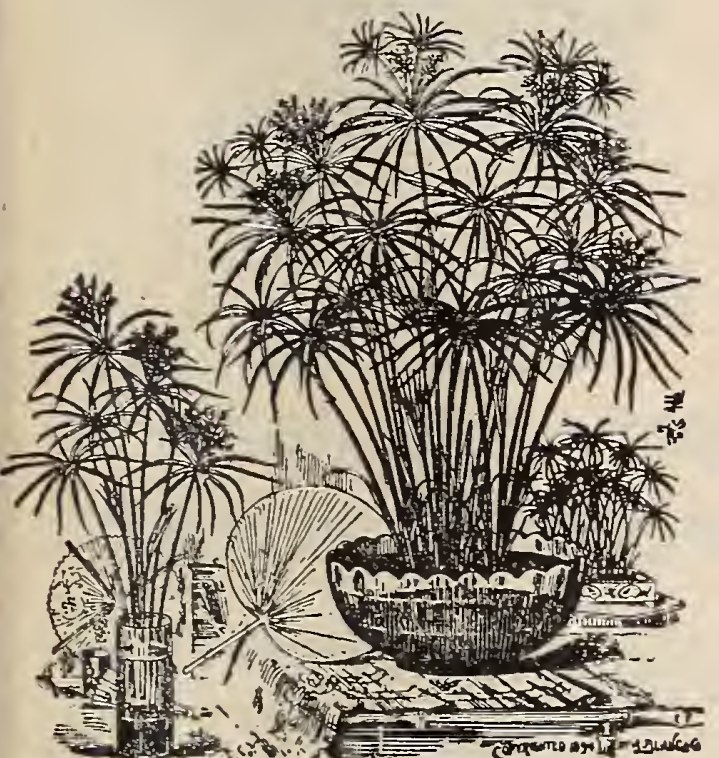

(Umbrella Plant) Cyperus Alternifolius

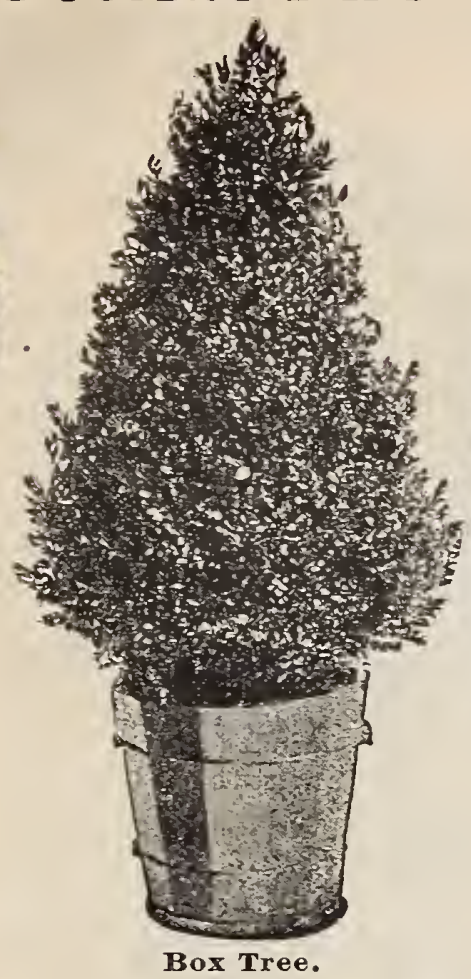

BOX TREE.

These are perfectly hardy, and will stand outdoors all winter without any protection. Valuable for outdoor decoration on porches, etc. Fine specimid form, each,

\section{ARECA LUTESCENS.}

One of the most beautiful plants in cultivation, brig\}t, glossy, green leaves and golden yellow tems. Plants $24_{2}$ feet high, $\$ 1.50$ each; 3 feet high, plants in a pot, $\$ 3.50$ each; 342 feet high, 3 plants in plants in a pot, $\$ 6.00$ each.

\section{LATANIA BORBONICA.}

A strong, hardy variety, useful for general decorative purposes.

Plants from 5-inch pots, $1^{\frac{1}{2}}$ feet high $75 \mathrm{c}$ each. 2 feet high, 3 or 4 leaves, $\$ 1.50$ each; 3 feet high, 5 to (leaves, $\$ 3.00$ each, 3 to 342 feet high. 4 to 5 feet pread, $\$ 6.00$ each.

U M BRELLA PLANT (Cyperus Alternifolius.) A rapid growing decorative plant, most suitable for the center of a table, also grows well in JAPANESE FERN BALLS.

They grow quite freely under the same cultivation given the general variety of house plants, and should be immersed in water quite frequently and do not require a $\$ 1.00$ each.

\section{SANSEVERIA.}

Its stripes are crosswise, with broad white variegations on a dark green ground. They gror to the height of from two to four feet, and will do well anywhere. 50 cents each.

\section{FICUS ELASTICA (Rubber Plant.)}

One of the best plants that can be grown for any decorative purpose. Young plants, from feet high, $₫ \epsilon 11$ to 18 inches high,

\section{ASPIDISTRA.}

This variety has long leaves springing from the pot, which grows erect about eighteen inches high. This is the most durable decorative plant grown. Plants from 5-inch pots, 8 to 10
leaves, $\$ 1.50$.

\section{COCOS WEDDELIANA.}

A small fine growing palm, suitable for the center of a table. Plants from 4-inch pots, about 1 ? inches high, $75 \mathrm{c}$ each.

\section{TRADESCANTIA MULTI-COLOR.} KENTIAS.

Very reliable palm for house decorations, not easily affected by change of atmosphere. Plants from $\$ 1.50$ each, 3 feet high $\$ 2.00$ each. $31 / 3$ feet high, bushy plants, $\$ 3.50$ each; 4 feet high, $\$ 6.60$ each.

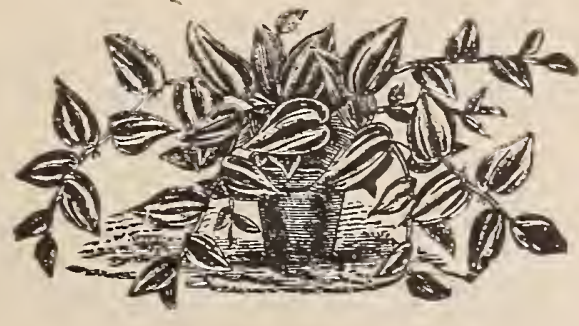

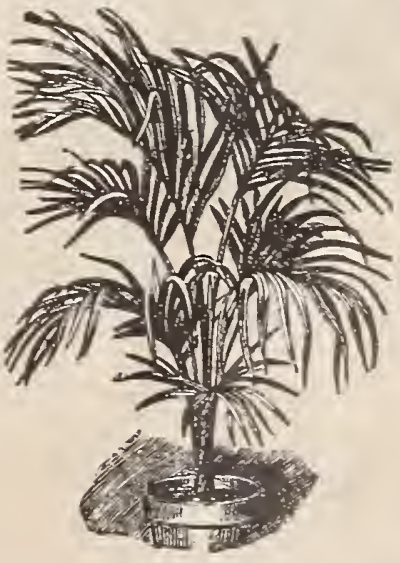

Kentia Palm.

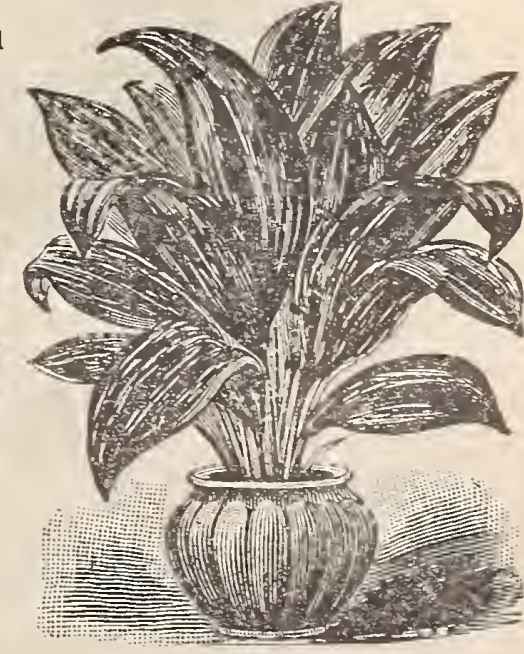

Aspidistra.

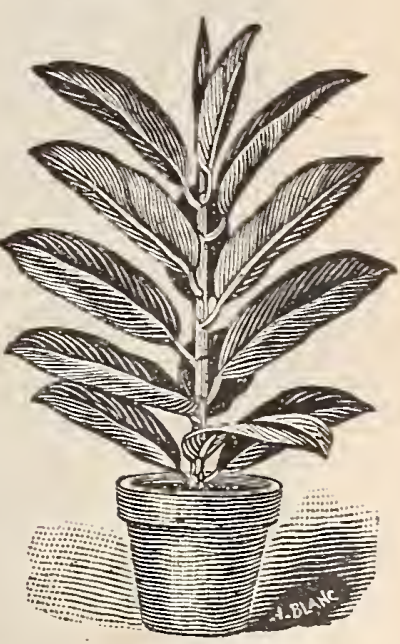

Rubber Plant. 


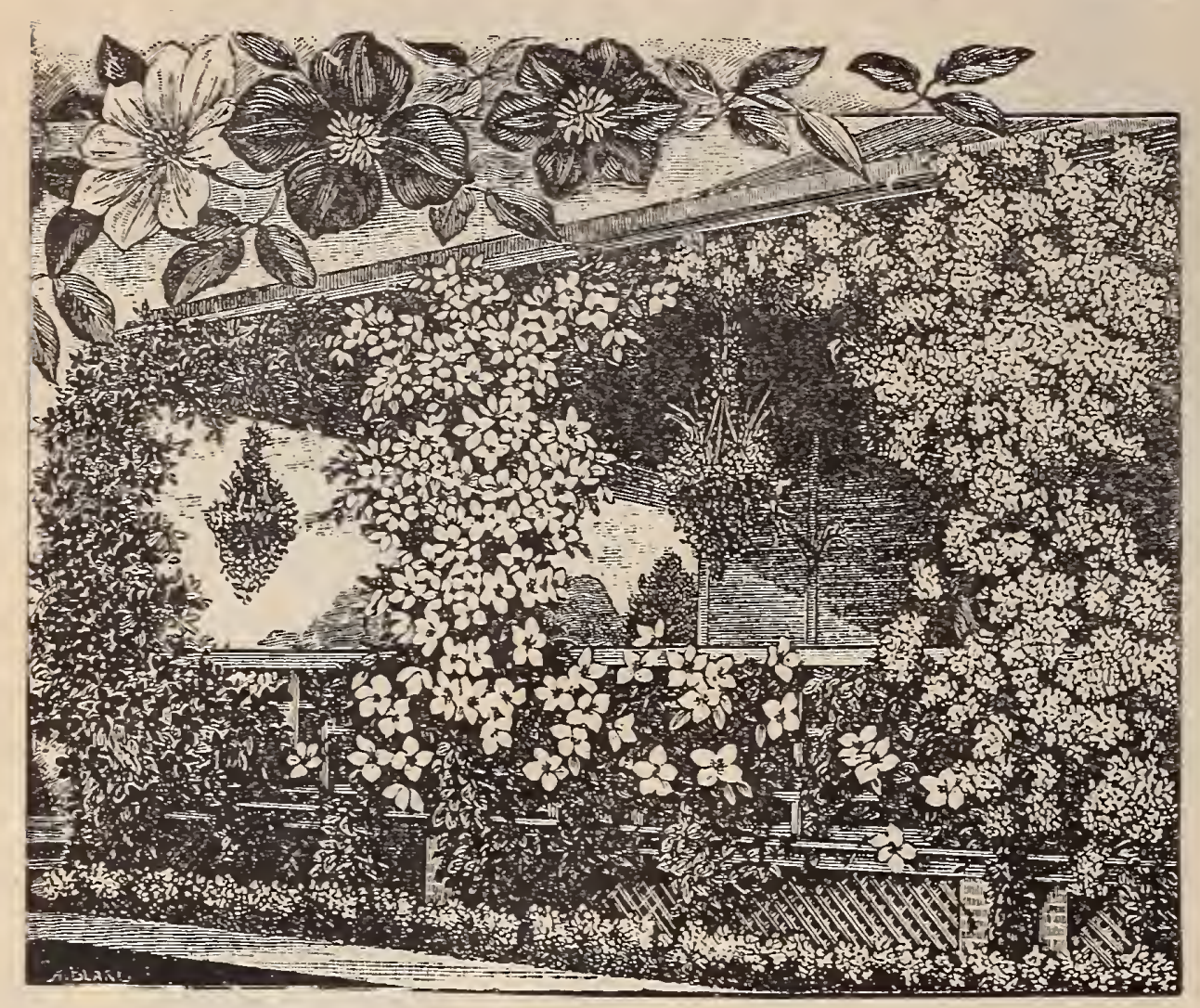

Clematis Jackmanị.

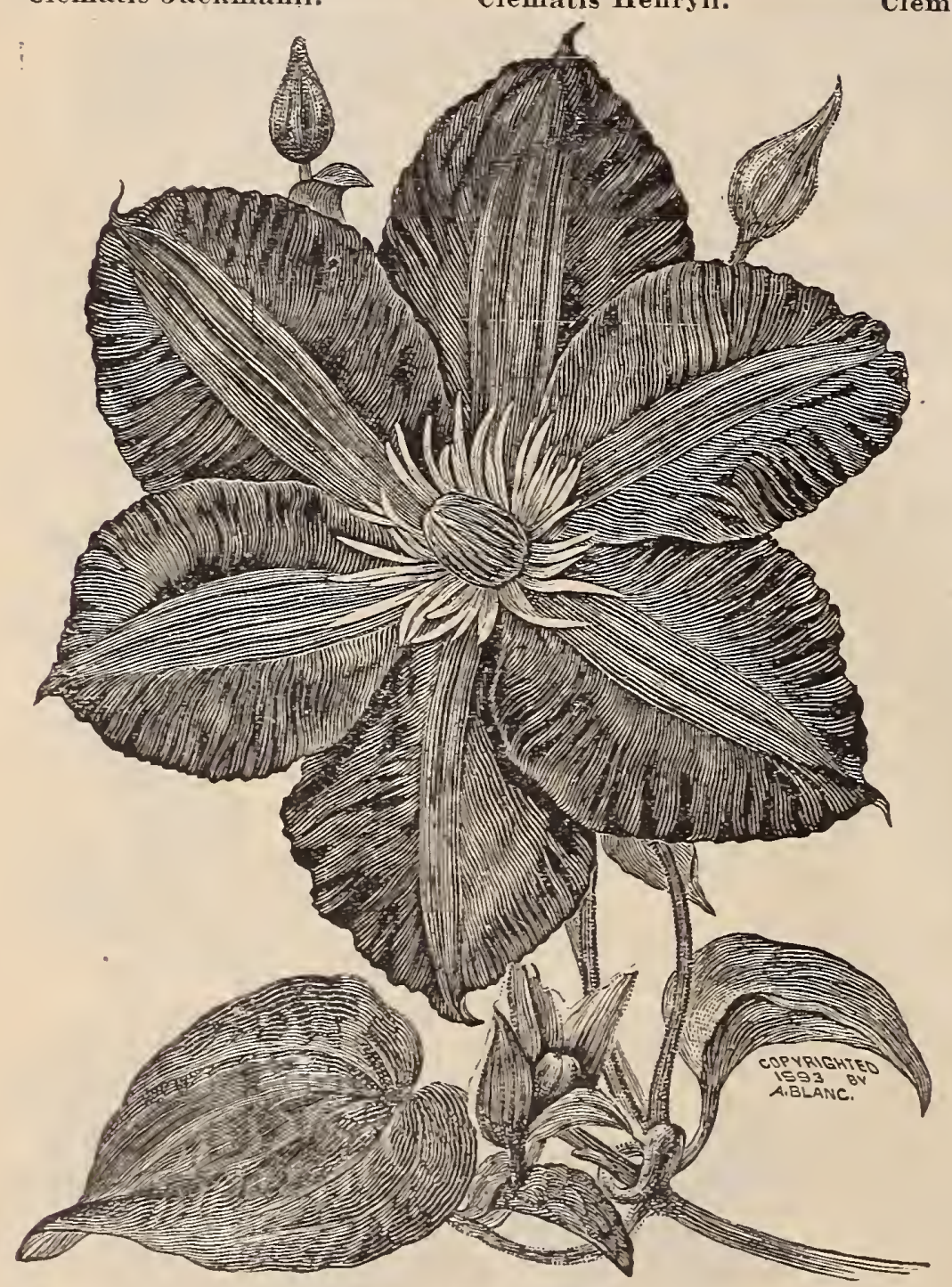

Clematis M. Koster.

NEW HYBRID CLEMATIS COCCINEA.

These are all new species of Clematis, somewhat similar to Coccinea type. The leares are small and the vines do not grow as strong as the well ive when in full bloom. The flowers are borne in great profusion during M. KOSTER-An exceedingly strong grower, which is not subject to any disease. Color, a dark purple, very fine. Each, 75c.
COUNTESS OF ONSLOW-Color à beautiful bright violet purple.

Each, 75c.

DUCHESS OF ALBANY-Bright pink shading to deeper color in center. EACh, ${ }^{75}$.
SPECIAL OFFER-The Set of 4 Varietiss for $\$ 2.00$.

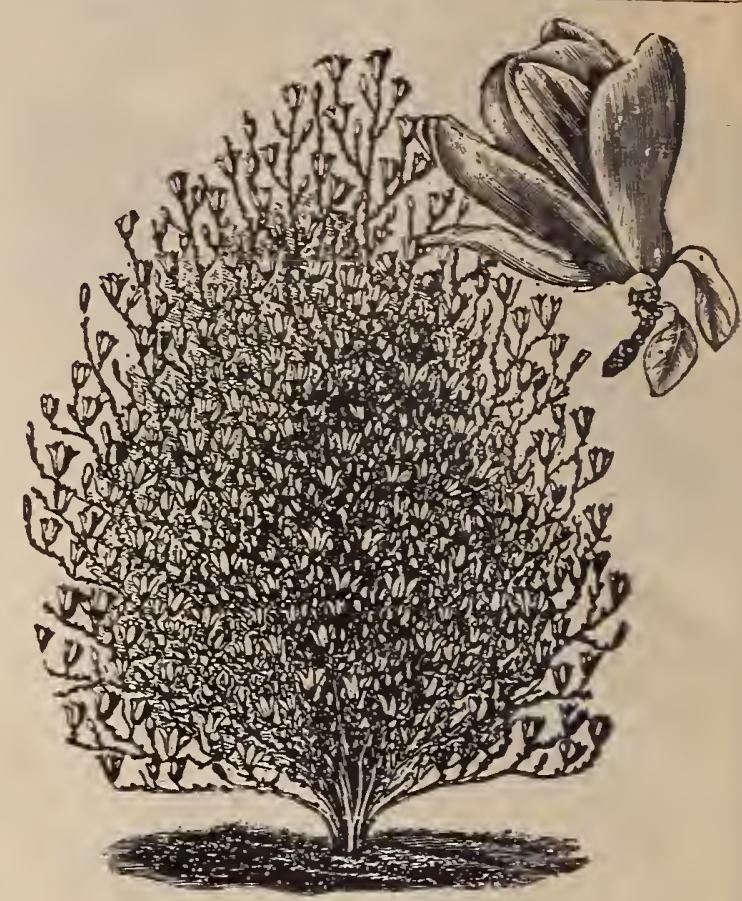

Magnolia Soulangeana.

\section{MAGNOLIA.}

\section{Two Hardy Fiowaring Shrubs that Live Out- doors Without Protection in Our Latitude.}

SOULANGEANA-Foliage large, glossy and massive growing into ree form: very profuse bloomer, color white and purple, strong plant, four feet high, well branched. $\$ 2.50$ each.

ALEXANDER-Flowers large, color white and red, and exceedingly ree bloomer. The flowers remain on the tree longer than any othe variety. Size 4 feet high; $\$ 2.50$ each.

\section{RAPID GROWING HARDY CLIMBING VINES. HOP VINE.}

Common. One of the very best climbers for covering unsightl piaces. It is a rapid grower and bears a profusion of seed pods suitable for many domestic purposes. $5 \mathrm{c}$ each; $50 \mathrm{c}$ per dozen.

Variegated. A golden leaved variety of the common Hop rine possessing the same strong climbing habit and hardiness but with bright per dozen.

\section{CLEMATIS.}

A beautiful class of hardy climbers, many of the rarieties with flowers five to seven inches in diameter. Excellent for pillars, trellises or when used for beding or running over rock mork or an old tree hardy. Need no protection in the winter.

$$
\text { These are strong } 2 \text { year old plants. }
$$

DUCHESS OF EDINBURG-Fine large flowers, light lavender very fine. $75 \mathrm{c}$ each.

HENRYII-Creamy white, rery large and fine shape, free grower and bloomer. $75 \mathrm{c}$ each.

JACKMANII-Flowers when fully expanded 4 to 6 inches in diameter, intense violet purple with a rich velrety appearance, distiuctly eined. It flowers continually from July until cut off by frost. $75 \mathrm{c}$ each

MAD. BARON VEILLARD-Flowers large light rose with lilac hading. $75 \mathrm{c}$ each.

SIEBOLDYA, (Boskoop Seedling)-A strong, rampant grower, and a true perpetual bloomer, flowers appearing on the last year's growth season; color deep rirh lavender. Price $75 \mathrm{c}$ each.

PANICULATA-One of the inost valuable of all hardy flowering vines, of exceedingly rapid growth, soon reaching a height of flfteen or forers borne in cret masses of panicles or clusters on long stems, so flowers bor withe profuse as to fairy corer the plant with a have ceased. 25c each; extra large field grown roots, 50c each. (Gee illustration on front page of cover.)

SPEOIAL OFFER-The full set of 7 choice varieties for $\$ 8.50$. 


\section{HARDY VINES AND CLIMBERS.}

Suitable for climbing on Verandas, Trellises, \&c.

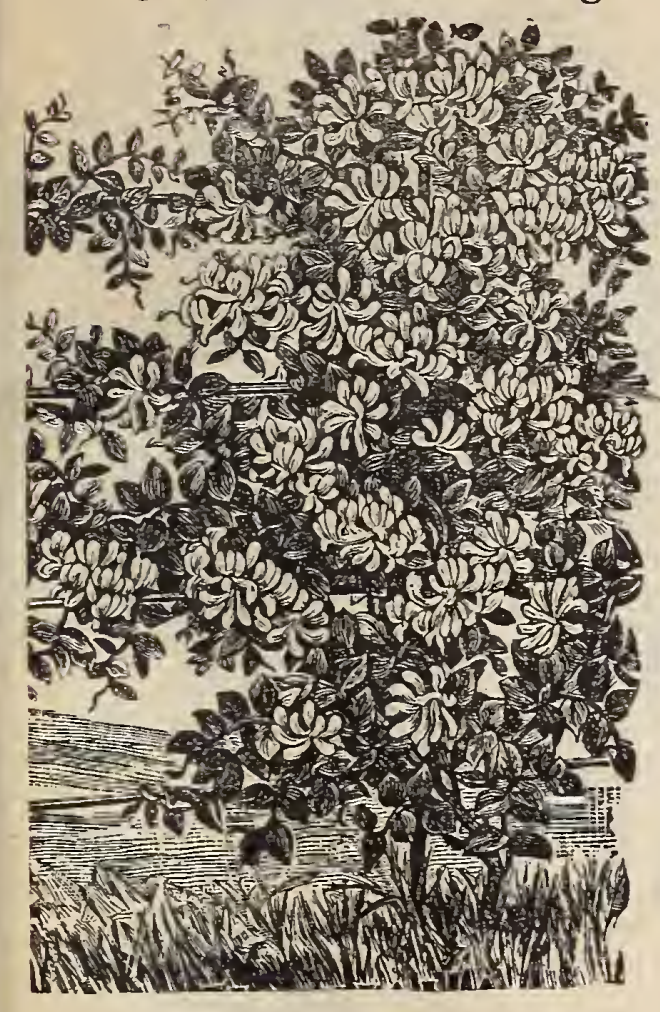

Honeysuckles.

HONEYSUCKLE.

HALLEANA. - It is evergreen and a constant bloomer; flowers pure whi e, changing to yellow; very fragrant, good for trellis or pillar. $25 \mathrm{c}$ each: extra large plants, $50 \mathrm{c}$ each.

SCARLET TRUMPET OR CORAL.-Very trong rapid grower, producing beautiful scar let flowers all summer; foliage very fine, thick and heary. $25 \mathrm{c}$ each; large plants $50 \mathrm{c}$ each.

MONTHLY FRAGRANT OR DUTCH.-A fine rapid growing vari ety, flowers large and very fragrant, color red and yellow, a constant bloomer. 25c each; extra large plants 50c each.

FELLOW TRUMPET. $-F$ ine grower; yellow flowers. 25c each; extra large size plants, $50 \mathrm{c}$ each.

\section{AMPELOPSIS VEITCHII.}

This is the most deservedly popular of all climbing plants, being entirely hardy in the most exposed places, attaining a height of thirty feet in two or three years, clinging to stones, brick or woodwork with the greatest tenacity. During the summer the leaves are a rich shade of green and lap over each other with great regularity, like a coat of mail, or like slates on a roof. But it is in the fall that it shows its exquisite beauty; the leaves then change to the brightest tints of scarlet, crimson and orange, so dazzling as to be seen at a great distance.

First size, extra strong pot grown, 2 to 3 feet, $35 \mathrm{c}$ each, $\$ 3.50$ per doz. Second size, 1 to 2 feet, $25 \mathrm{c}$ each, $\$ 2.50$ per doz.

Third size. 6 to 9 inches, $15 \mathrm{c}$ each, $\$ 1.50$ per doz

\section{AMPELOPSIS QUINQUEFOLIA.}

(American Ivy or Virginia Creeper.)

A strong, rapid grower, clinging firmly to walls, brick and stone or wood without support. $25 \mathrm{c}$ each.

\section{BIGNONIA RADICANS.}

(Trumpet Creeper.)

A splendid climbing plant, suitable for covering dead trees, walls fences. etc., producing large clusters of trumpet-shaped orange red flowers in August, about three inches long; very handsome in bud, as well as in flower. 25c each.

\section{WISTERIA.}

SINENSIS (Chinese Glycene)-The favorite variety, producing thousands of pendulous clusters of delicate violet blue blossoms, richly per fumed. 50c each.

SINENSIS ALBA. - Of similar habit to Sinensis, with pure white flowers, A lovely climber, 50c each.

SINENSIS ALBA FLORA PLENA. -This is similar to the other varieties of Wisteria in growth, the flowers are much larger, pure white and perfectly double.

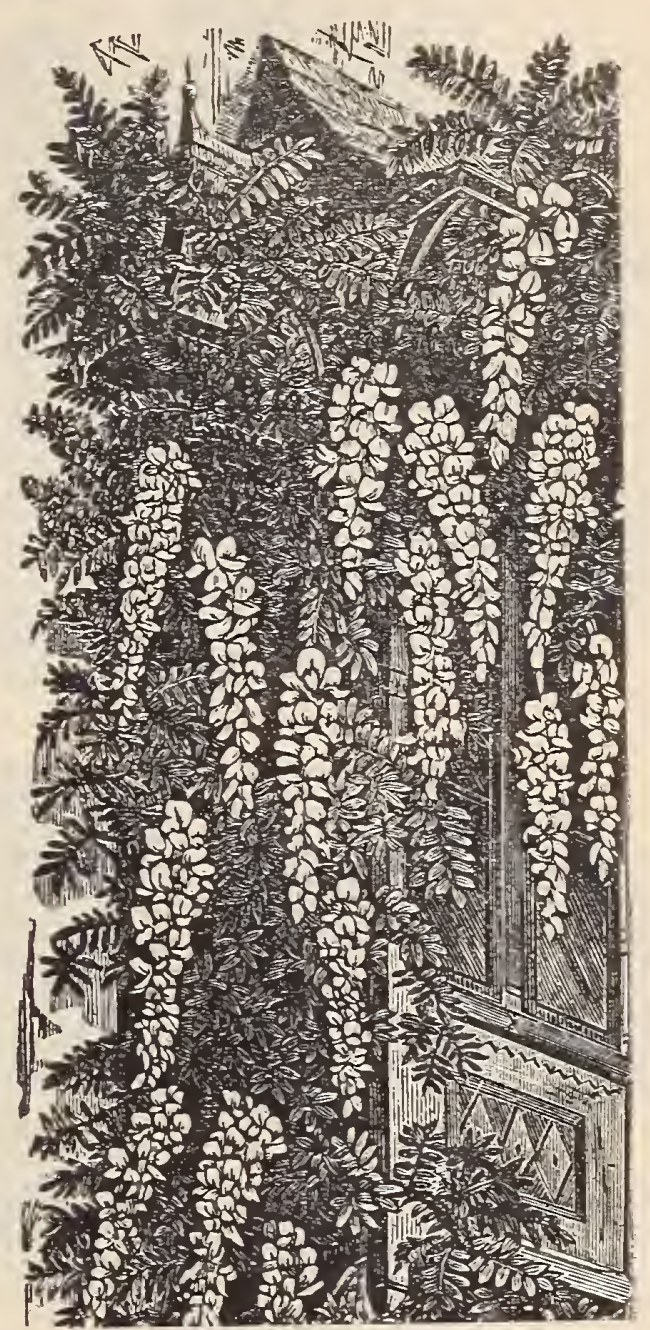

Wisteria.

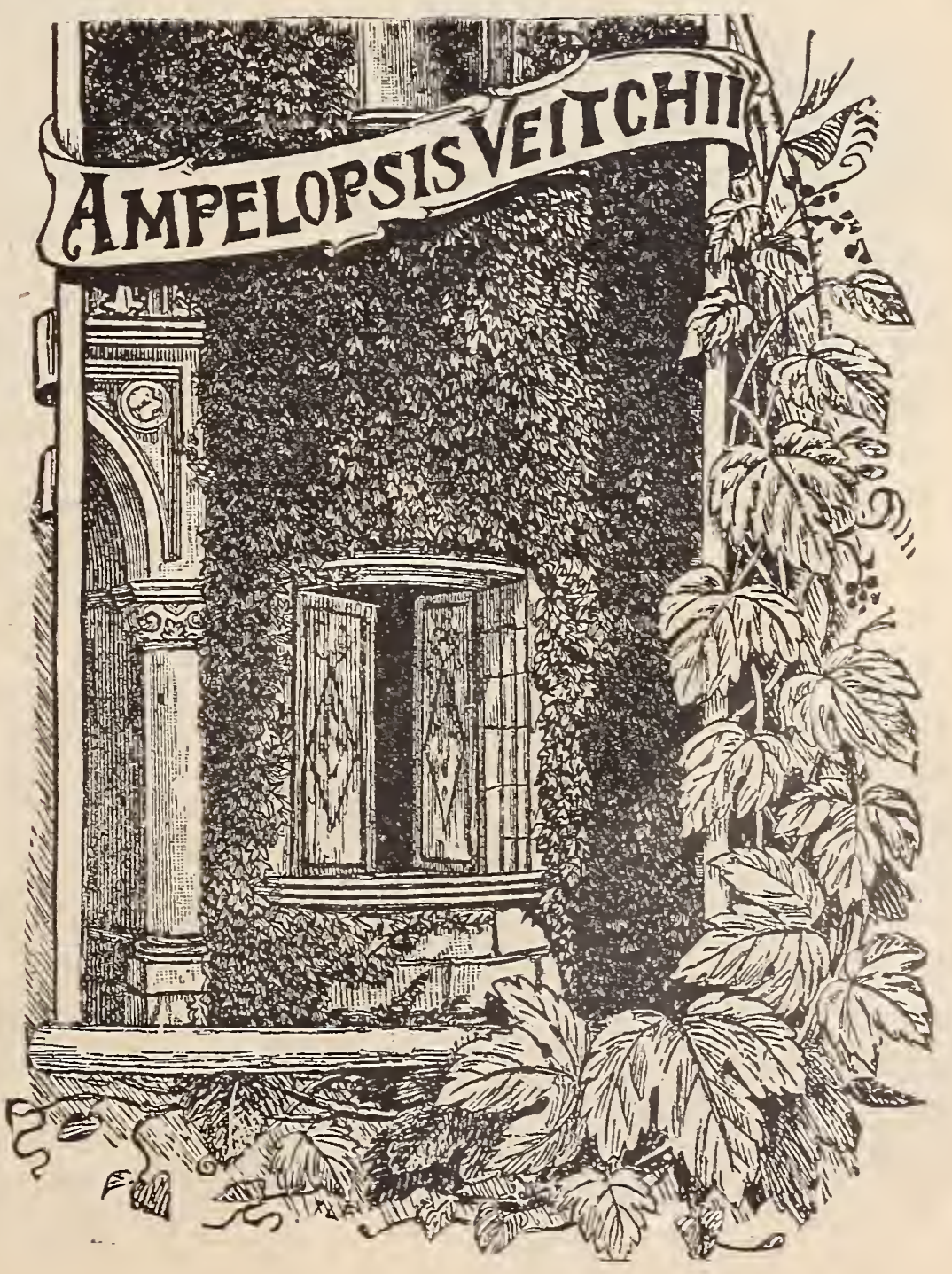




\section{Hardy Herbaceous Plants.}
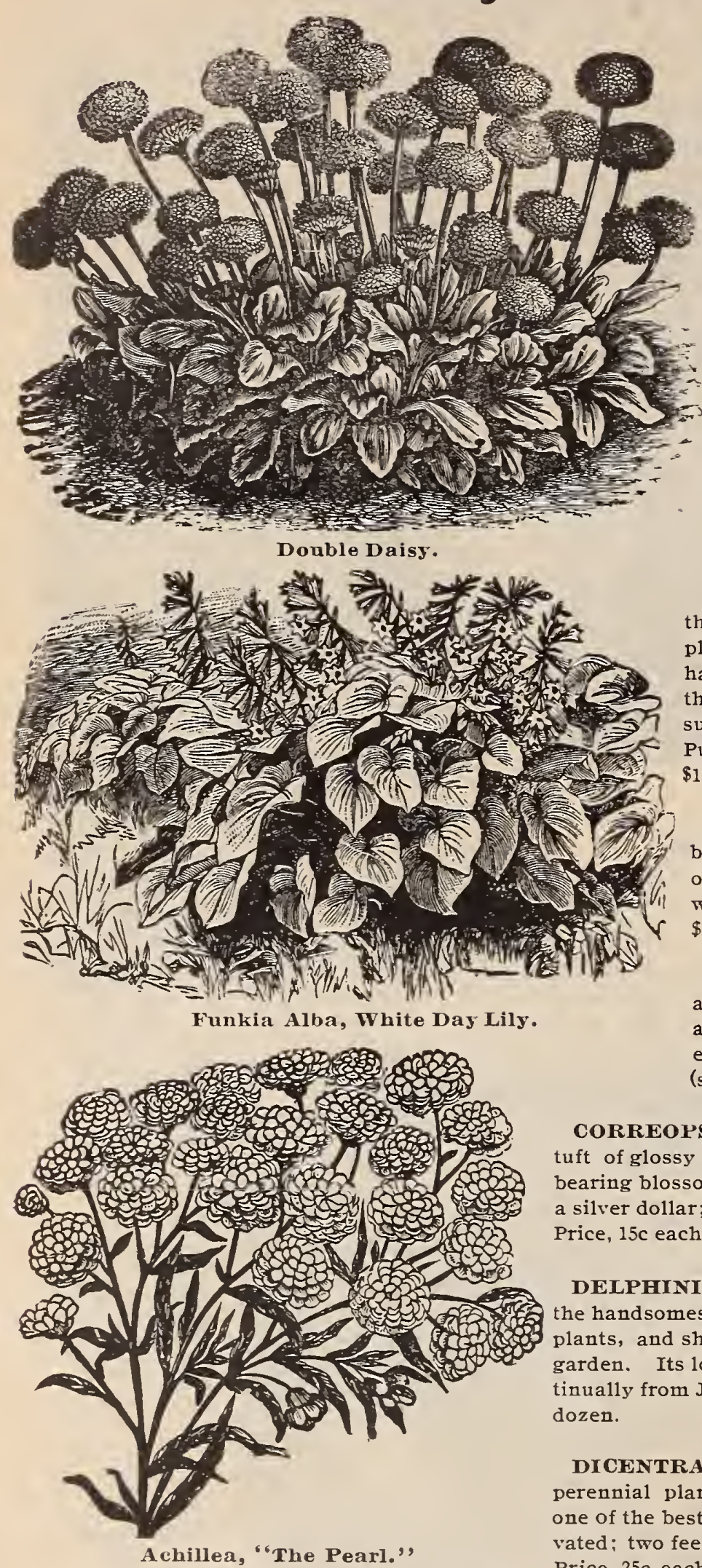

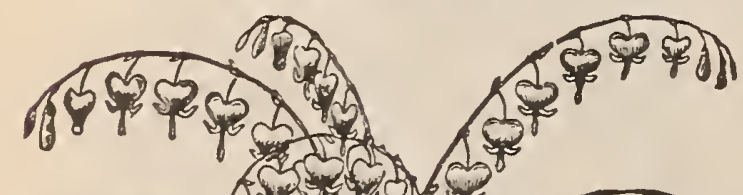
is -3 in 69 -

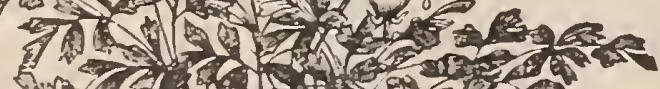
are 1 l m

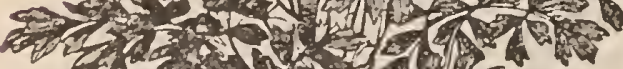
(6) 5 . aํ.

Dicentra Spectabilis. dozen. $\$ 1.50$.

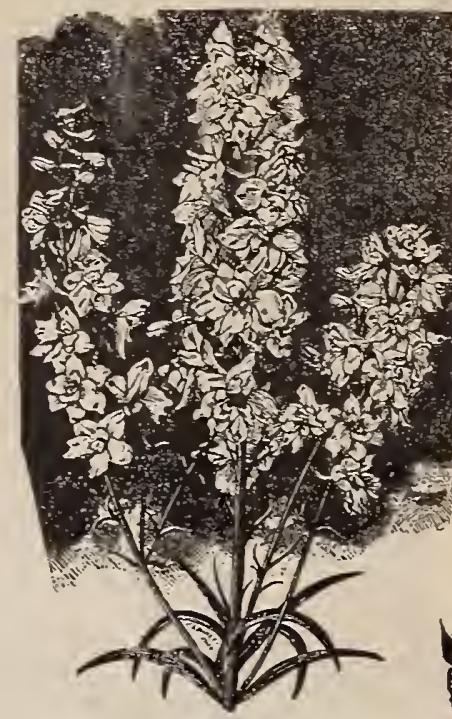

Delphinium Formosum.

ACHILEA PEARL-One of the very best white-flowered plants for the border, perfectly hardy. The flowers are borne in the greatest profusion the entire summer, on strong erect stems.

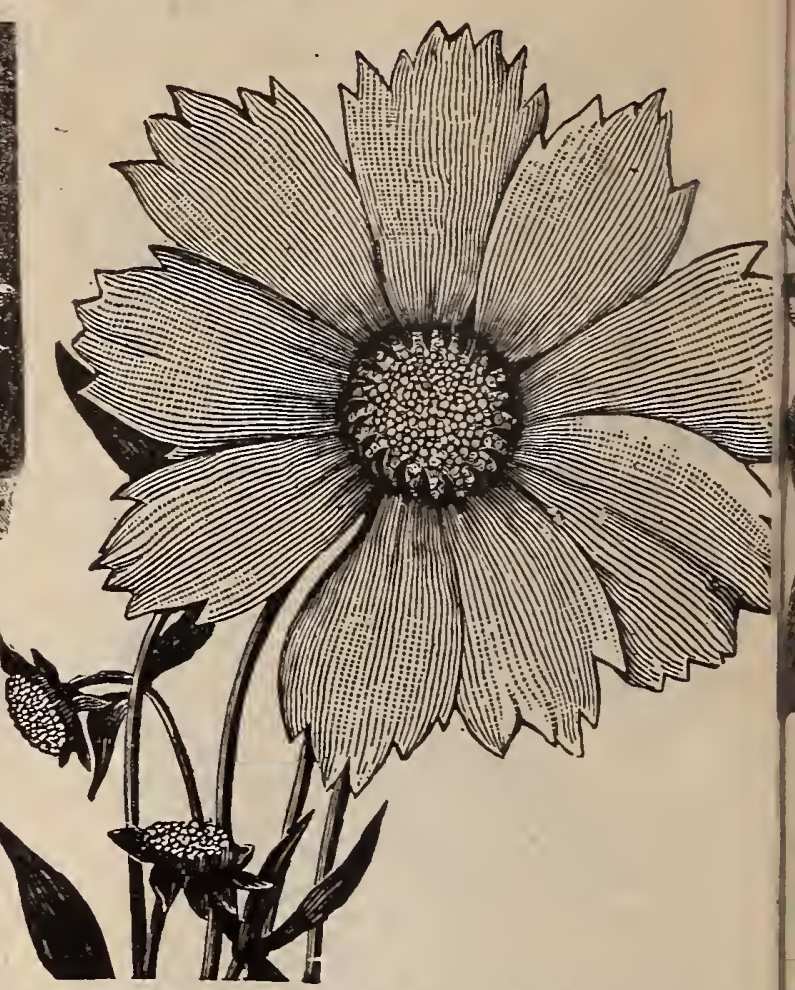
Pure white in color. $15 \mathrm{c}$ each;

Correopsis Lanceolata Grandiflora.

AQUILEGIA CERULEA-A fine species with broad flowers, often 3 inches in diameter. The outer sepals are deep lilac or blue, petals white, while the deep blue spur is tipped green. $15 \mathrm{c}$ each $\$ 1.50$ per doz.

AQUILEGIA CHRYSANTHA-Grows two and a half feet high forming a bush two or three feet across. which is covered for two months, with golden yellow flowers with long spurs perfectly hardy (see cut). 15c each; $\$ 1.50$ per doz.

CORREOPSIS LANCEOLATA-This plant makes a dense tuft of glossy foliage, which is rich and bright until hard frosts, bearing blossoms of the most brilliant golden yellow, as large as a silver dollar; entirely hardy and will grow in any soil (see cut). Price, $15 \mathrm{c}$ each; $\$ 1.25$ per doz.

DELPHINIUM FORMOSUM (Perennial Larkspur).-One of the handsomest and most satisfactory of all the hardy herbaceous plants, and should be planted extensively even in the smallest
garden. Its long spikes of bright blue flowers are produced congarden. Its long spikes of bright blue flowers are produced con-
tinually from June until frost (see cut). Price, $15 \mathrm{c}$ each; $\$ 1.50$ per

DICENTRA SPECTABILIS (Bleeding Heart). A hardy

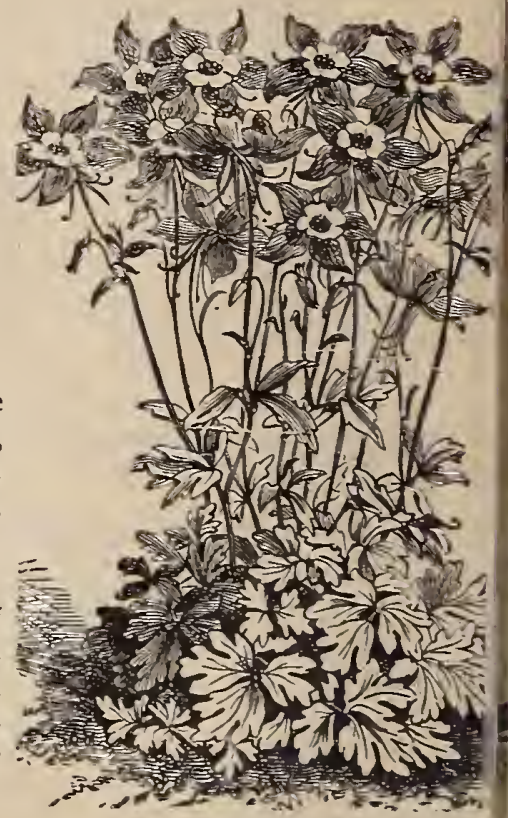
Aquillegia. perennial plant with rose-colored flowers in great abundance; one of the best border plants; perfectly hardy and easily cultivated; two feet high; flowers in April or May (see cut). Price, 25c each.

DAISY DOUBLE-A very pretty border plant, in two colors, pure white and rose, large size flowering clumps (see cut).5c each, 50 c per doz.

FUNKIA ALBA (White Day Lily)-Showy plants, and this is the best of the class. Beautiful, broad ovate leaves, with large, lily like, pure white, fragrant flowers in large clusters (see cut'. Price, 20c ea $: h ; 6$ for $\$ 1.00$.

GAILLARDIA, HARDY GYPSY QUEEN-This is an improvement over the older varieties. The coloring is something gorgeous. The center is dark, reddish brown, while the petals are orange, crimson and red. It is perfectly hardy, increasing in size and beauty from year to year. Very freeflowering (see cut). Each $15 \mathrm{c}$; per doz.

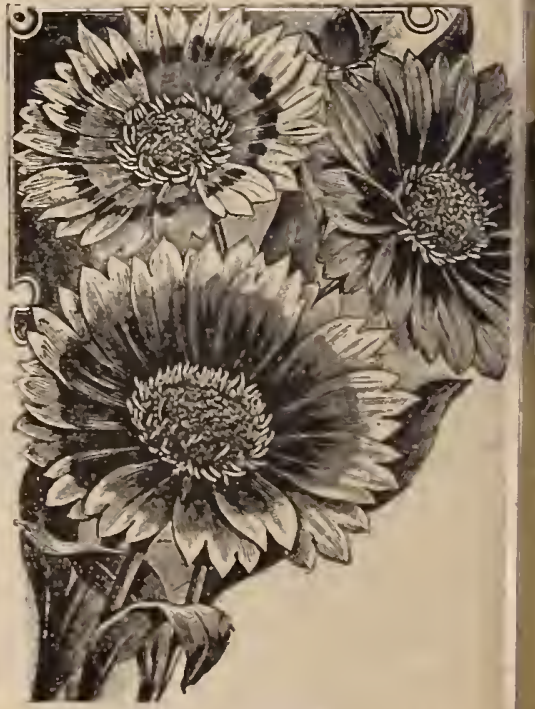

Gaillardia, Gypsy Queen. 

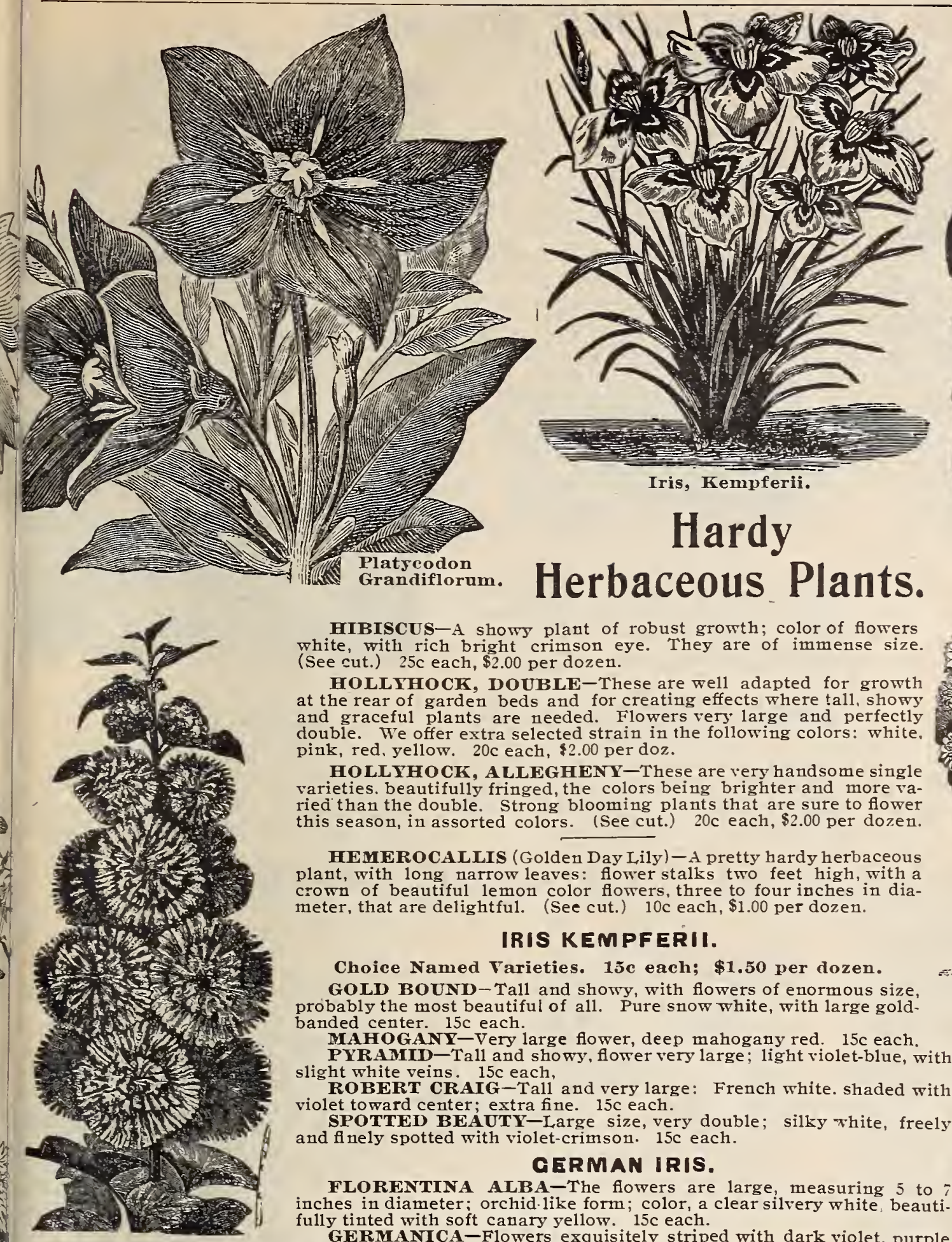

Hollyhock.

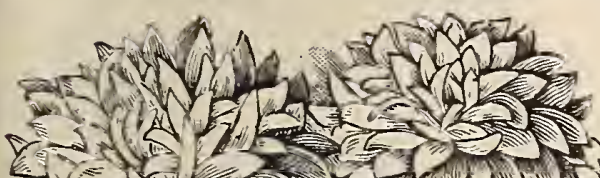

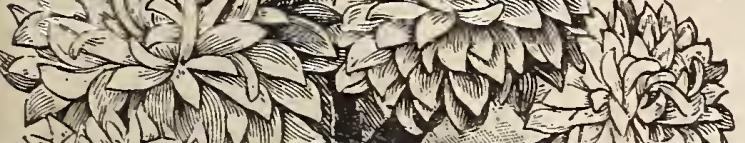

(5)

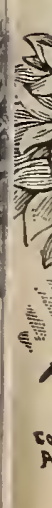
sis 3

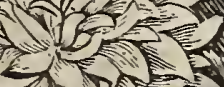

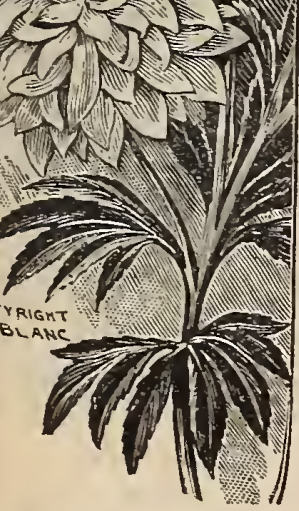

1)

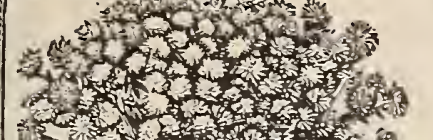

IRIS KEMPFERII.

Choice Named Varieties. 15e each; $\$ 1.50$ per dozen. GOLD BOUND-Tall and showy, with flowers of enormous size,

MAHOGANY-Very large flower, deep mahogany red. $15 \mathrm{c}$ each.

ROBERT CRAIG - Tall and very large: French white. shaded with SPOTTED BEAUTY-Large size, very double; silky thite, freely

\section{GERMAN IRIS.}

FLORENTINA ALBA-The flowers are large, measuring incer orchid.like form; color, a clear silvery white beauti-

GERMANICA-Flowers exquisitely striped with dark violet, purple
GER winted with soft canary yellow. $15 \mathrm{c}$.

\section{PAEONIES.}

A very showy and most useful class of hardy plants. They are exceedingly hardy, and will
flourish in any section of the country, no matter how cold: colors, white, pink, crimson. (See PLATYCODON.

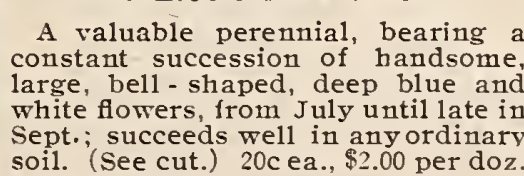

\section{RUDBECKIA.}

LACINITA, fi. pl. Golden Glow perennials, flowering from August
until frost: throwing up masses of large, double yellow flowers.

MAXIMA-A rare and attractive oval glaucous, green foliage and immense flowers, frequently 6 in. across,
of bright yellow with a cone 2 inches long. It flowers continuously from June to septem
SUNFLOWER. DOUBLE DWARF. (Helianthus Multiflorus, pl.)

Grows about 3 to 4 feet high, bearing numerous large golden colored flowers as large as dahlias, continuing in bloom until

udbeckia, Golden Glow. frost. (See cut.) Each, extra size, 15c: $\$ 1.50$ per dozen. ight whicher -One of the most desirable of hardy

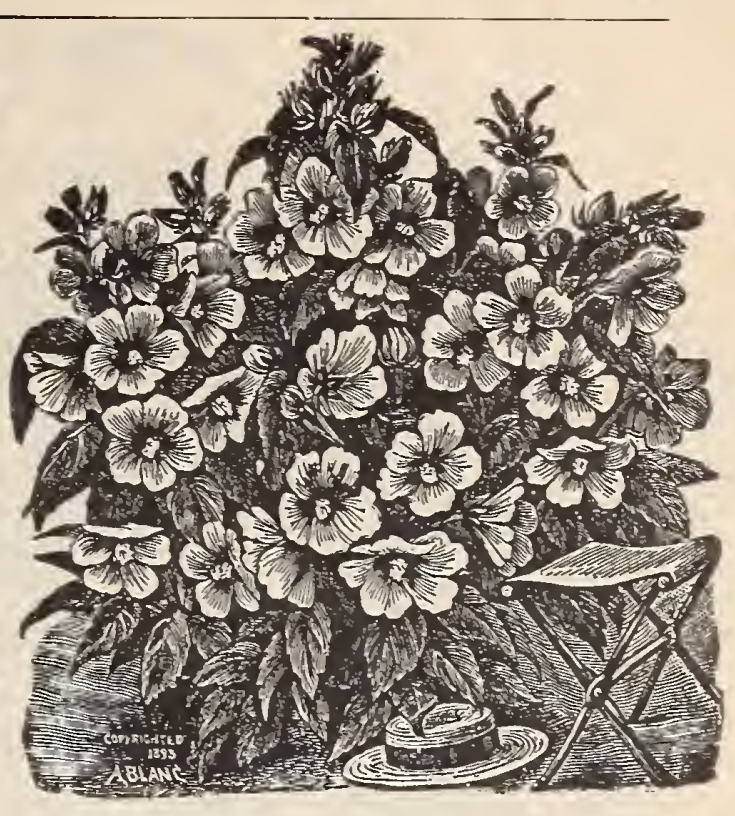

Hybrid Hibiscus.

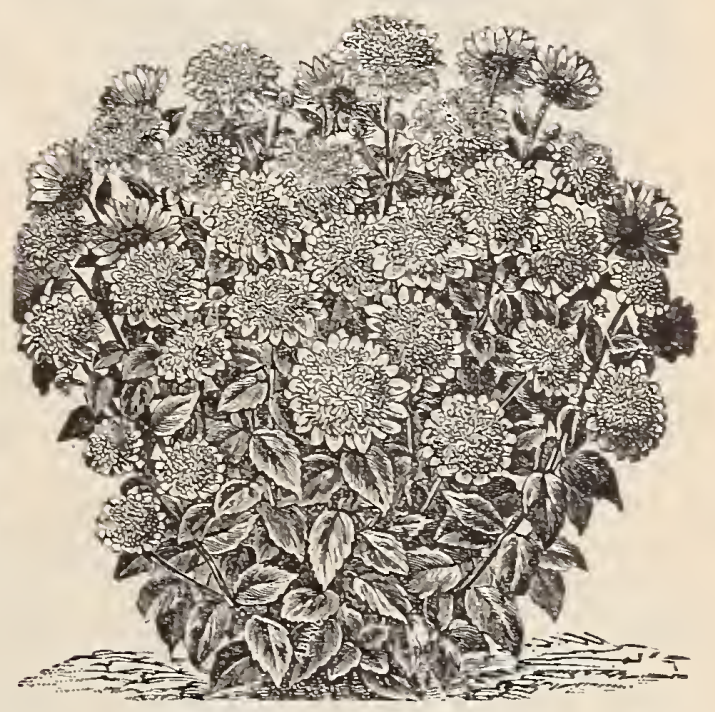

sunflower, Double Dwarf.

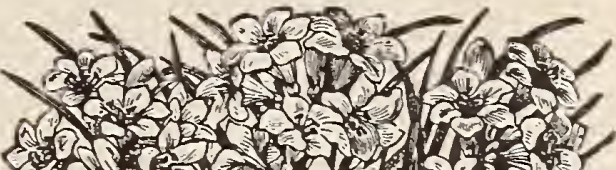
S.) 7.1. 3 . 110 to \&)

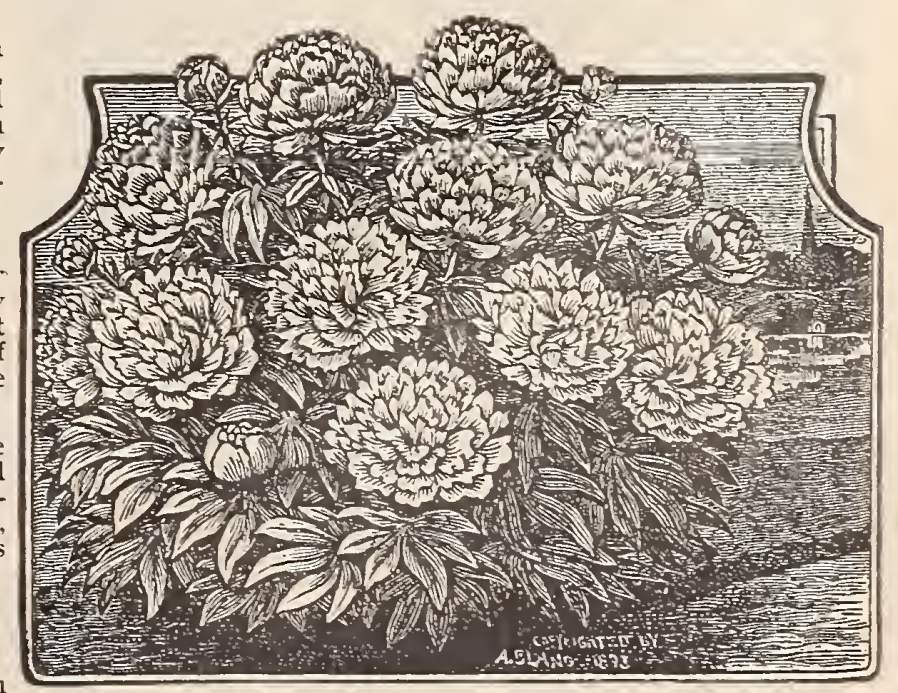




\section{HARDY HERBACEOUS PLANTS.}

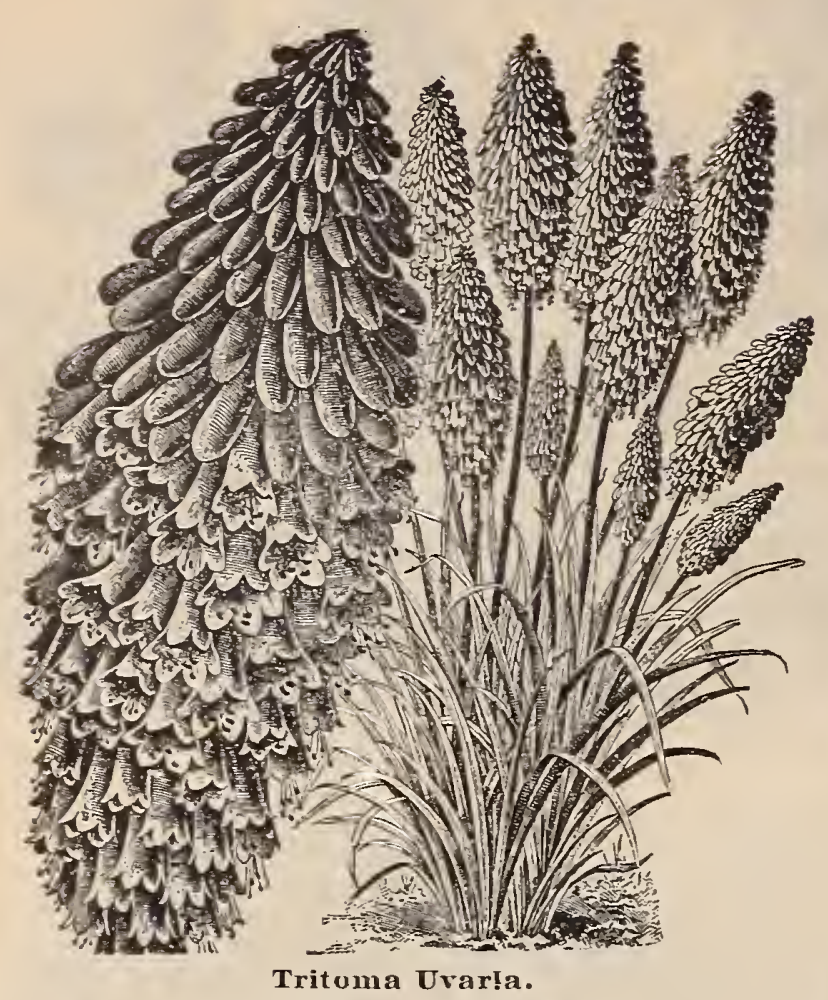

TRITOMA UVARIA.

\section{Flame Flowers.)}

An attractive summer and autumn flowering plant. producing tall spikes of bright orange red flowers. Commonly known as "Flame Flower" or "Red Hot Poker PIant." (See cut.) 25c each.

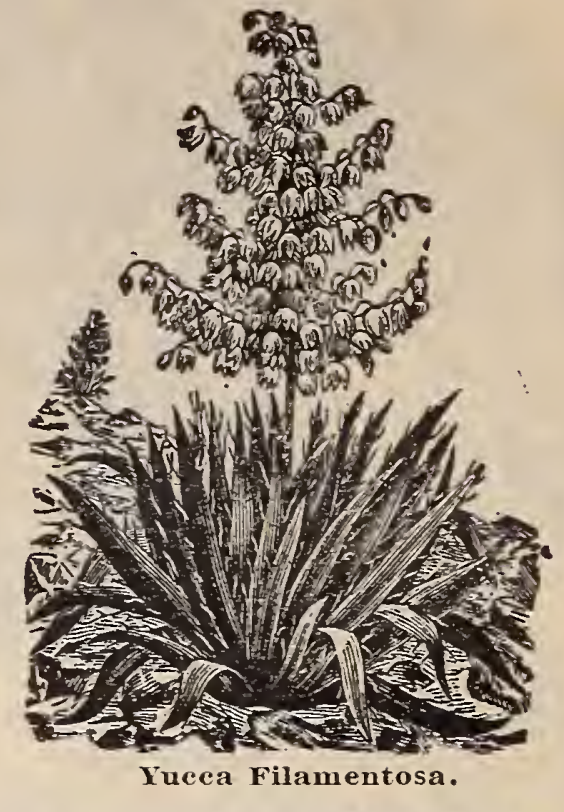

YUCCA FILAMENTOSA.

An evergreen. The flower stalks are 4 to 5 feet high, with 50 to 200 bell-shaped, creamy arms. Hardy. (See cut.) 35c. each.

\section{VINCA MINOR CERULEA.}

Grows close to the ground; invaluable for carpeting the ground in shady places. Largely used for covering graves, for which purpose no plant is so wel
$10 \mathrm{c}$ each. $\$ 1.00$ per dozen.

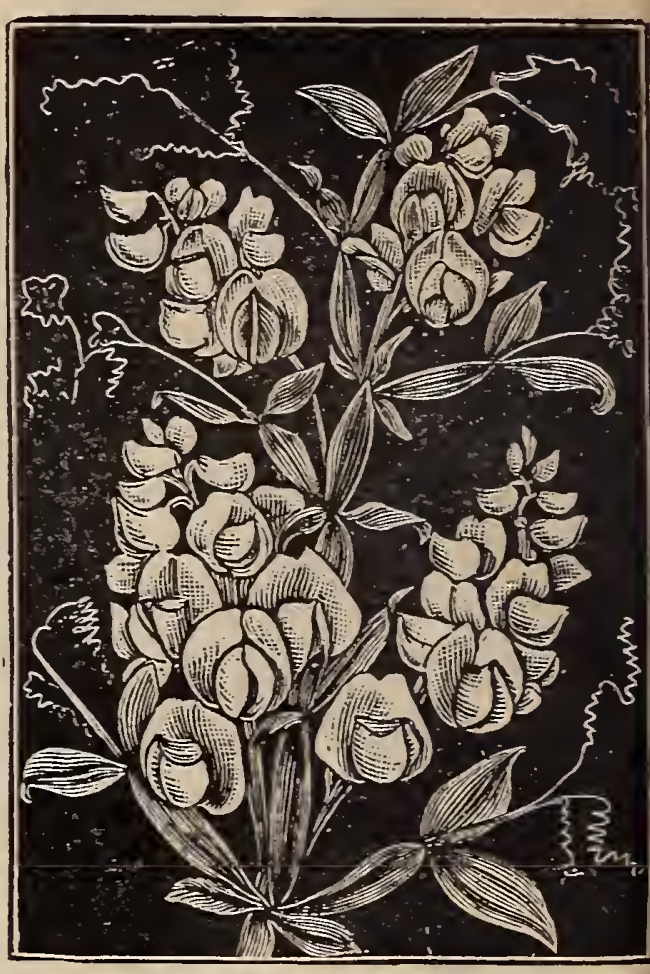

Sweet Pea, Bardy Everlasting.

SWEET PEA.

HARDY EVERLASTING

A hardy climber, producing pure white flowers the entire summer in great abundance: admirably suited for curering trellises.
etc. (see cut). Price, $15 \mathrm{c}$ each; $\$ 1.50$ per doz.

\section{HARDY ORNAMENTAL FLOWERING SHRUBS.}

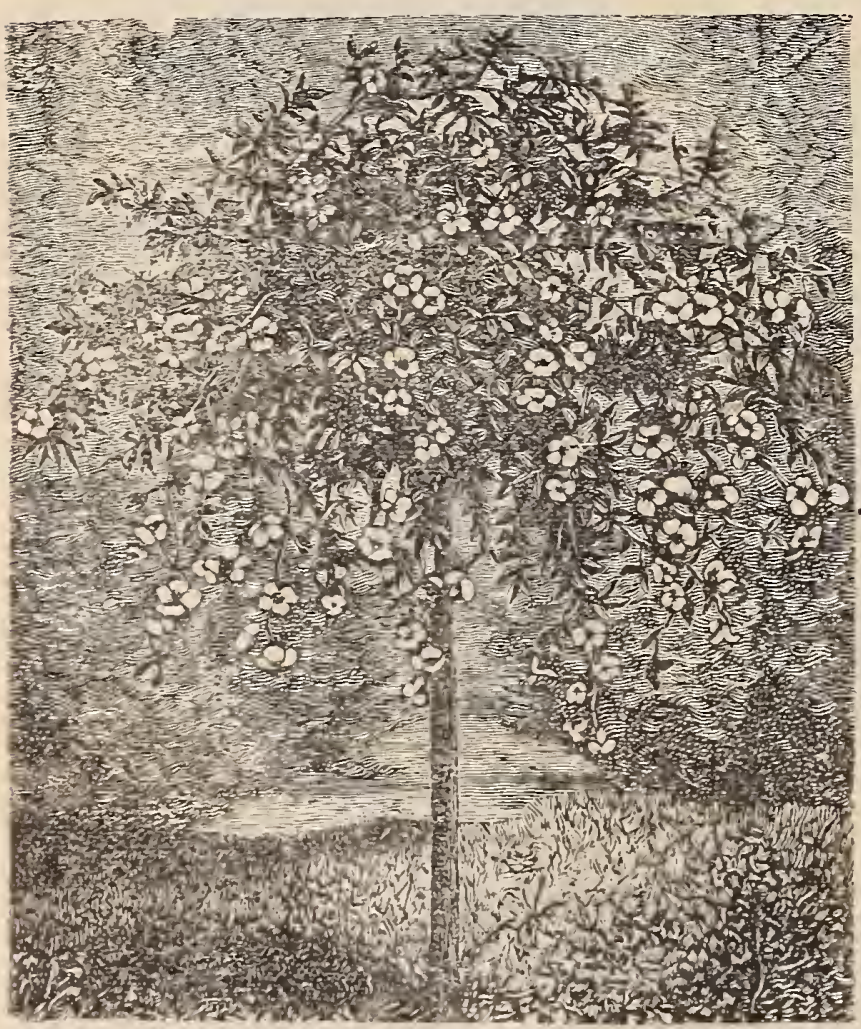

STANDARD GROWN SHRUBS.

These hardy shrubs are grown in standard shape. which makes a rery handsome specimen for a lawn. The single shaped head, from 24 to 40 inches in diameter, making

FORSYTHIA VIRIDISSIMA (or Golden Bell) - A rery eally flowering shrub, of beautiful golden yellow HYDRANGEA PANICULATA GRANDIFLORAvery free flowering, bearing immense panicles of white florers, tinged with pink. $\$ 1.00$ each.

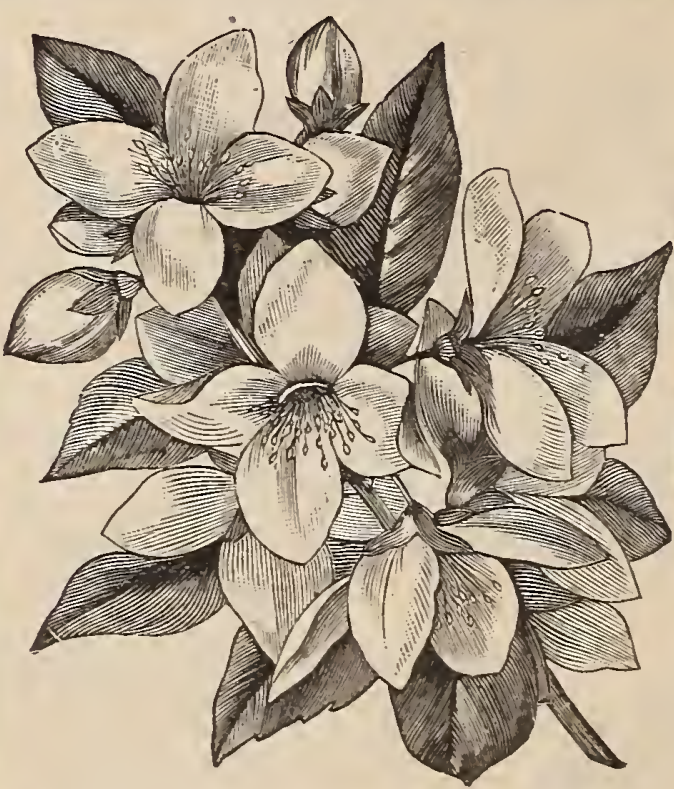

Syringa Grandiflora. (Mock Orange,)

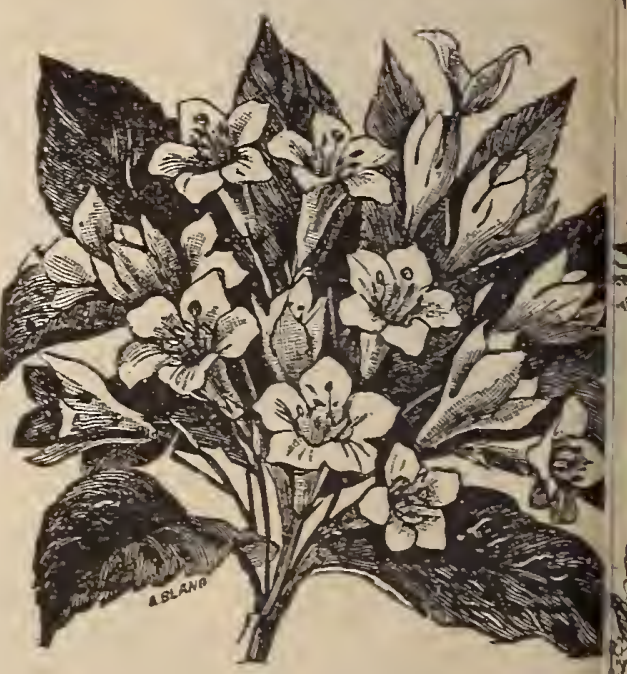

HARDY FLOWERING SHRUBS.

Small size, grown expressly to be forwarded by mail.

Price, 10e each; $\$ 1.00$ per dozell.

ALTHEA-Double white, variegated, pink and white, variegated lea DEUTZIA CANDIDIA, fl. pl.-Pure white, double flowering.

FORSYTHIA SUSPENSA-A drooping shrub with yellow flowers.

FORSYTHIA VIRIDISSIMA (Golden Beli)-Blooms early, yellow flowers. SYRINGA GRANDIFLORA-(Mock Orauge,)

SPIREA DONGLASI-Flowers a beautiful pink.

SPIREA VAN HOUTTI-Flowers pure white. Perfectly hardy.

TAMARIX GALILICA-Of weeping habit, with handsome pink flowers.

WEIGELIA ROSEA-Bright pink flowers.

WEIGELIA CANDIDA-Pure white flowers. 


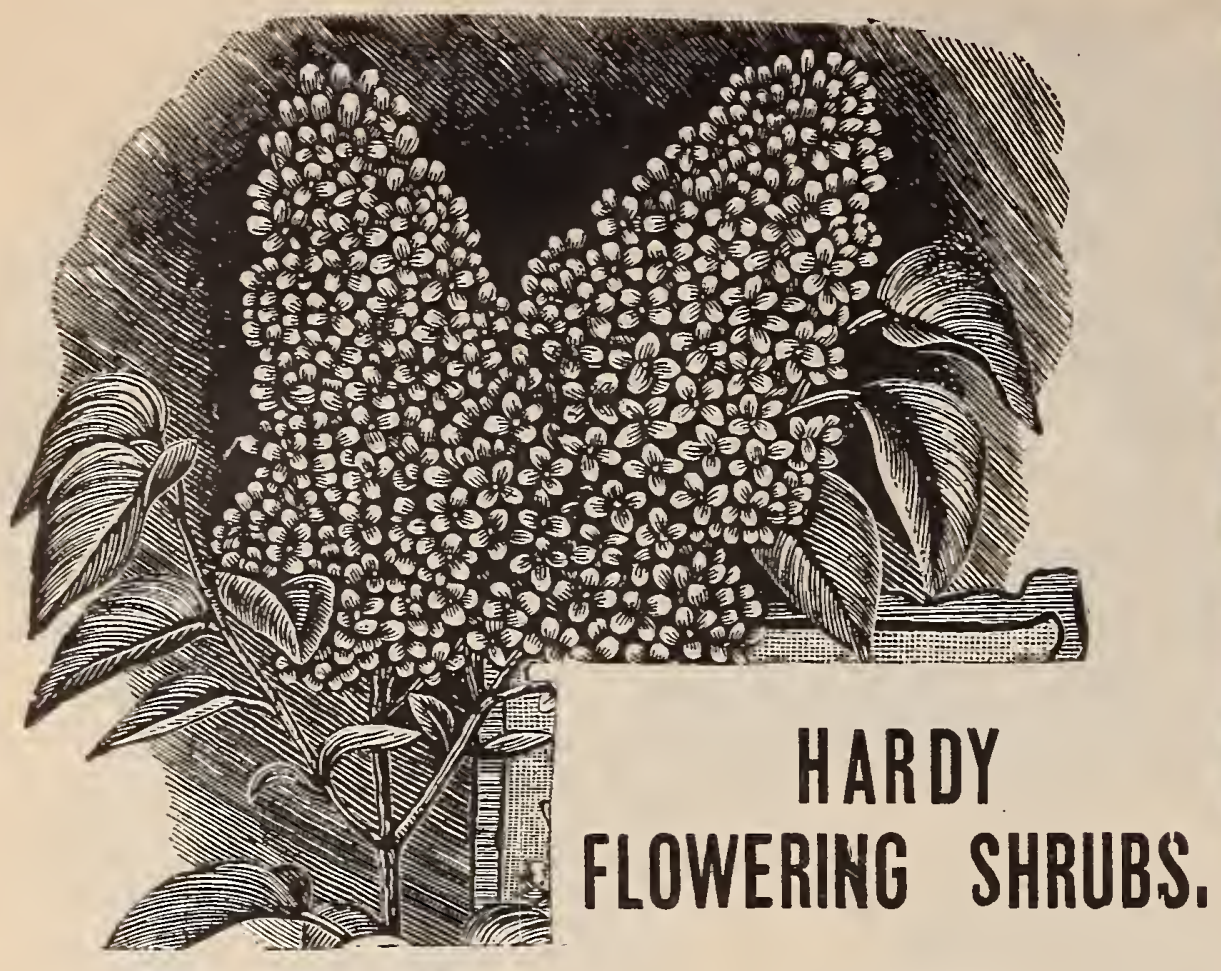

White Persian Lilac.

FORSYTHIA SUSPENSA (A) (Weeping Forsythia)-A shrub resembling the above in its flowers; drooping habit. Price, 35c each,

HYDRANGEA PANICULATA (H) (Hardy Hydrangea)-I,arge white panicles of fowers, Used largely in cemeteries. Large bushes, $24 / 2$ to 3 feet, $50 \mathrm{c}$ each. 3 to 4 feet, well branched, $\$ 1.00$ each.

LILAC, VULGARIS (B) (Common Lilac)-Bluish purple flowers. A standard variety, $35 \mathrm{c}$ each.

LILAC, PERSIAN WHITE (B)-Beautiful sprays of white flowers. A grand plant for cemeteries. 35c each.

LILAC, CHINESE WEEPING (B)-A variety of graceful drooping habit, color purple. \$1.00 each.

PHILADELPhUS CORONARIUS (D) (Syringa or Mock Orange)-Pure white fragrant flowers, 35 c each.

PHILAdelphus TOLIUS AUREUS (D) (Syringa or Mock Orange)-Very ornamental; bright yellow foliage, white flowers, very graceful. 35c each.

PHILADELPHUS NIVALIS (D) 'Syringa or Mock Orange)-Strong growing variety, very free flowering and very fragrant. $35 \mathrm{c}$ each.

PRUNUS PISARDi (D) (Purple-leaved Plum)-Foliage, fruit and shoots of bright purplish red. 50c each.

PRUNUS TRILOBA (D) (Double-flowering Plum)-Large, pink flowers; ver double; a very attractive shrub. 50c each.

PYRUS JAPONICUS (A) (Japan Quince) - A very showy and popular shrub, which blooms profusely in early spring; flowers dazzling scarlet, pink and white. 5c each.

SAMBUCUS AUREA (F) (Golden Leaf Elder)-The finest golden-leaved shrub and invaluable for grouping. 35c each.

LONICERA MORROWII (D) (Upright Honeysuckle)-A fine variety from Japan, noted for its fine fruits. $50 \mathrm{c}$ each.

SPIREA ARGUTA (D)-Of dwarf habit, flowers clear white. The best early flowering white Spirea. $35 c$ each.

SPIREA PRUNIFOLIA (G) (Bridal Wreath)-Pure white double flower, com pletely covering the branches. $35 \mathrm{c}$ each.

SPIREA BUMALDI (F)-A very handsome species from Japan. Habit dwarf but very vigorous; foliage narrow, flowers rose-colored, appearing in great proSPIREA VAN HOUTTI (D)-Flowers pure white, borne in greatest profusion. One of the best in its class. 35 each.

SPIREA ANTHONY WATERER (D)-A fine new dwarf variety with fine dark crimson flowers. 50c each.

SPIREA THUNBERGEII (D)-Of dwarf habit; flowers small white; appearing early in the spring. $35 \mathrm{c}$ each.

STEPHANANDRA FLEXUOSA (D)-Hardy deciduous shrub from Japan. Flowers pure white,

SNOWBALL, COMMON (Viburnum Opulus)(D)-Large white flowers: scaret berries late in Fall and Winter. 50c each.

SNOWBALL, JAPAN (D)-Superior in foliage and flower to the above. 2 vs to

TAMARIX GALILICA (C) (Weeping Beauty of the Forest)-Slender graceful habit, covered with pretty pink flowers. $35 \mathrm{c}$ each.

WEIGELIA CANDIDA (F)-Pure white flowers. $35 \mathrm{c}$ each

WEIGELIA ROSEA (E)-Rich rose-colored flowers. $35 \mathrm{c} \mathrm{each.}$

WEIGELIA ROSEA VARIEGATED-A variety bearing rose-colored flowers with beautifully variegated foliage. $35 \mathrm{c}$ each.

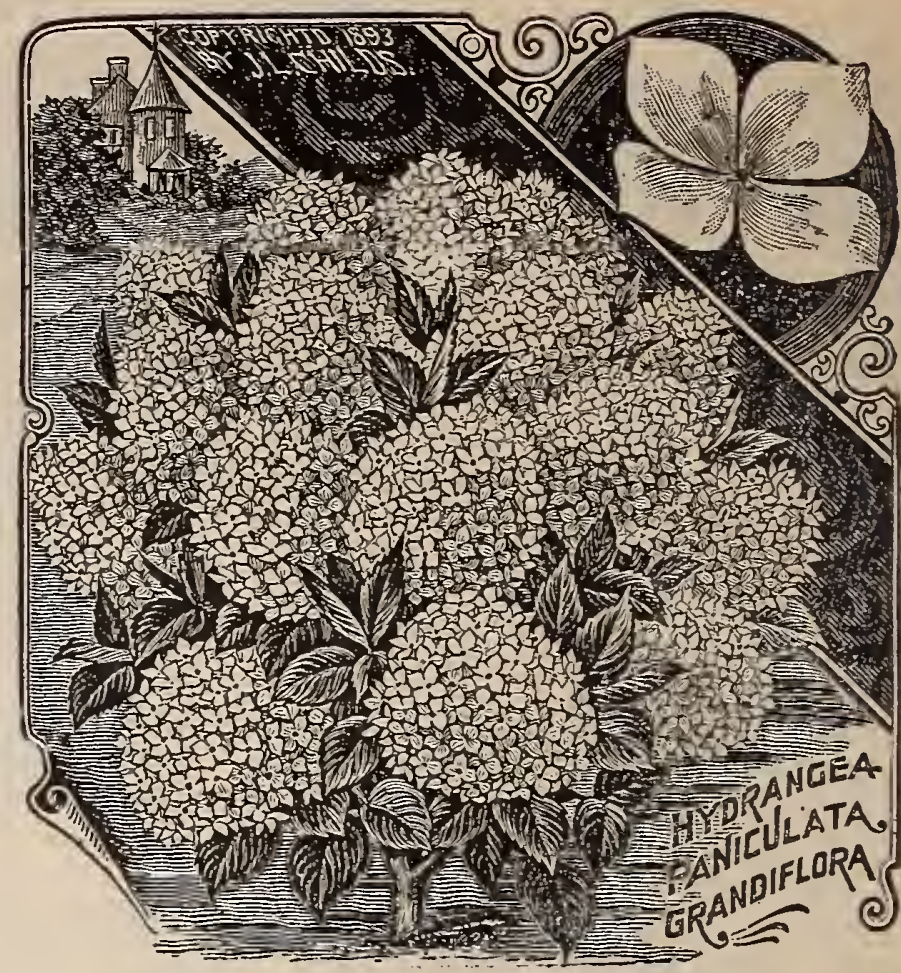

Hydrangea Paniculata.

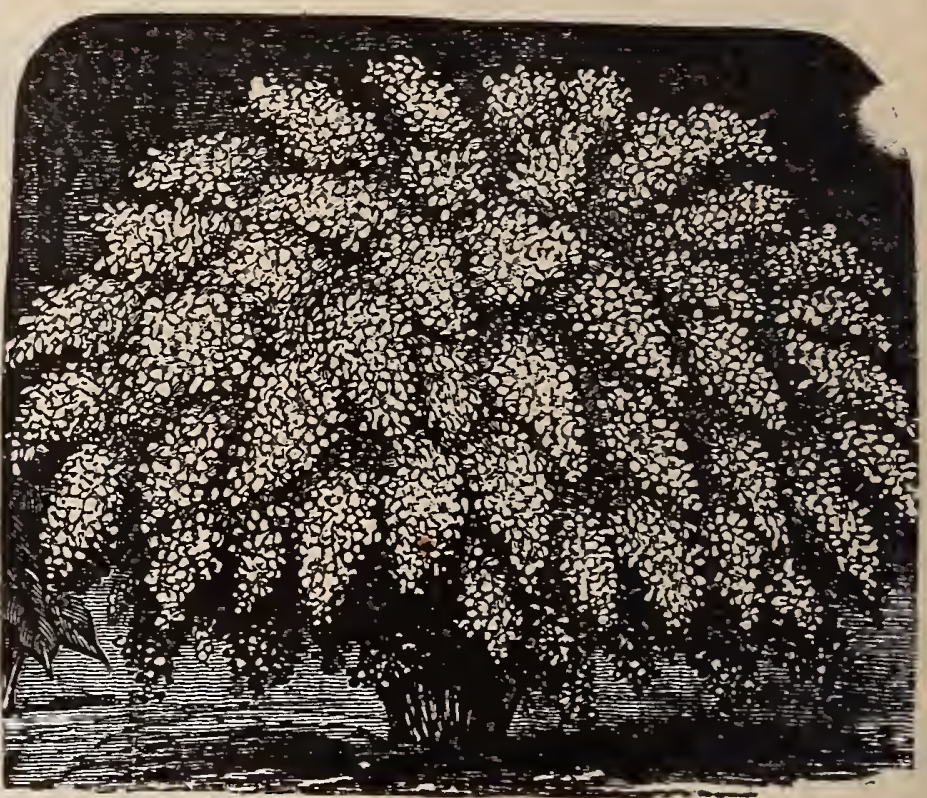

Spirea Van Houttii.

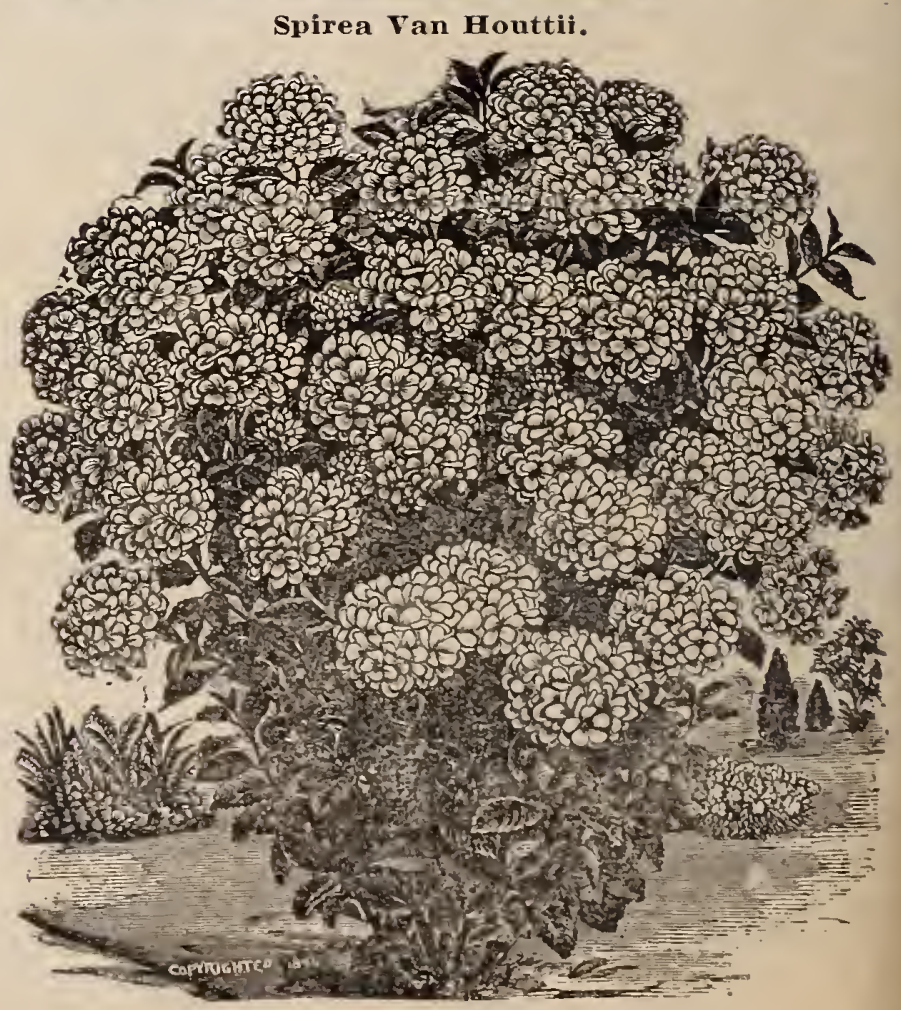

Japan Snowball. 


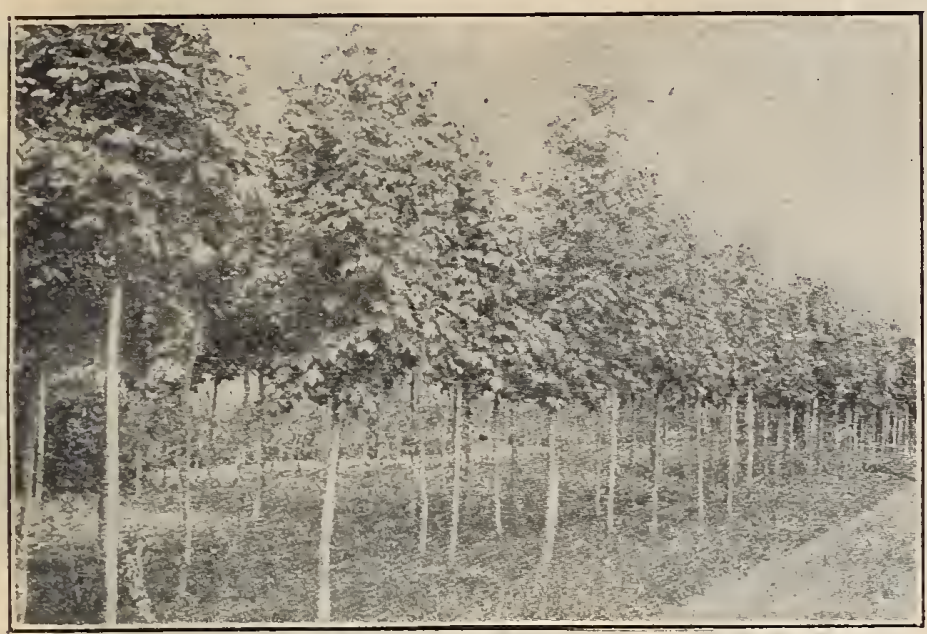

Tree Sugar Maple.

\section{Shade and Ornamental Trees.}

We have an immense stock of fine trees, including every variety that can be grown in this climate, all large, splendid specimens, free from blemish. With good heads, that are sure to grow if properly planted. For price, size and description, see our illustrated circulars on ornamental trees. Free on application.

About replacing trees and shrubs-Some persons so neglect or badly plant their trees as to cause their loss, still they believe the nurseryman should be responsible and replace them. We desire to say that if our sug. gestions for planting, pruning and cultivating are followed, little or no loss. will result. But we cannot be held responsible for unfarorable seasons or other causes beyond man's control, and the purchaser must take the same risk that we do in that respect. We guarantee trees to be healthy, fully up to grade, true to name and show signs of life after planting, but do not insure their living after having passed out of our hands and care. In no case will we be responsible for the growing of trees beyond the flirst leafing out in spring.

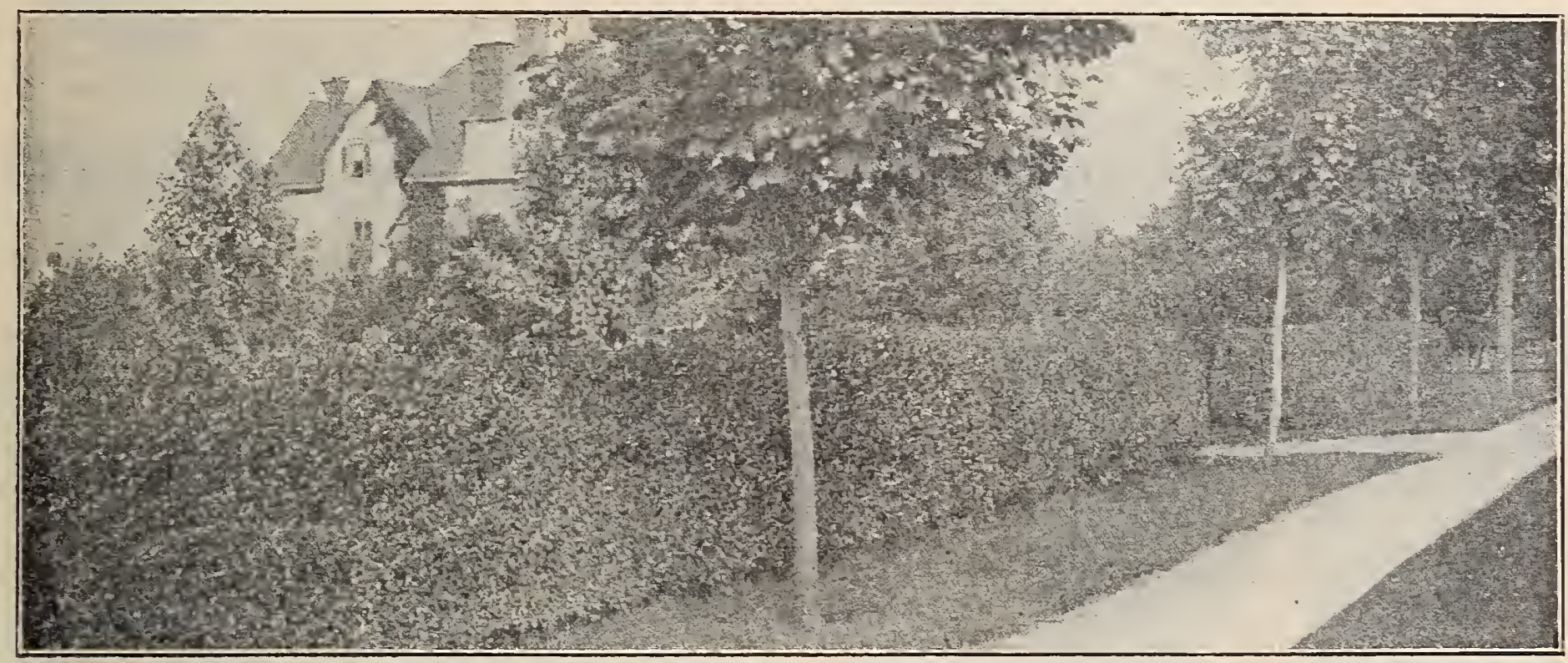

\section{HARDY SHRUBS FOR PLANTING HEDGES.}

BARBERRY THUMBERGIA-A very pretty hedge shrub with small foliage, changing to a coppery red in the autumn. $20 \mathrm{c}$ each; $2 .{ }^{2} 0$ per dozen; $\$ 12.00$ per 100 .

CALIFORNIA PRIVET-Is one of the best shrubs for planting a hedge, grows rapidiy in any soil, perfectly hardy; can be pruned into any shape desired and is nearly evergreen. Extra fine stock, twice transplanted, and well branched. $20 \mathrm{c}$ each; $\$ 2.00$ per dozen; $\$ 8.00$ per 100 . OSAGE ORANGE-A rapidly growing thorn shrub which makes a very effective hedge, 18 to 25 inches high. Per $100, \$ 2.00$; per $1000, \$ 15.00$. PYRUS JAPONICA-A very hardy shrub, bearing bright crimson flowers early in the spring before the leaves grow. $20 \mathrm{c}$ ea.; $\$ 2.00$ per doz.; $\$ 15$ per 100.

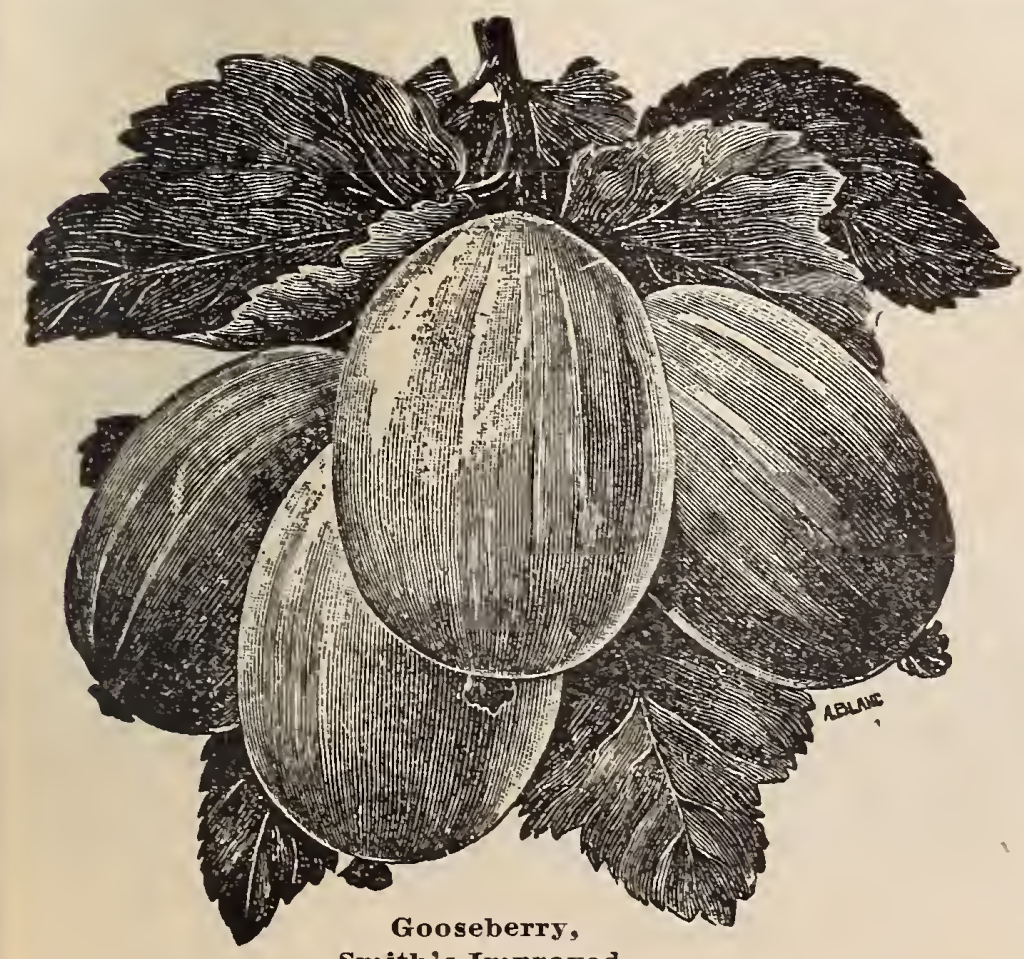

Smith's Improved.

\section{Small Fruit.}

Gooseberries.

If ordered to be sent by mail add $10 c$ to dozen price.

Downivg - A large pale green variety; splendid for table use or cooking; a vigorous grower, one of the best for family use. Each 15c; $\$ 1.50$ per dozen HOUGHTON-One of the best sorts, always reliable, color pale red; sweet, tender, very good, enormously productive. $15 \mathrm{c}$ each $\$ 1.50$ per dozen.

S I I T H' S IMPROVEDLarge, pale greenish yellow, skin thin, of excellent quality being unsurpassed by any other variety for table use; moderately vigorous grower and excessively productive. $15 \mathrm{c}$ each; $\$ 1.50$ per dozen.

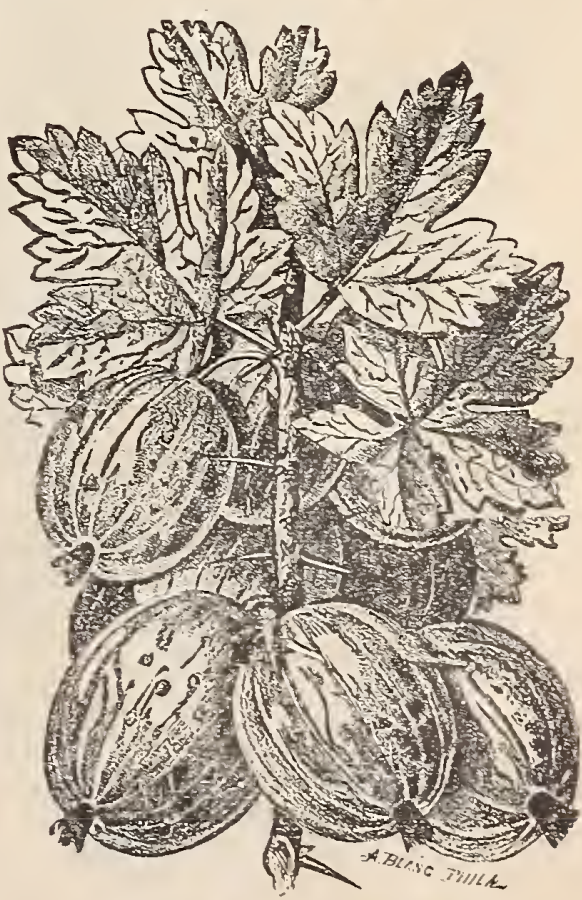

Gooseberry, Downing. 


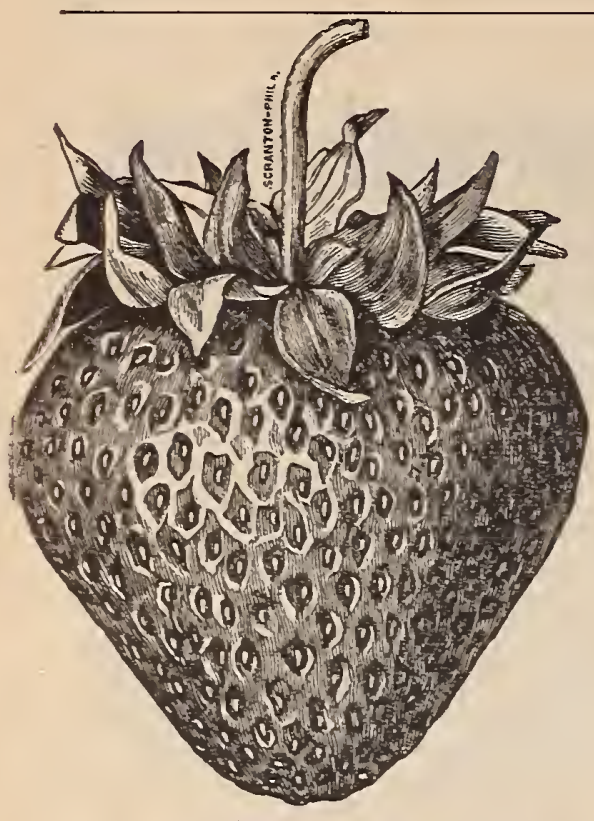

Corsican.

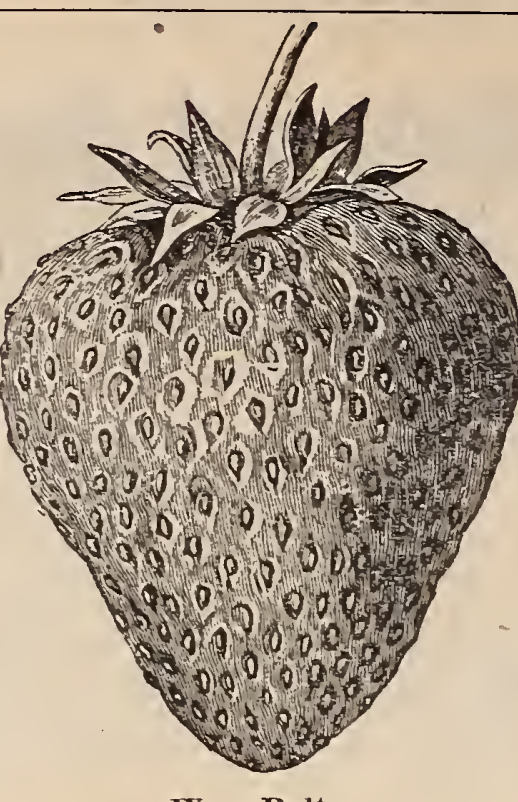

Wm. Belt.

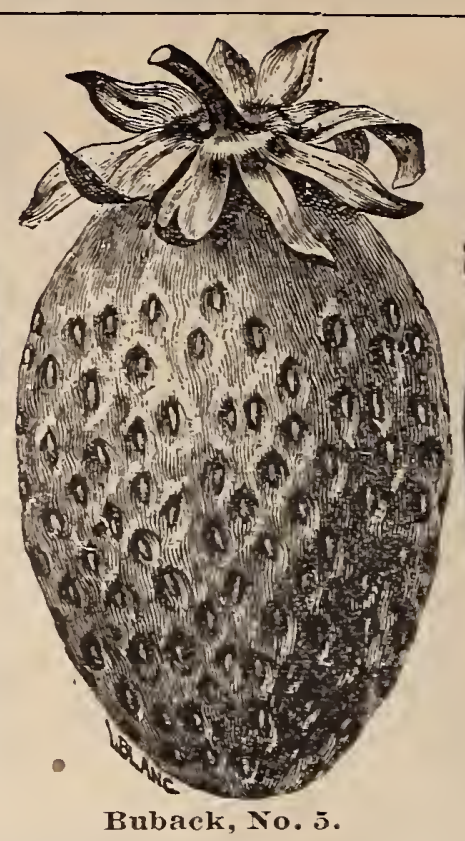

Buback, No. 5 .

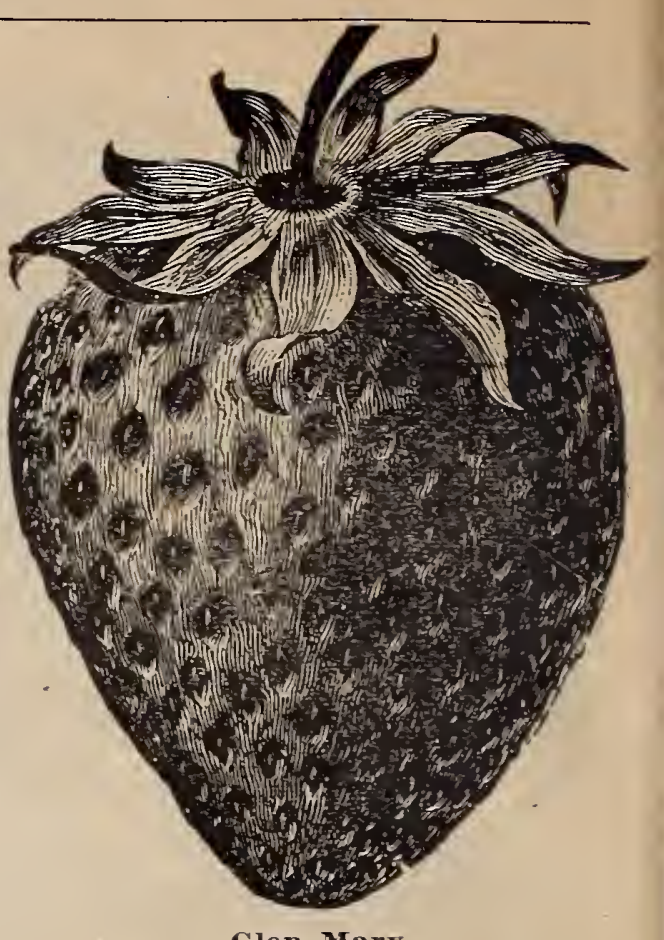

Glen Mary.

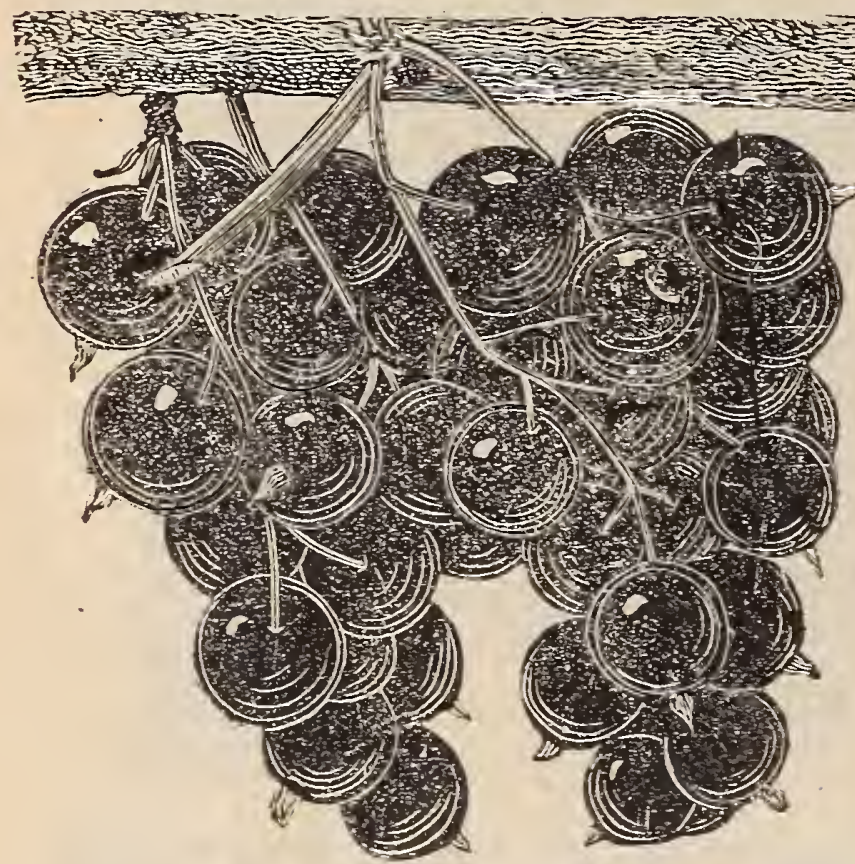

\section{Strawberry Plants}

Pot Plants, 60c per dozen, $\$ 3.00$ per 100 , by Express only. Layer Plants, 40c per dozen, $\$ 1.50$ per $100, \$ 8.00$ per 1,000 .

If Layer Plants are ordered by mail add $25 \mathrm{c}$ to the 100 price.

The blossoms of those marked with $\mathrm{P}$ are destitute of stamens and are termed pistillate, and unless a row of perfect flowering varieties are planted at intervals not exceeding about a rod, they will produce imperfect fruit, and but little of it; but when properly fertilized, as a rule they are more prolific than those with perfect flowers.

Auroma-The largest strawberry that we have ever fruited, enormously productive, berries very large, bright red, exquisite quality, ripens late.

Bubach No. 5-P. Fruit large and handsome, roundish, conical, bright scarlet, moderate firm, desirable for home use; season early to medium.

Corsican-Conspicuous for its size, shape, color and quality, color crimson, flesh moderately firm, and quality extra good.

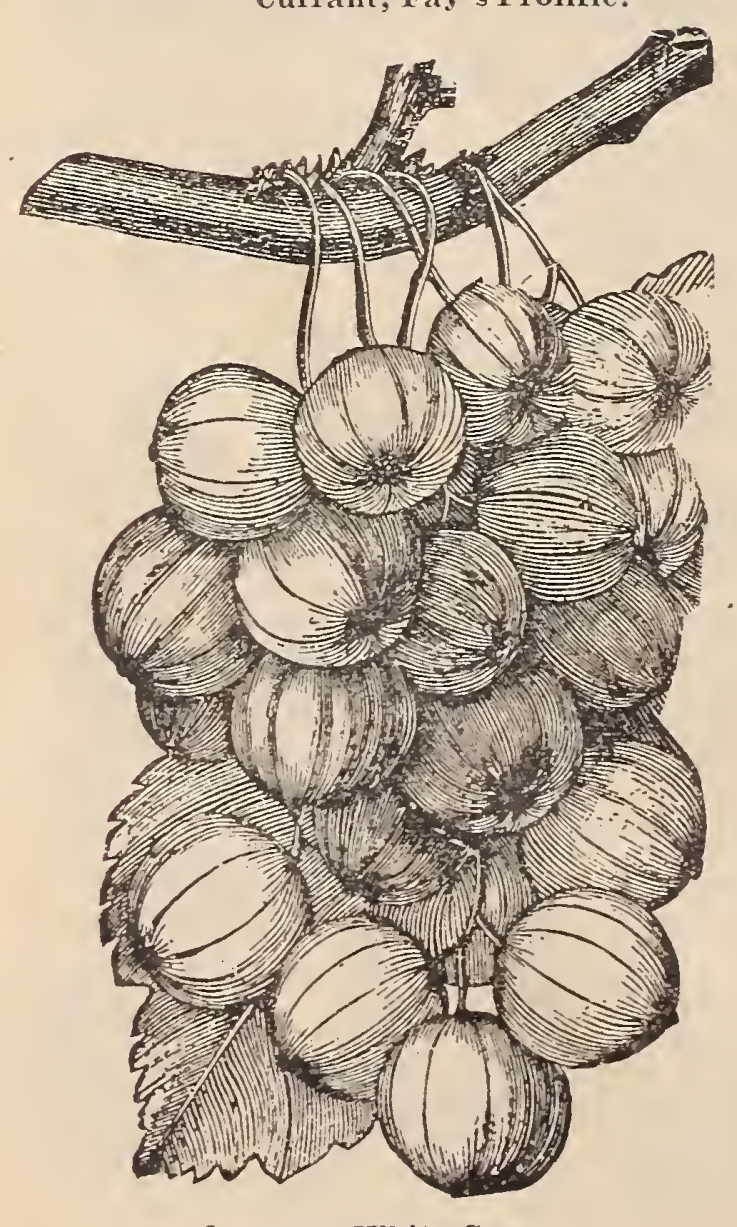

Currant, White Grape.
Clyde-Large, roundish, conical form; color, bright scarlet; fair quality, season, medium; vigorous grower and productive.

Excelsior-One of the very best of its class, very productive, and yielding berries which are large, firm, high colored and of fair quality.

Glen Mary-An extraordinay large size, color a dark glossy crimson, fairly firm and of excellent quality.

Kansas-A valuable new late strawberry, an exceedingly robust grower. The fruit is wonderfully large, very dark colored, and extremely firm.

Marshall - Unsurpassed for table use and noted ever ywhere for its fine quality.

Monitor-The berries are all of large size. The fruit is of a bright, shiny red, uniformly large, firm and attractive, of excellent flavor; early.

New York-This is the best and largest new variety. It is a robust grower, berries measuring over 7 inches in circumference, color a crinsson scarlet, dark; the flavor is deliciously rich and melting.

Senator Dunlap-The best berry for the family table or home market. Quality unsurpassed, the size will average large; berries nearly round, bright crimson.

Sample-P. One of the very best berries, and seems to succeed nearly everrwhere, producing in profusion large dark colored berries of uniform size.

Wm. Belt-A well-tested variety, that is giving remarkable satisfaction, as a large, handsome, productive berry for market or home use. Berries extra large.

\section{CURRANTS.}

(If ordered to be sent by mail, add 10c per dozen for postage).

Pamona-The most profitable currant grown, a vigorous grower, free from disease and exceedingly productive, color of fruit a clear, transparent red, flaror sweeter than the common varieties. $15 \mathrm{c}$ each; $\$ 1.50$ per doz.

Fay's Prolific-The leading red variety, and one that bears very early, fruit large and of a bright red color, good flavor. See cut. 10c each, $\$ 1.00$ per doz.

Cherry-A popular market sort, with very large berries, often measuring 1

inch in diameter, under good clutivation. Burches are short. A very vigorous grower. 10c each, $\$ 1.00$ per dozen.

White Grape-The largest White Currant with a sweet mild acid flavor excellent for table use. See cut. $10 \mathrm{c}$ each; $\$ 1.00$ per doz.

Black Victoria-The largest black currant in cultivation, of recent introduction from England. 15c each; $\$ 1.50$ per dozen. 


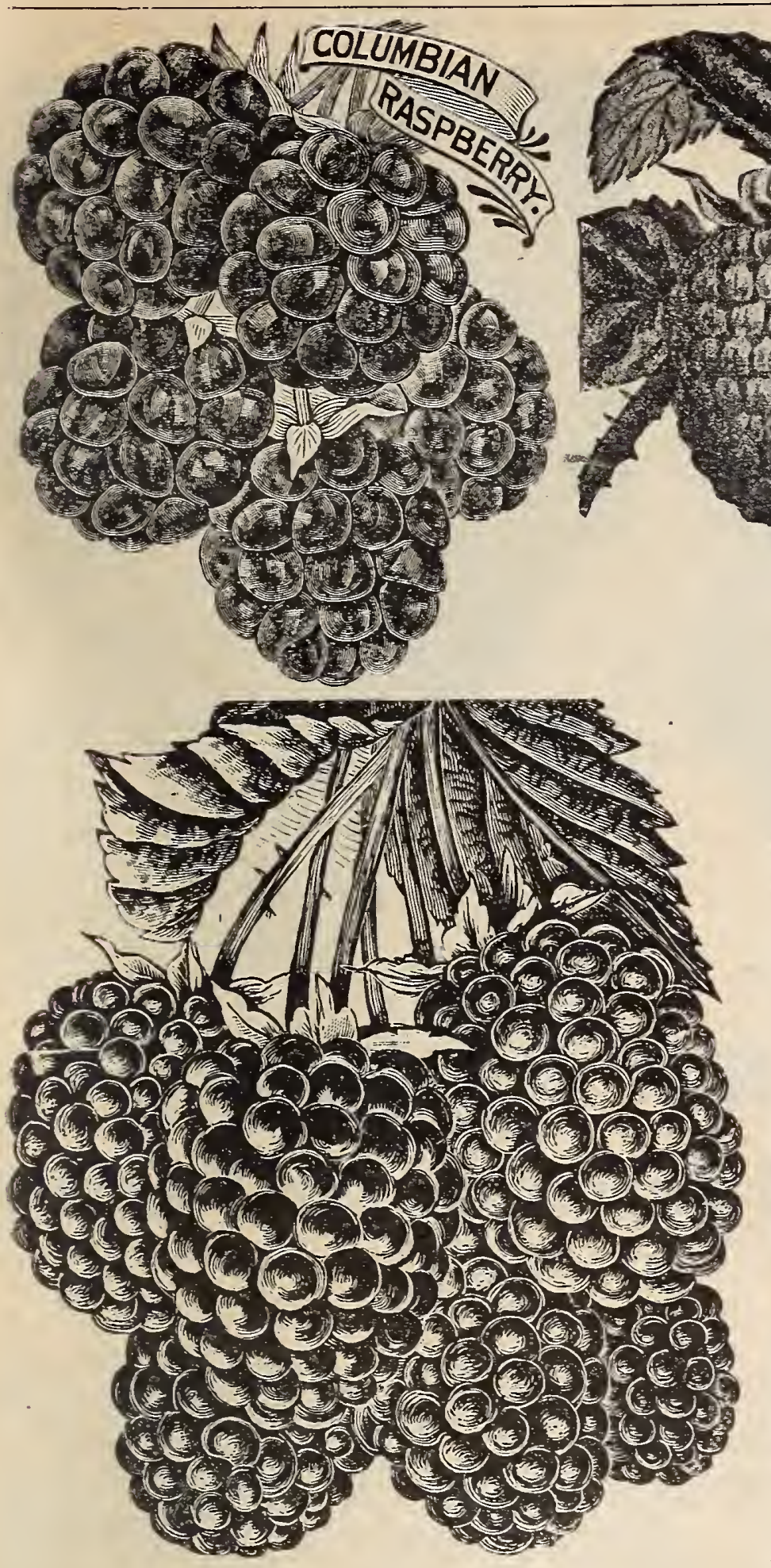

Raspberry Rathbun.

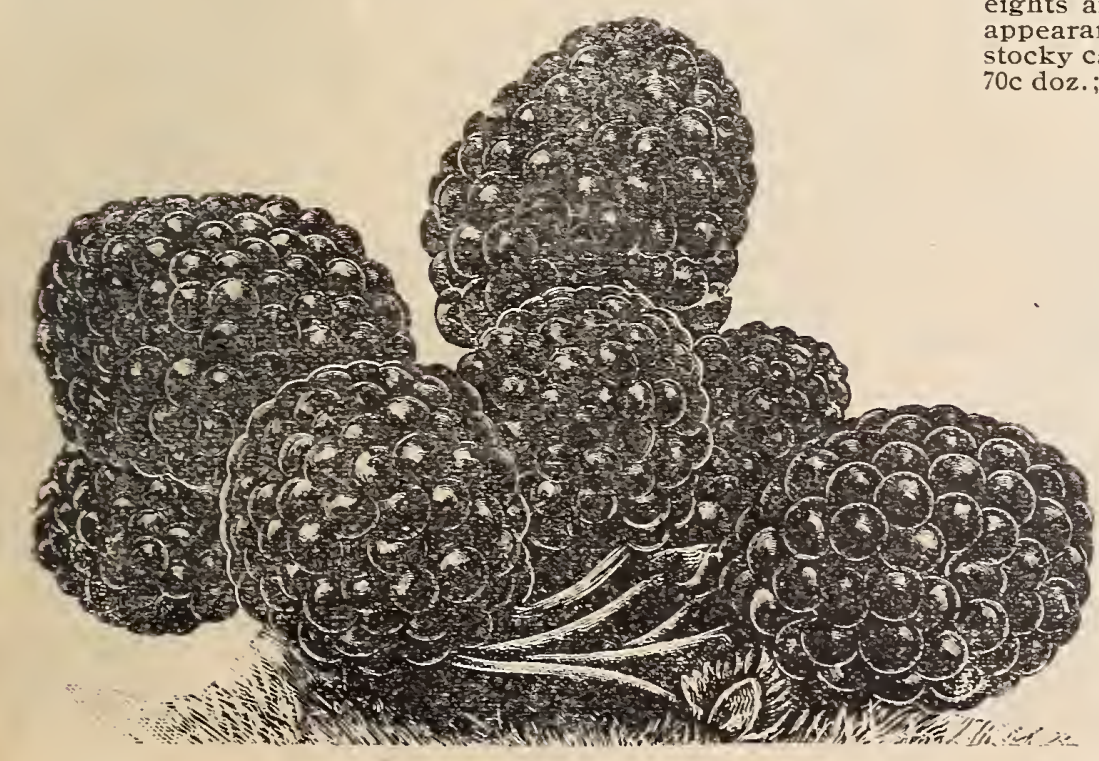

Cumberland Raspberry.

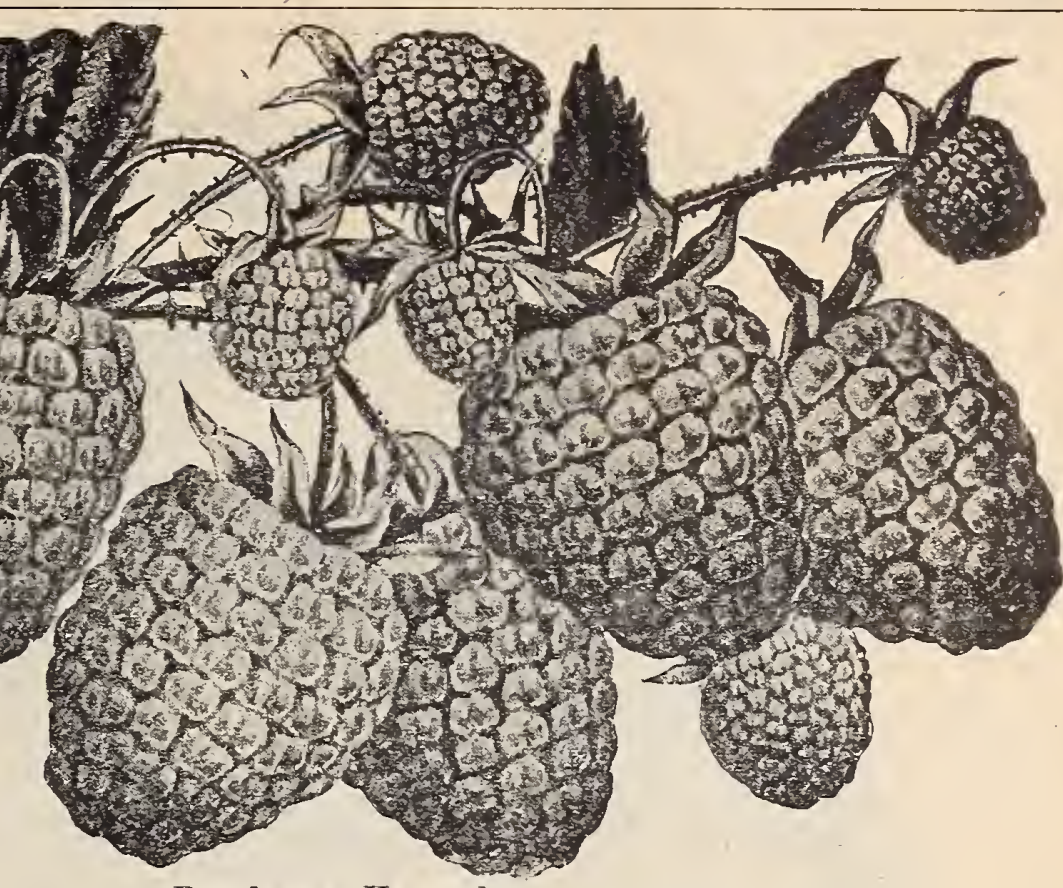

RED RASPBERRIES.

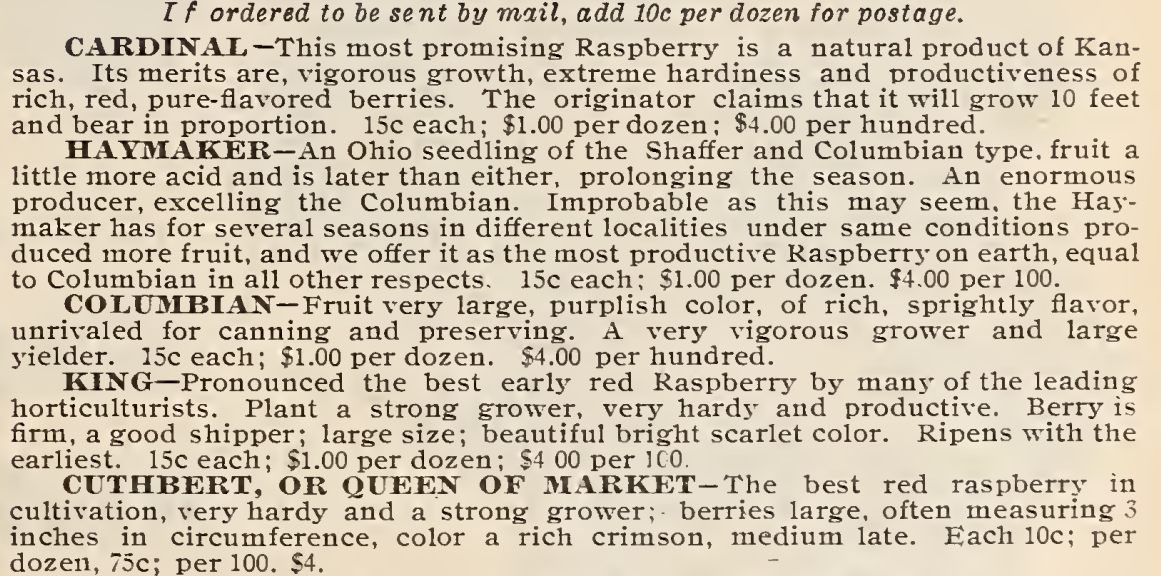

BLACK RASPBERRIES.

GREGG-For many years the standard leading variety. The best known

market sort. Very productive, large size, flrm meaty

KANSAS-Strong, vigorous grower, standing extremes of drought and cold, from bloom. Very firm; presents a very handsome appearance. The best Black Cap

on our grounds. 10c each; 70c per dozen: $\$ 4.00$ per 100 . (n) CUMBERLAND-The largest black Raspberry known, has been
CUM paring any other sort. The berties

is exceeningls healthy and vigor BLACKBERRIES.

\section{If ordered to be sent by mail add $70 \mathrm{c}$ per dozen postage.}

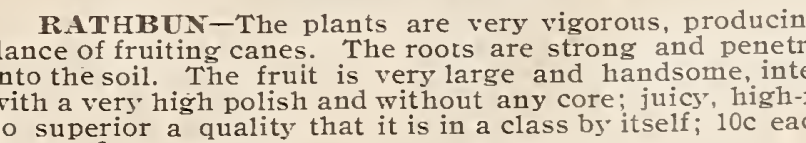

doz $\in$ n; $\$ 3.50$ per 100 .
EARLY HAR VEST-A very early variety, medium siz
for general use, as it is more productive than any other va
treme dry weather. Each $10 \mathrm{c}$; $60 \mathrm{c}$ per dozen; $\$ 3.00$ per 100 .

ELDORADO-Vines vigorous, hardy, and their yield is enormo

Berries large, jet-black, borne in large clusters, and ripen well to-

gether; sweet, melting and pleasing to the taste;

;

far the mSEREAU-This early mammoth, iron-clad blackberry is by time. It originated in Northwestern New York, where the mercury culture for many years without the slightest protection, never being blight, or other disease, or produced a double or "rose" blossom. 10c each; $75 \mathrm{c}$ per dozen; $\$ 3.50$ per 100 . 


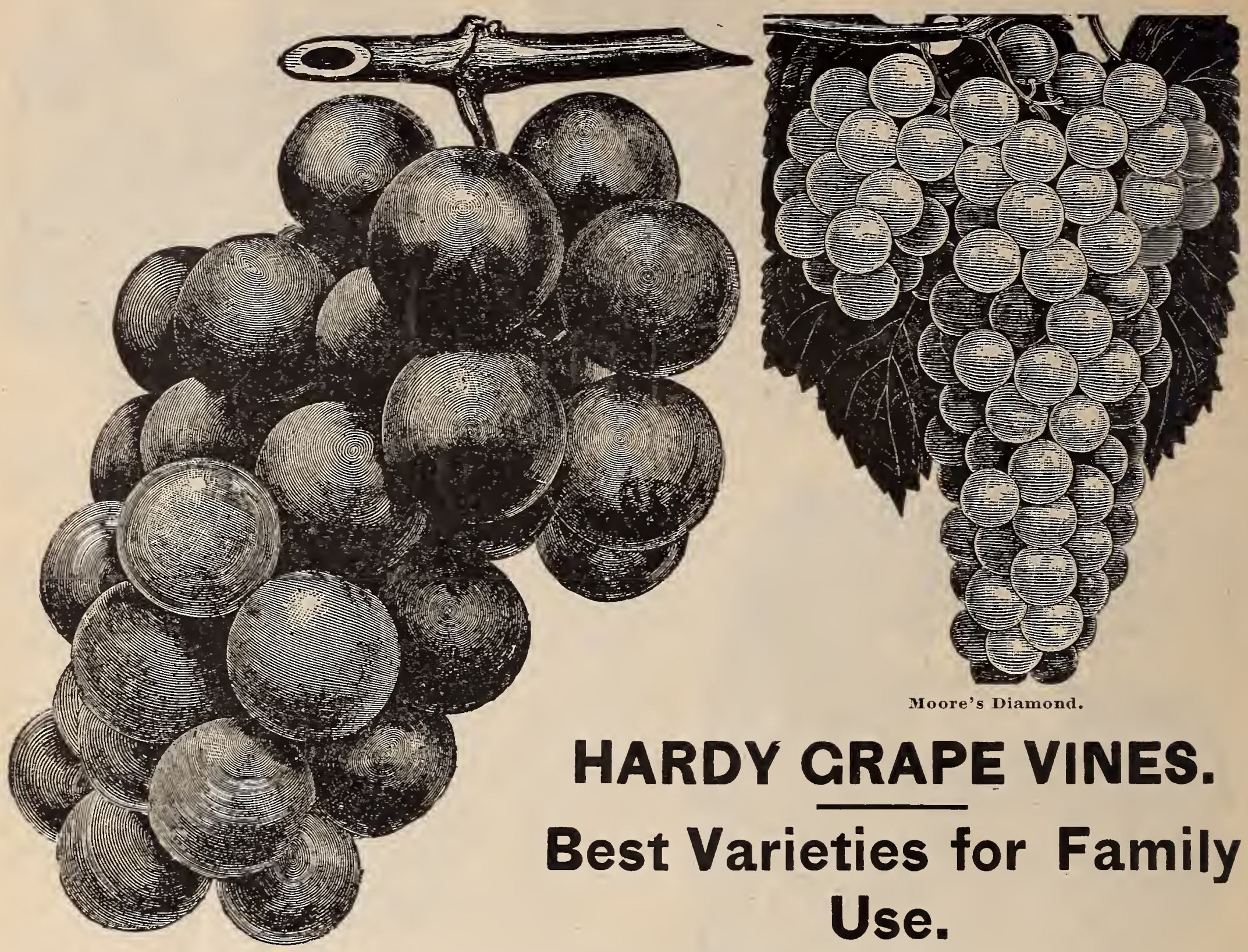

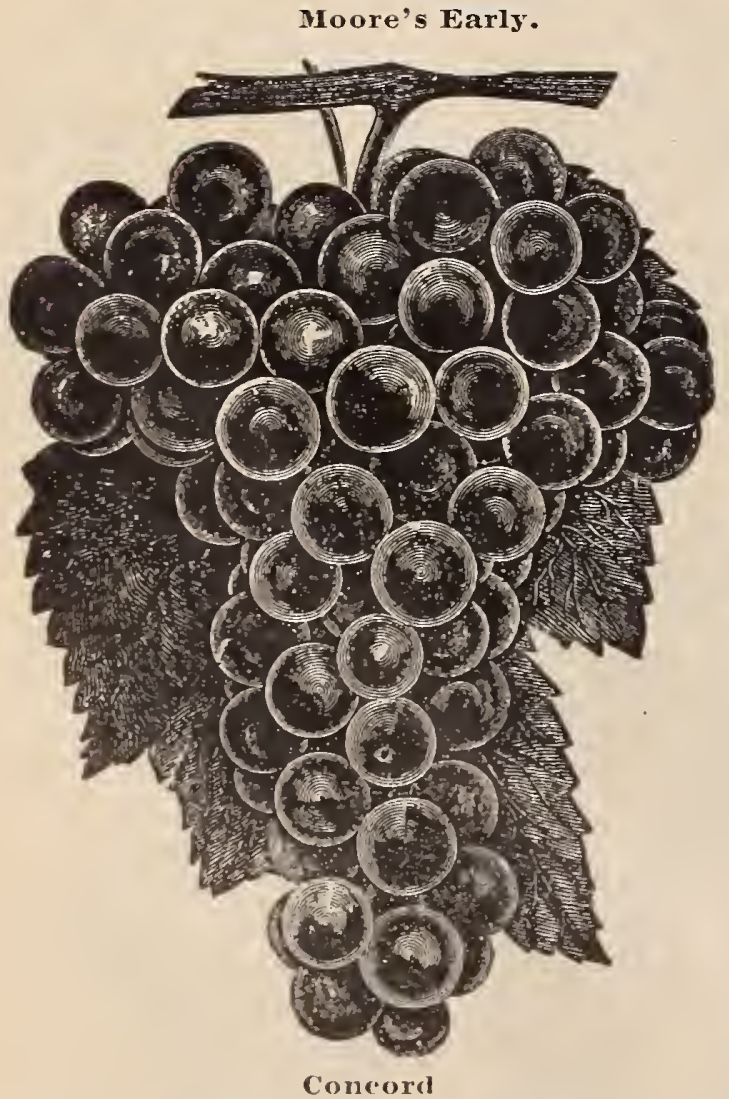

AGAWAN-A fine large red grape; bunches of; good size and form. quality excellent. Ripens early. Each, 20c; ' per dozen, $\$ 2.00$.

BRILLIANT-Vine a strong grower, hardy and productive with healthy foliage. bunch and

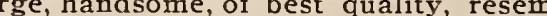

CAMPBELL'S EARLY-Its strong, hardy, vigorous growth, thick healthy foliage, early ripening and abundant bearing of large clusters of most excellent quality, remarkable keeping and shipping properties, form a combination equalled by no other grape. Bunches larg shouldered, moderately compact; berry large, nearly round, black, skin thin, flesh juicy, flavor
sweet, rich, aromatic. Its season is early. 35c each; $\$ 3.50$ per dozeu. CONCORD-An old, popular variety; good grower; berries and bunches large: color black, dozen, $\$ 1.50$

DELAWARE-An early red variety, with compact bunches and small berries; very sweet aud of the most excellent flavor, Each $25 \mathrm{c}$ per dozeu, $\$ 2.50$.

EMPIRE STATE-This vine is a strong grower; free from mildew; bunches large; berries nearly round, aud are white, tinged ellow. Each, 25c; per dozen, $\$ 2.50$

GOLDEN POCKLINGTON-This variety is rery hardy aud productive; the bunches and herries are very large aud showy; color a greenE,ach, 20c; $\$ 2.00$ per dozeu.

GREEN MOUNTAIN, (Winchell) - An extra early variety, skin thin; pulp tender and sweet; quality superb; bunch and berry medium size; vine hardy, vigorous and productive.
HARTFORD PROLIFIC-A popular, early variety, very reliable as a cropper; bunches large and color of berries

MOORE'S DIAMOND - Large, greenish white, juicy, little pulp and of good quality has succeeded well wherever grown; yields abundantly; fruit perfect and showy. Ripens Mory early. (See cut.) Each, 15c, per doz., 1.50. variety. resembling the Concord in style of growth, ripening two weeks earlier. (See cut.) Fach, 20c; per dozen, $\$ 2.00$.

MARTHA-One of the best greenish white grapes. A good grower and of easy culture. Each, 15c; per dozen, \$1.50.

NIAGARA-A grand white grape, enormously productive, very hardy aud a good, cleau grower; bunches large, berries greenish white, turning to a pale amber. Flavor very sweet. Each 20c; per dozen, $\$ 2.00$

SALEM-A splendid coppery, red colored grape berries very large, flavor good, one of the best. Fach, 25c; perdozeu, $\$ 2.50$.

WILDER-The finest of all the black grapes. Good grower, very productive, berries medium in size, bunches large. Fach, 20c; per dozen. $\$ 2.00$.

WORDEN-Au improvemeut ou Concord being larger in buncli and berry. Color, black of excellent flavor. Each, 20c; per dozen, $\$ 2.00$

WYOMUNG RED-A red grape resembling the Delaware iu color and flavor, but much arger. Ripens about ten days earlier. Very eu, $\$ 2.00$. 


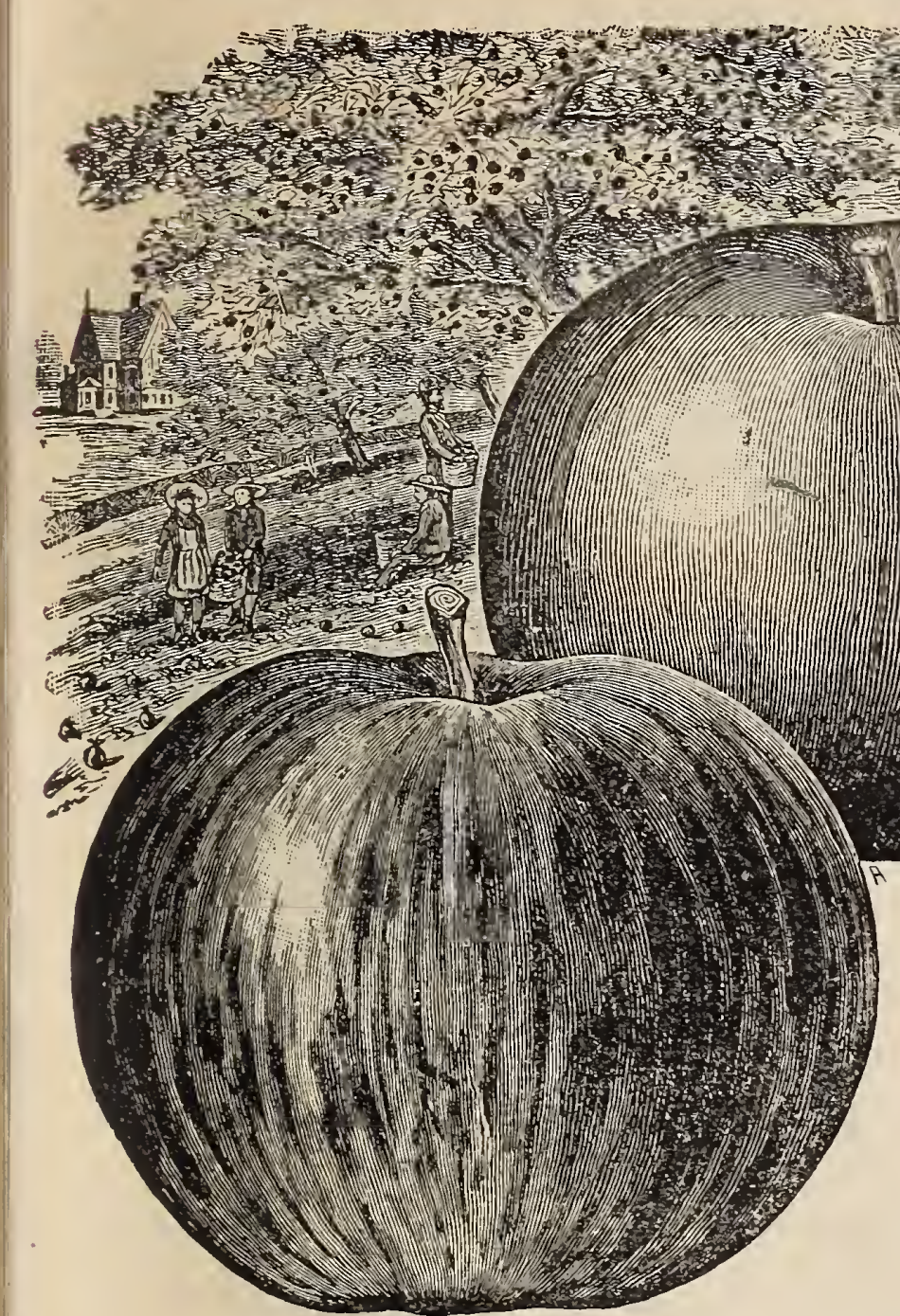

Apple, Ben Davis.

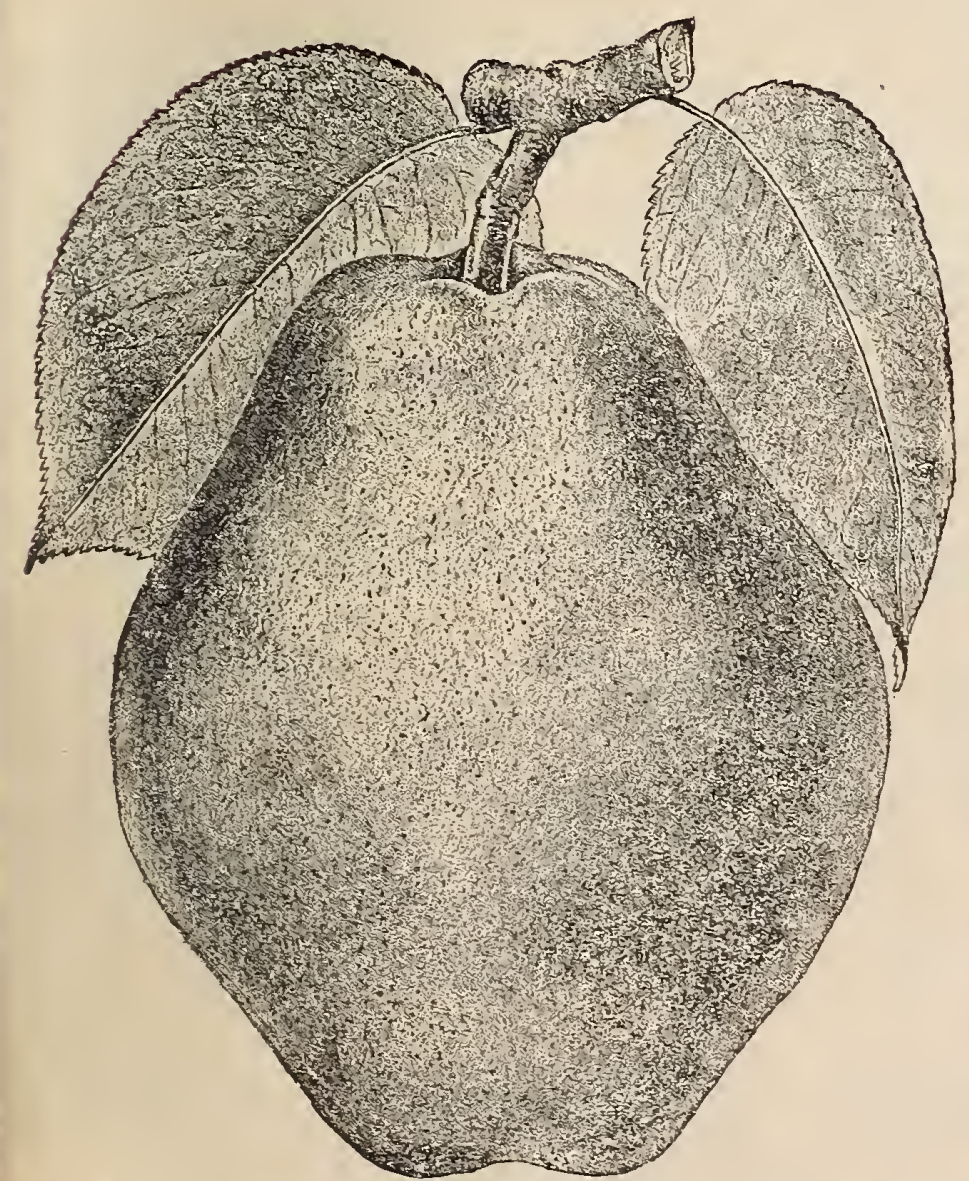

\section{APPLES. Selected Varieties. \\ Standard, 5 to $;$ feet, 35c each:} $\$ 3.00$ per dozen.

\section{Summer Varieties.}

FARLY HARVEST-Medium to large size; pale, yellow, tender, with a mild flavor; a good bearer, one of the first to ripen: middie to end of August.

YELLOW TRANSPARENT-A Russian apple of medium size, skin pale yellow when fally matured;

\section{Autumn Varieties.}

MISSOURI PIPPIN-Very large, oblong, yellow; flesh tender, tich and delicious; a free grower and a fine bearer; one of the most valuable varieties for table or market. October to December.

WEALTH - A fine medium roundish, skin smooth and mostly covered with dark red; flesh fine, juicy and very good flavor; very hardy and a free grower; very

\section{Winter Varieties.}

BEN DAVIS-A very handsome striped apple of good quality; tree very hardy, vigorous and productive. A late keeper. from December to March.

GANO-I,ike Ben Davis in growth, productiveness Wealthy. and size, a much handsomer fruit, being nearly covered with deep, dark red, making it very attractive. December to March. GRIMES' GOLDEN-Medium to large size, skin golden yellow, sprinkled with gray dots; flesh crisp, tender and juicy; tree hardy, vigorous and productive. January to April.

NORTHIVESTERN GREENING-Yellow, smooth, and of good size, resembling Grimes' Golden in shape and color; of a good quality and an extra long keeper;

tree hardy, vigorous and abundant annual bearer. January to June.
WINE SAP-A large, roundish, deep red, medium quality; keeps well. Tree a moderate grower and good bearer; largely planted for market in West and Southwest. December to March.

a color, shaded ree thrifty and very productive; fruit medium and of

\section{CRAB APPLES.}

\section{5 to 7 feet. $40 \mathrm{c}$ each; $\$ 4.00$ ver dozen.}

TRANSCENDENT - Tree immensely productive, bearing after second year and producing good crops by the fourth year. Fruit from 11/2 to 2 inches in diameter. most popular. September and October.

\section{PEARS.}

5 to g feet. $40 \mathrm{c}$ each; $\$ 4.00$ ver dozeu.

BARTLETTvery juicy and high flavored; bears early and abundantly. Very popular. August FLEMISH BEAUTY-A large, beautiful. juicy, melting, rich and fine: good bearer; one of the hardiest, and does well everywhere. September and October. Krefere very rigorous and ornamental. commencing bearing dessert fruit, and one of the very best for canning and preserving. Its shipping ere SECKEL. Small, skin rich, yellowish brown; when fully ripe with a deep rownish red cheek: flesh very fine grained, sweet, exceedingly juicy melting. of the richest and highest flavored pears known; tree a moderate grower. Septemand October.

GARBER One of the Japan Hybrids: earlier and larger than Kieffer; hardy.

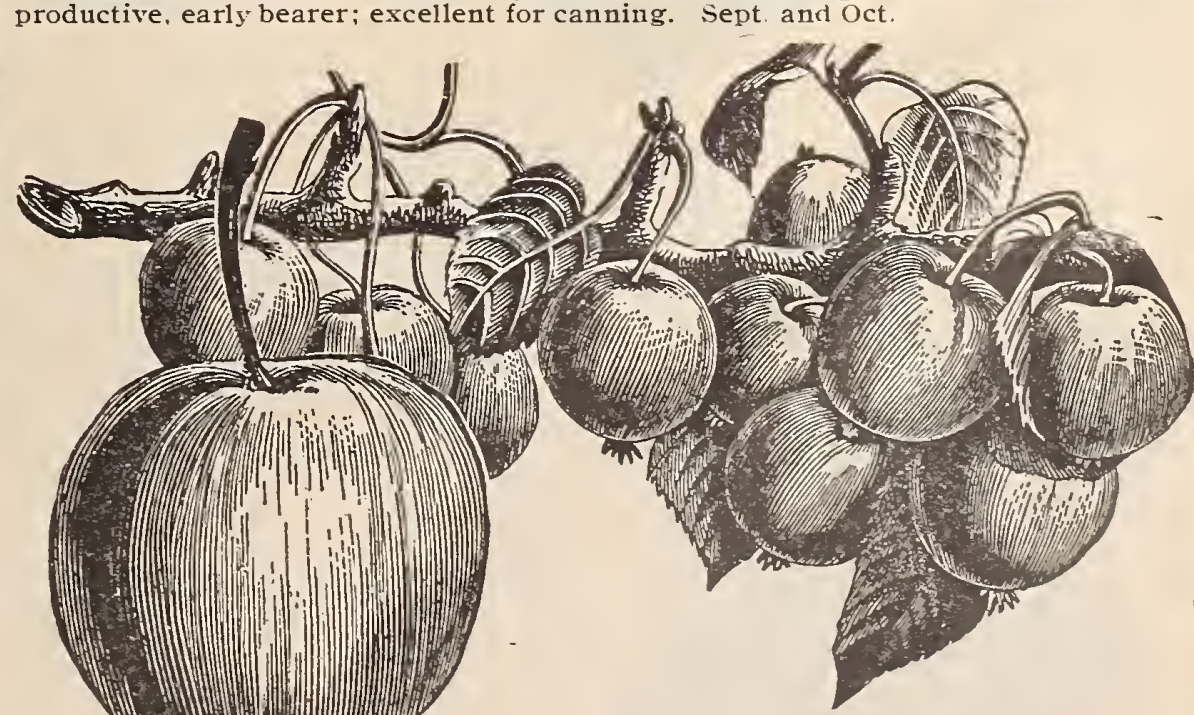

Crab Apple, Transparent.

Pear, Kieffer. 

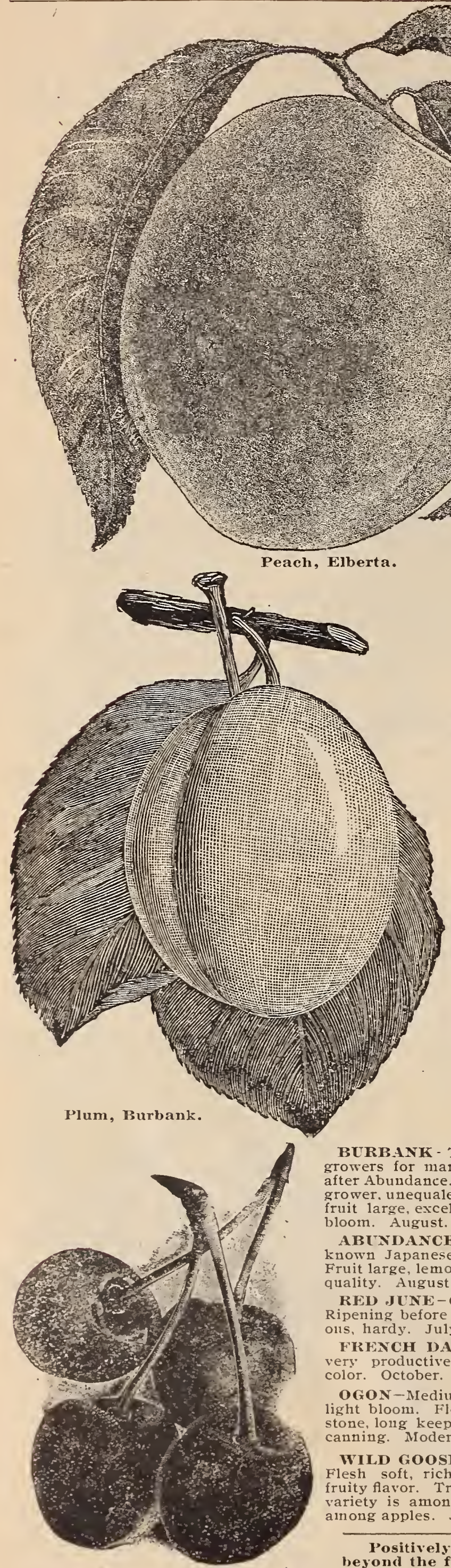

BURBANK - The best and most profitable among growers for market, ripens ten to fourteen days ater Abundance. Tree hardy. sprawing, ngorous grower. unequaled in productiveness, bears young, bloom. August. (See cut.)

ABUNDANCE - One of the oldest and best known Japanese varieties, hardy and productive. Fruit large, lemon yellow, with heary bloom. Good quality. August.

RED JUNE-One of the best Japanese varieties. Ripening before Abundance. Tree upright, vigorolis, hardy. July.

FRFYCH DAJISOy - A liardy annual bearer. very productive, Fruit medium, dark, coppery

OGON-Medium size, clear lemon yellow, with light bloom. Flesh thick, meaty, dry, firm, freestone, long keeper, second quality. Excellent for canning. Moderately productive. August.

WILD GOOSE-Large, rich, crimson, beautiful, Flesh soft, rich, melting, delicious, with a full, variety is amone plums what the Ben Davis is anong apples. July.

\section{Apricots.}

ROYAL-Large yellow, with an orange cheek rich and delicious. A rerv fine variety. August. Price, $30 \mathrm{c}$ each.

\section{Cherries.}

4 to 6 feet, $40 \mathrm{c}$ each; $\$ 4.00$ per dozen.

DYE HOUSE - Very early and sure bearer: ripens in June.

EARLY RICHMOND-Medium, dark red, juicy, rich, acid. June. (See cut.)

GOV. WOOD-Light red, juicy, ricl1, delicious. Healthy grower, very productive. June.

MONTMORENCY ORDINAIRE - Large, red acid and exceedingly productive. (See cut.)

\section{Quince.}

\section{4 feet, 40 cents each.}

ORANGE or APPLE-Fruit large, round, with a short neck, of a bright golden yellow color. Tre has rather slender shoots and oval leares, rery prultivated for the fruit. Ripeng in Ostober. 


\section{YOUNG'S TRANSPLANTED VEGETABLE PLANTS.}

\begin{tabular}{|c|c|c|c|c|c|c|}
\hline Add $25 \mathrm{c}$ per 100 if ordered to be sent per mail. & Per Doz. & Per 100. & 6) & Add $10 c$ per dozen if ordered to be sent per mail. & Per Doz. & Pet 100. \\
\hline 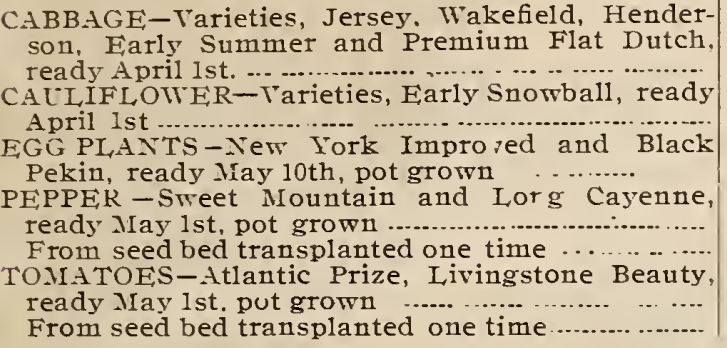 & $\begin{array}{r}40 \\
25 \\
+\quad 40 \\
25\end{array}$ & $\begin{array}{ll}\$ & 50 \\
1 & 25 \\
3 & 75 \\
3 & 00 \\
1 & 50 \\
3 & 00 \\
1 & 50\end{array}$ & $\int_{0}^{1}$ & 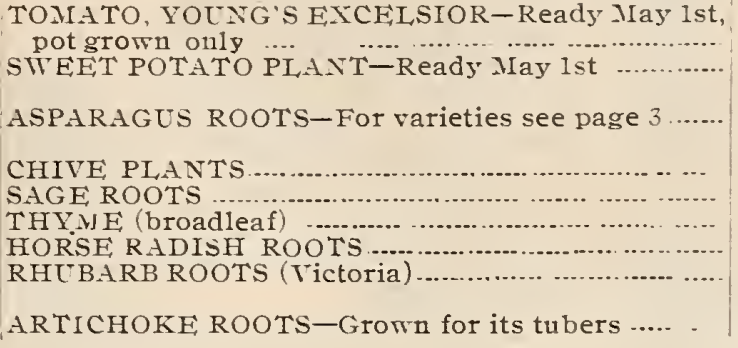 & $\begin{array}{c}\$ 50 \\
35 \\
\text { Per } 100 \\
90 \\
\text { Each } \\
\$ 10 \\
15 \\
15 \\
5 \\
15 \\
\text { Per Pk. } \\
\$ 50\end{array}$ & $\begin{array}{c}\$ 350 \\
250 \\
\text { Per } 1000 \\
\$ 500 \\
\text { Per Doz. } \\
\$ 150 \\
150 \\
150 \\
25 \\
150 \\
\text { Per Bu. } \\
\$ 150\end{array}$ \\
\hline
\end{tabular}

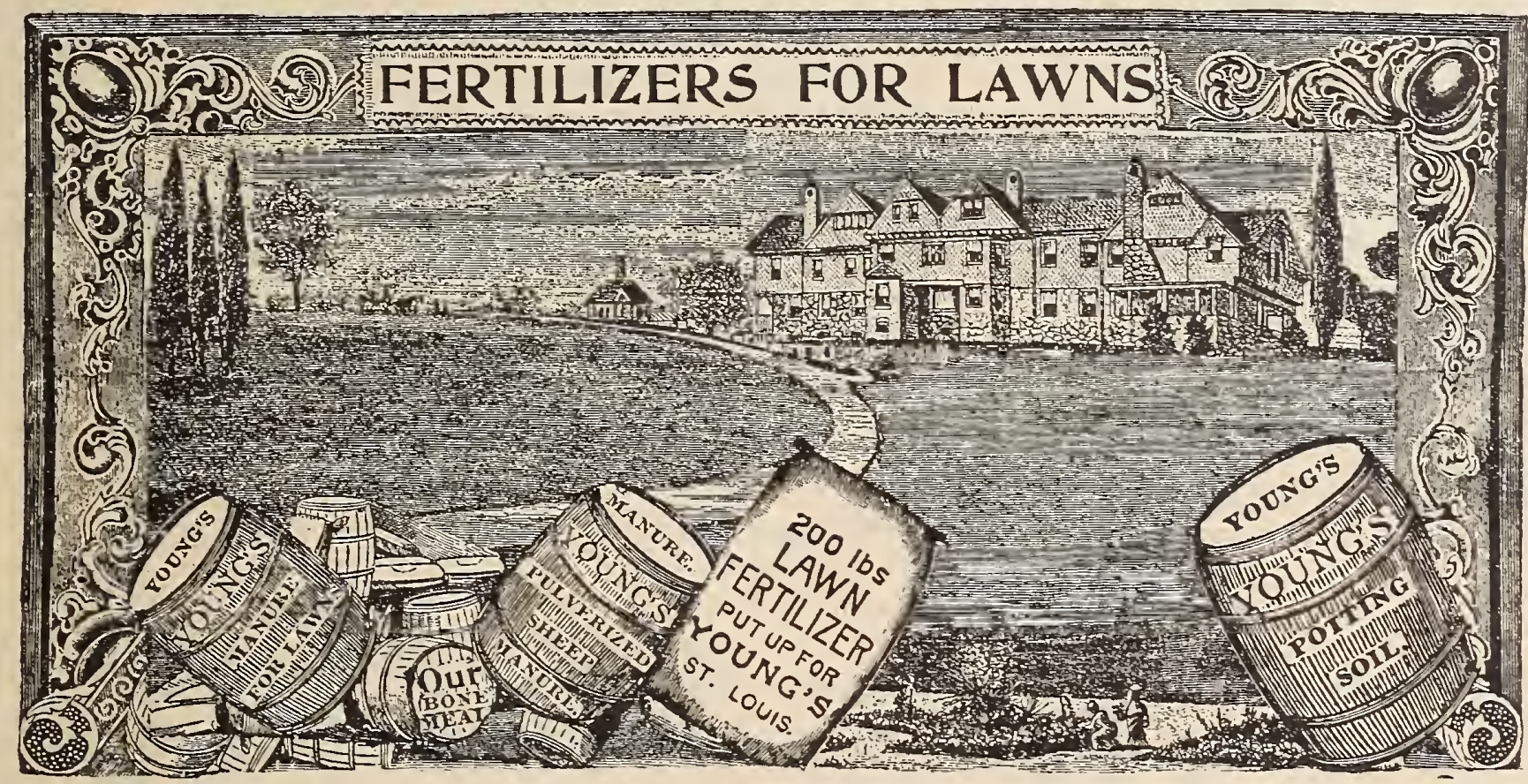

\section{FERTILIZERS.}

PURE BONE MEAL-This is ground very fine, is excellent for top-dressing larins ànd well adapted for mixing with soil for potting purposes, for which one part of meal to fifty of soil is about the right proportion. Price - 2 lbs. (not mailable)

BOWKER'S FOOD FOR FLOWERS-A fertilizer free from odor, clean to handle. Made expressly for flowers grown in the house or garden, producing a healthy, luxuriant growth and induces early and generous flowering. It can not in any way harm the plants it a pplied according to directions, which accompany every package. Small package, $15 \mathrm{c}$; by mail $25 \mathrm{c}$

PULVERIZED SHE

作 parts of soil. 50 lbs., $\$ 2.00 ; 100$ lbs., $\$ 3.50$

LEAF MOULD-It is very valuable for the growing of ferns and all plants that require a light rich soil; should be dy loam, about one-quarter of Leaf liould to three-quarters of loam. It is qerfectly dry and light. Per $1 \mathrm{~b}$. $35 \mathrm{c} ; 2$ 10s., $60 \mathrm{c}$, by mail, postpaid; 5 1b.; by express, $75 \mathrm{c} ; 10$ lbs., $\$ 1.25$.

POT PIN C SOIL-We have had a mixture prepared that will be suitable for most all kinds of plants. It is made up of clear sod loam. with the right proportion of rotten manure, leaf mould and good sharp sand. It is finely sifted and ready for immediate use. Per bushel, $75 \mathrm{c}$; per barrel, $\$ 1.50$.

MANURE FOR LAWNS-This is the best of the fertilizers for lawns, producing a thick, luxuriant growth of igras with this fertilizer in the fall. Per barrel, \$1.50; six barrels, \$7.50. per freight or express at buyer's expense.

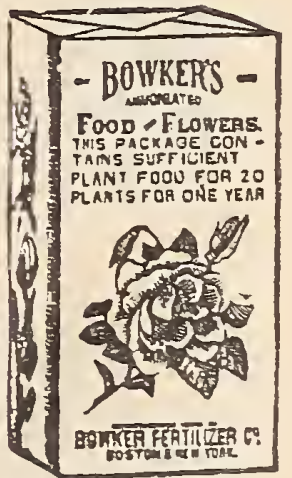

\section{IN SECT DESTROYERS.}

SLUC SHOT-This is a powder poisonous to insects. either killing them or driving them away. For the destruction of the potato bug, striped bug on melons and cucumbers, black flies on turnips and radishes, and the green worm on cabbages, we know of nothing so effectual. 1-1b., canisters with perforated top, $25 \mathrm{c}$ each; by mail. 35c; 5-1b., packages, 30c; 10-1 J., packages, 50c. HELLEBORE-For destroying rose slugs and currant worms.- A few applications only are necessary, and it is thoroughly effective. Per
., 20c; $1 / 2$-1b., 30c; 1 lb., 50c. By mail, $16 \mathrm{c}$ per lb., extra.

YOUNG'S INSECT POWDER-This powder is what we have been using in our greenhouses and gardens for the past two years for destroying aphis or green fly on potted plants, roses, etc. It has never failed. Also the best powder for the destruction of the rose slug and any other

FLOWER OF SULPHUR-A preventive and cure for mildew on roses, graperines, etc. Per 1b., 10c; per $31 \mathrm{bs}$., $25 \mathrm{c}$. If by mail, add $8 \mathrm{c}$ per $1 \mathrm{~b}$.

TOBACCO STEMS-For fumigating plants infested by green fly. Per $1 \mathrm{~b} ., 15 \mathrm{c}$; per barrel of $20 \mathrm{lbs}, \$ 1.00$.

TOBACCO DUST (Fine)-For green or black aphis, fleas, beetles, etc. Splendid fertilizer and preventive for insects in the ground and around roots. Ten cents per lb., or by mail, $20 \mathrm{c}$ per $1 \mathrm{lb}$.; 5 lbs., $35 \mathrm{c} ; 10 \mathrm{lbs}$., $65 \mathrm{c} ; \$ 3.00$ per bbl.

NICOTINE-An economical and powerful nicotine extract. One part to 600 uf water is sufficiently strong to kill all insects except scale, for which use 1 to 400 . Pint, $\$ 1.50$.

PUNK-Very useful and convenient article for fumigating plants infested with aphis, mealy bug, or other insects. When ignited, it does not produce any flame, but a large quantity of smoke, which is not offensive. Large size box, $75 \mathrm{c}$ each. 


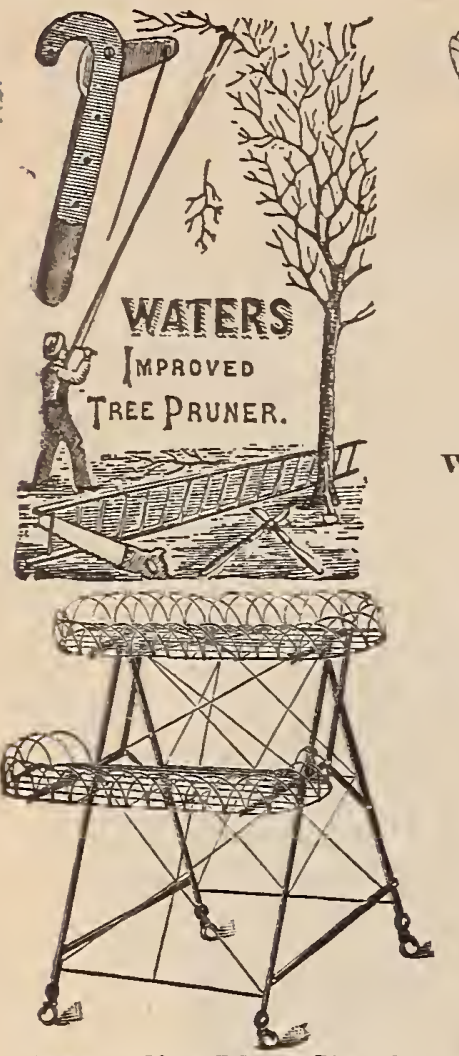

Wire Folding Plant
Two Trays.

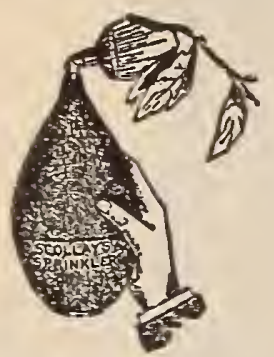

Angular Sprinkler.

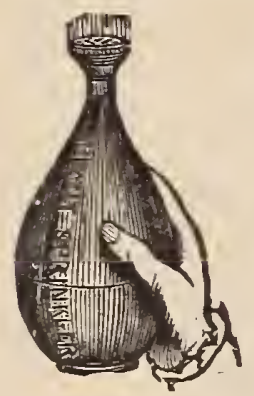

Plant Sprinkler.

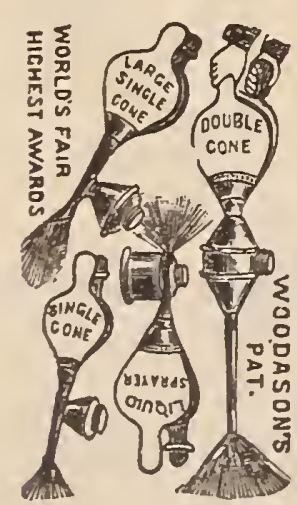

Bellows.

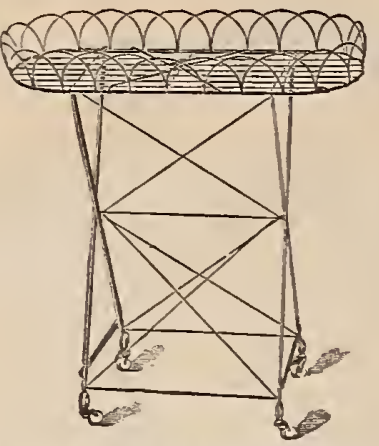

Wire Folding Plant Stand One Tray.

Wire Folding Plant Stands.

One Tray.

No. 22, size $10 \times 24$, price each

Two Trays.

Three Trays.

Water's Tree Pruners.

The best Pruner on the market; cuts limbs to $4 /$-inch in diameter.

4 feet..... \$ $.75 \mid 10$ feet....... \$1.15

6 feet

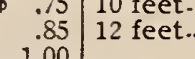

RAFFIA.

For tying, 25c per 1b.; 5 lbs., $\$ 1.00$. $101 \mathrm{bs} ., \$ 1.75$.

Scolley's Rubber Sprinkler.

Indespensable for floral work aud window gardening. 50c, $75 c$ and $\$ 1.00$ each

ANGULAR SPRINKLER.

For spraying under the leaves of plants, $\$ 1.00$ If sprinklers are ordered by mail, add $10 \mathrm{c}$ to the above prices for postage.

\section{BELLOWS.}

Single Cone Bellows-Woodson's Fluid Vaporizing.

For spraying plants with fluid decoctions for inects and fungus. Throws a spray as fine as mist (for house use), $\$ 1.25$.

MOLE TRAP.

Operated either by sping or weight, or both

TROWELS.

(Postage extra, 5c each,)

-inch, Solid Steel (see cut)

\section{ANGULAR TROWEL.}

Solid steel; largely used by gardeners in putting SHEARS.

Lee's Pruning-Improved Spring.$$
\text { 8-inch } \$ 085
$$

\section{EUREKA WEEDER}

The'best little hand weeder for loosening soil around plants that we know of: thin forged steel fingers. Short handled, 25c; long handled. $35 \mathrm{c}$

\section{TREE AND PLANT TUBS. Painted Green.}

Wade of Louisiana white pine, with extra iron hods, drop handles and iron leg

Size, 14 in deep and 14 in in diameter, inside; 1.80 each

$\$ 1.40$ each. $\$ 1.00$ each.
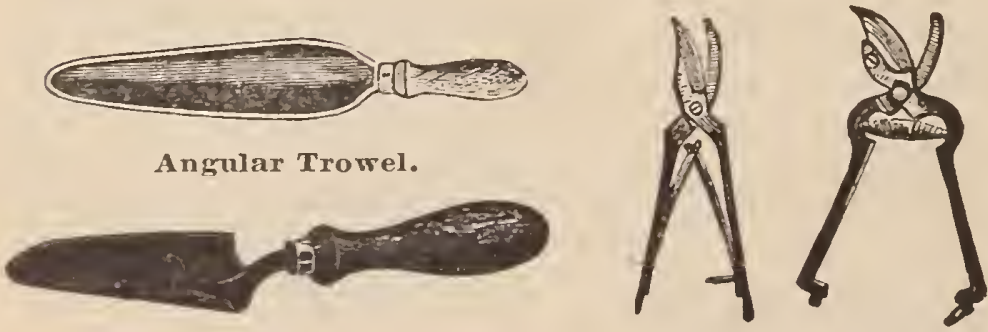

Steel Trowel.

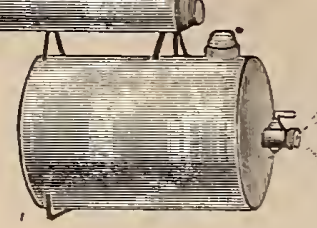

Blizzard Sprayer.

BLIZZARD SPRAYER

hand sprayer for the following cattie, trees, etc. and forgreen-

houses, and nursery stock: also used for and nursery stock: also ing purposes. ranized iron, very strong and endurable. \$2.00 each.

\section{Painted Plant Stakes}

Long Tapering.

1 ${ }_{1}$ feet, light............ $\$ .20$ \$ $\$ 1.10$

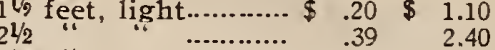

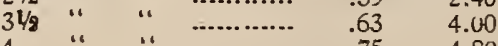

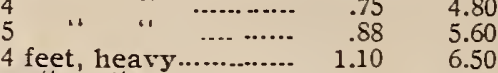

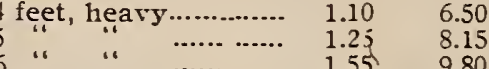

CANE PLANT STAKES.

From 6 to 8 feet in length; can be cut to any desired size. Per 100, $\$ 1.00$.

\section{SYRINCES.}

\section{Solid Brass.}

No. A. A. Barrel. 8 inches long, one spray, each
No. O. Barrel, 12 inches long. one

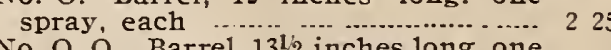

No. O. O. Barrel, 131/2 inches long, on

coarse spray, each .......................
No. 12. Barrel, 13 $\mathrm{V}_{2}$ inches long, one

stream rose, each ........................... 325

PAPER FLOWER POTS.

Paper Flower Pots have been given full and repeated tests in growing bulbs for blooming, and have proved fully satisfactory in every res pect.

3-inch, by mail ...

4-inch, by mail

6-inch, by mail

3-inch, by express, not paid

4-inch, by express, not paid

5-inch, by express, not paid

Standard Earthen Flower Pots

Par doz. Per 100

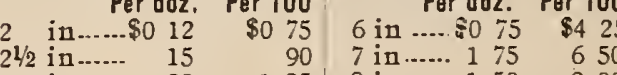

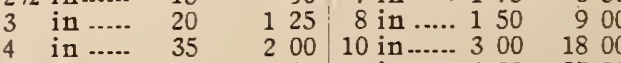

\begin{tabular}{lllll|llllll}
4 & in ..... & 35 & 2 & 00 & 10 & $\mathrm{in} . . . . .$. & 3 & 00 & 18 & 00 \\
5 & in ..... & 45 & 2 & 85 & 12 & in..... 4 & 00 & 27 & 00
\end{tabular}

Common Flower Pot Saucers.

Perdoz. Perdoz.

4 inch ................. \$o $25 \quad 9$ inch

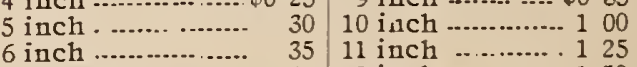

7 inch ................ 40 12 inch ............... 150

8 inch .................. $50 / 14$ inch ............... 1

LABELS.

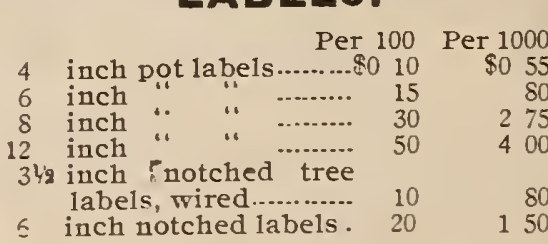

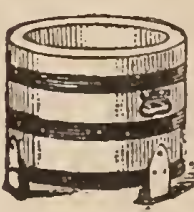

Tree and Plant Tubs.

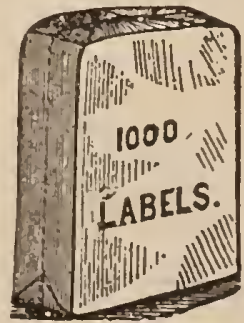

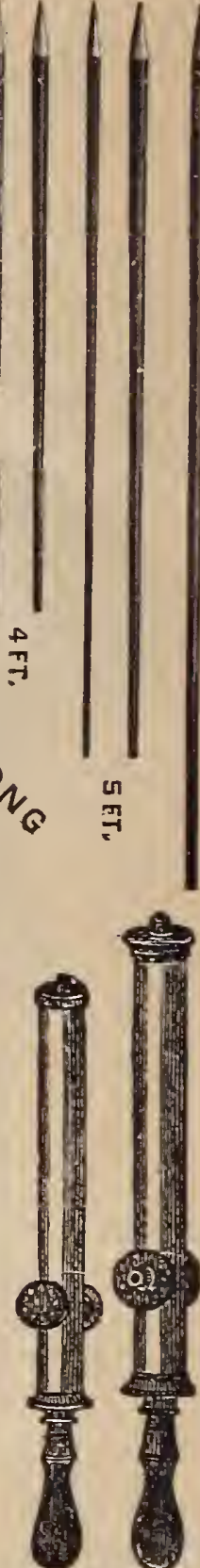

Syringes.

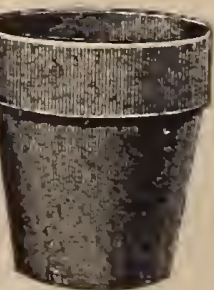

Earthen

Flower Pots

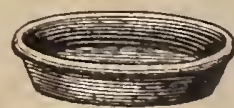

Saucer.

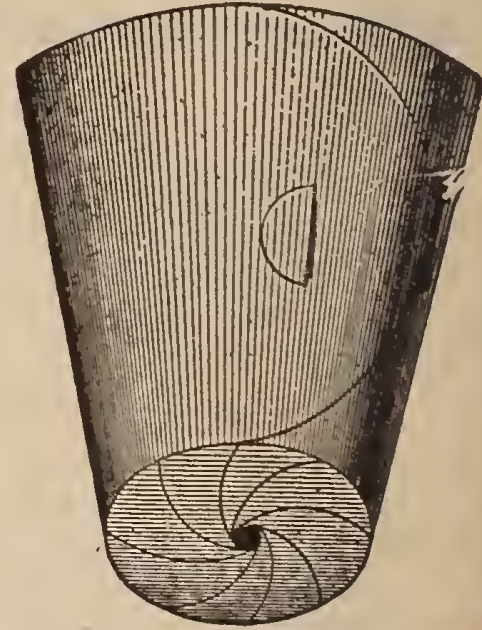

Paper Flower Pots. 


\section{- 4 in

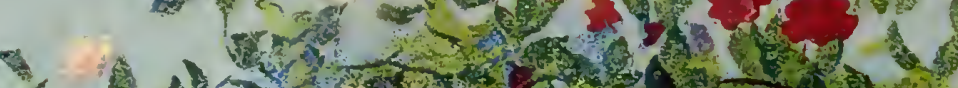

H.

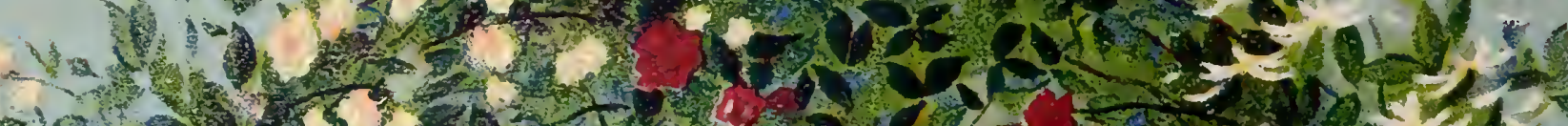

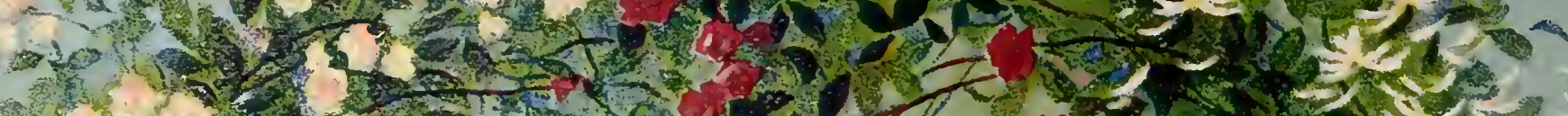

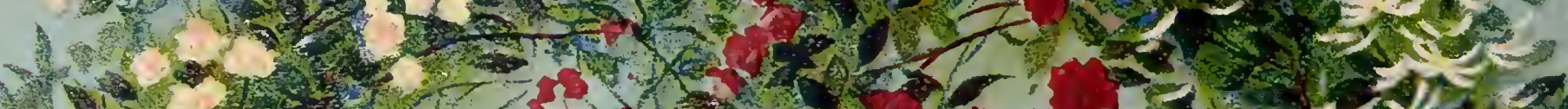
I.

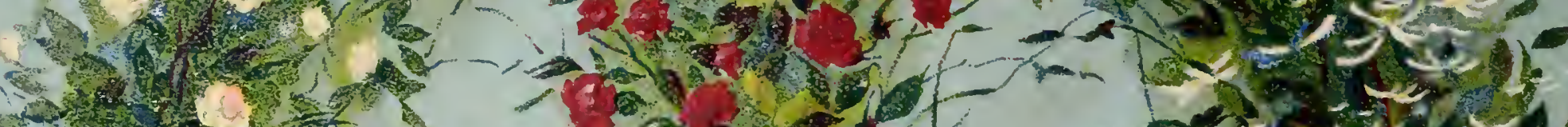

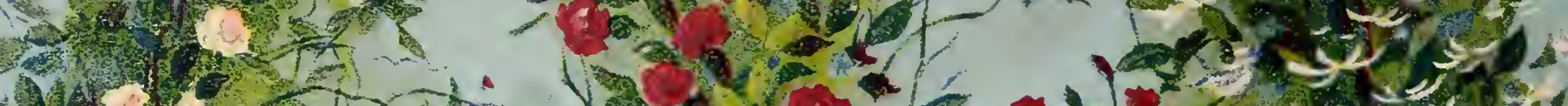

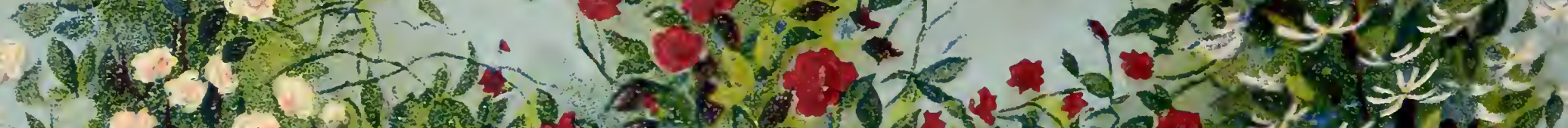

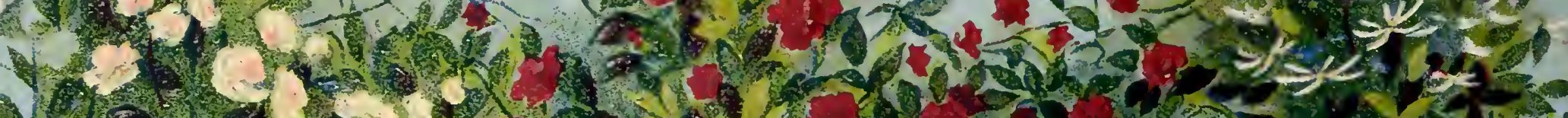
m.

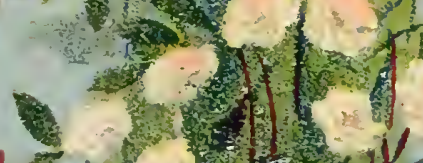

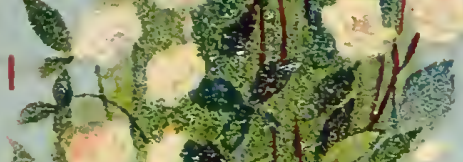
- 30 .

a. 10109 10,010

(1) $x^{2}, y+4$

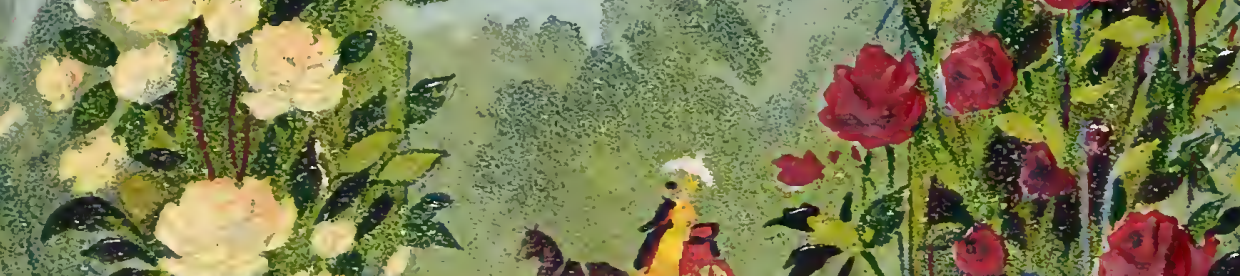
2.

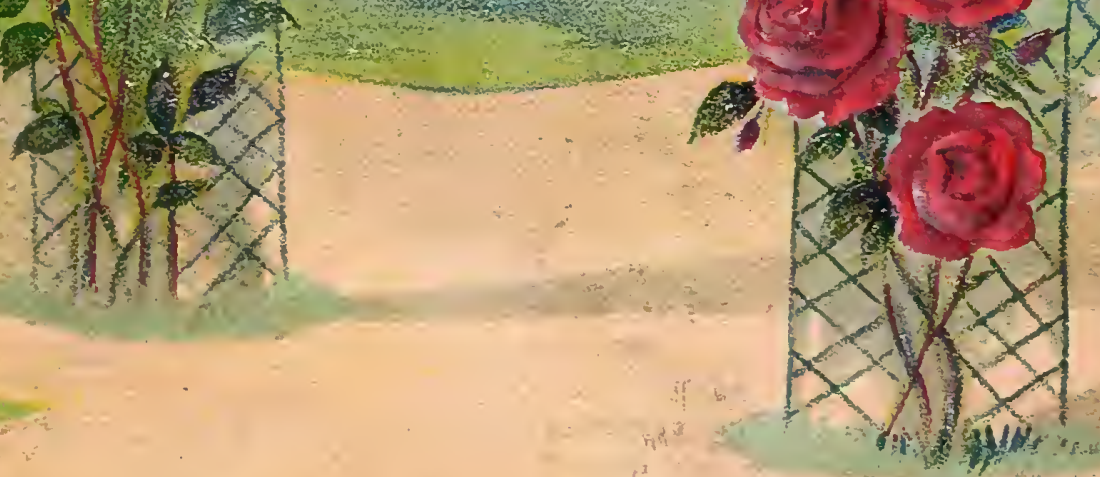

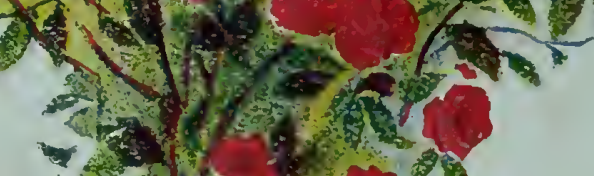

2 की

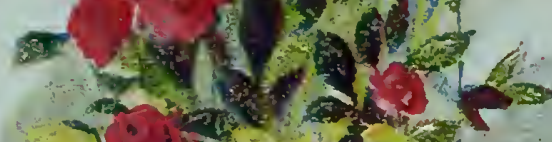

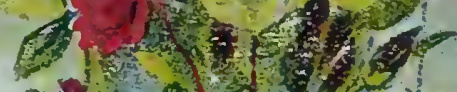

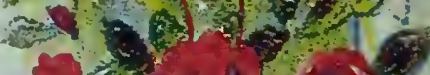

tom 30

th.

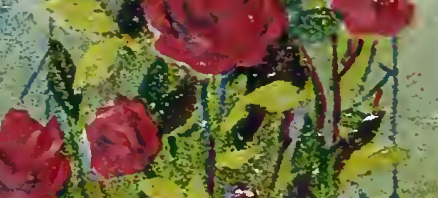

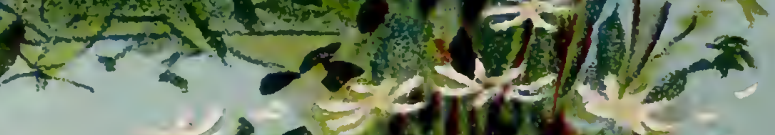

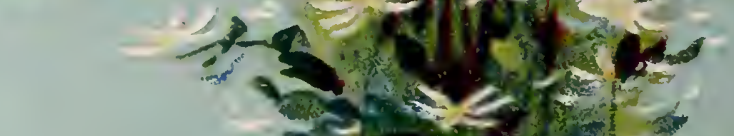

$30(-2-2)$

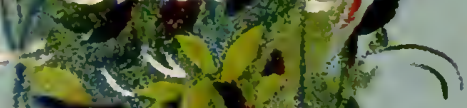
$90^{2} 107^{2}$

$-20(6 \pi)$ $n v^{2}=0$

se

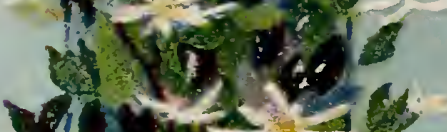

$x^{2}\left(\frac{1}{2}\right)^{2}$ $34+7$ it 